UNIVERSIDADE DE SÃO PAULO

FACULDADE DE FILOSOFIA, LETRAS E CIÊNCIAS HUMANAS DEPARTAMENTO DE HISTÓRIA

PROGRAMA DE PÓS-GRADUAÇÃO EM HISTÓRIA SOCIAL

Marcus Vinícius de Moura Telles

A relação entre representação e experiência: um estudo crítico da "filosofia existencialista da história" 
Marcus Vinícius de Moura Telles

\title{
A relação entre representação e experiência: um estudo crítico da "filosofia existencialista da história"
}

\author{
Versão corrigida
}

Tese de doutorado apresentada ao Programa de Pós-Graduação em História Social do Departamento de História da Faculdade de Filosofia, Letras e Ciências Humanas da Universidade de São Paulo, como parte dos requisitos para a obtenção do título de Doutor em História.

Orientador: Prof. Dr. José Antonio Vasconcelos 


\section{Ficha catalográfica}

Autorizo a reprodução e divulgação total ou parcial deste trabalho, por qualquer meio convencional ou eletrônico, para fins de estudo e pesquisa, desde que citada a fonte.

Telles, Marcus Vinicius
T274r A relaçăo entre representaçăo e experiência: um estudo critico da "filosofia existencialista da história" / Marcus Vinicius Telles ; orientador José Antonio Vasconcelos. - São Paulo, 2019. $426 \mathrm{f}$.

Tese (Doutorado) - Faculdade de Filosofia, Letras e Ciências Humanas da Universidade de São Paulo. Departamento de História. Área de concentração: História Social.

1. representaçăo. 2. experiência. 3. Hayden White. 4. Louis Mink. 5. Frank Ankersmit. I. Vasconcelos, José Antonio, orient. II. Título. 


\section{Folha de aprovação}

TELLES, M. A relação entre representação e experiência: um estudo crítico da "filosofia existencialista da história". 2019. Tese (Doutorado) - Faculdade de Filosofia, Letras e Ciências Humanas. Departamento de História, Universidade de São Paulo, São Paulo, 2019.

Aprovado em:

Banca examinadora

Prof. Dr. Instituição:

Julgamento: Assinatura:

Prof. Dr. Instituição:

Julgamento: Assinatura:

Prof. Dr. Instituição:

Julgamento: Assinatura:

Prof. Dr. Instituição:

Julgamento: Assinatura: 


\section{Agradecimentos}

Agradeço à FAPESP e à CAPES pela bolsa que possibilitou a realização desta pesquisa (bolsa FAPESP/CAPES, processo $n^{\circ}$ 2014/17263-7).

Ao prof. José Antonio Vasconcelos, pela generosidade com que acolheu este projeto e com que dividiu seu conhecimento e suas sugestões. Aos professores Carlos Oiti, Jonathan Menezes e Sara Albieri, pela disposição para ler o trabalho e participar da banca.

Às pessoas que me orientaram no passado e que seguem como fonte de exemplos, admiração e inspiração: Leandro Rust, Lia de Aquino Carvalho e Felipe Charbel.

Às amizades preciosas que fiz durante este período morando em São Paulo: a família da "Dissidência" e do "Coemergência", Alisson Granja, craque Daniel Cunha, Kalyne Vieira e Manu Laranjeira; Guilherme "Ghee" Ikeda, Murillo Antonini, Carol Reymunde, Gustavo Gitti, Carol Fernandes, Lígia Linhares, Michelle "Michellito" Torres, Ana Carolina Boero, dentre muitas outras pessoas. Está sendo uma grande alegria, enquanto escrevo estas palavras, repassar a imensidão de bondade $\mathrm{e}$ generosidade que recebi de cada um de vocês, na forma de muita paciência, incentivos, pinhas, conversas, espaço físico, espaço mental, bilhetinhos, comidinhas, práticas, ofertas de revisão, e, felizmente, mais pinhas.

Às amizades iniciadas enquanto morei em Petrópolis, sem as quais o começo e a continuidade da minha passagem pela academia não teriam sido possíveis, incluindo, dentre tantas, Barbara "The Fall" Castro, Thais Freitas, Janaína "TréTré", Valeria Bordalo, Arilson Ceschini, Rafael "Will”, Luiz Paulo, Ana Laura Cheroto.

Aos amigos do mundo acadêmico, especialmente o João Ohara, grande aquisição para os quadros da UFRJ, Jonathan Menezes, que por várias vezes dividiu materiais e ideias comigo com uma baita generosidade, e Bennett Gilbert, que não tem medo de escrever sobre o que importa, e cujos conselhos foram um grande apoio em momentos difíceis da pesquisa.

À sabedoria e compaixão expressada por grandes seres como o Lama Padma Samten, o Lama Alan Wallace e Tenzin Wangyal Rinpoche.

Por todo o amor, cuidado e exemplo, verdadeiramente além de qualquer coisa que as palavras possam expressar, que recebi da minha família: Cida Ferreira, Paulo César, Ercília Thereza, Celeste Julio, Ana Paula, Rapha Prata, as tias e primo(a)s. Agradecer aos cachorros fica estranho? Tetê e Martin, vocês são uns lindos! Qualquer qualidade mais profunda que eu aspire algum dia manifestar, recebi primeiro de vocês. Muito, muito, muito obrigado!

A vocês, e a todos ligados a vocês, e assim até todos os seres: "Que todos possam estar felizes e seguros, e que todos os corações possam ser preenchidos por alegria." "Que todos se estabeleçam em perfeita tranquilidade." 


\section{Resumo}

As noções de "representação" (tropologia e enredamento, compreensão, atribuição narrativa de substância) e "experiência" (subjetiva e sublime, presença) no que pode ser chamado de "filosofia existencialista da história" requerem uma ontologia comum para que sejam operacionalizáveis: embora pareçam conceitos de difícil reconciliação, é possível mostrar que as diferentes "realidades" que presumem são, na verdade, diferentes graus de reflexividade da consciência operando em um mundo "sublime" (não inerentemente significativo), no qual a incontornável impermanência de tudo que é material implica, juntamente com outros fatores, a provisoriedade de toda atribuição de sentido. Como toda continuidade se desfaz, é possível ler o debate - e assim o fazemos - como abarcando os dois lados da relação entre qualquer nível reflexivo mais alto com um nível reflexivo mais baixo: assim, o enfoque em "representações" mostra a produção de continuidades para um mundo descontínuo, enquanto o enfoque em "experiência" e "presença" enfatiza a descontinuidade dos processos, bem como de seus efeitos psicológicos manifestados a partir do momento em que se torna existencialmente (mais que apenas epistemologicamente) insustentável ou indesejável produzir sentido a partir de recursos estéticos continuístas. Em nossa leitura dos autores narrativistas e experiencialistas, a interação entre os diferentes níveis de realidade se dá pela movimentação da atenção entre um e outro: a atenção tanto pode ser direcionada para aspectos do mundo quanto atraída por eles. O trabalho trata as formulações de Mink, White e Ankersmit como exemplares do primeiro caso, e as de Ankersmit (em sua fase experiencialista) e Runia como exemplares do segundo. Ambos os momentos precisam de uma concepção da relação sujeito-mundo em que o sujeito não é concebido como existente de maneira separada dos mundos natural e social.

Palavras-chave: representação; experiência; Louis Mink; Hayden White; Frank Ankersmit; Eelco Runia. 


\begin{abstract}
The concepts of "representation" (tropology, emplotment, comprehension, narrative substance) and "experience" (subjective \& sublime historical, presence) in what can be called the "existentialist philosophy of history" require a common ontology so that they can be operationalized: even though they might seem to be hard to reconcile, it is possible to show that the different "realities" that they presume are, in fact, different levels of reflexivity of human consciousness acting in a sublime (or non-inherently meaningful) world, in which the unavoidable impermanence of everything implies, along with other factors, the provisional character of every gesture of meaning attribution. Given that every continuity eventually gets undone, it is possible to read the debate as encompassing both sides of the relationship between a higher level of reflexivity and a lower one: thus, the focus on representations highlights the production of continuities in a discontinuous world, while the focus on "experience" and "presence" emphasizes the discontinuity of the processes, as well as the psychological effects that manifest themselves from the moment on in which it becomes existentially (more than only epistemologically) unsustainable ou undesirable to create meaning through aesthetic resources that presume continuity (such as "realistic" ways em emplotment). In our reading of narrativist and experientialist authors, the interaction between different levels of reality (human and otherwise) happens through the movement of the attention between them. Relevant here is the fact that attention can be directed to aspects of the world as well as it can be attracted by them. The text treats the works of Mink, White, and Ankersmit as exemplars of the first case, and of the later Ankersmit and Runia as exemplars of the second. Both traditions (or both parts of the tradition) need a conception of the subject-world relation in which the subject is not presumed to exist apart from the social and natural worlds.
\end{abstract}

Keywords: representation; experience; Louis Mink; Hayden White; Frank Ankersmit; Eelco Runia. 
Índice

Introdução

10

Parte I - A produção de continuidade para um mundo sublime

Capítulo 1 - Os "insights narrativistas": sublimidade e anti-fundacionalismo ..... 23

1.1. A primazia da estética e sua continuidade com a cientificidade ........................... 23

1.2. Relações com o passado: narrativismo e experiencialismo como dois elementos de

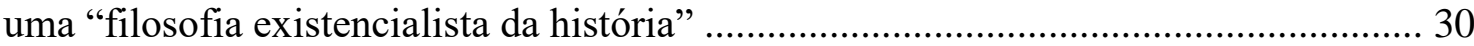

1.3. História, historiografia e filosofia da história contemporâneas .............................. 34

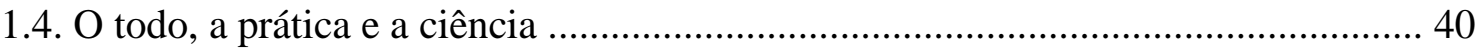

1.5. Significado (de representações) e experiência: apontamentos gerais ...................... 47

1.6. Quatro suportes instáveis para significados instáveis: anti-fundacionalismo com

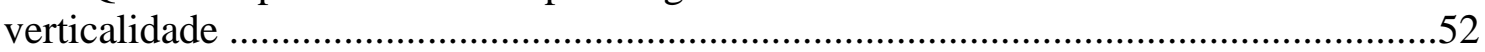

Capítulo 2 - Representação: Síntese de sínteses de heterogêneos ........................... 62

2.1. Formas de repetição do narrativismo anti-fundacionalista: imaginação histórica,

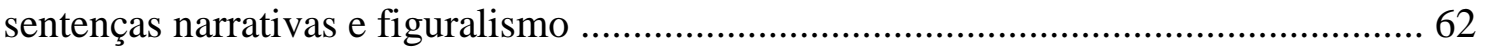

2.2. Louis Mink e a representação como produção de simultaneidades ......................... 84

2.2.1. A relação entre narrativa e "mundo real", presente e passado, representação e

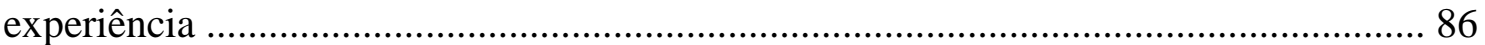

2.2.2. Síntese de sínteses de heterogêneos: Mink à luz de Carr e vice-versa ................. 94

2.2.3. A distinção entre descrição (de eventos) e narrativas ......................................... 98

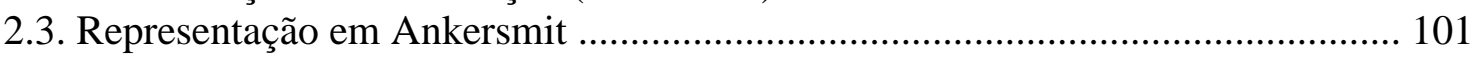

2.4. Ver o rio de cima da montanha é ver a história de fora? ..................................... 112

2.5. Como lidar com "o fardo da história" em um mundo de descontinuidade, disrupção

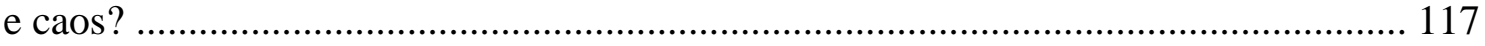

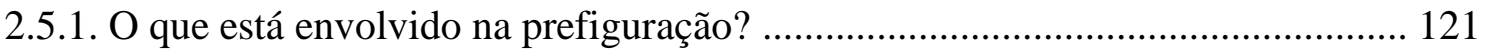

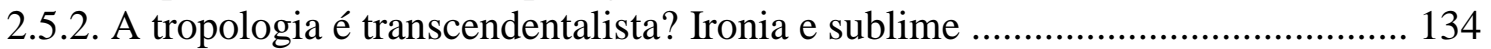

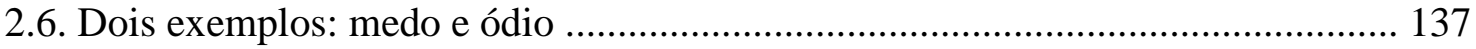

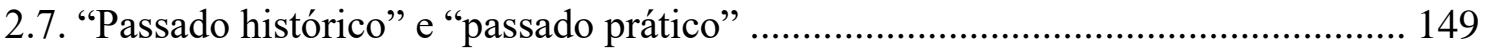

2.8. Estado nacional, autoridade e temporalidade .................................................... 167

2.9. Representação e experiência (1): o que torna uma representação eficaz, as verdades

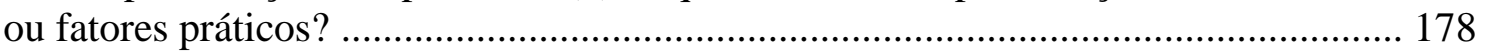

2.10. Representação e experiência (2): Como testar referenciais éticos e estéticos? .. 186

2.11. Compreensão com energia: as teses narrativistas à luz da "experiência estética" de

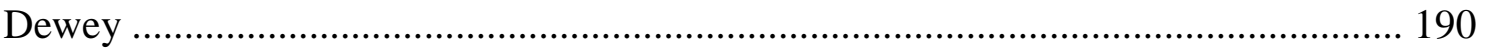

Parte II - Os momentos disruptivos: "experiência histórica" e "presença" ........ 203

Capítulo 3 - Experiência histórica subjetiva _.................................................... 206

3.1 Os vários tipos de experiência em Ankersmit ..................................................... 206

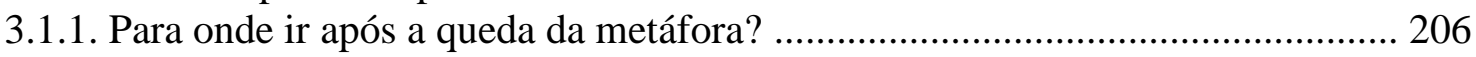

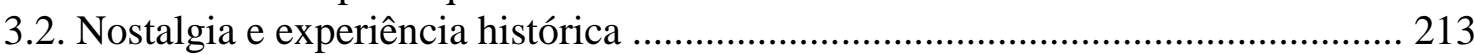

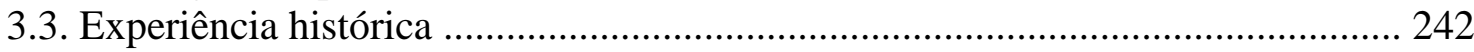

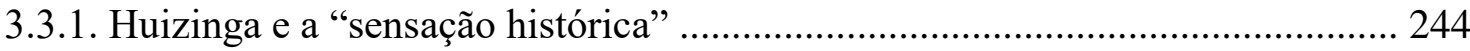


3.3.2. A divisão antecedida por uma unidade básica

3.3.3. "Contato com a realidade": mas "contato" e "realidade" em que sentido? Ou:

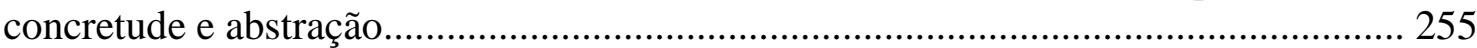

3.3.4. Que sujeito-no-mundo pode experienciar o passado? ....................................... 267

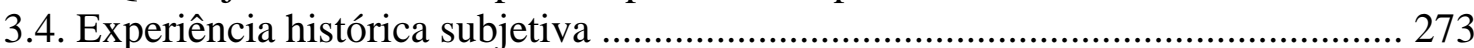

3.5. Questões gerais sobre experiência histórica em Ankersmit ................................ 298

Capítulo 4 - Experiência histórica sublime ............................................................. 320

4.1. Esquecimento e identidade: historicismo, Nietzsche e Hegel ............................. 324

4.2. A reação melancólica do trauma 2 é inevitável e será permanente? ..................... 328

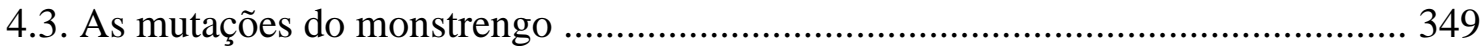

4.4. É difícil, mas não impossível, ver nossas representações .....................................354

4.5. Mito como groundless ground, não como fundamento natural .............................. 357

4.6. Sem linguagem e historicidade, há apenas um estado em branco? ....................... 361

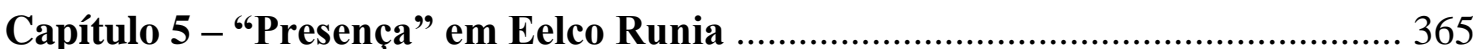

5.1. Presença, em relação com representação ............................................................. 365

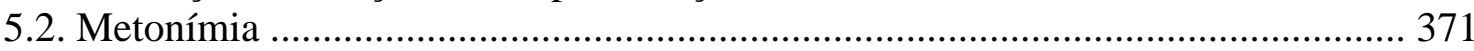

5.3. Agência produtora de descontinuidades, agência inventora de continuidades ..... 375

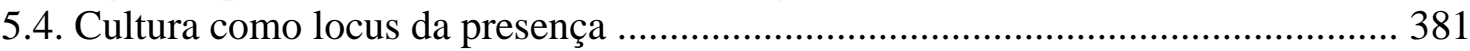

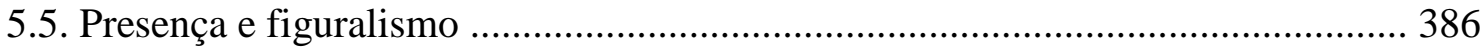

5.6. Estamos mesmo condenados à ingenuidade? Ironia e presencialismo ................. 394

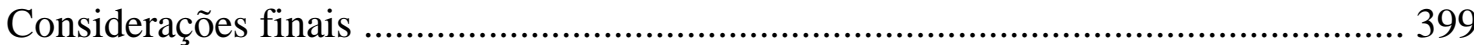

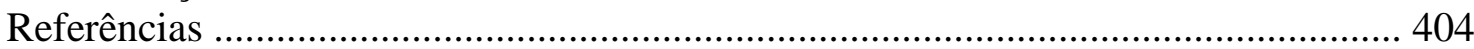




\section{Introdução}

Em 1966, Hayden White publicou na "History and Theory" um ensaio notavelmente anômalo em relação ao tipo de discussão que aquele periódico veiculava desde sua primeira edição, em 1960. ${ }^{1}$ Tratava-se de "O Fardo da História", texto em que ele proponha uma liberação da criatividade dos historiadores diante das amarras profissionais que os prendiam à tentativa de mediar entre arte e ciência de uma maneira peculiarmente inútil, já que suas próprias concepções do que era arte e do que era ciência estavam ultrapassadas. O ensaio mobiliza vários exemplos de manifestações culturais que explicitam a perda de confiança na capacidade da disciplina histórica de fornecer orientações "para a vida". O tema da nietzscheano da existência de múltiplas formas de se relacionar com o passado, incluindo o reconhecimento de que o acúmulo de informações e conhecimento de caráter científico não necessariamente resulta em recursos práticos que resultem em um aumento de potência para os vivos, ressoa no fundo de "O Fardo da História". Para Nietzsche e para White, algum tipo de esquecimento ou seletividade é necessário, e o critério para avaliar o quanto dele deve ser empregado não vem de fundamentos últimos mas das circunstâncias nas quais se age. Ou, para enfatizarmos a filiação existencialista de White, o melhor critério é a avaliação oriunda do engajamento do agente com a situação em que ele se encontra.

White ainda tentaria exortar os historiadores por algumas décadas, até que, a partir do início dos anos $1990,{ }^{2}$ passaria a apostar sobretudo na ficção como forma de produzir relações eticamente informadas, e praticamente engajadas, com o passado. $\mathrm{O}$ par conceitual "passado prático" e "passado histórico", formulado por ele na última década de sua vida - ele faleceria em março de 2018, aos 89 anos -, tipifica duas formas de relação, uma na qual a inserção do agente no seu mundo é reconhecida e a responsabilidade por qual passado é trazido à vida na forma de tradições, exemplos e memória é assumida, e outra na qual ela é ofuscada ou tratada com desinteresse.

Nos debates da filosofia da história ocorridas ao redor da obra de White, porém, por muito tempo a ética e a prática não foram tópicos centrais. A discussão tendeu a ser marcada pela resistência de historiadores e de filósofos realistas à afirmação de que o significado dos textos não é meramente uma reprodução ou espelhamento do passado,

\footnotetext{
${ }^{1}$ Ver o balanço de Richard Vann em ANKERSMIT \& KELLNER, 1995.

${ }^{2} \mathrm{O}$ evento publicado sob o título Probing the Limits of Representation: Nazism and the Final Solution, ocorrido em 1990, parece ter sido como que um ponto de virada para White. Ver o ensaio de Maria Inés La Greca em BENTIVOGLIO \& TOZZI, 2017.
} 
mas uma criação do historiador no presente. Em grande medida, o debate era sobre $o$ que realmente importa: a dimensão estética do texto (para White e seus aliados, o fator central por meio do qual ele produz efeitos no mundo) ou a dimensão epistemológica (privilegiada pela maioria dos historiadores, realistas e pela filosofia analítica da história até praticamente os anos 1970; narrativistas, especialmente Ankersmit, situarem a epistemologia basicamente nas frases singulares dos textos históricos). Mas mesmo a afirmação de que o que realmente importa são as verdades factuais tendeu a envolver um argumento ético por parte de quem as fazia. Segundo este argumento, a historiografia seria incapacitada de sua função se fosse meramente igualada à literatura, como eles temiam que White, e mais ainda os pós-modernistas que o seguiram, estivesse fazendo. (E White muitas vezes utilizou termos como "ficção" de forma solta - a descuidada ou provocativa? - o suficiente para justificar tais temores.)

Quando estes debates chegaram ao seu esgotamento natural, o cenário histórico e historiográfico era consideravelmente diferente daquele dos anos 1960 no qual eles começaram. No contexto da Guerra Fria, as afinidades de White com o existencialismo, o marxismo e o anarquismo eram manifestações de resistência à toda aparência de fundamentação de legitimidade no exercício de autoridade, por parte de grupos profissionais de modo geral e dos estados nacionais em particular, sobre como a realidade deve ser representada realisticamente. O que conta como "realista" é inseparável de quais são os planos realistas de ação no mundo, e denunciar a arbitrariedade de tais realismos era (como é) inseparável de abrir espaço para usos utópicos da imaginação. Mas não apenas este elemento utópico do pensamento de White pouco foi visto na fortuna crítica de sua obra nas três ou quatro décadas, aproximadamente, seguintes à publicação de Metahistory em 1973, como também, a partir do fim da Guerra Fria, em 1991, ele passou a ser amplamente desacreditado. Formulações teóricas como a grade tropológica de Metahistory eram facilmente lidas como expressões mais amplas da circunstância que Michael S. Roth aptamente caracterizou como "a prisão do ironista".

Assim, nas últimas duas ou três décadas aproximadamente, cresceu gradualmente o interesse pelo "real" sobre o qual a linguagem - inclusive a historiográfica - busca falar. Seria a prisão tão inescapável quanto alguns teóricos davam a entender? É com questões de fundo mais ou menos parecidas com esta que surgiram várias formas de "retorno à experiência" na historiografia e de discussões sobre conceitos como "experiência" e "presença" na filosofia da história. 
Uma sensação comum relatado por pensadores como Hans Ulrich Gumbrecht, Frank Ankersmit e Eelco Runia - o trabalho dos dois últimos, que discutem história e são mais diretamente conectados com os debates narrativistas, serão discutidos entre os capítulos 3 e 5 - desde por volta da virada do século é a sensação de alienação em relação ao mundo e desejo por algum tipo de contato com este "real". Não seria o caso de forçar explicações sociologizantes, e de difícil demonstração, sobre como a configuração das sociedades capitalistas no pós-Guerra Fria e desde então estimulou esta sensação, mas desejo aqui afirmar que algumas de suas características contribuem para esta sensação de "falta de contato" com o real. Vladimir Safatle descreve "o modelo hegemônico de circuito de afetos próprio a nossas sociedades de democracia liberal, com suas regressões securitárias e identitárias periódicas”, em termos hobbesianos, situando o medo como o afeto político dominante (enquanto princípio filosófico, no caso de Hobbes, ou enquanto condição contingente, no caso da nossa cultura). Disto decorre a definição da "figura do indivíduo como defensor de sua privacidade e integridade como horizonte, ao mesmo tempo último e fundador, dos vínculos sociais." (2015: 19) E ele especifica: “'Integridade' significa aqui também a soma dos predicados que possuo e que determinam minha individualidade, os predicados dos quais sou proprietário." (idem, ibidem)

Esta concepção do indivíduo idêntico a si mesmo como base das dinâmicas de reconhecimento social se conecta com nosso trabalho de uma maneira que, à primeira vista, não é óbvia. Em seu primeiro livro, Narrative Logic, Ankersmit mostrou como a construção de "substâncias narrativas" se dá pela individualização de tal substância por meio de seus predicados - que, no caso de textos históricos, são as frases singulares que individualizam uma representação. Isto também deve valer para a produção de sentido para indivíduos, e não apenas para o passado: construir uma identidade para eles é construir uma substância narrativa (sendo eles desprovidos de substância ou essência inerente). Assim, uma tendência de nossos tempos é adequadamente identificada e criticada por Judith Butler (2005) como a de nos reconhecermos com referência às nossas identidades (i.e., os significados, conectados ao que contamos como a história de quem realmente somos), o que nos leva a perder de vista o quão amplamente somos perpassados por tudo aquilo que nos é impróprio.

Os desejos manifestados por Gumbrecht, Ankersmit e Runia vão na direção oposta das consequências desta dinâmica individualista e identitária de reconhecimento - mas argumento neste trabalho que o fazem parcialmente, ainda mantendo elementos 
cujas bases filosóficas e consequências pragmáticas considero insustentáveis e/ou indesejáveis. Por exemplo, enquanto as narrativas mantém a atenção presa em uma esfera de abstração, Gumbrecht enfatizará o desejo pelo concreto, por aquilo que afeta sensorialmente o corpo; enquanto as identidades fecham o sujeito no familiar, Runia e Ankersmit mobilizarão conceitos como presença e nostalgia para expressar o desejo pelo contrário com aquilo que aliena o sujeito de si mesmo - ou melhor, deste si mesmo inautêntico, porque parcial e incapaz de dar conta de toda a complexidade que qualquer narrativa inevitavelmente simplifica.

Em 2003, pouco antes de publicar seu principal livro sobre o tema da experiência, Sublime Historical Experience, Ankersmit descreveu dessa forma sua experiência do mundo contemporâneo de então:

\begin{abstract}
Para dizer em uma frase, é essa falta de senso de urgência o que eu deploro muito profundamente na cultura contemporânea e que se manifesta primariamente no nosso hábito de nos vermos quase automaticamente para uma discussão do problema x para o que foi escrito sobre o problema x, ou, pior ainda, para o problema de escrever sobre o problema $\mathrm{x}$, ou, ainda pior, ao problema do que o outros escreveram sobre o problema de escrever sobre o problema x. Isto é o que eu acho tão absolutamente sufocante sobre a cultura contemporânea: ela se tornou inteiramente incapaz de qualquer contato autêntico e imediato com o mundo, ela encontra seu centro de gravidade exclusivamente em si mesma, e não mais nas realidades que ela deveria entender, ela não sente nenhuma outra vontade que não a de contemplar exclusivamente o seu próprio umbigo e agir com a crença narcisista de que o próprio umbigo é o centro do mundo. (ANKERSMIT, 2003: 418-9)
\end{abstract}

Se o argumento sobre o mundo (ocidentalizado, capitalista) contemporâneo parecer pouco convincente ao leitor, os capítulos sobre experiência em Ankersmit fornecerão evidências adicionais oriundos de outras épocas sobre um ponto que estou fazendo: o anseio nostálgico é, por definição, a sensação de não pertencer ao local onde se está; e os vários tipos de "desejo pelo passado" utilizados como exemplo em Sublime frequentemente descrevem grupos na condição de pertencerem a um mundo com o qual não se identificam.

Mas muitos dos exemplos de Sublime mostram algo mais. Veremos no capítulo 4 que, segundo a leitura proposta por Ankersmit, grupos como os conservadores e reacionários no pós-Revolução Francesa tiveram uma experiência traumática daquele evento, mas de um tipo peculiar de trauma: um trauma que não pode ser -e nunca será reconciliado à própria identidade, de modo que os membros de tais grupos constroem uma identidade coletiva com referência a um passado e passam a desejar este passado. Ankersmit afirma que alguns, como os conservadores, sabem que a mudança social é 
irrevogável e sublimam este desejo na forma de um "desejo de conhecer" o passado; outros, como os reacionários, ainda manifestam "desejo de ser" quem outrora eram. Algo parecido se manifesta nas variantes "reflexiva" e "restauradora" da nostalgia, conforme a distinção proposta por Svetlana Boym e apresentada com aprovação por Ankersmit.

Pois bem, em ambos os casos, o desejo dos membros de tais grupos está direcionado à construção de identidades para si próprios e à ausência de horizontes utópicos que englobem a sociedade como um todo. Então há algo ainda de "predicativo" na maneira pela qual eles expressam seu desejo. Se passarmos do nível da descrição do tipo de experiência que eles tiveram para o reconhecimento das possibilidades de ação no presente, então é evidente que, com a distância fornecida da perspectiva e pela reflexão filosófica sobre as ações deles, é possível desejar estabelecer relações com o passado de outras formas. Minha hipótese, para expressar sucintamente, é que as sensações de inautenticidade, de deslocamento, de afastamento da realidade expressadas pelos experiencialistas e por alguns dos atores estudados por eles - devem ser reconhecidas com toda a legitimidade que têm, mas que elas não podem se resolver senão com ações no presente nas quais as causas que as produziram sejam resolvidas. $\mathrm{E}$ as causas, individual e coletivamente, estão ligadas a esta concepção predicativa do indivíduo, e, de modo mais amplo, a um modo de vida no qual o tempo, o trabalho e as relações são perpassadas pelo contato com o "próprio". O contato com o passado é apenas parte do que está em questão: o indivíduo parece desejar um contato com o mundo, e então busca o contato com o único mundo que lhe parece desejável, aquele do passado. Mas esta forma de desejar, como todas, é historicamente contingente.

Mas, neste gesto, parece estar presente uma certa forma de lidar com representações (significados, identidades) que, por si só, já produz afastamento em relação à "realidade". Nos termos de White, é possível dizer que a linguagem mítica direciona a atenção de quem a usa para alguns elementos do mundo, mas obscurece vários outros; nos termos de Ankersmit, podemos dizer que uma representação pode desvelar aspectos do mundo, mas isto também significa que, como o mito em White, se tomada como referência de como as coisas são - incluindo quem eu sou e quem outros são - então ela também obscurece mais do que revela. Nosso trabalho argumenta, por isso, que ironia em relação à capacidade da linguagem de expressar o mundo e pluralismo em relação aos méritos de cada representação são posições desejáveis, e que elas têm uma contrapartida ética e prática. Sua contrapartida ética, na linha das 
discussões de White, é que elas permitem o exame da situação a partir de múltiplas perspectivas, aumentando o conjunto de ações possíveis; mas sua contrapartida prática, para discussões como as do desejo pelo passado por Ankersmit, são ainda mais relevantes no momento. O que elas indicam é que contato com a realidade não é apenas contato com o mundo material, passado ou presente, nem com as circunstâncias já fechadas do passado. Contato com a realidade é também a capacidade ética de direcionar a atenção aos seres vivos contemporâneos, de reconhecê-los para além de suas identidades, de sentir interesse por eles como seres complexos (que sofrem, desejam, envelhecerão e morrerão) para além de qualquer representação possível. Pois "mundo" - o mundo vivido - é algo que surge na interação da consciência incorporada e do ambiente no qual ela se encontra, invariavelmente incluindo a interação intersubjetiva com o mundo social. Assim, paradoxalmente, aquele que investe grandes parcelas de sua energia na imagem passada de si próprio está duplamente afastado da realidade: por um lado porque ele não "é" aquela imagem, mas por outro lado porque, ao direcionar sua atenção preferencialmente a uma imagem que apenas era reconhecida em um mundo passado que não existe mais, ele obscurece a pessoalidade, muito mais real do que qualquer imagem, daqueles que vivem ao seu redor, e também daqueles que vivem à distância e compartilham com ele a interconexão como seres vivendo no mesmo planeta (pensemos sobre como os altos índices de consumo, inevitavelmente ligados a imagens do que é uma vida bem vivida e às identidades dos próprios consumidores, têm efeitos sobre todo o ecossistema). Em suma, uma relação de objetificação com o mundo contemporâneo invariavelmente produzirá o tipo de sensação de alienação descrita por Runia e Ankersmit - e o tipo de desejo manifestado por figuras como os reacionários do século XIX inevitavelmente produzirá frustração. Vimos que Ankersmit é crítico da tendência de seu tempo de "agir com a crença narcisista de que o próprio umbigo é o centro do mundo." Em pleno acordo com ele, o trabalho enfatiza a importância de estabelecer relações com o passado capazes de ampliar solidariedade, compaixão, unselfing, e afirma que isto já é feito em vários campos da historiografia: não é difícil encontrar exemplos nas histórias de gênero, da escravidão ou das relações trabalhistas, mas qualquer objeto pode, a princípio, alimentar tal propósito.

Tendo isto em mente, ao longo do trabalho, tentarei reinserir dois aspectos da linha whiteana do narrativismo nas reflexões de Ankersmit e Runia. Ao mesmo tempo, como veremos, a justaposição das perspectivas dos experiencialistas (ou mesmo de 
Ankersmit em sua fase narrativista) com a de White também enriquecerá as posições deste último.

II

O principal destes aspectos é a ênfase na liberdade presente nas reflexões de White, e outro, ligado a ela, é a afirmação de que as sociedades escolhem retroativamente suas identidades. Estes insights evidentemente são reconhecidos por Ankersmit e Runia, mas não são levados em conta em alguns pontos centrais.

Juntamente com Arthur Danto - também falecido durante a realização do presente trabalho, em 2013, e também aos 89 anos - e sobretudo com Louis Mink, White mostrou que as representações produzem sentido retroativamente, articulando holisticamente em um texto uma multiplicidade de eventos. As representações são o que produzem esta síntese da multiplicidade. Estes autores mostraram que descrever ou representar um evento é produzir significado para eles, pois eventos reais não contam a si mesmos, nem prescrevem uma única maneira pela qual podem ser contados. Isto talvez não soe particularmente polêmico, mas outra forma de dizê-lo é: o passado não oferece resistência à imaginação ativa do historiador.

Nada disto significa, é claro, que diferentes membros de uma comunidade não conseguem examinar evidências que contradigam afirmações factuais sobre o passado: significa apenas que esta discussão epistemológica se dá a partir da base de um protocolo linguístico comum, formulado imaginativamente, a partir do qual os membros da comunidade falam.

Este princípio também está presente em Frank Ankersmit, uma geração mais jovem que White e Mink: para ele, há um espaço estético entre a representação e seu representado na qual a liberdade de ação, não submetida a regras fundacionais ou transcendentais de qualquer tipo, se manifesta. Isto ocorre na relação entre o estado e a população, por exemplo, mas ocorre também na relação entre as descrições verdadeiras de eventos e as representações: as verdades que sabemos sobre o passado não nos obrigam a organizá-las de uma ou outra forma em um texto, e, desta forma, o que elas significam é sempre decidido pelo historiador.

Porém, as discussões sobre experiência e presença adicionam outro elemento importante a esta questão - elemento este que esclarece também o que está em jogo no debate sobre representação. Runia e Ankersmit (em seu momento experiencialista) discutem as circunstâncias psicológicas nas quais os sujeitos se relacionam com o 
passado, e não as características formais da tropologia ou a lógica das substâncias narrativas. Isto já deve chamar nossa atenção para o fato de que a produção de significados para o mundo é feita por seres humanos de carne e osso, mediando entre um organismo, com todo tipo de demandas físicas e psicológicas, e o ambiente. Assim sendo, o presente trabalho atribuirá grande valor às reflexões de John Dewey, que rejeita o sentido de, primeiro, hipostatizarmos um sujeito desconectado do ambiente, para, em seguida, buscarmos meios de explicar como um se relaciona com o outro. Assim, afirmarei, com Dewey, que significados surgem na relação entre os polos indivisíveis do sujeito e do mundo, e, transferindo seu raciocínio para o caso da história, na relação entre sujeito e passado. Como é possível fazer tal transposição, se o ambiente tem o poder de afetar o sujeito, mas o passado - ao menos se pode argumentar, e em certo sentido obviamente com razão - não existe mais? O presente trabalho também rejeita o pressuposto desta pergunta. Uma pessoa - antes mesmo de ser constituída como sujeito, e mais ainda depois, e a cada reconstituição - é feita de processos temporais, oriundas de seu corpo e da sua cultura: lembremos do exemplo de Certeau, que aponta que até mesmo as estratégias de sobrevivência das plantas sobrevivem em nós, e lembremos também de Bourdieu, para quem o passado se reproduz, dentre outras formas, no corpo dos sujeitos, por meio do habitus. É um tanto mais fácil ver isto quanto mais entramos no campo das manifestações culturais, sobretudo as mais abstratas. Aqui, R. G. Collingwood é nosso maior guia: em sua perspectiva, não apenas o passado sobrevive no presente por meio de sublações dialéticas, mas também ele pode ser re-pensado, trazido de volta à vida, com a óbvia diferença de contexto do pensador, de uma maneira que processos meramente físicos ou naturais não podem. ${ }^{3}$

A atenção à psicologia - e não a formulações apriorísticas - enriquece consideravelmente as reflexões narrativistas, porque adiciona o elemento de facticidade inseparável de toda liberdade manifestada pela consciência, que portanto não é absoluta, mas situada. Ela também explica por que é possível que sejamos "movidos pelo passado", como fala Runia: é porque somos agentes no presente, feitos de passado (ou de processos), que estamos sensíveis às demandas que eles impõem sobre nós. Estamos no mundo com nossos desejos e aspirações, e o contato sincrônico ou diacrônico com o mundo ativa - em nós e no mundo - tais desejos. Segue havendo liberdade acerca de

\footnotetext{
${ }^{3}$ Ao longo do texto, ficará claro que Ankersmit vê suas reflexões como radicalmente distintas da de Collingwood. Para Ankersmit, Collingwood não reconhece o que há de mais essencial na historiografia, que é precisamente a diferença de perspectivas entre o agente e o historiador. Mas, em minha leitura de Collingwood, sua obra comporta perfeitamente tais diferenças.
} 
como responder a eles, mas, ao mesmo tempo, eles têm poder sobre a nossa atenção. Os casos enfatizados por narrativistas e por experiencialistas podem então ser localizados em um continuum: em alguns casos, temos mais autonomia sobre como direcionamos nossa atenção sobre o mundo; em outros, o mundo têm poder de tração fortíssimo sobre ela e a possibilidade de ação autônoma se reduz. O trabalho feito por um historiador altamente competente seria um exemplo do primeiro caso, a experiência de uma dor física desesperadora seria um do segundo. Pois a dor chama a atenção, e não é à toa que, em textos independentes entre si, White, Ankersmit e Michel de Certeau tenham associado o ato de direcionar a atenção ao passado às experiências de sofrimento, perda, luto.

E, sobretudo, cabe apontar que esta autonomia da atenção é contingente, podendo ser aumentada por algumas práticas (dentre as quais, idealmente, está a filosofia da história) ou diminuída por outras (incluindo, por exemplo, descrições desumanizadoras dos demais seres humanos, que estimulam ações violentas e destróem as condições culturais, econômicas e sociais necessárias para a existência de campos com autonomia relativa dedicados à prática reflexiva e/ou de sujeitos interessados em se engajar nelas).

Mas, ao discutir o tópico da autonomia relativa da atenção e da possibilidade de ampliá-la, proponho uma série de reelaborações nas reflexões de Ankersmit e de Runia. Isto aparecerá sobretudo em relação às discussões sobre nostalgia e sobre o conceito de "experiência histórica sublime" de Ankersmit. Se por um lado reconhecerei o valor do reconhecimento do anseio nostálgico quando ele se manifesta, por outro não vejo como pode ser verdade que o trauma de uma parcela da elite francesa será sentido por toda a sociedade francesa para todo o sempre, como o conceito de "experiência histórica sublime" afirma. (Evidentemente redescrevo o argumento de Ankersmit em termos que dão mais clareza ao meu próprio, mas no capítulo 4 veremos que não se trata de uma descrição injusta.) $\mathrm{O}$ maior dos méritos da variante whiteana do narrativismo foi precisamente o de mostrar que as identidades das sociedades não são um dado da natureza, mas resultam de escolhas por meio das quais os membros se identificam com certas tradições e as trazem à vida. O próprio Ankersmit, em suas reflexões sobre representação histórico, permite-nos ver que a distinção entre substância e seus acidentes não pode ser sustentada como natural - pois a substância é criada retroativamente por um ato mental e não é outra coisa que a totalidade de predicados atribuídas ao sujeito - e portanto não há uma "mesma" França ou Brasil ou qualquer 
outra nação ou povo. Há ainda, no conceito que Ankersmit apresenta em Sublime, uma naturalização da nação como o telos da história e/ou da historiografia que não resiste às reflexões decoloniais das últimas décadas. Outras formas mais de determinismo se manifestam nas reflexões experiencialistas de Ankersmit e de Runia, e o presente trabalho propõe que elas sejam eliminadas. Elas são melhor pensadas, a meu ver, como constrangimentos, não como determinações.

Nesse sentido, as teses de Ankersmit e de Runia podem ser interpretadas - e aqui o são - como uma segunda onda de respostas sobre a questão de como lidar com "o fardo da história" (e Sublime de fato faz alusão ao problema do esquecimento em Nietzsche, assim como em Hegel e no historicismo, em seu capítulo chave): elas iluminam diversos momentos em que este fardo é no mínimo tão pesado quanto White, dando voz aos escritores modernistas, o avaliou em 1966. Mas eles também afirmam ou naturalizam uma certa impossibilidade em liberar tal fardo, além de expressarem uma certa fascinação por formas de estabelecer relações com ele que o ampliam, e, por tabela, reduzem a margem de liberdade das sociedades contemporâneas para produzir os futuros que lhes pareçam desejáveis. Não se trata de dizer que toda forma de "nostalgia" e de desejo por "contato com o real" produzam isto, muito menos que estes pensadores propõem ativamente posturas reacionárias ou mesmo conformistas, mas certamente se trata de afirmar que, sendo o fardo da história contingente, então a margem de liberdade e de potência para a ação humana também o é - e portanto pode ser ampliada.

III

Por fim, há outro fio condutor que perpassa todos os capítulos do presente texto. Ele surge, aqui, como resposta à seguinte pergunta: como é possível englobar em uma única perspectiva as duas correntes, narrativismo e experiencialismo? Meu argumento é que elas compartilham o princípio filosófico do anti-fundacionalismo e - o que se mostrará apenas após uma discussão mais detalhada, no cap. 1 - uma ontologia comum.

Sobre o anti-fundacionalismo, ele surge como consequência da ausência do que Ankersmit chamou de "regras de tradução" entre o passado e o texto: nenhum fundamento última determina como o passado será apresentado. Assim, como White enfatizou, a decisão se dá sempre em bases práticas. Lee Braver (2012) cunhou um termo muito útil, ao qual recorrerei em alguns momentos do trabalho: "groundless grounds", algo como "fundamentos não-fundamentados". Interpretando o Heidegger de Ser e Tempo e o Wittgenstein das Investigações Filosóficas, Braver encontra em suas 
filosofias a ideia de que qualquer justificativa de uma regra requereria outra justificativa para si, e assim infinitamente; mas que, ao mesmo tempo, a prática fornece elementos necessários para que os seres possam agir. Eles apenas não são últimos. Em White, e também em autores como Keith Jenkins, isto às vezes é apresentado como significando que as decisões sobre como prefigurar o passado são ideológicas, isto é, são feitas de acordo com uma imagem de sociedade considerada desejável por aquele que narra. Mas isto não deve ser visto nem apresentado como um tipo de anything goes, pois as diferentes imagens de sociedade podem ser avaliadas com um refinamento da atenção aos seres que serão afetados pela promoção de tais imagens, inclusive por parte de textos de história (históricos ou práticos). Nossa tese conecta fortemente, portanto, o anti-fundacionalismo à desejabilidade da produção de uma sociedade inclusiva, em vez de excludente, pacífica, em vez de violenta, com predomínio de amor, em vez de ódio. Uso estes termos de propósito para me opor a uma curiosa tendência dos debates acadêmicos: vemos como inteiramente legítimas as tentativas de oposição à crueldade e ao sofrimento, mas parecemos hesitar em falar positivamente tópicos como amor e felicidade. ${ }^{4}$ Seria arriscado fazê-lo, de fato, se tais falas pressupusessem a existência de fundamentos capazes de determinar como é e como produzir uma sociedade "feliz", mas não é necessário retornar ao fundacionalismo ou a ingenuidades. Como não conheço nenhum bom argumento na direção contrária, evitarei os bons modos de apenas ser contra a crueldade: o narrativismo é efetivamente marcado por uma visão positiva, compatível com ideais utópicos, embora não necessariamente com alguma visão utópica em particular.

Em entrevista de 2008 publicada postumamente, White comenta a respeito:

White: ... eu acho que Jesus foi o maior professor de todos os tempos.

Harrison: Por causa da sua doutrina do amor?

White: Bem, sua doutrina do amor é muito complexa, não é? "Ame seus pais, mas siga a mim." Toda a sua noção, ao menos como São Paulo a explica, de que o cumprimento da lei é reconhecer que amor é o princípio dominante na busca conhecimento e na vida.

\footnotetext{
${ }^{4}$ Em entrevista dada a Robert Pogue Harrison em 2008, que citarei no próximo parágrafo, o entrevistador havia perguntado a White sobre amor, focando em sua conexão com o tópico do conhecimento. Apenas destaco o comentário de White no final de sua resposta: "Nós podemos ficar relutantes em levantar esta questão na atual atmosfera científica, mas eu não fico". Na conversa, Harrison e White reconhecem (como afirma White): "É possível estudar o bem sem ser bom." Mas ao longo do trabalho veremos que é ao menos possível estudar o passado de modo a modificar a si próprio por meio do contato com o ele; e que, em relação aos outros seres, os meios retóricos são formas eficazes de afetá-los. Estudar o que quer que seja, então, pode ser um meio de ativar este objeto de estudo: pode-se estudar para produzir o conceito e as práticas do que quer que se entenda por "bem", como algo digno de nossas aspirações utópicas.
} 
Harrison: Eu estava pensando mais especificamente em termos do processo de aprendizado.

White: Eu digo aos meus alunos, "Vejam, nós estamos aqui para discutir o sentido da vida." O sentido da vida é que no momento eu estou vivo. Eu estou em um mundo que está fazendo demandas contraditórias sobre mim. O que eu faço?

Por fim, afirmamos que o trabalho afirma haver uma ontologia comum que perpassa o narrativismo e o experiencialismo. Ele é o outro lado da moeda da afirmação sobre significados serem feitos: isto significa que aquilo que é significado não possui o significado em si mesmo, sem a atuação da consciência do ser vivo que se relaciona com ele. Em White, esta é a tese da condição "sublime" do processo histórico (mesmo o termo "sublime" aqui indicando o tipo de reação que o caos, a ausência de continuidade e da possibilidade de domesticação provocam naquele que contempla a história ou o mundo). Mas argumento algo mais, que terá efeito tanto sobre as teorias narrativistas quanto sobre as experiencialistas: argumento pela necessidade de reconhecer o duplo espaço estético presente em textos historiográficos, que são sobre o passado. Mais especificamente, não é apenas que historiadores do presente produzem significado para um passado sublime. Também é o caso que os agentes no passado também produziam significado para seus próprios mundos, e o que tais "mundos" - deles e de qualquer ser humano - eram compostos pela interpenetração holística de vários níveis diferentes de atividades reflexivas da mente (que no capítulo 1 explicaremos com apoio na noção collingwoodiana de "escala de formas", tal como Mink a leu).

As implicações desta tese serão discutidas nos capítulos 2 , em relação à representação histórica: argumentarei que ela produz não apenas "sínteses de heterogêneos", mas mais especificamente "sínteses de sínteses de heterogêneos"; e nos capítulos 3 e 4 em relação aos conceitos de Ankersmit de "experiência histórica subjetiva" e "experiência histórica sublime". A meu ver, sempre que Ankersmit fala em "experiência do passado", ele está falando de experiências de representações (não no sentido "representacionalista" que Rorty justificadamente criticou, mas no sentido de “apresentações”, Darstellung). Mas isto não é uma má notícia, pois, como Danto falava, seres humanos são ens representans, e a "atmosfera" de qualquer período histórico é composta, em sua dimensão mais básica, pela maneira pela qual seres humanos desvelam o mundo com suas consciências incorporadas. E também não significa que estas representações sejam sempre linguísticas: há dimensões delas que antecedem a linguagem. Quanto ao tipo sublime de experiência, embora seja difícil categorizar as 
experiências de maneiras muito precisos, afirmo também haver algo como uma experiência da sublimidade da história: isto é possível porque, (a) sendo a realidade humana composta por multiplicidades de representações por parte de seres incorporados, situados e em relação, e (b) sendo tais representações feitas, então (c) há momentos em que tais representações - como tudo que é feito - se desfazem. Ankersmit considera que, em momentos assim, a realidade é experienciada an sich. Mas, no presente trabalho, minha leitura é de que a realidade não deve ser concebida como algo atrás da linguagem, pois isto reinstala um pressuposto transdencendalista na obra de um filósofo que, com considerável sucesso, fez esforços para pensar uma filosofia da história não-transcendentalista. A realidade humana surge na interface entre os referenciais do sujeito e os ambientes natural e social: mas não como algo espremido no meio dos dois, e sim como um sistema holístico no qual sujeito e objeto - o observador e aquilo que é observado - se afetam mutuamente. Experienciar o mundo quando há uma quebra dos referenciais parece ser desorientador, mas fornece subsídios para que, com reflexões posteriores, a natureza de toda experiência da realidade seja compreendida. 


\section{Parte I - A produção de continuidade para um mundo sublime}

\section{Capítulo 1 - Os "insights narrativistas": sublimidade e anti-fundacionalismo}

Neste primeiro capítulo, apresento uma caracterização geral do que considero terem sido as mais relevantes contribuições da tradição narrativista para a filosofia da história. Elas são, como o título indica, sua concepção de que o processo histórico não é inerentemente significativo e não há fundamentos últimos capazes de determinar sua significação ou os meios de conhecê-lo. Disto segue a dimensão prática de todo texto resultante de uma operação historiográfica. Em seguida, argumento pela harmonia entre esta perspectiva teórica e as circunstâncias históricas e historiográficas que, desde os anos 1980 aproximadamente, estimularam o crescimento de um novo tipo de "relação com o passado", no qual os discursos de memória, trauma, testemunhos etc. - tudo aquilo que Ankersmit (2001) chamou aptamente de "privatização do passado" ganharam espaço. Ao mesmo tempo, aqui e ao longo do trabalho, enfatizo que o narrativismo não prescreve o tipo peculiar de relação com o passado que parece dominante na contemporaneidade, e que subjaz a ele o tema da liberação da imaginação para fins utópicos, já que nenhuma afirmação de autoridade sobre como estabelecer tais relações pode ser fundamentada em última instância.

Os conceitos de "passado prático" e "relações com o passado" são amplos o suficiente para englobar as duas correntes da "filosofia existencialista da história", a narrativista do último terço do século $\mathrm{XX}$ e a experiencialista ou presencialista do século XXI até o momento. O restante do capítulo fornece os quadros gerais por meio dos quais argumentarei que representação e experiência são dois aspectos processualmente conectados da maneira pela qual seres humanos produzem continuidade e sentido para um mundo onde tudo é perpassado pela impermanência e desprovido de sentido inerente.

\subsection{A primazia da estética e sua continuidade com a cientificidade}

Em sua tentativa de formular o que chama, em livro homônimo, de Postnarrativist Philosophy of Historiography, Jouni-Matti Kuukkanen toma como ponto de partida para suas próprias propostas o que considera ser o "insight narrativista": segundo este insight, os textos históricos possuem algum tipo de estrutura 
unificadora, sintética, que articula suas frases individuais em uma totalidade e não pode ser descoberta por meio de pesquisa.

Em seu uso do termo "narrativismo", Kuukkanen situa sua aparição em meados dos anos 1970. De fato, o uso mais antigo que já identifiquei é de W. H. Dray, em 1970; mas ele se refere, retroativamente, às discussões sobre o assunto feitas por filósofos analíticos ou críticos da história na década anterior, ${ }^{5}$ de modo que o narrativismo pode ser situado ainda antes disto. Kuukkanen se baseia em outra forma de categorizar o movimento, formulada por Frank Ankersmit nas páginas da History and Theory em 1986, no texto "The Dilemma of Contemporary Anglo-Saxon Philosophy of History": para ele, a filosofia da história anglo-saxônica encontrava-se em um "dilema" entre uma abordagem "epistemológica", centrada em frases isoladas, e uma abordagem "narrativista", atenta ao texto enquanto totalidade (1994: 44-74). Curiosamente, apesar de caracterizar sua abordagem como pós-narrativista, um dos conceitos centrais a que Kuukkanen recorre é o de "coligação", introduzido na historiografia por W. H. Walsh já em 1942: um conceito, portanto, que pode com justiça ser chamado de narrativista (se não de pré- ou proto-). Desde então e antes dos anos 1970, uma série de autores ou retomou a proposta de Walsh ou propôs sua própria versão do que surgiria como o "insight" destacado por Kuukkanen. ${ }^{6}$

Em Postnnarrativist Philosophy of Historiography, Ankersmit e White são figurados como os dois principais filósofos desta corrente intelectual "narrativista", em diálogo com a qual também formulamos aqui uma filosofia da história. Para Kuukkanen, "White e Ankersmit equivalem coletivamente à filosofia da historiografia mais desenvolvida e compreensiva que existe." (2015: 25) Ele especifica ainda que,

\footnotetext{
${ }^{5}$ O termo visava se referir a um conjunto de "filósofos analíticos da história" (como W. B. Gallie, Arthur Danto, Louis Mink) que discutiam o tema da narrativa, em contraposição aos seus antecessores (Carl Hempel, Morton White, Maurice Mandelbaum), focados no tema da aplicabilidade do "modelo das covering laws" à história.

${ }^{6}$ W. H. Dray, seguindo Collingwood, propôs toda uma série de tipos de explicação possíveis fornecidos pela historiografia, que poderiam ser considerados satisfatórios na medida em que produzissem familiaridade diante de uma situação diante da qual outrora se sentia espanto (puzzlement); W. B. Gallie considerava que a compreensão histórica consistia em seguir uma narrativa rumo à sua conclusão; Arthur Danto elaborou um modelo causal que buscava esclarecer como a mudança em um sujeito era explicada; a empreitada de Morton White, pensador afeito ao modelo das covering laws de Hempel, pode ser descrita em termos semelhantes, embora seu modelo seja consideravelmente diferente. Em todos estes casos, estava implícito que a historiografia explica por meio de um relato, que só pode ser um relato inteiro - mas as implicações disto ainda não havia sido desdobradas. Ainda mais atento ao caráter sintético da historiografia foi R. G. Collingwood, mas sua influência em relação a este aspecto só se fez sentir no campo a partir das leituras que Louis Mink (em 1969) e especialmente Hayden White (a partir de 1972) fizeram de suas obras. Aqui, insistiremos repetidamente na relevância da interpretação de Mink - publicada sob o título Mind, History, and Dialectic: The Philosophy of R. G. Collingwood - para os debates contemporâneos.
} 
apesar de suas diferenças, "eles têm o suficiente em comum para serem tratados como compartilhadores de uma filosofia com um núcleo comum." Esta perspectiva será adotada aqui também, e, como tratamos mais especificamente da relação entre representação e experiência, terá ainda a peculiaridade de enriquecer aspectos da filosofia de um com aqueles apresentados pelo outro (bem como de "pérolas" soltas na tradição, como nas obras de Danto, Dray, Gallie, Mink e Collingwood). Adicionalmente, cabe observar que a tese segundo a qual historiadores apresentam como resultado de suas investigações não meras frases isoladas, mas juízos sinópticos, aparece com sua plena formulação não em White ou Ankersmit, mas nos escritos de Louis Mink publicados a partir da década de 1960.

Por isso, neste trabalho, afirmo haver um "núcleo comum" na filosofia destes três autores. Ao fazer isto, não busco algo como uma ampliação do recorte de Kuukkanen: é sempre possível buscar antecedentes para qualquer formulação teórica. Pretendo apenas enfatizar em um ponto mais fundamental. A tese de Kuukkanen, que o presente texto endossa em linhas gerais, com alguns desacordos menores, é a de que a historiografia produz atos de fala racional-argumentativos. Não é de se subestimar a importância deste ponto: embora historiadores tenham se contraposto por muito tempo às teses narrativistas, especialmente quando estas receberam roupagens "pósmodernistas", pouco se avançou ao longo de todo o debate a questão do papel da racionalidade por meio da qual a historiografia apresenta suas justificações cognitivas. Porém, é preciso proceder sem desperdiçar o reconhecimento do caráter estético e ético que informa o "insight narrativista" (podendo incluir aí o reconhecimento de um tipo de racionalidade pertencente a estas esferas), especialmente como ele aparece em White, ${ }^{7}$ na esteira de Mink e Collingwood. Não é tarefa fácil: o próprio White frequentemente perdeu de vista o entrelaçamento entre ética, estética e epistemologia, desenfatizando o aspecto cognitivo abordado por Kuukkanen. Mas, em seu livro mais recente, The Practical Past (2014), também White considera que a historiografia produz "atos de fala". É possível que a abordagem de White, que enfatiza prática (que é como ele denomina o entrelaçamento de estética e ética), e a de Kuukkanen, que enfatiza racionalidade, coexistam, por haver, segundo o próprio White, continuidade entre

\footnotetext{
${ }^{7}$ Paul Roth (2016) observa corretamente que Kuukkanen enfatiza a contribuição de Ankersmit e pouco discute a de White.
} 
imaginação e razão. ${ }^{8} \mathrm{O}$ presente trabalho, reconhecendo os méritos tanto na ênfase de Kuukkanen na racionalidade e nas dimensões cognitivas ${ }^{9}$ quanto na ênfase de White em estética e ética, enfatizará tal continuidade entre as dimensões.

Introduzo aqui um ponto de referência ao qual recorrerei na sequência de todo o trabalho para explorar as semelhanças e diferenças entre os debates sobre representação e sobre experiência. Este fim justifica nossa leitura da tradição narrativista tomando-a como um conjunto um tanto mais amplo do que Kuukkanen o faz, e reconhecendo nela, retroativamente, a figura de R. G. Collingwood. Isto já seria suficientemente justificado em bases históricas, pois tanto White quanto Mink têm em Collingwood um importante ancestral intelectual (ver PARTNER \& FOOT: 41-66; JAMES, 2010), e o inglês foi, ainda que postumamente, $a$ principal figura na oposição ao hempelianismo na filosofia da história desde os anos 1940, no contexto a partir do qual surgiu o narrativismo. Mas há uma justificativa filosófica também.

Em Mind, History, and Dialectic: The Philosophy of R. G. Collingwood, de 1969, Mink destacou um ponto ainda pouco ressaltado na biografia intelectual do inglês, em especial em suas implicações para a historiografia: sua concepção dialética da mente, que conhece a si mesma unicamente por suas ações, e cujas manifestações são nada menos que o próprio processo histórico. Mink sintetiza o projeto de Collingwood entre 1933 e 1941 nestes termos:

... enquanto, por um lado, ele estava buscando uma análise da natureza dialética da mente, por outro ele estava fazendo uma análise dialética dos produtos da mente. A forma que esta última assume é uma história do desenvolvimento de conceitos fundamentais, guiada pelo princípio de que, na história do pensamento, tais conceitos fundamentais mudam na maneira do que Hegel chamou de Aufhebung, mantendo e ao mesmo tempo transformando seu próprio passado. (MINK, 1969: 17).

A maneira pela qual Collingwood concebe a dialética da mente fornece um recurso para pensarmos a atuação da imaginação na produção de representações. Mas, ao mesmo tempo, ela esclarece também a maneira pela qual o processo histórico - e portanto as experiências do passado, que são de ou sobre parte deste processo - também sobrevive no presente. Collingwood esclarece esta processualidade da história ao enfatizar a diferença entre acontecimentos naturais, que simplesmente deixam de existir

\footnotetext{
${ }^{8}$ Ver, a este respeito, sobretudo a introdução de Trópicos do Discurso (WHITE, 1994: 13-37). Vico é o principal interlocutor de White sobre esta questão.

${ }^{9}$ Não falo aqui em "epistemologia" porque não há epistemologia do juízo sinóptico, mas sim de vários dos seus componentes objetiva ou intersubjetivamente passíveis de verificação. Em outros momentos, porém, será apropriado empregar tal termo.
} 
uma vez que tenham se concluído, com os históricos, que existem por meio da sobrevivência do passado no presente. A história não é composta apenas de pensamentos, mas se distingue da mera natureza pela presença da dimensão mental. ${ }^{10}$ (COLLINGWOOD, 1994: passim; AHLSKOG, 2017) Assim, ao longo do trabalho, enfatizarei as maneiras pelas quais as discussões sobre "representação" e "experiência" têm em comum o fato de que, sendo componentes da realidade humana, são atividades mentais - mais especificamente, por mentes incorporadas -, que ocorrem como parte de processos que se interpenetram entre si, e não são compostos por coisas como blocos isolados uns dos outros. Sem isto, qualquer discussão sobre experiência ou presença do passado seria desprovida de cabimento.

Em sua leitura, Mink identifica no sistema filosófico de Collingwood a presença de uma "escala de formas" que, quanto ao aspecto cognitivo da mente, opera da seguinte maneira: há, no nível mais básico, o processo corporal orgânico, um "fluxo sensório-emocional não-diferenciado". Quando a mente reflete sobre ele, surge o "segundo nível de consciência", que realiza distinções neste processo, e é, portanto, um pré-requisito para pensamentos mais abstratos. Embora Mink não o diga explicitamente, este nível realiza as funções que (como veremos) Mink atribuiu ao tipo de compreensão típico da historiografia, que chamava de configuracional (ver experiências isoladas como um todo simultâneo) e, como se não bastasse, as que White atribuiria à linguagem "mítica" (direciona a atenção, diz como pensar, dá ênfases em certos aspectos do fluxo outrora não-diferenciado e ofusca outros) e as que Ankersmit em certos momentos atribuiria à representação. Vejamos, por exemplo, como este último autor propõe a distinção entre descrição e representação: “A representação é prática; a descrição é teórica e abstrata. ${ }^{11}$ Animais e bebês, não tendo (ainda) o uso da linguagem, têm a capacidade de reconhecer formas na realidade e, consequentemente, de representá-la,

\footnotetext{
${ }^{10} \mathrm{O}$ que não se trata de negar, evidentemente, que outros seres tenham consciência, mas de distinguir uma peculiaridade humana que resulta da capacidade de incorporar-e-modificar pensamentos passados no presente. Se tomarmos como exemplo o contraste não com a biologia, masc com a física ou a química, o poto de Collingwood fica ainda mais claro.

${ }^{11}$ Esta frase se harmoniza de maneira reveladora com a distinção que White posteriormente formularia entre "passado prático" e "passado histórico", de modo que pode ser proveitoso adiantar um pouco do argumento que virá a respeito. O "passado histórico" é um tanto teórico, i.e., abstraído do processo vivo de onde surge, permeado de preocupações práticas. A distinção, por sua vez, remete ao já citado "dilema da filosofia da história anglo-saxônica": assim, o "passado prático" de White seria indistinguível de uma abordagem que concede grande importância à dimensão estética da representação, enquanto o "passado histórico" surgiria com uma preocupação sobretudo epistemológica. Mas lembremos também que não há descrição sem representação, e portanto não há passado "histórico" que não seja "prático": ele apenas surge da (tentativa de) recusa ou obscurecimento da prática.
} 
embora não sejam capazes de descrevê-la". Assim, entre as duas, a representação é "o nível mais elementar em nosso encontro com o mundo" (ANKERSMIT, 2001: 73). ${ }^{12}$

O "segundo nível da consciência" compartilha com as propostas teóricas de cada um dos três autores, apesar de suas especificidades, esta característica básica ou "elementar" da consciência de significar seu ambiente, produzindo um "mundo" peculiarmente humano, significativo, intersubjetivo. Em todos os autores Collingwood, Mink, White, Ankersmit -, cada um à sua maneira, a atividade mental deste nível - a representação produzida pela imaginação - é anterior à possibilidade de se distinguir entre verdadeiro e falso: esta só se aplica às atividades proposicionais subsequentes. Não à toa, a este segundo nível corresponde a forma de experiência que, em Speculum Mentis, Collingwood chamava de "Arte", e a atividade mental que, em The Idea of History e em The Principles of Art, ele chamava de "imaginação" - dois termos recorrentemente usados por White para se referir à historiografia. ${ }^{13} \mathrm{~A}$ compatibilidade reaparece quando Mink afirma que "o tipo de frase que expressa a consciência de segundo nível é uma metáfora ou imagem poética" (grifos adicionados). A semelhança entre a operação da metáfora e a representação também é enfatizada por Ankersmit (2001; ver também, sobre arte, DANTO, 2011). A imaginação, explica Mink, tanto é a responsável expressar linguisticamente as experiências humanas do nível inferior quanto é condição de possibilidade para os pensamentos mais abstratos e racionais: ela atua como uma "ponte" entre as sensações corpóreas e os pensamentos mais avançados: a "percepção" (terceiro nível) e o pensamento racional (quarto nível), este último subdividido entre "pensamento empírico" e "pensamento sobre pensamento". Apenas neste nível reflexivo mais alto há a possibilidade do tipo de ações éticas, inclusive as que White demanda por parte da historiografia. Por isso, veremos que a autoconsciência (que identificarei a um certo sentido da noção de "ironia" em White) é pré-requisito para o uso livre dos recursos imaginativos (nesse caso literários) que ele deseja, ao mesmo tempo em que só pode surgir como resultado de processos (imaginativos, perceptivos, racionais) anteriores. E para a linhagem de autores que vai

\footnotetext{
${ }^{12}$ A afinidade de Ankersmit com este aspecto da teoria de Collingwood é espantosa, já que o inglês é frequentemente criticado pelo holandês em sua obra por seu "intencionalismo", além de ser (como é observado por ROTH, 2005) um dos poucos dentre os mais conhecidos teóricos sobre a experiência ignorados em Sublime Historical Experience.

${ }^{13}$ Não se trata de coincidência: White construiu sua teoria dos tropos em diálogo com, dentre outros, o trecho de The Idea of History que trata da "imaginação histórica", que opera exatamente no "segundo nível da consciência"; e tanto a compreensão de Mink quanto (cf. KELLNER, 1992) a tropologia de White assemelham-se ao juízo kantiano, com base no qual o próprio Collingwood (1994: 234-248; cf. D’ORO, 2002: 155) também construiu seu conceito de imaginação.
} 
de Vico a White, passando por Collingwood, tal autoconsciência pode facilmente ser perdida, pois depende de condições históricas contingentes para seguir se manifestando. ${ }^{14}$

Todos os principais pensadores narrativistas, Carr, Mink, White, Ankersmit, recorreram ao exemplo da música para caracterizar o que, na minha análise, são atividades de "segundo nível de consciência", seja em seus textos sobre representação, seja naqueles sobre experiência e presença. No caso de Mink, se tratava de apontar que a forma narrativa não pode ser "dita", mas apenas "mostrada" - pois apenas as atividades de "terceiro nível de consciência" dizem, referencialmente ou não. Também Hayden White e Michel de Certeau compararam a forma narrativa à música em termos semelhantes. $\mathrm{Na}$ distinção do "Ankersmit representacionalista", a representação equivaleria ao elemento "musical" do "segundo nível de consciência", em que uma forma de olhar o mundo é mostrada, e a descrição às atividades do terceiro nível, em que frases sobre o mundo são ditas. Veremos que Ankersmit experiencialista também recorrerá à metáfora para caracterizar outro elemento que também situamos no "segundo nível de consciência", talvez em sua sub-divisão interna ainda mais básica (em sua discussão de Collingwood, Mink propõe a existência de tais subdivisões): a Stimmung - ou "atmosfera" ou "humor" - de um período. ${ }^{15}$

Tendo isto em mente, podemos desdobrar ao menos três pontos. Em primeiro lugar, o insight narrativista do texto historiográfico enquanto totalidade pode ser melhor aproveitado se pensarmos que tanto a estética quanto a racionalidade são produtos diretos ou indiretos da atuação da faculdade da imaginação. Longe de ser uma mera criação ex nihilo indiferente às pesquisas e à razão, para autores como Vico e Collingwood a imaginação é pré-condição para o exercício da razão. Da mesma forma, uma série de elementos outrora concebidos como alternativos são mais adequadamente pensados como contínuos: outros que também podem ser contrapostos à razão por estarem ligados ao corpo, como emoções, sensações, impulsos, desejos, podem então ser vistos como processualmente conectados a ela.

Da mesma forma, e em segundo lugar, subjetividade e objetividade são mais adequadamente vistos na forma de um continuum e não como alternativas

\footnotetext{
${ }^{14}$ Como Collingwood afirma, em uma conhecida passagem de The Idea of History: "O autoconhecimento da razão não é um acidente; ele pertence à sua essência. Este é o motivo pelo qual o conhecimento histórico não é um luxo, ou um mero entretenimento de uma mente que está livre de ocupações mais urgentes, mas um dever primordial, cuja realização é essencial para a manutenção, não apenas de alguma forma ou tipo particular da razão, mas da própria razão.” (1994: 228)

${ }^{15}$ Estas discussões serão retomadas e exemplificadas no capítulo 3.
} 
(KUUKKANEN, 2015) - e, assim, o mesmo vale para a distinção entre "passado prático" e "passado histórico", proposta recentemente por White (WHITE, 2010, 2014; ele provavelmente discordaria de nossa afirmação). Ao mesmo tempo, se "prática" for concebida como a conjunção entre ética e estética, então a prática tem primazia sobre a cientificidade (do passado histórico). Na mesma linha, há um ponto particularmente importante para o nosso argumento: ética, estética e epistemologia (não precisamos nos restringir a binômios) também se influenciam mutuamente, a partir de uma base estética fornecida pela atividade imaginativa.

O ponto central aqui é também o mais relevante para os demais exemplos: é necessário abandonar a expectativa de que algo - os tropos, o enredo, a razão, o desejo, a ideologia, a pesquisa arquivística, o habitus profissional ou o que quer que seja - atue como determinante em última instância. ${ }^{16}$ Pois a atividade do segundo nível de consciência não é um fundamento, mas um ato de criação, em que o indivíduo utiliza os recursos de sua coletividade para fazer - ou, para empregar o termo polêmico repetidamente empregado por White, ficcionalizar - um mundo, na relação com o ambiente no qual ele se encontra. ${ }^{17}$ Para falarmos nos termos mais claros de nosso problema, na relação entre a tropologia (por meio da qual o mundo ou o passado são significados) e experiência (que, mesmo quando já significativa, é significada pelo tropeamento), há uma anterioridade da estética mas não há uma determinação da estética.

\section{2. "Relações com o passado": narrativismo e experiencialismo como dois momentos de uma "filosofia existencialista da história"}

"Anterioridade da estética" significa, em termos whiteanos, que antes de lidarmos com o mundo precisamos constituí-lo pelo ato de prefiguração. Esta questão usualmente foi debatida, não sem justificativa, por um prisma epistemológico: se a prefiguração antecede a apresentação discursiva das verdades do passado embasadas em evidências, então o postulado realista de que a mente reproduz aquilo que está fora, sem nada adicionar, já não pode se sustentar. Mas o interesse de White reside muito mais na consequência ética disto: se a prefiguração não vem do mundo, então há uma liberdade

\footnotetext{
${ }^{16}$ Como argumentou este leitor atento de Jacques Derrida que é Dominick LaCapra (1985), em sua discussão de Trópicos do Discurso.

${ }^{17}$ A conexão entre sujeito e ambiente será explicada, mais adiante, com apoio na filosofia pragmatista de John Dewey. A afinidade do pensamento de Collingwood com o existencialismo e com o pragmatismo é afirmada por Mink (1969: 7-12).
} 
do agente para proceder. Ao mesmo tempo, a afirmação que há liberdade de prefiguração só tem valor se a recusa do realismo não produz um tipo de idealismo ou solipsismo em que o texto não versa sobre o mundo, e White não se ocupou em examinar como isto seria possível. ${ }^{18}$ Mas sua obra possui uma tese sobre o mundo, uma tese negativa, sem a qual a afirmação de que os significados são produzidos por recursos linguísticos não faria sentido: é a tese de que o processo histórico é desprovido de significação inerente. Significações são atribuídas ao mundo por indivíduos com liberdade para assim fazê-lo.

O primeiro destes elementos, a centralidade da ética para White, entrou irreversivelmente em sua fortuna crítica na última década. Na biografia intelectual Hayden White: The Historical Imagination, publicada em 2011, Herman Paul mostra existir uma abordagem ética existencialista perpassando toda a trajetória intelectual de White. Este elemento nunca passou completamente despercebido, ${ }^{19}$ mas, se aparece em virtualmente toda a sua obra, é menos marcado exatamente na "aventura estruturalista" de White ao longo dos anos 1970, que mais a tornaram conhecida (PAUL, 2011: 82108). Retroativamente, é difícil não ver a exatidão da leitura de Paul: todos os primeiros textos de White, publicados a partir de 1957, podem ser lidos a partir do par conceitual cinco décadas mais recente que opõe o "passado prático" ao "passado histórico", preferindo o primeiro deles. Paul mostra que a "rebelião [de White] contra modos de realismo anti-utópicos e sua recomendação de modos de representação anti-narrativos foram invariavelmente motivados pelo ideal, inspirado pelo existencialismo, de indivíduos humanos que assumem a responsabilidade por sua própria existência e ousam enredar o curso de suas vidas [...]" (idem: 11). Como dissemos, muito do que se manifesta nesta variante narrativista do existencialismo possui afinidade, e ocasionalmente filiação intelectual, com o pensamento de Collingwood: o diálogo com sua obra é parte importante do processo pelo qual Mink e White pensam a narrativa a partir de noções como reflexividade e auto-consciência e de como traduzem para a filosofia da história o papel da "escolha de um passado" de uma perspectiva situacional de ética.

\footnotetext{
${ }^{18}$ LaCapra (1985) critica a tendência presente em White de conceber a atividade historiográfica como aquela em que um sujeito todo-poderoso projeto sentido sobre um passado inerte. Por considerar que a teoria literária, por si só, não era capaz de atender às necessidades de uma filosofia da história interessada em pensar $a$ relação entre o texto e o mundo, Ankersmit buscou formular uma filosofia da representação que suprisse tal lacuna. Ver sobretudo ANKERSMIT, 2001 e ANKERSMIT, 2012.

${ }_{19}$ Hans Kellner já o apontava em seu texto de 1980, “A Bedrock of Order: Hayden White's Linguistic Humanism".
} 
Mais ainda do que o debate ético, a questão sobre "o mundo" ou "a realidade" foi mais pressuposta do que afirmada em Metahistory e nos ensaios de Tropics of Discourse. Ela é abordada um pouco mais explicitamente no ensaio de 1982, "The Politics of Historical Interpretation: Discipline and De-Sublimation" (WHITE, 1987: 58-82). Mas mesmo ali é ênfase é menos sobre o que já se afirma ser o caráter "sublime" do processo histórico do que sobre as consequências anti-utópicas da historiografia profissionalizada de "de-sublimizá-lo", atribuindo-lhe um sentido inerente que pode ser "interpretado" ou "explicado". O movimento argumentativo de White (que remonta ao de Kant diante das "antinomias da razão") consiste menos em tentar provar a sublimidade da história e a liberdade prefigurativa humana do que em insistir ser eticamente desejável partir deste princípio. Mas é evidente que White presume a sublimidade do mundo, e que possui bons motivos para fazê-lo; há um "mundo narrativista", i.e., um mundo compatível com, e necessário para, a operacionalidade das teses narrativistas em ética, estética e epistemologia. Mais ainda, a tentativa de compreender a natureza deste mundo enriquece, e é enriquecido por, os esforços recentes para pensar o que inicialmente parecem ser, senão uma mera mudança de assunto, teses irreconciliáveis com as reflexões narrativistas: aquelas sobre “experiência” e "presença", das quais destacamos as avançadas por Frank Ankersmit e Eelco Runia.

Recentemente, em 2017, Ankersmit publicou um artigo intitulado "Representation in Retrospective", afirmando que, pelo termo "retrospectiva", buscava afirmar explicitamente ter ocorrido uma mudança para uma fase mais recente na filosofia da história. Isto é, sua perspectiva enfatiza o oposto do que afirmo aqui; pois, se não pretendo de modo algum negar as várias novas abordagens surgidas no campo, consideramos proveitoso que elas sejam desenvolvidas à luz dos "insights narrativistas" - não só o holismo destacado por Kuukkanen, mas a sublimidade e a primazia da prática que inevitavelmente resulta do anti-fundacionalismo. Para Ankersmit, esta nova fase seria marcada não só pelos estudos sobre experiência e presença, mas também por tópicos e conceitos tão variados como memória, esquecimento, perda, a função dos monumentos, o Holocausto, sublime, experiência do tempo (ANKERSMIT, 2017: 1934). Ele a denomina de "filosofia existencialista da história", em contraposição à antecessora, focada em "representação". Não deixa de ser curioso que ele proceda assim: a filosofia de White é muito apropriadamente caracterizada como uma filosofia da história "existencialista" - como Paul apontou no livro que, cabe agora apontar, 
derivou de uma tese originalmente orientada pelo próprio Ankersmit. Ao descrever as características dessa nova filosofia - e misturando-a com exemplos historiográficos, como os volumes Les lieux de mémoire, editados por Pierre Nora - Ankersmit chega muito perto de como White descreve o "passado prático":

Aqui o passado adquirir toda uma nova e desconhecida diretitude [directness] e imediaticidade em seu relacionamento com o presente e com nós mesmos. Ele se tornou um passado que realmente importa para nós, um passado que é, de fato, uma parte de nós. Ele é um passado com o qual lutamos, que pode nos deixar desesperançosos de nós mesmos, ou, inversamente, fortalecer a nossa crença em nós mesmos. [...] É um relacionamento que verdadeiramente envolve você, que é parte de você e essencialmente contribui para o ser humano individual que você é. Isto irá te fazer reconhecer a imensa diferença entre o conhecimento que você possa ter do mundo e como você se relaciona com o mundo. (ANKERSMIT, 2017: 194)

A diferença descrita é por ele é entre conhecer o passado e se relacionar com o passado. ${ }^{20}$ Ele afirma que este giro será capaz de levar em conta um insight apresentado por Heidegger inicialmente na famosa conferência de Davos, em 1928: o de que mentes humanas são finitas e, portanto, nunca poderão objetificar o mundo a partir de um ponto de vista fora ou além do delas, como Kant achou possível. Assim, curiosamente, em sua caracterização de seu - por que não empregar este termo? - pós-narrativismo, Ankersmit reintroduz uma das preocupações que marcaram sua própria filosofia narrativista desde seu primeiro livro, Narrative Logic: a necessidade de superar o "transcendentalismo kantiano", propiciando uma relação ${ }^{21}$ estética com o passado (no caso das substâncias narrativas ou representações). Quanto à obra de White e dos demais narrativistas, é justo afirmar que ela nunca levou em conta o insight de Heidegger? Na nossa visão, que será demonstrada ao longo do trabalho, é de que o figuralismo de White, a "compreensão" (comprehension) de Mink e a escala de formas de Collingwood, especialmente na interpretação do próprio Mink, podem facilmente ser lidos (ou no melhor dos casos, retrabalhados) de maneiras que não presumam que o

\footnotetext{
${ }^{20}$ A noção de que a filosofia da história contemporânea tem as "relações com o passado" como agenda também é desenvolvida por PAUL, 2015.

${ }^{21}$ A noção de relação efetivamente está em sua obra desde o princípio. Como vimos, sua crítica à variante whiteana do representacionalismo é exatamente a de que ela não foca nas relações entre a representação e aquilo que é representado; mas é esta a lacuna que sua filosofia buscou suprir. Adicionemos então: o que as reflexões sobre experiência adicionaram foram a possibilidade de um contato ainda mais direto. Em Sublime Historical Experience, ele considerava a possibilidade de que também as experiências do passado (e não representações sobre o passado) tivessem caráter estético; mais recentemente, se retratou desta visão e tem afirmado, como fazia em 1994, que as experiências históricas são experiências da distância entre passado e presente. (ANKERSMIT, 2012: 175-190; ANKERSMIT, 2017; ANKERSMIT, 2018)
} 
historiador ocupa uma posição fora da história. ${ }^{22}$ Além disso, White consistentemente fez um chamado aos historiadores e teóricos para que se atentassem ao tópico das relações com o passado, ainda que sua recepção tenha sido mais focada em aspectos de sua obra nas quais o passado aparece como ausente ou "morto". Mas tal leitura não é necessária. Nossa tese é de que ambos, White e Ankersmit, apresentam filosofias justamente chamadas de "filosofia existencialista da história", mas que suas concepções de o que é o "passado" e de o que é o "presente" precisam ser modificadas em alguns pontos centrais para que textos de história (no caso de White) e as experiências históricas (no caso do Ankersmit recente) possam fazer o que eles esperam delas: produzir relações "autênticas" com o passado.

\subsection{História, historiografia e filosofia da história contemporâneas}

Vejamos agora como a perda de obviedade dos "chãos" estáveis tradicionais, vários deles interligados (o estado, o arquivo garantido por ele, o historiador cuja autoridade é por ele reconhecida, a política como "ossatura da história", o "sentido" como uma "descoberta" naturalmente resultante da prática historiográfica em que todos estes níveis se articulam) se manifestou em vários níveis, começando pelo mais amplo, o processo histórico, para depois abordar manifestações particulares em seu interior: a historiografia e as reflexões filosóficas (sobre a historiografia e sobre o processo histórico). A conexão entre estes níveis ficará mais clara na próxima seção.

Como White observa, a historiografia se disciplinarizou de maneira intimamente conectada com as atividades do estado nacional moderno. ${ }^{23}$ Esta conexão, por sua vez, remete a uma outra: aquela entre a nação e o "regime de historicidade" moderno, inseparável do capitalismo então em plena fase de consolidação. Reinhart Koselleck mostrou como a modernidade vivenciou uma aceleração da experiência do tempo desde fins do século XVIII. A historiografia, neste processo, perdeu sua antiga função de ensinar exemplos do passado, já que este, agora, era percebido como cada vez mais distante do presente:

A ciência histórica, ao levar em conta o ponto de vista temporal, transformase em uma disciplina investigativa do passado. Essa temporalização das perspectivas foi certamente favorecida pelas rápidas transformações da experiência provocadas pela Revolução Francesa. Tais rupturas de

\footnotetext{
${ }^{22}$ Para uma leitura de White que enfatiza sua afinidade com elementos do pensamento de Heidegger, ver DORAN, 2012: 1-33.

${ }^{23}$ A conexão entre o estado nação e uma certa forma de experiência da temporalidade será discutida no capítulo 2.
} 
continuidade pareciam querer livrar-se de um passado cuja crescente estranheza só poderia ser esclarecida e recuperada pela pesquisa histórica. [...] [Já na filosofia do progresso pré-revolucionária] O princípio de uma possível repetição dos eventos foi abandonado. Uma vez, então, que toda a história é única e singular, o passado tem que ser, por conseqüência, diferente tanto do presente quanto do futuro. Em uma palavra: a "historicização" da história e sua interpretação progressista são dois lados da mesma moeda. (KOSELLECK, 2006: 174-5)

Porém, esta forma tipicamente moderna de experimentar o tempo (simultâneo, linear, teleológico) foi sendo gradualmente modificada ao longo do século XX - este, diz Hartog, "começou mais futurista que presentista, e terminou mais presentista que futurista." (HARTOG, 2013: 107). De acordo com este diagnóstico acerca do surgimento de um novo "regime de historicidade", estabelecido mais fortemente desde o fim da Guerra Fria, nem o passado nem o futuro têm mais a função central de referência que outrora tiveram: há "a sensação de que apenas o presente existe, um presente caracterizado de uma só vez pela tirania do instante e pela esteira do agora interminável" (idem, xv).

Em On the Difficulty of Living Together, Manuel Cruz comenta que com a "crise das metanarrativas" (termo de Jean-François Lyotard) ao longo do século XX-aqueles discursos em que o presente é mais ou menos situado à luz do processo histórico como um todo, este culminando em coisas que vão desde o Juízo Final até a implantação do comunismo-, não apenas perdemos as fontes de significado tradicionais; junto com esta perda, descobrimos algo sobre a natureza dos próprios significados: eles não estão inerentes no processo histórico, são criações humanas, são uma performance e não uma descrição, mesmo quando se apresentam como descrições. Antes, achávamos ter recursos para interpretar os acontecimentos (frequentemente ligados à identidade e às tradições dos grandes blocos políticos do mundo); agora não apenas nos vemos sem qualquer chave interpretativa e sem uma utopia correspondente, mas também sabemos um pouco mais sobre o próprio ato de interpretar. Embora Cruz não trate da tradição com a qual nos ocupamos aqui, é difícil não tomar os insights whiteanos sobre sublimidade como o cumprimeiro das promessas de seu contexto histórico: Lyotard publicou A Condição Pós-Moderna em 1979, sendo contemporâneo das reflexões de White entre Metahistory (1973) e The Content of the Form (1987), que gradualmente assumiriam a forma mais explícita (dentre outras coisas) de uma teorização sobre o sublime - tema sobre o qual Lyotard também se debruçou. 
O presente, assim, parece particularmente marcado pela sensação de falta de referenciais - seja no passado, seja em qualquer outro referecial estável. Não à toa, Chris Lorenz considera que a imagem abaixo ilustra bem nossa "condição presentista" contemporânea-e esta "falta de chão", deveríamos então insistir, é a condição humana mesmo quando não percebida: mas o presente forneceria uma "atmosfera" favorável para a elaboração filosófica desta verdade.

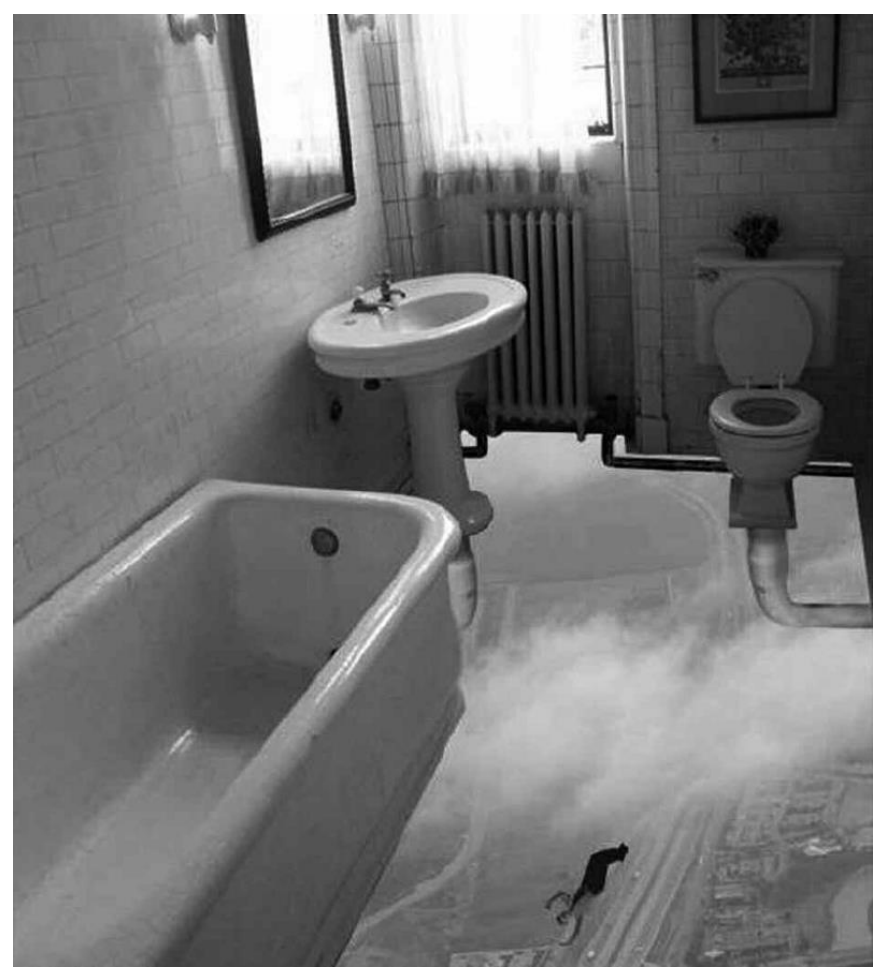

Imagem 1: A condição presentista da história

A historiografia, mais ou menos na mesma época do diagnóstico de Lyotard sobre a "crise das metanarrativas", presenciou também uma série de mudanças. No mesmo ano de 1979, Lawrence Stone identificou o que avaliou como "retorno da narrativa": o interesse por abordagens estruturais e sócio-científicas vinha perdendo espaço para abordagens de menor escala, com enfoque mais descritivo. Nas décadas de 1980 e 1990, a tendência se consolidou, com o crescimento da micro-história, os estudos de memória, trauma, testemunhos, história oral, história da vida cotidiana, etc. ${ }^{24}$ Ankersmit se interessou por esta mudança já nos anos 1980, fase em que ele se intitulou

\footnotetext{
${ }^{24}$ Alguns exemplos que apontam neste sentido encontram-se em: STONE, 1979; BURKE, 1992; IGGERS, 2005; REVEL, 1988, POLLAK, 1992, THOMPSON, 2002, D'ALESSIO, 2001, GINZBURG, 1989, 2002, 2007, ROTH: 2007. É digno de nota, por exemplo, que os recursos narrativos empregados por um micro-historiador como Ginzburg se filiam mesma à tradição modernista à qual White também se alinhava. Ver seus comentários no ensaio "Micro-história: duas ou três coisas que sei a respeito" (2007). Foi o professor Felipe Charbel que, anos atrás, me chamou atenção para este fato.
} 
como pós-modernista. Em "Historiography and Postmodernism", palestra de 1986 publicada em 1989 na History and Theory, ${ }^{25}$ ele descreveu a mudança com apoio em uma metáfora arbórea:

\begin{abstract}
A tradição essencialista na escrita histórica ocidental focou a atenção dos historiadores no tronco daquela árvore. Este foi, é claro, o caso com os sistemas especulativos; eles definiram, por assim dizer, a natureza e a forma do seu tronco. O historicismo e a escrita histórica cientificista, com sua atenção basicamente digna de elogios ao que de fato aconteceu no passado e sua falta de receptividade a esquemas aprioristas, estava situada nos galhos daquela árvore. Porém, a partir daquela posição, sua atenção continuou focada no tronco. [...] Dentro da visão pós-modernista da história, porém, a meta não é mais integração, síntese e totalidade, mas sim aqueles restos históricos que são o centro da atenção. [...] Se nós queremos aderir ao essencialismo ainda assim, nós podemos dizer que a essência [para os pós-modernistas] não está situada nos galhos, nem no tronco, mas nas folhas da árvore histórica. ${ }^{26}[\ldots]$ É característico das folhas que elas fiquem presas de maneira relativamente solta à árvore e que, quando chegam o outono ou o inverno, elas são sopradas para longe pelo vento. Por várias razões, nós podemos presumir que o outono chegou para a historiografia ocidental. $(1994: 176)^{27}$
\end{abstract}

${ }^{25}$ Este ensaio deu ensejo a um pequeno debate sobre Ankersmit e Perez Zagorin, que documenta a dificuldade de compreensão mútua entre "modernistas" e "pós-modernistas" àquela altura. A revista Topoi publicou o debate no Brasil em 2001.

26 Percebamos uma estranheza na formulação, que segue a uma recusa do essencialismo com um raciocínio que aparentemente só se consegue dizer em linguagem essencialista. Será mesmo o caso? Não me parece, se mantivermos em mente a possibilidade de oscilar a atenção entre tronco, galhos e folhas sem presumir que nenhum deles seja $a$ essência da historiografia.

A estranheza desta frase de Ankersmit resulta das dificuldades inerentes ao uso da linguagem: neste momento, o holandês parecia interessado em se afastar do essencialismo, mas (como ele mesmo notava) a questão sobre o que realmente importa em cada tradição parece se confundir muito facilmente com a introdução de uma nova essência. Daí seu uso de uma linguagem hipotética sobre o essencialismo, nesse momento. A meu ver, o mais proveitoso para uma postura não-essencialista - que suponho ser implicada por todo não-fundacionalismo - é manter-se capaz de focar nas diferentes durações, produzindo ora sínteses e ora análises de partes, em um movimento no qual a memória das investigações anteriores se mantém. Um não-essencialismo, assim, não precisaria se focar nas folhas, mas precisaria preservar sua capacidade de adotar diferentes abordagens. Isto está em plena afinidade com dois elementos da filosofia de White: (a) sua afirmação de que há diferentes modos de realismo; (b) a postura "irônica" - sem a qual a afirmação anterior sequer poderia ser feita - que não perde de vista o pluralismo e se recusar a tomar uma única abordagem (seja do tronco, dos galhos ou das árvores) como a única correta: não há fundamentos últimos - e pode-se produzir ou pressupor fundamentos práticos - para escolher entre elas.

Menezes nota outro "tropeço na linguagem" em "Historiography and Postmodernism". Ankersmit (citado em, e traduzido por, MENEZES, 2018: 109) dizia: "O que presenciamos pode muito bem ser nada menos que o adeus definitivo, por enquanto, a todas as aspirações essencialistas que vêm dominando a historiografia através de toda sua existência". Mas, como observa Menezes, "Se é 'definitivo', não pode ser 'por enquanto'; faria mais sentido se fosse 'para sempre', não?” (idem: 111) Ele prossegue, sintetizando a tese de Frank Ankersmit: As Metamorfoses do Historicismo: "Mas esse tropeço na linguagem não é fortuito, uma vez que Ankersmit, não menos do que Ginzburg, nunca conseguiu dar um 'adeus definitivo' para o tronco da árvore; no máximo, foi um momentâneo 'até breve." (idem: ibidem)

${ }^{27}$ Sobre os limites da metáfora proposta na citação, ver, novamente, MENEZES, 2019. Ankersmit se retrataria em pouco tempo, ao menos em relação à micro-história: Sobre sua conexão com o pósmodernismo, ver MENEZES, 2018: 86-145; ANKERSMIT, 2012b. 
Lorenz (2010: 83) assim avalia o impacto destas mudanças sobre a historiografia: "Não o próprio passado, mas as maneiras diversas e conflitantes em que o passado foi experienciado e representado por grupos específicos se moveu para o centro do palco". "Experienciado e representado": na teoria da história, a convivência entre "experiência" e "representação" não tem parecido tão óbvia. A afinidade aparece mais naturalmente na historiografia: basta lembrarmos que o "retorno da narrativa" enunciado por Stone pode também ser caracterizado como o "retorno da experiência" à historiografia (europeia), após um longo interesse por estruturas predominante sobretudo na segunda geração dos Annales. Assim, ao contrário do que Ankersmit insinuava em 1995, em “The Dialectics of Narrativist Historism” (2001: 123-148), considero haver uma grande afinidade entre os estudos historiográficos que adentraram a cena por volta aos anos 1990 e as reflexões sobre narrativa e representação (que ele situa como afins ao historicismo, i.e., ao paradigma que àquela altura ele considerava dialeticamente superado). Pois estas não apenas ampliaram substancialmente nossa compreensão da natureza da representação histórica, mas também são articuláveis com todo este conjunto de novas questões agora abordada por novos pesquisadores, e até mesmo as estimulam: ora, tratar de memórias, história oral e representações sociais é precisamente lidar com significados, com a subjetividade, e não apenas com o que é mensurável e impessoal.

Em recente balanço do campo da filosofia da história publicado no Journal of the Philosophy of History, na sequência da primeira conferência do International Network for Theory of History (INTH), ocorrida em 2013, Bevernage et al. (2014) identificaram uma mudança no campo "de questões epistemológicas e metodológicas rumo a éticas, políticas e existenciais”. Agora, como já vimos com Paul, a obra de White - embora tenha gerado incontáveis discussões epistemológicas - sempre teve como orientação questões de caráter "ético, político e existencial". ${ }^{28}$ Há um motivo central para isto, que o presente trabalho enfatizará devido à sua importância teórica: narrativas e representações permeiam tanto a história-processo quanto a história-escrita,

\footnotetext{
${ }^{28}$ PAUL, 2011. Talvez não seja à toa que, ao publicar seu próprio balanço sobre o evento da INTH, Paul viu com olhos diferentes a relação entre as temáticas estudadas pelas diferentes gerações do campo. Ele identificou "duas tendências entre os teóricos da história contemporâneos: um interesse na história para além da academia e um desejo de superar a polarização teórica que caracterizou o campo até recentemente." Ele descreveu as duas tendências, por sua vez, como potencialmente relacionadas a uma única agenda de pesquisa, descritível em termos de "relações com o passado" (mesmo termo que Ankersmit empregou no referido texto de 2017). Ver: PAUL, 2015. Isto não significa, é claro, que as diferentes tendências sejam harmônicas entre si, mas que noções como "relações com o passado" e "passado prático" são adequá-las para englobá-las.
} 
e são centrais para quem quer que deseje estudar memórias, traumas e tópicos afins. ${ }^{29} \mathrm{O}$ comentário de Bevernage et al. (2014: 147-8) também concebe a noção de "passado prático" como uma agenda viável para a teoria e prática da historiografia contemporânea:

O que nós advogamos é uma abordagem mais reflexiva que é mais próxima ao que Hayden White chamou de "passado prático". Nós saudamos o chamado de White para abraçar o passado prático, contanto que o termo "prático" seja interpretado em uma dupla maneira: por um lado como uma denotação de um objeto de estudo (a maneira pela qual o passado é utilizado para mudar ou conservar o presente), mas também, por outro lado, e talvez de forma ainda mais importante, como uma exortação para fazer a nossa pesquisa praticamente relevante.

O presente trabalho defende que uma filosofia da história capaz de contribuir para estes esforços deve manter o "insight narrativista" acerca da sublimidade da história e da consequente característica prática do processo pelo qual a "realidade humana" é "feita" (nesse sentido, "ficcionalizada"). Isto não se dá apenas no nível do objeto de estudo, mas também do sujeito que pesquisa no presente. Dessa forma, como argumentarei no capítulo 2, qualquer identidade que ela possa se atribuir ao preencher figuras do passado de uma certa maneira também é construída, e dessa forma será necessário abandonar o pressuposto de que haja um sujeito estável, equivalente à sua identidade, ocupando um lugar no espaço e no tempo (KLEINBERG, 2017: 70), tão identificável a sua enredo a ponto de não possuir mais dimensões de opacidade a si mesmo (cf. BUTLER, 2005). Além de um conjunto de reflexões de inspiração vagamente hegelianas a respeito, adicionalmente, em relação ao papel dos sujeitos, recorrerei à abordagem "pós-hegeliana" de Judith Butler, compatível com o que Safatle tem chamado de "concepção anti-predicativa do reconhecimento" (BUTLER, 2005;

\footnotetext{
${ }^{29}$ Notemos, por exemplo, a mudança de tom na recepção de White nas últimas décadas. No evento Probing the Limits of Representation, de 1990 (publicado em 1992), o organizador Saul Friedländer propôs que as teses de White fossem postas à prova por teóricos e historiadores, com ênfase na questão sobre a representação do Holocausto. O tom geral do evento foi notavelmente agressivo contra ele. Em uma nova coleção sobre o mesmo tema publicada recentemente, Probing the Ethics of Holocaust Culture (FOGU, KANSTEINER \& PRESNER, 2016), há um notável o consenso ao redor da tese de White sobre a praticidade (no sentido já mencionado da conexão entre ética e estética) de toda representação, incluindo a de eventos reais. Os dois primeiros artigos do livro são de White e Friedländer, respectivamente, e a distância da posição de ambos é consideravelmente menor. O próprio Friedländer, historiador notavelmente preocupado com as implicações éticas de narrar o Holocausto, parece ter levado em conta posições como a de White na escrita dos dois volumes de Nazy Germany and the Jews: ver FRIEDLÄNDER, 1997, 2007; ver também a afirmação de que o segundo volume de Friedländer oferecia um exemplo historiográfica da proposta de White sobre a adoção de técnicas literárias modernistas em KANSTEINER, 2009. Sobre a maior aceitação das posições de White, em menos no nível teórico, ver MOYN, 2015; ainda assim, sobre a atração exercida pela ideia de um retorno à segurança do realismo ontológico, ver KLEINBERG, 2017.
} 
SAFATLE, 2015). Assim, se Ankersmit aponta corretamente que uma "substância narrativa" opera por meio da atribuição de predicados a uma substância central, e se reconhece também que "Eu" é uma substância narrativa (ANKERSMIT, 1983), então caberá adicionar que, devido ao insight acerca da sublimidade de tudo que é histórico, substâncias são atribuídas por meio de narrativas e representações, e não achadas ou auto-existentes. Esta expectativa, afirma Kleinberg (2017: 70), ainda se manifesta menos nos "teóricos da presença". No fim das contas, como diz este autor, a esperança de um passado estável é também a esperança de um presente estável, de um "presente presente". E como ele coloca, ainda mais enfaticamente:

\begin{abstract}
$\mathrm{Eu}$ argumentaria que é precisamente o medo inspirado pela possibilidade de uma história ou identidade que não é predicada em uma fundação [ground] estável e definitiva que envia estes pensadores (ortodoxos e iconoclastas) "de volta" ao alicerce [bedrock] da experiência, presença e do sujeito estável — de volta ao arquivo onde as origens podem ser encontradas porque nós "sabemos" que elas estão lá, porque nós a experienciamos. Ele nos envia de volta ao realismo ontológico. A realização unheimlich de que história e identidade são alvos em movimento, de que o passado habita um território inquietante [uncanny] que tanto é quanto não é, é revelado pela desconstrução e encarada com medo e repressão.
\end{abstract}

E isto significa, por fim, que o reconhecimento da sublimidade da história e da provisoriedade de toda atribuição de sentido demandam também virtudes epistêmicas ligadas ao destemor e à curiosidade, e estas, por sua vez, têm mais chances de se manifestar em um campo profissional e em uma sociedade que os valorize. Um exemplo é a defesa de Judith Butler de uma dinâmica de reconhecimento pautada menos em identidades aparentemente estáveis e coerentes e mais abertas ao que poderíamos chamar de "experimentação" e a possibilidades alternativas, tanto em suas expressões "profissionais" quanto "práticas", tanto por parte do sujeito quanto no objeto da representação. (BUTLER, 2005; SAFATLE, 2015) O "insight narrativista" demanda o abandono de qualquer expectativa de encontrar pontos fixos, seja em identidades presentes, seja em passados míticos pelos quais se possa estar nostálgico.

\title{
1.4. O todo, a prática e a ciência
}

Em seus últimos anos de vida, Edmund Husserl desenvolveu um forte interesse pela história, virtualmente ausente de sua obra até então (cf. CARR, 1980). Em "A Crise da Humanidade Europeia e a Filosofia" (HUSSERL, 2008), ele argumentava que as ciências têm origem no "mundo da vida", e criticava as consequências de tal 
esquecimento. Este mundo da vida, retrabalhado por David Carr $(1991,2014)$ no debate narrativista por meio da noção de "realidade humana", é - quaisquer que sejam suas outras características - significativo. Ou, como Danto afirma, "os seres humanos são ens representans, seres que representam o mundo" (2011: 11). Como tal, para sermos mais exatos, o mundo da vida existe na instável intersecção entre aquilo que está ou demanda estar significado em nossos sistemas de representação e aquilo que não está. Daí que à noção de significado ("meaning”) seja sempre atribuída uma função mediadora e que ela seja sempre anterior a todas as divisões e individualizações existentes na realidade humana. Primeiro é necessário surgir um mundo apresentado à consciência, para que depois seja possível dizer proposições verdadeiras e tomar decisões éticas.

Uma característica do debate narrativista, implícita desde seus primórdios e explícita mais recentemente, é o interesse pela dimensão "prática" da história, embora frequentemente enfatizando mais seu retorno ao "mundo da vida" do que as consequências de sua origem nele. White, Mink e, parcialmente por meio deles, o "retroativamente narrativista" Collingwood, Carr, Danto (com a tese de que a narrativa compõe a "metafísica da vida cotidiana"), bem como Ricoeur e (para citarmos um autor um pouco mais afastado do debate) Rüsen (para os quais a historiografia fornece orientação temporal para a existência humana), todos enfatizam tal dimensão.

Como já mencionamos, no coração da tradição narrativista reside a tese de que significado nunca é algo que se encontra no passado ou no mundo, mas que se atribui a eles. Em coerência com a perspectiva existencialista, não há como não participar ativamente do processo de escolha de um passado, embora se possa escolher a recusa da escolha, lidando com "má-fé". ${ }^{30}$ Há de se observar, porém, que em maior ou menor medida, Mink, White e Ankersmit tratam mais comumente do significado de textos de história do que da circulação de significados na realidade intersubjetiva humana. Assim, algum cuidado será necessário para situar a validade do argumento para um ou outro destes níveis - que são, porém, absolutamente indissociáveis. Assim, se por um lado os autores aqui estudados situam a produção de narrativas históricas no "mundo da vida", por outro implicam que os significados do mundo da vida e sobre o mundo da vida não possuem sentido inerente.

Se a atribuição de significados tem essa função mediadora, fundamental, básica, anterior e condicionante de todas as demais, então cabe perguntarmos $o$ que ela media.

\footnotetext{
${ }^{30}$ Sobre este ponto: DORAN, 2013; CRAIB, 2000.
} 
Duas características principais podem ser apontadas: primeira, ela realiza a transição entre o inconsciente ou não-consciente e o consciente; segunda, nesse processo de tomada de consciência, o que era até então um todo indivisível é dividido em coisas ou seres individualizados, com ou sobre os quais é possível agir ou pensar. Assim, a realidade humana já surge como o recorte de um universo mais amplo: afinal, todo sistema de representações possui um pano de fundo fornecendo-lhe o contraste, e, entre o que é representado e o que não é, há toda uma zona de penumbra que apenas parcialmente chega à consciência dos seres.

Seguindo a pista iniciada pela leitura de White como um existencialista, podemos recorrer a Jean-Paul Sartre e diferenciar estes níveis do ser como Em-si e Parasi. Enquanto Em-si, o ser apenas é: é pura identidade consigo mesmo. O Em-si, enquanto totalidade e em seguida fragmentado em "istos" individuais, só vem efetivamente a ser por meio deste ser cognoscente que é o Para-si, que o conhece como aquilo que ele não é. Mas isto significa que "uma fissura impalpável deslizou pelo ser" para que ele pudesse ser "presença a si". Sartre usa o exemplo da crença: diferentemente de algo como uma mesa, a crença não se distingue da consciência da crença: ela "é sua própria presença a si”. O que também equivale a dizer: “O ser da consciência, enquanto consciência, consiste em existir à distância de si como presença a si, e essa distância nula que o ser traz em seu ser é o Nada" (126-7). Assim, enquanto o Em-si apenas é, o Para-si "não é o que é e é o que não é" (128). Por conceber a si como não sendo o Em-si para quem está presente, o Para-si se projeta no futuro com vistas a uma completude sempre inalcançável. Este caráter sempre temporal e sempre incompleto da consciência aparecerá com frequência nos debates narrativistas e em nossas discussões sobre eles: é pela liberdade envolvida na escolha do futuro que se torna possível e inevitável aquilo sobre o que White teoriza, escolher o passado.

A natureza da articulação destes níveis não pode ser por si só significativa, já que os significados surgem exatamente da própria separação da consciência em relação a si mesma. O mesmo também vale para as circulações de sentido "horizontais" no nível da "realidade humana", em que se desenrolam e se entrelaçam os múltiplos projetos ekstáticos por meio dos quais os seres humanos constituem a si mesmos. A linguagem é um instrumento útil para que seres humanos lidem com ambos os níveis, tanto as coisas do mundo quanto os demais seres conscientes com os quais devem se engajar em projetos individuais e coletivos: ela "paralisa" ou "cristaliza" o que, caso contrário, 
perceberia como um fluxo temporal constante, por meio da atribuição de significados. ${ }^{31}$ Mas ela também o falsifica tão logo nos esquecemos, como tão frequentemente acontece, o caráter construído dos significados. Quando nascemos, nascemos em um mundo já permeado de significados prévios (i.e., previamente feitos) que nos constituem como sujeitos, ${ }^{32}$ e só então, com variados graus de autonomia dependendo de nossa situação (em que se articulam nosso corpo, o ambiente físico e social ao nosso redor e significados diversos ${ }^{33}$ ), podemos ressignificar o mundo. Neste nível, que Carr chama de "realidade humana", a linguagem já significou e cristalizou o fluxo temporal. Aqui, as narrativas atuam como o que Danto chamou de "metafísica da vida cotidiana". É por isso que o mundo prático, situado neste nível de articulação mais básico entre o corpo e seus significados, entre "natureza" e "cultura", possui uma "instabilidade constitutiva". ${ }^{34}$

No interior deste mundo prático, surge aquilo que, tomando como base um certo tipo de uso da linguagem, pode ser individualizado como um novo nível: o das práticas científicas, inclusive uma certa historiografia. Assim sendo, historiadores tanto podem privilegiar uma abordagem mais conectada aos interesses do mundo prático quanto podem focar nos elementos intersubjetivamente verificáveis típicos de uma abordagem "científica". White chama os "passados" resultantes de tais abordagens de, respectivamente, "prático" e "histórico". Mas ainda que neste último caso o historiador não enfatize a atribuição de significado ao mundo, em ambos os casos ele o faz ou fornece subsídios para que outros o façam.

Em qualquer que seja a abordagem, as representações produzem sentido para o fluxo temporal não-significativo. Autores narrativistas e pós-modernistas insistem, com

\footnotetext{
${ }^{31}$ Embora não haja necessidade de compararmos a não-significação deste todo com o fluxo bergsoniano, o que nos obrigaria a lidar com questões tais como seu dualismo entre matéria e mente, estas reflexões sobre a linguagem são relevantes em sua filosofia. Há um motivo: como veremos por meio da nossa discussão da conexão entre linguagem e temporalidade, especialmente em Arthur Danto e Louis Mink, a incontornável transitoriedade da realidade pode ser adequadamente contrastada com o uso da linguagem para significá-la. Com Mink, veremos que há uma conexão entre significar e "cancelar o tempo". Sobre a linguagem em Bergson e sobre a ideia de "franja" mencionada no parágrafo anterior, ver LEOPOLDO E SILVA, 1994.

${ }^{32}$ Recorro principalmente às reflexões de BUTLER, 2005.

${ }^{33}$ Ver a última seção deste capítulo.

${ }^{34}$ Este útil termo é empregado por Hélio Rebello Cardoso Jr. (2016) no artigo "Peirce and Foucault on time and history". Em relação a este aspecto de nossa argumentação, o autor mostra que, para Foucault, toda uma série de práticas (vários regimes de conhecimento, medicina, prisões, escolas, sexualidade...) que ele estudou ao longo da vida são sedimentadas por hábitos (no sentido de Peirce) em que vibra uma instabilidade constitutiva (2016: 29). A reflexão de Butler, citada acima e bastante relevante para a nossa argumentação, também é debitária de Foucault. La Greca (2016) tem comparado proveitosamente o figuralismo whiteano à performatividade de Butler.
} 
razão, na distinção entre "passado" e "história": 35 mas os dois elementos da distinção compartilham este "construído" por existirem como formas de significação do todo ou de partes do todo. Há, então, três níveis: o todo, a realidade humana passada e as representações de aspectos deste passado. Esta sublimidade é, como já disse, um dos “insights narrativistas" cujas implicações pretendemos manter em mente. Dela decorrem os outros dois pontos já mencionados: a continuidade entre imaginação e razão - esta antecedida por aquela,$-{ }^{36}$ possibilitada pela base imaginativa a partir da qual qualquer sentido é produzido; e o elemento ético envolvido no uso da imaginação, na medida em que a produção de significado é invariavelmente resultado de escolhas. Assim sendo, do fato de que significados são atribuídos pela imaginação decorre o entrelaçamento entre estética, ética e epistemologia, na qual esta é antecedido por aquelas mas nenhum nível é determinante em última instância.

A filosofia de R. G. Collingwood foi formulada de maneira um tanto independente da de Sartre, mas, na apropriação que White faz de suas reflexões, um elemento em comum se destaca: a liberdade relativa atribuída à consciência em sua relação reflexiva com o mundo. Não se trata de subestimar o papel da situação que os agentes humanos se encontram, mas de recusar um papel passivo à consciência no processo de significação do mundo.

Se este modelo sartreano que estamos adotando como referencial do que é uma ontologia narrativista se justifica devido à importância que sua obra tem para White, o equivalente para Ankersmit poderia ser encontrado na filosofia da representação de Arthur Danto. No capítulo 2, veremos que Danto é uma figura de grande importância para a filosofia da história devido às suas publicações da década de 1960, especialmente Analytical Philosophy of History. Mas para o presente trabalho, o fato de que Ankersmit estabeleceu um intenso diálogo com suas discussões sobre representação, sobretudo $A$ Transfiguração do Lugar-Comum, de 1981, é especialmente relevante. ${ }^{37}$ A afinidade da

\footnotetext{
${ }^{35}$ MUNSLOW, 2006; PIHLAINEN, 2012; ICKE, 2011.

${ }^{36}$ Para reflexões mais recentes sobre diferentes aspectos desta conexão, ver STONE, 2016; LANG, 2018; KUUKKANEN, 2018.

${ }^{37}$ Após publicar sua brilhante contribuição à filosofia da história, Analytical Philosophy of History, em 1965, Danto pouco retornou ao campo. Seu interesse na história se manifestou como parte de um projeto mais amplo, no qual ele pretendia construir uma "filosofia do significado de ser humano", abrangendo também os tópicos do conhecimento, da ação, da arte e da mente. O último destes não chegou a ser publicado, os dois primeiros compuseram, juntamente com o livro sobre história, uma trilogia de livros cujo título iniciava com Analytical Philosophy of... - respectivamente, History, Knowledge e Action -, e o quarto, A Transfiguração do Lugar-Comum, de 1981, acabou por se tornar sua publicação mais influente. (Esta descrição se baseia no relato autobiográfico publicado no prefácio escrito por Danto para a edição brasileira da Transfiguração [DANTO, 2011: 11-2]). Embora originalmente este último livro não fosse
} 
filosofia de Danto com a de Sartre é esclarecida por este comentário de Nicolás Lavagnino (2015: 47):

... la constelación de proposiciones que dan vida a la filosofía de Danto se estructura siempre teniendo como base el requisito de un modelo básico de asimetría cognitiva que se proyecta en los diversos órdenes: de allí la asimetría de las modalidades de la consciencia (pour soi y pour autrui), del lenguaje (inserto causalmente y representacional), de la acción (como irreflexividad o acción básica no mediada por un lado, y como acción intencional, modo complejo de intervención, por el otro), de la temporalidad (causalmente estructurada en secuencias cerradas, fijadas por la interpretación retrospectiva y a la vez abierta a la capacidad de agencia e intervención de los sujetos que inciden proyectualmente en ella), de la historia (como plano de eventos delimitado por estructuras históricas objetivas y como ámbito abierto de infinitas posibles retroducciones), y por último de la representación misma -ya que como práctica supone un tipo de asimetría entre el original, la mera cosa, evento u acción respecto de la cual la misma se propone como una mímesis, una duplicación o una apariencia (Danto 1981, 293-295).

Esta duplicação aparece na filosofia de Ankersmit por meio da ênfase não só na distância estética entre representações e representados (políticos e históricos), mas também como parte da "tragédia da existência humana": na esteira de Danto, Ankersmit atribui grande importância à distância entre a perspectiva "interna" dos agentes históricos que vivem um determinado período e a perspectiva "externa" dos historiadores que não o vivem. Em seus textos sobre representação, esta distância será o motivo chave para a rejeição de toda forma de hermenêutica, focada na perspectiva dos agentes, como modelo para o que realmente importa na historiografia, pois o central para Ankersmit é precisamente o que os agentes não podiam saber. Mas esta distância também é da maior relevância para seus textos sobre experiência: a "experiência nostálgica" (1994, 2012) surge precisamente do reconhecimento da distância irrevogável entre passado e presente (combinada por algum desejo por este passado, mesmo que tal desejo possa não presumir a possibilidade de "retorno": em 2012, Ankersmit segue Svetlana Boym na rejeição da "nostalgia restauradora", promovendo a variante "reflexiva"). ${ }^{38}$ E uma experiência histórica sublime pode ser descrita como o

uma contribuição à filosofia da história nem figurasse em qualquer discussão sobre o narrativismo, sua recepção por parte de Ankersmit fez com que, duas décadas depois e desde então, se tornasse mais do que justificada sua inserção nesta tradição. (Ver ANKERSMIT, 2001: 218-248; 2005: 344-350; 2012: $41-47$ e passim; 2007: 364-393, HERWITZ \& KELLY, 175-197) Lembremos que uma demanda feita pelo próprio Danto às obras filosóficas é que elas sejam capazes de explicar a si mesmas (DANTO, 1995): assim, é com apoio filosófico no próprio Danto que justificamos a inserção de A Transfiguração do Lugar-Comum na tradição narrativista.

${ }^{38}$ Esta distinção será esclarecida no capítulo 3. 
trauma resultante da perda da perspectiva "interna" e da descoberta de uma perspectiva "externa" sobre um dado período. ${ }^{39}$

Mas uma modificação será central para todo o nosso argumento, especialmente para as reconsiderações que demandarei das filosofias de Mink e de Ankersmit: no caso da história, a relação entre a representação e a coisa representada possui uma peculiaridade, que é: aquilo que é representado foi também, parcialmente, experienciado na forma de representações em primeira pessoa no passado. E não é possível compreender as "formas de olhar" do passado (que é como Ankersmit caracteriza as representações em Historical Representation) sem ativá-las (com modificação) no presente. A assimetria entre a mera coisa e a representação não existe simplesmente entre o passado e o presente, pois a própria realidade humana passada comportava tal duplicação. Se, como vimos, Danto considera que os seres humanos são ens representans, então também os seres do passado (representados no presente) também eram ens representans, e representá-los é adicionar uma camada à mais de representação. Eles representavam o mundo (e representavam representações do mundo), e nós representamos suas representações do mundo a partir de nossa perspectiva, bem como o mundo deles a partir da nossa perspectiva, que não é a deles. Quando, no capítulo 2, for apresentada uma tentativa de "compromisso" entre as filosofias de Mink e de Carr - ou enriquecimento mútuo delas -, falaremos em tal dupla relação representativa ou dupla camada de narrativas como a produção não só de sínteses de heterogêneos, mas de "sínteses de sínteses de heterogêneos", e só não empregamos o retorno infinito para não abusar da paciência do leitor. Mas reconhecer que ele seria possível é importante para enfatizarmos o anti-fundacionalismo da nossa abordagem: não há um passado sólido, composto por blocos prontos para serem sintetizados, que forneça o chão com base na qual a estética pudesse ser adicionada. Por isso a estética não é um mero floreio retórico ou embelezamento do texto: a criação da representação cria também seu próprio chão, ou, para retomarmos a metáfora anterior, cria o tronco das árvores. Outro jeito de olhar para as folhas - ou de tomar certas evidências como folhas - produz outros troncos; ou vice-versa: quando todas as partes do sistema compõem um todo holístico, modificar qualquer um dos pontos é modificar todo o sistema; da mesma forma, decidir fixar um dos pontos é torná-lo referência para os demais. E é necessário, na prática, fixar (ainda que provisoriamente) alguma coisa: os

\footnotetext{
${ }^{39}$ Pode não ser irrelevante apontar que a filosofia de Danto aparece, portanto, como fio comum entre o Ankersmit representacionalista e o Ankersmit experiencialista.
} 
troncos, os galhos ou as folhas (ou, sem tentar produzir uma correspondência exata: os pressupostos filosóficos, estéticos e ideológicos, as estruturas, os fatos, os detalhes reveladores...). Mas esta é uma escoha resultante de uma necessidade prática, e é sempre possível des-fixar o que foi fixado.

A referência à filosofia sartreana também justifica de uma maneira adicional nossa tentativa de construir pontes entre as teorias narrativistas e experiencialistas, apontando para a ontologia comum que as funda. A realização de uma "filosofia existencialista da história" também demanda a compreensão processual da relação entre a liberdade de significar e as condições que a limitam. Franklin Leopoldo e Silva (2004) avalia que, entre $O$ Ser e o Nada e a Crítica da Razão Dialética, Sartre enfatiza a liberdade de dois modos diferentes, mas complementares: no primeiro, o caráter originário da liberdade; no segundo, sua efetivação no processo histórico. Pode-se dizer que dialética semelhante ocorreu no interior da filosofia da história nessas décadas em que surgiram, em sequência, o narrativismo e o experiencialismo. Ao mesmo tempo, isto demandará uma reconsideração daqueles momentos em que o foco do experiencialismo e do presencialismo na facticidade acabam se convertendo numa espécie de determinismo, ou de behaviorismo, ou na naturalização da tendência humana de lidar com o mundo por meio de uma reatividade inautêntica como a única maneira possível de existência. Isto precisamente porque liberdade e facticidade são melhor compreendidos em sua dinâmica processual, e não separadamente.

\subsection{Significado (de representações) e experiência: apontamentos gerais}

Argumentei que o insight de que o significado do texto como totalidade não existe no passado nem pode ser decomposto é resultado de uma tese mais fundamental, que não cabe apenas em uma filosofia da historiografia mas também em uma filosofia da história: a de que significados são sempre "feitos", sempre possuem autonomia em relação àquilo que é significado - no caso, as experiências. Vimos também, com Sartre e Danto, que isto decorre da separação “por um nada", mais um nada que é um abismo, produzida pela reflexão da consciência.

Para uma tese tão central, porém, é importante reconhecermos que ambos os elementos centrais - "significado", que é produzido pelas narrativas e/ou representações, e "experiência" - abrangem uma vasta gama de significados, e no debate narrativista estes e outros termos equivalentes frequentemente são empregados com significados presumidamente compartilhados, sem que isto seja o caso: "ficção" 
em White, por exemplo, não é o que parece ser; a "experiência" de Ankersmit não é a de Carr, e a "narrativa" de Mink também não é a de Carr. Em relação ao par significado e experiência, é importante portanto reconhecermos esta dificuldade, detalhando um pouco nossos princípios adotados quando usamos os termos, neste momento, e esclarecendo a imensidão de diferentes usos no debate, na continuidade do trabalho.

A imprecisão terminológica deveria nos surpreender menos no caso de "experiência”, já que o debate narrativista enfatizou o polo oposto (o que não é exatamente uma justificativa, já que se tratava, frequentemente, da atribuição de significado às experiências). Além disso, é notável como investigadores da trajetória filosófica desta noção se deparam com a dificuldade quase incontornável de sua polissemia. Como seu emprego depende de sua localização em relação ao sistema filosófico mais amplo de um dado autor e da relação deste com a totalidade das teorias de sua tradição e sua época, é difícil encontrar sobreposições conceituais consideráveis entre os diferentes usos ao longo do tempo. Em Songs of Experience, por exemplo, Martin Jay discute a história do termo no Ocidente desde os gregos até o presente sem buscar qualquer princípio unificador ou linha narrativa coerente; dificilmente seria possível proceder de outra forma.

À primeira vista, poder-se-ia supor que nosso recorte mais restrito de cronologia e de tradição permitiria contornar ao menos parte da dificuldade; porém, a multiplicidade de significados segue enorme. Em What we Mean by Experience? (2012), Marianne Janack escolhe, com alguma (legítima) arbitrariedade, focar em autores mais ou menos contemporâneos aos narrativistas e temas mais ou menos próximos aos deles: Rorty, Kuhn e Quine, ligados ao linguistic turn e ao antifundacionalismo; e autoras feministas interessadas ou em resgatar a utilidade da noção ou preocupadas com as consequências de tal resgate. ${ }^{40}$ A tendência geral traçada por ela é próxima da que se desenrolou no narrativismo: após uma marginalização geral da experiência, engolida pelos poderes da linguagem de atribuir significado a ela, nas

\footnotetext{
${ }^{40}$ A este respeito, no contexto dos estudos surgidos na sequência do que Stone chamou de "o retorno da narrativa", ver o importante artigo de Joan W. Scott, "The Evidence of Experience", de 1991, em que a autora recusa as tentativas de essencialização da categoria de experiência. Ela considerava o termo tão problemático que manifestou até mesmo o desejo de abandoná-lo, embora reconhecesse a impossibilidade de fazê-lo. Mas propunha que, ao menos, fosse reconhecida sua natureza discursiva. Apenas para situá-lo em relação ao nosso debate, notemos que uma das discussões introduzidas por Ankersmit busca reconhecer a existência de uma dimensão não-discursiva da experiência; mas o artigo de Scott tem o mérito de recusar fundacionalismos, mesmo baseados na experiência, para todo o espectro (muito mais amplo) de casos em que a consciência lida com o mundo mediada por representações, narrativas, conceitos - que são os momentos em que se está no que, com Carr, chamamos de "realidade humana."
} 
últimas duas ou três décadas o retorno à experiência foi também parcialmente ligado às "experiências" dos movimentos de minorias, embora com uma série de outras especificidades que serão discutidas mais adiante - a principal delas, que opera em um ponto chave de intersecção entre significação e experiência, diz respeito ao papel das identidades. No momento, nosso interesse é apontar que, também na filosofia da história, uma injustificável tendência oriunda do linguistic turn foi a marginalização da experiência ter se dado sem qualquer discussão explícita sobre os significados possíveis do termo.

Mais recentemente, recorrendo a um corpus de autores mais diminuto em relação ao de Jay (com uma adicional ênfase em Hegel, que curiosamente recebe pouco espaço em Songs of Experience), David Carr propôs a distinção entre quatro sentidos principais de "experiência":

1. A "inocência" das sensações de Locke, das impressões de Hume, do primeiro sentido de Erfahrung de Kant [Carr identifica três sentidos principais do termo em Kant, sendo um deles próximo aos de Locke e Hume aqui citados]. A isto podemos adicionar, sem que estejamos distorcendo demasiadamente, Erlebnisse em Dilthey e Husserl, desde que eles sejam desacoplados de seu papel fundacional em epistemologia.

2. O sentido temporalmente estendido e cumulativo de experiência encontrado em Hume, juntamente com sua versão negativa e dialética em Hegel e Dewey.

3. O segundo sentido de Erfahrung em Kant, conhecimento empírico de objetos.

4. O sentido místico-religioso de Erlebnis em Buber e a "experiência religiosa" em James (CARR, 2014: 30).

No debate narrativista, o sentido marginalizado do termo de modo geral é o primeiro: é esta "experiência" (ou outros tipos indevidamente identificados a ela) que, de modo geral, tem sua relevância para a compreensão da representação histórica descartada pelo fato de não ser a fonte de sua própria interpretação ou representação. Mas todos os outros sentidos também aparecem. O movimento da consciência descrito pela tropologia de White tem algo da dialética hegeliana, na medida em que esta última também avança pela percepção da consciência da inadequação de seus esforços para apreender o mundo; uma importante diferença reside em seu ponto de culminância, que não é a reconciliação do espírito consigo mesmo, mas a ironia (i.e., o reconhecimento da impossibilidade deste sentido ser, em última instância, "cômico" ou de qualquer outro tipo $)^{41}$, e a dialética opere não "na história" mas, mais estritamente, na consciência,

\footnotetext{
${ }^{41}$ Que é como White (1995) o lê em Metahistory: enredando a história como tragédia, em menor escala, e como comédia, em maior escala.
} 
concebida de modo tal que uma não pode ser identificada à outra. ${ }^{42}$ Ankersmit e Kellner também apontam, a meu ver justificadamente, que a tropologia funciona como condição de possibilidade da experiência, de maneira análoga às categorias do entendimento de Kant, com a importante diferença (apontada por Ankersmit) de ser possível escolher a maneira de prefigurar o mundo, i.e., de estabelecer relações entre seus elementos. ${ }^{43}$ White usa repetida e especificamente o termo "experiência" ao caracterizar o processo. Por fim, fenômenos mais enfatizados após o esgotamento do debate sobre o linguistic turn, como "presença" e "experiência histórica sublime", que neste texto propomos caracterizar de maneira pouco usual como decorrentes de rupturas de sistemas de representação, remetem - especialmente na visão de seus críticos - ao último dos sentidos mapeados por Carr. ${ }^{44}$

Há um motivo simples para a polissemia do termo: o contato de seres humanos com o mundo se dá em todos estes níveis, de formas variadas e quase sempre sobrepostas. Há, como Ankersmit (2005: 74) aponta em crítica à tese de Rorty segundo a qual a linguagem é onipresente na atuação da mente - "language goes all the way down" -, experiências que possuem autonomia diante da linguagem, como a sua "experiência histórica sublime". Mas o termo não precisa ficar restrito a esta dimensão, como ele parece crer ao afirmar que "a linguagem está onde a experiência não está, e a

\footnotetext{
${ }^{42}$ Assim, Allan Megill caracteriza um elemento central da obra de White como o de uma "dialética retórica" (MEGILL, 2009). Isto porque, como White insiste: “[...] conceitos existem apenas em pensamento, não no tempo e no espaço, e não em coisas ou eventos. Então não pode haver história dos conceitos - exceto na medida em que "história" é construída como consistindo de conceitos como sua substância. E só um louco - ou um gênio como Hegel - pensaria isto.” (WHITE, 2013: 210)

${ }^{43}$ ANKERSMIT, DOMANSKA \& KELLNER, 2009: 34-53; KELLNER, 1992.

${ }^{44}$ Por exemplo, ICKE, 2012 e PIHLAINEN, 2015. Em Sublime Historical Experience, o próprio Ankersmit, analisando o tipo de experiência que Huizinga chamava de "sensações históricas", afirma que elas propiciam um tipo de "verdade que surge de uma união quase-mística com o mundo que não mais se permite ser encantado pelas abstrações que todos nós usamos tão não-problematicamente. É um misticismo que não nos põe a uma distância da realidade, mas que nos traz a seu próprio coração." Em livro posterior, Ankersmit caracterizará esta experiência como "experiência histórica individualista" (ANKERSMIT, 2005: 137; 2012: 175-219), e, retomando sua maneira de pensá-la apresentada na década de 1990, enfatizará que mesmo na experiência, o que é experienciado é a distância entre passado e presente. Considero importante apontar que os dois tipos de experiência que Ankersmit propõe em Sublime são ocasionalmente confundidos, especialmente em sua reformulação apresentada em Meaning e artigos mais recentes, e devem ser distinguidas mais claramente, pois elas envolvem níveis diferentes. A experiência histórica subjetiva aponta para uma união "figural", no sentido de White, em que uma figura significativa produzida por seres humanos no passado se permite ser significativamente preenchida no presente. É por isso que tanto ela é uma união com o passado (em sua dimensão significativa) quanto esta união envolve o reconhecimento da distância. Minha leitura é de que a "experiência histórica subjetiva" atua em outro nível que (conforme a caracterização do livro de 2005) a "experiência histórica sublime". Esta, a julgar pela descrição de Ankersmit, não pode descrever o contato com "o passado", pois este termo só pode apontar para dimensões significativas intersubjetivas de uma "realidade humana" outrora existente. No primeiro caso, a atenção é movida por uma potência de significação; no segundo, por uma impotência, que por si só pode vir a ser produtora de significações no futuro, retroativamente. Mais sobre isto nos capítulos 3 e 4 .
} 
experiência está onde a linguagem não está" (2005: 79). Afinal, como afirma Collingwood, "há mais na experiência que meras sensações; há pensamento também" (1958: 159). Mais especificamente, em "History as Re-enactment of Past Experience", ele afirma:

\begin{abstract}
Um ato de pensamento é certamente uma parte da experiência do pensador. Ele ocorre em um certo momento e em um certo contexto de outros atos de pensamento, emoções, sensações e assim por diante. Sua presença neste contexto eu chamo de sua imediaticidade; pois, embora este pensamento não seja imediaticidade, ele não é livre de imediaticidade. A peculiaridade do pensamento é que, em adição a ocorrer aqui e agora neste contexto, ele pode se sustentar por meio de uma mudança de contexto e se reviver em um contexto novo. (COLLINGWOOD, 1994: 297).
\end{abstract}

A última frase (cuja pertinência defenderemos) talvez seja polêmica, mas as demais não precisam ser. Assim, sem desperdiçar o ponto incontornável de que o significado é indeterminado em relação à experiência, duas observações precisam ser avançadas. Em primeiro lugar: exceto no livro mais recente de Ankersmit, de 2012, a igualmente central noção de significado também é empregada sem qualquer especificação. Se procedermos com mais cuidado, fica claro que não se trata de uma noção meramente linguística, mas sobretudo existencial, ligada ao sentido "prático" que White recentemente tem enfatizado, que interfere com um ato de fala na circulação social de significados. Estes significados serão constitutivos da experiência que os seres terão de seu mundo social, que é sempre uma "experiência significativa". Veremos este aspecto em nossas discussões de Mink e White, mais adiante.

Em segundo lugar, outra afirmação usual, correta porém inespecífica, é a de que a relação entre experiência e significado é "causal". Cabe observar aqui que indeterminação não significa desconexão: ela deriva do processo de apresentação (Darstellung) da experiência mais imediata e transitória: assim, a experiência é trazida à consciência por meio do processo de significação, e, ao sê-lo, é também modificada. ${ }^{45}$ Há, também aqui, o recurso a este fator social de significação que é o enredo.

\footnotetext{
45 Ver HELFER, 1996. O termo Darstellung é usado com este sentido por Hegel na Fenomenologia do Espírito, e parece ter chegado por meio dele a Collingwood, e, consequentemente, aos narrativistas. White também se compromete com esta noção por meio do diálogo com outro pensador hegeliano, Erich Auerbach. A noção de "figura", que White busca em Auerbach, opera nos moldes da "apresentação" mais que da "representação". Daí que, em The Practical Past, White sinta a necessidade de observar, em uma nota: "Apenas porque ninguém parece achar importante, eu vou apontar uma vez mais que o subtítulo do livro de Auerbach, "Dargestellte Wirklichkeit," deveria ter traduzido em inglês como "Presented Reality," [no original] em vez de “A Representação da Realidade.” (2014)
} 
Em ambos os casos, em vez de situar fenômenos como "experiência", por um lado, e "representação" ou "apresentação" (nos sentidos de "Vorstellung" ou "Darstellung", respectivamente) e "linguagem", por outro, em dimensões isoladas da existência humana, cuja separação é usualmente caracterizada pela metáfora de uma "tela" entre a mente e o mundo, é preferível considerarmos que estes níveis frequentemente se interpenetram, e, ao fazê-lo, modificam uns aos outros. Se eles são separados, como de fato o são, não é negligenciável que o são por um nada, um nada que permite a presença-ausente da experiência transitória à consciência. É por causa desta interpenetração que toda uma série de binarismos devem ser concebidos na forma de um continuum e não como mutuamente excludentes. Esta interpenetração se manifesta também no texto histórico, que cria uma totalidade ao articular emoções, pensamentos, ideias, argumentos etc.

Não à toa, tanto "experiência" em um sentido próximo do de Hegel ${ }^{46}$ quanto "linguagem" em casos mais gerais são frequentemente caracterizados como dotados desta função mediadora que White atribui à consciência e que em muitos, mas não todos os casos, envolve a atribuição de significados, inclusive por meio da linguagem. Mink, Collingwood, e especialmente o Collingwood de Mink apontam para a mesma direção. Em menor ou maior medida, a atuação da imaginação no "segundo nível de consciência" é chave para entender esta função.

\subsection{Quatro suportes instáveis para significados instáveis: anti-fundacionalismo com verticalidade}

Um dos pontos de partida da grade geral da relação entre representação e experiência que estamos apresentando neste primeiro capítulo, e que será examinada em detalhes nos próximos com apoio em exames mais concretos nas obras de Mink, White, Ankersmit e Runia, pode ser colocado nestes termos: é no interior de um "mundo prático" presente que os historiadores produzem significados para eventos ocorridos em "mundos práticos" passados; tais significados retornam então ao "mundo prático", como um gesto "performativo". No capítulo 2, veremos que, refletindo especificamente sobre o segundo dos "atos mentais" (aquele feito por historiadores em seu presente), Mink mostrou como ele "cancelava o tempo". Mas tal cancelamento é parte de um processo, e, de fato, o próprio gesto de atribuição de significações não faria sentido senão como parte dele. $\mathrm{O}$ cancelamento, portanto, é provisório. O que também significa que, no

\footnotetext{
${ }^{46}$ Ver, por exemplo, o estudo de BARBOSA, 2010.
} 
exato momento em que é retroativa, a compreensão histórica é também prospectiva, antecipando suas consequências práticas de modo tal que a antecipação reflete sobre a totalidade do texto. Vimos que, para Danto e Ankersmit, os eventos narrados pela historiografia exemplificam a condição "trágica" da existência humana; o atual raciocínio deve nos levar a afirmar que a produção deste ato historiográfico no presente tem, também ele, consequências imprevistas. Isto pode ser posto também em uma luz positiva na medida em que, ao preencher eventos passados, o texto se torna uma figura passível de ser preenchida por maneiras que um historiador em sua circunstância particular não poderia imaginar.

$\mathrm{Na}$ "realidade humana", materialidade e significação se interpenetram, com o mundo sendo "apresentado" - não representado - em uma articulação que já é significativa. A análise filosófica com base na qual se afirma a liberdade da significação está correta: não só os fatos não engendram o valor, mas também não é possível distinguir claramente um do outro, acessando um nível básico onde haja puros fatos. É possível utilizar a percepção sem projetar categorias linguística sobre o que é percebido, embora não exista percepção meramente passiva, mas a constituição de um fato já envolve o uso de categorias que, não possuindo fundamentos, são estabelecidas por critérios práticos. Tudo que parece ser um fundamento natural é, na verdade, para adotarmos o termo muito útil de Lee Braver, um groundless ground (um fundamento sem fundamentos).

Ao negar a existência de fundamentos últimos para o conhecimento, Rorty (1994) negava ao que quer que se possa entender por mundo objetivo a possibilidade de arbitrar entre as diferentes maneiras pelas quais falamos sobre eles. Isto não significa, claro, que o mundo externo não exista ou não possa ser conhecido. ${ }^{47}$ Mas também não precisa significar, como ele muitas vezes dá a entender, que nossas trocas de vocabulário são apenas horizontais. Como Joseph Rouse objetou a Rorty, a concepção puramente horizontal do processo retém ainda um pressuposto representacionalista, que parte da dicotomia entre a linguagem aqui dentro e o mundo lá fora. $\mathrm{Na}$ "realidade

\footnotetext{
47 "Nós precisamos fazer uma distinção entre a afirmação de que o mundo está lá fora e a afirmação de que a verdade está lá fora." Pois no primeiro caso estamos apenas reconhecendo que a maioria das coisas no mundo não incluem estados mentais humanos, e no segundo estamos reconhecendo que só há verdades quando há frases, e estas são criações humanas. Rorty especifica em termos muito próximos ao argumento narrativista de Mink, White e Ankersmit: "Esta conflação é facilitada por confinarmos a atenção a sentenças singulares em vez de a vocabulários. [...] Quando a noção de 'descrição do mundo' é movida do nível de frases governadas por critérios dentro de jogos de linguagem para jogos de linguagem como totalidades, jogos que não escolhemos com referência a critérios, o sentido a ideia de que o mundo decide quais descrições são verdadeiras não fica mais claro.” (RORTY, 1989: 4-5)
} 
humana", o sujeito e seus projetos, por um lado, e o mundo que ele experiencia, por outro, surgem inseparáveis. Mais ainda: como Gadamer argumenta, a comunicação entre pessoas e grupos só é possível quando a fala do outro é tomada como uma fala que pode dizer verdades sobre o mundo. Isto não é um objetivismo, mas uma concepção simultaneamente horizontal e vertical da comunicação, na qual um mundo comum surge de maneira intersubjetivamente válida. Se é verdade que não conversamos com o passado, também é verdade que nós (feitos de passado e de intersubjetividade) conversamos com outros (feitos de passado e de intersubjetividade) sobre o passado (que nos fez) e sobre o mundo. ${ }^{48}$

Este quadro, a meu ver, comporta e enriquece tanto as teorias narrativistas quanto as experiencialistas, permitindo-nos vê-las como parte de um processo dinâmico incongelável em que significados são criados, paralisando o fluxo do mundo, e gradualmente perdem sua capacidade de iluminá-lo, e portanto sua eficácia, devido à mudança ou do mundo ou das vontades, desejos, conhecimento ou princípios morais das pessoas. ${ }^{49} \mathrm{O}$ que nos leva ao ponto central desta seção: na "realidade humana", as significações são formas de fazer algo com o mundo - material, significativo ou $\operatorname{ambos}^{50}$-, e, portanto, circulam socialmente com "suportes" que os permitem perdurar relativamente, com modificações performativas a cada nova atualização. Ao contrário de um sonho, em que diálogos, imagens e atmosferas surgem e cessam rapidamente, as significações que criamos acordados e em relação com outros seres têm suportes que perduram por um tempo: desde coisas relativamente fluidas como suas memórias, desejos e expectativas até suportes mais estáveis, como corpos, artefatos e lugares.

\footnotetext{
${ }^{48}$ Sobre esta questão, há um ponto collingwoodiano de extrema relevância trazido à tona recentemente por Jonas Ahlskog (2017), que mencionaremos a diversos momentos neste trabalho: quando o historiador tenta conhecer um passado (e todo ser humano é perpassado por processos temporais, ou seja, feito [também] de passado), ele deve mudar a si próprio, deixando de ser alguém que não era capaz de pensar os pensamentos daquele passado até se tornar alguém que é capaz de fazê-lo. Então, um passado que (neste exemplo) não o havia feito agora é um passado que o fez. Eis um motivo a mais para enfatizarmos que a relação entre presente e passado deve ser entendida como dinãmica, não havendo um passado fixo, mas também não havendo um sujeito fixo que estuda o passado sem ser afetado por ele. Discussões adicionais sobre a inexistência de pontos fixos, conforme Collingwood e outros filósofos mais, serão feitas no capítulo 2 .

${ }^{49}$ No que diz respeito ao poder de predição, que facilita a ação individual e coletiva em relação ao mundo, ela oscila muito mais quando toma como objeto seres ou sociedades humanas do que quando o faz com a natureza

${ }^{50}$ Eles se manifestam conjuntamente, no sentido de que já lidamos o mundo material por meio de nossas formas de significá-lo, mas a ênfase do pensamento ou da ação pode ser em um dos aspectos. A parte consensual, ainda que seja significada, surge como o "mesmo" ao qual se propõe uma outra significação. Da perspectiva dos significados, eles podem ser acessados abstratamente, sem que se atente aos seus suportes (que continuam sendo necessários), de uma maneira que a fala sobre o mundo não pode. Ou seja: não há acesso unicamente vertical ao mundo, mas há atos de fala que se direcionam apenas horizontalmente. Alguns problemas da predominância desse procedimento serão discutidos adiante.
} 
Porém, não apenas as pessoas produzem diferenças a cada performance: a matéria muda incessantemente, de modo que, além de não existirem chãos naturais e estáveis, também os chãos convencionais tremem sob dos nossos pés.

Gostaria de tentar aqui um mapeamento dos principais pontos de referência de sentido possíveis: o corpo (ou mente incorporada, se quisermos incluir aí as atividades não-reflexivas da mente), ${ }^{51}$ a intersubjetividade, o ambiente físico e, no caso da historiografia, as evidências. ${ }^{52}$ Todos eles manifestam temporalidades e/ou causalidades específicas, frequentemente heterogêneas. No caso da historiografia, estas temporalidades podem ficar temporariamente "dormentes" quando o escritor ou o leitor foca no significado do texto como um todo (a etapa de "cancelamento do tempo" que discutiremos no capítulo 2), mas são ou podem ser reativadas tão logo sejam feitas perguntas que direcionem a atenção de volta para suas partes, ou para a relação entre o texto e algum elemento do mundo externo não contemplado por ele - e tanto a questão quanto o significado da parte são influenciados pela experiência de ter lido o texto como um todo. Como trato do narrativismo e de sua relação com as reflexões posteriores sobre "presença" e "experiência", recorro a "ancestrais intelectuais" de ambas as tradições, especialmente Vico e Collingwood no primeiro caso, ainda que a mesma discussão possa ser feita com apoios muito diversos.

Em primeiro lugar, dentre os "suportes" em dos quais as representações não se separam inteiramente, mas das quais não derivam, há o corpo. Eu iniciaria lembrando de Collingwood, para quem a imaginação tem a função de mediação entre as sensações corpóreas mais básicas (do "primeiro nível de consciência") com aquelas mais abstratas, que consistiam em reflexões sobre os níveis antecedentes. Na filosofia de Vico, "ancestral intelectual" tanto de Collingwood quanto de White, encontramos a ideia de que a consciência dos primeiros seres humanos estava ainda muito presa ao imediatismo de suas sensações corpóreas e emoções. Tudo era, portanto, muito imediato, vívido, urgente, assustador. Pensamentos abstratos (científicos, filosóficos, históricos) eram ainda impossíveis. A partir do momento em que tais sensações foram apresentadas na linguagem feita por seres humanos, o fluxo de sensações ganhou - apenas nessa versão duplicada - uma permanência à mente que, contrariamente, não possuiria. Este primeiro gesto por meio do qual é criado o "mundo social” (que, seguindo Carr, tenho chamado

\footnotetext{
${ }^{51}$ Ao mesmo tempo, optamos por uma terminologia ampla o suficiente para que não precisemos entrar na difícil questão da relação mente e corpo, mente e mundo externo, etc.

52 Elementos do pensamento de White, Collingwood e Ankersmit que possam aparecer como pressupostos serão esclarecidos em mais detalhes no próximo capítulo.
} 
de "realidade humana") é metafórico. Neste momento, não é possível ainda haver clareza sobre como a linguagem se relaciona com o mundo. Como Vico, White considera que a consciência repete o padrão que, após a metáfora, passa pela metonímia e pela sinédoque, culminando na ironia. Aqui é finalmente possível operar com a linguagem de maneira autoconsciente.

Para Vico, a mente focada em operações linguísticas abstratas e excessivamente desconectada do corpo declina rumo a um "barbarismo" (Vico, 1948; Verene, 1981), algo que Collingwood também temeu no século XX. (E argumentarei que as filosofias do Ankersmit experiencialista, de Runia - e também de Gumbrecht e de tantos outros são uma reação a semelhante tipo de alienação.) Podemos seguir Sartre e Collingwood e nos referir a esta desconexão como um processo (ou um acúmulo de muitos processos, ou um hábito subjacente) de "má-fé" ou "corrupção de consciência". Embora White também visse com maus olhos o que considerava ser a condição irônica de seu tempo, seu objetivo anunciado em Metahistory foi o de realizar uma "volta da ironia contra a ironia”. Baseando-nos em suas reflexões mais recentes, poderíamos dizer que parte das possibilidades abertas pela autoconsciência da mente acerca de como ela prefigura o mundo externo é um retorno a outros modos de produção de sentido, incluindo aí o direcionamento da atenção a uma certa imediaticidade das sensações típica do modo metafórico que Vico via nos primeiros homens, mas sem perder o distanciamento promovido pela ironia. ${ }^{53}$ É o que encontramos, por exemplo, em sua leitura de É Isto um Homem?, de Primo Levi: contra as leituras que consideram que a força da obra reside em suas descrições literais da experiência de Levi em Auschwitz, White argumenta que é o uso de figuras de linguagem que nos permite entender como Levi se sentiu lá. (WHITE, 2004)

Em White, a "imaginação histórica" tem também este caráter mediador do "segundo nível de consciência" collingwoodiano. Em Metahistory, seu foco é na relação da imaginação com um dos elementos primordiais da historiografia: a tradição intelectual (cujo ciclo tropológico é então investigado por White, no caminho da metáfora rumo à ironia). Outro elemento, o passado que aparece como referente do discurso e as evidências por meio das quais se pode descobrir verdades sobre ele, foi trazido à tona na reação ao livro, já que foi posta em parênteses por White: ele apenas parte do princípio que o processo pelo qual tal relação não opera no modo realista, já

\footnotetext{
53 Sobre a centralidade da ironia para White, ver os comentários recentes de KLEINBERG, 2018 e PEDEN, 2015.
} 
que falar do passado demanda a produção de protocolos de descrição ou redescrição de eventos. Em outros textos, porém, a relação com o corpo e com o inconsciente aparece com clareza, dando suporte ao nosso argumento. (WHITE, 1995: 229-234; WHITE, 1999: 101-125)

Roger Chartier percebeu de modo especialmente a tensão na obra de White entre, por um lado, um sujeito que produz sentido livremente e por outro, estruturas linguísticas que determinam o nível mais profundo de sua consciência. Em um cenário intelectual (o francês das décadas de 1960 e 1970) dominado pelas mesmas tensões, aquelas entre existencialismo e estruturalismo, Pierre Bourdieu mobilizou o já existente (em Aristóteles, em Elias, em Panofsky) conceito de habitus como alternativa a esta dicotomia, i.e., entre sujeito e estrutura. Em uma das várias definições propostas, Bourdieu o caracteriza como "um sistema de disposições duradouras e transponíveis que, integrando experiências passadas, funciona a cada momento como uma matriz de percepções, apreciações e ações, e torna possível a realização de tarefas infinitamente diversificadas" (BOURDIEU, 1977: 82-83). Ora, o habitus pode então ser entendido como uma forma de "presença do passado", uma presença situada em corpos de indivíduos concretos - os mesmos que "escolhem seu passado", como apontam White e Runia. Lembremos de uma das definições do termo, na p. 255 das Meditações Pascalianas: "o habitus é essa presença do passado no presente que torna possível a presença do porvir no presente."

Cito o exemplo do habitus sobretudo para enfatizar a maneira pela qual o próprio corpo, sem mencionarmos os elementos intersubjetivos que constituem os indivíduos como sujeitos, atua já como facticidade, limitando na prática a liberdade de suas ações. Enquanto Collingwood e White enfatizam o ganho gradual de liberdade, estes fatores demarcam os condicionamentos dela; não há uma coisa sem a outra. Todos eles manifestam, de diferentes maneiras, formas de manifestação do passado no presente ou de ativamente presente do passado que não operam bem nem nos moldes "realistas" nem nos moldes "construtivistas", que operam a partir de noções como "presença" ou "ausência". Ilustrando com os exemplos citados e alguns outros: (a) a transitoriedade das experiências pré-linguísticas; (b) a suspensão temporária do tempo produzida pelas experiências sublimes analisadas por Ankersmit; que ele entende como uma espécie de fusão com "o passado - o que só faz sentido se abandonarmos a dicotomia presença/ausência; (c) o tipo de "presença do passado no presente" que condiciona as escolhas presentes, na forma de habitus; (d) a retroatividade do trauma 
lido em termos do figuralismo por White em The Practical Past; (e) as desestabilizações no presente passíveis de serem produzidas pela atividade do inconsciente, que, como Kleinberg enfatiza (discutindo o "processamento paralelo" em Runia), estão em "alteridade radical em relação ao conceito vulgar de tempo". (KLEINBERG, 2017: 67)

$\mathrm{Na}$ pessoa incorporada - que manifesta corpos individual e social (cf. SAFATLE, 2015) - se encontram diversas formas de temporalidade e causalidade: (a) as causalidades ou operacionalidades típicas da física e da biologia; ${ }^{54}$ (b) as causalidades históricas de tipo relativamente linear, tal como foram debatidas no caso da aplicabilidade das covering laws à história, em que uma série de eventos em um dado momento provoca outro em um momento seguinte; e (c) a causalidade figural, retroativa, por meio da qual uma ou múltiplas tradições são postas (ou se põem em) relacionamento. ${ }^{55}$ A temporalidade das tradições, entendidas aqui em seus aspectos mais abstratos em vez das maneiras mais concretas de aplicação (mais conectadas a experiências e contextos específicos), embora continue inseparável de corpos e suportes físicos, pode assumir um caráter mais um menos espectral, não tão nitidamente presente dependendo das circunstâncias, mas não inteiramente ausente: ela sempre está presente como um campo de possibilidades não inteiramente conhecido, e o quão "assombrosas" estas possibilidades são depende das esperanças e medos das comunidades presentes. Pelo princípio do holismo, como sempre há alguma espectralidade, o todo representado (inclusive, mas não só, em textos históricos) é sempre marcado por ela: não pode ser compreendido nem em termos de inteira presença nem de inteira ausência. Vale o mesmo para a existência cotidiana, inclusive se quisermos um exemplo que não envolve explicitamente a temporalidade, tão central para a realidade humana: a presença de muros não é suficiente para fazer com que um "teatro" seja algo inteiramente presente, já que o teatro não pode ser encontrado em tijolos específicos nem em muros específicos, e também não na soma de tijolos ou de paredes: como as caixas de Brillo Box que são arte e as que não são (cf. DANTO, 2011), a mesma configuração material poderia se tornar uma outra coisa sem nenhuma mudança material. Ainda assim, o teatro também não é uma mera imaginação de seus frequentadores e existe em uma realidade humana compartilhada na dependência de tijolos e paredes.

\footnotetext{
${ }^{54}$ Elas operam não apenas no mundo externo, mas também no próprio organismo. Assim, qualquer dualidade entre o sujeito incorporado e a natureza ou o mundo deve levar em conta esta unidade anterior.

${ }^{55}$ Também ela será discutida no capítulo 2.
} 
As maneiras específicas de como tais relações entre as causalidades e suas temporalidades específicas se estabelecem são contingentes e históricas. Apenas para citar um exemplo: a morte de um corpo causada pelo impacto brusco de um objeto externo, impossibilita que o sujeito seja afetado pela leitura de um livro sobre o pensamento grego, processo em que, retroativamente, ele se faria parte dessa tradição e modificaria a maneira pela qual ela interfere em seu mundo social contemporaneamente. (Quem interfere, a tradição ou o sujeito? Como separá-los?)

Já que a imaginação efetua a mediação entre sensações corpóreas e os significados atribuídos a elas, ou as toma como "tópica" ou base para construir discursos mais complexos, ela também faz a transição entre a experiência em sentido individual e a experiência intersubjetiva da "realidade humana". É neste horizonte que qualquer representação histórica se situa, independente do quão mais estreito seja o público de interlocutores a que ela busque afetar. Aqui, o tipo de experiência é de tal natureza que os elementos individuais e coletivos são reunidos em uma totalidade. Em termos whiteanos, poderíamos dizer que a prefiguração é sempre um ato mental individual, mas que o enredo (ou outro instrumento de significação) sem o qual mesmo a experiência individual não poderia ser apresentada à consciência circula coletivamente. A partir daí, diferentes dimensões (epistêmica, ética, etc.) se abrem, nenhuma das quais pode ser estabelecida como critério último do que seja "a representação histórica" e não dependente da decisão do historiador de performatizar como quem faz um lance em um jogo que não controla completamente - em relação a uma dada comunidade a partir de dados recursos linguísticos. Na última década da sua vida, White insistiu na possibilidade e desejabilidade de enfatizar a dimensão "prática" (ética mais estética) da relação com o passado mediada pelo texto. Mas, ainda que ele não seja unívoco ao tratar dos passados "prático" e "histórico", o que considero possível depreender da leitura de sua obra é que mesmo textos "históricos" (ou que não focam na dimensão prática) são práticos, i.e., estão inseridos em um mundo social no que têm efetividade, mas (seguida a pista de Robert Doran) se relacionam de má-fé em relação a tal inserção, recusando-se a agir ou obscurecendo suas implicações ideológicas por meio de uma "ideologia da não-ideologia”. (WHITE, 2010; DORAN, 2016) Ainda assim, mesmo de uma perspectiva prática e engajada, não devemos esquecer que os textos adquirem significado como parte de uma rede - uma rede mediada materialmente, mesmo no caso de textos publicados na internet - e não em isolamento, e portanto a 
efetivação da combinação de textos "históricos" e "práticos" pode facilmente ser defendida em bases práticas.

O terceiro caso é o do ambiente físico. Ele é parte central do que se chama de fenômeno da "presença", que discutiremos no capítulo 5. Exemplos são as memórias e reflexões de Gumbrecht sobre a "atmosfera" do pós-Guerra e as reflexões de Domanska e Runia sobre a presença material do passado no presente. O caso das Mães da Praça de Maio no pós-ditadura argentino, tal como estudado por Bevernage, mostra bem a conexão entre a ocupação de um espaço físico específico e a eficácia na performance de uma narrativa, nesse caso a recusa em reconhecer a tentativa do governo argentino de produzir "fechamento" narrativo e a proposta de uma narrativa "espectral" alternativa ainda por cima, por agentes cuja legitimidade em promover tal narrativa era reconhecida socialmente. Anuncio estes exemplos apenas para situá-lo no contexto do presente argumento, antes de aprofundá-lo no capítulo apropriado: é digno de nota que, se temos em mentes que discutimos significados em constante circulação, amparados por bases materiais diversas, então temos um argumento a mais em prol da importância de enfatizar a inseparatividade das discussões sobre como o significado é projetado sobre o mundo e daquelas sobre como o mundo - da nossa perspectiva, nós que vivemos nele, somos vulneráveis ao seu movimento, e pretendemos fazer algo em relação a ele resiste a tais significados.

No caso da historiografia, cabe comentar brevemente um quarto e fundamental suporte, as evidências: como bem sabem narrativistas, pós-modernistas, desconstrutivistas e afins, as evidências possuem relação de sub-determinação com o sentido atribuído a elas nos textos. Não existem regras de tradução de como as evidências devem produzir textos (ANKERSMIT, 1983), mas conseguimos estabelecer regras que tornem as evidências fundamento negativo: (a) existem ou podem existir acordos intersubjetivos mais ou menos definidos sobre o que uma certa representação permite esperar dos arquivos, em coerência com o que a própria representação nos diz sobre um evento; e, como membros de uma espécie comum, utilizamos de maneira suficientemente parecida, ou podemos compreender/imaginar como outros usam: (b) órgãos sensoriais e (c) referenciais espaço-temporais.

Como sentidos são produzidos e não vêm diretamente da percepção, eles precisam de constante sustentação emocional, material e intersubjetiva para serem novamente atribuídos. Sartre exemplifica esta não-aderência da significação àquilo que é significado com o caso do garçom que, por mais que atue como garçom, nunca se 
pode impedir de em algum momento deixar de sê-lo. Não apenas por circunstâncias externas, mas também não pode impedir seu eu futuro de decidir significar a si mesmo de outras maneiras. É exatamente por este caráter instável dos sentidos que fenômenos como "experiência histórica sublime" e "presença" são possíveis. Não à toa, outro dos exemplos de Sartre é retomado por Eelco Runia em Moved by the Past: o da experiência da angústia diante de um lugar alto, resultante não do medo de cair mas sobretudo do reconhecimento de que jamais se pode impedir o eu futuro de saltar. Runia fala metaforicamente do "salto no abismo" como um gesto de ruptura com um certo conjunto de esquemas de representação. Ora, temos portanto uma dinâmica de retroalimentação entre os mundos material e social, por um lado, e os significados que atribuímos a eles, por outro. Como Ankersmit aponta em seu livro mais recente, o fato de que as significações são criadas, em vez de achadas, nas coisas, não impede que, por convenção e diferenciação, estabeleçamos elos entre elas (ANKERSMIT, 2012). Assim, quando fazemos uma ação que altera a materialidade ou frustra expectativas intersubjetivas, interferimos em um dos polos da dinâmica de significação entre em-si e para-si (que parte sempre da consciência, mas toma como ponto de referência o mundo externo) e, assim, modificamos também todo o processo. Para o nosso exemplo, cabe apontar, então: o garçom só pode se sustentar como garçom em um restaurante, se relacionando com pessoas que se assumem na função de clientes, colegas ou chefes, em uma cidade, em um certo modo de produção econômico. Os níveis se interpenetram de modo que um nível afeta o outro: o capitalismo afeta o modo de desejar, de experienciar da temporalidade dos corpos; estes, por sua vez, limitam a lógica capitalista de busca indefinida por lucro na medida em que ficam doentes, envelhecem e se deprimem em certas condições.

Um argumento mais geral sobre a processualidade da relação entre significado e experiência pode ser feito em relação à presente discussão sobre os "suportes" artificiais com referência aos quais os significados circulam. Não são apenas as sensações corpóreas, reconhecidas pela consciência de primeiro nível, que estão em constante mudança. Também o mundo material, incluindo nossos próprios corpos, estão sujeitos à constante ação do tempo. Dessa forma, mesmo que a linguagem produza cristalizações temporárias de certas configurações do mundo, o mundo ao qual elas se referem segue em movimento, fazendo com que, mais cedo ou mais tarde, sejamos obrigados a reconhecer que os conceitos de outrora já não nos permitem revelar nem mesma a pequena fração da realidade que outrora eles revelavam. 


\section{Capítulo 2 - Representação: Síntese de sínteses de heterogêneos}

\subsection{Formas de repetição do narrativismo anti-fundacionalista: imaginação histórica, sentenças narrativas e figuralismo}

\section{a) Collingwood e Danto}

Já mencionamos o "elo collingwoodiano" entre as reflexões de White e de Mink. Além dele, um outro autor fornece uma chave importante para compreendermos as formulações narrativistas: Arthur Danto. Não é usual que Danto e Collingwood sejam aproximados, e vários aspectos de suas filosofias da arte e mesmo da história de fato são consideravelmente distintos. Mas eu gostaria de apontar para um elemento comum que surge em suas reflexões sobre uma característica presente na história-processo, na história-escrita, e na relação entre ambas, decorrente da atenção dos dois autores à relação entre estética (por meio da atividade imaginativa no caso de Collingwood e pela linguagem no de Danto) e temporalidade: trata-se da ausência de "descrições padrão" ou "pontos fixos" a partir das quais se possa determinar um ponto de partida para a produção de representações. Assim, suas filosofias fornecem importantes pontos de apoio para a abordagem antifundacionalista que afirmamos encontrar em White e Ankersmit, e a possibilidade de situar ambos - Collingwood e Danto - retroativamente na primeira geração do que veio a ser o narrativismo fornece subsídios para que toda a tradição possa ser pensada a partir desta prisma.

Os autores da abordagem que Ankersmit chamou de filosofia epistemológica da história não enfatizaram a noção de imaginação em sua recepção de Collingwood, mas a de re-enactment, isto é, a capacidade de seres humanos de repensar o pensamento de outros seres humanos. Aqui, Collingwood segue Vico e seu princípio verum factum, segundo o qual os seres humanos podem compreender o mundo social porque eles o fizeram. Porém, apesar da ênfase no re-enactment, para Collingwood este conceito não é inteiramente separável do de imaginação. Se as ações passadas e o historiador no presente estão nas condições necessárias para a produção de conhecimento histórico (se há vestígios da ação suficientes para responder a questão presente, se as pressuposições absolutas da época analisada são compreensíveis a partir do presente, se o historiador adota uma postura simpática ${ }^{56}$ ), então é possível que o historiador proceda - como um

\footnotetext{
${ }^{56}$ Como aponta NIELSEN, 1981: 1-31.
} 
detetive $^{57}$ - por meio da faculdade da imaginação. É dela que trata o texto "The Historical Imagination", escrito em 1935 e publicado postumamente em The Idea of History, em 1946.

Quando pretende narrar um conjunto de acontecimentos passados, afirmava Collingwood naquele texto, o historiador se depara com uma grande quantidade de "autoridades", evidências em potencial. Seu primeiro passo, então, é selecionar a quais delas recorrerá. Em seguida, por meio da construção, ele realiza inferências, efetivamente transformando as autoridades em evidências. Depois, realiza a crítica das evidências, podendo mesmo colocar em questão a confiabilidade da autoridade. Nesta etapa, Collingwood considerava que F. H. Bradley havia realizado uma "revolução copernicana", ao mostrar que os critérios por meio dos quais a autoridade é criticada não são intrínsecos às fontes ou ao passado, mas sim oriundos do próprio historiador. Sua referência aqui é a Kant, que considerou realizar semelhante revolução ao mostrar que a experiência e o conhecimento humanos são possibilitados por categorias a priori. Collingwood pretendia fazer com a dimensão construtiva o mesmo que, em sua visão, Bradley fizera com a crítica.

Usualmente, aponta ele, argumentar-se-ia que os "pontos fixos" a partir dos quais o historiador realiza interpolações são fornecidos pelas evidências; mas, como as evidências só adquirem este status após serem selecionadas e criticadas, somos trazidos de volta à questão sobre qual é o fundamento destes critérios. Ora, as evidências são contempladas a partir de um pensamento histórico prévio; desse modo, quanto mais conhecimento histórico temos, mais somos capazes de fazer perguntas que transformem o mundo perceptível aos nossos sentidos em evidências, produzindo novos conhecimentos históricos. Isto significa que, para Collingwood, "o pensamento histórico é uma atividade original e fundamental da mente humana". A “ideia” de passado é "inata", atua a priori em vez de ter sido formada a posteriori, e, por meio da imaginação, constrói seus conteúdos específicos, estes sim incontornavelmente históricos. A indesejabilidade desta concepção apriorista será afirmada ao longo do nosso trabalho, mas a abordagem por meio da qual a presença da consciência é percebida como parte constituinte da produção de conhecimento histórico e não como um obstáculo a ele é de suma importância.

\footnotetext{
${ }^{57}$ A seção “Who killed John Doe?” de The Idea of History é moldada nesta premissa.
} 
A incontornável instabilidade e a co-emergência na relação entre passado e presente - que, como veremos, Danto trouxe à tona a respeito das sentenças narrativas, e que White (em parte por meio de suas leituras de Danto e de Collingwood) atribuiria à própria essência dos "sistemas históricos" -, Collingwood afirma para as "imagens" produzidas pela "ideia da história". Em sua tese, qualquer passado construído é necessariamente o passado deste presente, e depende do que está presente em cada momento histórico para ser construído. O presente, por sua vez, resulta da efetivação de possibilidades do passado. Não existe algo como um passado an sich, capaz de ser conhecido em sua completude e com uma significação inerente a si mesmo.

Quando a esta questão específica, Danto chegaria à mesma conclusão. O problema da conexão entre linguagem e temporalidade, incluindo especialmente suas consequências para a ontologia histórica, é o fio condutor do livro Analytical Philosophy of History, publicado por ele em 1965 - cujo capítulo central, "Narrative Sentences", aparecera na History and Theory em 1962. Um experimento mental proposto por Danto é bastante elucidativo do que está em jogo nesta conexão. Imaginemos, propõe ele, que um "Cronista Ideal" fosse capaz de registrar todos os eventos no exato momento em que ocorrem. Este registro perfeito de modo algum comporia um texto compreensível, significativo. A um historiador que recorresse aos registros do Cronista Ideal no intuito de empregá-los como fonte para seus próprios textos, restaria ainda todo trabalho de selecionar e de articular eventos - aquilo que Collingwood chama de seleção e de construção, se supusermos que a crítica não fosse necessária neste caso. O Cronista Ideal teria apenas ampliado consideravelmente a quantidade de informações confiáveis disponíveis.

Em outros termos, ao nosso hipotético historiador restaria ainda o trabalho de redescrever as descrições feitas pelo Cronista Ideal de modo a torná-las significativas. Então, para repetirmos o exemplo clássico de Danto, uma frase como "A Guerra dos Trinta Anos começou em 1618" jamais poderia ter sido enunciada pelo Cronista Ideal, já que ela conecta dois eventos afastados temporalmente, ressignificando o anterior à luz do posterior. Ela é uma instância do que Danto chamou de "sentenças narrativas". Veremos adiante que White aponta no elemento de vontade envolvido neste processo: a lógica não determina quais conexões decidiremos fazer; ela apenas nos impede de conectar no modo tradicional de causalidade baseado em causa e efeito - que, como veremos, não é o único operativo - eventos que não se conectaram de tal maneira no processo histórico. No caso de Danto, o elemento da liberdade humana aparece mais 
centralmente em sua ênfase na impossibilidade de prever as descrições de evento futuras. ${ }^{58}$

Assim, Danto considerava que a tentativa dos filósofos especulativos da história de descobrir o significado do processo histórico em sua totalidade não era justificada. ${ }^{59}$ Em menor escala, como o futuro não pode ser previsto e as consequências de eventos passados seguem se desenrolando, não é possível prever também as descrições possíveis de eventos. O passado é constantemente realinhado à luz de acontecimentos posteriores. Em ambos os casos, está em jogo a liberdade: no caso de White, a liberdade do processo de narrativização; em Danto, a liberdade de ação humana, que impede que saibamos por antecipação os eventos futuros. Em “The Politics of Historical Interpretation”, de 1982, White rejeitaria o determinismo com bases éticas: negando tanto a conservadores quanto a centristas e revolucionários a autoridade de determinar o sentido do processo histórico, ele foca menos em argumentar em defesa da natureza sublime dos eventos (embora evidentemente e acertadamente presuma-os assim) do que em criticar as consequências práticas do obscurecimento da dimensão ideológica presente em toda atribuição de significado (1987: 81-2). Já Danto rejeitava o determinismo apontando não para a liberdade de atribuir outros significados para ações e processos, mas para a liberdade dos agentes sempre fazerem diferente do que fora previsto, e, assim, invalidarem qualquer projeto de predição histórica. Em mais um experimento mental, ele pede que imaginemos um livro escrito em 1815 predizendo os acontecimentos da Batalha de Iwo Jima. Por mais refinados que fossem os métodos de predição histórica de seu autor, o que não é possível é que os agentes da batalha "saibam que a predição foi feita e não sejam capazes de falsificá-la, desde que o evento predito ainda não tenha ocorrido.” A descrição mostra o absurdo de pressupor o contrário:

Imagine que a pessoa sabe da predição de que irá mover seu pé esquerdo em t1 e o seu pé-direito em t-2. Ela tenta falsificar isto: tenta apenas ficar parado

\footnotetext{
58 Sua preocupação, como a de Popper em The Poverty of Historicism, era sobretudo a de rejeitar a legitimidade das "filosofias especulativas da história", que, em sua visão, dependiam da produção de "profecias" (cf. DORAN, 2013: 109-117) que pressupunham um ponto de vista que seus autores não podem efetivamente adotar, o do futuro.

59 Aqui, ele se juntava à desconfiança geral do pós-Guerra em relação ao que Karl Popper chamava de "historicismos". De fato, autores como Hayden White e Haskell Fain buscaram, na década de 1970, reabilitar a empreitada, apontando que a tentativa de marginalização das filosofias da história (que a historiografia profissional buscara desde seus primórdios do século XIX e a filosofia "analítica" ou "crítica" da história do pós-Guerra também ambicionava; ver, por exemplo, a Introdução à Filosofia da História publicada por W. H. Walsh em 1951: WALSH, 1978) era inviável. Para White, "os modos possíveis de historiografia são os mesmos modos possíveis de filosofia especulativa da história", pois ambas são "formalizações de insights poéticos" antes - termo que deve ser entendido literalmente - de serem explicações, quando o são (WHITE, 1973: xii).
} 
em t-1, ou mover o seu pé direito, mas apesar de todos os seus esforços, a predição se confirma! Os pés caem nas pegadas pré-determinadas: como se a pessoa tivesse perdido o controle dos próprios membros, eles agora se movem por conta própria. Ou imagine tentar não gritar, mas descobrir que, apesar disto, surge um berro rasgando os próprios lábios. Pense em todo um campo de batalha de homens passando por esta estranha alienação. [...] (DANTO, 2007: 179)

Danto e White focam portanto em duas faces da mesma moeda: ${ }^{60}$ as duas faces são a liberdade de agir diferentemente e a de significar diferentemente retroativamente as ações, e a moeda é a abertura incontornável do futuro, da qual segue a abertura incontornável do significado do passado - que é aquilo que, em sua facticidade, tornouse fechado. ${ }^{61}$

Liberdade e linguagem são conectados em narrativas históricas de múltiplas maneiras, então: indivíduos no passado agiram livremente, criando representativamente seus mundos e planejando suas ações por meio da linguagem; e historiadores no presente narram ações passadas a partir de seus próprios interesses pragmáticos, novamente com uso da linguagem. Há, incontornavelmente, um duplo "espaço": o espaço entre as ações planejadas e suas consequências efetivas; e o espaço entre as ações e/ou os usos de linguagem e a linguagem usada para descrevê-las. A primeira diz respeito à história-processo, a segunda à história-escrita. Em ambos os casos, a estética tem papel central: como não há "descrição padrão", nem forma padrão de produzir "mundos" por meio da representações, cada uma das ações de agentes históricos e de historiadores aqui descrita poderia ter sido feita de outra forma.

Assim, que não se trata apenas de um problema de seletividade: como não há um protocolo capaz de decidir sem arbitrariedades como um Cronista Ideal deveria descrever os eventos - pois a descrição varia, no mínimo, de acordo com a articulação temporal que se deseja fazer entre os eventos, mas também envolve a carga emocional e qual de suas partes se deseja enfatizar, dentre tantas outras coisas - trata-se de simultaneamente decidir como descrever um evento e com o que articulá-lo. Não há uma base sólida (fundamento, chão, ponto fixo) de onde partir: não temos como primeiro possuir uma descrição correta e depois encontrar as articulações possíveis, nem temos como primeiro já saber quais eventos conectar e depois buscar as formas

\footnotetext{
${ }^{60} \mathrm{O}$ trecho de Danto, notemos ainda, foca em ações intencionais. Na filosofia de White, encontramos ora a ênfase da possibilidade de escolher como agir e significar, ora na importância de elementos menos reflexivos como desejos, emoção, imaginação, vontade. A tensão entre estes níveis - que envolvem as dimensões do inconsciente e do consciente, e também as dimensões de emoção e imaginação, por um lado, e da razão, por outro (tais distinções, notemos, não são equivalentes) - surgirá em diversos momentos do trabalho.

${ }^{61}$ Ver MINK, 1953, JORDHEIM, 2012, DANTO, 2007: 363.
} 
linguísticas apropriadas e pré-existentes para proceder. Não havendo base segura, só resta ao historiador imaginar hipóteses, como se já soubessem de onde partir, e então abduzir descrições possíveis. ${ }^{62}$

Com base nestas reflexões, Danto afirma que nossa linguagem cotidiana é perpassada de temporalidade a tal ponto que a narrativa constitui nossa "metafísica da vida cotidiana". O que também implica que, de modo geral, a vida cotidiana de seres humanos é já perpassada por algum afastamento do fluxo temporal, na direção de usos mais ou menos cristalizados da linguagem. Como vimos, a produção da representação produz uma dobra que cria simultaneamente uma realidade com a qual ela se relaciona em termos de aboutness - mais especificamente, cria uma bifurcação entre a representação e a realidade sobre a qual a representação é. Nos termos de nosso trabalho, isto significa que (a) a relação entre representação e experiência é parte constitutiva da "realidade humana", e (b) a tensão entre a temporalidade narrativa e a descontinuidade da experiência também o é.

Danto não escreveu suas reflexões tratando do tema ao redor do qual organizamos as presentes reflexões, que é o anti-fundacionalismo, em termos gerais, e a ausência de pontos fixos a partir do qual se possa produzir conhecimento ou significado históricos, em particular. Mas sua abordagem em Analytical Philosophy of History mostra ciência de tal ausência em ao menos mais um momento. Quando da publicação do livro, o debate sobre a aplicabilidade do modelo das covering laws à história, iniciado havia mais de duas décadas, ainda era relevante. Autores como Carl Hempel e Morton White defendiam um modelo preditivo de explicação, por meio do qual o evento particular poderia ser "explicado" quando o historiador fosse capaz de subsumilo, juntamente com outros eventos, a uma lei geral. O que aconteceu em seguida, assim, seria a princípio previsível. Danto, como vimos, rejeita a previsibilidade histórica, baseando-se na relativa liberdade humana de decidir fazer diferente do que foi previsto, uma vez que a própria previsão pode chegar à consciência dos agentes. Mas ele não descarta inteiramente o modelo hempeliano: ele o modifica profundamente, estetizandoo. Não seria o caso, para ele, de negar que as explicações históricas subsumem eventos particulares a leis gerais. O relevante seria perceber que, ao produzir tal subsunção, o historiador precisa redescrever o evento de modo a encontrar um nível adequado de generalidade por meio do qual a lei se aplique, bem como uma descrição que apresente

\footnotetext{
${ }^{62}$ Danto afirma explicitamente a condição "abdutiva" da atuação da imaginação na construção de
} narrativas históricas. 
o evento como uma instância de tal lei. E esta redescrição, por sua vez, depende de qual mudança o historiador escolheu explicar: se ele escolhe tratar da política francesa entre 1789 e 1815, é a partir de tal decisão que os eventos entre o início da revolução e a queda de Napoleão serão descrito em certos termos. (Mesmo os termos "início da revolução" e "queda de Napoleão", que emprego aqui, dependem da questão prévia que se tenha escolhido explicar.)

Antes de seguirmos, cabe ainda uma comparação sobre a implicação das abordagens de Collingwood e de Danto ao tema da presença do passado, que será introduzida mais adiante neste trabalho. De uma perspectiva formal, tanto o reenactment de Collingwood quanto as "sentenças narrativas" de Danto estabelecem a relação retroativa entre dois eventos afastados temporalmente. Mas, dada as preocupações do presente trabalho, a filosofia collingwoodiana tem a vantagem adicional de pensar processualmente a relação entre t2 e t1: ela dá, explicitamente, por parte de uma consciência em t2 que acessa internamente a ação mental executada por outra consciência em $\mathrm{t} 1$, repensando aquele pensamento e reativando-o no presente. ${ }^{63}$ Assim, t2 e t1 não são pontos estáticos no tempo: o fato de que o pensamento ocorreu em t1 é um fato imutável, mas o evento mental ocorrido em t1 é reativado em $\mathrm{t} 2$, influenciando o presente. $\mathrm{O}$ caráter mental de tal relação - e isto não significa desincorporado nem "irreal" - significa que não há algo como um abismo intransponível entre um passado "lá atrás" e o presente "aqui". O que ocorre é uma interpenetração retroativa entre presente e passado, que permite-nos pensar o próprio presente - ou ainda, a própria história - de uma perspectiva processual.

\section{b) Figuralismo em White}

O problema da relação entre dois eventos afastados temporalmente, ou entre a relação retroativa entre a compreensão presente e o evento passado, aparece na obra de White por motivos éticos, centrados no exame da função existencial do passado, antes mesmo das análises estruturais de textos historiográficos como aquelas publicadas em Metahistory. Em 1967, dois anos depois da aparição do livro de Danto, White apresentou a comunicação (que viria a ser publicada apenas em 1972) "What is a Historical System?”, em que uma lógica semelhante à das sentenças narrativas é

\footnotetext{
${ }^{63}$ Esta questão será retomada no capítulo 3, quando argumentarei que a leitura de Collingwood oferecida por Ankersmit perde de vista a tensão entre os diferentes contextos do pensamento. A noção collingwoodiana da "identidade do pensamento" (AHLSKOG, 2018) será mais de uma vez empregada para viabilizar o próprio conceito de "experiência histórica" de Ankersmit.
} 
estendida à própria dinâmica dos "sistemas históricos", pensados em contraste com os "sistemas naturais". Ele não parece ter se inspirado especificamente em Danto: ao republicar o texto em 2010, mencionava ter se inspirado na genealogia nietzscheana. ${ }^{64}$

Para discutirmos "What is a Historical System?", cabe lembrar que o texto programático “The Burden of History” havia sido publicado por White na History and Theory pouco antes, em 1966. Discutiremos aspectos deste ensaio mais adiante, mas por ora cabe relembrar que ele traz para o palco da filosofia da história esta dimensão "prática" da historiografia que, em sua trajetória intelectual, White enfatizou praticamente desde o princípio, mesmo quando ainda atuava como um medievalista (cf. WHITE \& JENKINS, 1998; ver PAUL, 2008; 2011; 2018; KORHONEN, 2006: 35-44). White estudou com Danto na Wayne State University, e ambos relatam ter sido profundamente inspirados por um carismático professor, William J. Bossenbrook (ver DORAN, 2013; PAUL, 2011). Bossenbrook, como White rememorou perto do fim de sua vida (2014: 1), "nos ensinou que a história era primariamente uma estória do choque de ideias, valores e sonhos (em vez de apenas corpos e máquinas)”. Este princípio se manifesta igualmente no posicionamento que ambos, White e Danto, assumiram diante do debate sobre o modelo das covering laws, que ainda dominava a filosofia da história em geral, e as páginas da History and Theory em particular, quando Analytical Philosophy of History e "The Burden of History" foram publicados. A comunicação muito menos conhecida - de 1967 manifesta como esta rejeição se aplica à questão da causalidade, que não surge em Burden. Também para White, o tipo histórico de relações entre eventos não é adequadamente caracterizado por uma forma linear de causalidade. O evento posterior precisa do anterior para acontecer - para tomá-lo como posterior mas não é causado por ele; do fato de que o evento anterior ocorreu, não surge nenhuma necessidade de que o evento posterior ocorra. Visto à luz de Burden, a dimensão ética da historiografia é inseparável desta visão sobre a peculiaridade da causalidade histórica: a decisão posterior de tomar o evento anterior como figura, e "preenchê-la" ou "cumprir sua promessa", faz com que os dois eventos se tornem o que são devido à relação que os agentes históricos escolhem estabelecer entre eles.

\footnotetext{
${ }^{64}$ De qualquer forma, Nietzsche pode ter servido também de inspiração parcial para Danto, que em 1965 publicou o livro Nietzsche as Philosopher. Sua apropriação posterior da abordagem de história literária praticada por Erich Auerbach para caracterização a relação entre eventos tipicamente históricos (WHITE, 1999: 87-100), que discutiremos em breve, seguiu distinguindo este tipo dos eventos naturais e afirmando que eles se relacionam nos moldes da genealogia de Nietzsche (idem: 95).
} 
Assim, também no figuralismo, nenhum evento serve como fundação para o estabelecimento da conexão, pois não se tratam de entidades isoladas de contextos e de uma redes por meio das quais lhes são atribuídos significados, na história-processo e na história-escrita. Novamente, então, não há pontos fixos. White manifesta aqui o princípio que, segundo Joanna Macy, surgiu em vários campos do conhecimento no Ocidente no século XX, e antes disso em tradições como o pensamento budista: o da “causalidade mútua”. Isto é, não há um evento que é naturalmente causa e outro que é naturalmente efeito: o efeito constitui o evento anterior como sua causa. Vejamos em mais detalhes como isto era apresentado em "What is a Historical System?".

Naquele texto, White desdobrava uma das implicações da tese de que um sistema histórico é marcado por "propósito, escolha ou intenção" de uma maneira que um sistema biológico não pode ser: ${ }^{65}$ isto permite que os membros de sistemas históricos possam modificar seu próprio passado ou, mais especificamente, escolher seus próprios ancestrais, no processo mesmo em que constituem quem são e por quais valores se orientarão no presente. Assim, por exemplo: "O que aconteceu entre o terceiro e o oitavo século foi que as pessoas pararam de se considerar como descendentes dos seus ancestrais romanos e começarem e se tratar como descendentes dos seus predecessores judaico-cristãos." White ainda especifica, empregando a polêmica noção de "ficção", em um contexto onde é mais facilmente compreensível não se tratar de algo irreal, mas da produção de algo real, de autopoiesis: ${ }^{66}$ "E foi a constituição das ancestralidade cultural ficcional que assinalou o abandono do sistema sócio-cultural romano." (WHITE, 2010: 132; grifos no original) Em The Greco-Roman Tradition, pequeno livro publicado em 1973, ele retoma o raciocínio, afirmando que tal tradição não "morreu" - isto é, no sentido em que, no texto anterior, ele afirmara poder ocorrer com um sistema biológico, mas não com um histórico. Pois, em raciocínio que remete a Collingwood - que em The Principles of Art (1958: 94-96) empregara o mesmíssimo exemplo da tradição greco-romana agora mobilizado por White - ele

\footnotetext{
${ }^{65}$ Raciocínio este que ressurgiria em textos centrais de sua obra, como "The Politics of Historical Interpretation": "Não é tanto o estudo do passado mesmo que garante que ele não se repita quanto como ele é estudado, com qual objeto, interesse ou propósito." (1987: 82)

${ }^{66}$ Como Macy afirma em relação à teoria dos sistemas, adotando a terminologia do biólogo Francisco Varela (MACY, 1991: 91-2). A pertinência desta perspectiva em relação à obra de White é defendida por MUSZYNSKI, 2017.
} 
afirma que, ao ser abandonada, uma tradição permanece como modelo passível de ser redescoberto por sociedades posteriores. ${ }^{67}$

Como o argumento apresentado até o momento aponta para a inexistência de pontos fixos, cabe mostrar a compatibilidade de White com reflexões mais recentes sobre a relação entre natureza e cultura, como aquela desenvolvida por Judith Butler. Percebamos que não se trata de apontar a ancestralidade romana como "natural" e a judaico-cristã como "cultural": embora ele não entre na questão, é evidente que qualquer ancestralidade envolve sempre os componentes da biologia, geografia, geologia, etc., juntamente com os dos valores de um dado grupo. A discussão que efetivamente será levantada por White em outros textos é sobre o quão autoconsciente é esta escolha. Assim, por um lado, em vários pontos de sua obra é nítida a recusa de uma "normalidade" em contraste com a qual os desvios "culturais" pudessem ser situados; por outro, ela também considera haver uma peculiaridade humana no que diz respeito à possibilidade de escolher a significação de sua própria vida.

Assim como as sentenças narrativas para Danto, a adoção de tradições em White também se dá nos moldes retroativos, em que um grupo de pessoas em t2 seleciona e ressignifica eventos (ou formas de significar eventos) de $\mathrm{t} 1$, de modo que o significado de 11 não existe por si só, mas sim a partir do que os seres vivos de seu futuro decidiram fazer com ele. Mantenhamos este argumento em mente: ele será importante quando discutirmos, no capítulo 4, a maneira pela qual, em Ankersmit, as sociedades que passaram por "experiências históricas sublimes" lidam com seus passados. E tendo isto em vista, adicionemos uma observação importante: a possibilidade de fazer escolhas (como afirma White) ou de apenas reagir aos eventos (como presume o Ankersmit experiencialista, no caso de eventos "sublimes") depende de circunstâncias, tanto aquelas externas ao sujeito quanto ao dos recursos acessíveis à sua própria consciência. Quando discutirmos sobre a tropologia de White, tenhamos em mente que o último dos tropos, a ironia, permite (embora não garanta) algo como uma responsividade aos

\footnotetext{
${ }^{67}$ A diferença da "morte" de tradições em comparação com a de indivíduos aponta para a pertinência da perspectiva collingwoodiana de que o passado pode estar "vivo" de uma maneira que não identifica passado apenas com sua imediaticidade material. Tradições não sobrevivem sem suportes materiais, incluindo os corpos, mas não dependem de corpos específicos para serem revividas em outros contextos, precisamente por envolverem a dimensão mental frequentemente enfatizada por Collingwood. Ao mesmo tempo, não se trata de dizer que os lugares e corpos nos quais as tradições podem ser revividas são irrelevantes, pois os significados se articulam holisticamente, unindo em uma totalidade as dimensões mental e física, abstrata e concreta, etc. A relevância da diferença de contexto é reconhecida por Collingwood em sua Autobiography.
} 
eventos, enquanto o primeiro deles, a metáfora, é mais propícia a uma certa reatividade a eles.

A partir da década de 1990, White recorreria à noção de figura, nos moldes empregados por Erich Auerbach em seu clássico Mimesis: a representação da realidade na literatura ocidental, para caracterizar a natureza da existência histórica: um constante realinhamento do passado, i.e., preenchimento retroativo de figuras frequentemente a partir da mobilização de tradições específicas - guiado pela necessidade de responder às situações presentes, para as quais não há modelos ou manuais éticos prontos. Em Mimesis, o amplo objeto de estudo é tratado como uma sucessão de preenchimentos retroativos de figuras, remontando às matrizes de Homero e do Antigo Testamento, por meio dos quais diferentes gerações buscaram representar realisticamente a realidade. Auerbach adapta este modelo da tradição cristã de interpretação bíblica, inicialmente praticada pelos Pais da Igreja. Ela opera por meio do estabelecimento de "uma relação entre dois acontecimentos ou duas pessoas, na qual um deles não só se significam a si mesmo, mas também ao outro, e este último compreende ou completa o outro". O evento posterior (o preenchimento), ao ser ligado ao anterior (a figura), projeta sentido sobre ele. No caso de Mimesis, as constantes atualizações são da própria tentativa de "apresentar" - não meramente "representar", como vimos White afirmar, "a realidade realisticamente": isto é, longe de haver um modelo padrão, os recursos de produção de significado para a realidade são também históricos: "Em suma," afirma White em "Auerbach's Literary History: Figural Causation and Modernist Historicism”,

\footnotetext{
Mimesis apresenta a história literária ocidental como a estória do preenchimento da figura da figuralidade. Ou seja, o conceito da literatura ocidental consiste no reconhecimento de que cada representação (Vorstellung) é também uma apresentação (Darstellung)... (1999: 88)
}

Mas, na leitura de White, o eixo diacrônico ou sintagmático da narrativa de Auerbach não é o único em que o figuralismo opera. Ele também se manifesta no eixo diacrônico ou paradigmático, das relações internas em um dado período histórico. White afirma que aqui a questão da representação tem precedência sobre a da apresentação, como quando nos perguntamos: "Em que sentido pode-se dizer que um texto representa o período ou contexto em que ele foi composto?" (idem: 91) Sua resposta é que, para Auerbach, 
... o texto literário representativo pode ser a uma só vez (1) um cumprimento de um texto prévio e (2) uma prefiguração potencial de algum texto posterior, mas também (3) uma figuração da experiência do autor de algum milieu histórico, e consequentemente (4) o cumprimento de uma prefiguração de um pedaço da realidade histórica. Em outras palavras, não é uma questão de um autor ter uma experiência de um milieu histórico e então representá-lo, figurativamente, em seu texto. Pelo contrário, a experiência já é uma figura e, na medida em que ela irá servir como o conteúdo ou referente de uma representação subsequente, ela é uma prefiguração que é preenchida apenas em um texto literário. (idem: 93)

Como o figuralismo opera diacrônica e sincronicamente, então não apenas eventos em $\mathrm{t} 2$ e $\mathrm{t} 1$, mas também sujeitos e o ambiente social se relacionam nos moldes de "causação mútua": o sujeito, suas ações e produções textuais não são um mero espelhamento do ambiente, mas o preenchimento que surge em sua dependência; suas ações, por sua vez, não mantém inerte "o período" ou "a sociedade" nas quais estão inseridos: elas são parte deste todo que representamos como um período ou sociedade, e afetam este todo de maneiras desiguais dependendo do tipo de conexão que eles têm com o espaço, a rede de seres, etc. Então, também aqui, nem sujeito nem milieu, nem texto nem contexto, são entidades estáveis; da mesma forma, mesmo ao término de uma vida ou de um período, nenhum ponto de vista sobre eles pode ser produzido fora da experiência de um ser histórico. ${ }^{68}$

Isto tem implicações para aquela que é, como veremos adiante, uma das preocupações subjacentes à filosofia da história de Ankersmit: a da necessidade de historicização do conhecimento reconhecida e demandada pelo historicismo. Ele criticará as filosofias de White e de Mink - e também, mais surpreendentemente, as de Gadamer e de Rorty - por elas ainda manterem o pressuposto de algum "ponto de vista" transcendental à história, não aplicando a si mesmas a historicização que reconhecem nos demais "pontos de vista". Porém, o presente texto já apresenta o que considero ser a melhor abordagem de White à questão, e, lidas e refinadas à sua luz, as teorizações do próprio White e de Mink nos anos 1960 e 1970, assim como as de Ankersmit à luz de toda sua trajetória, são mais adequadamente apreciadas como inteiramente históricas. Mais ainda, ao examinar os conceitos de experiência histórica (subjetiva e sublime) em Ankersmit, argumentarei que ele perde de vista a historicidade de um tipo de eventos traumáticos (que ele chama de "trauma 2") e substancializa o sujeito que passa por tais

\footnotetext{
${ }^{68} \mathrm{O}$ que isto não significa é que, da relatividade ou historicidade de todos os pontos de vista, não haja a possibilidade de reconhecer - no distanciamento filosófico e no engajamento prático - a historicidade da própria perspectiva, e os méritos (cf. Gallie) das perspectivas diferentes. Em diferentes momentos do presente trabalho, defendo que historicizar todos os pontos de vista implica também em não presumir haver uma única maneirade se relacionar com a relatividade das próprias perspectivas sobre o mundo, à qual por algum motivo estariam condenados todos os agentes históricos.
} 
eventos (o estado nacional) de maneira insustentável. Levar a sério a leitura que White oferece de Auerbach - especialmente sobre a questão do historicismo, tão cara a Ankersmit - é uma forma de evitar estes problemas.

Como se vê sobretudo em "A Meia Marrom”, o último capítulo de Mimesis, Auerbach "historiciza o próprio historicismo". Ao fazê-lo, para White, ele mostra ser possível ser historicista e modernista ao mesmo tempo. Os referenciais usuais do historicismo, conectados à sociedade de classes, ao estado nação e ao humanismo do século XIX, são vistos como históricos, e não mais necessários para representar realisticamente a realidade de agentes históricos vivendo na primeira metade do século XX (WHITE, 1999: 97-8). O argumento aqui, cabe observar rapidamente, se manifesta na noção de "evento modernista". ${ }^{69} \mathrm{O}$ século XX, para White, produziu eventos cujos “escopo, escala e profundidade inimagináveis por historiadores precedentes” (idem: 72), além de ter presenciado o desmantelamento do conceito de evento como objeto de conhecimento científico e da noção de estória como recurso estético mais apropriado para a sua apresentação (1999: 71-72; 1978: 27-50). Em "The Burden of History", White já havia argumentado que os historiadores haviam mantido uma concepção de ciência e de arte há muito superada por cientistas e artistas contemporâneos. Trinta anos depois, em 1996, além de apontar para a "revolução" produzida pelo modernismo, ele considerava que também "as tecnologias de representação tornadas possíveis pela revolução eletrônica" (1999: ibidem) haviam contribuído para tornar obsoletas as concepções tradicionais de evento e de história.

Assim, ao propor a adoção de formas modernistas de narração por parte da historiografia, ${ }^{70}$ White estava fazendo o mesmo movimento que reconhece na "produção do conceito" de história literária por parte de Auerbach: por um lado, eles conceituam uma forma que é figura de uma experiência particular da história, aquela das sociedades ocidentais do século XX; por outro, vêem todo o processo histórico como passível de ser explicado nesses moldes, entendido não como uma aplicação externa mas como inerentes aos próprios eventos. O desenrolar das tentativas de representar a realidade realisticamente culminaria, nesta interpretação, na descoberta de que . Assim, por um lado White afirma que as formas modernistas de narração são apropriadas para os "eventos modernistas" devido a um tipo de similaridade estrutural,

\footnotetext{
${ }^{69}$ Os ensaios "The Modernist Event" e "Auerbach's' Literary History", publicados em Figural Realism no ano de 1999, apareceram ambos originalmente em 1996.

${ }^{70}$ Ver, além de "Burden" e "Modernist Event", o ensaio "Historical Emplotment and the Problem of Truth" (WHITE, 1999: 27-42).
} 
envolvendo formas peculiares de experienciar o tempo, a diferença entre os estados fascistas e o papel do estado no século XIX, etc. Por outro, como vimos, considera que toda a história se desenrola em moldes figuralistas, de modo que a escolha de ancestralidade praticada pelos romanos e a relação dos europeus com o evento da Revolução Francesa poderiam também ser explicados pelo figuralismo. Haveria no modernismo algo de particular e histórico, mas também a revelação de uma verdade aou trans-histórica, que é a própria verdade da historicidade radical. Deixo em aberto a difícil questão do quão paradoxal é esta afirmação, limitando-me a afirmar que o debate narrativista, na medida em que trata das questões ligadas ao historicismo, conduz até ela.

White conclui seu ensaio apresentando algumas características distintivas do modernismo, segundo Auerbach: a desaparição do escritor como narrador de fatos objetivos; a dissolução de qualquer ponto de vista fora da novel a partir do qual as pessoas e eventos dentro dela podem ser observados; um tom de dúvida e questionamento; o uso de recursos retóricos como erlebte Rede, fluxo de consciência, monologue intérieur; e de novas técnicas para representar a experiência do tempo e temporalidade. White afirma que, embora isto não apareça no nível manifesto de Mimesis, mas sugere, de maneira vaga, que é possível "procurar por similaridades entre Mimesis e os texto clássicos do modernismo literário." (idem: 100)

Cabe especificar: no nível manifesto, Mimesis é a história de como a "mistura de estilos" gradualmente se inseriu na literatura, e, paralelamente, de como as diferentes classes sociais gradualmente passaram a ser vistas como dignas de representação literária, devido a um crescente reconhecimento de sua humanidade. Mas, como é usual em suas análises, White detecta também um nível profundo em Mimesis:

De fato, se, em muitos aspectos, Mimesis é em última instância a estória de como a literatura ocidental veio a compreender a historicidade como o modo distintivo da humanidade de ser no mundo, este modo de ser no mundo é representado como um em que indivíduos, eventos, instituições e (obviamente) discursos são apreendidos como se relacionando uns com os outros de uma maneira distintivamente figural. ... Isto significa que coisas históricas podem ser apreendidos em sua historicidade apenas na medida em que eles são compreendidos como elementos de totalidades... (idem: 99)

Qualquer que seja a resolução que adotemos para o problema do que é particular e o que se aplica a toda a história, podemos reconhecer que nem todos os recursos modernistas serão úteis ou necessários para expressar toda a multiplicidade de experiências históricas - mas que a história, como quer que seja que a concebamos (e 
não, a este respeito, de maneira diferente de como Collingwood argumentou), não existe senão na experiência de agentes e de historiadores - que experienciam os aspectos reexperienciáveis de tais experiências, e os aspectos sincrônicos e diacrônicos que escaparam aos agentes -, sempre situados, limitados, partes de totalidades que não podem conhecer senão parcialmente. A ausência de pontos fixos - eventos, formas de enredamento, contextos - significa também historicidade radical.

\section{c) Figuralismo e "presença"}

O figuralismo - como a dialética de Collingwood, e como a de Hegel, mas de maneira não-teleológica - também realiza suprassunção: Auerbach considera que o estabelecimento de relações figurais entre eventos do Novo e do Velho Testamento foi importante para o Cristianismo desde seus primórdios, remontando a Paulo. Em seu "sistema de profecia figural", "o novo Messias preenche e anula [aufhebt] ao mesmo tempo a obra realizada pelo seu precursor." (AUERBACH, 2007: 44) ${ }^{71}$ Mas há um aspecto importante importante na maneira pela qual tais preenchimentos eram realizados: "em Paulo, essas concepções judaicas combinavam-se com uma hostilidade declarada às idéias dos judeu-cristãos e [...] é esta atitude que lhes dá uma significação especial." (idem: 43) Tomemos o caso da hostilidade como um exemplo mais amplo de como a atitude com a qual se relaciona com o passado se torna parte de como ele é reativado no presente: a atitude não apenas constitui "propósito, intenção ou escolha", que White afirmou ser central em seus contextos sobre figuralismo, mas também é parte do que chamaremos adiante de "condições de prefiguração" do passado. Tal hostilidade, no caso deste exemplo, é por sua vez ligada aos seus interesses práticos situados, que por sua vez demandavam uma mudança de interpretação dos textos antigos: "Essas passagens das epístolas paulinas que contêm interpretações figurais foram quase todas escritas durante a penosa luta de Paulo no interesse de sua missão entre os gentios; muitas eram respostas aos ataques e perseguições dos judeu-cristãos; quase todas procuravam eliminar do Velho Testamento seu caráter normativo e mostrar que nele tudo é apenas uma sombra das coisas futuras." (idem: 43-44) Assim, seu pensamento “combinava de modo notável a prática política com uma fé poética criativa”. (idem: 44) Esta nova chave interpretativa, por sua vez, abriu possibilidades de preenchimentos posteriores que ainda não haviam sido concebidas: Auerbach cita, por exemplo, que, por

\footnotetext{
${ }^{71}$ Minha atenção a esta passagem foi chamada por PORTER, 2017: 93.
} 
tornar a Bíblia não mais "um livro de leis de uma nação remota" e sim "uma parte da religião universal da salvação", ela mais adiante "passa[ria] a ser aceitável para celtas e germânicos." (idem: 45)

Para a presente seção, o relevante a destacar é que a suprassunção nunca cancela as possibilidades de figuração não realizadas, que podem ser reativadas na medida em que sejam reconhecidas, por motivos teóricos ou pela perda de efetividade do preenchimento anterior. É assim que a dinâmica do figuralismo, longe de ser linear e irrevogável, carrega consigo sempre os "passageiros clandestinos" destas possibilidades de preenchimento não realizadas - e, como enfatizarei ao discutir experiência histórica em Ankersmit, inclui também figuras que por muito tempo causam dor e não são preenchidas de maneira que produz uma expectativa de fechamento. Característica que, notemos de passagem, White também atribui aos "eventos modernistas", que também resistem às formas tradicionais de narrativização e permanecem em aberto, testemunhando a incapacidade dos grupos que o experienciaram de articular significativamente seu presente e seu futuro. Os eventos modernistas, afirma White, "funcionam na consciência de certos grupos sociais exatamente como se pensa que traumas da infância na psique de indivíduos neuróticos" (1999: 69). Isto é, eles

... não podem ser simplesmente esquecidos ou excluídos da mente , ou, conversamente, lembrados adequadamente, o que quer dizer, identificados clara e inequívoca quanto ao seu significado e contextualizado na memória do grupo de maneira tal que reduza a sombra que eles lançam sobre a capacidade do grupo de entrar em seu presente e vislumbrar um futuro livre dos seus efeitos debilitantes. (idem, ibidem)

Tanto quanto os "passageiros clandestinos" adentrarem o foco de atenção de quem escreve ou lê, conscientemente por meios intelectuais ou inconscientemente por meios emocionais e afetivos, elas efetivamente irão compor o significado (meaning) do ato mental. A própria pesquisa histórica, dependendo das circunstâncias, tem a capacidade de reabrir potencialidades ainda não reconhecidas. Dessa forma, como relata Auerbach, se "por quase mil anos" a concepção figural "havia de permanecer como a única visão aceita da história", ainda assim, "Só muito mais tarde, provavelmente só depois da Reforma, os europeus começaram a ver o Velho Testamento como história e lei judaicas" (2007: 45).

Para nossos propósitos aqui, é especialmente importante notar que a constituição retroativa do passado a partir do presente demanda a mesma ontologia histórica que a das sentenças narrativas de Danto - constitutivas de uma "metafísica da vida cotidiana", 
como ele diz em Analytical, de maneira bem harmonizada com a visão dos seres humanos como ens representans apresentada em Transfiguration -, mas em escala muito maior. Por isso que, como veremos (dentre outras coisas), após tentar longamente entender as consequências da inexistência de uma "descrição padrão de eventos", Mink insistirá no ponto muito mais abrangente de que não há "História Universal" e White na "sublimidade" da história-processo. E este insight evidentemente será levado por Runia, Ankersmit e pensadores afins para a discussão sobre experiência: de fato, é porque os significados são construídos, histórica e historiograficamente, que eles se rompem de tempos e tempos, ora com maior atividade e ora com maior passividade por parte dos agentes, e é isso que torna possível as experiências históricas "subjetivas" e "sublimes". É sintomático, neste sentido, que White sempre exemplifique estes momentos de escolha retroativa do passado com momentos subsequentes a "experiências históricas sublimes": a perda da identidade romana com a crise do império; o período subsequente à Revolução Francesa, evento que não só a historiografia do século XIX estudada em Metahistory mas toda a intelectualidade europeia do período tentou "alcançar" (como analisa RUNIA, 2014; ver também ANKERSMIT, 2005, e COMAY, 2011); e o período pós-Primeira Guerra Mundial, fenômeno relevante da "queda" no "estado irônico" ao qual White se opunha propondo a escolha dos ancestrais da "era de ouro" da historiografia do século XIX e, de modo mais geral, dos intelectuais anteriores à profissionalização da historiografia, livres da "supressão da retórica" ocorrida posteriormente no campo. ${ }^{72}$

Todos os exemplos de conexão entre eventos afastados temporalmente, no qual o evento em t2 (re-)significa retroativamente o evento em t1, envolvem uma dimensão de atividade consciente por parte de historiadores ou agentes históricos. É interessante, neste contexto, e devido aos interesses deste trabalho, notar que o giro rumo à presença e ao experiencialismo em décadas recentes também envolve relações deste tipo, com uma diferença crucial: embora o evento em $\mathrm{t} 2$ siga reincidindo retroativamente sobre aquele em t1, este exerce um "poder de tração" sobre a consciência do agente. Isto acontece em vários fenômenos de "presença" estudados por Runia, como o que ele

\footnotetext{
${ }^{72}$ Gumbrecht (2012) nota que o impacto da Primeira Guerra Mundial sobre a intelectualidade europeia foi ainda maior que o da Segunda, apesar do número de mortos e do alcance da violência ter sido maior nesta última. Esta observação é próxima da de Ankersmit (2005), que considera que as "mutações históricas" resultantes de experiências históricas sublimes (ou "trauma 2") não têm relação direta com a violência do evento (que podem produzir traumas no sentido psicanalítico tradicional, que ele chama de "trauma 1"). Retomaremos esta última questão mais adiante.
} 
(questionavelmente) caracteriza como a repetição inconsciente, por parte de soldados norte-americanos, de práticas como a tortura nas prisões de Abu Ghraib, outrora praticadas a mando de Saddam Hussein. Quanto à história-escrita, apenas para adiantarmos um exemplo, Runia estuda o relatório feito a mando do governo holandês sobre a atuação das forças de paz do país durante o Massacre de Srebrenica. Ele considera que os estudiosos reproduziram (em especial textualmente, mas também em fatores como suas hierarquias de grupo) aquilo que estudavam, devido ao fenômeno do parallel processing. Dominick LaCapra também tem apontado para esta direção em suas discussões sobre o conceito de "transferência", definido por ele como "primariamente a implicação de alguém no outro ou no objeto de estudo com a tendência de repetir em seu próprio discurso ou prática tendências ativas em, ou projetadas em, o outro ou o objeto.” (LaCAPRA, 2004: 74) As análises de Runia e LaCapra, ambas focadas em eventos traumáticos, apontam para processos em que os pesquisadores são inconscientemente afetados por um passado que, não podendo ser domesticado ou mantido à distância, se faz presente e age sobre o historiador. As expectativas tradicionais em relação à distância - temporal e afetiva - não se aplicam nestes casos. Assim como no caso da relação entre figura e preenchimento, a presença de distância temporal não significa que, a partir de outros critérios, passado e presente não se relacionem com maior proximidade. ${ }^{73}$ Embora haja uma distância cronológica entre o evento original e sua repetição, ela pouco serve para explicar o que ocorre no caso de eventos que não apenas são experienciados como presentes (pela vítima do trauma), mas também se fazem presentes à revelia da consciência dos pesquisadores. A tendência de dividir o processo histórico em um passado que já passou, por um lado, e um presente que é nitidamente, separado por ele, por outro, não se sustenta nesses casos: não é nítido sequer onde acaba o evento original e onde começa a sua repetição. Fenômenos de "presença" e eventos traumáticos, então, frequentemente são verões acentuadas do que já se constata mesmo nas manifestações "normais" da relação figural entre eventos, em que $o$ que é o evento original (quando e onde começa e termina, o que significa, o que tem de importante e de desimportante) depende das ocorrências posteriores.

\footnotetext{
${ }^{73}$ Se seguirmos Mark Salber Phillips, podemos falar mais especificamente de quatro tipos de relações possíveis entre presença e distância "que dão forma à nossa experiência do tempo histórico": (a) questões de estrutura formal e vocabulário; (b) impacto afetivo; (c) interpelação moral ou ideológica, ou seja, as implicações da representação para a ação; e os (d) pressupostos fundamentais sobre explicação ou compreensão (PHILLIPS, 2013: 6, passim).
} 
Assim, não deveria nos surpreender muito que mesmo um pensador tão pouco afeito aos debates sobre "experiência" e "presença" quanto White tenha afirmado, em The Practical Past, que também a noção de trauma - adequada a um "novo tipo de evento", que não pode ser produzido pela escrita "realista" mas sim pela ("na falta de um termo melhor") "pós-modernista" -, opera em moldes figuralistas: ${ }^{74}$

Apenas após a Revolução ter ocorrido que se tornou possível ver o que a Reforma havia tornado possível.

E assim é com o assim chamado evento "traumático" ou "traumatizante" de Freud. Não há necessidade absoluta de que uma molestação anterior de uma criança por um adulto venha à tona mais tarde em sua vida como um "trauma" e produza efeitos debilitantes no adolescente ou no adulto. Tudo depende da ocorrência de um segundo evento similtar ao primeiro, mas abertamente identificável como o que é ou se pretende que seja que dispara a resposta de reconhecimento-repressão que agora afunda ou bloqueia o acesso a ambos os eventos e os relaga a um espaço fora da "história real" à qual eles pertencem. (WHITE, 2014)

As consequências deste caráter retroativo das narrativas (sejam elas de eventos verdadeiros, sejam elas a base da "metafísica da vida cotidiana", sejam elas a condição constitutiva dos "sistemas históricos") não podem ser compreendidas nos moldes nem de uma ontologia realista, que, embora nem sempre conscientemente, trata o passado como uma história não-contada passível de ser representada, nem nos moldes de uma ontologia construtivista (à qual, como veremos, White ocasionalmente retorna), que concebe o passado como ausente, o que, por contraste, presume que haja algo como um presente presente para si mesmo. Como afirma Ethan Kleinberg, "nós não deveríamos retornar a estas 'tradições' predicadas nem na revelação da presença nem na ausência...", porque o "passado é e não é, ele vem e vai, e os fragmentos que de fato temos são perpassados com a não-sincronicidade de relatos históricos antecedentes." (2012: 135$)^{75}$

White, àquela altura, não tratava de textos de história, mas da própria existência histórica. Mas a atenção ao caráter prático da relação humana com o passado

\footnotetext{
${ }^{74}$ Embora possamos lembrar o comentário de Michael S. Roth (2007: 230-246), escrito antes de White falar explicitamente em "passado prático", de que a filosofia de White é "traumatofílica": ela se harmoniza bem com estudos de tópicos como trauma e memória. Concordo com Roth, e adiciono que isto fica claro se temos em mente que White descreve a produção de continuidades linguísticas não para promovê-las, mas para abrir espaço para a manifestação do que Harry Jansen (2015) chama de "temporalidades heterogêneas".

75 Já que estamos tratando da auto-construção de indivíduos e sociedades no processo de escolha de um passado por meio do qual eles definem o que são, cabe mencionar que Sartre apontou em direção semelhante. O tipo de relação marcada pelo termo "era", diz ele, indica "que, servindo de intermediário entre presente e passado, não é em si mesmo nem inteiramente presente nem inteiramente passado." Assim, ele "designa ... o salto ontológico do presente ao passado e representa uma síntese original desses dois modos de temporalidade." (2011: 167)
} 
evidentemente seria central quando ele passasse a examinar a função das narrativas em textos históricos. Por sua vez, ao tratar de narrativas, Danto não falava ainda de um aspecto central que autores como Louis Mink e o próprio White introduziriam na filosofia da história a partir da década de 1970: o fato de que os textos compõem uma totalidade. Na década anterior, Danto e um ainda pouco influente White elucidaram de que maneira as narrações agem retroativamente sobre o passado; agora, Mink e White enfatizariam que elas procediam por meio da introdução de uma simultaneidade no que outrora fora um processo histórico. Na geração seguinte, Ankersmit refinaria ainda mais a compreensão da maneira pela qual as representações produzem tais simultaneidades. Antes de discutir a maneira pela qual ele apresenta o conceito de representação, é útil dar enfoque ao momento em sua trajetória em que ele mais marcadamente harmoniza suas discussões com o insight destacado nesta seção, segundo o qual a relação retroativa entre t1 e t2 se dá de maneira tal que ambos os eventos - incluindo a produção da representação em t2 e a realidade representada, originalmente ocorrida em t1 - são mutuamente constituídos, sem que um predetermine o outro, seja fundamentando-o epistemologicamente, seja tropologizando-o aprioristicamente.

\section{d) Sistemas holísticos}

Como vimos, para White, o figuralismo não opera apenas na dimensão sintagmática da relação entre eventos históricos, mas também na relação sincrônica entre o texto e seu contexto. Em ambos os casos, a própria relação produz uma forma específica para os dois pólos envolvidos, a causa e o efeito, o texto e o contexto: não há uma forma padrão, anterior ao estabelecimento de alguma relação por meio da qual o significado é produzido. Assim, o princípio holístico que os narrativistas localizam no interior do texto, na relação entre as partes e a representação (que é o todo), ${ }^{76}$ atua também nestas outras formas.

\footnotetext{
${ }^{76}$ Não estamos afirmando, porém, que a relação parte-todo do texto se dá em termos do figuralismo, pois, de acordo com a análise de Ankersmit, não há "espaço" entre a representação e suas partes, configuradas na forma de um único "representado". O espaço é entre a representação $e$ a realidade.

Mas a produção da representação é figuralista, pois a totalidade é uma forma específica de dar forma às figuras do passado. Uma vez tornadas partes desta representação, porém, temporariamente não há espaço: redescobrir o espaço, i.e., a possibilidade de redescrever as partes a partir de outra imagem geral ou forma, é precisamente reabrir o processo de produção de significado para a realidade passado. A relação com a realidade passada é outra a partir do momento em que aspectos seus foram revelados por uma outra representação. Assim, mesmo que produzamos outra representação ao modificar as partes de uma representação anterior (com um representado unicamente seu), a nova relação estabelecida com $a$ realidade passada não se perde e pode encontrar (uma nova) expressão neste nova representação
} 
O princípio holístico que o narrativismo atribui às representações históricas, e que afirmo existir também na relação entre texto e contexto (cf. o figuralismo lido por White) e entre sujeito e o ambiente (cf. Dewey), também é compatível com o princípio dos sistemas descritos por Macy:

\begin{abstract}
Von Bertalanffy descobriu que totalidades, sejam elas animais ou vegetais, células, órgãos ou organismos, podem ser mais bem descritos como sistemas. Um sistema é menos uma coisa que um padrão. ... o caráter de um sistema como um padrão de organização é alterado com a adição, subtração ou modificação de qualquer parte. Portanto ele é mais que a soma de suas partes. ... [Este "mais" é] um novo nível de operação que a interdependência de suas partes permite. (MACY, 1991: 72)
\end{abstract}

Nem texto nem contexto, nem sujeito nem ambiente são, assim, pontos fixos, espelhados ou expressados pelo outro: o texto se manifesta como o preenchimento do autor e de seus vários contextos (tornados figuras), mas não é "causado" por ele. Como na "causalidade mútua" que Macy descreve, ele surge "na dependência" daquilo que toma como causas - da mesma forma que um certo pensamento surge "na dependência de" condições como pressupostos, forma de incorporação e fatores contextuais, mas não é causado por ele. Por isso, como Danto insistiu, conhecer o conjunto de causas não permitiria a predição histórica: um agente pode fazer outra coisa em um mesmo conjunto de condições, pode produzir outros eventos. Pelos princípios do figuralismo, é possível dizer que até mesmo o que são estas condições depende do que o agente fará com elas, já que ele pode produzir diferentes descrições, ou, nos termos muito úteis que Ankersmit empregará posteriormente, desvelar diferentes aspectos delas. ${ }^{77}$ Esta relação entre o tipo peculiarmente histórico de causa e efeito é precisamente o que permite que haja, entre um e outro, o "espaço estético" que Ankersmit atribui à relação entre a representação histórica e seu objeto: sendo sobre um passado real, a representação depende dele (e dos princípios éticos e estéticos empregados pelo historiador) para ser produzida, mas nem o passado "causa" a representação (i.e., não a determina: em sua dependência, muitas diferentes representações podem ser criadas), nem os princípios

E o figuralismo, como as demais formas de causalidade mútua, explica precisamente a produção destes "sistemas abertos". Ao filosofar sobre representações históricas, por sua vez, Ankersmit estuda estaticamente um momento destes sistemas - o que é legítimo, mas é a produção de um "objeto teórico" (cf. BRAVER, 2012; mais sobre isto adiante) e deve ser visto como tal. Em última instância, o holismo deste sistema é parte de um processo holístico mais amplo, que é rearranjado a cada momento em que uma nova representação é produzida, em que uma parte é compreendida como todo, etc.

${ }^{77} \mathrm{E}$ isto significa que mesmo o termo "desvelamento" não pode marginalizar o caráter performativo, na qual ocorre simultânea e indissociavelmente uma descoberta e uma criação. Ver WHITE, 1999: 87-100 e o ensaio de Maria Inés La Greca em BENTIVOGLIO \& TOZZI, 2017. O evento surge no encontro entre a realidade e a representação da qual ele é parte. 
éticos e estéticos são aplicados de maneira independente sobre ele, na forma de uma "aplicação" "78. Mais especificamente sobre os eventos que compõem uma representação, também eles não são tijolos auto-existentes que alguém poderia reunir para produzir um muro, mas, se fôssemos insistir na analogia, tijolos estranhamente maleáveis que que mudam suas próprias formas ao serem reunidos. Da mesma forma, o muro não é um mero resultado do acúmulo de tijolos, mas algo qualitativamente diferente, cuja forma governa a própria maneira pela qual os tijolos são organizados. Tratando deste raciocínio no contexto de uma discussão sobre o quão funcionalista é a filosofia da mente de Aristóteles - adotada, ainda que sem muitas especificações, por Ankersmit, em seus textos sobre experiência histórica - K. V. Wilkes afirma o seguinte:

Um tijolo é uma 'forma' relativa à palha e o barro (sua matéria - ainda assim, palha e barro são eles mesmos substâncias do nível inferior); mas o tijolo é 'matéria' relativamente ao muro, que 'forma' os tijolos mas que é ele mesmo, por sua vez, 'matéria' para a construção: e a construção, uma vez que é usada para ocupação, é a matéria que é 'formada' como uma casa. Se algo é considerado enquanto forma ou enquanto matéria, isto é uma função da descrição sob a qual ele é colocado. (NUSSBAUM \& RORTY, 1995: 112)

A citação facilita nosso trabalho de conectar as reflexões de White com as de Danto, ao empregar a noção de "eventos sob descrição". Como ela deixa claro, se algo é a figura ou o cumprimento, o conteúdo ou a forma, depende da maneira pela qual sua relação é estabelecida entre suas partes e a totalidade. Não há, assim, "descrições padrão" de eventos porque os eventos históricos não são unidades que naturalmente assumam a função de "conteúdo" (desprovido de forma, e da possibilidade de surgir como diferentes conteúdos a partir dos recursos para atribuição de sentido disponíveis ou inventáveis em uma cultura) para uma certa "forma" (desprovida de "conteúdos"), da mesma forma que uma certa quantidade de barro pode ou não ser figurada como tijolo, e este como parede, ou casa, ou cidade.

$\mathrm{Na}$ tradição budista, onde Macy encontra a dimensão "sistêmica" de tais conexões entre matéria e mente, conteúdo e forma, etc., tais exemplos são muito comuns; eles aparecem, por exemplo, na discusão de Düdjom Lingpa, de fins do século XIX, sobre a ausência de substancialidade de qualquer coisa que possa ser tomada como base de designação dos nomes; dentre seus exemplos, ele cita também o do nome casa, que não tem como substância suas partes específicas, incluindo o barro (LINGPA, 2016: 11-2). Cada parte que compõe o todo pode ser ela própria tomada como todo, ou

\footnotetext{
${ }^{78}$ Justamente criticada em ANKERSMIT, 1994: 22-24. Ver o cap. 3 para mais detalhes.
} 
como parte de outro todo, sem que nenhuma base de designação possa ser tomada como o próprio fundamento do nome aplicado, ou como a substância sobre cujas propriedades se possa tratar na linguagem. Esta questão aparece em Ankersmit na discussão sobre a relação entre "compulsão da experiência" e "compulsão da linguagem". Nem o polo da nomeação/representação, nem o polo daquilo que é nomeado/realidade, são fundamentos ou "pontos fixos" a partir do qual se possa estabelecer o outro - nem são, a partir do momento em que a relação entre eles é estabelecida, independentes um do outro. O conceito de "revolução", por exemplo: dependendo de como ele é levado à realidade, uma parte dela pode ou não surgir como sua instância; por outro lado, o estudo de vários movimentos populares pode nos levar a ampliar o conceito, permitindo que ele inclua casos que ele outrora não incluía. Nenhum dos pólos fornece um parâmetro estável a partir do qual se possa deduzir o outro.

Isto vale até mesmo para a noção de fato histórico, tão fundamental para a disciplina historiográfica. Não se trata de nada como "negar a realidade" ou de algum tipo de anything goes epistemológico. Mas imaginemos um acidente de carro: o início e o fim do fato pode ser delimitado com referência ao momento em que os veículos se chocam, ou ao momento em que um dos condutores se distrai, . Não é o caso, então, que primeiro temos um fato pronto, e que depois ele pode ser significado de maneiras diversas ao ser inserido em uma narrativa: é o caso, sim, que diferentes instrumentos cognitivos produzirão diferentes fatos, capazes de ser articulados com diferentes modos de enredamento, argumentação e implicação ideológica (cf. White), e que todos os níveis (da seleção de evidências à produção do texto como um todo, passando pelos "fatos") se constituem mutuamente - a modificação em um dos pólos modifica todos os demais. No caso da historiografia, o pacto entre os membros do campo e entre autores e leitores demanda que os fatos sejam verdadeiros - e não há contradição entre eles deverem ser constituídos e esta demanda por verdade. Há também a demanda de que $a$ narrativa seja verdadeira (ver OHARA, 2019), mas o significado preciso desta expectativa não é simples de esclarecer. Os narrativistas, como veremos a seguir, frequentemente avaliaram que a operação de organização de verdades no texto como um todo tem caráter muito mais estético do que epistemológico, e nas raras vezes em que aceitam empregar o termo "verdade" para tais fins, é precisamente em um sentido mais estético que eles o fazem.

\subsection{Louis Mink e a representação como produção de simultaneidades}


Vimos que a principal motivação para a introdução da narrativa como tópico central na filosofia da história era ligada a uma peculiaridade das ciências humanas ou sociais (com algumas discordâncias em relação a este último caso) em relação às naturais: a imprevisibilidade oriunda da liberdade humana. Uma segunda tendência se desenhava gradualmente por volta de meados dos anos 1960: a de pensar o texto histórico como uma única estrutura sintética, não apenas como uma soma de frases individuais. Essa preocupação aparece em pensadores como Walsh (para quem a história explica "coligando" eventos "sob um conceito"), parcialmente em Danto (pois o próprio texto tem, em escala mais ampla, estrutura análoga a uma "sentença narrativa", buscando explicar a mudança entre um e outro ponto) ${ }^{79}$ e W. B. Gallie (para quem compreendemos o texto ao segui-lo rumo à conclusão). ${ }^{80}$

Estas duas questões irão convergir na produção de uma filosofia narrativista em autores como White e Mink - a liberdade interessa especialmente ao primeiro, enquanto a totalidade do ato compreensivo se difundirá especialmente por meio das reflexões do segundo, inclusive quando White a retoma. Mink as mobilizará com vistas a um problema de que se ocupava já deste a escrita de sua tese de doutorado em 1952: o da conexão entre temporalidade e conhecimento. Era importante, para ele, "levar o tempo a sério", reconhecendo a diferença entre o conhecimento do passado - que em certo sentido está fechado, por mais que, como Danto mostrou, seu significado seja sempre aberto - e o conhecimento do futuro - que está em aberto.

Ao longo dos anos 1960, a ênfase de Mink passará a ser na descontinuidade entre as experiências "vividas" e as estórias "contadas" - ou, na linguagem de David Carr, entre o que se poderia chamar de "mundo real" e as "narrativas", ou ainda, nos termos do presente trabalho, entre "experiência" e "representação". ${ }^{81}$ Tal descontinuidade, tal como ele a pensa, nos conduz a uma segunda dimensão em que se manifestam as relações entre tempo e narrativa: aquela interna ao texto, que diferencia as descrições de evento da narrativa ou (como dirá Ankersmit) representação enquanto

\footnotetext{
${ }^{79}$ Em seu posfácio à republicação de Analytical Philosophy of History (DANTO, 2007), Ankersmit critica Danto por não ter percebido, já nos anos 1960, que a conclusão de suas reflexões sobre a distância entre a perspectiva dos agentes e a de quem reflete sobre as ações posteriormente deveria ir além das sentenças narrativas e se aplicar também ao texto enquanto totalidade. Mas o próprio Ankersmit se beneficia de uma perspectiva inacessível a Danto para fazer tal crítica! De qualquer forma, não se trata de uma postura representativa da maneira um tanto elogiosa que Ankersmit adota em relação a ele - e também a Mink.

${ }^{80}$ Mas também implicitamente em Dray (pois o puzzlement só pode ser removido com uma narrativa inteira) e Morton White (pois, embora fosse ligado ao positivismo lógico de Hempel, enfatizava o encadeamento de conexões causais e não meramente conexões específicas como a fonte da explicação).

${ }^{81}$ Cada um destes termos, é claro, é polissêmico, e os pares não equivalem entre si.
} 
totalidade - a primeira se manifestando de maneira linear, a segunda de maneira simultânea. O principal crítico da posição de Mink, David Carr, argumentou por sua vez que, como as próprias ações já se desdobravam no tempo, elas próprias já eram estruturadas narrativamente. Com apoio sobretudo na contraposição entre Mink e Carr, mas também a partir da perspectiva processual deste trabalho, proporemos duas duas importantes reelaborações - mais que exatamente correções - no argumento "narrativista" de Mink: primeiro, será necessário reconhecer a semelhança “configuracional" entre partes e todo(s) do(s) texto(s); e, segundo, teremos subsídios adicionais para avançar a tese do próprio Mink segundo a qual a narrativa é um "instrumento cognitivo". Neste caso, tratar-se-á de conceber que, se por um lado este instrumento opera por meio de um "cancelamento do tempo", por outro ele este próprio gesto deve ser concebido como parte de um processo cognitivo que só se realiza em movimento, mais especificamente com a movimentação da atenção.

Um terceiro ponto pode ser dito agora, mas será esclarecido mais adiante, quando entrarmos nos terrenos da "experiencialidade" e do "experiencialismo": a necessidade de empregar instrumentos retóricos modernistas para representar os "eventos modernistas" em White, e a possibilidade de "acessar" a atmosfera do passado em Ankersmit, ambos dependem de algum tipo de semelhança formal entre as representações (materializadas ou "internas") no presente e o passado que elas representam. Isto porque o próprio passado existiu na forma de representações do mundo por parte de seres humanos. Adiantemos: esta semelhança formal reside precisamente no fato de que agentes no passado e historiadores no presente lidam com o mundo por meio de "compreensão", reunindo partes (elas próprias todos de outras partes) em totalidades simultâneas.

\subsubsection{A relação entre narrativa e "mundo real", presente e passado, representação e experiência}

\section{a) Compreensão configuracional: uma "rede de descrições sobrepostas"}

A preocupação inicial de Mink não era tanto com textos mas com o próprio "ato mental" que chamava de "compreensão". Inserindo-se em uma longa lista de críticos do "imperialismo metodológico" dos proponentes do modelo das covering laws, que consideravam que toda explicação consiste na subsunção de um evento particular a uma lei geral, Mink afirmava haver ao menos três "modos de compreensão", todos 
igualmente legítimos, que se distinguem como diferentes formas de articular partes e todo. A compreensão teórica, típica das ciências, articula um ou vários elementos particulares a um geral; mas há também a compreensão categorial, típica da filosofia, que aproxima apenas generalizações uma das outras; e a compreensão configuracional, típica da história e da literatura, que articula elementos particulares por meio de narrativas. Em comum, elas possuíam a característica de reunir em um totum simul experiências que ocorridas seriatim no tempo.

Examinando em maior detalhe o funcionamento das narrativas historiográficas ao longo dos anos 1960, Mink buscou em Arthur Danto a noção de "eventos sob descrição" e afirmou que tais textos possuíam ao menos cinco tipos de descrição: as descrições reais (tipo 1) ou possíveis (tipo 2) de ações na perspectiva dos próprios agentes; as "sentenças narrativas" de Danto, que, como vimos, reúnem eventos afastados temporalmente (tipo 3); os conhecimentos obtidos por técnicas inventadas apenas em momentos subsequentes à ação (tipo 4); e descrições baseadas em conceitos surgidos apenas após a ação narrada (tipo 5). Assim, dizia Mink, a historiografia se caracteriza por compor uma "rede de descrições sobrepostas" - isto é, temporalmente sobrepostas, já que as frases e conceitos se imbricam temporalmente e fazem referências mútuas -, que se articulam no todo.

A leitura destas descrições procede linearmente, mas, ao ser compreendida, a narrativa muda de caráter: é compreendida como simultaneidade. Assim:

[N]a compreensão configuracional de uma estória que alguém seguiu, o fim é conectado com a promessa de um começo bem como o começo com a promessa de um fim, e a necessidade de referências para trás cancela, por assim dizer, a contingência das referências futuras. Compreender a sucessão temporal significa pensar em ambas as direções de uma só vez, e então o tempo não é mais o rio que nos carrega, mas o rio em vista aérea, montante e jusante vistos em uma única panorâmica (MINK, 1987: 56).

Mink conclui, com base nisto, que a narrativa histórica "cancela o tempo", a ponto do o tempo não ser "da essência" dos juízos históricos. E, assim, afirma que “estórias não são vividas, mas contadas". Três observações podem ser feitas em relação a este slogan.

Primeiro, ainda que não exatamente falsa, ele dá a entender uma concepção estática da atividade prática de narrar o passado - e Mink sem dúvidas concordaria que tal atividade é essencialmente prática, já que, em texto de 1965, assemelhou o juízo histórico à phronesis. Além desta concepção não se sustentar quando aplicada à 
(re)inserção do significado expressado pelo texto no mundo da vida, ele também falha em relação à dinâmica interna da leitura do texto histórico, que culmina na sua compreensão. Em 1968, ele apresentava e aprofundava as reflexões de Danto, que a seu ver, possuíam a rara virtude de "levar o tempo a sério", como contraponto às de W. B. Gallie. Em Philosophy and the Historical Understanding, de 1964, Gallie havia introduzido o conceito de "followability" ("seguibilidade"), segundo o qual a compreensão histórica resulta do processo de seguir a leitura o texto rumo a uma conclusão. Gradualmente, na leitura, aquilo que se apresentava como aberto vai se fechando, produzindo inevitabilidades em situações outrora contingentes. Mas, de uma perspectiva segundo a qual o ato de escrita interfere na circulação social de significados, não se trata tanto de um cancelamento quanto de uma reconfiguração, na medida em que a memória do processo da experiência de leitura não se perde quando as partes são reunidas mentalmente em uma certa configuração simultânea. Tal experiência é parte constitutiva de como o leitor realizará o "ato mental" de compreender uma rede de eventos. Além desta sobrevivência da experiência da leitura, o fato de a compreensão ocorrer no mundo da vida e ser caracterizável como um ato de fala destinado a uma comunidade implica que o cancelamento do tempo presume, logo em seguida, um retorno do movimento, no qual, porém, a memória da compreensão simultânea se mantém. A mesma lógica se repete na ida do todo à parte. Embora seja verdade que o todo da representação não pode ser decomposto sem que cada parte mude de sentido e que o todo mude de sentido, pode-se ir à parte mantendo o todo em mente. Adicionalmente, notemos ainda que, ainda que as promessas abertas pelo texto se cumpram em uma configuração específica, o simples fato de que elas tenham se anunciado na experiência já implica que elas podem ser reabertas e cumpridas em outro texto, de outra maneira. ${ }^{82}$

Esta conservação de uma memória da experiência anterior está presente na filosofia de Collingwood, da qual Mink deriva o "tipo 5" de descrição. Em

\footnotetext{
${ }^{82}$ Como observa Jonathan Gorman (2013: 18), há uma grande diferença "entre, por um lado, filosofar sobre os significados - sentidos, referências, intenções e afins - das sentenças breves com as quais os filósofos analíticos e teóricos dos atos de fala mais caracteristicamente lidam, e, por outro lado, filosofar sobre significados no nível das narrativas. A diferença mais marcante é que o primeiro tipo de filosofar lida com conceitos que tomam tão pouco tempo para pensar que eles são comumente analisados como se não tomassem tempo nenhum." E, como ele complementa mais adiante: "mas pensar o conceito expressado por uma narrativa requer tempo." (grifo no original). Mink leva muito a sério a distinção apontada por Gorman entre sentenças e narrativas, e sem dúvidas também "leva o tempo a sério". Mas ao dissociar o conceito da narrativa da experiência de leitura que o produziu, ele dissocia a narrativa dos processos vitais dos quais ele efetivamente pertence.
} 
Collingwood, a preservação das experiências anteriores, em forma modificada, em um nível de consciência mais reflexivo aparece como uma caracterização não (apenas) da história-escrita, mas da dialética operativa na história-processo. Embora ele não o diga neste caso, uma implicação de suas reflexões é que a distância conceitual entre a ação e a narração não só se manifesta nas descrições, mas também contamina todo o texto. ${ }^{83}$ Isto é: a própria natureza das demais descrições é modificada na medida em que o texto parte de um "esquema conceitual" distinto (expressado tanto pelas descrições de "tipo 5" quanto pela sua organização holística), mesmo que o significante de cada descrição individualmente não seja modificado. (Mas, adicionalmente, isto nos conduzirá à questão colocada por Mink sobre o que pode significar o termo "mesmo evento"; afinal, onde termina o evento real e onde começa o seu significado é algo difícil de especificar.) Afinal, se, como mostrou Saussure, o processo de significação é produzido pela relação dos significantes com todos os demais, também é verdade que o significado de cada parte depende de sua relação não só com as demais partes, mas também com o todo em que ela está inserida. ${ }^{84}$ (Para dizer de modo mais simples: as descrições de "tipo 1" não têm significado por si só: sua justaposição com as descrições de "tipo 5" interfere em seu significado.) Esta conclusão é demandada pelas teses do próprio Mink. Isto também é uma forma de dizer que as descrições não são blocos autônomos que compõem um todo; e, no entanto, também não devemos cair no equívoco oposto e negar uma autonomia relativa às partes: embora a configuração de uma experiência refigurada em descrições do tipo 1 se modifique à luz de sua totalidade, algo de sua condição original se mantém, ainda que como parte de um novo todo.

No sentido empregado por Danto, Mink e White, o evento é uma "unidade de compreensão": isto significa que a unidade não existe no passado, como se os eventos fossem blocos previamente delimitados, mas sim que ela surge no próprio ato de compreender. O evento-compreendido, por sua vez, só existe no interior de uma narrativa, que é, também ela, segundo Mink e White, uma unidade de compreensão. Uma consequência deste raciocínio é que a compreensão não necessariamente "cancela o tempo". O "plano de fundo" (cf. CARR, 2014) do "evento" é mais apreendido pela

\footnotetext{
${ }^{83}$ Assim, Mink e Collingwood são uma dupla que levam tão a sério quanto Ankersmit e Danto o problema da mudança conceitual de um período histórico para outro.

${ }^{84}$ Para o endosso acertado de Ankersmit a esta tese, aplicando-a não às descrições no interior de uma representação, mas à dependência de uma representação em relação a todas as demais para que ela tenha significado, ver ANKERSMIT, 2012: 126-156.
} 
atenção do que o plano de fundo" da narrativa como um todo, mas esta narrativa pode ser, ela própria, compreendida como um evento dentro de uma totalidade mais ampla. $\mathrm{O}$ gesto de atenção por meio da qual a percepção se direciona a este nível mais amplo já muda seu significado. Certeau aponta nesta direção ao falar na necessidade de recortar um presente para que se possa narrar sobre o passado: o passado narrado tem como "plano de fundo" tanto um passado ainda mais antigo (em Sublime, Ankersmit afirma ser esta a função do "mito", necessário para que haja "história") quanto um presente presumido como diferente dele. A diferença é a ênfase de atenção: a compreensão da narrativa como um todo é mais propícia a ser isolada da totalidade em que se insere, mas adquire seu sentido (ao menos implicitamente) a partir de como se situa em relação a ela. Em última instância, o significado da representação é sempre situacional. Neste sentido, White tinha razão ao afirmar que toda história propriamente dita pressupõe também uma filosofia da história: um evento existe em contraste com o plano de fundo de uma narrativa; mas a narrativa também se situa no contraste de uma imagem mais ampla, ainda que vaga, de como é a história como totalidade, e se a atenção for redirecionada para este nível, então ela ressurge no formato de um "evento" e não mais no de uma "narrativa de eventos". A reunião entre partes e todo(s), por meio da qual se produz compreensão, é (potencialmente) uma constante atividade de congelamento e descongelamento (não só do tempo, mas, para ampliarmos a metáfora, das próprias unidades). Isto é uma concepção adicional do anti-fundacionalismo: não apenas não há pontos de partida fixos, mas também não há blocos indivisíveis naturais: a compreensão produz um bloco que só faz sentido enquanto unidade, e, nesse sentido, é “indivisível". Mas o destino de toda unidade é ser dividida e reconstruída em outras formas - e nesse sentido, devido à sua participação na sociedade humana e portanto fundada sob suportes instáveis, ela é invariavelmente "divisível".

Em segundo lugar, ao caracterizar uma dada descrição de eventos como uma “promessa”, Mink indica, acidentalmente, a afinidade entre a sua noção e o figuralismo. Assim, a relação entre a figura e o preenchimento é de natureza tal que, ao conectar uma à outra, a natureza de ambas muda. Mas também é parte do processo, como apontamos, que algo de sua condição anterior sobreviva no novo formato. Em relação à discussão da contingência entre Gallie e Mink, o relevante é que, dependendo da atitude filosófica (que pode ou não ser "irônica", como argumentaremos adiante), é possível manter em maior ou menor grau a condição de ter sido contingente do evento que, em seguida, é "fechado". 
Em texto sobre Auerbach, Ankersmit (2001: 203) comenta que “é impossível não ser impactado pela similaridade da figura com o que Louis O. Mink se referiu como a compreensão configuracional." Ele então descreve como, para Mink, os eventos compreendidos são reunidos e remetem uns aos outros. Mas, em nota, aponta também uma "importante diferença": "Embora a figura tenha a ver com a própria realidade histórica e seja, no fim das contas, uma noção ontológica, a compreensão configuracional de Mink é uma resposta à questão da natureza do conhecimento histórico e, logo, tem um status epistemológico." (idem: 307) A observação é correta, mas, como Mink trata de atos mentais realizados por seres humanos em sua existência histórica (i.e., nos termos "figuralistas" de White, membros de "sistemas históricos"), suas reflexões sobre compreensão configuracional devem ser, de alguma forma, ontologizáveis. ${ }^{85}$ Vale para este deslocamento do que originalmente encontramos na filosofia de Mink o que Gadamer explicou acerca da de Heidegger (GADAMER, 1999: $385-408)$ :

Compreender ... é a forma originária de realização da pré-sença, que é ser-nomundo. Antes de toda diferenciação da compreensão nas diversas direções do interesse pragmático ou teórico, a compreensão é o modo de ser da pré-sença, na medida em que é pode-ser e "possibilidade" (grifos no original). (idem: $392)^{86}$

Assim, da perspectiva da processualidade histórica, a representação preenche alguma das potencialidades históricas - não apesar de sua autonomia de significação, mas com ela - e abre outros usos possíveis para o futuro. Aqui, compreender é incontornavelmente um ato prático, i.e., simultaneamente ético e estético.

Ankersmit, especialmente, considera que a distância entre a perspectiva dos agentes e o significado retroativamente atribuível às suas ações é o elemento essencial a ser destacado das filosofias da história de Danto e Mink. ${ }^{87}$ Cabe apontar, aqui, que esta relação entre uma certa descrição da experiência de agentes passados e a coligação ou o texto que em que se entrelaçam eventos - isto é, entre as próprias dimensões que Ankersmit aponta serem incontornavelmente afastadas, que poderíamos caracterizar

\footnotetext{
${ }^{85}$ Algumas especificidades são importantes, porém. Como veremos, uma delas é a "complexidade" do entrelaçamento entre descrições presentes na história e na literatura.

${ }^{86}$ As semelhanças entre Mink e Gadamer são ressaltadas em várias passagens do capítulo de Sublime Historical Experience que Ankersmit dedica a Gadamer.

${ }^{87}$ E como vimos, mesmo o caso de Danto, que discutimos no presente parágrafo, não leva em conta tão plenamente quando Ankersmit gostaria esta tese - que é, em suma: "Significado histórico é diferente da intenção do agente.” (ANKERSMIT, 1994: 35) No mesmo local, Ankersmit cita Walsh, Danto e White como exceções ao que, em sua leitura, equivalia ao abandono desta questão: a ênfase da filosofia da história no tópico da pesquisa, mais do que no da escrita (momento em que o significado é produzido).
} 
como "pesquisa" e "escrita", com o risco de obscurecer a constituição mútua de uma e outra - já se dá no modelo figural. E assim entra o jogo o fator ético da escrita da história, o terceiro item do nosso conjunto de observações sobre a relação entre "narrar" e "viver" a partir de Mink.

Como a história-escrita está situada em uma realidade humana que é ela própria histórica, a história-processo, esta atividade por meio da qual membros específicos de uma sociedade refletem sobre seu passado ativa ou deixa sem preenchimento as figuras do passado. Neste novo nível reflexivo, repete-se a própria lógica já operativa no nível do qual ela se afasta para que possa tomá-lo como objeto. Neste processo, como não é possível não proceder ativamente na narração de um passado que não fala por si só, não há como não se fazer algo com aquilo que agentes do passado fizeram.

Este entrelaçamento e suas implicações éticas ficam claros em um raro diálogo público entre Danto e White - estimulado por Robert Doran pouco antes da morte de Danto, em 2013 - sobre as semelhanças entre os "sistemas" de Danto e de White. Doran sugeriu a Danto que a "mimesis figuracional" que White buscou em Auerbach serviria como elo entre ambos. ${ }^{88}$ Danto distinguiu esta mimesis da "profecia" que já criticara em Analytical Philosophy of History. No caso da mimesis figuracional, "algo como a história acontece duas vezes", permitindo que a história seja um "guia para os perplexos". Aqui Danto reconhece a semelhança entre ambos, e acrescenta: "A ideia de White é de fato muito rica, um produto de Wayne em seu auge". Por um lado, como afirma Danto, uma frase como "Petrarca abriu o Renascimento" não corresponde a algo que Petrarca poderia ter consciência de estar fazendo, já que articula suas ações a eventos ocorridos posteriormente. Assim: "O que quer que Petrarca tenha feito, ele não teve a intenção de abrir o Renascimento." (DORAN, 2013: 113) Porém, como complementa White em resposta:

Mas quanto a Petrarca: embora ele certamente não tenha "pretendido abrir o Renascimento", é inegável que ele visualizou um renascimento [renaissance or rebirth ${ }^{89}$ de sua noção de cultura clássica, que ele tinha avançado como um programa possível para a sua própria época ou para alguma época futura. Esta possibilidade, na forma específica em que Petrarca a apresentou, repousou como que adormecida até que viesse a ser selecionada por acadêmicos e intelectuais posteriores como uma possibilidade para eles mesmos de uma maneira que não era para Petrarca. Ao construir seu programa com base no de Petrarca, eles efetivamente constituíram Petrarca como um dos arquitetos daquilo que, por meio de suas ações, se tornou o Renascimento (mas mesmo este "Renascimento" não foi constituído como uma realidade

\footnotetext{
${ }^{88} \mathrm{E}$ a seção anterior, como vimos, endossa esta proposta.

${ }^{89}$ White repete aqui a terminologia de "What is a Historical System?"
} 
"histórica" antes dos escritos de Jules Michelet e Jacob Burckhardt no século XIX).

São considerações como estas que me levaram a ver a historiologia ou historiosofia (Ocidental) como um relacionamento dialético complexo entre pessoas ainda vivas e aquelas que estavam mortas ou morrendo, em vez de um processo em que alguma abstração chamada "o passado" influencia, coloca limites a, ou determina uma outra abstração chamada "o presente". ${ }^{90}$ De fato, é um processo em que o que parece estar ainda vivo ou ao menos ainda não morto do passado pode ser violado, desrespeitado, transformado e destruído pelos vivos. Por que tal violação, desrespeito, transformação ou destruição deveria nos horrorizar, e por que, ainda que ela devesse nos horrorizar, ela pode não fazê-lo, é o problema que motiva a reflexão ética sobre história, consciência histórica e o valor que a história tem para nós. (DORAN, 2013: 213)

Esta concepção do relacionamento entre presente e passado, entre vivos e mortos, é uma caracterização retroativa justa, embora nem sempre facilmente visível à primeira vista, da produção intelectual de White já há quase seis décadas. Porém, verse-á requer algumas modificações das propostas dele sobre enredamento e tropologia e também, para os nossos propósitos, das de Mink sobre compreensão - nem sempre compatíveis com suas concepções e finalidades éticas. Muito disso passa pela tensão entre as dimensões descritivas e as dimensões prescritivas de suas análises da representação histórica: White, muito mais prescritivo que Mink, indica a desejabilidade de narrações abertas, tensas em detrimento das fechadas, coerentes; mas ambos descrevem um tipo de operação que usualmente produz fechamento (tropologia, enredamento, compreensão). Mas insisto que este fechamento, situando-se no nível instável da realidade humana, é mais bem compreendido à luz de sua natureza processual e provisória, o que equivale a dizer, para empregarmos o termo oposto: aberta. (Macy dá conta desta dinâmica entre fechamento e abertura dos sistemas, que operam holisticamente - o "sistema histórico" de White, estruturado no modo da

\footnotetext{
${ }^{90}$ Cabe notar que este trecho pode ser lido com ao menos duas ênfases diferentes. Um deles é a indesejabilidade de tomar passado e presente como dois blocos temporais autônomos, e a preferência pela ênfase na relação entre t2 e t1 - relação esta que é precisamente o que Mink esclarece com a noção de compreensão, por meio da qual múltiplos eventos se entrelaçam figuralmente e são vistos à luz de uma totalidade - sempre parcial - de relações. De fato, em "Uneven Temporalities/Untimely Pasts: Hayden White and the Question of Temporal Form" (DORAN, 2013: 119-150), Harry Harootunian localiza em alguns pontos da obra de White uma abertura para "temporalidades desiguais", para formas múltiplas de interpenetração entre o que poderíamos chamar de passado e presente. Mas isto também significa que em muitos outros pontos esta abertura inexiste. Uma segunda forma de ler o trecho é reconhecendo sua ênfase na retrospecção da relação entre passado e presente. Esta retrospecção existe, mas nesse caso pode ser que ele presuma que, da impossibilidade do passado de "influenciar, colocar limites a, ou determinar" o presente, siga que ele não possua poder de tração sobre as decisões do agente no presente. Com isto não concordo (e trata-se de uma afirmação comum por parte de White e dos autores pós-modernistas de modo geral), e a segunda parte do trabalho exemplificará alguns argumentos e explicará os motivos do nosso posicionamento. Basta notarmos que, no próprio argumento que White apresenta aqui, o que as gerações seguintes fizeram com o "renascimento" intencionado por Petrarca não foi causado por ele, mas produziu algo novo na dependência do que ele fez.
} 
"compreensão" que Mink caracterizou, não é exceção - falando em "sistemas abertos".) $)^{91}$ Desse modo, a manutenção de uma posição autoconsciente diante do processo - possibilidade prevista e requerida pelas filosofias de Collingwood e de White -atua como antídoto para os riscos dos textos produtores de fechamento.

Em terceiro lugar, e de maneira particularmente central, surge a necessidade de complexificarmos a relação entre narrar e viver (Mink), ou entre estórias narradas e estórias vividas (Carr), ou ainda entre representações e representado (Danto), quando esta última distinção é aplicada para escrita histórica e a experiência vivida dos agentes históricos. Vejamos.

\subsubsection{Síntese de sínteses de heterogêneos: Mink à luz de Carr e vice-versa}

A formulação de Mink, sobre a qual discorremos na última seção, é um dos alvos centrais de David Carr no livro Time, Narrative, and History, de 1986: para ele, Mink (como outros autores de uma tendência que ele descrevia como "de destemporalização da narrativa") operava uma "distinção totalmente falsa entre viver e narrar". Recorrendo à fenomenologia de Husserl e Heidegger, e mais adiante à teoria do reconhecimento de Hegel, ${ }^{92}$ Carr argumenta que mesmo as experiências individuais mais básicas contêm referência a um passado imediato (retensão) e expectativa de futuro (protensão). O exemplo de Husserl é o de ouvir uma melodia. Assim, dizia Carr, “a função narrativa é prática antes de ser cognitiva ou estética”. Isto, para ele, se estende também ao nível coletivo. Indivíduos se identificam e agem socialmente por meio da formação de identidades coletivas; assim sendo, já nascem em um mundo préconfigurado e precisam lidar com estas configurações já dadas, seja aceitando-as, seja buscando modificá-las. Carr desenvolve sua argumentação com recurso à famosa passagem de Hegel sobre a "Dialética do Senhor e do Escravo" na Fenomenologia do Espírito (HEGEL, 1992, 119-134). Para Carr, os processos descritos por Hegel - luta de

\footnotetext{
${ }^{91}$ Como entidades lógicas, a compreensão e as "substâncias narrativas" são fechadas. Mas como elas são teorizações de criações de organismos vivos, elas estão destinadas a ser reproduzidas a partir do feedback dos ambientes em que se encontram - desde o contexto intelectual até as demandas sociais - e mesmo naturais: sem tomar literalmente demais a distinção entre cultura e natureza, tomemos o exemplo do colapso climático antropogênico - mais amplas. Ankersmit contra-argumentaria, com razão, que cada novo feedback produz uma nova "substância narrativa" ou "compreensão". Não discordo, mas observaria - de acordo com Kuukkanen, por exemplo - que há algo de "destacável" nas representações, de modo que a nova representação produzida pode ser dita como possuidora de uma "tese" compartilhada com um conjunto de outras representações.

${ }^{92}$ Em 1974, Carr publicou um estudo sobre a ampliação do espaço concedido à história no pensamento de Husserl, intitulado Phenomenology and the Problem of History. Antes disso, em 1970, foi publicada sua tradução para o inglês de A Crise das Ciências Europeias e a Fenomenologia Transcendental.
} 
vida e morte, dominação e comunidade - não descrevem um processo processo histórico empiricamente verificável tanto quanto um esquema das relações comunitárias em geral. É relevante, para ele, que os indivíduos tenham se associado por meio de sua ação consciente: "O grupo é constituído por indivíduos que estão conscientes e assertivos de sua independência ( $\mathrm{Eu})$ mas que voluntária e livremente se associam (Nós)", de modo que as diversas "consciências-de-si essentes" possam se interpenetrar, formando um "Eu, que é Nós, Nós que é Eu". Afinal, a adesão por dominação nos levaria de volta ao problema do senhor que domina o escravo: seu reconhecimento não provém de outra consciência igualmente livre, e, dessa forma, não satisfaria o desejo último que conduz todo o processo, que é o desejo por reconhecimento. ${ }^{93}$ (CARR, 1991: 138-146)

Ora, Carr trata da semelhança estrutural, narrativa, entre aquilo que foi vivido no passado e aquilo que é "contado" no presente; Mink, por sua vez, fala de como eventos específicos recebem retroativamente uma ordenação que não possuíam. Assim, as teses de ambos podem ser articuladas, pois se é verdade que "as ideias" (CARR, 1991: 26) de início, meio e fim também se manifestam na experiência, ainda assim os inícios, meios e fins dos eventos refigurados no interior de uma dada narrativa não possuíam tais funções no momento de suas ocorrências. Carr (1991: 176) reconhece a distância entre a consciência dos agentes e os resultados de suas ações; sua insistência é na forma semelhante entre ambas as narrativas. Estes "espaços" entre as significações passadas e suas ressignificações no presente são a própria fonte da liberdade humana de redirecionar o processo histórico no qual estão inseridos e em relação ao qual constróem agentes coletivos por meio de narrativas. Esta margem de liberdade nem sempre é pretendida ou desejada: as formas de produzir sentido tendem a ser relativamente comuns e compartilhadas e podem persistir por tempo suficiente para serem "a mesma" (i.e., subsumíveis a um mesmo tipo, o que não significa que as representações individuais sejam repetíveis) na representação posterior e seu conteúdo de representações anteriores. Nesse caso, a simples transformação de uma síntese

\footnotetext{
93 Retomaremos este argumento mais adiante com Judith Butler, que enfatiza as consequências despossuidoras desta existência sempre já no interior de horizontes temporais narrativizados. Não se tratará de negar a importância do elemento voluntário e argumentar que as constituições de agentes coletivos envolvem coerção (pois, embora o façam, é certamente argumentável que não produzem reconhecimento mútuo nestes casos), mas de enfraquecer um possível identitarismo que poderia ser depreendido das leituras de Carr, White e até mesmo Runia. Esclarecerei isto adiante. Há aqui uma ponte adicional com a segunda parte do trabalho, que trata de experiência: o papel das dinâmicas de reconhecimento no estabelecimento de um certo tipo "melancólico" de "relação com o passado" que aparece na sequência de "experiências históricas sublimes" será discutido no capítulo 4.
} 
completa em parte de outra síntese completa modifica sua função, mas mantém intactos elementos que, como argumentarei adiante, são parte do seu significado: a emoção ou afeto predominante, o tipo de atitude proposto diante dela, o tipo de enredo a que suas diferentes particularizações são submetidos, possivelmente também o que afirmaremos ser o elemento "destacável" de sua tese. Mas estes momentos de aparente coerência entre linguagem e mundo (entre presente e passado) são momentos em que o "espaço estético" e a liberdade dele decorrente não é percebido como tal, mas isto não significa que ele não exista, nem que não esteja operando ali: a relação sendo entre figura e preenchimento, há uma relação, mas ela não é de espelhamento ou mera repetição sem diferença. O que significa também que, parafraseando Carr, a função só pode ser "prática" por ser primordialmente estética; ao ser cognitiva, ela segue exercendo estas duas funções.

A crítica de Carr permite-nos reformular a tese de Mink. Não se trata mais de afirmar que "estórias não são vividas, mas contadas"; mas sim de apontar que as estórias contadas não são as mesmas que foram vividas. A ação contada no contexto de uma estória, vista à luz de suas consequências e ressignificada ao ser ponto no contexto narrativo específico em que se encontra, já não é a mesma. Se levarmos em conta que cada um destes eventos no interior de representações foi vivenciado na "realidade humana" com forma narrativa, então temos que considerar que as representações historiográficas apresentam tensão entre ordens narrativas (JAY, 1992). Ora, o que as representações fazem, primordialmente, é direcionar a atenção para aspectos da realidade, enfatizando alguns e obscurecendo outros. Não creio que seja diferente do que cada descrição de evento e mesmo cada percepção faz: ${ }^{94}$ apenas parece ocorrer que, se a linguagem humana já naturalmente possui multiplicidade de significados possíveis, esta margem se torna tão incomensuravelmente maior quando se trata de articular toda uma gama de eventos em uma totalidade simultânea significativa que este uso "de segundo nível" da linguagem se torna um tanto mais autônomo que os eventos nela

\footnotetext{
${ }^{94}$ Este aspecto é insinuado em certos ensaios de White em Trópicos do Discurso, especialmente "A Interpretação na História"; buscarei trazê-lo a um papel mais central, de modo compatível com a formulação mais recente de Ankersmit acerca da representação histórica. A centralidade da atenção no caráter processual da relação entre representação e experiência parece se dever ao fato de que, em primeiro lugar, só há movimento por haver consciência, e só há revelação ou desvelamento do mundo por meio da atenção. $\mathrm{O}$ fato de que a atenção pode ser demandada (ainda que não obrigue a uma resposta, menos ainda a respostas específicas) nos impede de cair em um solipsismo berkeleyano ou um presentismo sugerido por certas afirmações de White. Tal demanda ocorre porque o sujeito e o mundo (passado ou presente) não são radicalmente separados, mas conectados de maneira processual e/ou física. Quanto ao aspecto mais imediato da percepção, também mencionado acima, creio estar de acordo com LEOPOLDO E SILVA, 1994: 100.
} 
inseridos. Amplia-se ainda mais a margem de liberdade estética de que falávamos anteriormente. Assim, se cada representação realiza uma "síntese do heterogêneo" (RICOEUR, 1994), e se, caso direcionemos nossa atenção sobre suas partes específicas, vejamos que também ali há "síntese de heterogêneos" (pois também há narrativas, representações, etc.), então a representação histórica realiza uma síntese de sínteses de heterogêneos. Mas sequer é possível, quando seguimos descendo de nível, e encontrar uma base sólida: todo o movimento entre parte e todo produz tensões adicionais que não chegam a se resolver, e reorganiza todo o resto. Assim, é necessário levar o holismo para além do interior de uma única representação, e reconhecer que as mudanças em um dos níveis do sistema afetam todos os níveis de uma só vez. Observemoso ainda: como o que é parte em uma representação não é necessariamente algo menor no mundo, a descida de nível não chega a um eventual nível atômico (ou, mesmo que ele inexistisse, a um nível onde não é mais necessário descer): a "descida de nível” rumo à particularidade de cada "heterogêneo" apresentado na síntese é relativa a cada reordenação narrativa, e portanto o processo pode seguir indefinidamente.

Relembremos a discussão do capítulo 1, no qual vimos que, para Danto, seres sujeitos são ens representans. Danto considera que o conceito de arte só pode existir em contraste com o conceito de realidade. Para as reflexões sobre história, porém, nossa hipótese é de que há algo uma dimensão estética comum que une viver e narrar, experienciar e representar, de modo que a realidade surge parcialmente entrelaçada com representações e narrações (pois se, em termos da escala de formas collingwoodiana, o primeiro nível de consciência não é representativo, o segundo é, e a "realidade humana" é composta por um entrelaçamento destes níveis e dos demais.) Assim, o surgimento histórica da arte em Danto equivale à ocorrência de uma experiência histórica sublime em Ankersmit: a introdução de uma dimensão reflexiva na realidade, que Danto descreve como simultaneamente dentro e fora da história, e que significa, talvez mais precisamente, que a perspectiva distanciada segue sendo histórica. Com o surgimento do conceito de arte, para Danto, a representação deixa de ser uma dimensão "mágica" da própria realidade e passa a ser uma substituição de algo ausente. Antes disso, havia para Danto a mesma imediaticidade que para Ankersmit (como veremos, e questionavemente) havia anteriormente às experiências históricas sublimes: a realidade não era contemplada a partir da perspectiva distanciada que se situa no - ou é possibilitada pelo - vão entre a realidade e sua representação. Mas uma das formas de afirmar nossa conclusão parcia sobre a relação entre representações do presente e 
representações do passado é afirmar que, no entrelaçamento entre viver e narrar teorizado por Carr, há algo de "mágico" na própria realidade - pois estamos falando da realidade humana, composta também por pensamentos e não por coisas estáticas que apenas posteriormente ganharão vida por meio de uma consciência historiográfica. Esta é uma forma mais impactante de propor que, como disse antes, não é que "a função narrativa é prática antes de ser cognitiva ou estética”, mas que a compreensão é simultaneamente prática e estética - e isto possibilita o tipo peculiarmente histórico que cognição, no qual sujeito e objeto se entrelaçam de uma maneira que não ocorre nos campos mais hard das ciências.

\subsubsection{A distinção entre descrição (de eventos) e narrativas}

Em "Narrative Form as a Cognitive Instrument", de 1978, Mink denunciava a permanência do pressuposto da "História Universal": ainda que já não fosse usual, no momento da escrita daquele artigo, a adoção explícita da tese de o passado é uma "estória não contada", cujos "eventos" são unidades encontradas no passado que podem ser reunidas em narrativas diversas no presente sem que isto modifique seu sentido, ainda assim a ideia sobrevivia, ainda que irreconhecida.

Havendo empregado o termo "evento" até as últimas páginas daquele texto, Mink refletia: "Mas praticamente nenhum conceito é menos claro do que o de 'evento."” Ele então especificava, em primeiro lugar, não haver dificuldade em conceber "um evento complexo cujas partes também sejam eventos." Como a articulação entre estes eventos-parte com o evento-todo teria caráter estético, esta afirmação de Mink indica a necessidade de se tomar a diferença entre representações e descrições de eventos nos moldes em que propomos, de tensão entre diferentes níveis. Isto tornaria possível falar em representações e sub-representações, ${ }^{95}$ com o intuito de indicar as diferentes de

\footnotetext{
${ }^{95}$ Mas isto, é claro, seria polêmico e abriria espaço para objeções como a da possibilidade prática do evento referenciar o passado, acompanhada da impossibilidade prática da representação fazê-lo: ela, para Ankersmit, apenas pode ser sobre o passado. Mas empregarei o termo provocativamente na próxima seção. Afinal, insistir no caráter estético das descrições e afirmar que, no processo de compreender o passado, elas são constantemente refiguradas em representações (são partes que viram todos) à luz do conhecimento prévio do leitor, permite levar em conta a crítica de Chris Lorenz (1998), para quem, não sem razão, White e Ankersmit professam um "positivismo invertido", localizando toda a referencialidade no nível das frases e nenhuma no nível estético. A estética está em todos os níveis, ela é apenas mais complexa nas representações que nas descrições. Mas, repitamos: o que é descrição pode ser reapresentado à mente como representação, e o que é descrição já produz significados (não há, afinal, descrição padrão).
} 
função de cada representação na relação parte-todo: ${ }^{96}$ tanto no nível do todo quanto de cada parte, uma dada descrição destaca aspectos do passado e propõe um ponto de vista a se adotar diante deles. É isto o que Ankersmit atribui às representações históricas (ver ANKERSMIT, 2012), e, como se verá em citação abaixo, é o que Mink implicitamente atribui às descrições de evento historiográficas.

Mink insistiu que o diferencial dos "instrumentos cognitivos" como a história e a literatura estava na sua natureza de "estórias complexas". Assim, a função descritiva de uma sub-representação demanda que ela destaque aspectos intersubjetivamente aceitos ou passíveis de aceitação, sem haver a necessidade de apresentar evidências adicionais. Afinal, quanto isto ocorre, aí sim é necessário apresentar o aspecto em questão na forma de representação, isto é, articulando partes específicas e a partir delas produzindo o significado desejado para o todo..

Mas as outras reflexões são ainda mais relevantes para a nossa discussão sobre a relação entre tempo e narrativa.

Em seu texto de 1978, Mink assim prosseguia - com claras referências a Danto - seu exame da noção de "eventos sob descrição": "é claro que não podemos nos referir a eventos enquanto tais, mas apenas a eventos sob uma descrição; então pode haver mais do que uma descrição do mesmo evento, todas elas verdadeiras mas se referindo a diferentes aspectos do evento ou descrevendo-o em diferentes níveis de generalidade. Mas o que nós possivelmente podemos querer dizer por 'mesmo evento'?” O problema com a ideia de "mesmo evento", mostra Mink, é ela pressupor que "o passado é uma estória não contada". Não há "mesmos eventos" porque um evento é uma abstração de uma narrativa, e por isso deveria ser repensado em moldes diferentes da "estrutura conceitual da ciência":

... o conceito de evento é primariamente ligado à estrutura conceitual da ciência (e àquela parte do senso comum que adotou a linguagem e os métodos da ciência); mas naquela estrutura conceitual ele está purgado de todas as conexões narrativas, e se refere a algo que pode ser identificado e descrito sem qualquer referência necessária à sua localização em algum processo de desenvolvimento - um processo que apenas a forma narrativa pode representar. Logo, falar de uma "narrativa de eventos" é quase uma contradição em termos. Que aquilo não seja percebido desta forma, eu sugiro, novamente reflete a

\footnotetext{
96 "Apresentações" seria melhor ainda, pelo motivo indicado por White citado anteriormente. Kuukkanen tem razão em criticar o uso da "linguagem representacionalista" por parte dos autores citados. Mas criaríamos confusões adicionais em trocar toda a linguagem empregada pela tradição acerca de um dos conceitos chave de nosso estudo. Então cabe observar, como contraponto a Kuukkanen, que o sentido de "representação" no narrativismo é, embora não de maneira unívoca, desde sempre mais inclinada para Darstellung do que para Vorstellung.
} 
medida em que a ideia de História Universal sobrevive como um pressuposto. (MINK, 1987: 200-201).

Eu diria que, se é por causa da temporalidade que "não há eventos, apenas eventos sob descrição", então a noção de "mesmo evento" só faz sentido de uma perspectiva científica ou cientificista que elimine previamente os aspectos processuais do evento, juntamente com todos aqueles para os quais não há acordo protocolar sobre a linguagem a ser empregada. A postura científica é parte útil e incontornável da produção de um texto historiográfico, mas não é capaz de fornecer um método indiscutível para determinar a natureza do evento sob descrição. Uma representação histórica combina o procedimento científico com a construção de sentido estético, este último tanto no nível da descrição quanto, com grau de indeterminação um tanto maior, no nível da representação enquanto totalidade. Mas mesmo no nível da descrição de eventos a relação entre epistemologia e estética é de subdeterminação: a obrigação de dizer verdades dá às fontes lidas por membros de uma dada comunidade "poder de veto" em relação a várias descrições, mas não determina como será a descrição efetivamente realizada. ${ }^{97}$

A conclusão de Mink é, a meu ver, irretocável. Mas o que ela nos permite dizer sobre a ideia, enunciada por ele próprio em 1970 e já criticada neste capítulo, de que a narrativa "cancela o tempo"? Se já não se trata de pensar as narrativas históricas em moldes cientificistas (o que, como já dissemos, não equivale de modo algum a ignorar a dimensão científica da operação historiográfica), talvez possamos inserir o movimento e a processualidade também no próprio ato de narração historiográfica, não apenas surgido, como Carr argumentou, do mundo "prático" da existência humana, mas também destinado a retornar a ele (como argumentam também Ricoeur e Rüsen). O título do texto de 1978, como dissemos, concebia a forma narrativa como "instrumento cognitivo". Ainda que, como Rik Peters observou recentemente, Mink não tenha chegado a esclarecer o que pretendia dizer com o termo (PETERS, 2016), a noção de instrumento nos indica a importância de focar em seu uso. Isto nos dará subsídios para avançar as perspectivas de Kuukkanen e de White em que a escrita de um texto historiográfico é mais bem compreendida como um ato de fala.

Assim, se por um lado a representação histórica momentaneamente "cancela o tempo", por outro, a atenção aos seus mecanismos internos e um movimento constante da atenção entre todo e parte permite que este instrumento seja usado de modo diverso:

\footnotetext{
${ }^{97}$ Tomo emprestado o termo "poder de veto" de KOSELLECK, 2006.
} 
para iluminar diferentes aspectos da realidade a partir de usos variados da linguagem. Por meio da autoconsciência, é possível evitar as cristalizações de linguagem que naturalizam certas formas de representar o passado, permitindo novamente o uso criativo da linguagem para apontar de múltiplas formas para o passado. Isto abre um espaço essencial para a própria filosofia da história na dinâmica temporal em que a significação de experiências humanas abre possibilidades específicas para projetos coletivos futuros.

\subsection{Representação em Ankersmit}

A formulação mais madura fornecida por Ankersmit sobre a noção de "representação histórica" aparece em Meaning, Truth, and Reference in Historical Representation (2012), e é dela que partirei. Cronologicamente, portanto, o trabalho dá agora um salto retroativo ao ponto de chegada provisório do debate sobre representações no contexto narrativista. Em seguida, discutirei aspectos dos pensamentos de Mink e de White, enfatizando tanto os aspectos que fornecem subsídios para pensarmos a relação entre representação e experiência quanto as objeções que Ankersmit faz a eles, vendo resquícios de transcendentalismo e propondo soluções mais radicalmente historicistas.

Em Narrative Logic (1983), seu primeiro livro, Ankersmit afirmava inexistirem "regras de tradução" capazes de governar a transição entre a realidade e o texto - que, àquela altura, ele chama de "substância narrativa" (Ns, ou, no plural, Nss). Sua preocupação, portanto, se aproxima do anti-fundacionalismo que afirmei haver - ainda que menos explícito, já que os próprios autores não necessariamente formularam suas teses nos termos que lhes foram atribuídos neste capítulo - desde meados do século no narrativismo. Já a partir dos anos 1980 e 1990 (como o próximo capítulo mostrará), Ankersmit se engajou mais diretamente com a obra de White. Em History and Tropology (1994), ele já marcava diferença em relação ao transcendentalismo que via nela. Em Historical Representation (2001), outro aspecto desta distância é enfatizado: aquele que surgiria pela preferência de White pela teoria literária, em contraposição com a do próprio Ankersmit pela filosofia da linguagem. Pois, para este, a abordagem da teoria literária, embora tivesse produzido muitos ganhos, não se ocupava do tema incontornável para a historiografia - $\mathrm{d}$ a relação entre a representação e a realidade.

Uma das distinções central na filosofia da representação histórica de Ankersmit é aquela entre descrição e representação. Ignorar a existência da segunda, cuja natureza 
é estética, e se ocupar apenas da primeira, de caráter epistemológica, era para ele o erro da "filosofia epistemológica da história" - o "dilema da filosofia da história anglosaxônica", como afirmou ele em artigo de 1986, era precisamente entre esta e a alternativa "narrativista", de sua preferência. Assim, já em Narrative Logic ele afirmava que "as frases em uma narratio não têm uma única função, mas sim dupla: 1) como frases elas se referem a (coisas em, ou aspectos de) o passado (de acordo com a interpretação realista da narratio), 2) (em adição à primeira função) como componentes da narratio elas têm a propriedade de uma "imagem" ["'image' or 'picture"'] do passado, i.e., de uma "substância narrativa" (em conformidade com a interpretação idealista da narratio)" (ANKERSMIT, 1983: 94).

Após intitular seu livro de 2001 como Historical Representation precisamente para enfatizar a relação entre duas coisas, a representação e aquilo que é representado, em seu livro mais recente Ankersmit foi ainda mais longe, afirmando que a representação é "um operador triplo" ("a three-place operator"): "a representação (1) nos oferece o apresentado [presented], ou aspecto (2) de uma realidade representada (3)".

Em ambos os livros, Ankersmit comparou o funcionamento das representações com as metáforas. Ambas nos convidam a ver uma coisa (A) em termos de outra (B). Ele aponta também as peculiaridades da representação histórica: usualmente, metáforas produzem interação de significados no domínio da linguagem; já as metáforas históricas, em sua visão, produzem interação de significados em uma só direção, da linguagem para o mundo. (2012: 75) (Embora correta filosoficamente, esta afirmação pode receber uma objeção psicológica: isto é feito no final desta seção. Não concordo que apenas outros historiadores podem produzir objeções: diferentes formas de ativar o passado produzem demandas sobre o sujeito no presente, já que modificam ele próprio, a tradição e o ambiente do qual ele não é inteiramente distinto.)

Mas como vemos o passado em termos de uma representação? Comparemos novamente com a descrição. Tanto a descrição quanto a representação têm regras sobre como articulá-las com o mundo: "as regras semânticas que definem as condições para a verdade proposicional", no primeiro caso, e "regras para relacionar os objetos, ou partes do mundo, com o representado", na segunda. (idem: 77) Mas há uma diferença, para Ankersmit, que é "uma diferença de ênfase": no caso das descrições verdadeiras, há regras intersubjetivamente aceitas sobre como realizar tal articulação; no caso das representações, "pelo contrário, não há acordo geral sobre estes sistemas notacionais: 
são eles que estão em jogo." (idem: 78) "Não é verdade, mas o estilo, o que conta aqui." (idem, ibidem), e "[a r]ealidade não dira em que estilo ela deveria ser representada"; o estilo "não tem fundamentum in re", "não pode ser testado contra a realidade (idem: 77), apenas projetado. E o estilo equivale aqui ao "apresentado", a este nível que não é nem a realidade nem a representação.

Em outros termos, a descrição fala sobre o mundo, e a representação manifestada por uma certa ordenação da totalidade de frases do texto - é um "falar sobre o falar". Cada representação possui seu próprio representado, que indiretamente é conectado à realidade devido ao fato de que cada frase referencial do texto se refere à realidade.

Em seus primeiros livros, Ankersmit reservava o termo "verdade" às frases singulares, referenciais. No mais recente, ele passou a falar também em "verdade representacional". O "apresentado" ou "aspecto" da representação, individualizado pela organização da totalidade de suas frases (incluindo as referenciais), é para ele parte do mundo - enquanto a verdade das proposições é parte da linguagem. Ela produz uma "auto-revelação do mundo para nós", em um nível mais profundo - mas também menos articulado - que a verdade proposicional (idem: 109). Ele especifica: como a aletheia em Heidegger, “o aspecto subsume em si mesmo um conjunto massivo de verdades com uma coerência determinada pela representação que os mantém reunidos dentro de uma totalidade."

Sobre este ponto, façamos duas observações. Primeiro, a ordenação cronológica e lógica funciona nos moldes da escala de formas de Collingwood. Não é Ankersmit pouco afeito ao filósofo inglês - quem o diz, mas lembremos que a escala de formas situa a atuação da mente representacional ou imaginativa no nível mais básico de contato com o mundo, possiblitando, posteriormente, a formulação de verdades proposicionais. Ankersmit dá o exemplo do sal e da água salgada: na lógica da verdade proposicional, sal são os grãos que temos no saleiro; mas a verdade representacional pode ser equiparada à própria água do mar, antes do sal ter sido extraído dela. (idem: 108).

Em segundo lugar, e muito importante, considero que a verdade não "está" de um lado ou de outro, ela surge na interface entre representação e realidade. Para Ankersmit, como disse, o "apresentado" é "um aspecto do mundo mesmo" (idem: 80). É o mundo tal como visto de uma perspectiva, ou seja, se situa na interface entre o mundo e o sujeito; não no sentido de que haja de um lado o mundo e do outro lado o 
sujeito, sem contato entre si, mas no sentido de que sujeito e a parte do mundo representada por ele são parte da mesma totalidade e não existem senão em relação. Os textos de Ankersmit manifestam esta tendência de situar "de um lado" a verdade ou a autenticidade de um lado tanto quando escreve sobre representação quanto quando escreve sobre experiência, mas, a meu ver, um dos grandes méritos de suas reflexões é mostrar que o mundo se manifesta a partir do "ponto de vista" de um sujeito experienciador, de um modo que nem é solipsista (o sujeito não apenas projeta categorias sobre um mundo cujas características são irrelevantes para o processo) nem realista (a mente do sujeito não meramente espelha o mundo, apresentando um modelo linguístico "correspondente" ao mundo). Então, a meu ver, é mais adequado - inclusive ao argumento do próprio Ankersmit - afirmar que o "apresentado" é o que se manifesta na relação entre o sujeito (que produz uma representação da realidade) e a realidade (que é representada pelo sujeito).

Assim, quando Ankersmit diz: "Eu proponho definir a verdade representacional como o que o mundo, ou seus objetos, revelam para nós em termos dos seus aspectos" (2012; grifo no original), ele tem o mérito de apontar que a verdade da representação não é uma projeção linguística sobre um mundo inerte. Igualmente, ele me parece apontar o grau de passividade necessário para o desvelamento de tais aspectos. Porém, ao formular a noção de verdade representaciona assim, ele exclui o equilíbrio necessário, ainda que talvez paradoxal, com a atividade envolvida em fazer o mundo se revelar. O mundo não se revela sem perguntas nem sem tradições para formular as respostas - ou ainda, para receber as respostas - e meu argumento em breve será que mesmo as experiências históricas, que envolvem também um equilíbrio entre atividade e passividade, também precisam de tradições para se expressar, em vez de serem antitéticas a elas. Talvez seja necessário um grande cultivo - de erudição, atenção, sensibilidade - para estar receptivo. Os aspectos, portanto, são melhor concebidos como surgidos na interface entre representação e realidade objetiva.

\section{Sobre-o-quê e existência}

$\mathrm{Na}$ próxima seção, proporemos que, da perspectivas da fenomenologia da leitura, e mais ainda da circulação social de significados, as fronteiras entre aquilo que é descrição e aquilo que é representação são muito mais maleáveis do que tal como Ankersmit as apresenta. Não há contradição, mas diferença de abordagens. Ankersmit talvez discordaria do direi a este respeito, mas é digno de nota que seu próprio 
argumento indica alguma disposição em relativizar a rigidez com a qual a distinção é feita (ou como a leio). Um dos momentos em que isto se manifesta é em sua discussão da noção de "aboutness" ("sobre-o-quê") das representações, em contraposição com a referência das descrições.

Os nomes próprios são, para ele, exemplo claro dos casos em que as frases se distinguem claramente entre o sujeito e suas propriedades. Sobre isto, minha posição é a que segue. Quando falamos "Napoleão existiu", há uma base - um corpo que perdurou por algum tempo - inequívoca, e certos acordos intersubjetivos formados no próprio passado igualmente inequívocos (ainda que feitos, como tudo na realidade humana), como os de general ou imperador. Então, de fato, a frase é referencial. Mas já nas descrições, raramente ou nunca apenas nos referimos: junto com a referência, especialmente se a descrição está inserida em um texto histórico, é trazida à mente, de maneira implícita, uma gama de outras informações (sob descrição, portanto que revelam algumas características e obscurecem outras) e de conexões. Assim como toda história tem uma filosofia da história implícita, tudo que é referenciado traz por tabela o que, em última instância, é um mundo inteiro implícito. A descrição existe (e é de fato distinta da representação) e funciona por uma questão de foco. E podemos notar que, embora Ankersmit provavelmente discordaria do raciocínio deste parágrafo, ele também afirma que a diferença entre descrição e representação é uma diferença de ênfase.

Assim, considero que, além do fato de que Napoleão existiu (estamos falando do mesmo ser), aquilo que aparece como "descrição verdadeira" Napoleão é uma que enfatiza aspectos de Napoleão que, intersubjetivamente, todos concordamos em destacar. Mas ela é sempre uma "descrição da representação"; podendo ser, em alguns casos, uma descrição dos elementos consensuais sobre como olhar para o ser realmente existente que foi chamado de Napoleão.

Em segundo lugar, nessa mesma linha, Ankersmit avança em Meaning uma discussão sobre a "existência" de entidades históricas como Napoleão, o PIB da França em 1950, Holocausto, Renascimento. Ele afirma - e com razão - haver um espectro entre existência e não-existência: "O PIB da França em 1950 existe ou existiu, e o mesmo é verdadeiro quanto ao Holocausto, enquanto o Renascimento é um termo puramente representacional que não tem contrapartida no próprio passado”. (idem: 83) O raciocínio sobre o espectro está correto, mas a maneira pela qual ele o aborda me parece demandar algumas reformulações. Por exemplo, ao tratar do Holocausto, ele me parece estar tomado pela compreensível preocupação em não ser acusado de "deixar 
espaço para ceticismo quanto à existência do Holocausto" (como Heikki Saari [2005] afirmou), e, assim, decide afirmar: “... duvidar da existência do Holocausto implicaria duvidar que certa de seis milhões de judeus foram brutalmente assassinados pelos nazistas - uma dúvida que pode ser imediatamente refutada por uma abundância de evidência histórica." Essa afirmação faz todo o sentido na medida em que os negacionistas questionavam os fatos do Holocausto, mas me parece conceder excessivamente quando tratamos do conceito Holocausto. Sobre ele, não me parece correta a afirmação que segue à que acabo de citar: "Isto traz o termo 'Holocausto' muito mais perto de 'o PIB da França em 1950' do que de 'o Renascimento. O Holocausto é parte do inventório do passado...”. (idem: 82) E a outra parte do extremo também não me convence inteiramente: em que sentido a França "existia mesmo"? Ela existiu como uma substância narrativa, suportada material e intersubjetivamente, visita como realmente existente por muitos seres no passado. Não se trata de irrealidade ou inexistência, mas do tipo "ficcional" de existência que White atribuiu aos objetos da historiografia. White também reserva o termo ficção ao que os textos fazem com o passado, em contraste com aquilo que está presente e está acessível à percepção, mas a meu ver é o caso de levar em conta que mesmo aquilo que está acessível aos sentidos deve ser "feito" ou "ficcionalizado" pelos seres humanos. Assim, as cadeiras realmente existem - e como existem, para além dos pedaços de madeira? Pela forma atribuída a ela por mentes humanas.

Reconhecida esta ficcionalidade presente em tudo que é humano, então se torna mais fácil concordar com a afirmação seguinte de Ankersmit, que distingue as descrições das representações com base no consenso intersubjetivo que há sobre qual é o pedaço da realidade que cada termo trata.

\section{Representações e realidade: pictórica, política, histórica}

Cabe ainda uma observação sobre como o conceito de representação aparece na obra de Ankersmit como um todo - lembremos que ele também possui uma considerável produção na área da filosofia política. Fundamental para a filosofia da representação de Ankersmit é o espaço estético entre representações e aquilo que elas representam. Como sintetiza Menezes (2018: 257):

A palavra "incomensurabilidade" aqui é fundamental, pois é ela que une arte, história e política em um mesmo milieu estético, ao pontuar a incomensurabilidade entre: (a) representação pictórica e paisagem; (b) representação histórica e passado; (c) representação política e o estado de 
coisas na vida pública. Em todas elas, a ausência de regras fixas que nos ajudem a preencher esse gap nos dá, como resultado, a imagem de um mundo partido ou fragmentado (a broken world).

Mas, sendo este trabalho sobre a relação entre representação e experiência, pode ser útil especular sobre as diferenças entre o tipo de relação que se manifestam nas relações entre representações e seus representados - diferenças que não surgem da lógica das representações, mas de algo que não cabe na análise puramente formal, a saber, a realidade sobre a qual elas tratam.A importância desta brecha citada por Menezes reside em que ela abre a possibilidade de agência. Ora, a paisagem não determina como a olhamos. Os seres do passado tiveram agência (desejos, valores, etc.), mas nós hoje temos liberdade em relação ao que fazer com o resultado do que eles fizeram. Há um tipo de responsabilidade ética - não no sentido fundacionalista que Ankersmit associa ao termo, especialmente no uso de Rawls, mas no sentido de White em relação a eles que já não existe em relação às paisagens.

No caso da representação política, o tipo de brecha é, ao meu ver, um pouco diferente. Pois, se as relações formais entre representação e representado se assemelham, as possibilidades efetivas do representado são diferentes. As pessoas que compõem o povo estão vivas, têm desejos ativos e, em menor escala do que o representante, possibilidade de agência. Pois o representado, nesse caso, tem um poder de exercer pressão sobre aquilo ou quem os representa em um nível que nem as paisagens e nem os mortos do passado têm. muito mais do que os mortos do passado e muito, muito mais do que as paisagens. E não se trata, de modo algum, de negar a margem estética de ação do representante, mas de conceber a relação entre representação e representado de modo muito mais dinâmico do que na caso das representações pictóricas e históricas.

Embora critique eticistas como Rawls por se perderem em princípios abstratos em vez de na realidade da vida, a teorização sobre as formalidades da representação também corre o risco de perder de vista as dinâmicas concretas em que cada tipo se efetiva.

Não se trata de negar a possibilidade de ação no nível do representante, mas sim de apontar que, no caso dos representados, é necessário que eles queiram ser moldados da maneira que o governante propõe. É um tipo de liberdade que o barro não tem diante do vaso. Aqui, há um movimento entre parte e (proposta de) todo ainda mais notável que no caso da representação histórica, onde, embora haja movimento, a agência 
intencional é sempre do presente em relação ao passado - embora também nela, embora o passado não possa objetar aos significados que lhe são atribuídos, a atribuição de significado tem efeitos psicológicos sobre os seres vivos no presente e é capaz de "movê-los" (somos "movidos pelo passado", inclusive por como estabelecemos "relações" com ele, incluindo aí a decisão de reprimi-lo).

\section{Descrições descristalizadas: representações e sub-representações}

Em Narrative Logic, como já disse, Ankersmit avança a distinção formulada por Mink entre descrições e representação. Lá, ele falava de uma "função dupla"; mas creio ser possível falar no mínimo em uma "função tripla" dos frases em uma narratio: além de referirem e de comporem parte de uma representação, seus sujeitos (não só as "descrições de evento" de que fala Danto, mas também pessoas e outras entidades mais) são também passíveis de refiguração na forma de representações, que podem ou não ser inseridas em uma representação maior - e, ao fazê-lo, automaticamente modificam a forma pela qual são "compreendidas" (Mink). O uso do termo "aspecto" já em Narrative Logic, que retornará em 2012 depois como instrumento da "verdade representacional" do nível do que em 1983 ele chamava de "substância narrativa", é talvez um sintoma dessa possibilidade de leitura, da qual Ankersmit certamente discordaria. $^{98}$

Assim, de acordo com nosso raciocínio, mesmo que usado de maneira referencial, "Robespierre" é uma representação - não o indivíduo, mas o conjunto de propriedades que nos vêm à mente - pois é na mente de um ser humano específico, com uma configuração particular de experiências e erudição, que a representação vem a existir, com o suporte material fornecido pelo livro - quando este nome é mencionado; "Revolução Francesa" é outra; "Era das Revoluções", mais outra; o texto que situa

\footnotetext{
${ }^{98}$ Por que a diferença entre as abordagens? Porque aqui - como indiquei na seção anterior - , como Mink notou em sua resenha do livro de Gallie, e especialmente de seu conceito de followability, o que está sendo feito é uma "fenomenologia da leitura" e, adicionalmente, da circulação social de significados. Já Mink e Ankersmit elaboram um "objeto teórico" a ser examinado logicamente, i.e., atemporalmente, descontextualizado do processo de leitura. Assim, uma descrição é logicamente distinta de uma representação, mas no processo de apresentar à mente o conteúdo de uma frase na qual sujeito e objeto são distinguidos, a atenção pode ser trabalhada de modo que a descrição seja a descrição de uma representação. E também pode não sê-lo, se a atenção do leitor repousar apenas nos aspectos consensuais, digamos, aqueles apontados pelo próprio historiador no texto. Mas é sempre possível que o leitor "abra a caixa preta", para empregarmos o termo que Bruno Latour utiliza no contexto da pesquisa científica. Nosso ponto é: no processo de circulação de significados, as cristalizações em forma de descrição e as descristalizações que transformam as descrições, na mente, de volta na forma de representações, ambas são possíveis. As noções de cristalização e o reconhecimento da relação processual entre a representação (que antecede) e a descrição (que sucede) são ditas claramente por Ankersmit em Meaning (2012: 64-87).
} 
"Robespierre" como um agente no interior da "Revolução Francesa" e esta como uma etapa da "Era da Revoluções" possui diferentes níveis representativos dialogando entre si, um mudando nossa compreensão do outro. Esta me parece uma conclusão incontornável da máxima de Danto segundo a qual "não há eventos, mas apenas eventos sob descrição". É por isso que, a meu ver, poderíamos então dizer que toda representação histórica inclui sub-representações. Toda descrição no interior de uma representação textual é também uma representação, que, por sua vez, compõe uma representação maior: em uma narrativa sobre o Renascimento, o termo Leonardo da Vinci se refere tanto a uma entidade individualizável quanto a uma "substância narrativa" com as propriedades que atribuímos a este indivíduo. Estas propriedades não foram simplesmente "achadas": a "representação Leonardo da Vinci" hierarquiza as informações, enfatiza mais uma que outras (destaca-se que ele era um pintor e escultor, mas não que era filho de A e amigo de B; destaca-se os poderes de sua mente e de suas mãos, mas não as de seus intestinos ou pulmões), produz sentido para algumas delas ("gênio", "homem do Renascimento", etc.) e destaca algumas dentre as suas inúmeras relações com alguns de seus contextos históricos. Esta "representação Leonardo da Vinci", por sua vez, invariavelmente deverá ser articulada (com maior ou menor grau de tensão) com as outras representações propostas, como "Itália", "Renascimento" e a "substância narrativa" do livro como uma totalidade.

Mink afirmou, como vimos, que a representação histórica possui descrições que se sobrepõem. Ora, o mesmo vale para representações: já existiam representações sobre o indivíduo isolável Leonardo da Vinci no tempo de sua vida, cada uma diferente da outra. Sua auto-imagem não era a mesma das de seus amigos ou mecenas. Mas, ao mesmo tempo, toda auto-imagem é construída em diálogo com as imagens feitas por outros. A forma pela qual um historiador constrói, hoje, sua representação Leonardo da Vinci é, em parte, possibilitada historicamente por sua interpretação das inúmeras representações já feitas sobre este mesmo indivíduo. Algumas são incontornáveis: por exemplo, se afirmo que ele era "orgulhoso", estou dialogando (em tom crítico) com uma das representações que ele próprio atribuiu a si em um dado momento. Aqui, a tensão entre representações afastadas temporalmente exemplifica perfeitamente o princípio verum factum. Outras, como representações de Da Vinci feitas no século XIX, talvez possam ser ignoradas - embora, como Ankersmit (2012) aponta, quanto maior é a variedade de representações existentes sobre algo, mais rica cada representação se torna. No seu livro de 2012, como vimos, Ankersmit afirmou que a representação 
histórica pode ser distinguida em três partes, a representação, seu aspecto ou apresentado, e a realidade passada sobre a qual o texto trata. Se pensarmos nas frases referenciais como sendo também sub-representações inseridas em uma representação mais ampla (que por sua vez pode ser inserida em outra representação mais abrangente, inclusive adquirindo a função de sujeito numa frase), poderemos ainda considerar que a caracterização de Ankersmit deve valer para os dois níveis representativos. Assim, as descrições de evento, por serem simultaneamente descrições $e$ representações - ou descrições representativas -, também são "operadores de três-lugares". O aspecto potencialmente verdadeiro do indivíduo Leonardo da Vinci destacado por sua autorepresentação mental não coincide totalmente com o aspecto destacado por seus contemporâneos quando pensavam neste mesmo indivíduo - isto é, a mesma estrutura corpórea situada no espaço-tempo, que, como existiu em uma sociedade e foi mencionada em diversas conversas desde então, dificilmente poderia ser individualizada sem que, juntamente com a menção ao seu nome, não viesse à memória do interlocutor um conjunto de propriedades que, em conjunto, compunham a representação mental "Leonardo da Vinci" (com o mesmo nome em todos os casos, mas com propriedades diferentes, embora parcialmente coincidentes, em cada um deles).

A relação entre descrições e representações é útil analiticamente, e se sustenta de modo relativamente estável caso isolemos uma única representação para tais fins (analíticos). Porém, de acordo com o próprio Mink, a representação histórica é um tipo de phronesis, o que implica que tenha um caráter prático, coletivo e de orientação no mundo (como também apontaram White, Rüsen, Ricoeur, Heidegger, Sartre...). Mais ainda, toda escrita de textos por parte de historiadores profissionais envolve também a expectativa de leitura por parte de um público (e, dependendo do engajamento político do historiador, este pode ser um fator bastante central em sua motivação) e dos pares. Ora, Danto apontou que um evento pode ser descrito em diferentes níveis de generalidade: "choveu em alguns locais de São Paulo ontem à noite" pode ser redescrito como "choveu ontem" ou como "choveu na Zona Oeste por 43 minutos no dia 11/04/2015". Da mesma forma, eu apontaria também, um evento pode ser descrito com ênfase em sua "imagem geral" (Batalha de Waterloo) ou em uma diacronia (caso em que se descreve a batalha). E o que vem à mente de cada pessoa quando da leitura do termo aparentemente neutro, "Batalha de Waterloo", envolve tanto o reconhecimento de algo comum com todas as demais representações, tal como certos referenciais espaçotemporais descritos em nível suficientemente amplo de generalidade - conseguindo 
falar do "mesmo evento" -, mas também sua apresentação por meio de aspectos inteiramente peculiares à experiência e ao conhecimento de cada um.

Uma das fontes de "instabilidade" das representações históricas é a possibilidade de que façamos perguntas. Quanto mais o leitor demandar da narrativa para sanar sua complexidade (cf. DRAY, 1957, provavelmente baseando-se na lógica de perguntas e respostas de Collingwood), maior pode ser a especificidade demandada de uma ou outra descrição (ou a riqueza descritiva, ainda que com menor tamanho: eis o que Diderot chamou de "energia"). Assim sendo, a distinção entre descrição e representação é estática, e, como a possibilidade de fazermos perguntas induz ao movimento, toda descrição pode ser tomada como representação novamente. ${ }^{99}$ Uma representação negacionista do Holocausto é inacreditavelmente frágil porque, ainda que seja construída com todo o cuidado para ocultar sua absurdidade empírica e moral, tem (para nos determos no nível epistemológico) total incapacidade de sustentar seus efeitos com a inclusão de novos dados.

Em qualquer nível em que estejamos, sempre é possível descer mais de nível, tornando a descrição mais ou menos específica. Isto não chega a ser uma ameaça para a referencialidade da historiografia, porque é fácil estabelecer consensos linguísticos sobre o que estamos individualizando no mundo por meio de certos termos. Assim, por exemplo, podemos identificar o "mesmo" Leonardo da Vinci, ainda que discordemos quanto às suas propriedades específicos, mas "Renascimento" tende a prosseguir como um "essencialmente contestado".

Mas há uma implicação relevante, caso pretendamos "levar o tempo a sério". Vimos que Mink contrapôs o tempo "cancelado" da estória como um todo às múltiplas temporalidades articuladas no interior desta estória. Digamos (sem a preocupação de originalidade quanto aos exemplos) que uma "representação" trate da Revolução Francesa, e as descrições se refiram a eventos específicos: a "tomada da Bastilha", o "grande medo", o "Terror", etc. Mas esta representação pode ser transformada em um "evento" no interior de outra representação: pode ser, digamos, o evento derradeiro da Era Moderna, o evento fundador da Era Contemporânea, etc. Como Mink apontou (em

\footnotetext{
99 Aqui, creio estar seguindo Frank Ankersmit, mas, ao mesmo tempo, creio também que muito provavelmente rejeitaria a análise: em livro de 2012, ele considera que a distinção entre descrição e representação depende do quão "cristalizados" socialmente - a ponto de haver um consenso sobre o que ele está permitindo selecionar e individualizar na realidade - estão os significados dos termos no primeiro caso, e a impossibilidade ou grande dificuldade disto ocorrer no segundo. Para ele, os termos começam sempre como representações e, quando perdem sua constestabilidade essencial, caem na condição de descrições.
} 
contexto apenas levemente diferente, pois falava de duas narrativas, mas sem discutir as diferenças de "níveis"), não é possível realizar esta operação sem modificar o sentido da própria representação. No nível mais alto em que olhamos, nossa compreensão "visual" tenderá a privilegiar a simultaneidade; no nível mais baixo, a compreensão "aural" requererá sucessão. Esta divisão de nível sempre existe e é analiticamente útil, mas cada subnível não cessa jamais de ser subdivisível. Isto indica que, caso façamos a pergunta, toda simultaneidade revelará suas tensões temporais internas. Todo evento, inserido numa narrativa diacrônica, pode ser apreendido pela mente como uma totalidade sincrônica e, com maior atenção, revelará ele próprio suas fraturas temporais internas. A distinção entre representação e descrição, então, possui dois níveis: uma é a relação parte e todo que se estabelece, e, nesse caso, a parte não se torna todo sem perder suas características peculiares de quando era parte (e era portanto vista à luz do todo): esta é uma das implicações, como vimos, de não haver História Universal; mas a descrição é também uma representação e pode ser reconhecida como tal desde que se evite uma atitude que a "cristalize". Mesmo os consensos devem ser entendidos assim: consensos mais ou menos claros acerca de qual aspecto escolher destacar.

\subsection{Ver o rio de cima da montanha é ver a história de fora?}

Na medida em que fizermos a transição das discussões sobre representação para aquelas sobre experiência, uma preocupação ankersmitiana surgirá recorrentemente: a de superar o transcendentalismo, que em seu uso aplicado à historiografia parece significar algo como o pressuposto de haver um lugar fora da história a partir da qual se possa produzir conhecimento sobre ela. Ankersmit tende a equiparar as visões transcendentalistas à epistemologia, e, na esteira do projeto de Rorty em A Filosofia e o Espelho da Natureza - e do seu próprio em Narrative Logic - sua expectativa era o abandono da epistemologia. ${ }^{100}$ As representações históricas seriam então empreitadas essencialmente estéticas, e à epistemologia (não-transcendental, fundamentada apenas

\footnotetext{
${ }^{100}$ Ver seus comentários a respeito em ANKERSMIT \& MENEZES, 2018. Ele leu Philosophy and the Mirror of Nature (1979), de Rorty, apenas depois de ter escrito Narrative Logic (publicado em 1983), mas até a publicação de Irony, Contingente, and Solidarity, em 1989, nutriu esperanças por encontrar na filosofia de Rorty uma solução para o problema que seguia pendente após o abandono da epistemologia por parte de ambos, o de como distinguir verdade de falsidade. E Contingency não satisfez Ankersmit, que relata a Menezes: "Bom, eu posso te dizer que nunca fiquei tão desapontado em toda a minha vida!" (idem: 259) Sua busca passaria pela filosofia da mente de Aristóteles a partir daí. Para o momento, o relevante a apontar é que, em Sublime, ele considera que Rorty e Gadamer - com quem Rorty dialoga no final de Mirror - não se libertam do transcendentalismo ao qual se opunham, mantendo ainda um "transcendentalismo linguístico".
} 
em práticas contingentes) caberia apenas o domínio das frases singulares que as compõem.

Em um ensaio que discutiremos em maiores detalhes no capítulo vindouro, "Historism and Postmodernism: a phenomenology of historical experience", uma das comparações que Ankersmit realiza entre estas duas correntes é do papel da epistemologia nelas. Aqui, ele lê a metáfora de Mink como incorrigivelmente inseparável do projeto historicista, de natureza epistemológica. Os méritos da "experiência nostálgica, pós-modernista do passado" eram, em sua visão, que ela "rejeita a dissociação do presente da experiência do passado", e experiencia a diferença entre ambos.

É verdade que o historicista irá também ver "diferenças", mas estas são sempre diferenças dentro do próprio passado (como, por exemplo, a distância no pasado correspondendo ao início e ao fim do rio que é visto de cima pelo historiador na metáfora de Mink. O presente, o próprio historiador, não é um ingrediente nesta diferença. Pois o historiador é reduzida a um mero self transcendental, transhistórico, sem um self empírico (temporal ou transhistórico). (1994: 218)

Ankersmit se pergunta então por como o historicismo pode solucionar este equívoco. Ele prossegue:

... como ficará claro se nós visualizarmos a metáfora de Mink, a desaparição do ponto de vista metafórico, em um lugar seguro no too da montanha (que agora foi trocado pelo ponto que o rio do tempo agora alcançou), também irá significar que a possibilidade de inspecionar o fluxo do tempo desapareceu, e a história se torna, consequentemente, essencialmente inarravél. (idem, ibidem)

Mas esta rigidez não me parece minimamente sustentável: ela pode ser uma leitura justa das limitações do historicismo, mas não segue de modo algum que qualquer tomada de posição "distanciada" em relação a um certo período histórico seja ou imersa "no rio" ou transcendentalista. Pois a imagem do rio remete a uma circunstância em que ou se está no mesmo plano do passado, não havendo perspectivas privilegiadas, ou a algo que obedece a gravidade. Não há um rio que suba, e isto apenas mostra o limite da metáfora (mobilizada por Mink para outros fins), e não a impossibilidade da adoção de pontos de vista históricos sobre a história que sejam relativamente distanciados. Se utilizarmos a mesma metáfora, podemos dizer que é possível ver o rio de cima, mas que isto não significa que se esteja fora da paisagem, ou que esta posição equivalha ao "ponto de vista de Deus": é apenas um ponto de vista. (A metáfora apenas falha no fato 
de que a temporalidade remete ao tempo, e a visão de cima da montanha é também temporal.)

A compreensão cognitivamente responsável inclui não só os eventos do passado - também os inclui - mas inclui conjuntamente os referenciais éticos e estéticos trazidos pelo historiador no presente. Inclui também, em algum grau, a experiência holística de mediação entre o passado e o presente, feita por uma consciência incorporada: dessa forma, o juízo histórico pode efetivamente se aproximar de um ato de phrônesis, como Mink e Gadamer quiseram, ou ser visto à luz de uma perspectiva situacional de ética, como White desejou - e não de uma concepção de ética que Ankersmit rejeita, a que se resume a ser a aplicação de princípios sobre o mundo.

Não havendo uma posição transcendental, da mesma forma que a escrita da história não ocupa uma posição transcendental em relação à história, nem mesmo a história da escrita histórica pode ocupar uma posição transcendental em relação à escrita da história. Porém:

Se nós optarmos pela historicização do sujeito histórico, a metáfora historicista que foi formulada por Mink de maneira tão apta irá se desintegrar na incoerência. Pois um ponto de vista metafórico do próprio passado - enquanto tal - não é mais possível; o que enganosamente se anuncia como tal visão se torna indiscernível de posições flutuantes da escrita histórica. Pontos de vista se misturam com pontos de vista, e o próprio passado com interpretações do passado. A metáfora espacial do ponto de vista destrói a si mesma. (idem: 220)

Do que podemos afirmar: sim, a metáfora mostra suas limitações, mas não o conceito de compreensão formulado por Mink. E a leitura oferecida por Ankersmit da noção gadameriana de Wirkungsgeschichte se harmoniza perfeitamente com o conceito.

A historiografia em sua forma tradicional repete no nível da objetificação da escrita histórica a mesma transcendentalização do sujeito histórico que nós encontramos no historism no nível da escrita histórica. O mesmo pode acontecer com a noção de Wirkungsgeschichte: se fôssemos dar conteúdo a ela (fazê-la se referir a uma fase ou aspecto da escrita histórica): por que parar nela em vez de também historicizá-la, e historicizar a historicização, e assim indefinidamente? Assim, a Wirkungsgeschichte se dissolve em uma proliferação sem fim de auto-reflexões históricas dentro de um presente historiográfico sempre em expansão. (idem: 222)

... para mim, a Wirkungsgeschichte é um movimento. Ela é um movimento que é perpendicular ao fluxo do rio do tempo de Mink e no qual a historicização da compreensão configuracional de Mink não tem início nem fim. Como tal, o movimento da Wirkungsgeschichte é, paradoxalmente, tanto o cumprimento quanto a morte do historicismo. Ela é o cumprimento já que a Wirkungsgeschichte não mais exclui da historicização o sujeito histórico transcendental, seguro no topo de sua montanha; ela é a morte do historicismo já que os pontos de vista historicistas que sempre permitiram ao transcendentalista historicista historicizar o passado perderam a fixidez que era 
essencial para a sua habilidade de funcionar como um ponto de vista. No movimento da Wirkungsgeschichte, pontos de vista absorvem pontos de vista e, já que não há fim para o movimento, não pode haver ponto de vista final ou superior a partir do qual nós possamos desenvolver e reconstruir os antecedentes e mais elementares. Assim, a forma mais consistente e radical de historicismo é, ao mesmo tempo, a transcendência do historicismo. (idem, ibidem)

Meu único ponto de discordância, ou estranhamento, em relação a este raciocínio diz respeito à necessidade de que um ponto de vista demande fixidez para funcionar como ponto de vista. De qualquer forma, notemos que é precisamente isto que deve ser feito com a noção de "compreensão", e tal preocupação não se encontra tão ausente de Mink. Não bastasse sua preocupação com o tema da mudança conceitual, e sua inserção na própria teorização de como se produz o "ponto de vista", vejamos também como ele descreve a filosofia de Collingwood, outra que também leva em conta a proposta aqui feita por Ankersmit (embora este o leia de modo muito diferente):

... Collingwood veio a perceber [em Essay on Philosophical Method, de 1933, e em contraste com Speculum Mentis, de 1924] que a escala de formas se aplica não apenas a formas de experiência, tal como ele as havia concebido, e não apenas a conceitos filosóficos, enquanto distintos dos 'científicos', mas também a teorias filosóficas e à história do seu desenvolvimento. (MINK, 1969: 76)

Não há, assim, um ponto último, mas uma constante adoção de pontos de vista sobre pontos de vista. E também não há um problema nisto, pois: (a) em Ankersmit, as diferenças entre os múltiplos pontos de vista enriquecem a compreensão que temos de um dado evento. Tais pontos de vista tanto os pontos de vista historiográficos antecedentes quanto, como estou enfatizando no presente trabalho, pontos de vista históricos; (b) em Collingwood, e certamente também em Mink, há a vantagem adicional de que os pontos de vista antecedentes são subsumidos nos subsequentes, de modo que a ausência de progresso rumo a um ponto final não significa que não haja ganhos qualitativos no processo pelo qual a mente conhece a si mesma.

Adicionalmente, lembremos que a crítica de Mink ao pressuposto de História Universal, bem como a tese de White sobre a sublimidade da história, são compatíveis com a tese de Ankersmit de que historicizar o sujeito do conhecimento é tanto a culminação quanto a superação do historicismo (ao menos do historicismo tradicional): pois é da inexistência de um ponto fixo a partir do qual os eventos possam ser significados que eles são "uma função da narrativa", isto é, da perspectiva adotada pelo historiador no presente. Então a compreensão é, no final das contas, o que Ankersmit 
gostaria que ela seja (sem a necessidade de ser uma variante da "nostalgia pósmoderna" que discutiremos adiante), e a discussão de Ankersmit pode ser lida mais um enriquecimento da posição de Mink. Especifiquemos como.

A historicização do sujeito do conhecimento, formulada aqui na releitura que Ankersmit propõe da compreensão configuracional e da Wirkungsgeschichte, permitenos finalmente ampliar o conceito de compreensão para incluir não apenas os elementos "horizontais" do passado, nos quais vários eventos são articulados a partir de fora. É bem verdade que a concepção das descrições de "tipo 5" já abre as portas para o reconhecimento de que as perspectivas históricas dos historiadores são parte de como a descrição se produz. Porém, é o caso de se reconhecer explicitamente que diferentes referenciais estéticos e filosóficos se combinam com os dados e produzem uma compreensão que é resultante não só das verdades (como querem os positivistas e hermeneuticistas), nem só das categorias empregadas pelo historiador (como às vezes o próprio White dá a entender, e certamente muitos pós-modernistas também, e como também se pode considerar ser a posição kantiana), mas do encontro entre elas. Assim, uma compreensão que não levasse em conta a interpenetração entre as dimensões horizontais do passado e do presente, bem como da conexão vertical entre passado e presente, poderia justificadamente ser acusada de incorrer em má-fé ou em corrupção de consciência. Uma compreensão com autenticidade, por outro lado, reconhece a participação da consciência humana na produção de sentido para o passado, mas não presume que um dos polos seja necessariamente dominante nesta relação.

Braver considera que um fio comum entre Heidegger e Wittgenstein é a tese de que a filosofia se equivocou ao pressupor uma forma específica de se relacionar com o mundo como a única possível: aquela que direciona ao mundo uma atenção temática ou teórica, perdendo de vista o comportamento engajado que os seres têm com seu ambiente. Trata-se de um "objeto teórico", descontextualizado. O tempo congelado pela representação histórica é, também, um objeto teórico ou temático que produz uma perspectiva no mundo da vida. Isto é muito útil - ela revela, de fato, aspectos do mundo - mas produz equívocos epistêmicos e problemas éticos se perdemos de vista que o distanciamento só faz sentido enquanto um afastamento necessário para a ação. Braver mostra como, para Heidegger, tanto o engajamento reativo no mundo da vida quanto a descontextualização abstrata de práticas como a filosofia. Para o presente trabalho, isto indica que engajamento e distanciamento são mais proveitosos se podemos produzir uma oscilação entre eles, na qual as memórias dos gestos de atenção são não meramente 
canceladas, mas dialeticamente incorporadas (e apenas nesse sentido canceladas) em gestos de compreensão. O "distanciamento" que ocorre em casos assim é a adoção de uma perspectiva, também ela histórica, e pode ser conectado com ações futuras no mundo da vida: pode ter, nos termos de White, caráter "prático" e não meramente "histórico".

\title{
2.5. Como lidar com "o fardo da história" em um mundo de descontinuidade, disrupção e caos?
}

Como já dissemos, Hayden White realizou suas primeiras intervenções no campo da "filosofia analítica da história" com textos que visavam reconfigurar o próprio debate em voga, até então centrado na discussão lógica sobre a aplicabilidade do modelo das covering laws para as explicações históricas. Suas primeiras publicações tratam de figuras como Collingwood, Toynbee, Christopher Dawson e Croce, e, em comum, combinam uma análise geral de suas proposições com um chamado à "libertação" das amarras do cientificismo. Seu problema não era o da ciência por si só de fato, em "O Fardo da História", ele criticava a concepção antiquada de ciência adotada por historiadores, mas não a ciência por si só -, mas a crença na existência de apenas uma forma possível de compreender o mundo. ${ }^{101}$ Como ele diria em texto de 1978:

\begin{abstract}
Apenas uma inteligência voluntariosa, tirânica poderia acreditar que o único tipo de conhecimento a que podemos aspirar é aquele representado pelas ciências físicas. Minha meta tem sido mostrar que nós não temos que escolher entre arte e ciência, que de fato não podemos fazê-lo na prática, se nós temos esperança de continuar a falar sobre cultura em contraste com a natureza - e, acima de tudo, falar sobre ela em maneiras que são responsáveis [em relação] às várias dimensões do nosso ser especificamente humano. (WHITE, 1978: 23)
\end{abstract}

Para esclarecer a posição de White diante das visões em prol da cientificização da história, é útil recorrer à distinção feita por Paul entre dois tipos de "ironia" presentes em sua produção desde seus primeiros textos. Ao longo da década de 1960, White gradualmente passou a adotar o que Paul chama de "ironia epistemológica": a descrença na capacidade da linguagem de apreender o mundo; desde o início, porém, ele se opunha a outro tipo de postura, a "ironia ideológica": a descrença na, ou recusa da, responsabilidade de intervir no mundo para fins utópicos (PAUL, 2006; ROTH, 1995:

\footnotetext{
${ }^{101}$ O primeiro capítulo do já citado livro de Paul aborda este período de formação de White. A coletânea
} The Fiction of Narrative, de 2010, apresenta os ensaios mencionados neste parágrafo. 
5, 137-161). Paul mostra como este posicionamento é resultado de uma postura existencialista que perpassa toda a trajetória de White, por meio da qual ele insiste que a escolha de como narrar o passado é parte da forma pela qual indivíduos e sociedades produzem sentido para sua existência (PAUL, 2011). Mostrar que as narrativas possuem este elemento ético, existencial, e dotado do que Metahistory chamou de "implicações ideológicas" foi uma das guinadas produzidas por White no debate sobre a narrativa histórica.

“The Burden of History", publicado em 1966, foi ampliado por sete anos até virar o livro Metahistory: The Historical Imagination in Nineteenth-Century Europe. ${ }^{102}$ Escrito a convite dos editores da History and Theory, dentre eles Mink, o ensaio destoava dos debates usuais de filosofia da história. ${ }^{103}$ Não se tratava nem de defender a aplicação do modelo monista das covering laws nem de propor uma alternativa pluralista como Dray e outros fizeram, mas de diagnosticar uma crise - a irrelevância da história de seu tempo, em descrédito por parte tanto dos cientistas quanto dos artistas. Em sua leitura, isto ocorria porque, embora os historiadores pretendessem situá-la entre a ciência e a arte, não percebiam que suas definições de uma e de outra já não eram compatíveis com as produções científicas e artísticas do século XX. Em sua consideração, era necessário considerar não apenas as diferenças, mas também as similaridades entre arte e ciência: assim como havia um elemento construtivo nas ciências, era necessário considerar que recursos artísticos também produziam conhecimento. Assim sendo, não havia motivos para não empregá-los, reconhecendo que "não há algo como uma única visão correta de qualquer objeto sob estudo mas que há muitas visões corretas, cada uma requerendo seu próprio estilo de representação". Ele ainda não delineava em detalhe a natureza de tais estilos e sua relação com os dados que elas organizariam. Mas já indicava sua concepção de que as narrativas "realistas" não eram adequadas para representar a realidade histórica do século XX: “O historiador não serve bem a ninguém construindo uma continuidade enganosa entre e mundo presente e aquele que o precedeu. Pelo contrário, nós requeremos uma história que nos eduque para a descontinuidade mais do que nunca antes; porque nosso destino é descontinuidade, disrupção e caos.”

\footnotetext{
${ }^{102}$ Ver o seu relato em JENKINS, 1998: 73-4 e DOMANSKA, 1998a, DOMANSKA, 1998b: 180.

${ }^{103}$ Um excelente panorama deste debate, mais compreensivo do que exaustivo, encontra-se em DANTO, 1995.
} 
Dois elementos importantes do ensaio podem ser destacados para os nossos propósitos. Em primeiro lugar, como a citação recém mencionada deixa claro, é sua abertura para a tensão entre continuidade e descontinuidade. Se os estudos sobre a retórica da historiografia que White escreveria como preenchimento do programa de "The Burden of History" enfatizaram a produção de continuidade, fechamento de sentido, coerência, etc., é nítido que isto se deu não como um programa prescritivo. De fato, a prescrição por White é por recursos narrativos que impeçam estes efeitos.

A ênfase de White na continuidade foi apresentada por Runia (2014: 157) como o contraponto de sua própria abordagem, interessada especialmente na produção de descontinuidade: "Um dos insights brilhantes de Hayden White foi que é importante 'entender o que é fictício em todas as representações putativamente realistas do mundo, e o que é realista em todas as manifestamente fictícias'. Nas décadas passadas apenas a primeira metade do projeto foi levada a cabo". Mais especificamente:

\footnotetext{
O representacionalismo whiteano ... é uma ferramenta principalmente "negativa", crítica. Quando usada em uma maneira positiva, "substantiva", "especulativa", ela cria - por ser ligada à metáfora continuidade no que quer que encoste suas mãos, e - após as descontinuidades inimagináveis da história do século XX continuidades fáceis não são o tipo de significados que nós podemos aceitar como apropriados, satisfatórios e convincentes. Em sua forma "substantiva", o representacionalismo whiteano é como o homem no conto de fadas que vê realizado seu desejo de que tudo em que ele toca vira ouro - apenas para descobrir que a comida que ele desesperadamente quer comer se transforma no metal precioso, porém não comestível, no momento em que ele a traz à boca. (RUNIA, 2014: 52-53)
}

Porém, me parece difícil compreender os dois projetos se nos contentamos com esta alternativa entre "presença" e "significado". Vimos que o próprio White critica as "continuidades fáceis" de que Runia fala. Cabe observar também que, em Metahistory, ele defende a legitimidade das abordagens "especulativas" tanto quanto Runia faz aqui, e que, em "The Politics of Historical Interpretation", ele rejeita qualquer tentativa de domesticação da sublimidade da história. Sobretudo, é difícil conceber o que seria o "uso positivo" do representacionalismo. Sendo ele uma abordagem teórica, seu uso prático só pode ser um pôr em movimento simultaneamente negativo e positivo, por meio do qual nos liberamos do uso de certos estilos para outros usos criativos. A reflexão teórica, aqui, nada mais pode ser senão uma ferramenta de autoconsciência, de autonomia, que podem ser usadas de maneiras diversas e em nada implicam em produzir uma continuidade tal como a do conto de fadas citado por Runia. De fato, ao 
apresentar o que considera ser sua alternativa, Runia recorre a alguns dos mesmos exemplos que White emprega ao longo de sua trajetória, como os da literatura de Tolstoi e Sebald, e, como apoio filosófico, a obra de Giambattista Vico.

Concluamos esta parte da argumentação apontando o seguinte: um projeto intelectual dificilmente pode ser levado a cabo por uma só pessoa ou uma só geração. E é evidente que gerações futuras lidarão com a tradição a partir de seus próprios interesses. Mas aquilo que White propõe em "The Burden of History" é evidentemente mais amplo do que o que Runia caracteriza como "representacionalismo whiteano", e sua referência à segunda metade do projeto permite-nos ler sua própria produção como parte da mesma tradição. É o que faremos no capítulo 5.

Avancemos ao segundo ponto, intimamente conectado ao primeiro, que diz respeito à relação entre significado e presença. Há algo de equivocado nessa aposta de que "não é significado o que queremos", mas sim presença (idem, 53). Seres humanos buscam ambas as coisas, embora membros de certas culturas ou de períodos específicos prefiram uma ou outra dimensão, exatamente como consequência da interdependência entre elas. Lembremos, por exemplo, de Gumbrecht, que distingue entre "culturas de presença" e "culturas de significado". O caráter sempre-construído da "realidade humana" dá base para a afirmação de White de que a descontinuidade é o nosso destino, mas cabe observar: a descontinuidade é tão radicalmente nosso destino que nem mesmo a condição comparativamente mais descontínua do século $\mathrm{XX}$ em relação aos seus precedentes pode dar garantias de persistir. Runia formula com muito mais justiça a relação entre continuidade e descontinuidade quando atribui ou à metonímia (ela própria um instrumento de significação, mesmo que possa, como Runia insiste, operar em dimensões extra-linguísticas) ou (o que não é a mesma coisa!) à interação entre metáfora e metonímia" a capacidade de articular "a simultaneidade da continuidade e da descontinuidade" (RUNIA, 2014: 66). Mas ainda assim o ponto não deveria ser tornar a metonímia mais fundamental que a metáfora. Se adaptarmos uma fala de Roth em discussão sobre Foucault, podemos dizer que seria ou contraditório ou paradoxal produzir uma fundamentação para uma concepção descontínua de história.

Se levarmos em conta a proximidade entre as diversas figuras - metonímia e sinédoque são usualmente aproximadas, e todas podem ser consideradas como tipos de metáforas -, especialmente o caráter metatropológico da ironia, então tanto o projeto delineado em "The Burden of History" quanto aquele delineado em "Presence", com quarenta anos de intervalo, apenas podem ser cumpridos com a nossa leitura da 
tropologia como um esquema geral da movimentação da atenção por uma consciência em suas mediações entre continuidade e descontinuidade, presença e significado. É esta leitura que apresentaremos em breve.

Um terceiro fator a ser destacado é que, naquele ensaio mais explicitamente do que nas propostas recentes, White propõe que a adoção de recursos estéticos tenha um caráter provisório. Seria o caso de reconhecer que "uma metáfora governante de um relato histórico poderia ser tratado como uma regra heurística que auto-conscientemente elimina certos tipos de dados da consideração como evidência." (1978: 46) Isto faz sentido na medida em que não há uma perspectiva correta acerca de um evento, mas muitas possíveis. Logo, a adoção de múltiplos protocolos forneceria vantagens em relação à adoção de apenas um. Não se tratava (mais uma vez) de eliminar verdades, mas de perceber que o reconhecimento de verdades depende da familiaridade com um certo "sistema de notação" - ou seja, o que temos chamado aqui de "anterioridade da estética". Mais adiante, argumentaremos que a provisoriedade e a "ironia epistemológica" são preferíveis a uma certa abordagem identitária e "substancialista" da construção de sujeitos coletivos, na medida em que esta pode ser incompatível com aquela.

\subsubsection{O que está envolvido na prefiguração?}

Em Metahistory, White analisa mais detalhadamente a "queda" da consciência histórica neste estado "irônico" de que The Burden of History havia buscado resgatá-la. Ali, ele propôs um sistema por meio do qual, de dentro da ironia, pudesse realizar "uma volta da consciência irônica contra a própria ironia": sua "grade tropológica", mobilizada para explicar os textos historiográficos de quatro historiadores e quatro filósofos da história do século XIX: Michelet, Ranke, Tocqueville e Burckhardt; Hegel, Marx, Nietzsche e Croce. A tropologia de White distingue entre o nível da crônica, sua organização em forma de estória, a "explicação da estória" pelo seu enredo (romance, tragédia, comédia, sátira), a explicação pelo argumento (formismo, mecanicismo, organicismo, contextualismo) e a "implicação ideológica" do conjunto (anarquismo, radicalismo, conservadorismo e liberalismo). Para articular estes três últimos níveis, White postulava uma "estrutura profunda" (os tropos da metáfora, metonímia, 
sinédoque e ironia), por meio da qual o "campo histórico" era prefigurado. Tudo isto se articula na forma de uma "tétrade quádrupla" ${ }^{104}$ :

\begin{tabular}{|l|l|l|l|}
\hline Enredo & Argumento & Implicação ideológica & Tropo \\
\hline Romance & Formista & Anarquista & Metáfora \\
\hline Tragédia & Mecanicista & Radical & Metonímia \\
\hline Comédia & Organicista & Conservador & Sinédoque \\
\hline Sátira & Contextualista & Liberal & Ironia \\
\hline
\end{tabular}

Por um lado, tudo isto já é sabido à exaustão. Por outro, White não apresentou discussões mais detalhadas sobre o conceito de prefiguração, embora tenha proposta diversas leituras de outros pensadores que consideram encontrar em suas obras o movimento de quatro partes das figuras de linguagem. O que nos interessa discutir é a maneira pela qual a possibilidade de direcionar ativamente a atenção ao mundo e ao passado, por um lado, e de tê-la estruturada e/ou atraída passivamente pelo mundo ou pela natureza da própria consciência, por outro, é concebida por White. Em Metahistory e em textos subsequentes, como mencionamos, White considerará ter encontrado em uma imensa gama de autores (Foucault, Piaget, E. P. Thompson, Freud) um padrão de movimentação da consciência em que primeiro a realidade é apreendida de modo metafórico (i.e., representacional: uma coisa é compreendida com referência a outra), em seguida passa pela metonímia (que é reducionista) e pela sinédoque (que é integrativa), por fim culminando em um estado irônico.

$\mathrm{O}$ ato da prefiguração presume a ausência de sentido inerente no mundo. É por isso que, segundo White, antes de interpretar um dado conjunto de eventos, o historiador deve povoá-lo com figuras por meio das quais ela possa discernir seus elementos (WHITE, 1995). Este elemento é apriorístico e a-histórico: é impossível produzir sentido para o mundo sem prefigurá-lo, mas, como contraponto a tal obrigatoriedade, os modos de prefiguração podem a princípio (como nota ANKERSMIT, 2009) ser escolhidos livremente. Porém, a individualidade da escolha

${ }^{104}$ Termo empregado por KELLNER, 1980: 8, ff. É importante notar que, como este texto não é uma introdução ao pensamento de White, não procederei a análises detalhadas da tropologia para além do necessário para o argumento. Isto já é feito, dentre muitos outros, por PAUL, 2011 e MUNSLOW, 2006: 149-174. 
existe em tensão com o caráter social e histórico do instrumento de escolha: a linguagem, e, no caso de narrativas históricas de um dado período histórico, o enredo.

Publicada cinco anos após Metahistory, a introdução de Tropics of Discourse é a sistematização mais madura da teoria dos tropos apresentada por White. Ali, três aspectos dos discursos são enfatizados: primeiro, sua função mediadora entre os domínios não-familiares da experiência humana e aqueles já familiares; segundo, o movimento constante por meio do qual o discurso realiza esta função; terceiro, a presença incontornável de decisões, da vontade humana, da liberdade no processo, o que, por sua vez, demanda reflexões éticas sobre como proceder - motivo pelo qual White considera necessário examinar detalhadamente o funcionamento dos tropos, permitindo seu uso auto-consciente. Assim: 'Um discurso se move 'para lá e para cá' entre codificações recebidas da experiência e a confusão dos fenômenos que recusam incorporação em noções convencionalizadas de 'realidade,' 'verdade' ou 'possibilidade'. Ele também se movem 'para trás e para frente' (como uma lançadeira?) entre maneiras alternativas de decodificar esta realidade, $[\ldots]$ ". "O discurso, em suma, é quintessencialmente um empreendimento mediador. Como tal, ele é tanto interpretativo quanto pré-interpretativo [...]”. Seguindo a Ciência da Lógica de Hegel, White insiste que o discurso não é regulado pela lógica: mesmo no modelo do silogismo há 'uma virada' do universal para o particular sobre a qual a lógica não pode presidir, já que é a própria lógica que está sendo servida por este movimento.” (WHITE, 1978: 3-4.) Desse modo, o fato de que a historiografia produz conhecimento epistemologicamente verificável em nada anula o papel da vontade: "as implicações morais das ciências humanas nunca serão percebidas até que a faculdade da vontade seja reintegrada à teoria." (idem, 23)

\section{Os fatores de prefiguração}

A afirmação anterior já é também um anúncio da segunda parte de nossa discussão sobre a tropologia. Apesar de White ser muito mais extenso em sua descrição de cada tropo do que em uma teorização sobre o que é a prefiguração, considero possível afirmar que ao menos quatro elementos estão envolvidos na produção de uma maneira específica de fazer com que o mundo apareça sob certas descrições, ligadas a um certo vocabulário: os desejos, os pressupostos filosóficos, a experiência da temporalidade e as emoções. Estes - no mínimo estes - são fatores que influenciam a maneira pela qual a atenção será, ativa ou passivamente, direcionada a certos aspectos 
do mundo e não outros, e permitirão à consciência prefigurá-los de uma maneira e não outras.

Comecemos pelo já tópico do desejo. Como White afirma, próximo do fim de "The Value of the Narrativity in the Representation of Reality":

... o valor conectado à narratividade na representação de eventos reais surge de um desejo de que eventos reais exibam a coerência, integridade, plenitude e fechamento de uma imagem de vida que é e apenas pode ser imaginária. A noção de que sequências de eventos reais possuem os atributos formais das estórias que nós contamos sobre eventos imaginários só poderiam ter sua origem em wishes, daydreams, reveries [wishes, daydreams, reveries]. (1987: 24)

Como se pode ver em "Freud's Tropology of Dreaming” (WHITE, 1999: 10125), ao menos nas circunstâncias dos sonhos, é com a mediação da tropologia que o pensamento onírico se manifesta, simbolicamente, como um conteúdo onírico. Como no caso das atividades imaginativas despertas, a experiência pessoal do sonhador se manifesta (e pode ser interpretada) por meio dos recursos simbólicos compartilhados por sua comunidade.

Além dos desejos, mais outros três fatores - separáveis apenas analiticamente podem ser caracterizados como diretamente envolvidos na prefiguração dos textos. ${ }^{105} \mathrm{O}$ segundo pode ser descrito como o conjunto de princípios filosóficos adotados implícita ou explicitamente pelo historiador. Assim, a adoção da metáfora como tropo dominante está conectada com o que poderíamos chamar de um realismo ingênuo, enquanto a ironia - embora possa ser compatível com mais de um movimento - rejeita abertamente tal realismo. Ao mesmo tempo, de uma perspectiva dominantemente irônica, é possível utilizar qualquer uma das figuras: o que mudará é a atitude de quem escreve ou lê. Como evidência adicional para a presença de pressupostos filosóficos (reconhecidos ou não como tais) dentre os fatores que produzem uma certa prefiguração, lembremos de que a escolha de um dos quatro modos de argumentação está intimamente conectado à concepção sobre o que, afinal, conta como uma explicação realista da realidade. Em terceiro e mais óbvio lugar, lembremos que uma das formas de ler a conclusão sobre a inseparabilidade entre história e filosofia da história é uma leitura mais literal do termo: pois se cada filosofia da história tem uma certa carga emocional que se expressa melhor a partir de enredamentos ora cômicos, ora trágicos e assim por diante, elas também se

\footnotetext{
${ }^{105}$ Sobre este ponto, ver a coletânea de KENAAN \& FERBER (2011) sobre "os fundamentos afetivos do pensamento".
} 
manifestam por meio de afirmações ou pressupostos sobre como as coisas são, o que se pode esperar delas e como se pode explicá-las.

Em terceiro lugar, há o fato de que a linguagem poética descrita pela teoria dos tropos expressa uma certa forma de vivenciar a temporalidade. Jonathan Gorman fez este ponto em artigo de 2013. Em um contexto de debate com Nancy Partner, ele afirma:

... Metahistory é enganosamente interpretado por Partner como relocando
'significado [...] da mente do autor para as propriedades expressivas do texto
(Partner 1998, 171, minha ênfase), pois - para re-expressar esta citação em
termos preferíveis - ela deveria ser entendida como relocando 'significado da
intenção do autor para as propriedades expressivas do texto'. Isto não é relocar
significado da mente do autor', pois é precisamente a mente do autor que o
texto narrativo expressa. (GORMAN, 2013: 18; todas as edições, grifos e
comentários do trecho, incluindo a observação "minha ênfase", são do próprio
Gorman).

Em seguida, ele especifica sua leitura de Metahistory, segundo a qual o elemento da mente do autor em questão é sua experiência da temporalidade, que adquire forma narrativa. Esta experiência e a forma que a expressa, por sua vez, são sempre compartilhados socialmente. O "presente”, por exemplo, não é algo que surge como um ponto com início e fim delimitáveis, mas uma parte da consciência histórica que é compartilhada pelos membros de coletividades, e é melhor expressada pela linguagem poética. (GORMAN, 2013: 19).

Em quarto lugar, e inseparável de todos os outros, encontramos as emoções. White não entra em uma discussão precisa de sua natureza, mas Collingwood as conectou com a atividade da imaginação que, conforme tanto White quanto Mink (1969), se manifesta no segundo nível da consciência. Tal como Collingwood as teoriza, elas são uma carga produzida sobre as sensações das atividades psíquicas de nível mais básico, e expressadas imaginativamente por meio da atividade mental que ele chama de arte. (COLLINGWOOD, 1958). A filosofia de Ankersmit também não produz nenhuma discussão precisa sobre as emoções, mas será sobretudo sua terminologia que usaremos para discutir alguns exemplos adiante: é porque sentimos e por que somos movidos - e, por meio da expressão, também desejamos mover e comover nossos pares - que destacamos aspectos específicos do mundo que representamos. E como esta sinopse deixa subentendido, enfatizar a maneira pela qual as emoções colorem as representações e experiência indica também que estas são formas de fazer algo em relação ao mundo. 
Sobre este ponto, temos acordo com outro dos teóricos de nosso campo discursivo, John Dewey.

Antes de prosseguirmos a dois exemplos de como os "fatores de prefiguração" se manifestam na produção de representações (históricas e historiográficas), vejamos um elemento ainda pendente em nossa discussão da tropologia: a afirmação de que, havendo condições de suficiente autonomia por parte de um intelectual (situado em um certo campo, como poderíamos acrescentar com Bourdieu), é possível escolher a maneira pela qual o mundo será prefigurado.

\section{Prefiguração e escolha}

A presença desta opcionalidade na formulação da tropologia leva alguns comentadores à conclusão de que ela redunda em uma espécie de "vale tudo" (“anything goes”). ${ }^{106}$ Mas façamos algumas observações sobre a noção de escolha em relação à tropologia. ${ }^{107}$

Antes de tudo, notemos que a formulação da grade tropológica de Metahistory se dá no momento de pico do movimento estruturalista (PAUL, 2011: 82-108). Chartier, por exemplo, se perguntou se não haveria uma contradição entre o determinismo linguístico dos tropos e a aspiração de liberdade expressa em sua formulação. Mas, como Ricoeur, não vemos motivos para presumir que tal coisa ocorra (CHARTIER, 2002: 103-8; RICOEUR, 2004); pois, como White afirma, o estruturalismo "é uma grande teoria da reprodução, que mostra como sistemas de poder podem funcionar apenas por exclusão, então em alguns sentidos eu vi isto como um complemento ao existencialismo, ainda que Lévi-Strauss seja o direto oposto a Sartre. Mas eu os via como complementares." (JENKINS, 1978: 74).

\footnotetext{
${ }^{106}$ Este pode ser tomado como o fio condutor de todas as tentativas de, contra a argumentação de White, apresentar a dimensão epistemológica como fio condutor privilegiado da atividade historiográfica (a título de exemplo, ver GINZBURG, 2007, CARDOSO, 2005 e MARWICK, 1995). Mas embora seja verdade que a historiografia se distinga de outras formas narrativas por um "pacto de verdade", insistir nisso em nada afeta a argumentação de White e pensadores afins acerca da apresentação discursiva de tais verdades.

${ }^{107}$ Em 1995, Roth observava que "até o momento, ele teve pouco a dizer sobre como tais escolhas [sobre "o conhecimento necessário para uma escolha livre dentre diferentes estratégias de figuração"] são feitas." (1995: 145) Daquele momento até o fim da vida, White viria a propor a noção de "passado prático", que atende algumas das questões sobre as quais Roth gostaria de ver esclarecidas, tais como: "O que nós queremos do passado, e o que nós devemos fazer com a nossa história uma vez que tenhamos entendido como ela não mais funciona como um tribunal de recurso? White conduz a estas perguntas, mas também toma cuidado em evitá-las (idem: ibidem). Mas sobre a relação entre escolhas e a tropologia especificamente ele não chegou a dizer muito, e portanto esta seção explora outras possibilidades em pensadores afins ao campo discursivo narrativista.
} 
Partindo deste princípio geral, exploremos então as questões decorrentes. Primeiramente, quem é este sujeito que escolhe? Argumentaríamos que este sujeito é melhor compreendido como a efetivação de algumas das possibilidades de sua sociedade, dentre as quais se encontra, quando há autoconsciência e quando há sensação de insatisfação com as formas pelas quais os recursos de significações presentes mediam sua relação com o ambiente, a possibilidade de buscar no passado novos recursos. Em um sentido, a lógica dos tropos se efetiva por meio dos seres mas é maior que eles, e a sensação de insatisfatoriedade - que só pode existir em corpos, situados em contextos - cria condições para que outras formas de significações tenham suas figuras preenchidas.

Dada esta inseparatividade entre sujeito e mundo, cabe adicionar aqui uma importante contribuição encontrada na filosofia de John Dewey. Lembremos como, para Rorty, o próprio problema da relação entre sujeito e mundo era uma herança da filosofia cartesiana, e cabia dissolver o problema em vez de resolvê-lo. O problema do ceticismo, em relação ao qual a filosofia de White foi tantas vezes discutida, surge neste quadro: havendo um sujeito já concebido como alienado em relação ao mundo, aqueles poucos indivíduos interessados nos jogos de linguagem filosóficos se perguntam então sobre como saber se efetivamente o sujeito conhece o mundo, em vez de meramente projetar suas categorias sobre ele (RORTY, 1994; BRAVER, 2012). Mas Rorty apresenta um ponto altamente insatisfatório, a meu ver, que é considerar dispensável o vocabulário que fala em consciência, preferindo um "behaviorismo epistemológico". Todo o potencial do narrativismo - especialmente o whiteano - envolve a possibilidade dos sujeitos realizarem escolhas, em vez de meras reações. Escolhas situadas, como vimos, e certamente também inseparáveis de desejos, emoções, da atuação do inconsciente - e, embora White não dê espaço a tais coisas, isto inclui os fenômenos de "presença" discutidos por Runia. Dewey formula a própria relação entre sujeito e mundo de maneira que já não presume um em posição transcendental em relação ao outro, mas sem descartar o papel da consciência. Retornaremos a seu pensamento mais adiante, mas notemos desde já que este raciocínio vale para o tópico, central para White, da atribuição de significados (meanings). Isto é, se por um lado White está justificado em tomar a consciência humana como o locus dos significados, por outro esta concepção pode ser consideravelmente enriquecida se, com Dewey, levarmos em conta também que (a) o significado não é simplesmente introduzido pelo pensamento, mas experienciado com o - e produzido pelo - corpo todo, e (b) o significado não é 
meramente imposto pela consciência, mas surge na relação entre a consciência incorporada e o ambiente, numa dinâmica entre passividade e atividade.

A menção a Dewey nos conduz à próxima questão, que, redescrita nos termos de nosso trabalho, seria: e o que estimula o movimento do organismo para produzir uma experiência? O fato de que o organismo e o meio se encontram inseparáveis explica como é possível que tanto o ser consciente mova seus arredores quanto, por estar sujeito a sofrimentos e a aspirar satisfações de corpo e de mente, ele também seja movido. Visto neste quadro geral, "representacionalismo" e "presencialismo" perdem não só a suposta contraditoriedade que se lhes poderia atribuir, mas também aparecem como dimensões inseparáveis da existência humana.

A insatisfação - e a subsequente busca por satisfação - pode se manifestar de diversas formas: percepção cognitiva da inadequação entre linguagem e mundo (White); problemas éticos oriundos da expressão inadequada de emoções em formas mais complexas e/ou racionais de linguagem, ou seja, "corrupção de consciência" (Collingwood); busca da completude de si no futuro, movida pela auto-constituição no presente enquanto falta (Sartre); experiência de perda irreversível do presente, tornado passado (Ankersmit); desejo de destruir a própria identidade por meio de "saltos no abismo" (Runia). Os exemplos mobilizados por Ankersmit sobre como "trauma e sofrimento" deram impulso à consciência histórica em Maquiavel, Guicciardini e na resposta do século XIX à Revolução Francesa (2005: passim) endossam inteiramente este ponto, e a motivação de atenuar o sofrimento e produzir condições de felicidade por parte da história vista de baixo, das mulheres, de gênero, etc., também o fazem. E White também fornece um exemplo particularmente compatível com o raciocínio de Ankersmit. Em “The Value...", observando os registros de acontecimentos nos Annals of Saint Gall, White cita de passagem a afirmação de Hegel segundo a qual períodos de felicidade e segurança são páginas em branco na história (WHITE, 1987: 11). O impulso para o registro para vir de ameaças ou concretizações de sofrimentos; nos demais anos, os anais apenas dizem: "nada aconteceu".

Adicionalmente, um elo comum entre todas estas possibilidades recém citadas de White, Collingwood, Sartre, Ankersmit, Runia - é a relação entre a representação do passado e a representação de si: todos estes pensadores percebem, cada um a seu modo, que a significação atribuída às próprias identidades resulta de atos de self-fashioning estritamente ligados à significação atribuída a uma parte do passado tomada como meu, o que por sua vez me demanda ações futuras para "alcançá-lo". A descrição temporal do 
mundo e a descrição temporal de que sou/somos são inseparáveis. Isto parece indicar que como resposta ao sofrimento, ou ao que Dewey caracterizaria como a percepção de uma desarmonia na relação com o ambiente, em todos estes casos o sujeito se lança ao futuro para produzir uma "experiência" na qual uma certa harmonia pode ser reestabelecida. ${ }^{108}$

Como a função destes discursos é mediadora entre o corpo e os ambientes natural e social (dimensões que, por sua vez, se interpenetram), a insatisfação pode surgir devido a mudanças de qualquer um dos elementos envolvidos e nunca isolados uns dos outros. A insatisfação indica ou produz um desequilíbrio entre eles. Por exemplo, como mencionamos, as emoções podem ser reprimidas ou expressadas inadequadamente no discurso, produzindo "corrupção de consciência"; mas podem estimular a modificação nos modos de apresentação, e, por meio deles, no ambiente, seja para expressar as próprias emoções, seja para produzir representações do mundo externo de uma maneira cujas carga emocional e implicação ideológica sejam expressadas ou buscadas de uma maneira que o sujeito que escolhe sinta como adequadas a seu desejo ou seus princípios morais. Os trabalhos recentes sobre presença e experiência tendem a enfatizar a capacidade de elementos do ambiente de provocarem respostas emocionais e (re)ações inconscientes. Na nossa leitura da tropologia, é perfeitamente plausível que, quando isto ocorra, o sujeito interfira ou nas suas próprias emoções, ou no discurso, ou no ambiente, mais conscientemente ou mais inconscientemente dependendo de suas próprias condições de autoconsciência e da tração que o "efeito de presença" tem sobre sua atenção e sobre sua autonomia psicológica. A tentativa de agir em relação ao ambiente social, por sua vez, pode ser direcionada a qualquer um dos níveis de "efeito de explicação": por exemplo, o convencimento cognitivo pode ser indispensável em campos ou ambientes em que esta demanda é exigida. Outros fatores condicionarão o lance necessário e seu sucesso ou fracasso: a autonomia relativa dos campos, a circulação social de afetos, as carências existentes e/ou sentidas por sociedades em épocas específicas (inclusive de sentido incluindo, na terminologia de Rüsen, "orientação" - e de presença), etc.

Como qualquer texto historiográfico, seja de caráter "histórico" ou "prático", não escapa inteiramente de sua inserção em um mundo social, e como (cf. WHITE,

\footnotetext{
${ }^{108}$ E quando, na parte 2 deste trabalho, virmos Ankersmit localizar em vários indivíduos e grupos a presunção de ter havido um momento em que tal unidade ou harmonia última existiu, anteriormente à "queda" dos seres humanos na condição histórica, afirmarei que tal presunção é aceitável como sintoma ou experiência histórica a ser descrita, mas não como princípio teórico a ser afirmado.
} 
2014, KUUKKANEN, 2015) o texto é adequadamente entendido como um ato de fala direcionado também a finalidades retóricas específicas, então cabe discutirmos também o critério proposto por White para o que, no debate mais epistêmico avançado recentemente por Kuukkanen, Zelenak e outros, se poderia chamar de avaliação dos textos. Seu ponto foi muito mais polêmico - e retoricamente mal sucedido, ao menos a curto prazo -, mas resgataremos dele algo de valor para nossos próprios fins.

Em alguns ensaios dos anos 1980 republicados em the The Content of the Form, White insiste que (nos termos de "The Politics of Historical Interpretation") a "eficácia" da narrativa é oriunda da sua capacidade de atribuir sentido à sublimidade da história, não das verdades que ela diz - embora as questões não sejam completamente inseparáveis, pois ele também aponta que todo conhecimento produzido em ciências humanas é mais compatível com certas interpretações da história do que com outras. ${ }^{109}$ Não poderia ser diferente: a constituição de sujeitos coletivos (no caso em questão, "Israel" e "Palestina") depende da adesão de outros indivíduos a uma coletividade, o que, por sua vez, é ligado ao conteúdo específico da ek-stase constitutiva de ambas as partes envolvidas, os agentes individuais e o(s) coletivo(s). Percebamos bem que isto não preclude a possibilidade de se criar condições sociais para que os membros de uma coletividade sejam mais atento a verdades singulares, à consistência discursiva, a questões éticas etc.

\footnotetext{
${ }^{109}$ Neste ensaio, White dizia que a interpretação sionista do Holocausto não é, como Vidal-Naquet chama "muito apressadamente", uma "inverdade" (em contraste com a interpretação negacionista do Holocausto, que, obviamente, ele considera uma "mentira"): "De fato, sua verdade, como uma interpretação histórica, consiste precisamente em sua eficácia em justificar uma grande quantidade de políticas israelenses contemporâneas...". Não se tratava de um apoio a tais políticas: White falava nos "aspectos totalitários, para não dizer fascistas, do tratamento israelense aos palestinos na Cisjordânia". O uso da noção de "verdade" aqui, porém, enfraquece seu argumento: é não apenas incoerente, mas sobretudo ineficaz!, ao menos levando em conta que parte de seu público era composto de historiadores. Embora não desejemos transformar o trabalho em um estudo da recepção de White, cabe mencionar que Carlo Ginzburg, em ensaio bastante conhecido publicado no volume Probing the Limits of Representation: Nazism and the Final Solution, organizado por Saul Friedländer, desdobra o seguinte deste trecho: "Nós podemos concluir que, se a narrativa de [o negacionista do Holocausto] Faurisson em algum momento viesse a se provar efetiva, White a consideraria verdadeira também." Um intérprete textual tão sutil quando Ginzburg certamente poderia compreender melhor o ponto de White, por mais ambíguo que ele tenha sido.

É digno de nota que, dentre os teóricos da representação histórica, não apenas White, mas também Frank Ankersmit tenham buscado disputar termos como "verdade" e "realismo" em suas publicações recentes, buscando significar-lhes para além da epistemologia, de maneiras compatíveis com a expressão de sentimentos (caso do realismo figural) ou do desvelamento de aspectos do mundo (segundo o Ankersmit mais recente). A partir do texto (apresentado em 1990, publicado em 1992) em Probing, a "verdade" ou "realismo" de White não é unicamente o critério "horizontal" da eficácia. Ele retoma o ponto já presente implicitamente em "The Burden of History" de que há uma afinidade estrutural entre o tipo de evento representado e a forma linguística ideal para fazê-lo. A afinidade não presume que a linguagem - como a linguagem modernista, por exemplo - "espelhe" os eventos, mas certamente depende da ideia de que certas formas artísticas expressam melhor que outras as experiências de certos períodos.
} 
É importante notar que a existência de uma base estética a partir da qual tudo na representação se articula não implica que deva haver uma dimensão determinante em última instância. A representação enquanto totalidade invariavelmente negocia com os níveis estéticos e epistemológicos das partes do texto e as preocupações éticas, práticas e políticas que o perpassam. Ora, uma descrição de evento só pode passar por uma operação de caráter epistemológico - tal como a inserção em um encadeamento causal (como mostrou Danto) ou a verificação arquivística - por ser redescrita em termos intersubjetivamente compreensíveis. Trata-se, portanto, de uma operação também estética em que toda uma gama de outras descrições possíveis é eliminada. A estética tanto pré-condiciona a epistemologia quanto é retroativamente limitada por ela.

Keith Jenkins, por exemplo, ao mesmo tempo em que recusa a possibilidade de determinação em última instância, parece reintroduzir esta mesma ideia ao afirmar, partindo de raciocínios plausíveis e perfeitamente compatíveis com a visão whiteana que estamos delineando, que a história é um construto pessoal produzido pela ideologia:

... não importa o quão verificável, aceitável ou checável, a história segue sendo, inevitavelmente, um construto pessoal, uma manifestação da perspectiva do historiador enquanto um 'narrador'. (JENKINS, 2005: 14)

Para mim, o que determina a interpretação, no fim [ultimately], reside além do método e da evidência, na ideologia. Porque, embora a maioria dos historiadores concordem que um método rigoroso é importante, há um problema em relação a qual método rigoroso eles estão falando. (idem, 18)

Ora, como o enredo e implicação ideológica se influenciam mutuamente (e ainda por cima devem negociar sua coexistência com um dado modo de argumentação) então a expressão emocional em relação aos eventos é feita em negociação também com o projeto de sociedade desejado pelo sujeito, cujo caráter é tanto individual quanto coletivo, de maneiras impossíveis de determinar a priori. O elemento identitário tende a ser forte aqui, na medida em que projetos de futuro devem ser feitos por atores coletivos, em relação ao qual o indivíduo se articula por meio de narrativas, constituindo a si mesmo no processo. Mas, sendo a historiografia um campo profissional, a "eficácia" do ato de fala argumentativo depende também do convencimento dos pares, e, portanto, o sucesso da dimensão ideológica passa em alguma medida pela argumentação formal, e, em um nível mais básico, pela redescrição das evidências de acordo com os protocolos aceitos no campo. Feita esta ampliação de escopo e removido o risco de uma interpretação fundacionalista, então, sim, nos parece 
correto argumentar que a representação do passado envolve uma incontornável negociação de desejos e projetos corretamente agrupados sob o nome "ideologia".

Da posição de Jenkins, e na esteira de pensadores como Foucault e Derrida, ocasionalmente se desdobra um argumento que considero equivocado, e ao qual gostaria de propor uma alternativa: a ideia de que atribuir significados ao passado seja uma questão de "violência" em relação a ele. Em seu livro sobre Ankersmit, oriundo de uma tese de doutorado orientado por Jenkins, Icke afirma:

[Os dados] serão buscados e selecionados para, coletivamente, individualizar o
"end game" substância narrativa, que não é parte do passado, mas, em vez
disso, é um ponto de vista imposto sobre o passado, uma violência ou forçar a
um formato [knocking into shape ${ }^{110}$ de um passado real que não tem
preferência como ser representado. (ICKE, 2012: 34)

Eis um exemplo de posição pós-modernista à qual o presente trabalho se opõe: violência e "knocking into shape" são termos que presumem que o passado tinha uma forma anterior sólida e tinha preferências, algo que não é coerente com as concepções de história dos próprios Jenkins e Icke. Qualquer imagem mental do que significaria "knock into shape" presume uma forma estabelecida anterior. Como Jenkins discute a concepção, proposta por Ankersmit $(1983,2001)$, de que a representação é uma "forma de olhar" para o passado, observemos que a representação faz não é isto: ela $f a z$ aparecer o passado de certas maneiras.

Fazer aparecer não é por si só violento - deste gesto, pode-se igualmente dizê-lo criativo. Mas é justo afirmar que existe violência em uma certa forma de fazer aparecer, aquela que não é pluralista ou (em sentido whiteano) "irônica": quando se congela uma forma de olhar como a única possível. Primeiro, porque aí (a) as possibilidades abertas no passado são temporariamente impossibilitadas de se manifestar no presente - até que a impermanência derrube este exercício de poder no presente, o que seria uma frase confortadora se ela também não levasse consigo as evidências e outros suportes materiais que nos permitem compreender o passado. Segundo, porque, em vez de ampliar a margem de liberdade pela qual os outros podem lidar com o passado, e, por tabela, com a qual podem viver e agir no presente, rumo ao futuro, o congelamento limita esta margem.

Assim, apenas para exemplificar a aplicação do raciocínio a um caso relevante para o nosso trabalho, que discutiremos mais adiante: qualquer concepção de que

\footnotetext{
${ }^{110}$ Não se trata de um termo com equivalente em português: ele indica não apenas uma atribuição de formato, mas emprega um termo com conotações violentas, "bater".
} 
"precisamos da ilusão de substância" (2014: 103) vai contra os interesses do próprio White de propor um pluralismo com base no qual se possa produzir convivência tolerância entre seres humanos. ${ }^{111}$ Toda "ilusão de substância" limita arbitrariamente que se veja, e portanto que se use, as possibilidades abertas no passado em uma direção futura que outro grupo possa considerar desejável.

Um mérito na formulação de Icke seria a seguinte. A ideia de que o passado é "violado" é uma forma estranha de dizer que o sujeito está no mundo e todo conhecimento que ele tem molda o objeto aos meios pelos quais ele pode conhecê-lo. Mas saber que uma apresentação é uma apresentação mantém aberto o fato de que outros podem apresentar o passado de outra forma. A parte correta do raciocínio de Icke é que, simplesmente por apresentar o passado, não se pode des-apresentá-lo: ela produz uma ampliação irreversível das maneiras possíveis pelas quais aquele passado se apresenta e produz uma ampliação da capacidade do próprio sujeito de fazer o mundo aparecer. Não há conhecimento da história que deixe o sujeito e a história intactos pois o sujeito é feito da história.

Na medida em que estamos falando de algo que "não tem preferências" - que não é uma entidade com consciência - o próprio conceito de violência perde o sentido. Mas não deveríamos levar em conta que a parte mais importante desta "substância narrativa" que chamamos de "o passado" foi composta por pessoas, que não têm mais consciência, mas que tiveram? Na medida em que nos atentarmos ao fato de que os seres do passado tinham consciência - e preferências - e que estabelecemos um certo tipo de relação, não diretamente com eles, mas com elementos culturais que existem parcialmente como consequência de suas ações, projetos e desejos, na medida em que podemos em alguma medida escutar ou ignorar suas vozes, ativar ou esquecer as tradições das quais eles foram partes, então se torna preferível falar na dimensão ética da relação com o passado. Não há ética que não inclua poder e violência em algum nível, mas o conceito é mais amplo. É possível também representar o passado de modo a ampliar a sensibilidade dos vivos em relação ao sofrimento (dos vivos e dos mortos, ou de uma coisa por meio da outra), a honrar a memória, a dar continuidade dos projetos iniciados ou interromper a continuidade dos projetos em andamento: formas de ação ética em que a pessoalidade dos seres do passado é reconhecida e respeitada. Isto não demanda pressupostos inocentes, justamente criticados pelos pós-modernistas, sobre o

\footnotetext{
${ }^{111}$ Ver o comentário de White, e a rejeição deste argumento por Ginzburg, em FRIEDLÄNDER, 1992, além de KERN, 2010 e TOZZI, 2014.
} 
que seria "conversar com o passado" ou reconhecê-lo como "presente". Trata-se apenas da afirmação de que as "relações com o passado" são mais justamente caracterizadas como "ativas" (não-transcendentais, como querem os próprios pós-modernistas!) do que como "violentas": não há como significar o passado sem fazer algo com ele.

E igualmente importante: sem que ele faça algo conosco, inclusive mais do que saberíamos que ele poderia fazer. Primeiro porque, como Gadamer já disse, a tradição traz consigo mais do que um sujeito historicamente situado pode saber a princípio. Segundo porque, apenas após conhecer a tradição de dentro, e portanto ser modificado por ela, o sujeito sabe o que estava ativando para o presente. Estes dois pontos, juntamente com a discussão desta seção, nos permitem afirmar que os pós-modernistas concebem o passado de maneira exageradamente inerte, como se ele fosse conhecível apenas de fora. $\mathrm{E}$ isto os leva de volta ao transcendentalismo: assim como o cartesianismo presumiu um sujeito inteiramente separado do mundo, eles presumem um sujeito no presente inteiramente separado do passado. Isto valeria para configurações materiais que se formaram e já cessaram, mas não vale para tradições, que, como Collingwood e Gadamer mostraram, têm existência temporal - e não em momentos atomísticos divisíveis - e só podem ser conhecidos de dentro. O significado é de fato produzido para tradições, mas o objeto que recebe o significado apresentava ao historiador ou filósofos "formas de olhar" para o mundo, e estas formas podem ser mobilizadas no presente. Então, na forma de tradição, (uma parte d') o passado fornece os recursos por meio dos quais (uma parte d') ele será olhada.

Ao mesmo tempo, formando não só a situação a partir da qual as escolhas são feitas, mas também o sujeito que escolhe, podemos observar que as condições de prefiguração são formadas por experiências passadas. Estas, por um lado, foram elas próprias prefiguradas, mas, por outro, também preenchiam padrões da natureza, juntamente com padrões antecedentes. Na medida em que, como Dewey, podemos apontar que os ritmos da natureza e da existência humana - que é inseparável da natureza - formam tais padrões, então uma certa forma de experienciar a temporalidade é uma das condições de prefiguração - que vêm do mundos passado e presente, e retornam ao mundo presente. Nas palavras de Dewey: "Sob o ritmo de cada arte e de cada obra de arte subjaz, como um substrato nas profundezas do subconsciente, o padrão básico de relações da criatura viva com o seu ambiente.” (1980: 150)

\subsubsection{A tropologia é transcendentalista? Ironia e sublime}


Uma queixa que Ankersmit recorrentemente dirige a autores como White e Gadamer é o de que eles não se desprenderam do transcendentalismo. Veremos estas críticas e as possíveis soluções de Ankersmit em mais detalhes adiante. Mas, por ora, adiantemos uma questão mais breve: a teoria dos tropos é transcendentalista?

Em um sentido, pode-se dizer que sim: ela é uma caracterização das possibilidades lógicas de inter-relacionamento entre parte e todo, de maneira não muito diferente dos modos de compreensão de Mink. Além desta dimensão a-histórica, ela possui um componente trans-histórico: ela afirma que a consciência necessariamente começa a apreender o mundo de forma metafórica, passa por metonímia e sinédoque, e só ao fim de um longo processo ela consegue refletir sobre aa maneira pela qual ela apreende o mundo, culminando no modo irônico. Mas isto a princípio não deveria ser um problema, pois o próprio Ankersmit considera que sua descrição das operações da "lógica narrativa" ou das "representações" também valem para todos os contextos, ainda que, em todos os casos citados neste parágrafo, as maneiras particulares pelas quais as representações são construídas são sempre históricas.

Mais especificamente, estamos propondo uma leitura da tropologia de White (como da compreensão de Mink e da representação de Ankersmit) em que tais descrições filosóficas descrevem a coemergência entre sujeito e mundo, incluindo o mundo passado, de modo que não temos um sujeito a-histórico e um mundo histórico, mas sim a descrição filosófica a- ou trans-histórica da relação entre sujeitos históricos com mundos históricos. Assim, todo o aparato que o sujeito leva para entender o mundo é também histórico: seu modo de usar a metáfora é histórico, o uso de enredamentos, argumentos e implicações ideológicas é histórico, e também o são toda a gama de desejos e pressupostos filosóficos, sem falar no caso óbvio da situação em relação à qual ele produz seu ato de fala.

Há um segundo motivo pelo qual é possível ler o conjunto da teoria dos tropos de maneira não-transcendentalista, que é sua culminação no tropo da ironia. Se, como Ankersmit afirma, a teoria dos tropos esclarece as condições transcendentais de possibilidade do conhecimento histórico, e se o conhecimento histórico é possível (e é "construído" relativamente a uma figura de linguagem: não são coisas incompatíveis), então a tropologia é um equivalente histórico à tentativa de Kant de esclarecer as condições de possibilidade do conhecimento científico. Porém, a tropologia tem uma diferença importante na sua própria culminação no tropo da ironia, que é parte do movimento dos tropos e ao mesmo tempo permite liberdade no uso dos tropos. A 
perspectiva autoconsciente ou irônica já não pode ser justamente caracterizada como transcendentalista. Então os tropos não são naturalmente instrumentos transcendentais: três deles, quando usados sem o meta-tropeamento irônico, são, mas o uso autoconsciente produz reconhecimento da historicidade e, com isso, desfaz a ilusão de que o sujeito esteja fora da história: o sujeito na história produz conhecimento sobre a história, e expressa na linguagem a situacionalidade de seu ponto de vista.

A ironia não "sai" da história, ela lida com a história de dentro, mas a partir de um conhecimento que é efetivamente trans-histórico: aquele sobre a historicidade de toda forma de conhecimento. Reconhecendo todo ponto de vista como parcial, a perspectiva irônica não adquire um ponto de vista de Deus ou de lugar nenhum, mas produz "formas de olhar" que estimulam que o leitor e a comunidade historiográfica não cristalizem esta forma de olhar como "a" forma correta (portanto a-histórica) de olhar, desveladora do sentido inerente da história. Em vez de cristalização, ela estimula que se olhe de múltiplas formas possíveis (e assim cada olhar é um meta-olhar que reconhece no evento a possibilidade de se mostrar de múltiplas formas, e reconhece a impossibilidade de esgotar todas as formas pelas quais isto pode ocorrer.)

Lembremos que Ankersmit propôs uma leitura da Wirkungsgeschichte e da compreensão configuracional segundo a qual estas devem ser melhor entendidas como parte de um movimento sempre histórico, no qual formas de olhar são englobadas por novas formas de olhar. De acordo com esta leitura, a Wirkungsgeschichte era tanto a culminação do historicismo quanto a sua superação. Este raciocínio, acrescentaríamos, nos conduz inevitavelmente ao sublime: não havendo um ponto de vista fundacional a partir do qual significar um processo histórico sempre em movimento, então nada na história - nem os eventos particulares, nem o processo enquanto totalidade - tem significado inerente. $O$ que nos permite concluir duas coisas. Sobre a tradição narrativista em geral, como esta é a tese apresentada por Danto já em "Narrative Sentences", notemos que a argumentação desenvolvida por ele já no início dos anos 1960 conduz diretamente às reflexões sobre o sublime desenvolvidas por White em 1982 e por Ankersmit em 2005. Temos portanto um argumento a mais em prol da leitura "continuísta" da relação entre "representacionalismo" e "experiencialismo". Sobre a filosofia de White em particular, notemos que é esta a visão de história que se abre a partir do tropo da ironia. A história pensada e escrita a partir deste tropo, incluindo os ricorsos por meio dos quais se pode empregar metáfora, sinédoque e metonímia, bem como os estilos anti-narrativizantes como os da literatura modernista, 
não presumem um lugar de fora da história a partir da qual o passado é significado. $\mathrm{O}$ sujeito histórico significa o passado com recursos históricos.

\subsection{Dois exemplos: medo e ódio}

Delineamos quatro elementos presentes no "segundo nível de consciência" que atuam como "fatores de prefiguração" (Mink), isto é, fatores que condicionam a maneira pela qual o mundo será compreendido (Mink) ou representado (Ankersmit): os desejos, os princípios ou pressupostos filosóficos, a experiência da temporalidade e as emoções. Sobre o "segundo nível de consciência", lembremos de dois pontos importantes: nele, ocorre uma interpenetração entre o individual e o coletivo, já que o sujeito utiliza a imaginação refletindo sobre sua própria atividade básica de primeiro nível de consciência (como a dor, no exemplo clássico de Wittgenstein), mas os recursos linguísticos que ele emprega para tal são necessariamente coletivos. É com a imaginação que surge o mundo social, em relação ao qual o sujeito se constrói como indivíduo e como membro reconhecido de uma coletividade. Isto significa também que a construção de identidades - tão central para o figuralismo de White quanto, como veremos, para as experiências de Ankersmit - têm relação direta com as atividades deste nível, o mais básico exceto aquele das sensações privadas. Mas notemos também, em segundo lugar, que as atividades de terceiro e quarto nível da consciência - formulação de proposições, história, filosofia - reincidem sobre a imagem mais básica do que é o mundo construída pela imaginação, e passam a ser parte até mesmo de como o sujeito interpreta e expressa, inclusive para si mesmo, suas experiências privadas. Então nenhum exemplo pode ser discutido que envolva apenas atividades do segundo nível: elas envolvem as sensações corpóreas e as múltiplas reflexões em uma única totalidade holística, em que todos os níveis são afetados.

Os dois exemplos que mobilizo aqui envolvem o medo e o o ódio, em algumas de suas várias manifestações e/ou discussões filosóficas possíveis - não há algo como "o medo" ou "o ódio" a-históricos. Ambos são úteis para examinarmos a maneira pela qual uma certa construção de "vocabulários" (Rorty) está intimamente conectada com as relações sociais entre os grupos, mas o medo tem a vantagem adicional de exemplificar também a relação com o mundo natural e com a temporalidade.

a) Medo 
Dentre as várias maneiras pelas quais poderíamos discutir o medo, uma especialmente útil para as várias preocupações de nosso trabalho aparece no livro Envolvimento e Distanciamento, de Norbert Elias. O objetivo de longo prazo anunciado por Elias naquele livro era o de contribuir para nada menos que "a quebra da tradição [...] que legaliza o uso da violência coletiva entre estados". O outro era romper com a tradição filosófica que aborda o conhecimento humano de maneira a-histórica. Para ele, era fundamental mostrar, pelo contrário, que todo conhecimento é transmitido de geração a geração, por meio do aprendizado, e está sempre sujeito tanto crescer quanto a declinar.

O segundo objetivo, na concepção de Elias, era necessário para a obtenção do primeiro: é por ainda não conseguir operar de modo "distanciado" que ainda persistia "a fraqueza das ciências sociais em relação à sua tarefa" (o texto original é de 1983). Visando fortalecê-las, ele mobilizou as noções - não opostas, mas existentes em um continuum - de "envolvimento" e "distanciamento". E isto torna sua discussão particularmente interessante para os fins do presente trabalho, porque as dualidades entre representado e representação, viver e narrar, experiência e linguagem, etc., frequentemente são construídas de modo dicotômico. E eu gostaria de mostrar que tal coisa não é necessária: é possível empregar um vocabulário - estar "dentro" de um período, como diriam Danto e Ankersmit - e não estar inteiramente reativo à maneira pela qual ele faz surgir um "mundo". Isto produz um tipo de distanciamento que não é o distanciamento transcendentalista temido por Ankersmit, pois se trata de experienciar o próprio mundo "ironicamente": a ironia é uma forma "distanciada" que não demanda o desengajamento, mas sim o pluralismo; trata-se, portanto, de um tipo de "envolvimento distanciado", e, se o termo soa paradoxal, podemos ao menos ter em mente que o próprio Ankersmit aproxima a ironia e o paradoxo.

Duas características são essenciais na concepção de conhecimento de Elias: em primeiro lugar, a de que ele não existe de maneira a-histórica; surge, sim, em um longo processo por meio do qual seres humanos ampliam a congruência entre seus símbolos e a realidade. Assim sendo, é necessário levar em conta que, onde hoje há saber, outrora houve a condição de não-saber. O ponto da congruência requereria uma discussão mais detalhada para o caso das representações historiográficas (que envolvem outros elementos mais e não deveriam ser entendidas em termos "realistas" de verdade como correspondência), mas o citamos apenas para enfatizar sua conexão com a segunda característica da concepção de conhecimento de Elias: esta congruência entre símbolos 
e realidade requer maior grau de "distanciamento"; quanto mais envolvimento há, especialmente de caráter emocional (no sentido que chamamos, mais cedo, de "reatividade"), por parte daquele que busca conhecer, menor será sua possibilidade de formular os símbolos crescentemente abstratos por meio dos quais a humanidade conhece o mundo. Esta afirmação não é incompatível com uma concepção mais pragmática de verdade. ${ }^{112}$ Por outro lado, quanto maior o distanciamento emocional (não no sentido de desconexão, mas no sentido de não-reatividade que permite o que chamamos de "responsividade"), maiores são suas possibilidades de obter um conhecimento mais "distanciado" tanto em termos de alcance temporal - pré-condição para a sociologia processual proposta por Elias - quanto em termos da independência dos símbolos de referenciais imediatamente acessíveis aos sentidos. Seu problema, então, era o de fazer com que as ciências sociais façam esta difícil transição, já efetuada pelas ciências naturais, da condição de não-saber para a de saber.

Para nossa presente discussão, três corolários da proposta de Elias podem ser destacados. Em primeiro lugar, a conexão entre afetos e/ou emoções e temporalidade. No texto "Os Pescadores e o Turbilhão", Elias ilustra sua tese com o conto "A Descent into the Maelström”, escrito por Edgar Allan Poe em 1841. No conto, dois irmãos estão afundando em um turbilhão. Um deles, tomado pelo medo, não sobrevive; o outro, porém, "se afasta" da situação e, devido a isto, consegue se salvar: "enquanto observava e refletia," diz Elias, fazendo analogia com a prática científica, "ele teve uma 'ideia'; uma visão reveladora do processo em que estava envolvido; e uma 'teoria' começou a se formar em sua mente." Embora acontecimentos assim envolvam variáveis diversas por exemplo, às vezes já é tarde demais para se salvar, às vezes é melhor deixar os instintos agirem mais espontaneamente, às vezes a solução é descoberta por acidente -, esta situação ilustra o que ele considera ser uma tendência geral: nela, "os níveis de

\footnotetext{
${ }^{112}$ Que se manifesta em um autor como White, por exemplo. Algo é verdadeiro na medida em que é eficaz. Veremos que este critério é criticado por autores como Ginzburg, mas lembremos que eficácia não envolve apenas a capacidade de mobilizar emocionalmente um dado público alvo, mas também (como vemos mesmo em um autor como Rorty, que privilegia muito mais as relações horizontais entre vocabulários do que a relação vertical deles com o mundo - ver o cap. 1) a capacidade de agir em relação ao mundo, o que, por sua vez, inevitavelmente depende da capacidade de predizer seu comportamento ou, como eu preferiria dizer, receber seu feedback e integrá-lo ao nosso sistema. O termo feedback indica a dimensão de relação entre sujeito e mundo (cf. MACY, 1991), e a filosofia da representação de Ankersmit tem, dentre seus méritos, o de se propor a pensar a relação entre representação e realidade (passada). Em minha visão, não é o caso de dizer - como os pós-modernistas e mesmo White - que exista tal relação, já que, sendo seres processuais, seres humanos são feitos de passado (e da direção futura - do futuro do passado - destas ações e pensamentos passados: o que equivale a dizer que seres humanos são, ao menos em algum grau, feitos de tempo).
} 
autocontrole e controle do processo eram, como se pode ver, interdependentes e complementares." (166)

Ora, devido a esta interdependência entre autocontrole e controle do processo bem explicada pelo fato de que, como temos argumentado, o sujeito existe sempre em relação a um mundo -, a dinâmica entre eles também ocasiona círculos viciosos: o perigo (ou a sensação de estar em perigo) gera uma alta emotividade, que, por sua vez, reduz as chances de avaliação realista da situação. Sem ela, por sua vez, indivíduos e sociedades não podem controlar o processo e agir de maneiras também realistas. Isto retroalimenta a sensação de perigo. Vimos que, para Elias - especialmente no que dizia respeito às relações cuja dinâmica é configuracional, como a relação entre nações e o risco de guerra nuclear por elas engendrado na segunda metade do século XX - tal realismo na avaliação só poderia ser obtido por meio de uma perspectiva de longo prazo. Isto significa, dentre outras coisas, que diferentes modos de circulação de afetos propiciam maiores ou menores condições sociais para a adoção de diferentes perspectivas temporais. Se Vladimir Safatle está certo em apontar que o medo é o afeto predominante na política (e na filosofia política) contemporânea, então a aplicabilidade de propostas como a de Jo Guldi e David Armitage, que recentemente advogaram pela retomada de perspectivas de longa duração na historiografia como antídoto para o "espectro" do short-termism da cultura contemporânea, requer também a modificação dos afetos envolvidos nas nossas escolhas de enfoque. ${ }^{113}$ Esta questão evidentemente se conecta com o problema de Metahistory sobre a existência de múltiplas maneiras de representar a realidade realisticamente: as diferentes emoções, vontades, desejos e aspirações morais que se manifestam no enredamento e na implicação ideológica condicionam também qual tipo de explicação conta como aceitável e qual não conta. A ênfase de White é mais em formas de explicação do que no alcance temporal delas, mas o raciocínio se estende igualmente para este caso. ${ }^{114}$

Um segundo fator de nosso interesse - também presente nas reflexões de Elias, também relacionado aos afetos e emoções, e também predominante na cultura (e na teoria cultural) contemporânea - atende pelo nome de "identidade". Elias aponta que a dificuldade de encerrar os conflitos entre nações se relaciona com a forma pela qual

\footnotetext{
113 Ver GULDI \& ARMITAGE, 2014, e também os ensaios no volume "The Aesthetics of Scale" publicado pelo Journal of the Philosophy of History em 2015.

${ }^{114}$ Sobre a inseparabilidade dos modos de enredamento, explicação e implicação ideológica, ancoradas em uma leitura de Northrop Frye, ver o artigo de Nicolás Lavagnino em BENTIVOGLIO \& TOZZI, 2017.
} 
estas coletividades criam identidades: "A notável propensão que as pessoas apresentam para projetar parte de sua auto-estima individual nas unidades sociais específicas, às quais estão ligadas por fortes sentimentos de identidade e de participação, é uma das raízes dos perigos que os grupos humanos constituem uns para os outros." Isto não significa que a relação das pessoas com seus grupos seja apenas de envolvimento: "Trata-se de notável mistura de auto-estima e altruísmo, de gratificação narcisista e de devoção ao coletivo. A situação paradoxal está intimamente ligada ao fato de o ego humano ser tanto ego-eu quanto ego-nós." Porém, diz Elias, os fatores de envolvimento dificultam a aceitação de teorias incompatíveis com os desejos e a auto-estima das pessoas. Um exemplo é a substituição da teoria geocêntrica pela heliocêntrica: embora esta última já tivesse se manifestado em pensadores da Antiguidade, ela só veio a se difundir com a "emergência de um enfoque da natureza mais científico, mais congruente com a realidade", que "foi uma manifestação de compreensível mudança na estrutura da personalidade das pessoas" e "encontrou expressão em muitos outros aspectos de suas vidas", como por exemplo nas artes. (idem: 55-57) Assim, não apenas a ciência moderna tinha maior grau de distanciamento que suas antecessoras, mas também na arte do período esta característica se faz presente - por exemplo, no gesto de Velázquez de representar a si mesmo em As Meninas (idem: 77-98). Antes disso, seu custo emocional era um dos fatores contribuintes para que ela não se difundisse.

Assim, Elias considera que: "O desencanto emocional que segue o rastro dos principais avanços científicos não é acidental; trata-se de uma característica estrutural desse avanço" (idem: 200) - ainda que não seja um processo sem compensações, tais como mais segurança e mais controle sobre a natureza. Há um movimento parecido quando é o desencanto que gera a reflexão: para Ankersmit, também a "consciência histórica" se originou de um processo de perda e desencantamento. Mas há, a longo prazo, um potencial libertador nesta dor inicialmente resultante da perda de uma identidade que sua filosofia - um tanto melancólica neste ponto - leva pouco em conta. Descobertas que removem o homem de sua posição central no universo são dolorosas para quem acreditou em tal posição: veremos, novamente seguindo Ankersmit, que esta dor é de um tipo específico, originária da experiência de perda. Mas ora, indivíduos que já nascem com outro "fundo de conhecimento já existente" não apenas estão privados de perder o que nunca tiveram, como também podem experimentar o prazer de novas descobertas científicas. Evidentemente, parte do argumento de Ankersmit passa pela afirmação de que os indivíduos "experienciam” uma memória coletiva que não é a que 
eles experienciaram individualmente, ${ }^{115}$ mas isto não significa que a experiência individual seja irrelevante para identificarmos este tipo de sofrimento ligado à perda de uma imagem de si mesmo e do mundo.

Por sorte, como divulgadores da ciência como Carl Sagan já afirmaram em outros momentos, o universo já é “encantado" o suficiente com características que, aliás, jamais poderiam ser conhecidas sob os velhos pressupostos. Elas ampliam o campo de ações possíveis e removem causas óbvias de sofrimento, como no caso de curas de doenças ou de facilidades de comunicação e transporte. Aqui, estamos falando das ciências hard: nelas, os praticantes atingem consensos temporários sobre quais protocolos linguísticos utilizar, de modo tal que seus símbolos podem ser congruentes com o mundo. A historiografia também possui estes recursos: seu praticantes podem consensualmente individualizar figuras como Napoleão ou Júlio César, e podem formular ou aplicar teorias de caráter sociocientífico. Porém, de acordo com o argumento narrativista, estas verdades (referenciais ou teóricas) são incluídas em representações que produzem sentido para o passado, em vez de meramente o encontrarem lá. $\mathrm{O}$ fato de que o sentido surge nesta conexão entre o passado e o presente por meio da representações cria uma sempre renovada possibilidade de "encantamento" do mundo: como novas possibilidades de representar a realidade surgem incessantemente, novos aspectos dos eventos sempre podem ser desvelados. Neste espaço indeterminado entre as verdades ditas sobre o passado e as variadas formas pelas quais ela pode ser expressada atua a liberdade da imaginação humana. Do distanciamento reflexivo gerado por experiências históricas sublimes, então, não se ocasiona apenas a perda de uma suposta imediaticidade do mundo, mas o ganho de novas possibilidades de fazer o mundo aparecer e agir sobre ele. Uma destas possibilidades será enfatizada nos capítulos vindouros: a possibilidade de construir solidariedade para além de vínculos identitários, o que passa pela ampliação da capacidade de ver o outro em sua pessoalidade, e não como um objeto. Não se trata de um acessório à prática historiográfica pelo simples fato de que esta é a realidade dos seres: eles efetivamente são sencientes, nossas ações realmente tem consequências sobre eles e vice-versa, e nossos modos de representá-los igualmente têm efeitos sobre eles e vice-versa. Ignorar estas verdades é construir "sistema histórico" insensível ao feedback dos outros seres e do mundo, e portanto ser incapaz de agir de maneira adequada em

${ }^{115}$ Ver o ensaio "The Postmodern Privatization of the Past" em ANKERSMIT, 2001. 
relação a eles (MACY \& BROWN, 2014): basta termos em mente as consequências de uma forma de representar o mundo que ignora a ciência climática ou o impacto da violência estatal sobre a população pobre e negra do Brasil, e lembrarmos que, ainda assim, tais coisas continuam existindo. Na linguagem de Elias, não há "controle" - ou, em uma mais adequada para o presente trabalho, resposta eticamente informada, capaz de criar uma vida significativa, quando os feedbacks do sistema são interrompidos. E o problema do "encanto" é evidentemente conectado com a capacidade de produzir significados ou sentido (meaning) para a vida - esta que é uma questão central da filosofia whiteana, e depende da manutenção da consciência histórica (Collingwood) ou da autoconsciência irônica (White) para ser efetivada. Estas, por sua vez, dependem da experiência de perda, originalmente produtora de sofrimento (Ankersmit), para surgirem após um longo processo histórico.

Uma das implicações destas reflexões, a meu ver, é que investimentos emocionais em identidades individuais e coletivas podem ser obstáculos à produção de conhecimento e à convivência pacífica entre indivíduos e sociedades. O objetivo de Elias, de romper os ciclos de violência entre as nações, não é concebível sem o distanciamento que, no presente trabalho, se manifesta no tropo da ironia. Que identidades invariavelmente etnocêntricas (ou de alguma forma "naturalizadas") sejam perdidas no caminho não é necessariamente algo a ser lamentado a longo prazo. Vimos como, para os narrativistas, representações sobre a realidade não "aderem" à realidade. Há uma sublimidade última do mundo que o torna irredutível a qualquer representação que dele se possa fazer, e todo movimento de atenção (experiência no sentido de Dewey) entre o conceito e o mundo assumirá a forma de um trabalho de negatividade. Ora, este raciocínio deve ser estendido também à construção de identidades, pois elas também são "substâncias narrativas". Juntamente com todo o potencial libertador que representações autoconscientes (seja sobre o passado, seja de identidades individuais ou coletivas) possam ter, há o risco de aprisionamento a cada vez que uma representação passa a ser interpretada da forma que Ankersmit chamou de "cristalizada", sob a falsa aparência de descrição literal da realidade. E há também uma implicação ética para isto: se uma escolha estética passa a aparecer como a única maneira realista de representar a realidade, então a ação escolhida com referência a esta representação aparecerá como a única ação realista a ser feita. O projeto utópico de White não é bem servido por uma consequência como esta. 
Como o objetivo da historiografia é, para Ankersmit, ampliar o número de representações possíveis de um evento, e não buscar a meta de Elias, que tem em mente a produção de símbolos congruentes com a realidade, cabe uma observação adicional sobre o que poderia significar "congruência com a realidade" no caso das representações históricas - ou ainda, da filosofia que discute tais representações. Para uma disciplina como a história, que busca disseminação e não redução, a postura metahistórica (que White mostrou ser inseparável da postura histórica) só pode ser a do pluralismo, a do reconhecimento de que uma mesma realidade pode ser representada de muitas maneiras diferentes. O reconhecimento de que não há uma realidade para arbitrar sobre a escolha de uma representação em vez de outra, embora obviamente haja uma realidade para discussões epistemológicas sobre outros aspectos da operação historiográfica, é um reconhecimento congruente com a realidade. E assim, para as humanidades, a conclusão que filósofos da história podem adotar é que todo etnocentrismo é "incongruente com a realidade". Esta afirmação depende de outras três que ainda não defendi adequadamente neste trabalho, mas que espero tornar evidentes no restante do texto. Primeiro, o reconhecimento filosófico da insustentabilidade da cristalização de identidades estimula a responsividade mais que a reatividade: não se pode coerentemente - mas não duvidemos do potencial humano para incoerências compreender o caráter construído de "substâncias narrativas" como as nações e, ao mesmo tempo, ser nacionalista ou xenófobo. Segundo, como Ankersmit deixa claro em Sublime, a impossibilidade de sustentar a própria identidade resulta em uma experiência de dor - mas uma observação, a meu ver muito importante, será feita no capítulo quatro: não é necessário construir o "sentido da vida" (White) ao redor da expectativa de reconhecimento coletivo de uma certa identidade, como muitos dos exemplos utilizados por Ankersmit naquele livro fizeram. A dor em questão ocorre, por exemplo, devido a acontecimentos externos consideravelmente mundanos, desde a derrota de um time de futebol para alguém que atribui a si a propriedade de "vascaíno" ou "botafoguense" até a descoberta de não ocupar o centro do sistema solar por grupos que atribuem esta característica à sua espécie; ocorre também pelo não-reconhecimento dos demais membros da sociedade. O desejo de evitar a dor envolvida na perda de identidades estimula a aversão a tudo aquilo que se afigura como ameaça a elas, sejam eles outros grupos, sejam novos conhecimentos.

Em terceiro lugar, a autoconsciência sobre o caráter construído e maleável das identidades permite um relacionamento mais maleável, e consequentemente mais 
tolerante, em relação a elas: é possível adotar identidades específicas (“brasileiro”) que estejam em maior harmonia com outras mais amplas ("humanidade", "ser vivo"), de modo que a diferença não seja percebida como ameaça - evitando assim, como deseja Elias, o círculo vicioso propiciado pela sensação de medo. Nossa leitura da noção de "experiência histórica sublime", de Ankersmit, deverá esclarecer o segundo ponto; as reflexões de White sobre a noção de ironia, o terceiro.

Às questões sobre temporalidade e identidade, adicionamos outra, a respeito da conexão entre epistemologia, estética e ética. Vimos como Elias aponta a existência de elos entre a ciência e a arte (utilizando o Renascimento como exemplo), que, de modo mais geral, indicam que sua conexão que perpassa as diferentes esferas da vida. Seu objetivo, como vimos, era ampliar o "distanciamento" da sociologia e, por meio do conhecimento produzido por ela, difundir tal distanciamento para as outras esferas com a qual a sociologia e as demais ciências estão conectadas. Falo em difusão porque, afinal, o distanciamento deve começar em algum lugar (no contexto de sua discussão sobre experiência histórica sublime, Ankersmit emprega a metáfora biológica das "mutações", que me parece bastante apropriada para explicar a ocorrência inicial de perspectivas distanciadas). Indivíduos, por mais envolvidos que sejam, variam seus graus de envolvimento em diferentes momentos do dia, nos diferentes ambientes que frequentam, etc. As relações humanas entre no interior de sociedades e as relações entre nações também apresentam variados graus de distanciamento ao longo do tempo. Então é presumível que, nestes momentos, alguns indivíduos ou grupos possam adotar perspectivas mais distanciadas e, percebendo a vantagem de adotá-las, busquem difundi-las para o restante da sociedade. Em momentos de maior receptividade, é mais provável que obtenham sucesso.

Elias, um sociólogo, busca um caminho cognitivo para difundir o distanciamento. White não formulou sua proposta nestes termos, mas irei refigurá-la neles. Ele e outros autores enfatizam uma solução estética, mas, como o próprio Elias mostrou, estas dimensões estão conectadas e a produção de maior distanciamento em uma esfera influencia todas as demais. Se a proposta de White é estética, seu caminho não é menos racional: ele escreve textos de história e de teoria da história para um público bastante específico, também composto por intelectuais, visando difundir neste campo os insights sobre enredamento oriundos da literatura modernista, mais tarde percebidos pela teoria literária e daí difundidos para outros campos. Hoje, uma parcela domesticada destes insights se espalhou até mesmo para a historiografia - a mesma 
disciplina que, como o próprio White frequentemente afirma, se envolveu na tentativa de "repressão" de sua dimensão literária na busca por distanciamento em relação ao passado. Ora, Elias aceita que mesmo a arte mais "distanciada" expressa e produz emoções. Assim, se há formas de envolvimento emocional (como o medo) que não produzem distanciamento intelectual, há outras formas de envolvimento emocional que estimulam proximidade (e o fato delas requererem o distanciamento autoconsciente para que possam ser resultado de uma escolha prática - ética e estética - não contradiz em nada esta afirmação). A arte, aqui, se torna um instrumento cognitivo. Uma aposta (que me parece obviamente uma aposta whiteana, ainda que dita em termos que ele não utiliza) é conceber o uso autoconsciente da estética como uma forma de produzir o que poderíamos chamar de "proximidade distanciada". Notemos que o "distanciamento" daquele que sobrevive no conto de Poe não é a recusa de se engajar na situação, mas, inversamente, a capacidade de reconhecer sua complexidade e agir a partir deste reconhecimento. Não houve "ironia ideológica" ali, e sim "ironia epistemológica", no sentido mais preciso de que um dos irmãos perceber que a situação poderia ser conhecida de outras formas que não aquela que se apresentava em sua imediaticidade.

E isto nos leva a enriquecer o significado deste tipo de ironia, já que descreve um tipo de operação bem descrito pelo Ankersmit mais recente: não se trata de negar que representações representem a realidade, mas de reconhecer que múltiplas perspectivas são mais desejáveis para revelar aspectos da realidade que uma só. Adicionalmente, cabe reconhecer que este pluralismo só é bem servido da perspectiva que White chama de irônica e a partir da manutenção da consciência histórica para a qual Collingwood dedicou seus esforços: para apresentar a realidade de múltiplas maneiras, é necessário manter as condições culturais e infraestruturais que permitem responsividade mais do que reatividade. $\mathrm{O}$ medo, no caso do exemplo discutido, permite apenas um pequeno espectro delas; sua temporalidade de modo geral é a da curta duração, e, quando há seres envolvidos percebidos como "outros", o aspecto destacado deles tende a tomar como referencial o "eu" que está em perigo.

O que nos leva à segunda exemplificação do argumento sobre as condições de prefiguração que se manifestam na transição do nível mais básico de consciência para os mais abstratos, passando pelo segundo - onde ocorre a tropologização ou a atuação da imaginação.

\section{b) Ódio}


Citamos como um afeto como o medo dificulta o exercício da mobilidade da atenção - e portanto de desvelamentos da realidade, e portanto da ação - rumo a diferentes perspectivas temporais, o que resulta, segundo o critério de Ankersmit, na redução da qualidade de uma dada rede de representações. Um segundo exemplo é o impacto do ódio, que - qualquer que seja a circunstância histórica particular - limita o outro a estereótipos: ou seja, desvela menos aspectos sobre ele. Assim sendo, condena aquele afetado por ódio a representações de baixa qualidade sobre o mundo, e, dada a conexão identidade-mundo-passado, também a representações de baixa qualidade sobre o passado.

O caso paradigmático é evidentemente o da maneira pela qual os nazistas descreviam os judeus durante o Terceiro Reich, como parte de uma visão de mundo que surgia como a própria realidade, e em relação às quais um campo de ações possíveis se delineava. A descrição desta visão de mundo por Peter Fritzsche ilustra bem o que está em jogo para os nossos próprios propósitos:

Esta postura deliberada, na qual o anti-semita ignorou indivíduos e viu apenas
a categoria, e o fez em nome de outra abstração, Alemanha, era o ponto de
partida para a violência contra os judeus. O antissemitismo "redentor" poderia
se tornar feroz e cruel de uma maneira que as medidas higiênicas contra os
"associais" ou os "débeis mentais" não se tornava, porque as ações contra os
judeus eram entendidas como tentativas propositais, certeiras de repelir a
condição de desunião e desordem da própria Alemanha. Foi ao longo deste
circuito, no qual os alemães se imaginaram vítimas de judeus e outros
"traidores" [backstabbers, literalmente: aqueles que esfaqueiam pelas costas],
que o "amor próprio" poderia se transformar em "ódio ao outro" letal.
(FRITZSCHE, 2008: 122)

Aqui ocorre efetivamente uma decisão que, se falarmos nos termos de Ankersmit que discutimos algumas páginas atrás, equivale a não olhar para a realidade, e sim para a representação. Isto não precisa significar, então, que se possa ter acesso à pessoa em si, mas que é inteiramente possível adotar múltiplas formas de olhar para ela que não se resumem a uma única forma, e que revelariam muitos outros aspectos que não os de uma única categoria abstrata.

Um problema adicional de afetos como o ódio é que, ao direcionar a atenção para categorias, ele não permite que se reconheça a pessoalidade dos seres com quem se lida. Mas este problema não ocorre apenas no caso do ódio: uma concepção do mundo em que seus componentes são redescritos em termos unicamente técnicos ou na forma de recursos também produz uma despessoalização de tudo que efetivamente existe de 
vivo nele. ${ }^{116}$ Tal visão pode ser ampliada também para a relação dos seres humanos com a biosfera, incluindo seus componentes materiais. ${ }^{117}$ Qualquer proposta de retorno ao "contato direto com a realidade", então, precisa dar conta de incluir o reconhecimento da condição viva dos demais seres - condição esta que não se resume a absolutamente nenhuma construção de significados, por mais complexa que ela seja.

Jay (2018) e Runia (2014: 103) recorreram à distinção de Roland Barthes entre studium e punctum para argumentar que o passado se faz "presente" não nos esquemas de bom gosto pré-concebidos por meio dos quais nos engajamos de maneira relativamente vaga com o mundo (studium), mas com os detalhes outrora despercebidos, não-posados, que surgem nas fotografias como o que Runia chama de "passageiros clandestinos" e nos atingem como flechas no presente. Uma experiência de tal tipo tida por Barthes foi a de ver sua mãe, por quem estava em luto, em uma fotografia de quando ela era criança, sem controle de como estava sendo representada. Uma distinção mais ou menos deste tipo pode ser feita aqui sobre como as figuras desumanizadores ou despessoalizadoras pelas quais indivíduos ou grupos são feitos surgir como "bandidos", "vagabundos", "vermes" e outros termos que os valham: elas

\footnotetext{
${ }^{116}$ Leiamos as palavras de Eduardo Viveiros de Castro (2017), para fins de comparação: "No mundo indígena tem excesso de gente, é um mundo saturado de intencionalidade. Inversamente, toda a nossa epistemologia popular envolve retirar intenção do objeto e reduzir a intencionalidade ambiente para que se tenha um conhecimento objetivo. Quanto mais você conhece menos você subjetiva. Talvez chegue um momento em que não conseguiremos interpretar palavras ingênuas como 'querer', 'desejar', 'imaginar' que serão substituídas por equações físicas de estados energéticos de uma rede neuronal. ... lá onde tudo é humano, o humano deixa de ser o que nos entendemos por humano. Se os porcos também são gente, a noção de gente perde esse sentido que damos à palavra, que restringe a condição metafísica, moral e jurídica ao homo-sapiens." Lembremos que a possibilidade de entender desejo e imaginação como um vocabulário dispensável efetivamente é expressada em uma obra que orbita o campo de interlocutores do nosso debate, a de Richard Rorty.

${ }^{117}$ Como afirma Ailton Krenak, em termos que nos remetem à discussão sobre o "encantamento" do mundo: "Muita gente tem problema com a palavra 'sagrado' e acha que aplicar esse termo à natureza é um exagero, como se fosse uma tentativa equivocada de estender à natureza conceitos que são só da cultura. É difícil, muita gente tem vergonha do sagrado ou de demonstrar alguma sensibilidade que não tenha a ver apenas com seu umbigo. Se reproduzir e se bancar com o máximo de consumo, qualquer idiota pode fazer, mas não é qualquer idiota que consegue transcender à fissura de si mesmo e ter uma percepção de que somos mais do que animais que se reproduzem e dominam territórios. Somos capazes de ideias, percepções e sentimentos que restabelecem para nós mesmos o sentido do sagrado. E sagrado pode ser tudo aquilo em que botamos os olhos, a depender dos olhos com que enxergamos o mundo. Se vemos uma montanha como toneladas de minério a serem transformadas em carros e outras bugigangas, então ela não pode ser sagrada. Se olhamos uma floresta e não conseguimos vê-la com algum significado transcendente, então ela vira só um estoque de recursos naturais. É quase o que acontece no Brasil hoje em relação à energia, todos os nossos rios estão sendo calculados em quilowatts. Então, alguém olha um rio e só pensa em quanta energia pode ser retirada dali. São verdadeiros vampiros que olham a natureza com as presas de fora."

Disponível em: <https://www.povosindigenas.org.br/pt/Not\%C3\%ADcias?id=131424> Acesso em 23 de outubro de 2018. Joanna Macy e Chris Johnstone comparam a visão capitalista com a dos indígenas Haudenosaunee em termos parecidos: "Um empresário madeireiro certa vez observou que, quando olhava para uma árvore, tudo que ele via era uma pilha de dinheiro sobre um tronco. Compare isto com a visão dos Haudenosaunee, segundo a qual as árvores deveriam ser tratadas com gratidão e respeito." (2012: 54)
} 
prescrevem uma relação na qual o estabelecimento de empatia - e daí de compaixão com o outro é bloqueado, no qual não há abertura para que o outro seja visto para além do que já se presume saber dele. O punctum nas fotografias, por mais que aja à revelia das intenções de quem as contempla, precisa da atenção desta pessoa para surgir como punctum. Pois, como argumentaremos adiante, só há passado vivo quando há uma atenção capaz de entrar em contato, ora ativa, ora passivamente, com este passado. E isto tem implicações para o papel da ironia no meu argumento. Concebida aqui como parte de uma visão pluralista de modo na qual se sabe que o mundo pode ser representado de outras formas e excede quaisquer que sejam suas representações, a ironia é pré-condição para que os outros seres sejam reconhecidos não a partir dos seus predicados produzidos por representações (tanto as que desvelam seus aspectos reais quanto aquelas que meramente projetam sobre o outro a condição de vida não-digna de luto), mas de sua pessoalidade básica. Está em jogo, em suma, o que fazemos com nossa atenção quando a direcionamos aos seres, vivos (no atual exemplo) ou mortos (no caso da historiografia). E neste último caso, a atenção aos mortos - os outrora-vivos - ativa também figuras que afetam os vivos.

Uma nota adicional sobre a conexão entre atenção e ética. Quanto à pessoalidade, o argumento é irresistível: os seres são efetivamente mais complexos que representações particulares, e mais ainda as simplificadoras. A discussão sobre o quão inclusivos são os critérios (éticos, práticos, ideológicos) que governam a produção de uma dada representação não envolve necessariamente erros (como o erro de identificar um sujeito a uma categoria), mas decisões com diferentes consequências pragmáticas. Um historiador pode ou não tomar a inclusividade como parte de seus critérios, mesmo quando sua motivação é a produção de um "passado prático". Para colocarmos diretamente, ele o fará se desejar. Aqui cabe apenas observar que, sendo ele um ser que co-existe com os demais vivos, é difícil conceber um auto-interesse viável que não envolva também o interesse de outros grupos. É difícil argumentar contra desejos, mas é possível apontar que eles produzem diferentes consequências práticas.

\section{7. "Passado histórico" e "passado prático"}

Em anos recentes, White tem atribuído grande importância à distinção entre "passado histórico" e "passado prático", formulada em outro contexto pelo filósofo Michael Oakeshott, para sintetizar e realinhar argumentos que perpassam sua carreira. $\mathrm{O}$ tipo de passado mobilizado por historiadores profissionais em seus textos, para ele, não 
é capaz de orientar seres humanos em suas tentativas de responder à questão (central na ética kantiana) “O que eu deveria fazer?”. O passado mobilizado de modo a responder esta questão é o de tipo prático, e, embora não discuta em detalhes as circunstâncias em que ele é aplicado, White acredita que a escrita figurativa de modo geral e a modernista em particular é especialmente capaz de efetivá-lo no atual contexto histórico (WHITE, 1999: passim; 2004). Em sua leitura, o processo por meio do qual a retórica foi reprimida na historiografia - sobre o qual White também falou ao longo de toda sua trajetória - consiste na tentativa de estudar o passado de maneira unicamente "histórica": "no século XIX, o estudo da história cessou de ter qualquer utilidade prática exatamente na medida em que foi bem-sucedida em se transformar em ciência." (2010: 10) O problema não é o uso de métodos científicos, mas precisamente o esquecimento acerca da motivação para se estudar o passado em primeiro lugar: "Os mortos podem ser estudados cientificamente, mas a ciência não pode nos dizer o que nós desejamos saber sobre o passado." Esse já era o problema não só de "The Burden of History", como já vimos, mas também de seus primeiros textos, sobre Collingwood, Toynbee, Croce e outros.

A recepção geral à distinção entre "passado histórico" e "passado prático" é marcada por uma mistura de rejeição e dificuldade de compreender qual é, exatamente, o ponto de White. ${ }^{118}$ Um ponto quase consensual é que a caracterização deste tipo de abordagem feita por White não corresponde (nem busca corresponder) ao que tem sido praticado de fato por historiadores profissionais. ${ }^{119120}$ Outro consenso, que pode ser lido explicitamente, por exemplo, no comentário de Maria Inés la Greca (2016), é a nãodesejabilidade de abandonar a abordagem que gera o "passado histórico", especialmente por ser desejável e mutuamente enriquecedora a coexistência de ambas as abordagens.

Toda uma gama de comentadores que defendem a importância relativa da abordagem "histórica" têm razão neste ponto. Se não estamos, como White argumentou

\footnotetext{
118 Tenho em mente, especialmente, SPIEGEL, 2013, LA GRECA, 2016, AHLSKOG, 2016; PIHLAINEN, 2016.

${ }^{119}$ Mas observemos que, em sua visão, este sucesso não foi, não pode e não deveria jamais ser completo, pois a ciência requer consenso quanto aos protocolos linguísticos empregados, o que não é factível por parte de disciplinas que empregam linguagem ordinária.

${ }^{120}$ White parece mais interessado em estabelecer uma tipologia do que em caracterizar empiricamente estados específicos de certos campos profissionais (ocidentais modernos). Mas, ao proceder assim, ele se permite um certo passe livre para proceder com caracterizações generalizantes sobre a historiografia. Tome-se como exemplo esta afirmação: "Este passado histórico, de acordo com o doxa dos profissionais, é construído como um fim em si mesmo, tem utilidade prática muito limitada, se é que tem, e contribui apenas minimamente para a compreensão do que o povo ordinário considera ser 'o presente'." (WHITE, 2010: 42)
} 
e como vimos no cap. 1, condenados a escolher entre razão e emoções, entre ciência e arte (o que é indicado pela existência de um solo comum entre ambos, que "The Burden of History" caracterizava como seu "caráter construtivo"), e, como mostra Kuukkanen, entre objetividade e subjetividade, então é não só possível como desejável que construamos passados tanto com atitude "histórica" quanto com atitude "prática". Mais ainda, a oscilação entre as abordagens é desejável porque, em ambos os casos, é possível preservar a memória oriunda da experiência anterior. O relevante é compreendermos a totalidade da empreitada de produção de conhecimento sobre o mundo - incluindo todas as artes e ciências - de uma perspectiva em última instância prática, mas reconhecendo as peculiaridades das múltiplas formas de investigação e vendo-as como produtoras de uma multiplicidade de perspectivas, incomensuráveis mas não auto-excludentes. (Assim como as representações históricas, para Ankersmit e Mink, não se reúnem em uma única História Universal - são incomensuráveis entre si mas esta riqueza de perspectivas é uma riqueza e não um obstáculo para a produção de conhecimento sobre o passado.)

Aprofundarei aqui outro ponto, um que me parece especialmente relevante para a compreensão da proposta de White: sua caracterização é de diferentes atitudes diante do passado. Ahlskog (2016) nota bem este aspecto, mas, ao mesmo tempo, considera a noção de "passado histórico" equivocada por presumir um passado "morto", cujas descrições não possuem automaticamente efeitos práticos. Recorrendo a Collingwood, ele insiste, em vez disso, que o "passado está vivo porque nós reconhecemos, sim, ações e elocuções no passado como respostas inteligíveis e reações a um mundo humano compartilhado. O que está completamente morto não poderia jamais ser ressucitado como performances significativas (meaningful) na imaginação do historiador.” (2016: 12) ${ }^{121}$ Veremos que neste último ponto ele tem razão; sobre o caráter "vivo" ou "morto" do passado em White, vejamos melhor.

A meu ver, esta abordagem em que o passado está "vivo" também pode ser lida no próprio White, ao menos em um certo White. Ele assim fala sobre o "passado histórico": "Uma conexão genealógica entre gerações fornece um simulacro de substância compartilhada por terra, povo, cultura e sistema social de uma totalidade histórica singular. Esta é a função social, política, ou, eu gostaria de dizer, ideológica do "passado histórico"” (WHITE, 2014: 98). Ou seja, poderíamos dizer igualmente que o

${ }^{121}$ Ver também seu aprofundamento da discussão da noção de "passado vivo" em Collingwood, comparando sua abordagem com a do paradigma da presença, em AHLSKOG, 2017. 
passado histórico tem, de acordo com o próprio White, uma função prática - ele apenas a mascara. A chave parece estar em sua identificação de "prático" com ético e estético, bem como de "histórico" com "científico", ou, mais especificamente, pretensamente científico. Um ponto chave a observar é que, desde a sua primeira formulação da díade, em debate com Dirk Moses em 2005, White ocasionalmente considera o passado mais como uma "ausência presente" (WHITE, 2005: 333) do que como uma mera ausência. Sobre as formulações do passado como ausência, falaremos adiante; sobre o primeiro caso, leiamos seu argumento:

\begin{abstract}
Eu considero que a ética é a diferença entre o que é (ou foi) o caso e o que deveria ser (ou deveria ter sido) o caso em algum departamento do comportamento, pensamento ou crença humana. Como de Certeau disse, o ético abre um espaço em que "algo tem que ser feito". [...] O passado histórico ${ }^{122}$ é "ético" no sentido que seu assunto (violência, perda, ausência, o evento, morte) desperta em nós os tipos de sentimentos ambivalentes, sobre nós mesmos e também sobre o "outro", que aparecem em situações que requerem escolha e engajamento em maneiras existencialmente determinantes. De modo a lidar com este tipo de eventos, que interessam ou deveriam interessar públicos modernos, deve-se apelar às tradições eticamente ricas de expressão literária; mas é precisamente delas que, em seus esforços para se tornarem "científicos" ou "objetivos" ou até mesmo "neutros", os historiadores se privaram ao longo do último século aproximadamente (WHITE, 2005: 338).
\end{abstract}

Ou seja, novamente aqui a ênfase é nas situações éticas e nos recursos adequados a lidar com elas; não se trata, nem no caso prático nem no histórico, de afirmar ou negar "vida" ao passado. Como White segue Danto e Mink em considerar que "não há eventos, apenas eventos sob descrição", então o passado, sempre potencialmente vivo, pode ser apresentado neste espaço significativo que é a realidade humana de maneira que efetive ou não sua "vida", i.e., sua capacidade de demandar atenção à consciência e de fornecer subsídios para a ação em uma situação. ${ }^{123}$ White considera que as exclusões estilísticas disciplinam a imaginação histórica e, ao afetar as regras de descrição, constituem o que conta e o que não conta como um fato histórico. (WHITE, 1987: 66). Tendo em vista tal conexão entre a descrição de evento e o campo de possibilidades aberto por ela, então, ainda que toda descrição presuma a condição

\footnotetext{
${ }^{122}$ Mas notemos que aqui ele não parece usar o termo em referência à distinção de Oakeshott.

${ }^{123}$ Examinando a noção de "passado vivo" em Collingwood, Rik Peters emprega uma frase potente: "A realidade é o passado vivo." Porém, como a realidade humana não existe separadamente da consciência que a constrói, pode ser útil distinguir entre os dois elementos inseparáveis que a compõem: tanto o passado vivo é a realidade externa que recebe ou demanda atenção da consciência (e então o caráter vivo do passado é o motivo pelo qual elementos dessa realidade podem irromper no interior de nossos esquemas representativos) quanto os elementos internos com os quais o sujeito lida com o mundo a seu redor (e então o passado vivo é este fluxo de significados que, primeiramente redescoberto externamente por meio dos vestígios, agora "são" os próprios sujeitos que significam o mundo).
} 
"viva" e com "significado" do passado (AHLSKOG, 2016: 13), nem todas são igualmente eficazes de uma perspectiva situacional.

Nesse sentido, Doran (2013: 10) tem razão ao caracterizar a crítica de White à abordagem "histórica" como a de uma crítica à má-fé dos historiadores, que consiste em negar sua condição de ser consciente, Para-si, que simultaneamente é e não é seu passado, e assumir a impossível função de trazer o passado à sua consciência e à dos membros de sua comunidade sem modificá-lo no processo, isto é, de se eximir de decidir sua significação. Assim, a noção de passado prático não traz consigo a presunção de ser possível de fazer abordagens não-práticas; o que é possível é não assumir a responsabilidade por fazê-las e, no processo, de toda uma comunidade se impossibilita de responder com eficácia às situações em que se encontram. Ora, isso não significa que uma abordagem histórica não gere um certo tipo de passado correspondente: ela enfatizará os aspectos intersubjetivamente verificáveis pelos membros da comunidade profissional, que, em momentos de "ciência normal", opera a partir de um mesmo protocolo sem maiores problemas. A abordagem "histórica" faz algo, apenas se nega a fazer outras coisas mais - se engajar com as questões urgentes do mundo ao redor.

Assim, ao adotar a postura que produz um "passado histórico", o próprio historiador se posiciona como pudesse se anular e deixar que a voz dos mortos fale por si mesma. Neste sentido, não é tanto o caso que o passado seja presumido como "morto" quanto que a própria pessoa em seu presente nega sua condição de agente responsável, fazendo-se "coisa". Por meio deste processo, são eliminados de vista (mas não de atuação) os desejos, a subjetividade, e daí, inevitavelmente, também a finitude do sujeito cognoscente, tornado transcendental. ${ }^{124}$ Além disso, como veremos, a própria equivalência entre sentido e mundo nada mais seria que a morte, na medida em que tudo o que é vivo se desfaz. Em texto de 1980, White recorreu a Benveniste para distinguir

\footnotetext{
${ }^{124}$ Comentando a "distinção entre o sujeito psicológico e o sujeito epistemológico" em Descartes e Bacon, Martin Jay aponta para esta característica, típica da concepção moderna de ciência: "A transcendentalização e despersonalização do [sujeito epistemológico] significou a extensão de seu tempo de vida para além daquele de um ser humano individual. O projeto de explorar a natureza era cumulativo, sem ponto terminal exceto o conhecimento perfeito. Como resultado, aquela confrontação profunda com a nossa finitude inevitável, que era parte tão importante da noção de experiência de Montaigne, agora estava banida." (JAY, 2005: 35-36) Em trecho de Metahistory que remete à argumentação de "The Burden of History", White examinava a pretensão do início do século XIX daquilo cuja permanência criticaria no século XX: a de que os historiadores deveriam assumir uma posição intermediária entre ciência e arte, praticando porém uma ciência menos "rigorosa" e uma arte menos "livre". Sobre a ciência, de acordo com esta perspectiva: "a história não era uma ciência positivista, e o historiador deveria se contentar com uma concepção baconiana, empírica e indutivista da tarefa do cientista, o que significava que a historiografia deveria permanecer uma ciência pré-newtoniana.” (WHITE, 1973: 136)
} 
entre as pretensões objetivistas da narrativa e o caráter abertamente subjetivo do discurso. Se neste é marcada a presença de quem fala, na primeira "os eventos parecem contar a si mesmos" - mas em nenhum caso isto efetivamente ocorre. É o que White desejava colocar em discussão: "Mas eventos reais não deveriam falar, não deveriam contar a si mesmos. Eventos reais deveriam simplesmente ser; eles podem perfeitamente bem servir como os referentes de um discurso, podem ser aquilo sobre o que se fala, mas eles não deveriam posar como os sujeitos da narrativa.” (1987: 3) Para ele, porém, a atribuição da forma de estórias aos eventos é resultado de "desejos, sonhos acordados, devaneios" (idem: 24) de que a realidade possua coerência, em contraste com os elementos de "nossos pesadelos diante do poder destrutivo do tempo". (idem: 11)

É verdade que "o passado" não fala, nem define como será significado, embora seja perpassado de falas e outros significados. Mas isto não deveria implicar que ele seja morto, nem que seja um recipiente passivo de significações presentes. Afinal, entre os "eu" e "nós" presentes e os passados potencialmente "seus" (cada um dos quais, por sua vez, capaz de permitir ao eu presente se lançar em diferentes direções, mudando seu próprio ser) há uma potencialidade de compreender significações (ditas ou pressupostas) criadas no passado e atualizá-las como respostas a questões suas no presente. Assim, se as reflexões sobre enredo e tropologia apontam adequadamente que o passado não define como será significado, o figuralismo aponta também para a necessidade de que uma potencialidade de significação esteja presente na figura: embora o processo seja retroativo, a abertura de possibilidades no presente e para o futuro se dá com a atualização de figuras do passado, que tem como parte de si as significações de outrora, embora nunca meramente repetidas.

Assim, o passado não fala mas a figura não é meramente um silêncio; não há passividade, embora haja retroatividade. Como o ser que escolhe um passado, ao fazêlo, por possuir caráter ek-stático, escolhe a si mesmo, então não é possível entender nem a natureza deste ser nem a natureza do "passado" por meio de uma dicotomia simples entre "vivos" e "mortos". Afinal, o que "sou" é também constituído pelo meu passado, e a escolha de um novo passado a ser tomado como meu é feito por um ser que não decidi ser em uma situação que não decidi estar, que construo e interpreto a partir de critérios estéticos que não escolhi e em relação à qual ajo a partir de exemplos e critérios que primeiro recebi e só depois modifiquei. "Liberdade" aqui seria a própria margem de modificação desse ser que é um processo temporal de significação, manifestado em corpos situados, mas que sequer se confunde exatamente com eles. Cada ação modifica, 
isto é, torna "vivos" ou "mortos", aspectos deste ser a serem preenchidos em situações futuros: o campo de possibilidades se modifica (ora sutilmente, ora de maneira brusca) a cada lance. Mas a própria possibilidade de ativação ou desativação de potencialidades significa que "o passado" precisa ser vivo, ou, mais exatamente, um entrecruzamento vivo de dimensões "vivas" e "mortas" não em si, mas em relação às possibilidades disponíveis no presente para ativar ou não suas significações - possibilidades estas que mudam a todo momento. Trata-se, então, de um tipo de "vida" diferente daquela manifestada pelo ser que age no presente, e, certamente, como vimos com "What is a Historical System?", um tipo de vida que não pode ser identificado aos sistemas biológicos, e que nem mesmo se confunde (embora também não se separe) dos corpos dos seres humanos. Há algo de vivo que está no presente, sendo ele a própria margem de liberdade que atua retroativamente, sobre outras dimensões espectralmente vivas. $\mathrm{O}$ que significa, por sua vez, que não há um ser literal e isoladamente vivo no presente, que não seja interpenetrado pelas potencialidades e pelos espectros do passado e pelas possibilidades e espectros do futuro. ${ }^{125}$

Lembremos de dois argumentos já mobilizados no presente trabalho. Primeiro, este sujeito individual que escolhe (e o faz enquanto um ser desejante) "é”, dentre outras coisas, um entrelaçamento do(s) "corpo(s) e seus enredos" (WHITE, 1995). Isto inclui tudo que é produzido pelas atividades reflexivas da mente, mas que antes foi prefigurado pela atividade da imaginação. Os diferentes níveis se influenciam mutuamente: os instintos e sensações físicas são apresentados por meio de enredos, mas os enredos também provocam emoções, modificando o nível corporal. Corpo (físico), imaginação e pensamento proposicional são efetivos não isoladamente, mas em sua articulação enquanto um corpo (significativo, i.e., social). Isto significa também que as fronteiras entre indivíduos e coletividades jamais são claramente delimitáveis, embora não sejam nunca irrelevantes. Segundo, lembremos que White associa a autonomia da escolha do passado a diferentes graus de autoconsciência. Dessa forma, enquanto sociedades diversas ou grupos profissionais como os historiadores dos últimos dois séculos podem passar por longos períodos reproduzindo de modo relativamente automático os modos de enredar o passado, pensadores auto-conscientes (como ele afirma no caso de Hegel) são menos suscetíveis a "influências" da tradição. Mas mesmo

\footnotetext{
${ }^{125}$ Pois, como disse Derrida, espectros também vêm do futuro.
} 
a escolha individual é feita com recurso a modelos socialmente aceitos e buscam produzir mudanças coletivas.

Em terceiro lugar, esta relação entre indivíduo e coletividade é também uma relação entre presente e passado. Estou afirmando, com Butler, que os indivíduos primeiro se formam como a individualização de um certo modo de produzir sentido de sua coletividade, localizado em um certo espaço de relações sociais, materiais, econômicas, culturais etc., e só então exercem a possibilidade de escolha - que está sempre presente por princípio, mas que nem sempre é realizada autoconscientemente sobre como modificar esta tradição. O que significa: modificar a si próprio modificando a tradição. Ora, se sujeitos se constituem por meio do preenchimento de figuras passadas, então seus corpos se tornam suporte para fluxos temporais oriundos de outros cronotopos. Mais especificamente: também isto, mas nunca apenas isto. É, em graus variados dependendo de cada caso, como Laclau (1996: 89) afirmou sobre a lógica da espectralidade: “A espectralidade pressupõe ... uma relação indecidível entre espírito e carne que, por sua vez, contamina estes dois polos. Ela pressupõe, neste sentido, uma forma enfraquecida de encarnação". Esta articulação entre múltiplos fluxos temporais que antecedem o corpo e não se articulam plenamente com os fluxos que circulam com o resto da sociedade, também não plenamente contemporâneos a si mesmos - com os corpos compõem os sujeitos e se relacionam com os mundos social e material no presente, já que direcionam a atenção para certos aspectos e apagam outros, hierarquizam estes aspectos entre si, estimulam um certo tipo de sensações, emoções e desejos, e, por meio de tudo isto, possibilitam um conjunto de ações para o futuro e eliminam todo um outro conjunto, sempre muito maior.

É possível afirmar, por tudo isto, que o comentário collingwoodiano de Ahlskog tem pertinência, especialmente se enfatizarmos o aspecto figuralista do pensamento de White. Apesar das diferenças entre as reflexões que desenvolvemos aqui e a noção de re-enactment, em um aspecto elas se iluminam mutuamente: Collingwood reconhece que, durante períodos históricos inteiros, certos pensamentos do passado serão incompreensíveis, inacessíveis, misteriosos. No entanto, nada impede que sejam novamente acessíveis no futuro. Para nossa atual discussão, poderíamos dizer que mesmo estes pensamentos (ou ancestrais intelectuais em potencial) estão mais indecifráveis do que exatamente "mortos".

\subsubsection{Também o que está presente deve ser imaginado}


Em outros momentos, porém, White não enfatiza apenas a retroatividade da relação entre passado e presente, nem a interpenetração entre indivíduo e coletividade, que, devido à narratividade que perpassa a construção de sujeitos coletivos, implica também na interpenetração de passado e presente. Em vez disso, há momentos em que White adota uma posição francamente "presentista". ${ }^{126}$ Como LaCapra o criticava, já em 1978: "É curioso que as tendências construtivistas de White, que constroem os tropos como as forças informantes de uma consciência criativa, às vezes o levam a dar crédito à ideia de um registro histórico não-processado. $\mathrm{O}$ registro é apresentado como o objeto inerte a ser animado pela mente moldadora do historiador." (LaCapra também reconhece, como fizemos acima, que esta não é a única tendência manifestada por White.) (LACAPRA, 1985: 79-80) Em 2012, White formulou, com algum humor, uma tréplica a algumas das objeções que frequentemente recebe:

... a distinção entre fato e ficção depende de eu acreditar na realidade do passado. 'White não acredita que o passado existe'. Ele existe? Onde ele está?. Ou ele está próximo de você aqui e, logo, não é passado, ou você não

\footnotetext{
${ }^{126}$ Dray (1989: 164) considera White como um "presentista cético"; Paul, enfatizando sua dimensão ética, a caracteriza como sendo "situacional' ou até mesmo 'presentista" (ANKERSMIT, DOMANSKA \& KELLNER, 2009: 67). Toda a produção de autores como Jenkins, Munslow e Pihlainen também está perpassada de tais referências, neste e em outros termos. Stefan Berger e Chris Lorenz (2006: 69) (seguindo Nora e Hutton) chegam a ver um elo entre a posição de White e o regime de historicidade que Hartog chama de presentista (evidentemente usando o termo com significado diverso do de Dray): "O resultado do reconhecimento do fato de que a nossa relação com o passado é inevitavelmente moldada pelos nossos de representação tem sido o que Hartog chamou do regime de historicidade 'pretentista'. Presentismo é o resultado do 'esquecimento' gradual do passado $e$ do futuro na segunda metade do século XX, de acordo com Hartog, com a onipresença do 'presente' como resultado." O elo seria forçado se incluísse um exame interno do narrativismo, mas sociologicamente ele existe. Em debate com Jameson publicado primeiro em 1982 e republicado em 1987, o próprio White levanta a possibilidade de que as concepções tradicionais de política, história e narrativa já não se sustentavam mais, e defende o modernismo diante de Jameson como apontando não como "uma regressão a uma condição pseudo-mítica da consciência", como pensava o crítico marxista, mas sim "um impulso para ir além da distinção história-mito." (1987: 168) Ora, o elo entre política, história e narrativa é evidentemente o estado nacional, que, em textos recentes, Lorenz tem apontado como já não ocupando o papel central das narrativas historiográficas que (como White há muito enfatiza) ocupou nos últimos dois séculos. Assim, o interesse pela representação (para o qual a obra de White contribuiu de modo um tanto central, especialmente na historiografia) pode ser, de fato, resultante de uma crise das narrativas ou metanarrativas tradicionais, tal como Jean-François Lyotard já anunciava em 1979 em A Condição PósModerna (LYOTARD, 1988). Não à toa, o "ressurgimento da narrativa" percebido por Stone no mesmo ano e mais adiante consolidado em abordagens tais como a micro-história já não operava nos moldes da narrativa tradicional. Como autores como Levi e Ginzburg já mencionaram ao refletir sobre sua produção, tais narrativas são mais abertas, experimentais, fragmentárias, além de, é claro, não tomarem a nação como quadro de referência. Nesse sentido, as reflexões sobre narrativa e sobre presença parecem ser duas respostas a um mesmo fenômeno de crise das formas tradicionais de produção de sentido. Ora, Runia (2014: 53) considera que o paradigma da presença indica uma "passion du réel"; da mesma forma, White considera que a história é um "discurso do real" (1987: 20), termo pelo qual ele deseja "sugerir que nós podemos compreender o apelo do discurso histórico reconhecendo a medida em que ele faz o real desejável" ao lhe impor uma coerência formal que apenas as estórias possuem. Pode-se levantar então a hipótese de que uma crise das formas tradicionais de tornar o real desejável seja um fator motivador para a busca por "presença", que frequentemente envolve narrativas não restritas ao espaço nacional, como no interesse historiográfico por memória, oralidade e testemunho.
} 
tem acesso a ele. 'White acredita que não há distinção entre fato e ficção'. Minha resposta é que é uma questão de níveis do discurso: ficções são feitas, fatos são feitos. É o que a palavra 'factum' significa: 'feitura' (making). (WHITE \& VANDERSCOFF, 2013)

Eu não discordaria da afirmação, mas insistiria que, pelos próprios critérios de White, poderíamos nos perguntar, então: e o presente, onde ele está? O que chamamos de presente é mais que um lugar e que configurações localizáveis, pois só existe em um contraste com o que conta como passado. Kleinberg aponta isto com clareza em Haunting History: o indício de que se está operando no paradigma da presença é a presunção não de que o passado seja estável, mas de que o presente o seja.

É a própria noção de "existência" que perspectivas como o narrativismo (e tantas outras) nos levam a modificar para além de uma perspectiva realista, segundo a qual existir seria equivalente a estar em algum lugar. As tentativas de confrontar White com o problema do negacionismo do Holocausto adotam esta posição realista, misturando a existência construída do conceito Holocausto com a existência (caberia acrescentar: ela própria construída por seres humanos no passado) dos eventos coligados por ele. Pois vejamos: o presente não é nada como um lugar ou algo situável em um lugar, mas, no mínimo e dentre outras coisas, a relação entre a consciência, ela própria temporal, e o lugar. É por isso que "ficções são feitas, fatos são feitos". As críticas de White ao realismo não deveriam valer apenas para o passado, sob pena de sequer se sustentarem. A liberdade de fazer a si mesmo por meio da escolha de passado é também a liberdade do famoso garçom de Sartre que, a cada momento, deve construir a si mesmo novamente como a síntese temporal garçom sem nunca chegar a ser garçom: sua presença a si como garçom é sob pena de jamais sê-lo, de jamais poder garantir que seus eus futuros permaneçam garçons. Daí também o fenômeno da vertigem, que se manifesta por eu jamais poder privar meus eus futuros da liberdade de saltar no abismo. Se percebo o garçom como garçom, já o significo; se o percebo como alguém a quem não posso atribuir nenhuma das categorias usuais (garçom, francês, humano), já não posso fazê-lo. Fenômenos assim certamente são mais usuais nos momentos de crise de significação discutidos por White, Ankersmit e Runia. Mas há ainda outra possibilidade, que demanda uma mente reflexiva ou "irônica": se o percebo como uma negatividade que pode se construir de formas diversas, inclusive a de garçom, estou me "distanciando" da atitude natural com que seres humanos usualmente lidam com a realidade a seu redor. Isto é um tanto mais raro de ocorrer em situações cotidianas e eticamente irrelevantes (embora de modo algum impossível). Mas em casos que 
envolvem não mais a percepção, mas a atribuição de sentido a uma multiplicidade de eventos que ninguém poderia experienciar (ou perceber) sozinho (como Mink argumentou), este distanciamento é, em minha leitura de White, condição de possibilidade para a prática de uma "historiografia da libertação". ${ }^{27}$

O caso da percepção parece fornecer a White um falso contraste entre "presente" e "passado". Para além da - insuficiente, a meu ver - afirmação de White de que o passado que não existe, o que considero relevante para a questão é que, sem negar as diferenças entre passado e presente (a percepção é parte de como lidamos com este último) e o passado e o futuro (devido à irreversibilidade produzida pelo tempo, aquele possui um fechamento e este uma abertura, em sentidos talvez difíceis de definir precisamente), ${ }^{128}$ também o presente é construído imaginativamente, não só pelo caráter ek-stático da realidade humana e dos sujeitos que a compõem, mas também pela necessidade de sustentar significações que nunca chegam a se acoplar plenamente àquilo que é percebido fisicamente, por mais que pareçam fazê-lo, como no exemplo do garçom de Sartre. Assim, esta dimensão "presentista" de White, quando se manifesta, só parece se sustentar por aparecer ligada a uma noção de percepção pouco compatível com suas demais reflexões - e deve ser abandonada, com o cuidado de não perdermos junto com ele o caráter retroativo da relação entre presente e passado.

Falando sobre o mundo narrativizado da historiografia, White afirma que, nele, a “realidade veste a máscara de um significado." (1987: 21) A metáfora é excelente na medida em que, embora não seja o rosto, a máscara aparece a quem observa como indissociável dele. Mais para o fim do mesmo ensaio, "The Value of Narrativity in the Representation of Real Events", White toma a percepção como parâmetro por meio do qual se poderia observar o caráter construído do significado. Ele pergunta: "O mundo realmente se apresenta à percepção na forma de estórias bem-feitas, com sujeitos centrais, começos, meios e fins apropriados, e uma coerência que nos permita ver 'o fim' em cada começo? Ou ele se apresenta mais nas formas que os anais e as crônicas sugerem, seja como uma mera sequência sem início ou fim ou como sequências de inícios que apenas terminam e nunca concluem?” (24) White é partidário da segunda resposta (não nos enganemos pelo tom pouco assertivo do trecho, que contrasta com a argumentação de todo o texto): "Se fosse apenas uma questão de realismo na

\footnotetext{
${ }^{127}$ Termo empregado por Paul em seu livro de 2011 para caracterizar a historiografia desejada por White. ${ }^{128}$ Tenho em mente, aqui, os argumentos feitos respectivamente por KOSELLECK, 2006 e MINK, 1952 e 1987.
} 
representação, se poderia fazer um bom argumento de que as formas tanto dos anais quanto das crônicas são maneiras pelas quais a realidade se apresenta à percepção.”

Como a argumentação de White sobre a distância entre os enredos e "a realidade" opera em uma escala ampla (em que todo um conjunto de experiências afastado temporalmente é significado), seria parcialmente equivocado (e portanto parcialmente acertado) argumentar que anais medievais e crônicas modernas, que também operam em recortes espaço-temporais muito mais amplos que a percepção, sejam mais fiéis a como percebemos o mundo. Há uma interpretação melhor para este raciocínio, que suspeito ser o desejado pelo próprio White, embora ele demande a referência à "percepção" propriamente. A chave é uma comparação feita por ele um pouco antes. Ao notar que, diferentemente da coerência das narrativas historiográficas, os anais medievais como o de Saint Gall apresentavam vários espaços em branco, ele refletia:

Mas a presença destes anos em branco no relato (account) do analista nos permite perceber, por contraste, a medida em que a narrativa busca pelo efeito de ter preenchido todas as lacunas, de ter posto uma imagem de continuidade, coerência e significado no lugar das fantasias de vazio, carência e desejo frustrado que habita os nossos pesadelos sobre o poder destrutivo do tempo. (idem: 10)

O contraste não com o cronista de Saint Gall, mas com o Cronista Ideal de Danto, permitiria chegar à mesma conclusão: também um eventual registro das várias narrativizações - os vários inícios abortados, futuros passados, ressignificações, etc. mostra a artificialidade da sensação de continuidade, e esta projeção no feita no presente presente não foi experienciada por seres humanos no presente passado. Nesse sentido, por projetarem menos falsas continuidades que a historiografia moderna, eles são, de fato, mais "realistas". Porém, também suas estórias eram "vividas" e atribuíam configurações às lacunas de suas próprias existências. As expectativas não cumpridas de seres humanos no passado são parte da realidade histórica.

Quando as narrativizações deixam de ser percebidas como construídas, então elas ampliam sua potencialidade de falsear sua condição: não como uma articulação seletiva dentre as várias descrições possíveis de eventos, mas como a própria realidade apresentada na forma de estórias. Em seu experimento, Danto dizia que, após as descrições de eventos, o historiador deveria utilizar a crônica para, recorrendo a "valores", aí sim escrever uma história com significado. Mas não nos enganemos: o limite do experimento pode ser extendido se insistirmos que mesmo o Cronista Ideal 
registra de acordo com valores. Podemos imaginar que um Cronista Ainda Mais Ideal produziria algo verdadeiramente mais caótico, de fato, tão caótico quanto White considera ser a própria realidade: a Biblioteca de Babel do conto de Borges, em que tudo está escrito, mas a maioria dos livros sequer possui significado discernível. Isto é, poderíamos imaginar que tal cronista registra todo o amplo campo de possibilidades de significação disponível para os seres humanos do passado, incluindo não são os valores realmente escolhidos (as descrições "tipo 1" de Mink), mas também as possivelmente significativas ("tipo 2"), sem perder de vista que os sistemas conceituais do passado e do presente dão conta de uma parcela minúscula de toda a realidade, e que portanto muitos outros registros poderiam ainda ser feitos.

Mas a maneira pela qual operamos usualmente, claro, é bem diferente. Quase sempre, na "atitude natural", seres humanos já reificam a realidade, como se suas narrativizações (eu insistiria, menos em suas descrições mais básicas) não fossem já construções. Assim, White tem razão que há uma brecha entre a percepção e a narrativização, como há uma brecha entre a máscara e o rosto; mas o limite de sua metáfora, e a atenção a outros de seus textos, nos demandaria questionar a própria dicotomia entre a máscara "figurativa" e o rosto "literal" por trás dela. Afinal, como White bem sabe, não há uma "descrição padrão" (oriunda da percepção ou de qualquer outra coisa) por trás das "descrições de evento". A descrição padrão é a que convencionalmente foi feita como padrão. Da mesma forma, os rostos da realidade humana - diferentemente dos rostos físicos dos corpos humanos - são eles próprios maleáveis: são as máscaras que os seres do passado fizeram para si mesmos.

\subsubsection{Abertura às situações demanda mais ênfase no processo do que no resultado da significação}

A argumentação de The Practical Past em grande medida (e muito justificadamente) nega a possibilidade de se tomar a atribuição de substâncias como base para a formação da identidade de uma comunidade. Embora não seja particularmente claro, White parece considerar desejável algum ponto intermediário entre a postura autoconsciente acerca da transitoriedade de todas as coisas e o uso prático da atribuição de substancialidade às coisas. Afirma ele: “...identidade é forjada em atos de escolha, decisão e performance em bases estéticas e éticas (embora eu combinaria estes dois tipos de faculdade sob o nome de 'prática')" (2014: 102). Mas ele é inespecífico sobre como isto poderia ser obtido. Por exemplo, ele afirma: "Ao 
fornecer uma distinção entre o passado histórico e o passado prático, Oakeshott forneceu uma base para mudar o fardo de constituir um passado usável da guilda de historiadores profissionais para os membros da comunidade como um todo." (2014: 9899) Mas como isto poderia ser obtido por meio de estilos narrativos que demandam um público tão cultivado, tais como (para citar seus exemplos favoritos recentes) aquelas que encontramos em livros como os de Sebald ou Roth? Além disso, a proposta é mencionada em frases como: "O passado prático pode ser entendido imaginativamente como um espaço de experiência em que o indivíduo que virá-a-ser [the would-be individual] pode inventar e substituir a ilusão de uma identidade substantiva pela delusão de uma substância de identidade auto-idêntica." (2014: 101) Comentando esta frase enigmática, Chorell (2016: 133) afirma: "Eu devo admitir que acho isto muito difícil de entender." ${ }^{129}$ Admito o mesmo.

É claro, de qualquer modo, que há uma tensão aqui: embora formulada com pouca clareza, ela envolve algo como o que, ao longo da trajetória de White, foi a postura de conciliar ironia epistemológica com a rejeição à ironia ideológica no processo prático de construção de identidades coletivas. Nesse caso, a tensão é entre dois sentidos possível do que pode ser atribuído ao termo "acreditar em estórias": se, por um lado, não cabe fazê-lo, na medida em que "estórias não são vividas, mas contadas", por outro White parece legitimar a necessidade de que grupos com interesses utópicos formulem interpretações ideológicas com recurso a estórias nãonarrativizantes. O que nossa discussão até o momento indica sobre esta tensão? Em que sentido estas abordagens poderiam (e deveriam) coexistir?

Quando discutimos a separação narrativista entre experiência e significado, por um lado argumentei que esta distinção tem caráter temporal, e, neste sentido específico, de fato equivale à distinção entre o passado e sua apresentação no presente. Mas, por outro, insisti também que este fato fundamental da existência histórica não deve nos levar a uma concepção dicotômica entre passado e presente, na qual se supusesse que o presente é idêntico a si mesmo de modo que nenhum ser consciente pode sê-lo. Dessa forma, em um sentido há um abismo insuperável entre ambas as dimensões: nosso contato mais básico com o mundo é transitório e irrepetível. Os significados de agentes do passado ou de um texto que interpretamos (em um sentido, também um texto do

\footnotetext{
${ }^{129}$ Queixa idêntica à que o mesmo autor fizera em sua resenha de Sublime Historical Experience dez anos antes: "Eu tenho que admitir que frequentemente tenho dificuldade de entender o que Ankersmit quer dizer." (CHORELL, 2006: 98) E trata-se de um leitor evidentemente competente.
} 
passado) podem ser compreendidos fora de contexto, mas o significado de um ato por meio do qual significamos o passado e o texto é sempre novo, pois é ligado a um contexto e portanto também sujeito à transitoriedade. Assim, no mínimo devido a isto, de fato há um abismo entre experiência e significado.

Em outro texto, Chorell trata deste fato básico da existência humana, buscando "uma filosofia do valor especialmente adaptada para o fato de que as coisas são temporais e eventualmente irão desaparecer.” (2015: 12). O “desejo pelo passado" surge da tentativa de seres humanos de lidar com isto. Autores como Runia, Ankersmit e Gumbrecht, na leitura de Chorell, operam no interior de uma tradição erótica clássica que concebe o desejo como resultado da incompletude do ser devido à ausência incontornável do passado. ${ }^{130}$ Preferível em relação a esta busca fadada ao fracasso, em sua leitura, é operar com outra perspectiva, a da possibilidade de "sobrevivência". Ele propõe, seguindo a leitura que Martin Hägglund faz da "lógica da sobrevivência" de Derrida, que "[e]m vez de um desejo baseado na falta, nós temos que aceitar um desejo que apenas quer mais tempo, indefinidamente". ${ }^{131}$ Isto é: não havendo cabimento em desejar o "cancelamento do tempo", que equivale à morte (idem: 9), é preferível desejar de modo que valorizemos aquilo a cuja existência pretendemos prolongar. Eu observaria, adicionalmente, que, tanto por motivos éticos quanto pela maior adequação

\footnotetext{
${ }^{130}$ Para ele, Runia apresenta a segunda (e desejável) possibilidade, mas ainda retorna à oposição entre "presença" e "ausência". Não creio que seja este o caso, como se verá em capítulo vindouro. Runia identifica a operação desta dimensão platônica do desejo em nossa cultura contemporânea, mas não a repete. A presença na forma de "passageiro clandestino" é mais um desejo por um elemento extrarepresentativo, em contraste com uma representação incompleta mesmo quando se pretende completa (o "real", não "o passado"), que não está ausente mas apenas não é percebido, e não por um passado realmente ausente. Creio que o termo "presença" é melhor entendido como um recurso retórico para indicar o "não-ausente".

De fato, penso que as duas situações apresentadas por Chorell (2015) são possíveis: uma de sentir que o presente está incompleto e desejar esta completude no passado ou no real (poderíamos acrescentar, com Sartre e Heidegger: também no futuro); outra, de sentir insatisfação com a completude do presente e agir para destruí-la. Em comum, há a insatisfatoriedade incontornável do processo de construção de identidades de uma perspectiva não-irônica, o que decorre da ausência de sentido intrínseco à realidade. Qualquer investimento emocional que requeira crença na substância de algo que não possui substância produzirá sofrimento, já que a transitoriedade constante dos mundos natural ou social em relação aos quais se pretende agir, em relação ao último caso inclusive obtendo reconhecimento da própria identidade, invariavelmente não produzirá os mesmos resultados com uma constância. Por isso, como estamos argumentando, é importante pensar a relação entre o making de uma identidade e as experiências históricas sublimes como um processo, não de modo estático.

${ }^{131}$ Mais especificamente, ele se pergunta: "Há outra maneira de conceber o desejo no pensamento histórico que não na noção platônico-idealista de falta?" (idem: 10). Porém, vejo mais sentido em propor diferentes formas de desejar do que propor que concebamos intelectualmente o desejo de uma forma diferente. Afinal, é possível desejar de formas diversas, dependendo do tipo de esperanças e de medos que projetamos quando lidamos com a transitoriedade da vida. Discutindo a abordagem irônica de Peter Novick em That Noble Dream, Michael S. Roth considera que ele faz precisamente isto naquele livro: por meio de redescrição, e não de teorização, ele busca "estimular o desejo por uma auto-consciência aguçada por meio de redescrição histórica.” (ROTH, 1995: 30)
} 
à transitoriedade da realidade, o desejo não precisa enfatizar a própria identidade e o investimento emocional não-irônico em estórias, mas pode ser proveitosamente direcionado a identidades coletivas autoconscientemente provisórias focadas em valores, exemplos, possibilidades, já que estes (e não qualquer identidade específica) efetivamente podem perdurar diante da transitoriedade, ainda que mesmo eles sejam limitados. Não é isto que as reflexões de "What is a Historical System?" deixam claro? Após Danto, não é possível deixar de reconhecer o descompasso incontornável entre o movimento constante do todo e (conforme Collingwood) das nossas sensações de parte deste todo, por um lado, e a cristalização ou "cancelamento do tempo" resultantes da atribuição humana de significados por meio de descrições e representações, por outro. Sempre que operamos na "atitude natural" de crer na substancialidade dos significados e das identidades, "presente" é aquilo que ainda não teve sua não-substancialidade explicitada pela impermanência. A experiência histórica sublime envolve algo disto: ela não é apenas o desejo pelo passado, mas o desejo pelo impossível retorno à condição anterior à descoberta da própria inevitabilidade da condição de transitoriedade. Então toda experiência deste tipo tende a resultar em ironia: ela nos tira de uma situação de envolvimento imediatista na realidade, quando - na formulação de Ankersmit significados e mundo pareciam equivalentes (isto é, quando a questão sequer chegava a ser posta), e nos põe em uma situação de distanciamento em relação ao que temos que ser, ao mesmo tempo em que estamos separados por um nada por este passado que somos. Se por um lado este processo é doloroso - Ankersmit observa que "trauma e sofrimento" estão na base da "consciência histórica" - por outro ela é um ganho cognitivo, na medida em que nos propicia uma compreensão mais adequada da nãosubstancialidade e da transitoriedade de todas as coisas. Como afirma White (2014: 103) ao concluir The Practical Past, logo antes de se posicionar em defesa da posição de que "precisamos da ilusão de substância": "esta queda no nada é o destino de todas as coisas cuja substância é matéria."

Mas, na medida em que haja uma tensão entre a posição de "ironia epistemológica" e a aposta na "ilusão de substância", a mim parece proveitoso retornar ao caráter auto-conscientemente provisório que White propunha para a adoção de “metáforas" em "The Burden of History" e subsequentemente. Esta autoconsciência é um ganho de difícil manutenção, que Collingwood situa no último nível da escala de formas, e que nada mais é que o próprio pensamento histórico. Vimos que White também argumenta consistentemente em defesa de uma postura ética e autoconsciente 
por parte dos praticantes da historiografia. Argumentamos, seguindo a linha adotada por Vladimir Safatle em $O$ Circuito dos Afetos, que a provisoriedade das representações (compatível com a "ironia epistemológica") é melhor mobilizada para fins práticos (ou contra a "ironia ideológica") por meio de uma ênfase na condição negativa dos próprios sujeitos que se constroem por meio de tais significações. Tal negatividade, cabe dizer, reforça o papel necessário da própria atividade reflexiva da filosofia da história, já que não pode vir unicamente da prática, do ethos profissional, do contato com os arquivos.

De acordo com a narrativa whiteana padrão, o efeito anti-utópico da desublimização da história efetuado pela historiografia profissional desde o século XIX teve o efeito domesticador de mascarar o que Safatle caracterizaria como sua condição ontologicamente "negativa". Sua leitura de autores do século XIX diverge da de White neste ponto: para ele, longe de privilegiarem a atribuição de "beleza" em detrimento de "sublimidade" ao processo histórico, autores como Hegel e Marx atribuíam aos seus respectivos "sujeitos" e "proletários" a característica última de serem irredutíveis a seus predicados. Mas sua insistência na relevância de se buscar por reconhecimento não por meio de características identitárias, mas na própria condição negativa - o que inclui também: livre - pode ser estendida aos raciocínios de White:

Se não há política sem incorporação, sem a criação de um corpo político, uma tarefa fundamental consistirá em pensar como é possível um corpo não mais assombrado pela armação da coesão imaginária e da unidade encarnada em figuras de soberania. Um corpo espectral com sua temporalidade múltipla, sua potência de desrealização dos limites da efetividade e sua processualidade contínua será forma capaz de abrir a produtividade da indeterminação e nos liberar de um pensamento ainda preso aos fantasmas da identidade coletiva ou mesmo do povo como unidade orgânica. Há de se levar até o extremo a liberação dos sujeitos políticos da procura em construir identidades coletivas, mas mostrando ao mesmo tempo a potencialidade de tais sujeitos em produzir um corpo político capaz de responder, para além das determinações identitárias, por demandas gerais de reconhecimento. (SAFATLE, 2015: 183)

Este tipo de demanda não-identitarista por reconhecimento é assim descrito por Judith Butler: ${ }^{132}$

... nós poderíamos considerar uma certa leitura pós-hegeliana da cena de reconhecimento em que precisamente a minha opacidade para mim mesmo ocasiona minha capacidade para conferir um certo tipo de reconhecimento para outros. Seria, talvez, uma ética baseada em nossa cegueira compartilhada, invariável e parcial em relação a nós mesmos (BUTLER, 2005: 41-42).

\footnotetext{
${ }^{132}$ Fui chamado a atenção a este aspecto do pensamento de Butler pelas aulas do prof. Vladimir Safatle no primeiro semestre de 2015, que também cita o trecho vindouro em $O$ Circuito dos Afetos.
} 
Vimos haver uma conexão indissociável entre temporalidade e narrativização, indissociável da constituição da realidade humana; vimos também, seguindo a própria Butler, que a narrativização de um indivíduo ou grupo se dá em negociação com um mundo social já pré-narrativizado, portanto recheado de outras temporalidades. Butler insiste que a diferença de perspectivas entre o discurso em primeiro pessoa e os demais tem um caráter desorientador, que é um tanto maior quando levamos em conta, adicionalmente, o tipo de desorientação propiciado pelos espectros que demandam nossa atenção para além de nossos sistemas representativos usuais. É necessário inserir esta "desorientação" em uma argumentação como a de Carr, pois, como já indiquei ao cotejar suas formulações com a de Mink, a continuidade de forma entre narrativas não implica continuidade entre as narrativas efetivadas. Mas, sobretudo, o White que enfatiza a condição negativa dos sujeitos que atribuem sentido a si mesmos e do passado a que eles atribuem sentido me parece mais compatível com uma ética que enfatiza o processo que o resultado do procedimento.

O mesmo vale para as questões que abordaremos no restante do texto. Se Safatle aproxima a "fenomenologia do espírito" de Hegel a uma "fenomenologia do espectro", John Russon também aproxima das formulações derridianas a temporalidade do Dasein em Heidegger (que, como a do Para-si sartreano, Doran mostrou ser elucidativo das posições de White): também ela só opera em uma lógica de identidade em que, na fórmula $\mathrm{A}=\mathrm{A}$, o segundo termo difere do primeiro: "Différance marca a realidade que não tem garantias quanto à sua própria identidade, o self que é propriamente si mesmo apenas em abertura." (105) Para Russon, isto significa que ele atua como a resposta a uma pergunta posta pelo primeiro. A bem da verdade, como vimos com Collingwood, Danto e White, a pergunta pode partir retroativamente em busca de um A a que o segundo A, também aberto, possa preencher. Seja como for, pode-se ver a conexão entre figuralismo e a "lógica de perguntas e respostas": este estado de inquietação inicial é uma potencialidade de significado que pode ou não vir a ser enredada ou significado. Quando o é, então o próprio caráter da figura se modifica: ela é "apresentada" por meio da linguagem figurativa. Esta inquietação, por sua vez, se manifesta no tipo de fenômenos como "presença" e "experiência histórica": elas não se tratam apenas de mera força causal, portanto, mas de uma demanda por significado cujo preenchimento dependerá do tipo de relação específica que possa ser estabelecido entre os recursos significativos de uma dada coletividade e os elementos ainda não- 
significados que, ao se fundirem com tais recursos, aparecerão aos seres sob uma certa "apresentação".

Discutindo as propostas de Heidegger, Russon afirma que "a autenticidade como abertura para o possível é precisamente abertura ao que eu não poderia esperar, o que eu não poderia determinar com base em meu encontro prévio com a realidade.” Este tipo de encontro (a que, como se pode ver, podemos chegar partindo de discussões sobre a "realidade humana" em autores como Sartre e Heidegger, sem que precisemos ser detidos pela existência de um fosso entre o que significa e o que é significado) é o que discutiremos nos capítulos vindouros, por meio das noções de experiência em Ankersmit e presença em Runia. Já deve estar claro que elas nos permitem e demandam pensar para além de fronteiras identitárias. De fato, com Heidegger, podemos dizer que é com a própria decisão de assumir uma existência autêntica que nos colocamos diante da possibilidade de encontrar significados que, caso contrário, não viriam à tona pelo trabalho de uma mente operando apenas nos parâmetros de uma identidade préestabelecida.

\subsection{Estado nacional, autoridade e temporalidade}

Segundo Michel de Certeau, em frase que White utiliza como epígrafe no ensaio The Practical Past: "A ficção é o outro reprimido da história". ${ }^{133}$ Em quase toda a sua carreira, White recorreu a uma narrativização da história da historiografia profissional que historiciza este processo de repressão. Mesmo em Metahistory, no qual sua abordagem é de caráter estritamente formalista, encontramos uma súbita interrupção de cerca de 10 páginas na qual White aborda em bastante detalhe a construção da história como uma disciplina profissional. Segundo ele (1973; 2010: passim), a retórica foi suprimida em prol da pretensão de cientificidade no exato momento em que a historiografia se associou aos estados nacionais. ${ }^{134}$

\footnotetext{
${ }^{133}$ Ver WHITE, 2010: 10-19. Uma versão maior deste texto foi republicado no livro homônimo de 2014. Ali, no corpo do texto, White também se refere a este trecho como sua epígrafe, mas, provavelmente por algum erro de edição, ela não consta.

${ }^{134}$ Em Imagined Communities, Anderson remete o leitor a Metahistory ao indicar a conexão entre temporalidade, nação e a profissionalização da historiografia. Ele assim caracteriza o processo: "É portanto compreensível que menos de duas décadas após a proclamação do Ano Um veio o estabelecimento das primeiros cadeiras acadêmicas em História - em 1810 na Universidade de Berlim, e em 1812 na Sorbonne de Napoleão. Pelo segundo quarto do século XIX, a História estava formalmente constituída como uma 'disciplina', com sua própria matriz elaborada de revistas." (ANDERSON, 2006: 194).
} 
Neste mesmo processo, a história buscou se afastar também dos projetos de "filosofia especulativa da história": tendo em Hegel sua figura mais marcante, este projeto consistiu (ao menos para seu detratores) na tentativa de interpretar o sentido do processo histórico enquanto totalidade, desvendando seu mecanismo subjacente e identificando seu telos. Em oposição, autores como Leopold von Ranke consideravam necessário abordar a história de maneira metódica, analítica, por meio de exaustivas pesquisas arquivísticas. ${ }^{135}$ É interessante notar que, embora a filosofia da história hegeliana tenha sido criticada por autores diversos no interior do campo filosófico, Frederick Beiser avalia que, "de uma perspectiva histórica ampla, a crítica de Ranke [a Hegel] foi mais efetiva e devastadora [que as de autores como Kierkegaard e Marx]. Por gerações, ela foi bem-sucedida em descreditar a filosofia da história de Hegel."136

Feito este duplo trabalho de abertura de espaço em relação à retórica e à especulação, a disciplina histórica pode legitimar sua pretensão à imparcialidade. Na prática, isto não poderia significar que suas narrativas deixaram de ter um telos, mas que, presumia-se, ele era encontrado no processo histórico, naquele agente que mesmo Hegel também naturalizara em seus escritos: o estado-nação. Por sua vez, o recurso aos arquivos - garantia metodológica de se evitar os perigos dos floreios literários e da especulação filosófica - também era garantida pelo estado. Chris Lorenz mostra que esta conexão entre a historiografia e o estado não era percebida como uma ameaça às pretensões de objetividade, mas como garantia dela: "a identificação metodológica da história acadêmica com a 'objetividade' foi implicitamente conectada à teoria política do estado-nacional 'supra-partidário', incluindo a premissa de que os arquivos estatais eram os depósitos primários de informação 'realística' para historiadores.” (2010: 74)

Em relação a esta pretensão, Lorenz aponta:

\footnotetext{
${ }^{135}$ Ver: MUNSLOW, 2012; BEISER, 2011.

${ }^{136}$ BEISER, 2011: 332. Porém, segundo o mesmo autor, as semelhanças entre ambos são tão notáveis quanto as diferenças. Após apontar algumas convergências entre Ranke e Hegel, Beiser afirma: "A razão pela qual historiadores aceitaram tão alegremente a perspectiva de Ranke sobre o método filosófico de Hegel é que eles são culpados por uma confusão simples: uma conflação da ordem do método com a ordem de existência [...]. Esta distinção significa que, embora universais antecedem os particulares na ordem de existência, eles são posteriores a eles na ordem do conhecimento." (idem: 342-343). O autor também mostra, porém, que, embora Ranke fosse 25 anos mais jovem que Hegel e que os dois tenham trabalhado no mesmo local, a Universidade de Berlim, por apenas três anos (entre 1825 e 1827), Hegel também conhecia e era crítico do trabalho de Ranke. Em outro livro, Hegel, Beiser afirma que a reputação deste autor como filósofo do historicismo deve ser reavaliada. Tudo depende do sentido em que se emprega o termo. Em fins do XVIII, afirma ele, havia no historicismo ideia de progresso no desenvolvimento da história (ideia que não aparecia em autores precedentes como Montesquieu, Hamann e Möser); neste sentido, Hegel era historicista e foi figura importante em sua propagação, embora não tenha fundado o movimento. Porém, no sentido de relativismo legal e moral, Beiser insiste que Hegel não era historicista. Afinal, a tese central de sua filosofia da história vai na direção oposta, afirmando haver razão imanente na história (BEISER, 2005: 261-263).
} 
Para a maioria dos historiadores acadêmicos do século XIX, a identificação com seu estado e nação (ou "povo", "raça" e "tribos", todas usados coxxmo sinônimos de "nação") apenas parecia natural, porque eles identificaram o próprio processo histórico com a gênese e o desenvolvimento de nação e "seus" estados. Por meio desta identificação (herderiana), a história nacional apareceu como $a$ representação adequada do processo histórico - como o seu "modo de ser natural", nas palavras de Woolf. No que diz respeito à história mundial ou "universal", ela foi concebida primariamente como uma "soma" de histórias nacionais e, logo, tipicamente como um projeto para o futuro. ${ }^{137}$ (idem: 72)

Ankersmit (2012: 23) aponta que tanto Hegel quanto historicistas como Ranke e Humboldt desenvolveram versões da noção de "ideia histórica": "Em ambos os casos, a ideia é uma enteléquia quase aristotélica operativa em um vago limbo entre a linguagem e o mundo, mas cuja natureza o filósofo especulativo ou o historiador deve compreender de modo a entender o passado." Ankersmit está consciente da óbvia peculiaridade de Hegel, para quem a possibilidade de compreender o mundo se deve à racionalidade imanente do próprio mundo, racionalidade esta que também se encontra naquele que busca compreendê-lo. Mas, embora não chegue a discutir os méritos da abordagem hegeliana, seu objetivo é outro: mostrar que a tese historicista acerca da "ideia histórica" está correta, exceto por uma confusão que, porém, pode ser corrigida: ela projeta sobre o processo histórico o que, em sua visão, na verdade é válido apenas para a escrita da história. $^{138}$

Se ampliarmos um pouco nossa perspectiva e observamos as características usualmente atribuídas pela historiografia ao estado-nação, a argumentação de Ankersmit se mostrará justificada. Lorenz lista oito características típico-ideais das histórias nacionais na Europa, que se manifestam especialmente em textos do século XIX, mas não apenas neles: 1. "Um caráter especial ou uma identidade nacional única foi reclamada para cada nação em relação com outras nações"; 2. Esta identidade única foi

\footnotetext{
${ }^{137}$ Este pressuposto é uma das configurações do que Mink descreveu como aquele subjacente à ideia da História Universal: ele presume que blocos históricos em menor escala possam ser agrupados em um de maior escala sem que isto produza uma diferença qualitativa. As distinções entre descrição e narrativa (Mink), ou entre descrição e representação (Ankersmit), contestam precisamente este pressuposto.

${ }^{138} \mathrm{O}$ livro mais recente de Ankersmit, no qual esta afirmação é encontrada, tem uma curiosa combinação de humildade e pretensão. Por um lado, apresenta-se de maneira um tanto humilde como continuador da tradição historicista. Por outro, este ajuste - a transferência da "ideia histórica" da realidade para a linguagem - não é tão simples de ser feito (e argumentaremos que a parte da filosofia de Ankersmit que trata de experiência a subestima em alguns momentos). Para fazê-lo, todo um trabalho filosófico é posto em movimento: de fato, é possível ler toda a obra de Ankersmit como sendo perpassada por esta tentativa. No livro em questão, Meaning, Truth, and Reference in Historical Representation, Ankersmit considera ter realizado sua meta ao demonstrar que "a representação precede a descrição verdadeira", e considera que "Esta, então, é a 'Revolução Copernicana' defendida neste livro." (2012: 156) A esta afirmação, segue uma nota na qual ele aponta Hegel como "meu ilustre predecessor".
} 
afirmada na base da negação de outras nações ou de outros grupos dentro da nação; 3 . Por isto, guerras e batalhas fornecem os fios narrativos dominantes para muitas histórias nacionais; 4. "A identidade da nação foi localizada nas origens comuns de seus membros e em sua história compartilhada desde então"; 5. Ela é representada como uma identidade contínua, que perdura desde as origens até o presente. A narrativa dessa identidade que se preserva ao longo das mudanças geralmente é narrada com uma estrutura temporal hegeliana/cristã: ela passa por um nascimento e florescimento original, seguida de ameaça externa e, por fim, renascimento; 6. Ela recebe atributos de uma pessoa ou uma família; 7. Seu caráter é o de uma "unidade harmoniosa". Lorenz especifica: "Esta lição era a função prática implícita ou explícita do estudo da história nacional, profissional ou não.”; 8. Ela é usualmente representada como servindo a causa da justiça. (LORENZ, 2010: 78-9)

Ora, estas são exatamente características que teóricos da história têm atribuído às narrativas, especialmente as tradicionais: elas encontram "origens" de modo retroativo, projetando sentido sobre acontecimentos do passado na medida em que os articulam com eventos posteriores; elas requerem, ou produzem, um elemento de continuidade-na-mudança; elas eliminam dissonâncias; elas organizam não apenas a identidade individual, mas também a coletiva; elas possuem um caráter primordialmente prático. Não se trata aqui de apenas apontar que a construção das nações requer narrativas, mas também que, ao se tomar as narrativas das nações como naturais e autoevidentes, acreditou-se na imanência daquilo que ela projeta sobre a realidade. Por isso é possível dizer que o que Hegel e os historicistas descreveram como parte do processo histórico, White, Mink e Ankersmit situam no nível da escrita sobre este processo.

Em um sentido, então, o relevante é perceber o processo de ontologização das narrativas e identidades: projetadas sobre o mundo sem que "estejam lá" realmente, elas criam uma impressão de continuidade em um mundo caótico. Isto faz com que narrativas sejam naturalmente instáveis, possibilitando a ocorrência de "experiências históricas sublimes": momentos em que a aparente aderência entre as máscaras e o mundo mostra o caráter convencional que, na verdade, sempre possuiu.

Porém, como argumentamos, ao narrar historiograficamente narra-se sobre narrativas: independentemente de como compreendamos filosoficamente seu status ontológico, indivíduos e sociedades no passado identificaram-se com narrativas e outras formas de atribuição de sentido para o seu mundo. Então, em relação a isto não basta simplesmente "trocar o nível", atribuindo-se à linguagem o que outrora se atribui à 
realidade. A questão passa a ser: por um tempo historicamente situado, seres humanos (sobre os quais construímos narrativas hoje) organizaram suas existências tendo como uma de suas referências a narrativa ontologizada do estado-nação. Seu caráter construído passa a importar menos, sob esta perspectiva, do que o fato de que seres humanos viveram como se o estado existisse naturalmente.

Ankersmit (idem: 1-29) aponta que parte da convergência entre Hegel e os historicistas se deve à recepção de Spinoza no cenário filosófico alemão pós-Kant, quando a filosofia monista daquele passou a ser percebida como uma solução ao dualismo sujeito/objeto concebido por Kant. Em sua opinião, a filosofia de Spinoza ou a dialética hegeliana (que adiciona movimento àquela) funcionam melhor ao menos em casos como o das humanidades, em que sujeito e objeto são ambos parte do mesmo mundo histórico. Ankersmit também considera que o mesmo se aplica ao princípio verum factum, de Giambattista Vico, que era então desconhecido na Alemanha, mas que viria a ser importante para as reflexões de autores como R. G. Collingwood e Hayden White, que também contribuiram - indiretamente, no caso de Collingwood; diretamente, no de White - para a "virada linguística" da enteléquia histórica.

Dentre os narrativistas, White foi um leitor especialmente atento de Vico. Parte considerável de seus textos anteriores a Metahistory leva em conta o princípio verum factum: não se tratava, naqueles textos, de compreender como historiadores constróem sentido para o passado, mas de como indivíduos e sociedades humanas o fazem. Sua tese era: seres humanos - seja um filósofo como Hegel, que não é "influenciado" por seus antecessores, já que escolhe quem são seus antecessores no próprio ato de desenvolver seu pensamento (WHITE, 1970: 343-363), seja uma sociedade que se via como "romana" mas que, não percebendo mais nessa tradição os elementos necessários para orientar sua existência, modifica sua própria ancestralidade, tornando-se "cristã" escolhem seus ancentrais de modo retroativo. White perceberia então que o mesmo ocorre em textos historiográficos. Porém, alguns de seus textos mais canônicos não enfatizam a tensão entre as duas ordens narrativas, tornando compreensivo que se perca algo de vista: seus textos não prescrevem a unidade temporal e identirária típica das narrativas sobre o estado nacional, mas antes descrevem como o texto as produz. As inclinações políticas anarquistas de White, de fato, são perfeitamente coerentes com o seu chamado à rebeldia diante dos mecanismos disciplinares que produzem falsas continuidades sobre o caos do processo histórico. 
Em "The Value of Narrativity in the Representation of Reality", White recorre à Filosofia da História de Hegel para defender a associação entre narratividade e "os tópicos da lei, legalidade, legitimidade, ou, mais geralmente, autoridade." Assim, White analisa os anais medievais de Saint Gall e conclui que, ali, não há "um discurso sobre eventos considerados como uma totalidade se desenvolvendo no tempo." Isto só é possível, em sua opinião, se houver 'um 'sujeito' comum a todos os referentes das várias sentenças que registram a ocorrência de eventos". White aponta que, para Hegel, tal sujeito é o estado, e especifica: "mas o estado para ele é uma abstração. A realidade que se presta à representação narrativa é o conflito entre desejo, de um lado, e a lei, do outro. Onde não há império da lei (rule of law), não pode haver nem um sujeito nem o tipo de eventos que se presta à representação narrativa.” (WHITE, 1987)

É acerca de o que fazer uma vez diagnosticado o papel do estado como fonte de continuidade-na-mudança na historiografia moderna que surge uma divergência central entre Ankersmit e White. Ambos tentam lidar com as consequências da "crise do historicismo": White a vê como a primeira manifestação do estado "irônico" (WHITE, 1973), pessimista, em que a intelectualidade europeia havia mergulhado em fins do século XIX e se mantinha em 1973. Sua tentativa, com a publicação de Metahistory e a partir de então, é a produção de uma abordagem "libertadora" (PAUL, 2011), que recusa à historiografia ou a qualquer outra disciplina o direito a se declarar como "autoridade" (cf. WHITE, 2005, MOSES, 2005) (WHITE, 2011), preferindo enfatizar modos disruptivos de discurso. Assim, não deveríamos nos surpreender com a sua declaração recente de que é "um niilista em ontologia, um anarquista em política." (WHITE, 2011) Ankersmit, por sua vez, considera que o estado ainda é o melhor recurso para garantir às coletividades humanas os recursos para lidar com os desafios contemporâneos. (ANKERSMIT, 1997; 2001) Assim, em 2012, ele não apenas reafirmava seu compromisso com os princípios do historicismo, mas também buscava restituir à política a condição de "ossatura da história". (ANKERSMIT, 2012) Em sua própria avaliação, a preferência de White pela ética e a dele pela política marca um ponto de ruptura entre suas obras. (ANKERSMIT, 2009) ${ }^{139}$

\footnotetext{
${ }^{139}$ Ver, sobretudo, o primeiro capítulo de Aesthetic Politics, intitulado "Against Ethics" (ANKERSMIT, 1996).
} 
A questão passa, então, pela conexão entre a arbitrariedade do poder estatal e a arbitrariedade de toda forma de produzir sentido para processos históricos. ${ }^{140}$ Esta relação também envolve formas alternativas de experienciar a temporalidade que não aquela homogênea do estado nacional e do capitalismo: as formas de resistência de grupos vítimas de violência estatal (cf. BEVERNAGE, 2011), ou as diferentes relações com o tempo por parte de grupos como os indígenas na sociedade capitalista brasileira, mostram que o exercício de poder do estado passa também pela imposição de uma certa forma de viver o tempo, portanto de narrar o tempo. Em Imagined Communities, Benedict Anderson mostra como o processo de formação de nações na Europa consistiu, de uma perspectiva temporal, na formação de um "organismo sociológico se movendo no calendário [calendrically] por meio de um tempo homogêneo, vazio, que também é concebido como uma comunidade sólida se movendo constantemente história abaixo (ou acima)." Duas formas discursivas que expressavam e difundiam esta forma de experienciar o tempo eram os jornais e os romances. Em The Burden of History e mais forçosamente em Metahistory, White argumentou que o tipo de narração adotado pelos historiadores profissionais era o dos romances realistas do século XIX. Assim, a forma narrativa típica da historiografia expressa uma temporalidade típica do estado-nação. As naturalizações do regime de historicidade moderno e do estado nacional contribuíram para que esta possibilidade de produção de sentido parecesse igualmente natural.

Assim como Ankersmit vê na obra de White um chamado aos historiadores para que eles valorizem a tensão entre os protocolos linguísticos, direcionando atenção às tensões da realidade mais do que às continuidades da linguagem, ele próprio valoriza o recurso do paradoxo devido à sua potencialidade de resistir ao tipo de fechamento narrativo típico do "realismo". ${ }^{141}$ Mas o trabalho de desnaturalização é difícil e

\footnotetext{
${ }^{140}$ Como White (2005: 335-6) afirmou em debate com Dirk Moses: "Moses afirma que eu questiono 'o papel da historiografia profissional de policiar a maneira pela qual o passado é invocado no presente para projetos políticos' (313). Eu certamente questiono. Eu não apenas nego a autoridade de 'historiadores profissionais' de 'policiar' o que quer que seja, eu também nego que historiadores, eu sua atual capacidade 'profissional', possuem os recursos necessários para fazer juízos 'eticamente responsáveis' sobre o que quer que chamemos de 'história'. Com sua tentativa de cientificização da história, White afirma, "a historiografia profissional não pode participar em discussões sobre as principais questões políticas, éticas e ideológicas que assolam uma sociedade que, estando privada tanto da religião quanto da metafísica, tem pouco mais que 'história' como uma base para fazer juízos cognitivamente justificados sobre questões de seu tempo."

141 "A ironia de White [...] sempre implica um momento de espelhamento de significado na ausência-designificado (meaninglessness) de uma manifestação quasi-noumenal da realidade (passada). Talvez eu possa adicionar que sinto a maior simpatia pela proposta de White. De fato, quando escrevia um livro sobre experiência histórica sublime há algum tempo, eu tinha algo similar em mente. Portanto, eu considero a conceitualização que White faz da ironia e do sublime histórico um dos aspectos mais fascinantes da sua obra. $\mathrm{O}$ único comentário que eu teria, porém, é que o termo 'paradoxo' teria sido mais
} 
Ankersmit, como tantos outros, não sucede inteiramente em realizá-lo. Anunciemos algo que será mostrado com mais clareza na discussão sobre "experiência histórica sublime": quando discute a relação entre uma identidade coletiva e seu passado, Ankersmit quase invariavelmente assume tratar-se de algo unívoco. Em Sublime, tudo se passa como se os traumas fossem vivenciados de maneira igual, como se luta de classes e dinâmicas de reconhecimento não fossem relevantes e não produzissem tensões nas disputas pelo significado de uma coletividade, como se a nostalgia (1994) ou o desejo de "ser" ou "conhecer" o passado (2005) surgisse de maneira homogênea. Talvez em parte por moldar muitas de suas reflexões centrais naquele livro em diálogo com Hegel, talvez por desejar enfatizar a importância do estado em sua filosofia política, Ankersmit apresenta lá uma filosofia que toma como dada a centralidade do estado-nação no processo histórico, e, nesse caso um tanto contraditoriamente com sua própria filosofia, produz como que uma ontologização das identidades coletivas construídas com referência a ele. Será necessário levar para as suas discussões sobre experiência o insight que surge mais claramente nestes debates sobre representações, especialmente após a historiografia passar a enfatizar o que ele chamou metaforicamente de "folhas", mais do que os "troncos" (1994: 162-181). Mas argumentarei que há contradiscursos no interior do próprio Sublime que permitem abrir espaço para a multiplicidade de experiências - temporais, emocionais, identitárias - que as narrativas moldadas ao redor da ideia de estado-nação perdem de vista.

\section{Exemplo: Viveiros de Castro sobre imaginação}

Para encerrar, buscarei cumprir ou preencher o alinhamento figural que propus entre Elias e White - por um lado com suas preocupações com os rumos da humanidade após duas guerras mundiais (Collingwood também se posicionou a respeito, ao término da primeira) e durante a Guerra Fria, por outro com propostas teóricas que, uma vez articuladas, foram por mim interpretadas como indicadoras da possibilidade da adoção

apropriado aqui que 'ironia'. Sim, paradoxo e ironia têm muito em comum, então no final das contas este certamente é um mero debate sobre terminologia. Ainda assim, esta abertura também pode ser atribuída ao paradoxo, a este passado quasi-noumenal mencionado anteriormente, enquanto a ironia deve necessariamente permanecer cega a ele, já que ela nunca requer que deixemos o domínio do significado linguístico." (DORAN, 2013: 56) Minha única oposição a esta afirmação é a que tenho apontado várias vezes ao longo do trabalho: a realidade passada é uma "realidade humana", e portanto não é "numenal". Acessá-la é já acessar significados, e isto só se faz por meio de interpretação. Não sou da opinião de que estamos presos a princípio aos significados e à linguagem, mas isto é uma forma de dizer que não estamos presos na medida em que, ao fazer aparecer aspectos do mundo, (a) reconhecemos tais aspectos como aspectos e não como o mundo em si, e (b) reconhecemos a possibilidade de fazer o mundo se manifestar em outros aspectos. 
de uma postura de "presença distanciada" - com um conjunto de afirmações feitas por Eduardo Viveiros de Castro em uma recente que ele e Deborah Danowski concederam à jornalista Eliane Brum em 2015. Tomarei a liberdade de, nesta breve seção exemplificadora, adotar um tom mais ensaísta, harmonizado com a oralidade da entrevista do próprio Viveiros de Castro. ${ }^{142}$

Dentre os autores discutidos nos dois primeiros capítulos deste texto, não apenas o narrativista White e o retroativamente narrativista Collingwood, mas também Norbert Elias lamentaeram a incapacidade de suas respectivas áreas de conhecimento de corresponder ao tamanho da ameaça oriunda do já imenso conhecimento técnico dos seres humanos. Se levarmos em conta as discussões deste capítulos, é possível argumentar que um crescimento equivalente em relação às questões humanas requeria, dentre tantas outras coisas, (a) o conhecimento da faculdade da imaginação, já que, por meio dela, significamos eventos presentes à luz de diferentes durações do passado, e vice-versa; (b) o emprego preferencialmente "livre" desta faculdade, no sentido de sem "cristalizações", o que requer auto-consciência e manutenção das condições de renovação desta auto-consciência.

Seguindo Giorgio Agamben e Walter Benjamin, Harry Harootunian argumentou recentemente que "se toda cultura produz relatos históricos de si mesma e se estes são 'antes de tudo' informados por uma 'experiência particular do tempo,' então nenhuma nova formação cultural parece possível sem uma alteração desta experiência." (DORAN 2013: 126). Safatle, por sua vez, argumentou: "Para começar outro tempo político, será necessário inicialmente mudar de corpo. Pois nunca haverá nova política com os velhos sentimentos de sempre." A capacidade de imaginar outra forma de articular a si mesmo como membro de uma coletividade cuja existência é temporal é indissociável deste processo da constituição de novos afetos. E vice-versa: como mostrou Elias, mexer em uma destas dimensões é mexer nas demais.

\footnotetext{
${ }^{142}$ Parte do que torna urgente a exemplificação das teses narrativistas sobre a insustentabilidade de toda atribuição de autoridade supostamente fundamentada é a situação de grupos como os indígenas na atual conjuntura política brasileira. (Outro exemplo muito recorrente nos discursos públicos contemporâneos é a suposição de que "sexo" é uma categoria igualmente fundamentada na "natureza".) O atual presidente do Brasil, por exemplo, declarou em campanha: "Não vai ter um centímetro demarcado para reserva indígena ou para quilombola." (Disponível em: <https://acervo.socioambiental.org/acervo/noticias/nemum-centimetro-para-quilombola-ou-reserva-indigena-diz-bolsonaro> Acesso em 18 de abril de 2019.) Seu discurso depois de eleito tem seguido a retórica da unidade nacional como forma de defender, por exemplo, a exploração de terras indígenas. Ver, a título de exemplo: "Bolsonaro defende exploração de terras indígenas e chama ONGs de picaretas." Disponível em: $<$ https://exame.abril.com.br/brasil/bolsonaro-defende-exploracao-de-terras-indigenas-e-chama-ongs-depicaretas/> Acesso em 18 de abril de 2019.
} 
Começo discutindo o tema da imaginação. Nas palavras de Viveiros de Castro: “O jeito como o mundo está andando não pode continuar porque se baseia numa ideia de que o crescimento pode ser infinito, quando a gente sabe que mora num mundo finito, com recursos finitos. Entretanto, eu nunca vi ninguém falar: "O crescimento vai ter que parar aqui”. O que é isto, senão uma incapacidade generalizada de imaginar um mundo diferente? Eu retornaria às reflexões de White sobre a relação entre realismo e imaginação, aqui. Uma forma autodeclarada "realista" de representar a realidade se torna um obstáculo quando bloqueia o uso da imaginação por parecer ser um veículo ideologicamente neutro por meio do qual o mundo se mostra por si mesmo. O mesmo ocorre no que diz respeito às formas de vida contemporâneas. A ideia de que a única atitude "realista" que um governo pode adotar é a busca de crescimento econômico perpassa amplos setores da direita e da esquerda da política tanto brasileira quanto mundial. A busca pelo crescimento econômico, aliada ao ciclo de prazo relativamente curto das eleições, por sua vez, introduz um referencial temporal com "urgências" específicas em relação à quais todo o resto deve se alinhar, automaticamente desprivilegiando as demais esferas da sociedade.

Se o sujeito coletivo organizado ao redor de uma dada nação - digamos, "Brasil" - estrutura narrativamente "ações de longo prazo" com finalidades estritamente econômicas, e se o alcance destas ações é tão curto quanto possibilitam a temporalidade da política e os afetos predominantes do medo e da esperança, então qualquer modo de vida não alinhado com estes objetivos e sua temporalidade não-simultânea provavelmente não será reconhecido como membro da comunidade, nem terá efetivados direitos em descompasso com as urgências que a orientação temporal dominante faz parecer "realistas". No caso brasileiro, o exemplo mais óbvio é o dos povos indígenas: "O que aconteceu com a história do Brasil é que foi um processo circular de transformação de índio em pobre. Tira a terra, tira a língua, tira a religião. Aí o cara fica com o quê? Com a força de trabalho. Virou pobre."

Mas há uma mudança talvez mais grave na relação entre imaginação e mundo. Viveiros de Castro cita Günther Anders, para quem as armas nucleares haviam colocado a humanidade nunca situação em que "somos capazes tecnicamente de fazer coisas que não somos nem capazes de imaginar". Então, da mesma forma que a biologia descreve "fenômenos subliminares, abaixo da linha de percepção", existiriam agora também fenômenos "supraliminares", que também não podem ser imaginados por serem grandes demais. A crise climática, para Viveiros de Castro, é um exemplo mais recente de 
fenômeno supraliminar, da qual resulta uma "paralisia cognitiva". Uma mudança de escala com grandes implicações cognitivas de fato parece estar em jogo, como indicam os teóricos da noção de Antropoceno.

Eu faria apenas um apontamento pouco pretensioso: é de longa data a preocupação com o descompasso entre a capacidade técnica e sua capacidade de distanciamento, que, como mostramos, pode adequadamente ser refigurada (com Collingwood e White) nos termos do que Viveiros de Castro chamou de imaginação. No entanto, como busquei argumentar, uma vez mais parte dos problemas sociais contemporâneos parece passar pela majoritária ausência do que estou tentativamente chamando de "presença distanciada". Vejamos:

\begin{abstract}
Os índios não acham que as árvores são iguais a eles. O que eles acham simplesmente é que você não faz nada impunemente. Todo ser vivo, com exceção dos vegetais, tem que tirar a vida de um outro ser vivo para sobreviver. A diferença está no fato de que os índios sabem disso. E sabem que isso é algo sério. Nós estamos acostumados a fazer a nossa caça nos supermercados, não somos mais capazes de olhar de frente uma galinha antes de matá-la para comer. Assim, perdemos a consciência de que nós vivemos num mundo em que viver é perigoso e traz consequências. E que comer tem consequências. [...] Acho que o símbolo da nossa relação com o mundo, hoje, é o tipo de guerra que os Estados Unidos fazem com os drones, aqueles aviões não tripulados, ou apertando um botão. Ou seja, você nem vê a desgraça que você está produzindo. Nós todos, hoje, estamos numa relação com o mundo cujo símbolo seria o drone. A pessoa está lá nos Estados Unidos apertando um botão num computador, aquilo vai lá para o Paquistão, joga uma bomba em cima de uma escola, e a pessoa que apertou o botão não está nem sabendo o que está acontecendo. Ou seja, nós estamos distantes. As consequências de nossas ações estão cada vez mais separadas das nossas ações.
\end{abstract}

Como se percebe, nosso distanciamento afetivo das consequências das nossas ações está conectado ao autocentramento de nossas formas ocidentais contemporâneas de vida, que nos incapacita - e nos reduz o desejo de - conectar eventos (ou: a falta de desejo também é o que nos incapacita). Acontecimentos presentes podem ser aproximados de outros afastados geográfica e temporalmente por meio da imaginação, que nos possibilita (diz Mink) vê-los como um totum simul. Porém, aqui há um obstáculo difícil de transpor. Imaginação demanda tempo, energia, e sobretudo desejo de empregar os próprios tempo e energia de maneiras específicas. A existência envolvida no interior de sociedades capitalistas de modo geral de modo geral parece deixar pouco espaço para a livre movimentação das perspectivas de tempo, de espaço e de afetividade, em proveito de uma cristalização de uma única ou poucas formas "realistas" de viver. A dificuldade de transpor estes obstáculos reproduz nas relações humanas o mesmo "círculo vicioso" que, segundo Elias, por muito tempo ocorreu em 
nossa relação com o mundo não-humano: por terem medo da natureza, os humanos não conseguiam se distanciar dela, e, por isto, não conseguiam controlá-la, o que impedia a redução do medo, reiniciando o ciclo. No caso do mundo social, não apenas o medo, mas todos os afetos ou ideias que mantém a nós humanos presos a uma visão de curto alcance (individualismo, identitarismo, especismo, consumismo) condicionam nossas ações a um alcance proporcionalmente curto de afetos e ideias.

\subsection{Representação e experiência (1): o que torna uma representação eficaz, as verdades ou fatores práticos?}

Uma questão sobre a conexão entre representações e a realidade (que surge como seu representado) pode ser colocada nos seguintes termos: se Ankersmit afirma que verdade operativa no nível das descrições não tem relação com representação (i.e., as descrições compõem a representação, mas a epistemologia e a estética não se combinariam), o que faria uma representação ser incapaz de englobar em seu "escopo" um grande número de detalhes? O que faz um detalhe "falsear" a representação? Estas questões são necessárias também como reflexão sobre a proposta de White em "O Fardo da História", para quem os historiadores deveriam utilizar com "tato" as metáforas enquanto elas se mostrassem capazes de englobar os dados oriundos das pesquisas, mas fossem abandonadas quando tal capacidade de esgotasse. Novamente, então: como saberemos quando a metáfora já não dá conta dos dados? O que é este tato?

O critério me parece, em Ankersmit, ser o de coerência estética, mas quando reconhecemos uma verdade passada da qual uma representação sobre o passado não dá conta de englobar, não é com base no critério epistemológico que perdemos a confiança na capacidade daquela dada representação de iluminar o passado para nós? O que significa, exatamente, demanda que uma representação seja capaz de englobar os dados?

Proponho a seguinte resposta. A representação não precisa necessariamente falar sobre o fato hipotético em questão, tomá-lo como exemplo, focar em seu nível de análise (micro-história) ou tratar do seu objeto (infância na Idade Média), mas não pode ser contradita por ele. Digamos, se uma narrativa nos faz ver as relações entre senhores e escravos no Brasil colônia de uma perspectiva relativamente pacífica e harmoniosa, então contra-argumentar apontando as violências do período a contradiz. Se a imagem em questão tem uma certa proposta moral, as verdades não obrigam o historiador a mudar sua visão moral, mas explicitam a escolha a ser feita. Digamos, se um resenhista 
mostra as consequências da escravidão no Brasil contemporâneo, isto não obriga ninguém a rejeitar uma visão idílica do passado, nem a defender que não sejam efetivadas políticas públicas compatíveis com uma visão menos idílica. Mas permitenos demandar dele ou do público que reúnam na consciência os fatos verdadeiros sobre o passado com a imagem idílica, como se perguntássemos: você está me propondo ver estes fatos como idílicos (produzir "compreensão" é fazer este procedimento de ver em conjunto)?

O exemplo clássico do debate narrativista se encontra na historiografia do Holocausto: uma vez havendo acordo sobre os fatos, por um lado, eles não nos impedem de representar o evento como comédia. Por outro, ao justapor as verdades sobre o evento à narrativa de alguém que o considera cômico, explicitamos os seus pressupostos morais de forma que seu livro certamente obscurece. O que levará o público a rejeitá-lo, e o que nos impedirá de sequer cogitar tal narrativa? A resposta oferecida por White diante de seus críticos em Probing the Limits of Representation é, para mim, correta: não são simplesmente os fatos, mas o fato de não acharmos graça nenhuma neles. É como nos sentimos - as sensações, retranalhadas, e articuladas holisticamente com nossos princípios éticos - diante dos fatos. Isto é, são os critérios éticos e estéticos, vistos á luz das verdades sobre as quais há consenso - e apenas com desontestidade há discordância quanto a verdades como a existência do extermínio de judeus - que nos levam a aceitar ou rejeitar uma narrativa. Não se trata, como tantos o acusaram, de inviabilizar a oposição aos negacionistas, mas apenas de localizar o ponto onde o debate realmente se dá.

Por um lado, o argumento feito por White em 1982, em "The Politics of Historical Interpretation”, foi muito certeiro em afirmar que o jogo dos negacionistas era retórico e não epistemológico. Isso inclui o reconhecimento de que o procedimento tradicional dos historiadores de vir a público e meramente contrapor fatos era estrategicamente ingênuo. Por outro, em um sentido são enganosos os argumentos do tipo: "não é uma questão de verdades, mas de retórica", e White se permite ler nesta chave naquele ensaio. Afinal, produzir uma "compreensão" - colocar junto - uma narrativa eticamente questionável com os fatos que ela obscurece é um uso retórico das informações adquiridas pela pesquisa. A questão então passa pela combinação entre ambos.

O problema adquire uma feição nova em tempos contemporâneos em relação aos problemas da "pós-verdade" e das fake news. Nos vários levantamentos feitos por 
jornais como o New York Times e o Washington Post, o número de afirmações mentirosas ou enganadoras feitas pelo presidente dos Estados Unidos, Donald Trump, ao longo de cada um dos anos de seu mandato, atinge sempre a casa dos milhares. ${ }^{143}$ Em 2017, a jornalista Naomi Klein havia apontado a insuficiência da estratégia de produzir desmentidos às falas de Trump. No livro No Is Not Enough, ${ }^{144}$ ela explicava que produção da "marca" Trump, em andamento desde a década de 1980, envolve a auto-atribuição de propriedades como o poder de estar acima das limitações financeiras, éticas e legais que coibem as demais pessoas. Assim, mostrar que ele havia mentido em alguma ocasião ou denunciar que ele não foi punido por ações que produziriam consequências para outras pessoas - meros mortais - apenas reforçava sua autorepresentação. A solução proposta por ela, como a de White nos anos 1980, atua no nível retórico. Ela nem é inteiramente dissociada dos fatos, como poderia dar a entender uma divisão nítida demais entre fatos e retórica como a que White faz; nem consiste apenas em reafirmar a verdade daquilo que foi negado. Em vez disso, ela parte de uma compreensão de qual jogo retórico está sendo jogado e utiliza os fatos, sob certa apresentação, como meio de enfraquecê-la. Assim, ela propõe: "Já que a marca pessoal de Trump é ser 'o chefe' que faz o que bem entende, uma maneira de enfraquecê-la é fazê-lo parecer uma marionete." Da mesma forma, "Já que toda a marca Trump diz respeito a ter grandes quantidades de dinheiro, a outra maneira de enfraquecê-la é fazêlo parecer menos rico.” (KLEIN, 2017: 53-56)

Adicionalmente, observemos que a dificuldade de separar onde termina a pessoa e onde começa a "marca" Trump exemplifica uma dificuldade geral da filosofia da história - pois há fatos, no sentido de que os vários "eventos" (dob descrição) podem ter como referente um "mesmo" referente, mas o problema de como delimitá-lo não é de simples solução - e outra mais particular para as circunstâncias que White chamou de "modernistas", em que os acontecimentos e sua divulgação midiática se sobrepõem de maneira ainda mais radical do que em outros momentos, devido às possibilidades tecnológicas ausentes em outros períodos.

\footnotetext{
${ }^{143}$ No levantamento mais recente antes do depósito deste texto, atualizado em 07/06/2019, eram 10.796 afirmações deste tipo em 869 dias (Fact Checker, The Washington Post. Disponível em: <https://www.washingtonpost.com/graphics/politics/trump-claims-database/?utm_term=.a1f14c62773a $>$. Acesso em 01/07/2019).

${ }^{144}$ Título que ressoa perfeitamente com a tese de Rorty em Irony, Contingency, Solidarity: quem deseja propor uma mudança de "paradigma" não sucederá se operar negativamente no interior do vocabulário que deseja rejeitar, mas sim operando positivamente com um novo vocabulário.
} 
Por outro lado, retomando o raciocínio de Klein, ela também direciona sua atenção para o que estamos chamando aqui que "condições de prefiguração". Traduzindo seu argumento para a terminologia do debate aqui estudado, ela enfatiza então a importância de atuar nos elementos do "segundo nível de consciência", onde surgem os significados em relação ao corpo, inseparável do mundo material e intersubjetivo em que ele se encontra, e não apenas no "vocabulário" que permite uma certa articulação dos vários elementos envolvidos. A estratégia narrativa de Trump é inseparável do ambiente do capitalismo tardio em que ele está inserido, e sua autoapresentação como um "vitorioso" permite-o explorar as potencialidades de enredamento mais compatíveis com o atual estado do modo de produção capitalista. Para propor as estratégias, ela novamente busca as bases de onde se constróem os vocabulários, que por sua vez fornecem os quadros para a produção de uma certa identidade. Uma das "condições de prefiguração" que ela enfatiza é um elemento que transcende os vocabulários específicos e se manifesta, ainda que com variações diversas, em todo o processo histórico: o desejo por conexão. Klein fala sobre o movimento de gangorra entre "o declínio de instituições comunais e a expansão de marcas corporativas na nossa cultura". Estas instituições eram a fonte de "senso de comunidade e identidades compartilhadas”. Ela avalia que é a reconstrução de fontes para "o desejo humano por comunidade e conexão" que poderá enfraquecer o poder das marcas sobre os cidadãos. E esta é "uma força muito poderosa", "que simplesmente se recusa a morrer". ${ }^{145}$ (idem: 67-68)

Neste sentido, White novamente parece ter acertado. Lido como um ato de fala, seu texto de 1982 busca produzir nos historiadores o reconhecimento da liberdade de propor outras utopias - outros sentidos para a história - como forma de conclamá-los a usar a retórica. Rorty também aparece em boa luz no atual cenário: de nada adianta dizer verdades dentro do vocabulário em voga, tentando superá-lo a partir de seus próprios termos; o desafio é propor um novo vocabulário e (para anteciparmos, com uso levemente desviante, um termo que será importante mais adiante) provocar mutações nas demais pessoas a partir dele. Mas a conexão entre uma certa forma de produzir significados para a história ou para a própria identidade, por um lado, com algo que se

\footnotetext{
${ }^{145}$ No livro Lost Connections, Johann Hari discute as causas sociais dos altos índices contemporâneos de depressão. Em vez de pensar a doença como meramente um desequilíbrio químico, livros como o dele permitem-nos nos perguntar sobre o que causa tais desequilíbrios. Fatores como uma cultura individualista, precariedade profissional, a configuração dos espaços públicos e tantos outros evidentemente devem ser levados em conta, junto com as circunstâncias psicológicas e bioquímicas do indivíduo em questão.
} 
manifesta em toda formação histórica (os desejos por conexão) ${ }^{146}$ e com o modo de produção vigente (o capitalismo, com suas estruturas culturais, econômicas, sociais e políticas específicas), bem como conjunturas e acontecimentos específicos, mostra também que o vocabulário filosófico sobre "vocabulários" não dá conta da complexidade do problema. O que está em jogo é certamente mais compatível com a visão de alguém como Dewey, que nos permite ver articula a estética à luz de todo o entrelaçamento entre sujeitos - com desejos, recursos intersubjetivos com os quais eles empregam sua imaginação em direções específicas, conhecimentos factuais, ética etc. e mundo - nas suas diversas temporalidades, incluindo o a orientação para o futuro. ${ }^{147}$

A discussão proposta por White não era uma das que ocuparam Ankersmit e Kuukkanen, aquela sobre os "melhores" critérios de avaliação de uma representação por parte de um campo profissional. A capacidade de dizer verdades é evidentemente parte desejável de qualquer campo historiográfico. Mas isto é inseparável da discussão de como deve ser o campo, o que, por sua vez, é inseparável da discussão de qual deve ser a contribuição deste campo para a sociedade, o que por sua vez é inseparável da visão ideológica sobre qual sociedade queremos.

No argumento anterior sobre como a história não é um anything goes, busquei mostrar que sua fundamentação (prática) não é apenas ideológica. Agora o argumento irá um passo além, afirmando que mesmo o campo da ideologia não é um mero anything goes. E isto por ele ser balizado por desejos mais básicos que aqueles de um ou outro vocabulário específico, formando um chão comum prático. Isto inclui que todos os participantes em debates sobre história (profissionais ou não) têm desejo de serem felizes e de não sofrer, incluindo por exemplo o desejo por integridade física; têm prazer em viver harmoniosamente com os demais e, ao menos a longo prazo, insatisfatoriedade em dominá-los; etc. Porém, isto não significa que todos tenham

\footnotetext{
${ }^{146} \mathrm{O}$ fato de que seres humanos - e certamente tantos outros seres vivos - manifestam tais desejos não é um fundamento - pois biologia e psicologia são históricas -, mas é um fundamento prático ou um groundless ground, já que possui uma duração longuíssima. A biologia humana se formou ao longo de alguns milhões de anos de processo evolutivo, e contém características de inúmeras outras espécies antecedentes. A psicologia humana é certamente mais contingente, mas é intimamente relacionada com ela. (De que maneiras exatamente, não cabe a este trabalho responder, nem é necessário que o faça.) A natureza exata da interação destes e outros níveis não é inteiramente previsível, pois se combinam em uma totalidade holística em que elementos que se transformam em ritmo lentíssimo se combinam com outros que mudam mais rápido. Assim, não é possível apontar onde começa a parte que quase não muda perceptivelmente (a necessidade por conexão) e a parte que muda (as maneiras históricas pelas quais essa necessidade se manifesta); mas isso não nos impede de afirmar que alguns elementos, tais como a referida necessidade, são transhistóricos. De fato, é evidente que tal desejo pode ser encontrado em muitas espécies.

${ }^{147}$ Detalharei este argumento em breve.
} 
clareza quanto à presença destes desejos. Assim, por exemplo, aqueles que desejam exercer o poder sobre outros não têm qualquer motivo para se pautar por critérios de verdade e honestidade. Se bem sucedidos, eles causarão sofrimento e, no entanto, não se satisfarão - por exemplo, pelo fato de que estarão recebendo reconhecimento de serem que não tomam como iguais. Assim, longe de ser possível separar epistemologia, ética e estética, aqueles que desejam produzir sociedades em que discussões sobre fatos são efetivamente realizadas têm muito a ganhar com a manutenção das reflexões sobre ética - uma ética não desencarnada, meramente normativa - e sobre os recursos estéticos capazes de servi-la. Pois a conexão entre verdade e eficácia não é a-histórica: o quanto os membros de uma dada sociedade desejam ser movidos por verdades é inseparável do quanto eles estão consideram desejável harmonizar suas identidades e ações com os fatos sobre o mundo. Se as construções de significados não produzissem efeitos práticos que possam ser avaliados como "melhores" ou "piores", e se não houvesse algum grau de sobreposição entre as formas de desejar capazes de produzir felicidade para os diferentes grupos, ${ }^{148}$ então qualquer sonho de produção de consenso ou avaliação racional de representações historiográficas deveria ser abandonado. Estaríamos de fato condenados à fundamentação prática ideológica, no melhor caso, e a um anything goes, no pior.

Afinal, como estamos argumentando, diferentes representações ativam diferentes elementos do passado, com diferentes consequências no presente. Tais diferenças não são irrelevantes para as vidas dos seres. Além disso, como o presente existe em relação processual com o passado, o conhecimento sobre as causalides históricas do presente é impedido por narrativas que incluem eventos falsos ou sustentam expectativas irrealistas sobre o que se pode esperar, do mundo e de si mesmo. No caso do mundo, por exemplo: a ideia de que a América era "grande" (se foi ou não, depende do que se entenda pelo termo) e de que esta grandeza pode ser ativada novamente é carregada de enganos, conceitos mal formulados, ocultações históricas sobre escravidão, guerras e desigualdades econômicas. Ela produz falsas expectativas em relação ao que pode ser feito. Também envolve ignorância geopolítica sobre as relações com o México e sobre o funcionamento do congresso, ao pressupor que seria possível fazer o México pagar por um muro na fronteira. Mas há também a dimensão "interna", que foca no pólo do

\footnotetext{
${ }^{148}$ Notar que eu não disse meramente "o que os grupos desejam". A capacidade de harmonizar os próprios desejos rumo a fins desejados não é inata, e uma cultura que não fornece aos seus membros os meios para realizar este raciocínio não pode realisticamente esperar ser um campo fértil para "discussões racionais" - incluindo as discussões racionais sobre os méritos de diferentes representações históricas.
} 
sujeito e não no mundo - que, como temos argumentado, são inseparáveis. Seguindo o exemplo, por haver a percepção equivocada de que tais e tais desconfortos são causados por imigrantes ou pelos movimentos de igualdade de gênero e raça, há a expectativa de que alguma felicidade virá por meio de outra configuração. O diagnóstico histórico é portanto inseparável de outro, aquele sobre como deve ser uma vida feliz. Eis a conexão entre história e utopia defendida por White, eis a dimensão de phronesis do juízo histórico apontada por Mink.

Em entrevista concedida a Jenkins em 1997, White afirmou algo nestas linhas, tomando como o exemplo das tradições a que ele próprio se liga:

O marxismo é uma teoria da história genuína na medida em que ele é uma teoria da mudança, da transformação; ele é não-teleológico, e (e isto conecta meu materialismo e meu marxismo com o meu comprometimento existencialista) sua história é também escrita em prol dos interesses da justiça social. Pareceria tolo para mim que alguém fosse querer produzir qualquer tipo de disciplina ou ciência que não fosse em prol dos interesses da justiça social (JENKINS, 1998: 73).

Se isto está longe de garantir a saúde dos debates historiográficos, isto garante que aqueles que recusam a busca do consenso e buscam exercitar poder sobre outros nunca estarão satisfeitos. Assim, há algo de insustentável em tais projetos. Por outro lado, sem a manutenção da memória de tal insustentabilidade, é inteiramente concebível que uma "má infinitude" se produza e que as novas gerações retomem os mesmos projetos. Algo como o princípio da solidariedade, mobilizado por Rorty, não é apenas a única coisa que nos resta agora que a filosofia desacreditou em todas as demais ilusões: é um dos fundamentos práticos ao qual a historiografia e a filosofia da história precisam estar conectados. Por quê? Para formular em termos propositalmente circulares, que indicam que chegamos a um groundless ground: porque é melhor, e a discussão racional só é possível quando com quem recebeu de sua sociedade os meios para considerar que assim é melhor. Se cabem todos os pontos de considerações históricas sobre como amor, compaixão, solidariedade etc. serão praticados em sociedades específicas, não cabe nenhum relativismo quanto ao fato de que eles são pré-condição necessária para esse algo bem mais específico que é uma prática historiográfica racional.

Vale aqui precisamente o que Donald Carveth falou recentemente acerca da psicanálise: 


\begin{abstract}
A terapia psicanalítica, por mais que ela tenha tentado disfarçar o fato, sempre escolheu, advogou e praticou implicitamente uma ética que ela se recusa a pregar, uma ética em que amor é melhor que ódio, vida é melhor que morte, bondade é melhor que crueldade, gratidão é melhor que inveja, etc. Eu compartilho e faço o meu melhor para praticar estes valores, mas não posso afirmar que eles são autorizados por Deus ou pela razão deificada com a qual muitos buscaram substituí-lo. (CARVETH: 2018: 56-7)
\end{abstract}

Nosso trabalho afirma que a produção e avaliação de trabalhos historiográficos apenas podem se sustentar com base neste conjunto prático, não fundacional, de princípios éticos, descrito em termos suficientemente gerais a ponto de deixar aberto um amplo leque de debates éticos acerca de seus contornos históricos particulares. Não há um único debate da "filosofia existencialista da história" - que, ao contrário dos debates ligados ao covering law model, aborda explicitamente a dimensão prática da historiografia - que considere o sofrimento e a crueldade desejáveis ou neutros, por exemplo. Não há consenso efetivo ou possível sobre o que é nem sobre como produzir uma sociedade "melhor", mas nem mesmo os autores pós-modernistas conseguiriam ser coerentes com um total relativismo neste ponto: mesmo Jenkins, quando busca levá-lo às últimas consequências, considera a liberdade imaginativa melhor do que restrições disciplinares, por exemplo; e é evidente que Rorty considera a solidariedade melhor que a crueldade. ${ }^{149}$

É uma falha prática e filosófica não reconhecer a conexão entre seres vivos, em um extremo - e não máquinas, algoritmos, mentes desincorporadas - e a avaliação abstrata de textos historiográficos, por outro. Prática porque nos impede de efetivamente produzir (filosofia da) história "para a vida", e teórica porque joga fora insights como os de Vico e de Collingwood sobre a questão. Se considerarmos que assuntos ligados a felicidade e sofrimento - compaixão, solidariedade, etc. - são assuntos que não cabem na filosofia da história e devem ser relegados à auto-ajuda, então estaremos caindo no erro que uma longa tradição, à qual este trabalho busca somar esforços, buscou apontar: o de tomar como mera discussão lógica e abstrata o que efetivamente se dá por meio de relações vitais e não pode ser adequadamente entendido fora dela.

\footnotetext{
${ }^{149}$ Que a compaixão tenha um enraizamento na realidade - não por espelhar a realidade, mas por permitir desvelar aspectos e até mesmo por ampliar a capacidade humana de agir em relação a ela -, em vez de ser um emoção, sentimento ou hábito tão realista ou neutro quanto (por exemplo) a crueldade, é esclarecido brevemente por Macy e Johnstone (2012: 67) nos seguintes termos: "Esta habilidade [de "sofrer com"] é evidência da nossa interconexão com toda a vida." O termo "interconexão" se refere a uma forma de expressar teoricamente um aspecto da realidade. Já a crueldade constrói uma imagem do outro necessariamente falsa, pois nega uma senciência - e mesmo uma complexidade - que existe na realidade, e depende de tal desacordo para justificar um certo conjunto de ações.
} 


\subsection{Representação e experiência (2): Como testar referenciais éticos e estéticos?}

A discussão anterior pode ser prosseguida de um enfoque mais peculiarmente teórico, se tomarmos uma proposta concreta formulada pelo próprio Ankersmit. Em "In Praise of Subjectivity", publicado em 2001, ele defende "a tese incomum de que o discurso narrativo ou histórico é o que temos de mais confiável quando nós desejamos decidir quais critérios morais e políticos fazemos bem em adotar.” (2001: 98) Ele propõe um procedimento em três etapas: "Nós devemos começar coletando um grande número de textos históricos que foram claramente escritos a partir de diferentes pontos de vista morais ou políticos", e também deveríamos garantir que "mais ou menos os mesmos fenômenos históricos ... são discutidos em todos estes textos." O próximo passo é observar "o veredito da história da escrita histórica em relação a estes textos", mais especificamente, um veredito formulado da uma perspectiva dos critérios estéticos tais como o próprio Ankersmit propõe. Feito isto, "nós deveríamos perguntar quais valores morais e politicos são dominantes no conjunto preferido de textos históricos. Estes, então, serão os valores morais e politicos que nós deveríamos adotar e usar como o nosso compasso para a nossa ação presente e futura, individual e coletiva." (idem, ibidem)

Que dizer destes critérios?

Primeiramente, por recorrerem à história, eles são evidentemente adequados para uma perspectiva não-fundacionalista e não-transcendentalista de ética, estética, epistemologia e da relação entre elas. White adota uma visão até certo ponto parecida:

\footnotetext{
"[Amy] Elias acredita - como eu — que quando se trata de pensar sobre 'o significado' da vida, a história é tudo que nós temos. 'Quando a religião se tornou mito, nós precisamos da história', ela escreve. De fato, quando a religião se tornou mito, a história se tornou a nossa metafísica - o que LéviStrauss chamou de 'o mito do Ocidente."” (2005: 151)
}

Assim, conclui White, o passado prático é “uma 'realidade' imaginada ocupando o lugar tanto da religião quanto da metafísica como o paradigma ou fundamento [bedrock] de 'o real." Porém, adotando esta perspectiva, segue que a história da historiografia não ocupa também uma posição transcendental - embora certamente ocupe uma posição reflexiva - capaz de fornecer o que Ankersmit espera dela. O que me parece ter acontecido é que, no intuito de descrever uma etapa da experiência de avaliação dos critérios estéticos, Ankersmit procedeu em termos demasiado estáticos. 
Assim, por exemplo, não se trata apenas de coletar as representações históricas já existentes e de encontrar as avaliações de história da historiografia já feitas, mas de, a partir da situação atual - em algum grau sempre inédita - realizar novas experiências de escrita e de avaliação. Estando em outra situação, as perguntas que fazemos são outras e, assim, tanto os textos quanto as avaliações nos servem de maneiras distintas. Afinal, os critérios éticos e estéticos que buscamos não são - como Ankersmit não quer mesmo que sejam - normas transcendentais, mas sim aqueles mais adequados para que possamos realizar um juízo prático adequado à nossa situação. E se o diagnóstico de "Burden" está correto sobre "nosso destino" ser "descontinuidade, disrupção e caos", então é bom levarmos ainda mais a sério o conselho do próprio Ankersmit e lembrar que o lugar de onde vemos o rio de cima é, ainda, um lugar situado. Em outras palavras, não se trata de testar a subjetividade (situada) de outros historiadores em relação ao passado, mas de fazê-lo a partir de alguma perspectiva presente também subjetiva (e situada). Diferentes perguntas feitas à historiografia e à história da historiografia passada resultarão em diferentes respostas; elas nos serão um apoio para modificar nossas próprias perguntas e nossa formulação das respostas - i.e., quais critérios adotar - no processo, mas segue havendo uma margem incontornável de liberdade. Em outras palavras, não é a história da historiografia que nos dirá como adotar uma perspectiva, mas as diferentes perspectivas que adotarmos de diferentes lições da história da historiografia. E o que surgirá como lições dependerá, como Collingwood e Gadamer bem disseram, das nossas perguntas. O passado pode ser uma boa fonte de respostas às nossas perguntas, e ele até mesmo permite-nos refinar as perguntas que colocamos, mas as perguntas são sempre nossas.

Em outros termos ainda, retomando aqueles que empregamos no início do capítulo: tomar a história como ponto de referência significa reconhecer que, diferentemente da metafísica, da religião ou do que se poderia esperar equivocadamente da ciência, não há pontos de referência fixos: a história serve como teste de pontos de referência.

Em terceiro lugar, há algo de a-histórico no pressuposto de que, ao testar um conjunto de referenciais em relação ao passado, ele continua sendo o mais adequado em relação ao presente e ao futuro (ver SIMON, 2015, 2018). Pois o ritmo de mudança histórica também é histórico.

Em quarto lugar: sobre quais partes do passado devem ser as representações que iremos escolher? Se forem as partes do passado cujos problemas são parecidos com o 
presente, isto dependerá de como representamos o passado e o presente, e isto fazemos com critérios cuja desejabilidade é o que está em jogo. Esta circularidade é inevitável; é como se testássemos o critério, dizendo, "supondo que o ideal seja adotá-lo, quais semelhanças surgem entre o passado e o presente?". Não sabemos previamente quais partes do passado se parecem com o presente, e a semelhança só se manifestará a partir de alguns referenciais. E se focássemos em outras partes do passado, que só são semelhantes ao presente quando vistas por outros critérios que não o que estamos vendo?

Reinserir o movimento demandado pela ausência de fundamentos significa que podemos adaptar o exercício proposto por Ankersmit. O melhor procedimento, a meu ver, é a abertura à experiência entre todos os diferentes elementos envolvidos na escrita histórica: a historiografia, a avaliação estético-racional (incluindo, nos termos de "In Praise", a história da historiografia) e todos os elementos componentes da situação presente. Isto é, a adoção de um certo critério testado no passado "passados práticos" diferentes dos que estavam ativos, modificando o presente e criando novas demandas, que responderemos empregando ou modificando os recursos que atualmente temos. $\mathrm{O}$ "teste histórico" é parte de um movimento mais amplo, que envolve também o teste das consequências pragmáticas no presente - e as que conseguimos imaginar para o futuro do critério que adotamos no presente com apoio na historiografia. Este movimento pode pode e deve ser estabilizado para fins práticos, mas, como White propõe em "Burden", deve ser retomado tão logo os critérios outrora adotados se mostrem insuficientes ou inadequados aos novos desafios.

Esta experiência não é apriorística, muito menos solipsista, porque ela é feita por seres incorporados, no mundo, e em relação, que sofrem e se alegram, física e mentalmente, e que possuem desejos, dentre os quais estão em algum grau - que não é fixo - os desejos por entendimento mútuo e pelo conhecimento da realidade. As causalidades do mundo natural atuam sobre estes seres, e a ação efetiva do presente depende da compreensão de sua dimensão temporal, já que o presente não é um período isolado de um passado que se foi pra sempre e sim uma constelação de processos temporais interpenetrantes, vivos e ativáveis.

A produção de uma historiografia pautada no desejo por dominação é sempre uma possibilidade, mas a necessidade de conhecer verdades para atuar efetivamente no mundo, e, daí, a necessidade de comunicação intersubjetiva honesta para o conhecimento destas verdades, têm como decorrência que todo projeto de dominação 
possui uma insustentabilidade essencial que não é compartilhada pelos projetos pautados por compaixão e honestidade.

Sintetizando o raciocínio acima, Ankersmit afirma que "não precisamos nos assustar" com a presença de valores morais e políticos na escrita da história, já que a estética é "o parceiro mais forte na interação entre o critério de sucesso estético e aqueles do que é certo eticamente, politicamente, ou cognitivamente." (2001: 102) Esta metáfora do "parceiro mais forte" é bastante recorrente na obra de Ankersmit; como algumas outras, ela aparece tanto nos textos sobre representação quanto naqueles sobre experiência. Aqui há um ponto importante a ser feito, que poderíamos caracterizar como um ponto "historicizante": como concordam Danto, Collingwood, White e Ankersmit, cada um à sua maneira, a estética antecede a epistemologia. Mas toda construção estética do mundo é de natureza tal que poderia ser sempre de outro modo. E isto significa que há uma liberdade a princípio cuja efetivação prática oscila de acordo com as condições. De acordo com as filosofias de Vico, Collingwood e White, esta liberdade se manifesta historicamente apenas após um longo processo de reflexão da mente sobre si mesma. A partir do momento em que ela entra em cena - em que a condição contingente das nossas representações do mundo são demonstradas enquanto tal -, e na medida em que as circunstâncias históricas permitem que as mentes mais livres produzam sentido para o mundo de formas múltiplas - segundo Ankersmit, "a estética se pode performar esta função se liberdade de expressão e de discussão sobre o passado estão completamente e incondicionalmente garantidos" (2001: 102) -, então, se fosse para falarmos em um "parceiro mais forte", a consciência moral é que utilizaria, dentro das possibilidades acessíveis ao agente em sua situação, da estética.

A estética continua tendo antecedência, no sentido de que ela atua na negociação mais direta entre sujeito e mundo, propondo formas de olhá-lo e significando os inputs do ambiente; mas esta dimensão é retroativamente influenciada pelas atividades cognitivas mais abstratas, que nunca se dissociam inteiramente da "atmosfera" mais básica de onde surgem. É como na tropologia de White: pode parecer impossível escapar à prisão da linguagem, no sentido de ser impossível significar o mundo sem tropeá-lo de alguma forma; mas é possível escolher como tropologizá-lo, e é possível que o principal critério envolvido na decisão diga respeito às consequências pragmáticas de uma escolha em vez de outra. Assim, ética e estética atuam em estreita proximidade, e, como a liberdade do uso da linguagem - bem como a liberdade diante das 
circunstâncias históricas e sociais - é contingente, não há uma fórmula capaz de dizer $a$ priori qual é "o parceiro mais forte".

Não seria o caso de escolher "a melhor representação", mas de escolher o “melhor" - em sentido puramente prático, não-fundamentado - valor: o pluralismo. Melhor porque permite a colocação da pergunta sobre o que fazer em cada situação, tendo em vista a felicidade e o sofrimento dos seres, sem presumir que haja fundamentos ou normas que explicitem o que é e como preduzir a ação mais adequada: um critério, portanto, radicalmente histórico. Como o passado pode ser apresentado de muitas formas, a melhor apresentação reconhecerá esta característica do passado - pois ele verdadeiramente é assim: inespelhável pela mente. (Isto é, a rejeição rortyana da tese da mente como Espelho do Mundo é simultaneamente uma tese sobre a mente e sobre aquilo que surge para ele como objeto - sobre "o mundo".) Assim, a natureza do ato de dizer deve ser reconhecida pelo que é para que possa expressar aspectos do passado. Qualquer ato de compreensão que presuma fechamento, coerência, domesticação está errado. Assim, um mesmo texto pode ser lido - compreendido - de mais de uma maneira, ainda que a única diferença seja na atitude de considerá-lo ou como uma visão ou como a visão. Este erro filosófico na leitura, ainda que de um excelente texto, produz um equívoco sobre a natureza do evento: ela está certa em entender que "este evento é de tal natureza que ele pode ser corretamente desvelado na forma de X", mas está equivocada se presume que "este evento é de tal natureza que não pode ser corretamente desvelado como X1, X2, X3, X4, e como Y, Z, A, B, C...” (X1, X2 ... sendo variantes da primeira representação, mas ainda operando em afinidade com sua metáfora governante "destacável", ${ }^{150}$ e Y, Z... sendo outras formas pelas quais o evento pode ser realisticamente representado).

\subsection{Compreensão com energia: as teses narrativistas à luz da "experiência estética" de Dewey}

Seguindo os exemplos sobre medo e sobre ódio, façamos agora um ponto teórico por meio do qual pretendemos enriquecer a noção narrativista de compreensão com a perspectiva pragmatista de Dewey sobre "experiência estética". Esta não trata de entidades analisáveis por meio de lógica (Mink, Ankersmit) ou métodos formalistas

\footnotetext{
150 Aqui manifestamos acordo com Kuukkanen, para quem a tese apresentada pelo texto pode ser destacada. Nossas visão é de que os narrativistas, especialmente Ankersmit, estão certos em presumir que o texto enquanto totalidade é uma estrutura indivisível e portanto não-destacável, mas também consideramos que um grupo de textos pode ser tomado como instâncias de um tipo de metáfora.
} 
(White), mas de uma atividade de seres incorporados e situados. Ela será, em nossas visão, a ponte ideal entre as discussões sobre representação que estamos quase encerrando e aquelas sobre experiência que em breve abriremos.

Para fazer isto, citemos então mais um exemplo do Terceiro Reich, oriundo do já mencionado livro de Peter Fritzsche:

\begin{abstract}
A atividade política [dos nazistas] tomava como premissa tanto uma confiança suprema e uma vulnerabilidade aterrorizante; ambos os estados de mente coexistiram e radicalizaram continuamente as políticas nazistas. O senso de "pode-se fazer" foi envolto em "deve-se fazer". Esta combinação liberou enormes energias enquanto milgões de alemães participaram na vida pública para renovar, proteger e preservar a nação. Ao mesmo tempo, o sendo de urgência dos nazistas fez suas políticas mais letais, já que eles acreditaram que a única maneira de garantir a preservação de vidas "valiosas" era destruir o que eles consideraram vidas "não-valiosas", incluindo os "inadequados" geneticamente, "a-sociais" e judeus. (2008: 5)
\end{abstract}

Este trecho ilustra vários das teses que estamos defendendo: as representações enfatizam alguns aspectos de indivíduos e grupos e obscurecem outros; as identidades se constróem de maneira relacional, geram urgências específicas em relação ao mundo social, e portanto são indissociáveis de uma certa experiência da temporalidade e de uma certa carga afetiva; o caráter prático das representações se mostra no fato de que as descrições são acompanhadas, em maior ou menor grau, de prescrições; estas, por sua vez, existem à luz de uma imagem do passado de seu grupo e do processo histórico mais amplo (é o sentido mais nítido da ideia de que toda história envolve uma filosofia da história); e esta imagem do processo histórico também expressa emoções, desejos e afetos específicos (este é o outro sentido pelo qual toda história envolve uma filosofia da história: o processo histórico é visto à luz de um "colorido" específico, do qual seu significado é uma expressão).

Estes itens, assim descritos, são transposições dos argumentos narrativistas, tirados - reconhecidas as devidas diferenças - do campo da historiografia para aquela da história. Mas cabe aprofundar uma discussão ainda: aquela sobre a conexão entre as representações e a maneira pela qual elas organizam, direcionam e potencializam as "energias" sociais em circulação. Isto significa que as discussões lógicas ou formais dos narrativistas devem ser reinseridas no mundo social de onde as representações históricas partem e para o qual elas retornam.

Ao fazer isto, a transição das discussões sobre representação para aquelas sobre experiência e presença estará quase completa, e, nessta transição, nosso argumento pela conexão processual entre ambas estará exemplificado. Uma experiência histórica 
sublime se constitui em um evento traumático, dentre outros motivos, pela impossibilidade psicológica de domesticá-lo por meio de uma narrativa reconhecida pelos contemporâneos como desejável. É evidente que um texto sobre tal experiência pode ser escrito como se fosse o sentido do evento fosse fechado: a impossibilidade de tal doemsticação se manifesta no corpo e nas interações sociais de quem lê. Os fenômenos de presença do passado também constituem em pressões, externas aos sistemas representativos, manifestadas por ou com apoio na memória dos desaparecidos (Bevernage), na presença material do passado (Domanska), na repetição inconsciente (Runia). O triste caso do exemplo de Fritzsche é o de um sistema de representações que efetivamente chega a ter eficácia em organizar e direcionar várias demandas em aberto e propor uma direção rumo à sua resolução. Dado o caráter particularmente trágico do nazismo, esta tentativa de resolução acabou, por sua vez, a deixar abertos vários outros elementos de presença que assombraram e assombram as construções coletivas de identidade das gerações subsequentes.

A filosofia de Dewey é particularmente interessante para os nossos propósitos porque Ankersmit a dá um espaço central desde suas promeiras discussões sobre experiência (1996, 2000), e reserva um capítulo de Sublime à "experiência histórica pragmatista" (2005, 241-262). Mas a nossa leitura tem uma ênfase que não é a dele: enfatizamos a continuidade entre as noções de representação e de experiência (estética), de modo que as discussões não surgem como radicalmente distintas. Assim, Dewey serve-nos para enriquecer a noção de compreensão, avançada por Mink, permitindo-nos compreendê-la à luz da inserção da historiografia no mundo prático (algo que já afirmávamos ser necessário quando discutimos as objeções da Carr a Mink); e serve-nos também para que, quando chegarmos ao próximo capítulo, possamos ver as experiências estéticas como experiências representativas. Isto será possível porque, ao romper com um sistemas de representações (ou compreensões) no presente e acessar "o passado", o que efetivamente se está experienciando é uma multiplicidade de outras representações - ou ainda, aspectos desta multiplicidade de outras representações.

Vejamos então. O ponto mais básico e mais relevante do conceito de Dewey, como já mencionamos, é que ele concebe que "cada experiência é o resultado da interação entre uma criatura viva e algum aspecto do mundo em que ele vive." Assim, ao perceber ou produzir alguma desarmonia em relação ao ambiente em que vive, o 
organismo dá início a um processo de "adaptação mútua entre self e objeto". (44) A experiência sempre se completa com "a instituição de uma harmonia sentida."151 (44)

Esta experiência, como várias daquelas outras conceitualizadas ao longo do trabalho, está efetivamente situada no que chamamos de "segundo nível de consciência”. Pois Dewey é específico ao afirmar que não concebe a vida como uma mera sucessão de ocorrências em fluxo. Assim, apontar para a presença de ritmos diversos é equivalente a reconhecer que a dimensão de fluxo onde a linguagem não opera é, na realidade humana, perpassada por produções de totalidades tais como as que Carr descreveu. Desse modo, experiência e temporalidade são inseparáveis; Dewey afirma que "cada experiência integral se move rumo a uma conclusão, a um fìm, já que ela cessa apenas quando as energias ativas nela consumaram seu trabalho." (41) Esta totalidade, para Dewey, só é "estética" quando a atenção do experienciador não cai nem em complacência nem em hiperatividade. Assim, ele está conceitualizando uma atividade um pouco mais complexa do que a de Carr, mas é importante notar que elas não são descontínuas: vida e arte, como vida e narrativa para Carr, são coextensivas.

Em segundo lugar, Dewey apresenta uma concepção de experiência que nem consiste na mera aplicação de categorias a priori sobre o mundo, nem no mero espelhamento de como as coisas são: nem idealismo, nem realismo. Para esclarecer esta relação entre atividade e passividade necessária para que a experiência seja estética, Dewey distingue entre "percepção" e "reconhecimento". Nos sentidos peculiares em que ele os emprega, o reconhecimento equivale a uma mera aplicação de categorias. Nela, "nós caímos, como quem estereotipa, em um esquema formado previamente." (52) Dewey afirma que a dicotomia entre percepção e reconhecimento também se manifesta na relação entre pessoas. (52-3) Uma tarefa ética relevante para uma filosofia da história que leve em conta suas preocupações é, então, estimular uma prática que produza o máximo possível de percepção e o mínimo possível de reconhecimento. Pois as hierarquizações disciplinares que, por muito tempo, excluíram grupos inteiros da

\footnotetext{
${ }^{151}$ Isto é válido para casos como os historiadores do Holocausto que temem produzir domesticação para o evento, para os sobreviventes de eventos traumáticos que temem cristalizar suas memórias (como Primo Levi, cf. BUTLER, 2009b), e para pessoas como as Mães da Praça de Maio, que recusam a tentativa do governo argentino de produzir fechamento para a narrativa da vida de seus filhos e filhas desaparecidos? Creio que sim: ainda que, escrevendo sem tais questões em mente, Dewey fale em harmonia, é concebível que as performances - a de escrita ou a de ocupação do espaço público - busquem não uma narrativa harmonizadora, mas o uso de uma narrativa não-harmonizadora como forma de harmonizar suas próprias visões morais sobre o que deve ser feito com a memória das vítimas e aquilo que as circunstâncias efetivamente possibilitam fazer (incluindo aí as tentativas de negacionistas ou militares de fazer outras coisas). A domesticação seria percebida, por estes grupos, como insatisfatória.
} 
historiografia, assim como as heirarquizações que, mais amplamente, dizem quais vidas são dignas de luto e quais não são, dependem sempre deste hábito cognitivo do mero reconhecimento. Nas palavras de Dewey:

O simples reconhecimento é satisfeito quando quando a etiqueta adequada, ou rótulo, é anexada, 'adequada' no sentido de ela ser uma que serve a um propósito fora do ato de reconhecimento - como um vendedor que identifica os produtos por uma amostra. Ela não envolve nenhuma agitação do organismo, nenhuma comoção interna. Mas um ato de percepção procede por ondas que se estendem em série por todo o organismo. Não há na percepção, portanto, tal coisa como ver e ouvir mais emoção. O objeto ou cena percebido é inteiramente pervadido emocionalmente. (1980: 53)

Assim, uma mera aplicação de um enredo ao passado, que tanto White quanto Ankersmit veem como indesejável, é uma circunstância em que não há efetivamente uma experiência estética. Mas a filosofia de Dewey tem a vantagem de manter a possibilidade de "percepção", na qual nem as categorias são meramente impostas, nem o sujeito apenas recebe inputs do mundo ou o espelha com sua mente.

Em terceiro lugar, como argumentamos em nossa discussão sobre a possibilidade de "cancelamento do tempo", Dewey reconhece a importância do tempo para a realização das experiências:

\begin{abstract}
Em cada experiência integral há forma porque há organização dinâmica. Eu chamo a organização de dinâmica porque ela leva tempo para ser completada, porque ela é um crescimento. [...] A incubação segue até que o que é concebido é trazido à frente e é tornada perceptível como parte do mundo comum. Uma experiência estética pode ser lotada [crowded] em um momento apenas no sentido que um clímax de um longo processo duradouro anterior pode chegar em um momento excepcional que engloba tanto todo o resto dentro dele que todo o resto é esquecido. (55-6) "A experiência, como a respiração, é um ritmo [que oscila entre] internalização e externalização [intakings and outgivings]."
\end{abstract}

Assim, da mesma forma que há na experiência estética um equilíbrio entre atividade e receptividade por parte do sujeito, há também um equilíbrio entre o avanço e a síntese (tal como Gallie e Mink, respectivamente, teorizaram no caso da historiografia):

Em seguida, um trecho mostra bem a dinâmica entre avanço e congelamento: "Como no avanço de um exército, todos os ganhos do que já foi efetuado são periodicamente consolidados, e sempre em vista do que deve ser feito a seguir. Se nós nos movermos muito rapidamente, nós ficamos distantes da nossa base de suplementos - ou significados acumulados - e a experiência é afobada, minguada e confusa. Se nós demoramos demais após ter extraído um novo valor, a experiência perece por inanição.” (56) 
Tomados em conjunto, estes componentes da experiência permitem-nos enriquecer nossa concepção do que é "compreensão", quando realizadas por seres humanos engastados no mundo. Antes de elencarmos nossos argumentos em defesa desta afirmação, vejamos que ele ainda permite adicionar um ponto, já mencionado de passagem na discussão precedente: aquele que reconhece a circulação de "energias" como parte da experiência estética. Isto é de extrema relevância para a nossa pesquisa, pois permite-nos entender melhor como é possível que o sujeito seja movido pelo passado ou que possa revivê-lo ou reativá-lo no presente (seja no sentido figuralista, seja no de re-enactment): isto é, movê-lo, ainda que em certo sentido ele evidentemente esteja fechado e portanto seus componentes não existam mais para serem movidos. Segundo Dewey (1980: 176-7):

No objeto estético, o objeto opera - como, é claro, um [objeto] tendo um uso externo também pode fazer - para reunir energias que tenham estado separadamente ocupadas em lidar com muitas coisas diferentes em ocasiões diferentes, e para dar a elas aquela organização rítmica particular que nós chamamos (quando pensando no efeito e não no modo de sua efetuação) clarificação, intensificação, concentração. Energias que permanecem em um estado potencial a respeito umas das outras, porém reais quanto a si mesmas, evocam e reforçam uma à outra diretamente em favor da da experiência que resulta.

Vários pontos em comum com o pensamento narrativista podem ser vistos nesta breve citação - e uma importante adição. Vimos que os modos de compreensão de Mink, e ainda mais particularmente a compreensão configuracional, reúnem eventos ocorridos separadamente em uma totalidade simultânea. O trecho aqui descreve o procedimento de maneira similar, mas com uma observação que nunca entrou no radar de Mink: o que são reunidas na experiência estética são energias. Que a produção de simultaneidade seja descrita não como um "cancelamento do tempo", mas uma refiguração dos ritmos da natureza em novos padrões rítmicos peculiares da experiência, também é digno de nota. ${ }^{152}$ Dewey permite-nos ver a inseparatividade (exceto para fins analíticos) do ato mental de compreensão com o corpo, e sua condição perpassada de dinâmicas espaciais e temporais.

As teses segundo as quais a substância narrativa produz uma "organização de conhecimento" (Ankersmit) e a o "reavivamento" figural de potencialidades do passado (White) também ressoam com este trecho, e têm ambos a ganhar se vistos como parte

\footnotetext{
${ }^{152}$ Ponto este que remete a Carr, e mais especificamente à versão mutuamente refigurada das teses de Mink e Carr que apresentamos aqui. A relação entre as filosofias narrativistas e a de Dewey foi discutida, com resultados diferentes do nisso, por Díaz-Maldonado (2017) e Tozzi (2018).
} 
das relações vitais das quais a descrição da narrativa como entidade lógica pode enganosamente separar. No caso das substâncias narrativas, cabe lembrar que, como defendemos nos capítulos anteriores, as descrições (as partes do todo que são as substâncias narrativas) são conhecimento $e$ são estética. Uma descrição de evento é uma forma de enfatizar alguns de seus aspectos e obscurecer outros, de sugerir uma atitude emocional em relação a ele, etc. A articulação das várias possíveis descrições em descrições efetivas é feita quando o historiador encontra um "ponto de vista" a partir do qual estes aspectos possam ser experienciados (entendidos, mas também sentidos) da maneira mais potente possível. A capacidade do "ponto de vista" de organizar tais potencialidades em uma totalidade é o que Ankersmit descreve como o seu "escopo", e remetem ao que Diderot já chamou de "energia" do discurso: sua capacidade de sintetizar o máximo possível de coisas com o mínimo possível de extensão. O sentido do termo "energia" é outro do que em Dewey, porque ele diz respeito ao poder de síntese da linguagem e não àquilo que ela organiza, mas os dois níveis (a organização ou, nos termos do nosso trabalho, significado; e aquilo que é organizado, a experiência vivida) são conectados. O critério do "escopo", de Ankersmit, na medida em que é afim à energia de Diderot, se harmoniza bem com a perspectiva de Dewey de que uma experiência estética é aquela capaz de potencializar o encontro de energias disponíveis.

Esta também também permite-nos dizer algo mais sobre o critério de White - ou aquilo que resta, pragmaticamente, quando não há critérios fundamentados possíveis -, a "eficácia". No exemplo de Fritzsche em questão, é a capacidade das representações nazistas de oferecer um direcionamento em relação ao qual o sofrimento experienciado naquela relação específica entre os indivíduos e o mundo (no caso, a situação geopolítica da Alemanha) parecia possível de ser resolvido. Tal promessa permitiu que este sistema de representações fosse "eficaz" no curtíssimo prazo, dando uma direção comum a vários diferentes desejos em circulação, mas é sua total desconexão com a realidade que a tornou tão imensamente ineficaz a longo prazo - se partirmos do pressuposto de que mesmo os nazista desejavam viver uma vida feliz. Suas representações não permitiam ver os demais seres humanos em sua complexidade, não conectavam a imagem de mundo produzida com o desejo que a gerou, e por isso e/ram marcadas por "corrupção de consciência". ${ }^{153}$ Eram, portanto, ineficazes. Pois nosso

\footnotetext{
${ }^{153}$ Lembremos dos comentários de Collingwood, em sua Autobiography, sobre como o fascismo era um movimento incapaz de reconhecer suas próprias motivações. Ele faz uma referência implícita a Gentile,
} 
argumento é que, se por um lado os significados mobilizam desejos e portanto sua eficácia não diz respeito a questões de verdade ou falsidade, por outro estes desejos resultarão em ações, em relação às quais o critério de realidade é incontornável. Além das representações falsas sobre o passado (como no caso dos já discutidos negacionismos) não serem uma base confiável para ações futuras, representações falsas sobre o mundo presente (pautadas em conspirações e na criação de imagens paranóicas do Outro) evidentemente também comprometem tais ações.

Adicionalmente, se concordarmos que muitas diferentes experiências estéticas (das substâncias narrativas) serão produzidas com o apoio de um mesmo "produto de arte" (o livro de história), então uma ênfase maior deverá ser dada à recepção dos textos e ao movimento entre a experiência do autor, a criação de um produto e a ocorrência de novas experiências, em contextos diferentes. A ativação (estéticocognitiva) do passado (objeto do texto) e da experiência do passado (por parte do sujeito que escreveu o texto) ${ }^{154}$ em outro contexto é parte central do processo de produção de conhecimento historiográfico, e, assim, a avaliação da eficácia de uma certa “organização de conhecimento" é inseparável da desorganização ou reorganização do mundo prático causada ou estimulada pela leitura do texto. Afinal, as energias do passado, experienciadas e refiguradas por historiadores também dotados de energias próprias, modificam qualquer que seja a configuração de energias do presente. Não há algo como uma escrita sobre o passado que não envolva uma ativação do passado, uma modificação do próprio historiador e de seu contexto. De fato, produzir tais modificações é, para Dewey, a motivação para o início do trabalho que culmina em uma experiência: o sujeito a realiza por reconhecer algum desajuste entre ele e o ambiente e buscar soluções para produzir um novo equilíbrio, que será invariavelmente temporário.

Outro ponto no qual Dewey fornece-nos uma ponte entre narrativismo e experiencialismo diz respeito ao espaço que ambos conferem à noção de autenticidade. Para compararmos as abordagens, notemos que o conceito de compreensão configuracional de Mink é muito mais amplo que o de experiência estética de Dewey, que é, como veremos, muito mais amplo que Ankersmit chama de "tipo-Huizinga de experiência" do passado - ainda que Ankersmit enfatize as semelhanças entre Dewey e

afirmando que sua adesão ao fascismo, por condená-lo a tal incapacidade, também o incapacitava ao pensamento filosófica (1978: 158).

${ }^{154}$ Isto poderia ser formulado também como: “... das experiências do passado (objeto do texto, junto com outros elementos) e das experiências das experiências do passado (por parte do sujeito que escreveu o texto...". Para não abusar da paciência dos leitores, restrinjamos a observação a uma nota de rodapé. 
Huizinga e não aponte explicitamente esta diferença. Ora, o tipo de compreensão produzido pela historiografia profissional tradicionalmente buscou tratar seu objeto com "distanciamento". Uma forma de produzir distanciamento consiste em focar a atenção mais nas atividades de "terceiro nível de consciência", que produz descrições factuais passíveis de verificação, do que nas do segundo ou do quarto, respectivamente mais artísticas e mais filosóficas. Um texto distanciado pode tratar de arte, filosofia, história, mesmo de emoções e desejos do passado, mas não os aborda explicitamente de maneira artística - buscando expressar a atmosfera do passado, ou expressar a própria experiência presente de tal atmosfera - ou filosófica. É assim que White frequentemente historiciza a profissionalização da historiografia: ela se deu por meio da tentativa de se distinguir da retórica e das filosofias da história. No primeiro caso, pressupõe-se, dentre outras coisas, que não é subjetividade do historiador que fornece acesso às verdades do passado $^{155}$, de modo que uma linguagem descritiva dos elementos compreensíveis em terceira pessoa são tudo que deve ser dito pela historiografia, e que a pesquisa determina a escrita (e não, como consideramos aqui, que ambas se co-determinam processualmente). Já ao se distinguir das filosofias da história, a historiografia evita propor um significado para o processo histórico como um todo, evitando abordagens apriorísticas.

A historiografia profissional, porém, não pode escrever textos sobre o passado sem que eles sejam informados por desejos (primeiro nível), tropeamentos e enredamentos (segundo nível), pressupostos (em todos os níveis ${ }^{156}$ ). O que ela pode é negligenciar tais níveis, ou negando que efetivamente empregue a imaginação antes de dizer verdades, ou buscando disciplinar a própria imaginação. $\mathrm{O}$ primeiro caso configura a variante collingwoodiana da má-fé: "corrupção de consciência". Assim, podemos apontar um interessante paralelo entre as filosofias da experiência em Ankersmit com a filosofia da representação de White: enquanto Ankersmit enfatiza que as experiências de Dewey e Huizinga são autênticas, White acusa os historiadores profissionais de má-fé, ou seja, de inautenticidade - o que também implica que, em sua fase propositiva, ele proponha abordagens de boa-fé. Nestas, a presença da própria subjetividade não é negada ou reprimida.

\footnotetext{
${ }^{155}$ Tese que Ankersmit defende detalhadamente em "In Praise of Subjectivity" (2001: 75-103).

${ }^{156}$ Em sua leitura de Collingwood, Mink argumenta que todos os níveis da escala de formas têm seu próprio conjunto de "pressuposições absolutas".
} 
White demanda que percebamos como a consciência, no presente, molda o passado. Ankersmit demanda que haja simultaneidade do passado e do presente. Kuukkanen deseja que compreendamos o texto historiográfico como um ato de fala direcionado aos pares. A noção de compreensão pode ser ampliada para englobar todas estas dimensões (incluindo os eixos vertical e horizontal de relações que se estabelecem na produção de um ato de fala sobre o passado): para isso, ela deve ser concebida de modo que não mais inclua apenas a "rede de descrições sobrepostas" que, embora feitas no presente, são sobre os eventos no passado. A compreensão é também dos desejos envolvidos na relação com o passado, das sensações no corpo de quem escreve ou lê o texto (e não o experienciaria igualmente se fosse apenas um cérebro ou um espírito imaterial), dos recursos estéticos mobilizados ou produzidos para a tarefa, dos eventos que foram experienciados existencial e cognitivamente no processos de pesquisa, escrita e leitura, da ação que é feita por meio da publicação do livro, dos princípios filosóficos que geram também uma experiência particular desta totalidade dos eventos. Um dos argumentos que defendemos na presente tese é esta forma consideravelmente ampliada de holismo, que faz com que toda representação do passado seja experienciada sempre pela primeira e única vez (como "representação" ou como "experiência"), mas com componentes repetíveis, nunca inteiramente novos.

Assim, é louvável a tentativa da historiografia profissional de enfatizar a necessidade do tipo mais científico ou metódico de experiência para a produção da experiência total que culmina no produto, o texto historiográfico, e na experiência, oriunda de sua leitura. Porém, a ênfase unidimensional na pesquisa obscureceu o movimento entre pesquisa e escrita feita por um historiador incorporado e situado. Por outro lado, se White mostrou o quanto segue havendo uma dimensão não-reconhecida de filosofia da história implícita na produção de escrita, por outro suas ocasionais tendências apriorísticas efetivamente impediriam a formulação de uma escrita autêntica: o historiador não poderia ver senão a si mesmo ao significar o passado, e a pesquisa seria irrelevante exceto como fonte de dados a serem moldados livremente. O pressuposto a ser abandonado diante deste apriorismo é aquele que imagina o presente como radicalmente separado do passado - não afirmo nem nego que ele possa ser radicalmente distinto do passado -, uma entidade "presente" em contraposição a um passado "ausente", perdido para sempre. Mesmo Ankersmit, que em seus momentos mais românticos sonha com o encontro com o passado, o manifesta. Ele é análogo ao pressuposto cartesiano que concebe o sujeito como radicalmente separado de seu mundo 
- pressuposto que, como estamos vendo, Dewey considera oriundo de uma concepção equivocada da experiência humana. Nos termos de Rorty, ele nem precisa resolver o problema: ele o dilui.

Poderiam outros tipos de escrita da história produzir experiencialidade da atmosfera passada? Ora, embora White não fale nestes termos, isto é pressuposto em suas reflexões sobre a necessidade de produzir novas representações capazes de expressar os "eventos modernistas". Mas Ankersmit não fala de textos de história capazes de produzir tal efeito, apenas de tentativas de expressar experiências já ocorridas, como O Outono da Idade Média. Para ele, objetos despretensiosos e obras de arte são muito mais potentes na produção de experiências-Huizinga. Ainda assim, é nítido que os eruditos que tiveram experiências Huizinga tiveram um número considerável de experiências do - ou sobre (about) o - passado fornecidos pelos tipos descritos por Mink e por Dewey, antes de virem a ter a variante mais intensa de todas. Parece ser o caso que compreensões produzidas por representações históricas e artísticas são pré-condição para as experiências ankersmitianas, mas não são o meio mais apto a culminar em experiências tão particularmente intensas.

Outra conexão entre narrativismo e experiencialismo se encontra na noção de movimento: quando o passado atrai nossa atenção, e quando somos nós que a direcionamos ativamente ao passado?

Runia organizou seus vários artigos sob a rúbrica da questão de como somos movidos pelo passado - e o que chamamos de energia aqui é precisamente tudo aquilo que produz movimento. Como o trecho destacado deixa nítido, esta energia já move aquele que busca articular a experiência na forma de uma totalidade significativa antes dele proceder. São energias do mundo. Que Runia decida focar sua atenção nos casos em que uma certa estabilidade é rompida, não há uma contradição: Dewey também considera que os equilíbrios temporários podem ser rompidos e que o ambiente pode demandar do organismo a realização de novas experiências.

Vimos que uma diferença entre White e Dewey a respeito da significação reside no fato de que, enquanto o primeiro concebe - acertadamente - que a significação parte sempre do sujeito vivo no presente, o segundo enfatiza - também acertadamente - que esta consciência existe como parte de um organismo no mundo, e que se relaciona com ele em uma dinâmica em que passividade e atividade se alternam. A visão de White, também apropriada pelos pós-modernistas, é a de que apenas o sujeito está vivo, e que ele se relaciona com os mortos. Pode haver algum sentido em que o passado é "vivo"? 
Como Ahlskog (2016) apontou, nenhum passado pode ser conhecido $e$ morto; ele critica White por presumir ser possível tal coisa. Sua própria visão pode ser melhor aproveitada se considerarmos que representar o passado com má-fé é tratá-lo como se ele estivesse morto, produzindo - para mobilizarmos mais um de seus conceitos - um "passado histórico". O "passado prático", por sua vez, surge da conexão entre o que se ativa no passado com as urgências práticas do presente. A noção de experiência estética de Dewey fornece um subsídio útil para aprofundar esta reflexão: seria possível dizer que, conforme a crítica de White, a historiografia profissional não se dedica a efetivamente realizar experiências. Afinal, para Dewey, a experiência surge de uma tensão entre organismo e ambiente, na qual o ser . Buscar conhecer o passado, nesse caso, seria reconhecer e pôr em negociação os próprios referenciais do sujeito - em qualquer um dos níveis ou qualquer uma de suas relações: desejos, imaginação, verdades factuais, princípios filosóficos -, a situação em que ele se encontra, e as dimensões do passado já ativas no, ou ativáveis para o, presente. Não trabalhar nesta tensão, e em vez disso pretender que o passado apenas fale por si mesmo, é presumir uma passividade que, para Dewey, não é possível; pois, para ele, a experiência se dá exatamente na negociação entre atividade e passividade por parte do sujeito em relação ao seu mundo.

A experiência estética demanda "vida". O que seria um passado "vivo", se não aquele capaz de mover sujeitos no presente, e não apenas ser movido por eles?

Ora, conhecer já é tornar vivo o passado: torná-lo vivo enquanto passado deste presente. Mas este processo não deixa o próprio sujeito no presente intocado. Conforme a tese collingwoodiana que Ahlskog relembrou mais recentemente (2018), o historiador precisa modificar a si mesmo para conhecer o passado. Ele precisa se tornar alguém capaz de pensar pensamentos que, anteriormente, não era capaz de pensar. Assim, da mesma forma que o passado não sai intocado de sua ativação presente - ela é reativado em outro contexto -, o historiador não sai intocado de sua relação cognitiva com o passado. Na medida em que o historiador se torna um potencial preenchedor do passado, o passado se torna uma figura potencial; ele pode ficar dormente dentre tantas outras figuras reconhecidas como mais urgentes para as demandas presentes, mas esta dormência - como a espectralidade - é um tipo entre vida e morte que não pode ser reduzida a uma mera condição morta, pois pode sempre ser reativada. Mas o passado "conhecido" cientificamente, embora não seja inteiramente desconectado da atmosfera em que surgiu (caso contrário, não faria sentido), é uma formulação muito mais abstrata 
em comparação com a sua inserção original em um mundo vivo. Assim, um tipo de compreensão configuracional como o produzido pela historiografia profissional não "revive" o passado da mesma forma que as experiências de Dewey, e menos ainda do que as de Huizinga. Assim, falar em "presença” do passado é também falar em um passado "vivo", e o passado vivo é vivo para nós, seres vivos, capazes de experienciálo: intui-lo, temê-lo, senti-lo enquanto latência, desejá-lo. E quem é capaz de experienciar o passado é aquele que possui os recursos de preenchimento capazes de fazer o passado surgir como figura: o interesse, a capacidade imaginativa, o conhecimento científico, pressupostos filosóficos relativamente análogos, etc.

Dewey explica que, a não ser que levemos a energia em conta, não podemos compreender o poder da arte "para mover e excitar, para acalmar e tranquilizar". Além disso, como as energias articuladas são tanto do passado quanto do historiador e do ambiente presente, é possível identificar a mente incorporada presente como o locus e agente da experiência - sem ele, não haveria "passado vivo" - sem que para isto precisemos conceber algum tipo de transcendentalismo ou de dominação por parte do sujeito ou do objeto. Sendo manifestação desta energia, a significação não ser inerente do passado não é algo como a violação de um passado inerte, uma projeção livre do presente vivo sobre o passado morto, de um sujeito vivo sobre um mundo igualmente morto. Se ainda é possível dizer que o historiador significa livremente o passado, é como um surfista que se move "livremente" no mar: utilizando margens de liberdade para lidar com energias muito mais fortes do que ele pode controlar, mas cuja potência ele pode direcionar. Este potência não vem de propriedades pessoais do agente: ela não tem dono, vêm da relação com o ambiente e não ficam apriosinadas em um único movimento estético. O mesmo vale para a atividade historiográfica: ao dialogar com uma tradição passada (como afirmou Gadamer) ou ao romper os sistemas representativos presentes e abrir espaço para o novo (Runia), não se sabe previamente tudo que se irá encontrar. E como este contato modifica aquele que promove o contato, não se controla inteiramente o próprio processo de vir-a-ser um outro.

Os próximos capítulos tratam desta dimensão incontrolável da relação com o passado. 


\section{Parte II - Os momentos disruptivos: "experiência histórica" e "presença"}

\section{Introdução}

No capítulo recém-findado, apresentamos argumentos em defesa da tese de que a "realidade humana" se manifesta enquanto "representação" $e$ enquanto "experiência" - pois ela não existe senão como experiência de um organismo em relação significativa (meaningful) com o mundo social e natural. Argumentamos também que, ao partir desta concepção, a compatibilidade e complementaridade das abordagens "narrativista" e "experiencialista" da "filosofia existencialista da história" fica manifesta. Ao mesmo tempo, disto não segue que representações historiográficas equivalham a meras experiências do passado, ou que as diferentes experiências não envolvam representações de maneiras muito variadas. Não significa nem mesmo, como Ankersmit desejou mostrar, que não haja casos em que os agentes experienciadores efetivamente se vejam incapazes de significar o mundo. Agora que discutiremos em mais detalhes os conceitos de "experiência" em Frank Ankersmit e de "presença" em Eelco Runia, cabe explicitar melhor como isto ocorre em cada caso, e esclarecer por que consideramos possível encontrar, por meio de uma perspectiva processual, o que há de comum entre duas dimensões da existência humana.

De acordo com o que concluímos a partir do exame das teses narrativistas e experiencialistas da "filosofia existencialista da história", a "realidade humana" surge como (a) representação, no sentido em que ela é composta por um enormidade de "perspectivas" que simultaneamente desvelam e "fazem" o mundo; e como (b) experiência, no sentido de que esta atividade tem como locus um ser vivo, uma consciência incorporada. E só se pode ser vivo no presente. Mas vimos que a experiência de mundo desta consciência presente frequentemente se manifesta, embora não sempre, pela organização de suas ações em uma totalidade temporal, não atomística e sim interpenetrante.

Como argumentei, a presença de "vida" - ou consciência - é anterior à produção de representações e experiências. ${ }^{157}$ Um tipo específico de ser vivo pode, por isso, fazer a "realidade humana". Este termo, portanto, descreve uma forma específica de viver: todo humano é vivo, mas nem todo ser vivo é humano; todo humano saudável

\footnotetext{
157 Neste sentido, é notável que, em Sublime Historical Experience, Ankersmit - que não discute explicitamente a questão - busque apoio em De Anima, de Aristóteles, que se pergunta exatamente pela definição do que é ser vivo.
} 
participa da "realidade humana", mas nem toda experiência deste ser é do tipo descrito por Carr, menos ainda do tipo que discutiremos neste capítulo, o de "experiência estética" descrito por Dewey, que demanda o cultivo de habilidades atencionais específicas. Isto significa que, se por um lado a realidade humana se estrutura temporalmente, como afirmou Carr, por outro ela não é algo como uma única coisa contínua - vista "de fora", objetivamente - e sim de uma constante produção e dissolução de mundos e sujeitos - vistos "de dentro" ou experiencialmente. Seres humanos também se engajam de maneiras mais imediatas e pré- ou não-linguísticas com o mundo, ativando e desativando a todo tempo suas conexões narrativas com o passado, e ativando figuras diferentes a todo tempo.

Cabe uma especificação sobre este ponto. Não faria sentido falar em passado "vivo" ou "morto" por si mesmo, e igualmente não faria sentido falar em um presente "vivo" ou "morto" por si mesmo. Quando aplicada ao "passado", que é um conjunto de eventos e não um ser vivo, tal adjetivação faz sentido se indicar que algo daquele passado (informação, significado, emoção) move o sujeito dotado de consciência, "vivo", no presente. Este poder nunca é inteiramente do passado, nem inteiramente do sujeito: os mesmos acontecimentos do Holocausto ou da ditadura brasileira afetam de maneira muito diferente cada geração subsequente a estes eventos, dependendo de tudo que está presente no consciente e no inconsciente destes sujeitos, e do tipo de circunstâncias em que eles se encontram em um dado momento.

Estamos distinguindo "sujeito" da condição de "vivo" ou "consciente" na medida em que a consciência tem anterioridade à formação do sujeito, com seus conteúdos e formas (e conteúdos das formas, e formas dos conteúdos) históricos: este último, tal como usamos o termo aqui, diz respeito ao ser formado historicamente por meio de atos e contingências diversas, seus e dos demais membros de sua sociedade. Imagine um bebê, que é já um ser vivo e que talvez siga vivo por muito tempo: sua constituição como sujeito se dará ao longo da vida, nunca se estabilizará, e não sobreviverá à morte do corpo-mente que é condição necessária, mas não suficiente para a sua constituição. Esta distinção permite-nos diferenciar o tipo de "morte" que ocorre quando de uma experiência histórica sublime: o ser segue vivo mesmo quando perde sua identidade: isto que está vivo é o que tem a experiência; sujeito é o que se forma e se desfaz. ${ }^{158}$ Por isso Ankersmit pode dizer que o trauma 2, por envolver "a transição de

\footnotetext{
${ }^{158}$ Este argumento me parece compatível também com o que Jonardon Ganeri formulou recentemente em Attention, Not Self: “A atenção precede o self na explicação do que é ser humano, e se há algo defensável
} 
uma identidade antiga para uma nova", "verdadeiramente é a perda do self (antigo) da pessoa. E qual perda poderia possivelmente ser maior - pois isto não é o mais perto da morte que alguém pode chegar?" $(2005,325)^{159}$

Da mesma forma que o sujeito é algo sempre em construção, e nunca estabilizável, também o "mundo" deve ser entendido assim. Ele não é uma realidade pronta "lá fora" a ser meramente captada pelo Espelho da Mente transcendental, mas sim a apresentação à mente - e produzida pela mente, naquela dinâmica entre atividade e passividade descrita por Dewey, com apoio dos "fatores de prefiguração" como habitus, emoções e pressupostos diversos - dos ambientes natural e social em que o sujeito se encontra e em relação com os quais se constitui. A materialidade do corpo e do ambiente ocupam como que uma condição infraestrutural com base na qual a consciência articula significados, com os quais, por sua vez, modifica os corpos e o ambiente, verticalmente, e também a rede intersubjetiva de significados, horizontalmente. Mas também aqui não há um ponto fixo capaz de servir como fundação: há elementos mais rígidos e permanentes que participam da totalidade holística da realidade humana, na qual natureza e cultura se interpenetram, formando um "mundo" - mas a natureza desta interpenetração está sempre em aberto, sempre pode ser negociada e nunca não pode ser negociada. Pode-se apenas presumir ou pretender o contrário, mas aí temos um caso ou de ignorância ou de má-fé.

A natureza de cada representação e cada experiência não é a-histórica: as habilidades atencionais, as demandas dos ambientes social e natural, a atividade em questão, as memórias e experiências passadas do sujeito, tudo isto interfere na habilidade do ser vivo lidar com seu meio. ${ }^{160} \mathrm{O}$ tipo de representação que pode ser produzido a partir do tropo da ironia, por exemplo, só se forma em circunstâncias históricas muito específicas (ver cap. 4). O receio da perda de consciência histórica por Collingwood, bem como as sensações de tédio, inautencidade e/ou alienação que Ankersmit, Runia e Gumbrecht descreveram em diferentes (con)textos, sem mencionar a epidemia de déficit de atenção em certos países no século XXI, igualmente indicam que nos diferentes contextos históricos os seres humanos estão em condição ora

no conceito de self, por exemplo como a expressão de uma subjetividade que é a uma só vez experiencial e normativa, então ele mesmo deve ser entendido em termos de seu relacionamento com a atenção. Então a atenção, não o self, é o que tem prioridade explanatória." (2018: 4).

159 Sobre a diferença da "morte" de indivíduos e de sociedades, ver WHITE, 2010 [1967]: 126-135; ANKERSMIT, 2005: 228, 343.

${ }^{160}$ Louis Mink considerava particularmente importante estimular, por meio de uma "educação liberal", a habilidade de produzir "compreensão", inclusive por meio de recursos como atividades esportivas (cf. ROTH, 2011; JAMES, 2010). 
favorável, ora desfavorável para realizações de "experiências" como as descritas por Ankersmit e para a produção de textos modernistas como os que White admirou, pois estes demandam circunstâncias muito específicas. Mas em algum grau, desde o senso prático boursieusiano, passando pela estruturação narrativa ou experiencial básica de Carr, até mais complexa "compreensão" descrita por Mink e a ainda mais complexa "experiência estética de Dewey, todos os seres humanos sempre realizam tais representações/experiências frequentemente - e, quando não estão articulando eventos temporalmente, seguem vivos, tendo experiência em um sentido mais básico do termo.

\section{Capítulo 3 - Experiência histórica subjetiva}

\subsection{Os vários tipos de experiência em Ankersmit}

\subsubsection{Para onde ir após a queda da metáfora?}

A trajetória intelectual de Ankersmit pode legitimamente ser narrativizada tanto com vistas às suas continuidades quanto às descontinuidades. Focando nas continuidades, por exemplo, Menezes reconhece nela subsequentes metamorfoseamentos de teses historicistas; já Domanska e Icke, focando nas descontinuidades - e escrevendo antes da publicação de Meaning em 2012 - viram um giro da linguagem para a experiência que, para o segundo, é também do "bom” para o "mau". O próprio Ankersmit tende a enfatizar a distância radical entre sua incursão no tópico da experiência e os textos sobre escrita histórica, afirmando veementemente que as questões do livro tratavam de "uma etapa que precede todas as questões de verdade e falsidade histórica" (2005: 15) e várias outras ligadas à escrita. ${ }^{161}$ Neste capítulo, foco em dois elementos contínuos em sua obra: o anti-transcendentalismo e, inseparável deste, o interesse por algum tipo de "relação" ou "contato" "autênticos" com o passado. Visto deste prisma, o inesperado giro rumo à experiência é uma nova tentativa de compreender de que maneira é possível se relacionar com o passado. E como teorias são feitas por pessoas, também é relevante apontar, com Icke, que "Ankersmit sempre

\footnotetext{
${ }^{161}$ Ver a seção "1.6. Directions for Use - And a Warning" (ANKERSMIT: 2005, 14-5), que encerra a introdução de Sublime, marcando essa diferença em um tom quase teatral de tão exagerado (e também ANKERSMIT, 2012: 190). Que parece ainda assim não ter sido suficiente para impedir desleituras; como ele se queixou em 2018: "Um tal de Peter Icke [a certain Peter Icke] escreveu um volume inteiro reclamando que eu não expliquei como a experiência histórica pode nos ajudar a obter conhecimento histórico. Mas o livro nunca pretendeu explicar isto." (ANKERSMIT, 2018: 191)
} 
nutriu uma necessidade profunda de recuperar o passado de alguma forma real, autêntica.” (2012: 102)

Sua primeira tentativa de desenvolver a noção de "experiência histórica" aparece já em 1994, apenas onze anos após a publicação de Narrative Logic, mas já a vinte e cinco anos de distância de 2019. ${ }^{162}$ A coletânea que ele publica naquele ano, History and Tropology, tem o curioso subtítulo de "a ascensão e queda da metáfora". Tal como ele os enxerga, dos sete capítulos do livro, os quatro primeiros operam com pressupostos kantianos ("ascensão da metáfora"), mas os outros três não ("queda"). A estratégia dos últimos três seria exatamente operar com a noção de "experiência histórica". Se este movimento de "queda da metáfora" já vinha ocorrendo na historiografia, por meio de uma atenção maior às "folhas" do que aos "troncos", na teoria e na filosofia da história ele ainda deveria ser produzido. Já se manifestavam os primeiros sinais de cansaço com as questões narrativistas e pós-modernistas, mas ainda não havia sinais claros das novas tendências. Parcialmente, então, o subtítulo emprega uma estratégia performativa: assim como ele ocasionalmente descreveu como a já existente "filosofia narrativista" o que na verdade era sua proposta para dar forma a algumas tendências já existentes, também a "ascensão e queda da metáfora" descreve sua trajetória pessoal e sua interpretação das tendências historiográficas como forma de expandi-la para um campo intelectual no qual a queda da metáfora ainda não ocorrera. $^{163}$

Na introdução de History and Tropology, Ankersmit avaliava que Hayden White e Hans Georg-Gadamer haviam chegado consideravelmente perto de uma concepção anti-transcendentalista, mas em última análise mantinham-se presos nos limites do transcendentalismo. Em Sublime Historical Experience, comentário semelhante seria feito em relação a Richard Rorty: este último, após demolir toda a possibilidade de filosofia transcendentalista, permaneceria como essencialmente um filósofo da linguagem, como "um incendiário que se tornou um bombeiro." Por isso, Ankersmit considerava necessário adicionar "um momento construtivo à destruição da epistemologia feita por Rorty em seu A Filosofia e o Espelho da Natureza, de 1979."

\footnotetext{
${ }^{162}$ E sua fascinação com a história das mentalidades, que estimulou suas reflexões iniciais sobre "experiência histórica" em contraposição ao que considerava ser essencialismo historicista, focado mais nas "árvores" do que nas "folhas" do passado, aparece (impressa) já em 1989. Faço estas observações apenas para desestimular qualquer tentação de considerar a experiência como apenas um desvio marginal em sua trajetória intelectual.

${ }^{163} \mathrm{E}$ ainda hoje não ocorreu. As tendências associativas da mente humana e a tentação de ter chãos seguros sob os pés são muito fortes (ANKERSMIT, 2005 e KLEINBERG, 2017 notam estes pontos).
} 
(2005: 12) E isto deveria ser feito levando-se adiante "as óbvias consequências revolucionárias que seguem de sua destruição pragmatista do regime do transcendentalismo e seus tertia", que são "esteticismo, experiência estética, um retorno às concepções aristotélicas de experiência e a possibilidade de um contato direto e imediato com a realidade (mais especificamente, o passado ou o texto)". ${ }^{164}$ (2005: 67)

White, Rorty e Gadamer, como se sabe, têm como ancestrais intelectuais figuras anti-cartesianas: White tem em Vico e em vários viquianos - Croce, Collingwood, Frye, Auerbach - sua maior inspiração (cap. 2), enquanto Gadamer e Rorty se filiam a autores como Aristóteles e Heidegger. Segundo as reflexões sobre experiência iniciadas em 1994 e consolidadas em 2005, é no retorno a Aristóteles que Ankersmit considera haver uma saída ao transcendentalismo cartesiano e kantiano; e é com referência à noção heideggeriana de aletheia que, escrevendo sobre experiência em 2005 e sobre representação em 2012, ele concebe a possibilidade de se relacionar de maneira "autêntica" com o passado.

Em 1994, Ankersmit reconhecia que o conceito aristotélico de phronesis, mobilizado por Gadamer, produz uma "fusão entre ser e conhecimento" que não é possível nos quadros da filosofia kantiana. ${ }^{165}$ Porém, Ankersmit ainda o considerava insuficiente para produzir uma experiência do passado dotada de "autenticidade" (24). O motivo é que, assim como ética aristotélica envolve aplicação de regras a um contexto, a experiência que temos de um texto e seu significado "não pode ser dissociada da questão de o que o texto significa para nós na nossa situação presente, isto é, de como o texto se aplica a nós e ao nosso mundo" (23). Embora seja útil, esta questão não o ajudava a produzir o tipo de teoria da experiência histórica que ele estava buscando. O motivo, podemos deduzir, é que noções como "aplicação" impediriam o passado de se manifestar independentemente de nossos interesses, esquemas e conceitos. A diferença, explicava ele, é que Gadamer estava interessado na "historicidade da experiência", e não no que Ankersmit buscava, que era a "experiência da historicidade". (1994: 23; 2005: 198-9)

Assim, ao tomar Aristóteles como guia, Ankersmit propõe que isto seja feito sem focar na sua ética (como Gadamer fizera), argumentando que toda ética é sempre,

\footnotetext{
${ }^{164}$ Confesso que, embora estas direções sejam de fato viáveis para uma filosofia não transcendentalista, não consigo vê-las como consequências tão "óbvias" assim. Havendo outros interesses filosóficos e existenciais que não os de Ankersmit, eles não apontariam para outros rumos possíveis, em relação com os quais o retorno a Aristóteles seria compatível mas não necessariamente central?

165 E como vimos no capítulo 2, já em 1965 Mink considerava a produção de compreensão configuracional um ato de phronesis (também NASCIMENTO, 2014).
} 
necessariamente, centrada no presente. (idem: 24) Em "Historism and Postmodernism" e em Sublime Historical Experience, ele prefere se apoiar na concepção de mente apresentada em De Anima. A vantagem é que, diferentemente do que aparece em Descartes e Kant, em cujas obras o sujeito assume uma posição transcendental em relação ao objeto, Aristóteles sugere "um máximo de continuidade ... entre o objeto da percepção e sensação ou o ato de percepção", não havendo qualquer necessidade da noção de "aplicação". (idem: ibidem) De acordo com a leitura que ele oferece de De Anima, ${ }^{166}$ a chave para esta continuidade é a identidade entre percepção e o que é percebido, por exemplo, entre o som no mundo e a audição. Em relação às atividades mentais, ele especifica: "Como Aristóteles acreditava que a mente funcionava basicamente da mesma maneira que as faculdades sensoriais, uma história grosso modo similar pode ser contada para o conhecimento. A mente é uma faculdade que tem a potencialidade ... de assumir as formas do que é conhecido e do que a mente entende." (idem: 25)

A analogia que aparece em Aristóteles para esta capacidade da mente - e antes dele em Platão - é com a cera. Para explicar como ela se aplica ao caso da experiência do passado, Ankersmit recorre a Freud, que também a aplicou. Um dos paralelos mobilizados por Ankersmit é o da semelhança entre o comportamento de um neurótico e a experiência traumática que gerou o comportamento: também aí haveria a "identidade de forma" que, no caso de Aristóteles, se manifesta na relação entre a percepção e o que é percebido. Outro (e melhor) exemplo é o do "bloco mágico" descrito por Freud em breve texto de 1925: um "pequeno dispositivo" cuja construção, para Freud, "coincide de maneira notável com essa minha hipotética estrutura de nosso aparelho perceptivo" (FREUD, 2011: 244). O bloco, como resume Ankersmit, tem três camadas: a cera, uma fina camada de plástico, e outra camada mais grossa, onde se escreve. Quando as duas camadas de plástico são removidas, tudo que foi escrito desaparece, mas a marca segue registrada na cera e, assim, pode ser lida com a luz adequada. Assim, a cera seria análoga ao inconsciente e as camadas de plástico análogas ao consciente. (ANKERSMIT, 1994: 27)

Com base nisto, ele propõe:

\footnotetext{
${ }^{166}$ Em History and Tropology, ele se refere sobretudo à interpretação de Jonathan Lear apresentada em Aristotle: The Desire to Understand (LEAR, 1988). Uma ampla variedade de interpretações de De Anima, e em particular da afirmação de que "o sentido é o receptivo das formas sensíveis sem a matéria" (trad. Maria Cecília Gomes dos Reis, ARISTÓTELES, 2006: 101), está compilada em RORTY \& NUSSBAUM, 1995.
} 
De maneira similar, deve haver uma experiência do nosso passado psicológico que tem as características de uma descoberta, sem que estejamos conscientes dela, do que sempre foi uma parte verdadeira da nossa constituição psicológica. E de tal descoberta nós podemos dizer que não é uma questão de apropriação ou domesticação de uma realidade intrinsecamente alheia [alien]. Pois o movimento é um tanto o oposto: nós somos confrontados aqui com uma parte de nós mesmos que parece ter adquirido uma independência infamiliar [inquietante, esttranha: uncanny] de nós ao longo do tempo. Isto não é uma familiarização do infamiliar, mas uma des-familiarização do familiar: bem no nosso coração, nós nos tornamos estranhos a nós mesmos. Aqui, então, nós podemos descobrir a diferença formal de um passado nas linhas aristotélico-freudianas e da concepção transcendentalista, metafórica da experiência. (idem, ibidem)

Aqui parece estar a semente da noção de "experiência histórica sublime" que ele explorará no livro homônimo de 2005: a de que há casos em que "a pessoa se torn[a] o que ela não mais é - com toda a ênfase no "não mais"”. A chave aqui parece estar em um aspecto que Runia enfatiza mais abertamente que Ankersmit: o de que tanto as pessoas quanto os processos históricos têm múltiplos níveis ou camadas, e que há sempre mais do que se manifesta nos sistemas representativos por meio dos quais buscamos dizer quem "somos".

Para Ankersmit, isto significaria que, "[c]ontrariamente às intuições de Vico, nós podemos portanto escrever 'Verum et factum non convertuntur': o mundo histórico é um Outro precisamente porque ele é um artefato humano." ${ }^{\prime 67}$ Este "Outro" diz respeito a uma identidade específica que adoto, e que não reconhece muito do que está em mim, que potencialmente pode ser conhecido mas não está ainda de fato atualizado. $\mathrm{O}$ "Mesmo" que produz este outro é uma construção, e a prática historiográfica é um dos recursos que a humanidade dispõe para produzi-lo. É possível que o contato com o outro vise reduzi-lo ao mesmo, mas é igualmente concebível que tal contato amplie o mesmo para torná-lo capaz de incluir o outro. Quem fez este outro é a humanidade inteira, não apenas a pequena parcela de seus processos que tomo retroativamente como componentes do "eu". A capacidade de invenção, em certo sentido, depende precisamente da capacidade de refazer - não imitar, mas reinventar - o que outros

\footnotetext{
${ }^{167}$ Vimos no capítulo 2 que o nível significativo da "realidade humana" é feito com base em suportes materiais físicos e biológicos, que estão em constante modificação e que nunca são esgotados pelos sistemas representativos. O nível dos significados nunca poderá esgotar aquilo que ela toma como "substância" para a produção da representação ou substância narrativa, seja um sujeito, um local ou uma nação. A leitura que Runia oferece da noção de "tópica" em Vico parece mostrar que a filosofia deste último é inteiramente capaz de alimentar reflexões acerca do momento destrutivo da dinâmica entre construção (ativa e passiva) e destruição (ativa e passiva) que se estabelece na relação processual de seres humanos com o mundo. Ela é capaz de indicar a presença daquilo que está mesmo quando não está representado (RUNIA, 2014: 63-5, 144-157).
} 
humanos fizeram. A solução de Runia, citada acima, recorre precisamente a Vico: há sempre mais "aí" do que aquilo que podemos representar, e encontrar "tudo que está aí", nos "lugares de tempo", tanto é o que nos permite criar o novo quanto é o que explica que o novo possa surgir à revelia de nossas tentativas de manter o mundo sempre familiar. Runia explica o processo em termos que, como veremos, são muito próximos da filosofia da experiência de Ankersmit:

\begin{abstract}
Inventio, por outro lado [em contraponto com imaginatio], é uma transcendência do nosso quadro de referência. É um processo estranho, um processo que sempre envolve um grau de dissociação. Quando nós somos realmente inventivos, nós nos transformamos em espectadores que estão olhando, empolgados mas também um pouco apreensivos, o que nós mesmos acabamos por estar fazendo. $\mathrm{Na}$ inventio, nós transgredimos as fronteitas do que nós viemos a considerar como a nossa identidade de uma maneira tal que nós invalidamos aquela identidade e acabamos em algo que nós não prevemos de antemão. A invenção verdadeira portanto produz o que os alemães chamam de Selbsthervorbringung e o que na biologia é chamado de autopoiesis (RUNIA, 2019: 19).
\end{abstract}

Em segundo lugar, esta perspectiva processual implica que o mundo histórico não é nem "mesmo" nem "outro" em si, mas sim em relação com a identidade do sujeito e tudo que ela "organiza" (seus elementos de consciência e inconsciência), que não é um fator fixo - o sujeito é feito pelo passado e pela sua sociedade, mas também faz a si mesmo. Chamá-lo de "mesmo" é produzir uma "substância narrativa", que produz homonegeidade (potencialmente enganadora) para as várias diferenças entre passado e presente; chamá-lo de "outro" é produzir duas substâncias e ignorar precisamente a interpenetração entre presente e passado, o que tornaria impossível a própria noção de experiência histórica. Isto nos colocaria de volta na separação insuperável entre o sujeito (o historiador no presente) e o objeto (o passado, inteiramente Outro) que Ankersmit tanto quer superar. Nesse sentido, ainda que em breve venhamos a apontar algumas restrições ao modelo da "nostalgia" proposto por Ankersmit em 1994 como "matriz" da experiência histórica, ele tem um mérito: por operar pelo princípio da diferença, ele não é compatível nem com o pressuposto de uma ipseidade nem de uma alteridade absolutas. Não estamos inteiramente alienados daquele passado, mas não podemos simplesmente nos fundir a ele. Na medida em que ele remete à dimensão Unheimlich, familiaridade e estranheza só podem conviver em tensão: aquilo que fizemos, mas não lembrávamos ter feito, é infamiliar por ter sido familiar. 
Acrescentemos ainda, seguindo Runia e a "escala de formas" de Collingwood, que estes elementos do "presente" e do "passado" operam em diferentes níveis na mente incorporada do sujeito, que é o locus onde diferentes processos e causalidades se encontram e interagem. Como o sujeito não meramente reproduz behavioristicamente todos processos históricos, mas lida reflexivamente com eles e toma-os retroativamente como seus ao fazer a si mesmo, os sujeitos e o processo histórico feito por eles possuem mais de uma camada. Veremos adiante que o tópico da reflexividade não está ausente da noção de "experiência histórica sublime", embora Ankersmit não o enfatize. Por hora, observemos que isto nos obriga a levar em conta a temporalidade envolvida na relação entre os níveis. Quando representam a si mesmos, os sujeitos sempre (a) "correm atrás" das experiências não-representadas, e (b) nunca esgotam todas as possibilidades daquilo que pode ser englobado nas metáforas. Mais adiante, argumentarei portanto que o "é" da ideia de que o sujeito "é" o que ele representa nunca esgota tudo que está nele, em suas memórias e em seu corpo, de modo que ele sempre pode se fazer de outras formas. Representar o mundo, como também no caso das representações históricas, é sempre produzir um novo nível reflexivo que, porém, não poderia jamais assumir uma relação de identidade com "tudo que está aí", na parte do mundo ou no sujeito sobre o que (about whom) esta representação é. A distância entre a representação e o representado, tão enfatizada por Ankersmit no caso da história, se manifesta também na relação do sujeito ao trazer alguns aspectos de si mesmo à consciência - também o sujeito se faz, e também neste caso isto se dá com a presença de um "espaço estético", da mesma maneira que significar o passado não é meramente imitá-lo, mas fazê-lo história. A possibilidade do "fazer" não existiria se o mundo já se esgotasse na linguagem: tratar-se-ia apenas da produção de uma duplicação; assim sendo, a possibilidade do fazer é inseparável da inevitabilidade do desfazer; ambos só podem existir em uma relação dinâmica. Parece mais proveitoso adotar uma concepção dialética da relação entre passado e presente, e isto está presente não apenas na tropologia que White criou com apoio em Vico, mas também no apoio filosófico relativamente surpreende que, como veremos, Ankersmit buscou para teorizar sobre a "experiência histórica sublime": Hegel.

Porém, como pretendemos discutir vários dos modelos de experiência que Ankersmit formulou a partir de 1994, retendo o que for proveitoso de cada caso, o caminho é longo. Comecemos examinando o modelo da "nostalgia" que Ankersmit 
propôs em 1994 como forma de explicar a possibilidade de experienciar a "distância" ou "diferença" entre passado e presente.

\subsection{Nostalgia e experiência histórica}

\subsubsection{A questão impertinente: há um passado independente da escrita histórica?}

Ankersmit primeiramente introduziu a noção de "experiência histórica" em um ensaio no qual discutia as afinidades os movimentos referidos pelo título: "Historism and Postmodernism: A Phenomenology of Historical Experience”. Àquela altura, 1994, ele se via como membro do pós-modernismo - o que, como Menezes mostra, foi sobretudo uma "estratégica mudança de tom" na busca por ser ouvido. ${ }^{168}$ Seu pósmodernismo se manifestava sobretudo no interesse pela totalidade dos textos, em contraposição à ênfase na epistemologia das frases que dominava o debate modernista (1994: passim). Mas aqui ele ousaria um tanto mais.

$\mathrm{O}$ argumento central de "Historism and Postmodernism" parte de um topos recorrente em seus textos: ao comparar os movimentos, ele propõe que tanto o historicismo quanto o pós-modernismo reconhecem que "formas históricas só podem ser conhecidas em termos de suas diferenças." Como o leitor pode notar, é assim também que o próprio Ankersmit teoriza as representações históricas: só sabemos seu significado à luz da totalidade das outras representações. ${ }^{169}$ Havendo uma só representação, ou poucas, como no século XIX, é fácil parecer que as "ideias históricas" estão no passado; assim, um período se revelaria em sua unidade à luz do contraste com os demais. Porém, em tempos de superprodução historiográfica e proliferação de interpretações como os fins do século XX, é mais fácil ver que a "ideia histórica" está na linguagem (2001: 123-148). Assim, o pós-modernismo - como também o próprio Ankersmit, mesmo depois que abandonou sua conexão com o movimento problematiza com maior facilidade a noção de realidade histórica do que o historicismo. (1994: 188). Mas o pós-modernismo não tinha nenhum conceito de "experiência histórica" (idem: 196). Ankersmit, insatisfeito a este respeito, se perguntava:

${ }^{168}$ Ver o cap. 2 de Frank Ankersmit: As Metamorfoses do Historicismo (MENEZES, 2018: 86-145).

169 A formulação mais bem acabada deste argumento aparece em ANKERSMIT, 2012: 138-152, formulado com apoio em Saussure. 
passado autêntica em que o passado ainda pode afirmar sua independência da escrita histórica. (idem: 194)

A noção de passado independente da escrita histórica pode ser lida de duas maneiras. Uma aparece nas objeções pós-modernistas feitas a Ankersmit por autores como Munslow, Jenkins, Pihlainen e Icke: o passado é o produto da escrita histórica; portanto, não há passado independente de alguma escrita histórica. Coisas aconteceram, claro, e é justo chamá-las de passado. Mas elas não podem ser conhecidas separadamente da forma textual em que são apresentadas, como se existissem em si. E se a pergunta é pela experiência desse passado, ela só pode ser sem sentido: ele já passou e portanto não pode mais ser experienciado (MUNSLOW, 2014; ICKE, 2011); “simplesmente não há conversa com o passado" (PIHLAINEN, 2014) o passado, não há presença do passado, não há experiência do passado. Porém, há uma segunda forma de ler esta frase, parecida mas não idêntica, próxima da que Pihlainen (idem, 580) reconhece em relação ao tópico da compreensão (e não da experiência): “A questão crucial: o passado pode interferir nas nossas compreensões de alguma maneira (disruptiva)?" Isto é, no caso de Ankersmit: o passado pode surgir na experiência sem ser previamente reduzido ao que é familiar, sem a aplicação de um esquema transcendental? Tendo em mente que os pós-modernistas colocavam, e seguem colocando, a questão em termos textuais, notemos que em suas formulações surge uma falsa dicotomia: a única alternativa, podemos nos questionar, é aquela entre o passado que já passou e o passado-como-história, textualizado? Ao longo do capítulo, veremos que os vários tipos de experiência do passado não se acomodam bem nos termos destas alternativas, pois envolvem artefatos, ruínas, fotografias, obras de arte e elementos afins.

Há de se apreciar as virtudes intelectuais de quem coloca a questão da experiência do passado em pleno auge do pós-modernismo: não se trata de alguém com receio de desafiar tabus ou conformado com as conclusões já obtidas, inclusive por suas próprias reflexões. ${ }^{170}$ Além disso, Ankersmit manifestava uma sensibilidade aguda às

\footnotetext{
${ }^{170}$ Ankersmit comentou em 2017 sobre a recepção de sua obra: "Eu mesmo frequentemente ponderei a questão de por que as coisas que eu escrevo frequentemente são recebidas com tanta agressão e hostilidade." (ANKERSMIT \& MENEZES, 2017: 252) Sem querer ser hostil a este diagnóstico, talvez ele foque excessivamente a metade vazia do copo. Mas na medida em que ele estiver correto, creio que parte considerável se deve à pouca tolerância da maioria dos intelectuais em aceitar o questionamento de tabus. Como Menezes nota (idem, 251), estas hostilidades vieram até mesmo de campos diferentes: o Ankersmit narrativista, como White, foi criticado - e, sim, hostilizado - por historiadores, positivistas, teóricos que vêem a história como ciência social; mas seus textos sobre experiência atraíram crítica e hostilidade do campo pós-modernista, o mesmo do qual inicialmente Ankersmit julgara estar partindo.
} 
mudanças históricas do período, e não apenas às da historiografia ou da filosofia: a defesa da autonomia do passado diante do presente não é apenas a rejeição a um certo postulado teórico frequentemente adotado por autores narrativistas e pós-modernistas, mas também a rejeição, já em 1994, ao estabelecimento de uma forma de experiencial temporal na qual (cf. FELIPPE, 2017: 129) o presente como que invade os demais tempos e os homogeniza.

E afinal, tal possibilidade existe? Se sim, pode ser explicada filosoficamente? Sua primeira resposta - de muitas a serem formuladas nos 25 anos seguintes - é positiva, e busca realizar-se de uma maneira bastante particular, por meio da noção de nostalgia:

... se de fato nós efetivamente possuímos a capacidade de experienciar o passado no sentido mais verdadeiro da palavra, é a sensação de nostalgia que tem o sinal mais claro de tal experiência e mais provavelmente será o ponto de partida mais adequado para descobrir a natureza de tal experiência. (196)

Registremos, portanto, que a dimensão nostálgica da experiência do passado não é a conclusão, mas o ponto de partida da investigação: Ankersmit decide investigar este tipo específico de experiências. ${ }^{171}$ Não há um motivo, a princípio, para imaginarmos que outros tipos de experiências também não sejam experiências "no sentido mais verdadeiro da palavra". ${ }^{172}$ A estratégia filosófica é justa, a de partir do familiar (i.e., do familiar para Ankersmit) para o não-familiar: a experiência nostálgica é (presumivelmente) autêntica, portanto serve como parâmetro para comparar duas correntes de pensamento, uma das quais já se sabe descartar a noção de contato autêntico com o passado (historicismo), e a outra sendo precisamente o que está em questão. Se isto vier a ser compreendido como significando algo mais - que a experiência histórica deve ser teorizada a partir da matriz da nostalgia, não vejo como o raciocínio poderia se sustentar. Basta nos perguntarmos: como se justificaria tomar a nostalgia como matriz da experiência histórica, sabidamente havendo experiências

\footnotetext{
${ }^{171}$ Embora eu considere se tratar de uma escolha bastante justificável em bases pragmáticas - como estratégia filosófica, afinidade pessoal, ou com um dado movimento intelectual, ou ainda com um período histórico -, não creio que nem o "então" nem o "consequentemente" da afirmação que segue sejam a decorrência natural de alguma argumentação demonstrada previamente: "Será a minha tese, então [ver o contexto nas pp. 196-7], que nostalgia e a lembrança nostálgica do passado nos dão a experiência mais intensa e mais autêntica do passado, e que, consequentemente, a nostalgia é a nossa matriz mais adequada se nós quisermos mapear as similaridades e dissimilaridades da experiência historicista e pós-modernista do passado." (1994: 197)

${ }^{172}$ Este recurso retórico de se referir a "X no sentido mais verdadeiro do termo" aparece frequentemente nos textos de Ankersmit, e para mim nem sempre é óbvio quais são os tais "sentidos mais verdadeiros".
} 
motivadas por outros afetos, humores e/ou sentimentos? Creio ser mais sustentável a hipótese de que a experiência nostálgica é um subtipo de um modelo mais amplo, que o próprio Ankersmit explica satisfatoriamente em termos de aletheia, e que vale tanto para "representações" (históricas) quanto para "experiências", i.e., tanto para um desvelamento mediado por textos quanto para um não mediado por eles (embora dependente deles). A aletheia seria perpassada de "autenticidade" mesmo em outros tipos de experiência. ${ }^{173}$ Mas, de qualquer forma, mesmo que investiguemos unicamente a nostalgia, que critérios de "autenticidade" valeriam unicamente para ela?

São questões que, de acordo com a minha leitura, ficam em aberto. Fora isso, levanto uma hipótese, que não chegarei a explorar, mas a qual é proveitoso citar. Pode haver algo como uma circularidade histórica no procedimento de Ankersmit: vivendo em um período que começa a engolir os demais, deixando de confiar em utopias e não mais tomando o passado como "espaço de experiência" (BOYM, 2017; FELIPPE, 2017; BECKER, 2018), alguém como Ankersmit poderia se sentir compelido a investigar a possibilidade de experienciar o passado autenticamente. Em seguida, ao partir dos pressupostos de sua própria época, ele poderia considerar como óbvia a escolha pela nostalgia, conectando-a à possibilidade de autenticidade, mas apenas porque outras formas de experiência não pareceriam autênticas da perspectiva de um europeu - um do tipo exemplificado por Frank Ankersmit - do imediato pós-Guerra Fria. Por exemplo, nos vários relatos de Ankersmit, a experiência da autenticidade pode ser associada à quebra da inautenticidade (para aqueles que experienciam sua identidade presente como inautêntica), ao evento no qual o infamiliar se mostra diante do narcisista. Assim, esta forma de conceitualizar já não se aplica a grupos menos arrefecidos a configurações específicas de suas identidades. Um segundo exemplo: em um momento de descrédito das utopias, as experiências de grupos minoritários - e especialmente as experiências capazes de mobilizar expectativas de emancipação - podem não qualificar como autênticas, mas apenas porque uma conceitualização prévia já as excluiu a priori.

A segunda justificativa apresentada por Ankersmit para a investigação se conecta com o conjunto de hipóteses que acabamos de levantar: é a "afinidade eletiva" entre a nostalgia e a atitude pós-modernista em relação ao passado. (198) Uma terceira, de grande relevância para a investigação dele e para a nossa, foi apontada na introdução do livro:

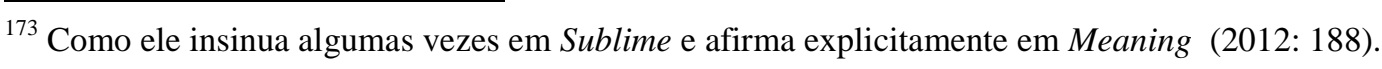


A nostalgia pode servir como uma matriz deste tipo porque ela não é a experiência de uma realidade reificada e objetiva que se encontra lá fora, mas de uma diferença (entre o presente e o passado): já que a diferença demanda a presença tanto do presente quanto do passado, ela permite algo que é tão essencial para a teoria da percepção de Aristóteles, este fluir junto de sujeito e objeto. (31)

Como dissemos e diremos, a nosso ver - e Ankersmit talvez não discordaria - há outros casos para além da experiência nostálgica em que esta fluência entre sujeito e objeto também se manifesta. Mas comecemos com a investigação do caso particular da nostalgia, tal como Ankersmit o descreve.

\subsubsection{Fixidez, deslocamento, distância}

Ankersmit toma como ponto de partida uma stanza do poema "Einst und Jetzt", de Nikolaus Lenau (1802-1850). Ankersmit avalia que "o poema de Lenau nos apresenta com o que é indubitavelmente a forma prototípica de nostalgia: o anseio nostálgico pelos dias perdidos da infância.” Ele especifica:

Provavelmente porque a infância é, ao mesmo tempo, tão claramente distinta da vida adulta e frequentemente dotada das caracerísticas de estabilidade e fixidez ..., ela funciona como o objeto favorito da experiência nostálgica. Quando consideramos as características da nostalgia tal como expressadas pelo poema de Lenau, nós iremos primeiro observar que a nostalgia é intimamente relacionada a uma consciência do deslocamento, ou de estar deslocado [displacement or of being displaced]. O sujeito da experiência nostálgica está dolorosamente consciente de estar onde e quando ela não quer estar. (1994: 198-9)

Além da pressuposta estabilidade do passado (exemplificado pela infância) e da sensação de estar onde não se quer estar, outro fator caracteriza a experiência nostálgica: seu objeto

... não é "o passado mesmo" (tal como concebido pelo historicista), mas a diferença ou a distância entre o presente e o passado. $\mathrm{O}$ assunto do poema de Lenau não é a infância do poema (como o historicista leria o poema) mas a diferença entre "Einst und Jetzt", entre a infância e o presente do poeta. ... a nostalgia nos dá a unidade do passado e do presente: pois a experiência da diferença requer a presença simultânea do que está nos dois extremos da diferença, isto é, tanto do passado quanto do presente. ... [O presente e passado] estão unidos [mas] estão ambos presentes apenas na sua diferença. (201)

Com estes três elementos em mente, façamos algumas observações.

Primeiro, a infância de indivíduos aparece aqui como uma analogia ou metáfora com a experiência de sociedades, que também experienciariam um tipo de unidade anterior à "queda" no mundo histórico. Vários outros exemplos desta unidade serão 
dados por Ankersmit ao longo dos anos: o rebanho que pasta sem se preocupar com questões de história (Nietzsche), a França pré-Revolucionária da perspectiva de conservadores e reacionários da pós-Revolução, o estado natural (Rousseau), a expulsão de Adão e Eva do Paraíso, a Vontade noumenal (Schopenhauer), o assassinato do pai da horda em Totem e Tabu (Freud), a experiência da sintestesia em Huizinga. ${ }^{174}$ Neste artigo e em outros lugares, Ankersmit insiste que esta transposição do individual para o coletivo é possível, mas não creio que chegue a dar uma argumentação para tal - e como exatamente ela pode ser feita esta longe de ser óbvio. ${ }^{175}$ São duas discussões com sobreposições, mas não idênticas: uma, há algo na processualidade de longa duração das sociedades que estrutura de maneira semelhante a vida dos indivíduos, ou vice-versa? A outra, a memória coletiva pode ser explicada de maneira análoga à memória individual ${ }^{176}$

Como Ankersmit viria a argumentar em Sublime, o que está em jogo nestas transições é a produção de um mito, que cuja suposta imutabilidade se contrapõe à história e seuas mudanças. Cabe então perguntar: é relevante afirmar, neste contexto, o fato verdadeiro de que o passado não é fixo? Ou insistir nisto é ignorar a condição mítica deste passado? Mas o que seria uma experiência "do passado", ainda por cima autêntica, se a verdade do passado não vem ao caso? O argumento recém descrito é de que a experiência não é do passado e sim da distância, mas que distância pode haver entre um ponto existente e um não-existente (digo não-existente, e não inexistente, porque o estatuto do evento mítico sequer envolve noções como existência ou realidade, entre um presente real e um passado mítico)?

Se o equivalente da "infância" no passado coletivo seria a condição animal dos seres humanos antecedentes à linguagem, é possível argumentar que, a partir deste

\footnotetext{
${ }^{174}$ ANKERSMIT, 2005, 2006, 2012: passim. Lytje (2019) cita ainda a instituição do arquivo em Derrida. 175 Aqui, ele observa, ao início da discussão, que sentimos uma "resistência imediata", mas não justificada, por presumir que passado coletivo (o "objeto óbvio da experiência histórica") é genericamente diferente do nosso passado pessoal, como se a história fosse o tipo de objeto "que só pode ser experienciado por um sujeito transindividual quase-hegeliano." A pergunta é provocativa e a meu ver bastante convincente: se ciência pode recorrer à experiência empírica individual dos cientistas, por que a história não? (1994: 196) De fato, pode. Mas uma explicação da possibilidade de transição não me parece ter sido dada, e que terá que ser tomada como satisfatória se o conjunto da explicação sobre a viabilidade da experiência nostálgica do passado for convincente. Em Historical Representation (2001: 149-75), a possibilidade é defendida com referência a Halbwachs, mas sem maiores detalhamentos. Em Sublime Historical Experience (2005), várias categorias psicanalíticas referentes a experiências individuais também são tomadas como analogias ou metáforas ou talvez mesmo diretamente aplicadas - também isto não é devidamente esclarecido - sem maiores explicações ao caso coletivo das experiências históricas sublimes: desrealização, despersonalização, e também o caso mais usual da categoria da trauma.

${ }^{176}$ Não entraremos nesta discussão: sobre este ponto, estamos apenas registrando as diferentes questões envolvidas.
} 
momento, sempre que houve "realidade humana" não houve este passado "estável" e "fixo". Pois se a biologia muda lentamente o suficiente para poder ser descrita nestes termos, todo o passado humano, vivido por seres que lidavam com o mundo natural e social por meio de mediação linguística, é sobretudo instável e caótico.

A meu ver, é necessário distinguir exemplos em que a unidade efetivamente existia daqueles em que ela é apenas imaginada. As pessoas adultas realmente tiveram infâncias e o que viria a se tornar a humanidade realmente existiu em uma condição que, grosso modo e talvez com algum desleixo terminológico, poderíamos chamar de pré-cultural $^{177}$ - embora isto não legitime quaisquer relatos particulares sobre o que foram a infância e este equivalente de um "estado da natureza". Nos demais exemplos desta unidade original, porém, a ruptura indica a passagem rumo a um estado de maior reflexividade ou consciência histórica, com a qual, no contraste, o passado possuía maior sensação de "naturalidade" em relação a uma configuração social que na verdade era apenas convencional. Nenhuma destas condições menos reflexivas, porém, chega a estar fora da história tanto quanto o mito presume posteriormente. Embora mitos não se submetam ao estatuto de verdades ou mentiras, a desejabilidade deste suposto "passado idílico" pode ser mais ou menos justificada, não sendo dada a princípio. Da mesma forma, não há normas éticas transcendentais ou algoritmos de sucesso capazes de determinar o que fazer com este desejo.

Ainda assim, Ankersmit trouxe à discussão a noção de autenticidade. Esta demanda parece expressar um desejo ligado a dois elementos contextuais que mencionamos no início da seção: por um passado que seja experienciado sem ser engolido pelos referenciais transcendentalistas presentes, e por um grau de concretude em contraste com a abstração linguística (RUNIA, 2014; GUMBRECHT 2010). Este último elemento, principal marca da variante gumbrechtiana de "presença", é também de grande importância para aquele que Ankersmit tomará como principal referência da experiência histórica, inicialmente afirmando a afinidade de sua visão com a experiência pós-modernista: Huizinga. ${ }^{178} \mathrm{O}$ uso do termo "autenticidade" para o primeiro destes pontos não é problemática de modo algum (mesmo para quem discorda que tal experiência seja possível), e, sobre o segundo, mais adiante argumentaremos que a abstração pode se articular com a concretude em um caso de experiência autêntica

\footnotetext{
${ }^{177} \mathrm{E}$ isto se ignorarmos que é certamente possível afirmar que animais têm cultura. Para o argumento, de qualquer forma, eles certamente não têm consciência histórica.

${ }^{178}$ Ver a próxima seção.
} 
(embora frequentemente não o faça). Quando não o faz, de fato, temos os casos de inautenticidade que Collingwood e Sartre teorizaram sob os termos "corrupção de consciência" e "má fé". Mas, em nossa visão, autenticidade precisa de ao menos um terceiro elemento, já que estamos falando de experiência histórica e queremos preservar a autonomia do passado citada no primeiro dos tópicos: precisa que a experiência seja de um passado verdadeiro.

A insistência do atual trabalho na importância da participação da verdade na experiência nostálgica que se pretende autêntica e do passado - participação, e não esgotamento, porque a experiência não se resume a mimetizar o passado como ele realmente foi - não entende a noção de verdade, porém, nos moldes do realismo historicista do século XIX, que na bibliografia sobre nostalgia é frequentemente justaposto a esta em um contraste no qual à historiografia caberia o "princípio da realidade" e à nostalgia a fantasia (cf. FELIPPE, 2017). Como o próprio Ankersmit argumentou, em artigo de 1998, ao comentar as críticas de Arthur Marwick a Hayden White, é a abordagem whiteana e não o realismo de Marwick que efetivamente nos põe em acordo com a realidade (ANKERSMIT, 2001: 249-61); o que ela impediria é exatamente o uso transcendentalista da linguagem que reduziria a estranheza do passado à familiaridade presente. Mas vimos também que o Ankersmit de 1994 (como em muitos momentos depois) via em White um transcendentalismo a ser evitado. A preocupação é justa: um passado experienciado autenticamente precisa conceber algum tipo de relação entre sujeito e objeto. À questão sobre White fornecer ou não esta relação, Ankersmit respondeu de muitas maneiras diferentes. Mas o que temos nós a dizer sobre a questão, buscando apoio em elementos mais dispersos na tradição narrativista - no que quer que possa ser útil -, de como se pode estabelecê-la?

\subsubsection{O objeto da experiência nostálgica: simultaneamente feito e encontrado, mesmo e outro, porque sua simultaneidade é retrospectiva}

Uma primeira pergunta sobre o que é experienciado na experiência nostálgica pode assumir a seguinte forma: A experiência autêntica é de uma substância criada no passado pelos agentes históricos ou de uma substância criada por historiadores (e afins) no presente? Sobre a noção de substância, trata-se de uma "substância narrativa" ou, como Ankersmit parece presumir, do "passado mesmo" (the past itself)? E agora, para denunciar pressupostos implícitos nestas duas perguntas: são de fato sustentáveis as dicotomias entre uma experiência de algo situado ou no passado ou no presente, entre o 
mundo passado e os mundos co-criados por agentes históricos em relação com o ambiente? Como o leitor sabe, nossa resposta passar por questionar estas dicotomias.

Uma das dificuldades da transição de indivíduos para sociedades é que, no primeiro caso, há uma fonte de continuidade dada entre passado e o presente: a infância e condição de adulto pertencem ao mesmo indivíduo, com um corpo contínuo e memórias individuais, e muito frequentemente uma ordenação narrativa que, ainda que seja a mais recente na sequência de várias outras que passaram por disrupções, tende a unificar estes fatores em uma totalidade mais ou menos coerente. Este elemento comum, óbvio no caso de indivíduos, não existe previamente nos textos historiográficos, que produzem as substâncias (ou essências) cujas mudanças (não-essenciais) serão explicadas $^{179}$ - às vezes repetindo o substrato do recorte espaço-temporal das substâncias já criadas pelos agentes do passado (“Império Romano"), mas modificando seu significado (o Império Romano de Gibbon não é o de um romano no século III, mesmo quando ele trata do "mesmo" período e portanto do mesmo espaço): nestes casos, a "substância narrativa" é outra, mas há um elemento de continuidade-namudança concebido como "mesmo".

Assim, nossa resposta à questão "feita ou encontrada?" é que a experiência especificamente histórica do "infamiliar" é de um caso em que o objeto foi simultaneamente encontrado (e encontrar já é recriar, como afirma Collingwood) e criado (no sentido de que ele é experienciado por um sujeito, que existe enquanto membro de outra rede intersubjetiva). O que permite explicar esta possibilidade é um avanço na filosofia de Ankersmit entre 1994 e 2012: gradualmente, ele parece ter parado de conceber as metáforas como necessariamente transcendentalistas. E portanto a própria dicotomia entre encontrar e criar se rompe, ${ }^{180}$ culminando na noção de “desvelamento". Assim, sua visão mais recente é - ou ao menos pode ser lida assim de que a produção de uma substância narrativa não é o que nos afasta do passado, como se fosse a lajota que tiramos para ver o passado atrás. ${ }^{181}$ Assim como as representações dos agentes faziam surgir um mundo histórico passado, as representações historiográficas são o que permitem vê-lo ou “tocá-lo". Sendo cabidas duas observações sobre esta relação entre visão e toque: (a) tocar, aqui, é uma analogia para a atividade

\footnotetext{
${ }^{179}$ Conforme a brilhante análise do próprio Ankersmit em 2001: 29-74.

${ }^{180} \mathrm{Ou}$ deveria se romper: às vezes seus textos seguem apresentando a ideia de que experiências e representações ocorrem em um dos "lados" - do que é efetivamente uma relação. Discutiremos este ponto mais adiante.

${ }^{181}$ Conforme a metáfora empregada em "Historiography and Postmodernism." (1994).
} 
mental: como a cera e a mão na epistemologia de Aristóteles ou de Freud, a representação é o que permite que o historiador seja influenciado pelo passado e influencie o seu significado na memória coletiva; (b) o Ankersmit mais recente, acertadamente, permite (às vezes apenas implicitamente) uma maior proximidade entre visão e toque. ${ }^{182}$ Esta aproximação deve efetivamente ser uma decorrência da observação de que a epistemologia não é fundamento da prática científica, mas sua “psicanálise". (1994: 187) Assim, se por um lado é compreensível que as perspectivas transcendentalistas tenham gosto por metáforas oculares, por outro isto não significa que nem a estética e nem mesmo a epistemologia não-transcendentalista devam abrir mão delas: basta que não confundam (para falarmos como no capítulo anterior) a visão de cima da montanha, que continua sendo uma perspectiva, com o "ponto de vista de Deus".

Uma das implicações desta discussão para a ontologia do objeto da experiência nostálgica é a seguinte. Não se trata de um objeto nem meramente feito, nem meramente encontrado. Vimos como Ankersmit deseja evitar estes dois extremos, o positivista, historicista ou hermenêutico, agrupados por ele todos em um lado, e o (que hoje chamaríamos de) pós-modernista, que presume uma onipotência criativa do historiador e a ineficácia do passado, no outro. O historiador encontra substâncias narrativas feitas no passado, mas para compreendê-la precisa fazê-las novamente, e este fazer não é uma reprodução de todos os seus aspectos, mas um desvelamento de um aspecto particular, a partir de uma perspectiva específica. Ele desvela aspectos de como os seres do passado desvelavam aspectos. Isto põe a historiografia em uma posição peculiar para experienciar o passado, e mais especificamente para experienciá-lo nostalgicamente. Uma discussão de Freud sobre o Unheimlich, no seu ensaio de 1919 sobre o tema, é útil para elucidarmos esta questão. A certa altura, ele distingue as manifestações do "infamiliar" da vivência com aquelas da literatura. O caso do infamiliar da vivência é subdividido em um antagonismo entre os retornos do recalcado e de crenças primitivas: estas crenças, que pareciam superadas mas não estão inteiramente, se mostram como "uma oportunidade para a prova de realidade"; já no caso dos acontecimentos recaldados isto não está em jogo. Freud prossegue afirmando que tal distinção (entre um tipo de fenômenos passível do confronto com a realidade e outro não) é insustentável na

${ }^{182}$ Ver, na seção seguinte, como os sentidos se misturam em Huizinga; mais adiante, como a representação histórica não é apenas o "rio visto de cima" para Mink e White, mas também a forma audível da música; e, ainda mais adiante, como Kellner (em leitura elogiada por Ankersmit) identifica a tentativa de traduzir entre múltiplos sentidos já em Narrative Logic. 
outra forma de experiências do infamiliar, a literatura. Ao menos não sem uma profunda modificação, "uma vez que o reino da fantasia tem como pressuposto de sua legitimação o fato de que seu conteúdo foi dispensado da prova de realidade.” (FREUD, 2019: 1304-1131)

A historiografia ocupa uma posição que não só confunde essa classificação de Freud, mas ainda por cima se mostrando como uma fonte privilegiada de experiências do infamiliar: ela busca compreender e representar as vivências tal como aconteceram, mas, como sabemos desde White, o faz com recursos literários - que por um lado não são, eles próprios, sujeitos a classificação de verdadeiros ou falsos, mas, por outro, não autorizam o historiador a abrir mão do princípio da realidade onde quer que ele se aplique. Dentre as muitas implicações que esta posição ambígua pode ter, uma é que a operação historiográfica, em suas várias etapas, pode enriquecer a complexificar as experiências de infamiliaridade, trazendo à atenção (e portanto ao mundo) as variantes que caso contrário não surgiriam na vivência. A historiografia ocupa o espaço de intersecção entre vivência (enriquecida pelos recursos literários) e literatura (do tipo que não abre mão do princípio de realidade). Lembremos ainda que a "imagem" literária não precisa estar registrada em tintas no papel, cabendo também na mente de eruditos em processo de pesquisa ou tomados por um ávido desejo de "sair de si mesmos" e/ou de "ver" ou "tocar" o passado. Assim, nos raros casos em que tanto o objeto quanto a imagem "literária" são capazes de produzir estranhamento para um dado sujeito, é concebível que a intensidade da experiência será notável - e isto explicaria as "experiências históricas subjetivas" das quais falaremos na sequência do capítulo.

Falando do escritor que se coloca na realidade comum, respeitando o princípio da realidade, Freud afirma o seguinte: "Mas, nesse caso, o escritor pode elevar e diversificar esse infamiliar bem além daquilo que é possível nas vivências, na medida em que ele deixa acontecer aquilo que, na realidade, raramente ou nunca chega a se tornar experiência.” (2019: 1357-1359). Pois esta me parece uma descrição bastante justa do que pode estar envolvido na operação historiográfica, por outro motivo: uma de suas potencialidades é precisamente ampliar os limites do que pode ser visto, incluindo aquilo capaz de surgir como infamiliar para certos sujeitos. A verdade por um lado parece uma limitação, porque limita as fantasias; por outro, como as maneiras pelas quais significamos o par identidade-mundo no presente limita nossa capacidade de compreender, experienciar o que nos é estranho é também uma ampliação de nossas possibilidades - e experienciar autenticamente, tanto quanto compreender, só faz 
sentido se a experiência é daquilo como de fato existia, embora não seja apenas isto, mas sim a perspectivação subjetiva daquilo que objetivamente existia. Além disso, como veremos, é concebível que seu objeto não seja tanto acontecimentos particulares, mas sim "atmosferas" realmente existentes. A "ficção" se interpenetra com a vivência. Ankersmit tem razão em rejeitar a ilusão de que a experiência - nostálgica ou qualquer outro tipo -, e também de que a compreensão histórica, sejam uma mera repetição-semdiferença do passado. Mas o que me parece ocorrer nas experiências autênticas não é tão diferente de como ele descreve as representações históricas no seguinte ponto: elas têm um nível de verdade e um nível de representação. Se assim é, vale aqui para a experiência nostálgica o que argumentei no cap. 2 acerca das representações: a distinção é útil mas apenas para fins de análise, pois na experiência - que é onde toda representação efetivamente se manifesta - a representação interpenetra as verdades, que também sempre são representativas (embora, inversamente, não seja o caso: as verdades não interpenetram as representações). Quando olhamos para a epistemologia, há também estética, embora o oposto não seja necessariamente verdadeiro. A atenção pode chegar a focar apenas no nível das representações, isto é, da dimensão da operação estética mais básica que constitui o mundo, mas ela deve ser compatível com as verdades que sabemos sobre aquele mundo, e só pode ser acessada após a acúmulo de um grande conjunto de conhecimentos verdadeiros sobre aquele mundo, que permite abduzir a representação. Tudo isto é compatível com o que Ankersmit depois descreverá como a base (construída) de "humores e sentimentos", que "colorem" ou dão o "tom" das verdades propositivas sobre o mundo, mas são mais básicas que elas. Por hora, o que podemos adiantar é a seguinte conclusão parcial. Se há o desejo de experienciar autenticamente o passado sem reduzi-lo ao mesmo, sem assimilá-lo ao esquema de representações que chamamos "presente", isto demanda também um desejo genuíno de derrubar os muros da própria casa (Heim): de des-naturalizar as compreensões familiarizadoras do que surge como "eu" e "mundo", de perder o (que parece ser) chão. Como veremos adiante, o mito é precisamente o chão artificial, embora útil, com o qual a historiografia opera em contraste. A infância idílica é a infância mítica; mas há também a infância que sobrevive em mim, ainda hoje, com uma temporalidade que contrasta com a continuidade artificial do que chamo de "eu". Porque este "eu" adulto não é um eu cronológico, mas um conjunto de esquemas representativos que não dá conta da totalidade dos múltiplos eus (os que tomo como meus e os que creio serem outros). 
É devido à distância temporal que a experiência nostálgica pode ter como objeto algo simultaneamente feito (no presente) e encontrado (no passado), e unicamente se concebermos esta relação temporal de maneira dialética. Isto é o que também explica outra característica de tal experiência, que caso contrário recairia em mera contradição: seu objeto é, da perspectiva do sujeito, simultaneamente mesmo e outro em relação a ele. É concebível que, em uma sociedade, as mudanças ocorram com o que White, citando Frye, chamou de "elemento sinfônico", na qual a configuração seguinte mantém algo da predecessora, mas não é determinada por ela (WHITE, 2010: 251): a totalidade é reconfigurada retroativamente. Em Sublime, Ankersmit indicará afinidade com a dialética não apenas ao recorrer à metáfora musical para caracterizar os períodos históricos ${ }^{183}$ - e isto nos justificaria a pensar na relação entre os períodos de maneira "modal". O caminho dialético de Frye, e com ele White, é neste ponto também o de Hegel, que assumirá papel central na filosofia de Ankersmit em Sublime. Conforme Safatle (2015: 165): "Em Hegel, a contingência não é vista como fruto de um 'defeito de nosso conhecimento', mas é integrada como momento de um processo de constituição da necessidade a partir de uma historicidade retroativa." Aquilo que retroativamente é tornado necessidade era antes contingência. (idem: 164) Isto significa também que o presente não harmoniza inteiramente as contingências, nem deixa de produzir novas. Assim, mesmo entre gerações diferentes, processos temporais seguem ativos, mantidos com modificação. Com Vico e Runia, podemos caracterizá-los como componentes de "tudo que está aí" (ou aqui), e suas consequências no presente podem surgir, em circunstâncias adequadas, como preenchimentos potenciais que tornem sua configuração passada uma figura: se trata do mesmo processo (de um processo com continuidade). A atenção atraída pelo elemento presente faria a função da iluminação adequada no exemplo do "bloco mágico" de Freud. Assim, de modo geral, a conexão do experienciador presente com o evento tem muito mais probabilidades de ser feita do que no caso de alguém formado em outra cultura, que apenas com grande esforço se torna preenchedor das figuras. O caso das experiências nostálgicas, por sua vez, trataria do caso mais específico em que o "outro" não é outra pertencente a cultura ou sujeito de continuidade-na-mudança (eg, nação, classe social, grupo minoritário, tradição), mas à

\footnotetext{
${ }^{183}$ Ver o capítulo 7 de Sublime, em que Ankersmit discute a noção de forma em $O$ Declínio do Ocidente, de Spengler. Para uma discussão da leitura que Huizinga faz de Spengler, propondo que as formas não devem ser entendidas como uma determinação presente no processo histórico mas como um conceito historiográfico, ver DAMAS, 2010, e ANKERSMIT, 2012: 212-3. A posição mais próxima da de Ankersmit é evidentemente a de Huizinga.
} 
sua própria, e está presente nele não como parte da "identidade" estabelecida retroativamente, mas como uma (potencialidade de) figura atualmente não preenchida. Isto inclui os exemplos do Unheimlich de Freud (2019), como o recalcado e as crenças aparentemente superadas, que deveriam permanecer esquecidos mas que podem retornar. As representações não esgotam o processo inteiro que constituem sociedades e indivíduos: o "eu" e "nós" representados são produtos de representações, mas os termos se referem a processos perpassados de "passageiros clandestinos". Assim, além do mesmo e do outro, todo sujeito - por ser constituído processualmente - comporta múltiplos outros em si mesmo.

Dando sequência ao argumento, diremos agora que a relação processual dialética entre experiência e representação se articula satisfatoriamente com a compreensão de Mink. Lembremos que a descrição da experiência nostálgica por Ankersmit tem como um dos pontos centrais o reconhecimento da distância entre passado e presente em uma única visada. Ainda que ali Ankersmit evite metáforas visuais, é difícil não notar que esta reunião retroativa da diferença na totalidade é precisamente um subtipo da atividade mental sobre a qual Mink teorizou. Ankersmit poderia objetar que, apesar da semelhança formal, o que está em jogo no caso da experiência é diferente do que se produz no caso de uma representação historiográfica: um "contato" autêntico com o passado com uma "autenticidade" inimaginável para o caso de textos históricos. ${ }^{184}$ Não discordo desta objeção imaginada. Ainda assim, é possível ainda assim dizer que experiência e representação históricas são duas variáveis da atividade de “compreensão"? Minha opinião é que sim, e, mais ainda, que uma atividade pressupõe a outra, em uma relação cuja natureza é - como recém argumentamos - dialética. Vejamos dois argumentos em favor desta tese.

O primeiro enfatiza, como propus no capítulo anterior, que a tradição narrativista e o pragmatismo fornecem elementos com base nos quais a "compreensão" é mais bem caracterizada se nos atentamos às suas dimensões existenciais que, no capítulo anterior, chamamos de compreensão "com energia" e "com autenticidade". Em sua formulação original, a compreensão de Mink, como a substância narrativa de Ankersmit, tem ares que em "Historism and Postmodernism" Ankersmit descreve como marcadamente "historicistas". Isto é, como vimos: ela foca no holismo das relações horizontais entre

\footnotetext{
${ }^{184}$ Mas ver o comentário de Kellner (2018), perto do fim deste capítulo, sobre a possibilidade da "substância narrativa" (que é o conceito ankersmitiano para a compreensão configuracional) traduzir elementos visuais em táteis.
} 
eventos passados. Ankersmit indica interesse em superar esta característica do historicismo. Da nossa parte, isto pode ser feito porque o que buscamos é um holismo de toda a atividade compreensiva, envolvendo presente e passado, em três polos: (a) a horizontalidade dos eventos passados, (b) a verticalidade da relação entre os eventos passados e a representação presente, e, quando há a tentativa de expressá-la, (c) a horizontalidade da relação entre a mente incorporada que produz o ato de fala e o seus leitores. Vista assim, a teorização de Mink sobre o que é a compreensão vira um instrumento para compreender a experiência nostálgica, e a reflexão sobre nostalgia vira uma forma de reconhecer o movimento dialético presente na compreensão: assim, se Mink afirma que as estórias reorganizam retroativamente o que foi vivido, cabe reconhecer que as potencialidades não reorganizadas voltam para assombrar e desorganizar a compreensão, demandando novos realinhamentos. E é inteiramente concebível, portanto, que há casos em que as circunstâncias - incluindo as experiências psicológicas dos agentes envolvidos - bloqueiam tais realinhamentos. Se é concebível a presença de tensões, incongruências, esquecimentos e dificuldades diversas no processo, é também concebível que algumas experiências sejam particularmente pouco adequadas à normalização narrativa. E é isto que ocorre, em minha leitura, com as "experiências históricas sublimes". ${ }^{185}$

Mas alguns ajustes devem ser feitos na argumentação de Ankersmit. Ele compara assim a noção de experiência do historicismo e a do pós-modernismo, por ele identificada com a experiência nostálgica: a historicista busca se identificar com o passado; a nostálgica, por sua vez, "por manter consistentemente a inalcançabilidade do passado, respeita a distância ou diferença que é necessária para a possibilidade de experiência histórica." A meu ver, os dois recortes, tal como os efetua, recaem no mesmo problema de conceber passado e presente como ou radicalmente identificáveis ou radicalmente separados. Porém, a diferença envolvida na experiência - como na de um adulto que em certo sentido é "outro" em relação à criança, mas em outro sentido é a “mesma” pessoa - não é diferença absoluta, e sim a de semelhança com diferença. Tal relação é, como argumentamos, dialética, sem o tipo de corte brusco entre períodos que tanto o historicismo quanto o pós-modernismo adotam, e que Ankersmit frequentemente deixa entrar pela porta dos fundos de seus textos.

\footnotetext{
${ }^{185} \mathrm{Da}$ qual falaremos no próximo capítulo. Cabe notar que, diferentemente de Ankersmit, não consideramos haver eventos cuja condição é incontornavelmente traumática. O motivo será explicado no momento adequado.
} 
Façamos um detalhamento acerca da leitura que Ankersmit fornece de Collingwood. Isto é necessário porque estamos afirmando que a capacidade de entender a experiência mental de outros seres, incluindo-a na totalidade da própria experiência em vez de apenas experienciar o passado, como quem experiencia algo desprovido de uma dimensão "interior" - é parte do que torna possível que historiadores experienciem o passado. Ankersmit está enganado ao atribuir à teoria collingwoodiana do reenactment a pretensão de meramente acessar o passado tal como ele foi. Em Meaning, ele chega a comparar o re-enactment à nostalgia restauradora, sobre a qual falaremos em breve. É verdade que este tipo de nostalgia restauradora almeja algo como um reenactment, mas é justo apontar, dada a recorrência desta leitura (ANKERSMIT, 1994: passim; 2012: 184), que a filosofia de Collingwood nem é incompatível com a experiência autêntica e nostálgica proposta em 1994, nem é próxima à nostalgia restauradora, como sugerido no texto de 2012. Em primeiro lugar, seu interesse pelo passado reside na conexão dialética entre ele e o presente, não envolvendo a expectativa pelo retorno de algo que não irá retornar. Com a vantagem de que, diferentemente de Ankersmit - e ao meu ver acertadamente - ele reconhece algo que de fato é repetível em múltiplos contextos, o pensamento, sem por isso presumir que o contexto passado seja repetível, nem ignorar que o contexto presente é outro. Em segundo lugar, a distinção de nostalgias propostas por Boym toma como referencial sobretudo o anseio envolvido em cada caso, e o anseio restaurador não aparece em momento algum em uma obra tão marcadamente rica de preocupações éticas focadas no presente como é a de Collingwood. ${ }^{186}$

Quanto ao aspecto metodológico, ao afirmar a possibilidade de estabelecer uma relação de proximidade com o pensamento dos agentes, Collingwood jamais nega - e ainda afirma o oposto - que a historiografia integra a perspectiva do agente ao seu próprio universo mental. Há então uma dinâmica entre proximidade e distância que, embora diferente da concebida por Ankersmit, é inteiramente compatível com a sua descrição da experiência nostálgica. Basta vermos este trecho de The Idea of History destacado por van der Dussen em sua discussão da filosofia de Ankersmit (2016: 227):

[O] Historiador da poesia, lendo Dante, faz re-enactment da experiência medieval que o poema expressa: mas enquanto faz isto, ele permanece sendo ele mesmo: ele permanece um homem moderno, não um medieval: e isto

\footnotetext{
${ }^{186}$ Lembremos de seu esforço para preservar a consciência histórica, após considerá-la em risco após a Primeira Guerra (cf. COLLINGWOOD, 1978), e sua pretensão de contribuir filosoficamente com as necessidades do contexto da Segunda Guerra em The New Leviathan.
} 
significa que o medievalismo de Dante, enquanto é genuinamente revivido e re-experienciado dentro da sua mente, é acompanhado por todo um mundo de ideias e hábitos fundamentalmente não-medievais, que o equilibram e mantém sob controle e previnem que ele jamais ocupe todo o campo de visão.

A análise aqui é de um caso normal da compreensão histórica, e não o tipo mais intenso discutido por Ankersmit, e portanto não concebe possibilidades como a ekstasis do sujeito e a descontextualização da experiência. Mas é nítida a compatibilidade entre ambas: o espaço de "compreensão" onde se produzir unidade-na-diferença está claramente delineado, e evidentemente não há qualquer pressuposto de que reenactment seja apenas uma repetição do passado.

Sobre contexto, teríamos apenas que reconhecer que, embora ocorra cronologicamente no presente, o contexto formado pela experiência não é o de uma homogeneização da experiência passada na rede de experiências presentes, nem, inversamente, uma anulação das experiências presentes com a imersão completa na experiência passada re-enacted. O que efetivamente ocorre é a produção de uma nova totalidade na qual os dois polos se fundem, efetivamente uma diferença-na-unidade que não pode ser situada nem no passado nem no presente. Do fato de que surge tal totalidade, passa a ser compreensível que existam variáveis casos de harmonização entre as experiências passadas e presentes, e que a justaposição produza disrupções em casos nos quais as diferenças se tornam peculiarmente visíveis onde outrora se presumia familiaridade, ou nos casos em que elementos do passado permanecem como Fremdkörper no contexto presente.

Enquanto este primeiro conjunto de ajustes envolve a relação entre experiência de Ankersmit e re-enactment em Collingwood, o segundo envolve a relação entre "mente, história e dialética" que, na leitura de Mink, é tão essencial na filosofia collingwoodiana. Sobre este ponto, cabe enfatizarmos uma diferença relevante entre o tipo de compreensão tipicamente produzida pela historiografia e aquela das “experiências" teorizadas por Ankersmit. Vimos que, conforme a leitura que Mink faz da escala de formas de Collingwood, neste holismo há elementos mais concretos (a sensação no corpo, a atividade de percepção oriunda da interação imediata com o ambiente) e outros mais abstratos (os pensamentos, as estruturas culturais), se interpenetrando de modo que um influencia o outro. Observemos ainda que a atenção não pode dar conta de tudo ao mesmo tempo, e pode focar ora mais nas dimensões abstratas, ora nas mais concretas, assim como pode focar nas conexões entre ambas ou 
pode se perder inteiramente em reflexão ou concretude. Adicionalmente, lembremos que estas dimensões se manifestam tanto na história-processo quanto na história-escrita, e que a história-escrita é uma atividade reflexiva de agentes situados na, e formados pela, história-processo. Assim sendo, ainda que ambas sejam "compreensão", os focos na experiência do passado (em contraste com a representação do presente) e na concretude (em contraste com a abstração) tem a potencialidade de produzir disrupção nestes níveis mais reflexivos. Se no capítulo 2 caracterizamos a historiografia como produtora de "síntese de sínteses de heterogêneos", agora podemos apontar que as "sínteses de heterogêneos" têm o potencial de tensionar ao limite as "sínteses de sínteses". Tomando estes elementos em conjunto, podemos distinguir o tipo de "experiência nostálgica autêntica" desejada por Ankersmit aqui das representações históricas usuais, e, ao mesmo tempo, tomar ambos como instâncias da capacidade humana de compreensão. Um tipo enfatiza o momento da des-familiarização (no contexto que só pode ser o de uma experiência de familiaridade), o outro o da familiarização (no contexto de desorientação prévia).

\subsubsection{Verdade, autenticidade, historicidade}

Retornemos então à questão levantada anteriormente: o passado desejado e experienciado nostalgicamente pode e deve ser real para ser justificadamente caracterizada como "histórica", ou esta questão deve ficar suspensa? Nossa resposta é a seguinte. Sim, efetivamente conhecer o passado demanda saber verdades sobre ele; mas este é o primeiro passo, necessário, de uma verdade mais profunda e existencial que se revela pelo estabelecimento de relação entre o passado e presente, pelo gesto de "ver junto" da compreensão histórica ou um tocar, sentir ou ouvir junto que metaforicamente poderíamos atribuir à experiência histórica. Em nossa visão, a verdade é parte do que está em jogo em uma experiência autêntica do passado, mas não se trata apenas do mero estatuto das verdades cientificamente estabelecíveis sobre o passado: toda experiência autêntica do passado é também uma experiência autêntica da historicidade.

Ankersmit está justificado em recusar as perspectivas hermenêutica e historicista que presumem que a atividade historiográfica (ao produzir representações ou experiências) consiste em um acesso ao passado "objetivo", independente do historiador. A experiência, em um caso assim, seria apenas um caso de duplicação do que já ocorreu. Ele está igualmente certo quando, em textos anteriores e posteriores ao de 1994, afirma que a subjetividade não é um obstáculo ao conhecimento histórico, mas 
precisamente o que possibilita o acesso às suas verdades a partir de múltiplas perspectivas. O conhecimento histórico é um entrelaçamento holístico entre subjetividade e objetividade, e assim é também a experiência. Desta perspectiva, a conexão entre experiência e representações e verdades não deve ser recusada, mas ampliada: assim como verdade não é irrelevante ou inatingível, mas é precisamente revelada de múltiplas maneiras a partir das perspectivas com que um certo evento é estudado, também a experiência não é impossível pelo fato de seu passado só poder ser acessado subjetivamente: isto é precisamente o que a torna possível. No texto de 1994, Ankersmit enfatiza que a autenticidade da experiência está conectada ao fato dela ser uma experiência do historiador; ainda assim, ela pode ser dita do passado porque, como afirmam seus textos sobre representação, a presença da perspectiva subjetiva única sobre uma parte do passado é o que faz com que ele se manifeste de maneiras que um sujeito transcendental intersubjetivo em terceira pessoa não poderia fazê-lo. ${ }^{187}$ Como explica Martin Jay sobre a reconfiguração filosófica propiciada pela ascensão deste sujeito:

O novo prestígio da ciência também significou abandonar a preocupação de Montaigne com introspecção e auto-descoberta; para ser digna de ser levada a sério, a experiência tinha que ser pública, replicável e verificável por instrumentos objetivos. Da mesma maneira, a ênfase de Montaigne em nos entendermos com a nossa própria mortalidade como a tarefa essencial de viver pareceu irrelevante para uma mentalidade que identificou o sujeito com a comunidade imortal dos pesquisadores científicos. A investigação científica foi entendida como fundamentalmente diferente daquela do peregrino progregindo para a redenção ou do humanista amadurecendo até virar um estóico capaz de olhar a morte no rosto; ela era uma busca infinita por conhecimento cujo telos era maestria, não reconciliação. (JAY, 2005: 40-1)

Mais ainda, não se trata apenas de reconhecer o passado real: se trata também de reconhecer a realidade da impermanência, da inexorabilidade das mudanças históricas, que incluem o próprio historiador, também histórico e mortal. Reconhecer a atual distância em relação a um passado que outrora foi presente, reconhecer que já não se possui a perspectiva "imersa" dos agentes, deduzir daí que a própria condição imersa também é contingente, tudo isto é possível quando a "experiência” em questão já não é apenas a científica, em terceira pessoa, mas existencial, em primeira.

\footnotetext{
187 Que é, como afirmou Jay, o tipo de sujeito envolvido na maneira de "experienciar" o mundo nos termos da revolução científica. Esta experiência é real e legítima, mas não é o tipo de experiência que Ankersmit está descrevendo neste momento.
} 
Citando um estudo de Barbara Cassin sobre as origens do topos literário da nostalgia, Felippe (2017) relata que a autora "percebe que o primeiro aparecimento dos vocábulos que propiciarão o nascimento do neologismo 'nostalgia' ocorre em uma cena literária na qual Ulisses propõe a recusa da imortalidade e escolhe o envelhecimento, a morte e a passagem do tempo." Desta forma, "Cassin propõe uma ampliação em que a situação nostálgica não se apresenta, necessariamente, como conceito, mas expressa a casa, o conflito geracional, a família, o envelhecimento, a mistura entre futuro, presente e passado, todas expressões da finitude humana." (2017: 127)

Isto é efetivamente atendido pela formulação teórica de Ankersmit, embora não tanto, ao que me parece, pelo tipo de desejo que creio identificar em seus textos. Assim como, em sua formulação teórica, a experiência nostálgica é uma experiência da distância entre passado e presente, da mesma forma podemos afirmar que a expressão da mortalidade à consciência de um ser vivo se dá sobretudo pela inexorabilidade da produção desta distância. Enquanto conceitos abstratos, a compreensão e a substância narrativa não elucidam isto; mas vistas como produto por uma mente incorporada em um ambiente, torna-se inevitável a percepção de que a cristalização do fluxo temporal produzida pela linguagem contrasta com a inexorabilidade da dissolução de corpos e coisas. A transitoriedade incessante garante que a compreensão e aquilo que é compreendido nunca coincidam, e nos momentos de mudança da maneira intersubjetiva de ver o mundo a impermanência mostra que mesmo no campo das representações, onde pareceria haver uma estabilidade, não há como fugir da mudança e da instabilidade.

Há várias motivações para a reflexão sobre a nostalgia. $\mathrm{O}$ reconhecimento da impermanência pode efetivamente ser posto a favor da vida. No mínimo, se tudo muda, também o presente é uma circunstância histórica e não “o fim da história”, como indicado pelo livro parcialmente homônimo que Fukuyama publicou no mesmo ano das primeiras reflexões de Ankersmit sobre nostalgia e sobre experiência histórica. Sendo ele circunstancial, há o que fazer. Não apenas isto, mas a revisão da noção de distância, segundo a qual elementos do passado sobrevivem em sua forma modificada no presente, permite que o próprio passado seja visto como fonte de recursos criativos como resposta à pergunta “o que fazer?”. Assim, "Narrar pela perspectiva nostálgica evidencia que a nostalgia parte do reconhecimento de que o passado não está ausente ou distante, não havendo uma profunda ruptura entre passado e presente; ao contrário, esse passado invade o reino do presente e o alarga." (FELIPPE, 2017: 128) Diante de uma eventual 
objeção pró-Ankersmit de que o passado está, sim, distante, em certo sentido do termo eu concordaria. O ponto relevante deste argumento não passa, de modo algum, por ignorar a irreversibilidade da passagem do tempo, mas por reconhecer que (para anunciarmos uma analogia que exploraremos mais adiante) o presente é mais uma cidade em que prédios altos e vielas antigas convivem proximamente, e menos uma metrópole na qual tudo é novidade e que em nada se confunde com as configurações passadas, só visíveis em fotografias. Isto equivale a reconhecer, com o Vico de Runia, a espacialidade da memória e a possibilidade de ativá-la no presente - com diferença, como enfatiza Ankersmit, mas sem o seu pressuposto de "períodos" históricos homogêneos. Vista assim, então a nostalgia passa a remeter a possibilidade de construir outros mundos. Ainda que usualmente ela seja concebida como um afeto decadente por meio do contraste com o progresso (que a possibilitou em primeiro lugar) (cf. FELIPPE, 2017), ela pode indicar precisamente a desejabilidade de outros mundos que não este pautado pela aceleração do tempo.

As duas observações anteriores permitem-nos ainda fazer uma defesa adicional da noção de "autenticidade" da experiência nostálgica de Ankersmit. A percepção da inexorabilidade da passagem do tempo e o reconhecimento de que há o que fazer são duas formas de recusa da má-fé ou inautenticidade.

Ao experienciar a constante mudança das coisas, em uma ação de compreensão na qual ele própria é participante ativo, o sujeito se depara com a própria mortalidade. Como pode haver distância e imediaticidade, e no que a visão de ambas em "totalidade simultânea" pode contribuir para uma experiência autêntica do mundo? Ora, um "mesmo" humor - "mesmo" pelo princípio da identidade dos indiscerníveis - que aparecia como natural no contexto holístico A (com outra intersubjetividade, materialidade etc.) pode ser estranho ao contexto holístico B. Mas tal humor, ou as metonímias que remetem à expressão de tal humor, estão presentes no próprio sujeito, formado pelo passado. Assim, distância e imediaticidade se manifestam na mesma experiência. E o que elas revelam é que, por haver deslocamento onde antes havia imediaticidade, há mudança no mundo, e portanto há mudança no sujeito (que é feito de mundo). Runia, como veremos, expressa isto com maestria ao tratar os elementos de presença como Fremdkörper. ${ }^{188}$ Pois aquilo que ele descobre como estranho não é alguma coisa supostamente objetivada no mundo, mas um aspecto do mundo que

\footnotetext{
${ }^{188}$ As referências à metonímia, teorizada por Runia, e à inseparatividade entre sujeito e mundo na noção de "humores e sentimentos" (ou "atmosfera") no Ankersmit de Sublime, serão esclarecidas mais adiante.
} 
formou a ele próprio, e ao qual ele agora redescobre. A descoberta da distância é a descoberta da mudança. Surge, daí, ao menos a possibilidade de abraçá-la, de reconhecer-se como incontornavelmente sujeito a ela (ou melhor, feito por ela).

Também é uma recusa da má-fé o reconhecimento de que as narrativas sobre o mundo presente e sobre o próprio sujeito não esgotam as possibilidades de ação no mundo presente. Em vez de se ver objetificadamente, como tendo sido feito pelo passado, o sujeito pode reconhecer no vasto acervo do passado presente nele mesmo (em suas memórias, desejos, habitus, na manifestação particular de um entrecruzamento de tradições que ele é) e no mundo (na forma de ruínas, monumentos, instituições etc.) uma vasta quantidade de figuras oriundas do passado que, se experienciadas, serão ativadas, abrindo possibilidades para o futuro.

Estas discussões nos conduzem ao campo da ética, que é o ideal para tratarmos do item restante na descrição feita por Ankersmit da experiência nostálgica como marcada por autenticidade, distanciamento e deslocamento. Afinal, a discussão de "para onde ir?" é inseparável daquela sobre onde se está.

\subsubsection{Estar deslocado no presente e se deslocar rumo ao futuro: nostalgia e ética}

Nenhuma discussão ética será proveitosa se perder a conexão com situações concretas. Não se trata de negar a validade de descrições suficientemente gerais, tal como a de que nenhuma crueldade é desejável e de que não devemos nos conformar com a manutenção de circunstâncias sociais de desigualdade e opressão. Ainda assim, como ponto de partida, reconheçamos: há vários motivos possíveis para não querer estar onde se está, e há vários motivos e meios para querer ir onde se quer ir.

Se a discussão até o momento focou no elemento do passado presente na forma tipicamente nostálgica da relação presente-passado-futuro, agora podemos focar no presente no qual um sujeito individual ou coletivo se sente deslocado. Não é apenas a relação com o passado que envolve uma interpenetração entre objetividade e subjetividade, a qual produz o desvelamento de aspectos do mundo. Também o mundo presente é assim. Desta forma, “onde se está" não é algo dado, como se nossa mente incorporada meramente espalhasse o ambiente tal como ele é, embora frequentemente assim o pareça quando estamos imersos em nossas preocupações usuais. Reconhecemos com alguma facilidade que a orientação para o futuro envolve uma abertura: cabe a nós decidir, a partir de nossa situação atual, a direção que seguiremos. Mas também o presente envolve uma dinâmica entre liberdade e facticidade. Considero que Runia foi 
especialmente perceptivo a isto, na medida em que ele aponta que fazemos "o novo a partir do velho", velho este que não é algo que passou para sempre, mas que está armazenado nos "lugares de tempo" do presente. Tanto ele quanto o Ankersmit de Sublime enfatizam a ruptura de nossas identidades; por que tal ruptura é importante? Porque é nossa forma de representar a nós mesmos e ao mundo - inseparavelmente, organizando as energias nossas e do mundo (energias essas que se movem verticalmente, já que os processos "externos" e “internos" são temporais, e horizontalmente, já que negociamos identidades, ações imediatas e projetos mais amplos intersubjetivamente) - que permite que vejamos algumas coisas coisas, e apenas alguns poucos aspectos destas coisas, e não vejamos tantas outras. ${ }^{189}$

O que estas observações nos dizem sobre a sensação de não estar no lugar certo? Que é possível lidar com esta sensação de maneiras que ampliam a potência do agente, e de maneiras que a reduzem. Não é o caso de deslegitimar o que quer que surja a um sujeito como desejo, mas de reconhecer que há múltiplas maneiras de agir em relação a ele. Lembremos que podemos dividir em ao menos três os elementos envolvidos nesta sensação: o agente no presente, o mundo natural e social no presente, e tudo que podemos chamar de passado. Para nossos fins, ainda pode ser útil em subdividir o passado entre aquela parte pela qual o sujeito sente nostalgia e todo o resto. Ora, vista assim, há algo de muito proveitoso na sensação de nostalgia: ela indica que algo não está bem e precisa ser modificado. Reconhecer todos os níveis envolvidos na relação entre presente e passado permite-nos mapear o que pode ser feito.

Dentre os inúmeros motivos pelos quais se sente nostalgia, há aquele em que uma relação com o passado demanda um trabalho de luto insuficientemente realizado, há a comparação entre um presente real com um passado idealizado, há a adoção de uma identidade estreita demais que produz alienação do sujeito de muito do que está ao seu redor. Todos estes exemplos envolvem o não reconhecimento da possibilidade de fazer algo no presente, como se a única maneira de reduzir o sofrimento na relação sujeito-ambiente-passado fosse mexer no polo passado da tríade. ${ }^{190}$ Ora, como a relação com o passado é estabelecida entre em uma combinação entre um passado objetivo e uma subjetividade, a mudança do presente modifica o passado. O passado está "fechado": os corpos que se decompuseram não se recomporão, a Antiguidade e a Idade

\footnotetext{
${ }^{189}$ Remetemos o leitor aos exemplos do medo e do ódio no capítulo 2.

${ }^{190}$ Argumentarei adiante que a maneira pela qual Ankersmit descreve o trauma 2 parte deste pressuposto.
} 
Média não se formarão novamente, a revolução científica não se desfará. ${ }^{191}$ Seu significado é aberto, porque envolve o elemento subjetivo, que pode ser modificado, em combinação com o evento já fechado.

Pois bem, se o nosso objetivo é sermos agentes históricos engajados em nosso mundo contemporâneo, não nos parecerá desejável investir a energia em algo que não curará nosso sofrimento, nem liberará nossa energia para o investimento nas questões importantes do nosso mundo. Nada nos obriga que tenhamos tal interesse, nenhuma fundação ética pode prescrever tal coisas, mas pragmaticamente é possível afirmar: o contato com o sofrimento de seres tão importante quanto nós (nossos fellow human beings, igualmente fellow sufferers, como diria Rorty), ${ }^{192}$ se justaposto ao reconhecimento de que podemos agir para aliviá-lo, pode ser tomado como base embora não seja uma base natural - para informar o estabelecimento de nosas relações com o passado. Desta perspectiva, quando o anseio pelo passado é a manifestação do desejo de sustentar uma identidade estreita - que torna o outro invisível para o sujeito então ele é contraproducente. Mesmo para os interesses do próprio sujeito que age de maneira autocentrada: por não ver as outras subjetividades que compõem o seu mundo, ele não pode estabelecer relações significativas com ele, e sofrerá; por sofrer, desejará um mundo em que não sofra; inversamente, se passar a ver os outros como sujeitos dotados de experiência em primeira pessoa, deixará de estar alienado do mundo em que vive e não terá mais motivos por ansiar por um passado no qual tal alienação não existia. A pergunta chave aqui é: por qual passado se anseia? Se é por um passado igualitário, então é eticamente desejável que o sujeito se alie àqueles de sua sociedade interessados em agir de modo a produzir uma sociedade desejável para todos. Ainda que poucos momentos do passado vistos como totalidade pareçam dignos de nostalgia para

\footnotetext{
${ }^{191}$ Confesso ter hesitado em escrever esta frase. Mas o que ela significa é que um eventual triunfo de movimentos obscurantistas no Brasil e no mundo pode no máximo produzir um novo obscurantismo, com crianças não-vacinadas, professores filmados em sala de aula, natureza da Amazônia explorada, aquecimento global negado, pluralidade de pensamento vista como ameaça e uma triste lista de et ceteras. ${ }^{192}$ Ciro o Rorty de Contingency, Irony, and Solidarity, mas com pleno acordo com as críticas de Bernstein e Elshtain (em GUIGNON \& HILEY, 2003) ao seu liberalismo, o primeiro por sua delimitação exagerada entre os campos da teoria e da prática (tema sobre o qual trataremos no capítulo 4) e a segunda afirmando e exemplificando, muito convincentemente, que as motivações para ações altruístas não necessariamente passam por conexões etnocêntricas: "Eu li muitos relatos de resgates e nunca encontrei "companheiro jogador de bocha" como uma razão proferida por alguém pelo motivo pelo qual ele veio a colocar sua vida e a vida de sua família em risco. A decisão de colocar a vida em risco não tinha muito a ver com razoabilidade irônica." (151) "Eles resgataram porque eles puderam generalizar para além das suas conexões imediatas em vez de meramente agir [enact]." (153) Estendo o raciocínio para o caso bem menos dramático da atual discussão, ao menos no que diz respeito à busca por soluções imediatas e arriscadas: motivações compassivas para o anseio por fazer do lugar em que se está um outro lugar são inteiramente concebíveis e teoricamente defensáveis.
} 
tal finalidade, a nostalgia pode sem problema algum se dirigir a aspectos do passado, incluindo suas promessas não realizadas. Se é por um passado em que os demais seres estão incluídos, então a melhor estratégia talvez não seja mexer no polo passado, mas no próprio mapeamento da relação contemporânea self-mundo, de modo que os demais seres sejam vistos como tão dignos de boas condições de vida quanto aquele que vê (o que quer que se entenda por "boas" condições aqui, pois tal critério é sempre situacional).

O princípio com base no qual este raciocínio pode fazer sentido é o seguinte: não é apenas possível transformar o (significado do) passado ou o mundo; o terceiro elemento da equação diz respeito à relação do sujeito consigo mesmo (o que, nos capítulos seguintes, será caracterizado por meio da metáfora de que todo sujeito carrega diversas "ruínas" passíveis de ativação em sua "cidade" interna). ${ }^{193}$ Se a relação deste sujeito com o passado concebido em termos objetivistas, o interesse por acessar o "passado como ele foi" não pode produzir desnaturalização dos referenciais com que ele constrói o mundo presente, e portanto não permite que tal contato o abra para tudo que é alheio ao seu eu (representado) presente. Não haveria interpenetração de fato entre sujeito e objeto histórico. O pluralismo da representação histórica teorizado por White e Ankersmit, para quem múltiplas verdades podem ser ditas sobre o mesmo passado, a cada vez em que é produzido o encontro "compreensivo" entre um sujeito no presente e evidências do passado, é preferível nesse sentido. Mas mesmo este pluralismo pode considerar que as variações se encontrar apenas no polo do sujeito, sem reconhecer que - como Gadamer, especialmente, considerava importante - este polo se modifica ao estabelecer relações com "objetos” passados. Ankersmit (1994) até dá espaço para que algo assim ocorra com a história das mentalidades, mas considero que todo acesso às dimensões estéticas por meio do qual se formaram os "mundos" passados também pode produzir tal modificação. Concebida dessa forma, a representação histórica se torna uma ferramente de autopoiesis, e isto também significa que pode haver ótimos motivos para "desejar o passado".

Em Meaning, Ankersmit retoma o tópico da nostalgia. Ele recorre agora à distinção formulada por Svetlana Boym entre as nostalgias "restauradora" e "reflexiva".

\footnotetext{
${ }^{193}$ Esta afirmação está afinada com a tese de Runia segundo a qual os seres humanos podem modificar os ambientes como forma de modificarem a si mesmos. Ele diz que somos "nossos próprios piores inimigos", mas como o que a ação do "salto no abismo" produz é uma disrupção da própria identidade, ela também libera o sujeito para potencialidades outrora não reconhecidas. O que ele chama de inimizade pode portanto ser uma forma de amizade consigo mesmo. Na linha do que estamos argumentando neste parágrafo: depende da motivação - e daí dependerá adicionalmente dos meios disponíveis na situação.
} 
Notemos que os dois tipos são, grosso modo, análogos às abordagens "historicista" e "pós-modernista" da historiografia, tal como Ankersmit as comparava em 1994. Segundo Boym: "Se a nostalgia restauradora termina por reconstruir emblemas e rituais sobre a casa e a pátria numa tentativa de domesticar e espacializar o tempo, a nostalgia reflexiva valoriza fragmentos esparsos da memória e temporaliza o espaço. A nostalgia restauradora leva-se muito à sério; a nostalgia reflexiva, ao contrário, pode ser irônica e bem-humorada." (BOYM, 2017: 161)

Como a última parte da citação mostra, a nostalgia reflexiva também é compatível com a postura de ironia. Seria possível argumentar pelo valor de algo como a "nostalgia reflexiva" no interior de uma tradição whiteana que deseja se livrar do "fardo da história" por meio de uma "volta da ironia contra a ironia"? Não seria o caso de, como propõe Jenkins (1997), de simplesmente fazer outra coisa alheia aos moldes da historiografia tradicional (que nem mesmo ética poderia ser chamada, por ser um termo ainda fundacional demais)? A resposta possibilitada por este trabalho é que, se pensamos a história sem perder de vista sua dimensão processual, então a própria potência de ação no presente depende do reconhecimento das potencialidades e dos problemas atualmente não presentes à consciência dos vivos: isto é, é preciso história ativa para se contrapor ao fardo da história. ${ }^{194}$

Assim como a experiência nostálgica pode envolver uma aceitação - ao menos em algum grau - da mortalidade, uma resposta ética ao anseio nostálgico é bem atendido pela aceitação total à situação presente. Por que isto não é um conformismo? Porque (a) a situação não se esgota no presente representado, na identidade do sujeito, mas na circunstância total, que inclui as representações que nos permitem ver algumas coisas e a presença de tudo aquilo que ainda não vemos; e porque (b) ela pode ser acompanhada de ações do sujeito coletivo (cf. Carr) orientado para o futuro, mas agora uma ação precedida de um mapeamento muito mais amplo das possibilidades disponíveis. À pergunta “o que fazer?”, tão enfatizada por White, não cabe uma resposta direcionada a um resultado sabidamente impossível tal como o retorno a um passado que nunca existiu. ${ }^{195}$ Ela é muito mais bem atendida pela proposta de Runia, de localizar

\footnotetext{
${ }^{194} \mathrm{Na}$ entrevista inédita que conclui a coletânea A Escrita da História, publicada pela EdUEL em 2012, Ankersmit afirma que toda sociedade precisa de uma perspectiva sobre o passado.

195 Movimentos que buscam dominação podem agir de maneira eficaz por meio da postulação de passados fantasiosos, tal como manifestado recentemente pelo slogan "Make America Great Again" e por fantasias sádicas acerca da ditadura brasileira. São ações bem sucedidas dentro do que se propõem. Aos movimentos com uma aspiração utópica mais compassiva cabe mostrar que ações de dominação bem sucedidas não propiciam a seus executores uma vida satisfatória. Sobre a distinção entre poder e
} 
"tudo que está aí", encontrando e combinando possibilidades mais ou menos como o bricoleur de Certeau (1994a, 1994b). Nos termos de Boym: "a nostalgia que analiso aqui nem sempre é pelo Antigo Regime, pela estabilidade da superpotência ou por um império derrubado, mas também pelos sonhos não realizados do passado e visões do futuro que se tornaram obsoletas.” (BOYM: 2017: 156) O anseio por um tempo diferente pode assumir direção retrospectiva, mas pode também ser prospectivo (idem, 154), inclusive ao direcionar-se às potencialidades abertas do passado - ou às outrora abertas, mesmo as não atualmente reativáveis, pois reconhecer o não-cumprimento de promessas passadas produz também efeitos sobre os sujeitos no presente, efeitos não detectáveis em um pensamento estritamente pragmático, na qual se esperasse "utilidade" do passado para o presente.

Outro comentário de Boym, sobre os riscos e potencialidades da nostalgia, permite-nos ainda dizer algo mais sobre a tese proposta em nosso presente trabalho. Ela diz:

\begin{abstract}
A nostalgia moderna é paradoxal no sentido de que a universalidade de sua saudade pode aumentar nossa empatia pelos seres humanos, e ainda assim, quando tentamos reparar essa saudade com um pertencimento particular - ou a apreensão da perda com a redescoberta da identidade e, particularmente, de uma comunidade nacional e pátria pura e única - nós frequentemente nos distanciamos de outros e encerramos o entendimento mútuo. Algia (saudade) é o que partilhamos, e nostos (ou a volta para casa) é o que nos divide.
\end{abstract}

Pois lembremos, com Butler e Safatle, que o que partilhamos é precisamente nossa irredutibilidade aos nossos predicados, tornados "nossos" por meio das

compaixão implicitamente mencionada neste tópico, ver GILBERT, 2017. Para falarmos em termos mais coloquiais: para mudar algo para pior, não é necessário produzir uma compreensão adequada do presente em sua dimensão processual; mudanças em uma direção compassiva, que busquem reduzir o sofrimento dos seres, demandam tais conhecimentos. Outro exemplo pode ser dado com apoio na introdução de Historical Representation. Lá, Ankersmit fala sobre as consequências éticas de adoção de diferentes metáforas: se represento a Terra como "uma nave espacial", isso pode convidar o leitor a tomar atitudes mais condizentes com o aquecimento global do que se a represento como "uma sala de estar", que convida a uma atitude mais autocentrada. Os dois atos de fala podem ser igualmente efetivos para eleger presidentes, mas um produzirá sofrimentos - não apenas no longo prazo, nem mesmo no médio - ligados ao aquecimento global, o outro não. E lembremos que, assim como o negacionista climático vive na Terra, muitos negacionistas da ditadura brasileira vivem no Brasil. Eles podem se blindar de várias das consequências dos seus atos de fala (especialmente se têm poder econômico para tal), mas se verão cercados de pessoas em condições precárias. Nenhuma falta de fundamentação filosófica última me impede de dizer que esta é uma vida infeliz. Cabe adicionar ainda: para que ela possa parecer menos desejável, é necessário alternativas positivas, e não rejeição nos quadros (Lakoff) ou vocabulários (Rorty) do outro. É nesse ponto que a afirmação de White é certeira: diante da interpretação sionista, os palestinos não têm força ao apresentarem mais verdades, mas ao produzirem interpretações mais eficazes. Se seu ponto parecia eticamente questionável na discussão sobre como combater os negacionistas do Holocausto, os negacionismos contemporâneos parecem indicar que ele estava correto. Ver a discussão a este ponto no capítulo 2. 
representações com as quais construímos identidades. Se percebidas assim, "as situações nostálgicas apresentam de modo privilegiado”, como afirma Eduardo Felippe, um "certo desamparo humano". Temos, portanto, dois pontos que se repetirão nas reflexões de Ankersmit sobre a experiência sublime em 2005: (a) a possibilidade de responder às experiências nostálgicas de modos que nos dividem ou de modos que, por perceberem o que partilhamos, refinam nossa atenção e escuta ao outro; (b) o reconhecimento de que a experiência de perda de um "mundo" ou "casa" antiga é relacionado a processos sociais mais amplos - envolvendo disputas por reconhecimento, luta de classes e tantos outros fatores mais - em relação aos quais se manifesta uma dor temporariamente inevitável, mas em relação à qual não há uma única forma padrão de resposta.

Embora não se possa fundamentar a preferência pelas soluções divisivas em vez de solidárias para tal sofrimento, as soluções solidárias são potencialmente mais harmonizadas com a realidade: perspectivas inclusivas e solidárias não demandam a construção e naturalização de barreiras, sempre arbitrárias, entre eu (e o que supostamente me é próprio) e outro. A solidariedade não demanda falsas fundamentações, pois pode se pautar no reconhecimento básico de que os demais seres não desejam sofrer, desejam ser felizes, dar e receber amor, ter suas dores ouvidas e reconhecidas, etc. Já as exclusões necessariamente postulam identidades construídas como se fossem naturais. ${ }^{196}$

A nostalgia, neste sentido, é mais bem compreendida como um indício de que há algo na vida social contemporânea a produzir sofrimento. Porém, como vimos em nossa discussão sobre os "quatro suportes" das representações, seres humanos não estão condenados - nem Ankersmit jamais afirmou que estejam - a responder behavioristicamente às suas emoções; dessa forma, a pergunta "que fazer na atual situação?" inclui a "cidade" interna do sujeito e a "cidade" externa do processo histórico, que terão partes de si - partes selecionáveis de si - combinados de modo a produzir um artefato (especialmente o texto) com o qual se pode fazer coisas no mundo. No parágrafo anterior, citamos como a nostalgia aponta para os limites do identitarismo, que reduz o "eu" ao que lhe é familiar, às suas propriedades, ao que lhe parece fornecer amparo. De modo mais geral, as experiências contemporâneas de nostalgia parecem relacionadas, segundo seus teóricos, à aceleração temporal da modernidade (cf.

\footnotetext{
196 Embora esta frase toque propositalmente em tabus filosóficos, em um nível existencial ela é obviamente verdadeira: é melhor praticarmos solidariedade do que crueldade, amor do que ódio.
} 
BECKER, 2018; BOYM, 2017; FELIPPE, 2017) Assim como no caso da concepção "identitária" de sujeito, também esta experiência de temporalidade aparece nas reflexões teóricas de Ankersmit - ao menos como o leio -como um fato que se impõe sobre a escrita histórica. Como se o contexto fosse o produtor do sujeito histórico e o explanans historiográfico, e não (como vimos na leitura que White faz do "historicismo modernista" de Auerbach) uma figura que pode ser preenchida de múltiplas maneiras. Em minha visão, a variante de historicismo que encontramos em White não apenas é preferível, pois reconhece a margem de liberdade dos agentes na produção do mundo (na experiência de seu mundo presente e na ação utópica rumo a mundos futuros); ela é também a mais adequada à filosofia do próprio Ankersmit, desde que, como temos feito no presente trabalho, afirmemos haver "espaço estético" não apenas entre a representação histórica e o passado, mas na própria relação de agentes históricos com o seu contexto. Outra forma de lidar com esta experiência de temporalidade, menos fatalista, reconhece a possibilidade de utilizar a escrita histórica - bem como a antropológica, já que estamos falando de distância no tempo e no espaço - para apontar a possibilidade de se relacionar com o tempo de outras formas. Se a justaposição produzida pela "totalidade simultânea" da compreensão - revela um presente insatisfatório, cabe ao teórico lembrar da possibilidade de recolocar a pergunta que, com Manuel Cruz, mencionamos no capítulo 1: o que queremos?

Estou propondo, assim, que a forma whiteana de manifestar "desejo pelo passado" é preferível à que aparece na obra de Ankersmit, e enriquece as reflexões deste último. Em White, a atenção é direcionada ao passado na busca por recursos para interferir na situação presente. Aqui podemos antecipar uma das objeções que faremos às formas de experiência discutidas em Sublime: em Ankersmit, a investigação do passado motivada pela sensação de não pertencer ao presente frequentemente não produz qualquer benefício para os demais seres vivos - vivos no presente -, e em muitos casos é manifestada pelo desejo de manter uma ordem social em que a exploração da maior parte das pessoas, não pertencentes a uma elite, é naturalizada. É evidente que ele não deseja apoiar tais pretensões, e, felizmente, a metáfora da cidade também vale para seus textos: há várias vielas inexploradas, esquecidas, onde outras direções podem ser tomadas. Da discussão sobre nostalgia, guardamos sobretudo a abertura a tudo aquilo que desapropria o sujeito de si mesmo. 


\subsection{Experiência histórica}

Um pouco como Metahistory, Sublime Historical Experience é um livro altamente experimental, tateante, tão cheio de insights quanto é de inconsistências. Da minha parte, este tipo de coragem intelectual desperta sobretudo admiração, e só com um alto grau de anacronismo as discussões posteriores poderiam cobrar coerência de alguém que buscou avançar por terrenos não-mapeados. Sublime explora a temática da experiência histórica por meio da discussão de um número tão grande de autores (Rorty, Huizinga, Gadamer, Dewey, mas também Derrida, Eichendorff, Benjamin, Rousseau, Hölderlin e muitos outros) que uma dificuldade natural gerada por ela é estabelecer uma tipologia clara das experiências em questão. Porém, na página 264 do livro, iniciando o sétimo e penúltimo capítulo, Ankersmit de fato oferece uma classificação. Ele propõe que se distingua entre (1) experiência histórica objetiva, (2) experiência histórica subjetiva e (3) experiência histórica sublime. ${ }^{197198}$

197 Como Icke (2012: 112-3) observa, “Ankersmit não entra em uma discussão substancial do seu ostensible subject matter, experiência histórica sublime, tal como indicado pelo seu título, antes de chegar no último capítulo (o oitavo), já passadas 317 páginas de texto.” Também van der Dussen (2016: 238): “o relacionamento com os capítulos precedentes nem sempre é claro, e na verdade um novo assunto é posto em discussão." Isto é certamente verdade: os dois primeiros capítulos, e em alguma medida também o quinto, sobre Gadamer, fazem um acerto de contas com a tradição, que limpa o terreno para a entrada nas discussões sobre experiência; do terceiro aos sétimo, o foco é no que aqui ele chama de "experiências históricas subjetivas"; e o oitavo é que trata mais especificamente da "experiência histórica sublime". Em Meaning, ele adotaria as nomenclaturas de experiência "individualista" para as "subjetivas" (ou ainda, do "tipo-Huizinga"), e "coletivista" para as "sublimes". Icke também critica os muitos "inícios falsos" apresentados na introdução de Sublime Historical Experience. A meu ver, isto é inteiramente compreensível, dada sua natureza exploratória. O raciocínio com o qual iniciamos esta seção se aplica bem aqui: o próprio Metahistory, justamente tomada por Icke (e por Jenkins, seu orientador) como modelo ou paradigma a ser seguido por teóricos da história, também tateia em várias direções diferentes e sua introdução sequer se harmoniza sem tensões com o restante do texto. Felizmente, porque nem White nem Ankersmit esconderam este processo do leitor (se não tentaram ou se não conseguiram, não importa tanto), os livros servem como fontes de insights para pensadores que os abordam a partir de várias perspectivas diferentes. A terceira edição da Ciência Nova de Vico talvez seja o exemplo mais nítido da potência destes livros exploratórios. Eu apontaria ainda que, vindo de um autor pós-modernista, esta crítica tem efeito contraditório em ao menos dois sentidos: (a) É evidente que a exploração por territórios intelectuais menos mapeados, e especialmente aqueles cujos objetos não são facilmente isoláveis por meio de uma linguagem protocolar, tomará um alto grau de risco e cairá em equívocos. Porém, partindo do princípio de que a escrita de um texto é apenas um lance em uma "conversa" (como diria Rorty), e não a produção de um objeto fechado em si mesmo, não é grave que um primeiro livro apresente coisas como "falsos inícios", já que outros poderão cumprir as promessas do livro de maneiras não antevistas pelo autor. Em vez de saudar a ousadia intelectual de Ankersmit, o livro de Icke dá mais enfoque a uma constante reafirmação dos dogmas pós-modernistas. Não seria justo interpretarmos com má vontade a narrativização da obra de Ankersmit feita por Icke, na forma de "bom" e "mau" Ankersmit: lidos com algum senso de humor, os termos têm o mérito de apontar a maneira pela qual o autor avalia as diferentes fases da obra de Ankersmit, tal como ele as distingue. Porém, combinada com a constante (já referida) reafirmação de dogmas presentes a todo momento no livro, esta estratégia (se disseminada) pode facilmente desestimular a inovação no campo intelectual, submetendo os autores a um ritual behaviorista no qual eles recebem a resposta de "bad boy!" (como que combinadas com um spray de água no rosto) quando se comportam mal e "good boy!" quando se comportam bem; um resultado assim evidentemente não interessa nem a Icke nem a Jenkins, que frequentemente denunciam a dimensão de poder envolvida nas disputas teóricas e evidentemente teorizam como meio de produzir liberdade diante de tais fardos, 
Ele ainda decide deixar de lado o primeiro caso, por considerá-lo ter sido suficientemente estudado pela filosofia da história desde o historicismo. A seguir, ele então caracteriza os dois tipos que receberão atenção nos dois capítulos seguintes. Primeiro, a experiência histórica subjetiva: ela

\begin{abstract}
... deveria ser primariamente situada em um contexto em que o passado já adquiriu sua independência do presente. Há um passado que é investigado pelo historiador e, então, repentinamente, parecendo surgir do nada, pode surgir esta fusão repentina do presente e do passado sugerida pela imagem do abraço de Romeu e Julieta. Eu chamo isto de experiência histórica subjetiva porque ela é uma experiência do passado pelo historiador, viz. o sujeito histórico." (ANKERSMIT, 2005: 264)
\end{abstract}

Todas as demais classificações agora ficam mais fáceis de ser organizadas: como Ankersmit deixa claro, seu exemplo central é a experiência histórica de Huizinga. ${ }^{199}$ Assim, podemos subordinar as demais discussões a esta. O capítulo "Subjective Historical Experience" discute dois exemplos adicionais, o de um capriccio de Francesco Guardi e do ornamento rococó. O capriccio de Guardi, em sua visão, nos daria acesso à Veneza do século XVIII; já o ornamento rococó adiciona algo à experiência: "a distância ou diferença entre o passado e o presente é também parte da experiência em questão. A experiência histórica, então, é um encontro direto não apenas com o passado em sua vestimenta quasi-noumenal mas também com a aura de um mundo que nós perdemos.” (264-5) Assim, em 2005, Ankersmit considerava que no primeiro caso a "distância" ou "diferença" não era um fator relevante, e no segundo sim. Em Meaning (2012) e em comentários recentes, retomando o que ele originalmente propusera em "Historism and Postmodernism" (1994), ele se retrataria das falas sobre "união" com o passado e preferiria enfatizar unicamente o ponto da distância: "Jay está certo quando critica minhas 'reflexões românticas sobre uniões místicas e beijos

nem deveria interessar a ninguém; (b) no caso de Icke, o argumento central é de que, com Sublime, Ankersmit sai do campo da história e adentra o dos estudos de memória, "onde é realmente seu lugar" (where they really belong) (ICKE, 2012: 144). Em primeiro lugar, a objeção de Icke só se sustenta se o termo "histórico" no título do livro se referir à escrita da história ou à operação historiográfica, mas é igualmente cabível que o termo aponte para o processo histórico, o "representado" dos textos de história. Neste último sentido, os estudos de memória são - ao menos se pode argumentar - "históricos". Em segundo lugar, é incoerente com seus próprios princípios um autor pós-modernista naturalizar fronteiras disciplinares, como Icke ao menos dá a entender, e performativamente sem sentido dedicar tanta importância a tais fronteiras.

${ }^{198}$ O que, por sua vez, tem a altamente desejável consequência de nos lembrar que seres humanos se relacionam com o mundo de múltiplas maneiras e qualquer tipologia muito simples seria enganadora, ainda que também confortante. O próprio Ankersmit nos lembra que não é possível distinguir inquestionavelmente um tipo de experiência dos demais.

${ }^{199}$ Como já havia sido em History and Tropology (ANKERSMIT, 1994) e voltaria a ser em Meaning (ANKERSMIT, 2012). 
ecstáticos"”, comentou ele em 2018 (ANKERSMIT, 2018: 485). ${ }^{200}$ De fato, parece haver uma compatibilidade entre a caracterização da experiência história (subjetiva ou individualista) como uma experiência do passado pelo historiador (2005) com a ênfase na experiência da distância $(1994,2012)$ ou diferença (2012) entre passado e presente, e parece haver uma tensão ou incompatibilidade entre aquela caracterização e a crença na possibilidade de "um abraço mútuo entre sujeito e objeto" (2005: 130), como o de Romeu e Julieta. ${ }^{201}$ Como veremos, não considero esta tensão irresolvível, embora as diferenças teóricas entre as formulações não sejam negligenciáveis.

\subsubsection{Huizinga e a "sensação histórica"}

Dentre todas as suas discussões, a que mais presumia a possibilidade de tal "encontro" com o passado foi a que tratou da "sensação histórica" de Huizinga em Sublime. No texto de 1994, a "sensação histórica" de Huizinga era apontada como o principal antecessora do que seria uma experiência histórica pós-modernista. No artigo "Can we experience the past?", apresentado no mesmo ano, ${ }^{202}$ ele afirmava que a "fenomenologia da experiência histórica" de Huizinga estava "fundamentalmente correta" - embora também fosse apenas "lamentavelmente esboçada" (1996: 50), ou “deploravelmente esboçada" $(2005,120)$ - e decidia tomá-la como ponto de partida para suas reflexões. ${ }^{203}$ Huizinga seguiria referência central em Sublime e em na discussão sobre "experiência individualista" em Meaning.

\footnotetext{
${ }^{200}$ Dada a centralidade da diferença para a noção de experiência histórica, cabe lembrar que também a compreensão de Mink é bastante elucidada por este conceito, e, adicionalmente, para os fins deste trabalho, cabe lembrar que a realidade (inclusive a passada) foi vivida, a partir de múltiplos pontos de vista, de maneira compreensiva - e que portanto toda experiência do passado é também uma compreensão (na terminologia de Mink) ou representação (na de Ankersmit).

${ }^{201} \mathrm{O}$ título original de Ankersmit seria precisamente

${ }^{202}$ Publicado em 1996. O contexto de sua produção encontra-se bem descrito em ICKE, 2012: 106 ff. Uma discussão detalhada da leitura que Ankersmit faz de Huizinga encontra-se em MENEZES, 2018: 208-221. Nesta seção, embora evidentemente busquemos exatidão, discutiremos apenas os aspectos conectados com a questão central de nosso trabalho, a relação entre representação e experiência, que afirmamos ter natureza processual. Aqui e nas demais seções, após descrever o tipo de experiência examinado por Ankersmit e discutir seus pontos gerais, buscaremos exemplificar a tese (cf. VAN DEN AKKER, 2012) de que as noções narrativistas de "realidade humana", escala de formas e figuralismo, tal como apresentadas no capítulo 2, estão presentes e/ou poderiam estar, com ganhos teóricos consideráveis, nas discussões sobre experiência e presença.

${ }^{203}$ Este artigo é estruturado de maneira muito parecida com Sublime Historical Experience, de 2005, e pode ser vista como a estrutura básica a partir da qual o livro nasceu. Como afirma Icke sobre ele: “... esta discussão da experiência histórica foi compreensiva o suficiente para justificar a tese de que a publicação posterior de Ankersmit, Sublime Historical Experience, pode ser tomada como um desenvolvimento e expansão dele em 480 páginas."
} 
Uma boa entrada para a leitura que Ankersmit faz dele é a citação de um trecho do artigo "Problemas de História da Cultura" (HUIZINGA, 1993: 9-83) ${ }^{204}$, de 1929, com base no qual Ankersmit avança suas reflexões em Sublime: 205

Há em toda consciência histórica um componente de suma importância, que pode ser mais adequadadamente caracterizada pelo termo sensação histórica. Também se poderia falar em contato histórico. ... Este contato com o passado que não pode ser reduzido a nada fora de si mesmo é a entrada em um mundo por si só, é uma das muitas variantes da ekstasis, de uma experiência da verdade que é dada ao ser humano. ... O objeto desta sensação não são seres humanos individuais, nem vidas humanas ou pensamentos humanos, na medida em que estes possuem contornos discerníveis. O que a mente forma aqui, ou pelo qual é formada [forms here or undergoes], dificilmente pode ser chamado de uma imagem. Na medida em que chega a assumir alguma forma, esta forma permanece composta e vaga: uma "Ahnung", que é tanto de ruas, casas e campos, de sons e cores quanto é de seres humanos estruturando suas vidas e sendo estruturadas por ela. ${ }^{206}$ Este contato com o passado, que é acompanhado pela conviç̧ão absoluta de completa autenticidade e verdade, pode ser provocada por uma linha de uma crônica, por uma gravura, alguns sons de uma velha música. Não é um elemento que o autor escrevendo no passado deliberadamente colocou em seu trabalho. Ela está "atrás" e não "no" livro que o passado nos deixou. O leitor contemporâneo a leva junto com ele em seu encontro com o autor do passado; ${ }^{207}$ é a sua resposta ao seu chamado. ... [Não é bem descrito pelo termo "Nacherleben", que] é demasiado sugestivo de um processo psicológico. A sensação histórica não se apresenta a nós como um reviver, mas como uma compreensão que é muito assemelhada à compreensão [understanding] da música, ou, melhor, do mundo pela música. (120-1; grifo no original)

Em suma, ao menos cinco características da sensação histórica podem ser destacados do trecho e redescritas para nossos propósitos: ela é (a) é uma variante da ekstasis, um tipo de "experiência da verdade"; (b) seu objeto é vago, não possui contornos discerníveis, é intuído (envolve Ahnung); (c) é acompanhada de "convicção absoluta de completa autenticidade e verdade"; (d) não é provocada por algo deliberado, mas por elementos de menor importância ${ }^{208}$ ou de "presença"; ${ }^{209}$ (e) envolve uma dinâmica entre atividade e passividade por parte do experienciador ("leitor"), que

\footnotetext{
${ }^{204}$ Para a discussão sobre sensação histórica, ver idem: 51-57.

${ }^{205}$ Fiz a tradução com base no inglês de Ankersmit (2005: 120-1), cotejando com a edição em espanhol publicada em El Concepto de la Historia y Otros Ensayos. Há diferenças consideráveis nos fraseamentos das duas versões e o significado das frases nem sempre é preciso.

${ }^{206}$ Em inglês: "structuring their lives and being structured by it". Em espanhol: "que mueven y son movidos".

${ }^{207}$ Em inglês: "The contemporary reader takes it along with himself in his encounter with the author from the past; it is his response to his call". Em espanhol: "El es el lector quien lo aporta al autor, como la respuesta a su llamada" (55).

${ }^{208}$ A menção à pouca relevância comparativa não é tanto uma descrição literal do que falou Huizinga quanto uma redescrição baseada no que Ankersmit discutirá a seguir.

${ }^{209}$ Runia também elenca as "sensações históricas", juntamente com as "experiências históricas sublimes", como instâncias de fenômenos de "presença". (RUNIA, 2014: 56)
} 
responde a um chamado do autor no passado; (f) não é um reviver, mas algo próximo da "compreensão do mundo pela música".

Como estes itens surgem em nossas discussões, e também nas de Ankersmit, de maneiras tais que vários itens estão em questão de uma só vez, procederemos por meio de uma análise relativamente solta destes tópicos, dividindo-os de acordo com os nossos próprios interesses.

\section{Objetos irrelevantes e a descontextualização da experiência}

Já vimos que Ankersmit buscava um tipo de experiência que fosse além do transcendentalismo linguístico que ainda julgava encontrar em White, Gadamer e Rorty. Em certas partes de sua discussão sobre Huizinga, é possível entrever a presença de Gadamer em seu plano de fundo. Mais especificamente, um desafio inicial para esclarecer a possibilidade de experienciar o passado é o de reconhecer a possibilidade de acessar o mundo sem as mediações da Wirkungsgeschichte gadameriana. É provavelmente isto o que Ankersmit tem em mente ao afirmar que "a grande arte está coberta por uma camada tão pesada de séculos de interpretação histórica, é em tamanho medida um exponente de toda a história da arte, que a descontextualização é quase impossível de obter.” (126) Mas no relato da sensação histórica encontramos uma situação em que isto não se aplica: a das "obras de arte menores": "Aqui nós ainda possuímos uma abertura completa a como o passado se revela para nós sob o disfarce destes registros despretensiosos da vida cotidiana na Holanda no início do século XVII e de como deve ter sido viver naquela época." (127) O mesmo vale para objetos aparentemente irrelevantes e despretensiosos: eles poderiam preservar a "aura" do passado, operando de maneira que Ankersmit descreve de maneira similar à que Runia (que sem dúvidas o leu) formularia em "Presence”, no ano seguinte: “... pode-se justificadamente dizer que o passado está nestes artefatos que ele nos legou. Elas são protuberâncias, por assim dizer, do passado no presente..." (115; grifo no original). ${ }^{210}$

Naiara Ribeiro se refere à noção de presença, de Runia, fazendo analogia a um elemento comum em dois momentos das reflexões de Huizinga sobre a historiografia. Ao descrever suas reflexões sobre "imaginação histórica" em sua aula inaugural em Gröningen, em 1905, ele dizia que a função da história envolve "reviver" ou Nacherleben e que seu objeto eram seres humanos em sua individualidade. Isto

\footnotetext{
${ }^{210}$ Lógica parecida se encontra nas reflexões de Carlo Ginzburg sobre o "paradigma indiciário", em que o detalhe revelador tem proeminência sobre os efeitos conscientes da obra.
} 
diferenciava a história das ciências, que operam com conceitos gerais. Com apoio nos elementos visuais da evocação de imagens, o historiador produzia uma "presença imaginária" do passado. Notemos que todos estes elementos são recusados na definição de "sensação histórica" do texto de 1926 destacada por Ankersmit. Como Ribeiro mostra, nos textos dos anos 1920 e 1930, incluindo o que estamos discutindo no momento, a ênfase de Huizinga passou a estar na capacidade da historiografia de “compreender" o passado, mais do que de "revivê-lo". A substituição das metáforas visuais pela auditiva, da "imagem" pela "forma", se mostra no trecho que transcrevemos, que compara a sensação histórica com a compreensão o mundo pela música. Ao citar as semelhanças entre as duas fases, Ribeiro afirma que, ainda que nesta fase mais tardia Huizinga considere que a sensação histórica fica "reclusa na subjetividade do historiador", ela "podia vir à tona de quando em quando na narrativa histórica através de lampejos em que o passado parecia viajar como um 'passageiro clandestino’ (RUNIA 2006, p. 315) para o presente" (idem: 245). Quando isto ocorre, o leitor pode adquirir "uma percepção mais nítida, mais versátil e intensa do passado" (idem: 245). Embora Runia não dialogue com Huizinga em seus textos, sua conexão entre presença e metonímia explicaria esta possibilidade. O passado se faz presente por meio do que no presente são Fremdkörpers, descontextualizados, mas que remetem metonimicamente ao contexto com o qual eles estavam harmonizados. Notemos que, para Runia, a possibilidade de "passageiros clandestinos" oriundos do passado estarem presentes pode parecer remeter a uma noção de "reviver" o passado, mas notemos que em alguns textos Runia enfatiza que a própria cultura é um depositório de presenças. $\mathrm{O}$ reconhecimento deste depositório poderia ser aproximado ao reconhecimento da "forma" cultural do passado.

Esta dimensão do que "não precisa ser dito" (RUNIA, 2014, 2019) pode ser mais aproximada à compreensão mediante formas vagas da sensação histórica do que algum pressuposto diante do qual se poderia objetar algo como "o passado já passou, portanto não há tal coisa como presença do passado". Como Huizinga deixa claro, a presença não é incompatível com a compreensão, por meio da qual se produz uma forma para o passado, forma esta que permite experienciá-lo. Daí portanto uma de nossas teses: a que afirma que a "direticidade" da experiência subjetiva e da presença não implica que a mente não produz formas e que acessa o mundo "em si". Pelo contrário: como este caso mostra bem, a percpeção de um objeto descontextualizado estimula causalmente a compreensão, por meio de uma forma, de como o passado realmente foi. Não há um 
objetivismo aqui: a subjetividade do experienciador é parte fundamental da configuração assumida pela forma. Mas não é um mero idealismo na experiência subjetiva: a forma revela o passado real. Pois é assim que qualquer realidade, passada ou presente, se revela. Demandar algo diferente só faz sentido caso se conceba que a mente espelha a realidade. Quando um pós-modernista objeta que o passado já passou, está pressupondo que o presente, que não passou, possa ser acessado sem formas, "diretamente". Assim, a experiência do passado é direta, mas direto não significa "sem forma".

A forma musical do que "não precisa ser dito", pré-individualização do mundo, se distingue de tudo que é individualizável e dizível no mundo: a forma é o que permite dizer. Esta não-contradição entre subjetividade e acesso ao passado é compatível com as reflexões de Ankersmit e de Runia: para este, para que o mundo se revele objetivamente é preciso mais subjetividade, pois o mundo se mostra a partir dos "pontos de vista"; para Runia, a presença do passado tem a forma da metonímia, que - complementemos é uma ação mental na qual a conexão do artefato percebido com um mundo outro, onde ele não era um Fremdkörper, é notada.

Adicionalmente, argumento ao longo desta tese que embora o passado em sua dimensão objetiva tenha passado irrevogavelmente, o fato de que a realidade humana entrelaça subjetividade e objetividade faz com que haja nela algo dotado da mesma maleabilidade que Ankersmit buscou expressar ao buscar, em episódios da história do pensamento ocidental, a figura da cera. Portanto, a subjetividade do passado pode ser acessada pela subjetividade no presente, capaz de atribuir-lhe formas que, longe de nos afastar dela, nos dão "acesso". Até a metáfora da cera pode ser rígida demais para tratar da maneira pela qual a subjetividade ${ }^{211}$ faz aparecer o mundo objetivo: pois o mundo que aparece na experiência já é o mundo perspectivado pelo sujeito que o habita, e este mundo pode ser "intuído". 212

\section{Passividade e atividade}

Mas além de "ser carregado pela experiência", como nos fenômenos de presença, cabe notar que a atitude com a qual o historiador interroga o passado envolve

\footnotetext{
${ }^{211}$ Que, como vimos com Dewey, estava no mundo e não em uma posição transcendente em relação a ele. É por isso também que não é justa a acusação contra Collingwood de que, por considerar que a história ocorre no pensamento, ele a concebe de modo que ignora inteiramente o inconsciente, as emoções, o ambiente natural.

${ }^{212}$ A discussão sobre "moods and feelings", mais adiante, endossa esta tese.
} 
sempre algum grau de abertura nos casos em que a experiência subjetiva se manifesta. A presença de "questões em aberto" são pré-requisito para que objetos como pinturas, câmaras funerárias e peças de mobiliário atraiam a atenção de alguém no presente. Pois uma das coisas que pode ser dita pela relação entre consciência e o ambiente é precisamente que a atenção tanto é ativamente direcionada quanto é atraída. Pensemos sobre como raramente notamos placas de "aluga-se" nas ruas quando o tema não mobiliza nosso interesse, e como as notamos quando buscamos uma casa para alugar - e tão mais se a busca é ligada a projetos pessoais nos quais temos grande investimento emocional. Algo de importante nesse caso é que o direcionamento da atenção não se dá apenas rumo a elementos definidos, mas também na forma de abertura ou questionamento: ela pode ser uma abertura às possibilidades do ambiente. Isto possibilita que ocorra o que Ankersmit descreve: "Parece ser uma assunção perfeitamente razoável que nestes objetos uma Hauch ou aura do próprio passado [of the past itself] foi preservada ao longo dos séculos e que o sujeito da experiência histórica repentinamente tomou consciência dele.” (115) E assim também na descrição de Huizinga: a sensação histórica é desencadeada por um artefato específico, que já se encontrava aberto a "ouvir seu chamado" mas não sabia previamente de onde ele viria, nem a forma que assumiria. E aquilo que é desencadeado não é, também, específico, mas a forma, música ou atmosfera do passado.

Ankersmit ressalta ainda outros dois elementos da experiência histórica descrita por Huizinga que se conectam com o ponto em discussão. Primeiro, ela vem sem ser anunciada e não pode ser provocada ou repetida voluntariamente. Segundo, assim como as intuições, elas produzem revelações súbitas; mas: “enquanto no caso da experiência histórica a mente do historiador é formada pelo passado, no do insight histórico é, ao contrário, o historiador que dá forma ao passado”. “... na prática haverá uma interação intensa entre os dois." (128) Sobre este ponto, duas coisas podem ser notadas. As reflexões teóricas de Huizinga parecem se harmonizar bem com a interpretação processual que aqui oferecemos das reflexões narrativistas. Como a "sensação histórica" e a "imaginação histórica" aparecem como dois momentos, um em que o passado molda o historiador e outro em que o historiador molda o passado, e é evidente que a existência de ambos funciona da maneira que, conforme Dewey, perpassa toda a experiência humana: a relação entre passividade e atividade - relação que, também no 
caso da historiografia, demanda um equilíbrio entre ambos. ${ }^{213}$ Entendidos como momentos, o que está em jogo não é mais a escolha entre um conceito transcendentalista e outro não-transcendentalista - ambos funcionam bem nos moldes anti-transcendentalistas da filosofia da história existencialista que Ankersmit deseja construir. Notemos, assim, que a "imaginação histórica" não opera com uma mera imposição de significados sobre os eventos, e a "sensação histórica" não prescinde da subjetividade daquele que a recebe. Há ora o predomínio de um polo, ora o predomínio de outro, mas "sujeito" e "objeto" estão sempre conectados - e sua superação é antecedida pelo pertencimento básico de ambos ao processo histórico, no qual o passado faz o historiador no presente, que por sua vez faz o passado.

Em segundo lugar, e seguindo o raciocínio anterior, esta relação processual produz como que uma dialética entre uma perspectiva mais aristotélica e outra mais "kantiana" - mas entre aspas, e já veremos por quê. Como Jonathan Menezes notou (2018: passim), Ankersmit oscila instensamente em sua relação com o transcendentalismo, buscando superá-lo enquanto pressuposto filosófico mas frequentemente apresentando-o como uma dimensão realmente existente, mas apenas não tão dominante de toda experiência como a tradição em Gadamer, os tropos em White ou o vocabulário em Rorty. Assim, haveriam os elementos transcendentais, e em suas margens ocorreriam as experiências históricas. Ainda que esta tensão exista e não seja resolvida, eu enfatizaria a validade de uma de suas soluções: quando aponta a presença de elementos transcendentais em Sublime, ele os trata como elementos contingentes da experiência, formados historicamente e passíveis de dissolução; são elementos psicológicos e não apriorismos. Ainda assim, o hábito faz com que usualmente operemos "aprioristicamente" (novamente entre aspas), não porque sejamos capazes de bloquear o input do ambiente (com o qual sempre estamos em relação), mas porque lidamos com ele de maneira que produz uma falsa familiaridade - como a atitude de quem já sabe o que irá encontrar e apenas "aplica" categorias (como Ankersmit buscava evitar). Mas trata-se de uma atitude psicológica, ainda que bastante usual, e não de uma condição incontornável. Quando há abertura ativa, surge a possibilidade de sermos passivamente arrastados no contato com estes objetos “irrelevantes" ou obras de arte "menores".

${ }^{213}$ Como afirma Ribeiro (2010: 245), ... a "sensação histórica" (Ahnung) molda a mente do historiador por meio de uma experiência "epifânica", enquanto a "imaginação histórica" do historiador molda o passado, possibilitando que a história funcionasse como o que Huizinga denominava de "ciência das formas". 
Isto tem implicações para a questão de como conceber a relação entre visão, por um lado, e os demais sentidos, por outro. Em uma perspectiva transcendentalista, a visão presumiria um distanciamento absoluto que simplesmente inexiste no caso da historiografia, e mais ainda da experiência histórica. Em uma perspectiva nãotranscendentalista, porém, a visão indica um distanciamento relativo, uma reflexividade que (como vimos com Collingwood) não pode jamais se separar inteiramente daquilo sobre o qual ela reflete. Vimos que, no caso de Huizinga, o abandono da metáfora visual em proveito da auditiva tem outro sentido ainda: a substituição da Nacherleben pela Ahnung. Do que se pode perceber que não há um sentido unívoco para o emprego destas metáforas. Há, porém, como apontar uma dimensão da existência a partir da qual elas se individualizam em formas distintas de perceber o mundo, literal ou metaforicamente.

\subsubsection{A divisão antecedida por uma unidade básica}

Em Sublime, como em Meaning, Ankersmit cita um projeto de tese de doutorado abortado por Huizinga. Sua ideia era "investigar as expressões para a percepção sensorial de luz e som empregadas nas línguas indo-germânicas" (2005: 129), produzindo, como Meaning enfatiza, uma teoria da sinestesia (2012: 200-205). Ele considerava haver palavras - palavras que "originalmente expressam uma sensação, um humor [mood], uma atmosfera, e não um conceito bem-definido" (129) - capazes de expressar o que há em comum com a audição e a visão (ou outros sentidos). Por exemplo, a palavra "feroz" (Ankersmit cita em inglês: "fierce"; em holandês: "fel") é um elo entre estes sentidos, graças ao qual a metáfora sinestética "o som vermelho do trompete" pode ser compreendida. Ela "expressa algo que ver e ouvir têm em comum."

E o que ambos têm em comum, neste caso, aparentemente ainda não foi diferenciado, ou separado, na correspondência com a natureza destes dois sentidos, e, logo, necessariamente nos refere a um nível no nosso contato com a realidade que é anterior a, ou mais profundo que, tanto ver quanto ouvir. Feroz portanto pertence à categoria de palavras que expressam a experiência mais íntima e direto que nós podemos ter da realidade.” (129)

Assim, se antes discutíamos a relação entre visão ("kantiana”) e toque (“aristotélico"), a discussão agora se foca em um ponto anterior à individualização da experiência nestes dois sentidos. Ele também antecede distinções epistemológicas como aquela entre sujeito e mundo. Ankersmit descreve este ponto comparando sua abordagem com a de Gadamer: 
Aqui nós realmente chegamos a um ponto no qual as barreiras epistemológicas entre linguagem, experiência e realidade começam a se romper e onde as três parecem se fundir uma na outra. Mas este contato mais íntimo não é obtido, como no caso de Gadamer, por um entrelaçamento de realidade, experiência e linguagem, mas por um contato entre os três no qual a natureza individual de cada uma delas é cuidadosamente respeitada, apesar do relacionamento mais íntimo que foi efetuado entre elas. (129)

De fato, chegamos a um ponto profundo o suficiente, onde se pode argumentar que a tese rortyana já não se sustenta: o que é experienciado neste nível pode posteriormente, e muito incompletamente, ser expressado por meio da linguagem poética, mas aqui não há ainda linguagem operando. Aqui efetivamente há experiência sem linguagem. Ao mesmo tempo, o comentário sobre Gadamer neste trecho não precisa assumir a forma de uma objeção (se foi ou não a intenção de Ankersmit, não sei dizer), pois o caso é que a hermenêutica gadameriana opera em outro nível e o tipo de experiência que ela busca é também de outra natureza. ${ }^{214}$ Mas aqui chegamos ao ponto que considero mais interessante: quando Ankersmit diz que a natureza de "realidade", "experiência" e "linguagem" é respeitada, e compara com a concepção gadameriana onde eles se interpenetram, as duas descrições estão corretas - pois, como apontamos, elas tratam de níveis diferentes. Com uma diferença: quando estamos no nível mais básico, não há ainda uma linguagem em operação; quando, nos níveis mais abstratos, a linguagem entra em jogo, então ela é interpenetrada por esta dimensão mais básica. Da mesma forma, quando as reflexões mais abstratas, de tipo científico ou moral, são realizadas, também elas não se separam da "atmosfera". Elas têm reflexividade e autonomia relativa, mas são sempre expressão de uma atmosfera mais básica. Da mesma forma, mesmo a atividade científica, que abstrai consideravelmente do mundo da vida, segue conectada a ele: a epistemologia não só segue esta dimensão estética mais básica, mas é também penetrada por ela. ${ }^{215}$ O que ocorre no nível mais básico, por sua vez, pode ser retroativamente afetado pelas atividades mais reflexivas, já que a experiência se organiza holisticamente.

Sujeito e mundo, assim, parecem surgir na experiência como separados (gerando o problema epistemológico de como o sujeito pode conhecer o mundo), mas suas

\footnotetext{
${ }^{214} \mathrm{Na}$ introdução de History and Tropology, Ankersmit afirma não discordar das conclusões de Gadamer quando estas são aplicadas à história intelectual e à filosofia, mas que no caso da história das mentalidades - primeiro lugar onde ele busca o tipo de experiência que tem como objeto o que "costumava ser parte de nós mesmos mas se tornou estranha, alienígena, ou desfamiliarizada." Gadamer, dizia ele, privilegia o processo de familiarização. Além disso, Ankersmit afirmava que nas experiências históricas de Huizinga e Goethe não há a limitação textualista da filosofia de Gadamer. (HT, 209-11, n59) ${ }^{215} \mathrm{O}$ que significa, para a distinção whiteana entre os passados prático e histórico, que o histórico nunca deixa de ser prático - apenas obscurece sua praticidade, quando age de má-fé, ou decide não enfatizá-la.
} 
configurações são ambas "coloridas" pela atmosfera que delimita o campo de configurações possíveis que eles podem assumir. Como a formação do sujeito e do mundo são posteriores à unidade básica da atmosfera, é inteiramente justificado que Ankersmit fale sobre como o sujeito "sai de si mesmo" e que se "descontextualize". Pois o contexto histórico e toda a rede de relações significativas que produzem a subjetividade ocorrem, em termos collingwoodianos, a partir do segundo nível de consciência.

Considero necessário, porém, reconsiderar a maneira pela qual Ankersmit concebe noções como "realidade" e "experiência". Seria concebível usarmos o termo "realidade" para a matéria e os outros seres externos a nós, mas percebamos que, ao falar de experienciar a dimensão mais básica da realidade, não é a isto que ele se refere: pois a atmosfera não se encontra nos tilojos dos locais nem na carne e osso dos seres (nem é, por outro lado, solipsista), mas na maneira pela qual a consciência se relaciona com eles. Assim, nesse sentido do termo, se presumirmos haver algo como "realidade" que não seja também "experiência", estaremos retornando aos pressupostos transcendentalistas. Um termo como "o contato mais íntimo" presume, ou dá a entender, esta externalidade da atmosfera em relação à consciência do experienciador: pois apenas assim ela seria algo da qual ele poderia ou chegar perto ou ficar longe. Não se tem contatos com a atmosfera; atmosferas são o "local", por assim dizer, onde o sujeito e o mundo se relacionam; ou, ainda, são o local de onde são produzidos o sujeito e o mundo. Por isso, como Huizinga e Ankersmit descrevem, não tenho como ser eu mesmo - de acordo com uma identidade presente, que foi individualizada e construída depois desta unidade mais básica, e inseparavelmente dela - e experienciar o passado. A experiência efetivamente é de ekstatis. Daí sua anterioridade à dicotomia entre sujeito e mundo: termos como "ferocidade" indicam a indivisibilidade entre eles neste nível.

Ao retomar a discussão sobre a teoria da sinestesia em Meaning, Ankersmit abordou a questão de um prisma um pouco diferente

\footnotetext{
Segue-se que o apelo de Huizinga aos humores e sentimentos é sugestivo desta fase primeva - em que a diferenciação entre presente e passado é obliterada de novo. Nós podemos falar então, com Huizinga, de um contato direto com o passado - não porque passado e presente tenham agora chegado infinitesimalmente próximos um do outro mas porque nós momentaneamente retornamos àquela fase primitiva [primeval] em que passado e presente ainda não estavam separados - e portanto na qual não podia ainda haver nenhuma distância entre ambos. (203)
} 
Não vejo como esta afirmação poderia se sustentar. O passado teve uma certa atmosfera - ou ainda, as múltiplas perspectivas de muitos de seus agentes tinham como base atmosferas comuns a ponto de podermos falar na atmosfera de um período (ou de como um grupo experienciava um período) -, que era sua unidade pré-diferenciação. Alguns grupos no presente compartilham suficientemente esta atmosfera para que, por meio das atividades mais reflexivas da consciência, possam reconhecer a dimensão mais básica de onde estas atividades abstratas partiram. Então há este "encontro", que mais adiante argumentaremos ser de natureza figural. E há efetivamente uma unidade, garantida pelo princípio da "identidade dos indiscerníveis" e pelo fato de que a experiência dos agentes, mesmo em seu nível mais básico, só pode ser acessada "de dentro". Então nesse caso defenderei que ele ocorre de modo mais radical do que mesmo o Ankersmit de 2005 estava disposto a considerar: não se trata de chegar "infinitesimalmente perto", como se atmosferas fossem tocadas de fora, gerando um "contato". Trata-se de experienciar um aspecto do passado devido à "afinação" comum entre as pessoas que o experienciaram no passado e a pessoa que o experiencia no presente (e que é feita de passados).

Por outro lado, a retratação me parece cair em um erro insustentável. Esta unidade entre presente e passado não resiste ao retorno àquele momento em que eles eram inseparáveis, porque a divisão entre aspectos da experiência em um sujeito simplesmente não é a mesma coisa que a divisão de um processo histórico entre presente e passado. Retornar à dimensão que gera as experiências de tempo, mas não se confunde com seus conteúdos particulares, equivale a não poder experienciar o passado, pelo simples fato de que ali não há passado. Não é possível respeitar a distinção entre presente e passado do mesmo jeito que é possível respeitar a distinção entre visão e olfato. Argumentando adicionalmente com um exemplo: nessa unidade básica de toda experiência, qual seria a diferença entre experienciar "o outono da Idade Média" e o passado mesopotâmico? Huizinga pode ter suas experiências, e também Ankersmit, e Jay, e Praz, e outros mais, porque operavam ou passaram ou operar no mesmo tom que o passado. Eram duas unidades, a do passado e a do presente, e elas foram transformadas em uma unidade-de-multiplicidades pela relação figural que se estabeleceu (e elas próprias, quando dizemos que eram uma, também era na forma de unidade-de-multiplicidades).

Assim como a "ferocidade" indica algo que existe no som e na cor, a atmosfera - que no caso daquela estudada e expressada no Outono Huizinga inclusive descreve 
também como a de "ferocidade" - indica algo que houve no passado e que há no presente. Mas, ora, já houve muitos passados, e o que se experiencia ao acessar uma atmosfera específica não é a união entre o presente e o passado, caso contrário teríamos que reconhecer que tal experiência não é a de Huizinga experienciando especificamente a Baixa Idade Média, nem de Ankersmit experienciando o século XVIII, nem de Jay experienciando um aspecto da Primeira Guerra Mundial à luz de guerras posteriores: a experiência teria que ser da indivisibilidade entre o presente e qualquer passado. Por esse motivo, creio que o Ankersmit de 1994 - refigurado pela nossa leitura - tem razão em considerar que a experiência é da diferença-na-unidade entre passado e presente: a diferença entre uma atmosfera específica (a unidade de um mundo cujos suportes materiais e orgânicos existiam) e outra atmosfera específica (a unidade do mundo atual, cujos suportes materiais e orgânicos existem), vistas enquanto totalidade no gesto em que, retroativamente, um experienciador no presente reconhece um aspecto da atmosfera passada, por ser ele próprio feito por uma atmosfera suficientemente parecida para que aquela possa ser tornada figura desta. Esta não é a unidade-com-diferença do presente com todo o passado, mas entre atmosferas históricas específicas.

\subsection{3. "Contato com a realidade": mas "contato" e "realidade" em que sentido? Ou: concretude e abstração}

Os termos descritos por Ankersmit carregam princípios ou pressupostos que, a meu ver, criam alguma confusão. O que seria a "realidade" sem "experiência"? O que seria uma "linguagem" existente fora da "experiência"? Se realidade for a materialidade, sim, podemos dizer que as pessoas no passado tinham contato com uma parede sem necessariamente projetar significados sobre ela, e, claro, que a parede estava lá quando ninguém a experienciava (até a palavra "parede" diz muito). Mas a experiência da "atmosfera" do passado é a experiência de uma dimensão, a mais básica, da realidade passada - "realidade" entendida aqui como aquilo que surge na relação inseparável entre sujeito e mundo. Um mesmo conjunto de tijolos surge (é apresentado) de maneiras muito diversas em mundos (experienciados) diversos, e aqui já estamos no campo da experiência. Experienciar o passado envolve sempre se mover no campo de entrelaçamentos passados entre o mundo material e da relação de mentes incorporadas com eles. $\mathrm{O}$ argumento de que o passado se perdeu para sempre foca na dimensão material - decisão um pouco contraditória quando é tomada por pós-modernistas, que insistem precisamente no fato de que é a consciência quem produz as significações do 
mundo. Ora, a dimensão mental pode ser acessada, e mesmo a apresentação à consciência do mundo material pode ser imaginada (como White mesmo reconheceu em vários momentos), se há informações e compreensão o suficiente para isto.

É possível manter distintos experiência e linguagem em muitos casos, mas toda experiência do passado envolve as significações pré-linguísticas e linguísticas atribuídas ao mundo. Nenhum mundo histórico surgiria como "feroz" se isso não ocorresse. Imagine alguém em profunda tranquilidade na França e nos Países Baixos de fins da Idade Média: esta pessoa não experienciaria o mundo como feroz. Imaginemos, inversamente, um CEO ainda muito conectado às urgências de seu emprego: enquanto esta forma de experienciar a temporalidade estiver presente nele, sua experiência das férias em algum país tranquilo do exterior não será idêntica à dos nativos. As características do espaço e a intersubjetividade afetam fortemente a experiência do tempo, mas até o que há de aparentemente objetivo - como a intersubjetividade - indica precisamente o fato de que a experiência da realidade não é meramente "objetiva". 216

Assim, se efetivamente desejamos operar fora do transcendentalismo, seria mais preciso falar não em um "nível no nosso contato com a realidade que é anterior a, ou mais profundo que, tanto ver quanto escutar", mas "um nível de experiência" mais básico, com tais características. E este é, em nossa visão, o componente mais básico do que Collingwood chama de "o segundo nível de consciência" e do que, ao discutir o pensamento de White, estamos chamando neste trabalho de elementos prefigurativos. Isto explica também porque a reflexão - manifestada como forma de lidar com os sofrimento causado por eventos sublimes - produz uma "perda" da imediaticidade: ela direciona a atenção para atividades mais abstratas, que são interpenetradas pela "atmosfera" mais básica do mundo, mas cuja conexão pode se perder, caso a atenção se foque apenas nos níveis mais abstratos e não produza integração entre seus diversos níveis. $^{217}$

Ao descrever a conexão de Huizinga com o movimento sentivista holandês, Ankersmit apresenta algumas imagens que tomaremos como base para discutir as consequências do argumento que acabo de apresentar. Ankersmit cita especialmente o caso de Van Deijssel, que foi uma influência importante para Huizinga. (130) Van Deijssel distinguiu entre "observação", "impressão" e "sensação", o último dos quais

\footnotetext{
${ }^{216}$ A discussão sobre condições de prefiguração e os exemplos do medo e do ódio mobilizados no capítulo 2 embasam esta afirmação.

${ }^{217}$ Em Nas Sombras do Amanhã, Huizinga localiza dentre os problemas de seu tempo uma redução da capacidade de julgar.
} 
“expressa o contato mais íntimo que podemos ter com a realidade, e aqui sujeito e objeto estão em completo equilíbrio - este é o estágio mais elevado do nosso encontro com o mundo. A sensação é, por assim dizer, um abraço mútuo de sujeito e objeto em que cada um se dá completamente e irreservadamente para o outro, sem nenhuma relutância. (130)

Aqui a objeção pós-modernista está correta. Ainda que possamos reservar agência ao mundo e/ou ao passado e falar em "passado vivo", este tipo de entrega na qual há "um abraço mútuo de sujeito e objeto" com as características descritas não se sustenta. Apenas uma pessoa pode relutar e se entregar. O que poderia, então, ser este encontro? Podemos falar em um nível individual e em um intersubjetivo. No individual: parte do que uma pessoa em conversa com outro pode fazer já foi feito por pessoas do passado, e parte do que ela poderia oferecer como resposta às nossas intervenções pode também ser imaginado. As tradições a que ela poderia dar voz seguem acessíveis a nós. Assim, a abertura ao que o outro disse e ao que o outro diria - acessível dentro dos limites negociáveis, e não rígidos, da nossa própria imaginação - possibilita este tipo de encontro. No intersubjetivo: o que podemos chamar de "aura" do passado é uma apresentação que é sobre aspectos do passado apresentados na mente de várias pessoas; é, mais especificamente, uma asbtração (ou produção de "totalidade simultânea") baseada no que alguém no presente pode preencher daquilo que vários seres do passado entenderam como "o mundo", i.e., do nível mais básico de suas experiências. Não há motivos para presumir que este mundo não pode, ao ser apresentado, ser experienciado no presente. Em um caso assim, na medida em que o historiador precisa não ser quem ele usualmente pensa que é - pois sua identidade é indivisível do mundo presente, tal como ele o experiencia -, esta experiência modifica os campos dos possíveis constitutivos de quem ele é. Usualmente este encontro se dá em níveis excessivamente abstratos do intelecto, mas aqui Huizinga busca precisamente operar no nível mais concreto possível, mais básico possível. A noção de escala de formas nos lembra que é possível fazer o movimento do nível mais abstrato pro mais básico, abdutivamente; a noção de figuralismo nos lembra que isto só ocorre se aquele que busca repetir a experiência no presente tem em si um preenchimento adequado para fornecer à figura do passado. Assim sendo, a experiência "concreta", capaz de remeter até mesmo às sensações físicas, ocorre no presente, mas é também uma experiência do passado, pois ela só ocorre quando há a descoberta desta afinidade entre o sujeito-no-mundo no presente e os sujeitos-o-mundo do passado (nesse nível em que sujeito e mundo ainda 
não se diferenciaram). Assim, a união entre sujeito e mundo não é a mesma coisa que uma união entre presente e passado: o que ocorre é que a atmosfera onde ocorre tal união pode ser compreensível, ou experienciável, para algumas pessoas no presente, que operam no que poderíamos chamar, por meio da analogia, de uma mesma tonalidade musical. É por isso que Ankersmit pode observar (embora sem chegar à mesma conclusão) que "Huizinga atribui ao homem medieval um contato com a realidade que é estruturalmente similar à sua própria experiência do passado medieval investigado por ele." (136)

Nosso ponto sobre a realidade ser composta da interprenetração de elementos concretos e abstratos pode ser refeito em sua analogia com "o abraço de Romeu e Julieta", que, como mencionamos, daria título ao livro: "amor é algo que você faz com os seus dedos, a sua boca, e assim por diante, não é?"

O componente mental não deve ser esquecido, e ele muda tudo: amor é algo que se faz com mente e corpo simultaneamente. Sexo entre humanos potencialmente não é o mesmo que entre animais, e isto envolve o entrelaçamento entre toques e significados. Isto é, os amantes não precisariam se perder em abstrações - ao menos, não é o que o presente trabalho recomenda -, mas o significado atribuído ao outro se manifesta (inclusive) no próprio toque, ainda que a princípio a sensação física de uma mão tocando na outra não seja, por si só, erótica. ${ }^{218}$ Como a própria reflexão sobre a concretude da arte sensitivista pode deixar claro, significações são atribuídas de forma mais concreta ou mais abstrata, e considero que reservá-la apenas ao nível abstrato obscurece esta característica mais básica da "realidade humana". A falsa alternativa que também não defendemos, por outro lado, seria projetar linguagem em tudo e afirmar que experiências sensoriais já estejam sempre invariavelmente predeterminadas pelo espaço dos possíveis da "prisão da linguagem".

Algo que creio necessitar de ajuste na posição de Ankersmit é a tendência de associar "realidade" ao concreto (ainda que no justificado afã de rejeitar a atribuição de realidade à abstração linguística): concretude e abstração, ambos são formas de experiência da realidade; ambas desvelam aspectos da realidade; e "o passado" que cuja

\footnotetext{
${ }^{218}$ Ver os comentários de Danto (2011: 155), comparando a relação sexual com o senso estético. Para ele, não seria sustentável presumir que este se diferencia daquele por ser "desinteressado": também nele pode haver um desejo de "possuir" o objeto, ainda que exemplos como o da contemplação do pôr-do-sol obscureçam tal possibilidade. Na linguagem do atual trabalho, que valoriza o princípio da despossessão, trocaríamos a concepção de "posse" pela do encontro, troca, união, onde o sujeito não busca transformar o "outro" em "mesmo" - por não ser sequer concebido como idêntico a si mesmo. Além deste ponto, Danto insere a discussão no contexto onde ele argumentava precisamente que faculdades como a de reagir não são meramente questão sensorial, mas também do tipo de valoração atribuído à situação.
} 
aura pode ser experienciada foi um entrelaçamento de ambos. Tanto é que, embora ele afirme que "o olho é o mais 'transcendentalista' dos nossos sentidos", e em seguida aponte que o sensitivismo se move rumo ao concreto - ao contrário do simbolismo, que se move rumo ao abstrato -, o exemplo sensitivista que ele dá envolve o elemento da visão:

... o sentivista quer entrar na realidade [ "creep into" reality] e superar todas as barreiras entre o self e o mundo. Assim, quando Herman Gorter (o inquestionado gênio literário dentre os sensitivistas) pode olhar para as cores do céu noturno e então se sentir afetado pelo silêncio de suas nuvens, isto foi para ele um reconhecimento subconsciente de ter se tornado, ele próprio, parte destas nuvens, e de participar de seu silêncio majestoso. (131)

Um pouco adiante, ele cita uma passagem de Huizinga em que, novamente, visão e intensidade (o que equivale a um tipo de "proximidade", a emocional, no sentido de que emoções intensas não permitem “distanciamento") aparecem relacionadas: "Enquanto eu escrevia este livro foi como se meu olhar estivesse voltado para as profundezas de um céu noturno, mas de um céu tomado de vermelho-sangue, pesado e desértico, de um cinza-chumbo ameaçador, revestido de um falso brilho cúprico". ${ }^{219}$ Ankersmit prossegue: "É assim que Huizinga, tal como expressada em uma única frase profundamente impressionista, experienciou, no sentido mais literal da palavra, 'a atmosfera' da Idade Média burgúndia tardia.” (135)

Ankersmit observa que, para os Tachtigers, "a linguagem deveria ser 'puxada de volta para dentro da realidade', por assim dizer, e portanto teria que rejeitar todas as intimações, reminiscências ou sugestões de abstração e do que não pode ser reduzido à percepção sensorial, melhor exemplificado pelo sentido do toque.” (135)

A atmosfera e, de modo geral, a experiência pode ser melhor expressa em termos da analogia com o toque, mas o estilo ou Hauch ou aura de uma época - que é o que interesse especialmente Ankersmit - não é simplesmente o que está acessível aos sentidos físicos. Sensações e emoções, também citadas no texto, são parte do que constitui uma atmosfera e não vejo como elas possam ser lançadas no mesmo pacote que a percepção sensorial exceto por uma certa frouxidão conceitual. Para citar apenas um problema, não há um algoritmo que determine quais emoções são mais adequadamente expressadas por referência a elementos concretos do mundo e não aos mais abstratos.

\footnotetext{
${ }^{219}$ Como minha edição utiliza português de Portugal, utilizo a tradução de Petra Jansen apud MENEZES, 2018: 213). A primeira frase foi traduzida por mim a partir da citação de Ankersmit.
} 
Dois contra-exemplos ao raciocínio de Ankersmit: a imediaticidade pode incluir emoções mas não incluir o toque. Emoções e sentimentos (como no caso da saudade) podem nos afastar da imediaticidade. Exatamente porque "realidade" inclui emoções - e também pensamentos e conceitos - perder-mos-nos em abstrações por si só nos afasta dela. Mas o desvelamento da "realidade" não deve ser igualada a "menos abstrato", e sim à possibilidade de apresentar as conexões entre os níveis concretos e os abstratos, relevando a maior multiplicidade possíveis de aspectos da "realidade humana" experienciada por seres humanos no passado. Esta última é perpassada pela "complexidade" da qual Ankersmit falou ao defender frente aos construtivistas a possibilidade de "experiência" do passado. Termos como "contato direto" e "realidade" dão espaço para a mistura entre estes dois significados porque são respectivamente vagos e polissêmicos. Mas Ankersmit, a meu ver, está misturando duas coisas diferentes.

Em Huizinga, faz sentido que a linguagem produza esta sensação de imediaticidade, pois tal característica é exatamente a que ele atribui ao seu objeto e à qual busca expressar textualmente. A atmosfera de uma sociedade pós-industrial, experienciada por alguém que a considera marcada por ênfase excessiva da abstração e na desconexão entre esta e as sensações e emoções mais imediatas - é como Donald Philip Verene a caracteriza -, poderia ser uma realidade só passível de expressão com recursos outros que não os que remetem à imediaticidade. Verene apresenta este exemplo por meio do contraste entre a concretude dos homens primitivos de Vico e a alienação em abstrações tão usual no século XX. Ao dizer isto, podemos observar que Huizinga caracteriza a experiência medieval em termos muito parecidos com os que Vico emprega para a experiência dos primitivos, comparando sua condição à de crianças: "toda a experiência tinha ainda, para as mentes dos homens, a condição direta e absoluta do prazer e da dor da infância”. (136)

Desta associação entre "concretude" e "realidade", Ankersmit extrapola para outra tendência da qual discordo em sua filosofia: a de situar a "verdade" em um dos "lados" do que efetivamente é uma relação entre passado e presente, seja na experiência histórica, seja na representação. Aqui, ele afirma: “A verdade está na realidade, não no que nós dizemos sobre ela; ela será encontrada no movimento rumo à realidade e não no movimento rumo à abstração que é a sedução perena da linguagem." A primeira frase propõe uma concepção que afirmei considerar equivocada, a de que a verdade "esteja" em um dos polos de uma relação dualista, neste caso entre "realidade" e "abstração". 
Isto já reinsere o problema transcendentalista que Ankersmit corretamente quer evitar. A segunda frase é melhor: a verdade pode ser concebida como uma relação. Nesse caso, falaríamos em concretude e não em realidade, termo que - no que diz respeito à realidade que surge como objeto da escrita histórica - deve englobar tanto a concretude quanto as abstrações do passado. ${ }^{220}$ Assim, podemos concordar com ele que uma verdade sobre a realidade passada é aquela a ser encontrada no movimento da linguagem abstrata para a concretude - e isto é especialmente verdadeiro no caso em que a característica da concretude, expressada na forma do texto, se encontra também no objeto - que é não algo como um "passado em si", mas a "realidade experienciada" que é a "realidade humana". É nesta mesma linha de raciocínio que podemos concordar com White acerca da necessidade de apresentar os "eventos modernistas" com recursos formais propícios - que podem ser aqueles fornecidos pela literatura modernista, embora também argumentaríamos, sem contradizer o raciocínio dele, que novas formas poderiam ser produzidas.

A presença de um artefato material, em sua concretude, acessível à percepção sensorial direta, tem o poder de provocar disrupção nas narrativas e representações que contamos usualmente. Isto é especialmente verdadeiro nas narrativas sobre o passado, que circulam quase sempre no movimento horizontal de abstração para abstração, e quando há movimento vertical, é de fontes arquivadas para a narrativa, e de volta. (Isto se concordarmos com White que as disputas historiográficas são mais sobre interpretações do que sobre fatos; não porque se possa prescindir destes, mas porque é mais fácil chegar a acordos relativos sobre eles, quando os membros do campo profissional atuam de boa-fé - por exemplo, não sendo negacionistas.) Quando compreende (reúne em totalidade) as estórias abstratas e o artefato concreto, agora descontextualizado ou reinserido no contexto de um museu, a mente pode vir a reconhecer o quão insuficientes são as abstrações sobre o passado para dar conta da complexidade da vida passada.

Afinal, o passado existiu (ou os passados existiram, já que a unidade surge pela substancialização narrativa) como uma complexa intrincação de linguagem e matéria, mas as estórias que contamos no presente não são uma mera repetição das estórias da vida no passado (quando são repetição, diferem do original no fato de que o original era

\footnotetext{
${ }^{220}$ Alguns passados foram mais marcados por uma atmosfera de concretude e outros por uma atmosfera de abstração, e portanto esta questão ainda se relaciona com aquela da relação entre a forma literária a ser adotada no presente e as experiências dos agentes no passado.
} 
original - e como todo original, envolvia suas próprias repetições, mas outra repetição que não esta). Pois mesmo que a estória seja igual, a igualdade é apenas formal: ela agora não existe como parte da vida, como lances em jogos linguísticos, como atos de fala. O contato com um artefato parece produzir, nestes casos, não uma atenção unicamente ao concreto, mas à imbricação entre materialidades e estórias (passadas, não as estórias presentes sobre o passado). Esta quebra da abstração de segundo grau (das estórias do presente) por meio do contato com a concredute aparece no relato de Martin Jay sobre uma experiência sua. A interpretação que ele oferece reafirma praticamente todos os pontos da sensação histórica de Huizinga e da interpretação de Ankersmit (descontextualização, autenticidade, passividade). Em seguida apontaremos algumas diferenças menores entre sua reflexão teórica sobre a experiência e a nossa. Com o perdão da citação longa, vejamos suas palavras:

Durante uma visita ao campo de concentração nazista em Theresienstadt no ano anterior [1994], eu cheguei inesperadamente na cela de prisão onde o assassino adolescente do arquiduque Franz Ferdinand apodreceu até sua morte em 1918, poucos meses antes do fim da guerra terrível precipitada pelo seu ato violento. Segurando as correntes enferrujadas que haviam prendido o pobre menino ao chão de sua gaiola, eu fui arrancado da narrativa de melancolia do Holocausto que eu vinha seguindo enquanto eu caminhava pelo campo. Eu lembrei mais tarde ter sido "como se repentinamente nas páginas de Middlemarch alguém houvesse subrepiticiamente introduzido um capítulo, digamos, de A Cartuxa de Parma." "21 Incluído na minha narrativa do Holocausto havia estado uma pesarosa [mournful] ruminação na vida truncada do poeta, dramaturgo e criador de marionetes Petr Kein, um jovem homem com quem eu havia claramente me identificado, e um daqueles fantoches estava à vista no museu no campo. "Como," eu me perguntei, "eu poderia reconciliar meu devaneio de admiração pelas mãos talentosas de um inocente jovem marionetista com o choque que eu senti na 'presença' das mãos algemadas de um assassino infame?" Minha resposta foi refletir sobre o emaranhamento do Holocausto com a violência desencadeada pela Primeira Guerra e a catástrofe ainda em andamento nas Bálcãs após a desintegração da Iugoslávia, que envolveu novas variantes da limpeza étnica que havia atingido seu ponto máximo no extermínio dos judeus pelos nazistas. Assim, eu fui levado a ponderar sobre a inextricabilidade do Holocausto, por mais que alguém possa querer pleitear sua singularidade inefável, na teia emaranhada de horrores descarregadas junto com a bala de um assassino e que ainda segue girando oitenta anos depois. ... Tais foram minhas tentativas de fazer sentido [to make sense] de um lembrete material inesperado da Primeira Guerra Mundial em um dos lugares mais perturbadores da Segunda.

Jay explica que a sublimidade de tais experiências, não podendo ser domesticadas por meio de enredos (White) ou contextualização (Skinner), reside na "resistência" delas "à representação ou explicação, estando elas além da capacidade da mera linguagem para redescrevê-las em termos comunicáveis", de maneira parecida

${ }^{221}$ Uma nota de rodapé no texto original remete a JAY, 1998: 197-203. 
com como Kant e Burke teorizaram o sublime. A "reação inarticulada" de Jay naquela ocasião expressa bem a limitação das palavras. Ele relata: "o impulso que tomou conta de mim foi o de sacudi-las o tão furiosamente quanto eu pude, enquanto lançava ao fantasma do garoto que certa vez as preencheu o epíteto terrestre que os prisioneiros de Theresienstadt teriam entendido muito bem: 'Schmuck!!!””

Comentemos alguns aspectos da experiência de Jay. Primeiro, sobre a resistência da experiência à significação. Vejamos ainda que ele especifica: "Talvez o movimento mais ousado [de Ankersmit em Sublime] tenha sido defender um encontro intenso com o passado que se recusa não apenas a ser explicado em termos causais, mas também a ser interpretado como significativo.” (434-5) Se havíamos dito que a experiência perceptual tem a potencialidade de quebrar inteiramente a sensação de "já sei" propiciada por narrativas, podemos ver agora que à quebra se segue o reconhecimento da pobreza de qualquer expressão linguística diante da experiência. Isto, para Jay, torna o evento "sublime". A categorização do presente trabalho é parecida mas não idêntica: estes eventos nos quais se experiencia a sublimidade de tudo a que se atribui significado mostram algo sobre todo o processo histórico. Uma distinção adicional pode ser útil: alguns eventos são psicologicamente sublimes, no sentido de que, enquanto os demais eventos parecem ser passíveis de subsunção a enredos, estes resistem a tal operação. O que isto significa é que, por ser mais intensa e pôr em questão um grande número de narrativas que o experienciador anteriormente sustentava, ele sentirá um afã comparativamente maior de expressá-la às demais pessoas, e se deparará com a impossibilidade da linguagem de fazer tal coisa. Porém, filosoficamente, todos os eventos e processos são sublimes, no sentido de que a linguagem também não os esgota. Esta distinção é a diferença entre os usos (compatíveis, porém distintos) da sublimidade em Ankersmit e em White. Dessa forma, embora White teorize sobre enredamento, ele também está alinhado com a tese de que os eventos são irredutíveis à narrativização.

Um segundo comentário é que o exemplo de Jay mostra a impossibilidade de diferenciar radicalmente as experiências históricas "subjetivas" das "sublimes". Huizinga relata o tipo de ruptura com o seu próprio contexto em termos de ekstasis, mas as narrativas e representações com as quais significa sua própria identidade e seu próprio período não são radicalmente postos em questão, como nos exemplos de experiência "sublime" que Ankersmit discute no capítulo 8 de seu livro. Não considero que a experiência do tipo Huizinga não é a experiência de significados: ela é a experiência do aspecto mais básico das realidades humanas passadas, que são 
significativas (ainda que este significado tenha sido feito por agentes e portanto não seja intrínseco aos eventos; mas a experiência acessa aquilo que outros fizeram, e acessa refazendo-o). Então elas envolvem a quebra da camada presente de significados e permite o acesso, por meio de compreensão retroativa, de aspectos, e não um "reviver", como enfatizou Huizinga. A menção aos aspectos não é ocasional: não é apenas em Meaning, e tratando de representações (históricas), que Ankersmit se refere à noção heideggeriana de aletheia. Já em Sublime ele a usa. ${ }^{222}$ Já as experiências que Ankersmit caracteriza como "sublimes" envolvem a experiência da realidade perceptual sem a mediação das representações usuais, sobre cuja convencionalidade sequer se estava consciente. Há então uma experiência da "sublimidade" da história em um sentido que não se manifesta no caso da experiência subjetiva ou Huizinga. Se compararmos nestes termos, a diferença, como veremos, é que a experiência sublime produz um passado. Em um segundo momento, o evento se mostra resistente à domesticação por todos aqueles que insistentemente tentam expressá-lo, ou que tentam produzir uma nova domesticação - para ele ou para o processo histórico como totalidade. Esta sublimidade psicológica do evento aparece nos dois tipos de experiência. Em um terceiro momento, sobre o qual Ankersmit não discute no livro mas do qual ele é um praticante exemplar, pode haver a reflexão filosófica sobre a convencionalidade de toda significação atribuída aos eventos: este é o sublime whiteano. Ele mostra que mesmo a familiarização é enganosa.

Um terceiro comentário diz respeito à conexão entre sublimidade e significação. Como dissemos, no caso de experiências-Huizinga e diferentemente das "experiências históricas sublimes", há ainda o acesso a significados, pois a realidade humana passada existiu de maneira significativa. E como significados só podem ser experienciados de dentro, há efetivamente uma experiência “direta” - que não é do passado inteiro, mas de um aspecto do passado, que se mostra para alguém do presente capaz de compreendê-lo e apenas nos elementos para os quais ele pode abduzir preenchimentos para suas figuras. Como já dissemos no caso do nível básico onde os "humores e sentimentos" se manifestam, também em experiências que envolvem representações com outros

\footnotetext{
222 Jay concorda: "Se tal experiência tem algum valor de verdade, é aquele de uma verdade revelatória próxima à aletheia de Heidegger, baseada em receptividade passiva em vez de interrogação ativa." Não concordamos inteiramente com o ponto sobre passividade e atividade: diríamos que a experiência é mais receptiva porque o agente está ativamente aberto a recebê-la. Discutiremos isto logo adiante. Notemos que Huizinga também associação a capacidade de produzir formas para o passado por meio de perguntas - mas todo o conceito de Huizinga é efetivamente mais "historiográfico" do que no uso "experiencial" de Ankersmit.
} 
conteúdos, mais abstratos, a terminologia da "proximidade infinitesimal" adotada por Ankersmit pressupõe uma divisão inexistente entre o sujeito e o mundo. Afinal, são representações ou "substâncias narrativas"223 que estão sendo experienciadas, por uma mente cujos corpos e ambientes se situam no presente mas permitem ao menos que se imagine os corpos e ambientes do passado, graças à maneira pela qual eles foram apresentados. O caso de Jay, tal como descrito por ele, parece misturar elementos dos dois tipos, "subjetiva" e "sublime".

Em quarto lugar, ainda sobre significações, mas agora em conexão com a percepção, notemos que Jay não experienciou a "algema em si", mas a algema de Princip, que deu início à primeira guerra. Assim, embora não seja impossível ter experiências sensoriais sem atribuir significados, nesse caso a ruptura foi dos significados de uma estória (de segundo nível), com a manutenção de um conjunto de conexões narrativas mais básicas (de primeiro nível). Sua descrição expressa bem nosso ponto: "como se repentinamente nas páginas de Middlemarch alguém houvesse subrepiticiamente introduzido um capítulo, digamos, de A Cartuxa de Parma." Como toda narrativização é organizada por uma base estética (que é o que Ankersmit chama de representação), não é difícil ver em seu relato que o sentido básico de sua narrativa era de horror, de repúdio à violência.

Por fim, e mais importante, notemos que o exemplo é particularmente rico nas conexões figuralistas, às quais estamos atribuindo tanta centralidade em nossa tese. $\mathrm{E}$ ele reflete sobre sua reação nestes termos: "Minha fúria visceral [sputtering, visceral fury] ao fantasma de Princip encaixou bem com a afirmação de Ankersmit de que algumas experiências do passado têm um efeito não mediado pela historiografia antecedente, talvez até mesmo filtrada pelas categorias do entendimento tradicional.” (idem: 435) Mas a reação foi mesmo não mediada pela historiografia, "não solicitada e não provocada pelas questões que nós colocamos ao passado ou pelas hipóteses sobre ele que nós testamos por meio da avaliação cuidadosa das provas" (idem, ibidem)? Minha hipótese é que, ainda que não houvesse nenhum tipo de questionamento acadêmico sendo feito naquele momento, a experiência reuniu muitos elementos de todo o amplo leque de preocupações morais e de erudição que Jay acumulou em sua vida, incluindo questões intelectuais, e também articulou-as com sua identidade pessoal. (E

${ }^{223}$ O termo "narrativa" é empregado por Ankersmit no contexto de uma discussão historiográfica mais precisa, e portanto pode não dar conta do que está em jogo no caso de algumas experiências - mas, como nossa tese a este respeito é de que a produção de "representações" é também a produção (não a descoberta) de "substâncias", optamos por empregá-lo aqui. 
como negar que para a experiência de mundo de um intelectual como Jay as abstrações são tão reais quanto a concretude era para as pessoas da Baixa Idade Média de Huizinga?)

Notemos que o próprio local onde a experiência ocorreu estimula conexões figurais, expondo um artefato da Primeira Guerra em um local da Segunda, e Jay as conecta com toda uma cadeia adicional de eventos, incluindo a biografia de Princip e do artista com o qual ele próprio se identificava. Até mesmo o xingamento que ele direcionou ao fantasma de Princip conecta a sua própria experiência dos eventos com os próprios eventos, que são dois, conectados temporalmente: em t3, Jay conecta $t 1$ e t2, e age como que em nome dos agentes de t2, tal como os entende. Algumas dessas conexões já estavam presentes na experiência dos agentes, e outras no primeiro momento da experiência de Jay, como acabamos de argumentar, mas as outras parecem ter sido feitas na sequência, como parte de uma reflexão de caráter ético e prático que se seguiu. Assim, ele acessou alguns significados passados, refigurou-os ao conectá-los com acontecimentos posteriores, e em seguida passou a buscar significações adicionais para eles, deparando-se com sua resistência.

Tanto quanto houve ruptura de significados, nossa interpretação é de que havia também significados em jogo. O tipo de significado é o da figura e da compreensão configuracional, no qual um evento concreto é visto à luz de outros. "Concreto", aqui, no sentido da imbricação de significados e materialidade, e não apenas da concretude de artefatos: isto porque este significado não envolve a subsunção dos eventos a leis ou regularidades gerais, no caso que Mink chama de compreensão teórica - que Huizinga também desejava evitar em qualquer forma de historiografia -, nem a enredos, como nas formulações de White. Este concreto teve significações criadas, e é, portanto, simultaneamente sublime e significativo: para um mundo sem significado intrínseco, agentes humanos passados criaram e negociaram significações; agora estas significações podem ser descobertas como parte da história tal como ela foi, mas não objetivamente e sim pelo estabelecimento de certas conexões com outros eventos (como também Huizinga via, cf. RIBEIRO, 2010: 244-5). O que elas resistem é à produção de uma segunda camada de significações, na qual a experiência destas experiências - que são também um evento: “a experiência das algemas de Princip por Jay em 1994”, e portanto existe já sob descrição - possam ser descritas, naturalizadas, familiarizadas, ou, quando as pretensões do experienciador são maiores, que a linguagem possa ser torcida 
a ponto de poder expressar apenas um pouco mais da experiência. Este último caso é o que gerou um livro como O Outono da Idade Média.

\subsubsection{Que sujeito-no-mundo pode experienciar o passado?}

Vimos ainda que Huizinga fala sobre a capacidade do historiador de escutar os chamados do passado. Quem pode escutar tais chamados, e por quê?

Ora, embora Jay - como Ankersmit ao descrever a experiência histórica de Huizinga (2005, 129) - afirme que sua experiência não envolve as camadas de interpretação historiográfica, algo pode ser notado sobre as experiências históricas "subjetivas": seus receptores são pessoas invariavelmente dotadas de uma grande erudição, que os possibilita ouvir (para falarmos nos termos de Huizinga) os chamados do passado. A erudição permite que eles possuam recursos de preenchimento que são imprescendíveis para que as figuras do passado surjam como figuras. Citando objetos que provocaram experiências em pessoas como Huizinga, Goethe, Mario Praz, Herder, Prescott e Burckhardt, lemos de Ankersmit (como já vimos) que "o passado está presente nestes artefatos que ele deixou para nós. Elas são protuberâncias, por assim dizer, do passado no presente." O que especificar sobre este passado que pode ficar presente? Ora, o melhor ponto de partida é... o presente, como não? Nosso mundo presente não se apresenta a nós de nenhuma maneira explicável por pressupostos do realismo filosófico, mas sim de maneira inseparável dos recursos subjetivos que temos para fazê-lo se manifestar de uma certa maneira e não de outra. Da mesma forma o passado: por isso, no mesmo trecho em que fala do passado experienciável, Ankersmit cite pessoas que estão em condições de experiênciá-los -qualquer outra pessoa teria outra experiência do passado, se é que seria capaz de conectar o objeto metonimicamente com outro(s) contexto(s). Assim, o que quer que se possa chamar de "contato autêntico com o passado" é coemergente com a mente do experienciador. Não porque o passado já passou, como argumentam os pós-modernistas e construtivistas, mas porque toda experiência de mundo (tida por sujeitos-no-mundo) é assim. O que significa que pós-modernistas adotam um pressuposto curiosamente realista quando negam isto. Assim, o conhecimento não precisa ser visto como uma "crosta", mas como um componente necessário para a irrupção de uma experiência subjetiva do passado. É plausível conceber que, pela ausência destes conhecimentos, possoas com pouco conhecimento histórico não sejam capazes de estabelecer as conexões que Jay estabeleceu, e sobre as quais Huizinga teorizava (e White, e Auerbach, e Mink, e 
Danto), e portanto não reconheçam o passado em sua diferença-com-semelhança no presente. É o que Ankersmit esperava em suas primeiras reflexões sobre experiência, ainda tratando de nostalgia, e é o que ocorreu com Jay. Desse modo, é concebível que, de modo geral, as relações com museus sejam muito mais domesticadoras que as de Jay por parte de pessoas que conhecem pouco sobre o passado. Conhecer muito não garante uma atitude de abertura: há muitas formas de tentar domesticar o passado e o mundo. Mas conhecimento e abertura, combinados, indubitavelmente são fatores componentes das experiências descritas por Ankersmit.

Vejamos como Ankersmit descreve a experiência histórica tida por Huizinga em uma exposição em 1902. Ele precisa começar fazendo como que uma concessão ou ajuste sobre a sua afirmação de que são os artefatos irrelevantes que propiciam tais experiências, e afirmando não ser impossível "remover a crosta de interpretação sedimentada nas grandes obras de arte e experienciá-las como se toda uma civilização a vida pela primeira vez", mesmo no caso dos van Eycks, de van der Weijden, Campin, van der Goes e outros, que "eram tudo menos pintores menores". (126) Nesta exposição:

\begin{abstract}
A vida desta Idade Média tardia, sua ferocidade, sua fascinação com extremos, seu desinteresse em descobrir novas formas por trás destes extremos, tudo isso agora saltou sobre ele e tomou conta dele da mesma forma que nós podemos ser tomados por música, digamos, pela Hohe Messe de Bach ou a Missa Solemnis de Beethoven. Isto é o que fez Huizinga escrever O Outono da Idade Média - embora o caminho da experiência histórica para o texto histórico continue sendo tortuoso e altamente complexo... (127)
\end{abstract}

Eu insistiria, porém, que a descoberta da ferocidade da Baixa Idade Média não se distingue da dimensão de pesquisa. Ela fornece a imagem por meio da qual as informações foram reunidas por Huizinga. Como afirmamos na discussão sobre "compreensão com energia", foram reunidas na experiência os elementos internos do próprio Huizinga, as informações que ele acumulou sobre o período e as possíveis conexões entre os eventos, o que ele já intuía sobre a atmosfera do período, e as potencialidades do próprio quadro. Quanto mais elementos ativos puderem ser reunidos em uma única experiência, mais intensa ela será. A experiência se deu com o suporte do quadro, mas organizou de uma maneira peculiar muitos processos presentes no corpomente de Huizinga e na história-processo: na experiência da arte, como na compreensão de um texto histórico, o "cancelamento do tempo" e do contexto se dá não por meio de 
uma dissociação do processo histórico, mas de uma reunião de suas potencialidades. A memória é parte da experiência.

$\mathrm{O}$ erudito tem amplo acesso às dimensões abstratas - acessadas por desafios hermenêuticos de notável dificuldade - e pode ter humores pessoais com afinidade eletiva com os humores do período. Mas o tempo inevitavelmente produz mudanças na intersubjetividade e na materialidade. Pelo primeiro motivo, sua experiência só pode ser mesmo muito passageira - e, de fato, uma alienação em relação à constituição intersubjetiva de sua própria época parece ser um fator estimulante ao desejo pelo encontro com o passado que motiva muitas das, embora não todas as, experiências do passado. O segundo motivo, por sua vez, explica como pode um artefato insignificante do passado ser tão potente quando percebido em união com todo o resto: ele é uma pequena fração que se articula holisticamente com uma ampla rede de significados e emoções. A atenção, segundo os relatos deste tipo de experiências, parece ser fortemente tragada por este objeto, mas, se Ankersmit diz que ela produz uma descontextualização, eu diria que isto é correto não no sentido de que o foco não tem um plano de fundo, mas no sentido de que ele ativa - e permite reunir em uma única experiência - a enormidade de energia investida na forma de desejo, compreensões, informações e experiências estéticas anteriores. Como mostra o caso de um autor como Huizinga, a energia canalizada por esta experiência pode então ser redirecionada para a sua expressão. Expressar intersubjetivamente uma experiência tão pessoal tanto pode provocar uma tensão grande demais entre o organismo e o ambiente - que pode levar o historiador/artista a optar por um silêncio amargurado, não havendo disposição ou talento próprios o suficiente, por seu lado, quanto receptividade do público ou condições institucionais, ${ }^{224}$ pelo lado externo - quanto pode provocar as grandes inovações necessárias para a resolução da tensão, quando seu grau é estimulante, nem pequena nem grande demais.

Esta concepção previne que caiamos em um falso pressuposto epistemológico que Ankersmit gostaria de evitar acerca da realidade histórica e das maneiras de representá-la ou experienciá-la: “... (muito da) epistemologia é baseada em um preconceito ontológico - a saber, o preconceito de que o mundo é feito de 'bens secos de tamanho médio...” (2005: 245) É por isso, especifica ele, que tratamos apenas o tipo

\footnotetext{
${ }^{224}$ Pensemos, por exemplo, em alguém sujeito a regras profissionais rígidas, a prazos incompatíveis com as demandas mais demoradas da expressão da experiência ou a dificuldades financeiras que impossibilitam os riscos envolvidos.
} 
epistemológico de experiência como digno de investigação filosófica e ignoramos a experiência histórica. (idem, ibidem) Isto nos leva a considerar mal-formulada, por exemplo, a questão de como Guizot ou Tocqueville "experienciaram" a Revolução Francesa, pois, de acordo com este pressuposto: "Nós podemos experienciar mesas, árvores e cachorros no sentido correto do termo, mas o que alguém poderia querer dizer ao falar que teve uma "experiência" de "coisas" tão dúbias como a Revolução Francesa [...]?” Esta frase já mostra bem como - conforme a análise de Carr - a presença de substâncias narrativas já na experiência contemporânea de cada pessoa em seu mundo, incluindo os agentes do passado, é importante para entendermos o que é existir historicamente. Ela quebra eventuais sensações de incompatibilidade entre as reflexões sobre representação e aquelas sobre experiência, porque ambos os processos são partes da existência histórica.

Com apoio em Dewey e numa justaposição Mink-Carr, temos proposta já esta congruência de base - seguida de inúmeras diferenças de superfície - entre "representação" ou "narrativa" e "experiência". Em um artigo recente sobre Ankersmit como leitor, Kellner apontou para um trecho de Narrative Logic que mostra a viabilidade da nossa tentativa de ler Ankersmit nos mesmos moldes. Ele considera que tanto o aspecto "visual" que Ankersmit atribui às representações das representações quanto o aspecto "tátil" que ele vê nas experiências cumprem, em sua obra, a função parecida de "dissolver as fronteiras entre sujeito e objeto":

\begin{abstract}
Surge um paradoxo. Ankersmit é claramente um leitor com uma visão. Como nós reconciliamos [isto com] sua asserção de que Aristóteles estava certo em elevar o toque ao principal sentido humano? Apenas se a visão pudesse fazer o que o toque faz, dissolver as fronteiras entre sujeito e objeto, borrar os contornos separados, da maneira pela qual a mão assume a forma do vaso que ela segura, o paradoxo poderá ser resolvido. Mas não é exatamente isto que a visão faz quando evoca humor [mood], Stimmung? Na experiência todos os sentidos se borram $^{225}$, incluindo ouvir e cheirar.
\end{abstract}

Isto se vê na citação de Narrative Logic (1983: 196) destacada por Kellner, que creio ser o único momento naquele livro em que é evocada a primazia "experiencial" do toque defendida vinte e dois anos depois, com apoio em (uma certa leitura de) Aristóteles, em Sublime Historical Experience: “... falando meraforicamente, poder-se-

${ }^{225}$ Isto é, se interpenetram: as fronteiras entre eles se borram. 
ia dizer que identidades ou Nss (substâncias narrativas) como 'Renascimento' ou 'Guerra Fria' são ‘cheirados' ou 'ouvidos' em vez de 'vistos' por historiadores.,"226

Não à toa, a linguagem da "revelação" aparece tanto em suas reflexões sobre experiência em Sublime... quanto naquela sobre representação em Meaning.... ${ }^{227}$ Em Sublime, comparando as noções de experiência em Dewey e em Huizinga, ele afirmava: "Em ambos os casos, a experiência é algo [which is undergone] em vez de ser uma violação (ativa) do objeto da experiência por quaisquer esquemas cognitivos ou categorias existindo na mente do sujeito. Ela possui todas as características de uma revelação, que é, em ambos os casos, descrita em formulações que beiram o místico. Em ambos os casos a experiência é acompanhada da convicção de ter um contato completamente autêntico com a realidade (do passado), um contato que não é contaminado por nenhum contato prévio ou por qualquer conhecimento ou teorias que nós já possamos ter tido do objeto de experiência em questão.” (2005: 252)

Assim, embora se tratem de formas diferentes de estabelecer relação com o passado, as experiências históricas e as representações compartilham a características de revelar aspectos apresentados do passado. Em ambos os casos, há a participação da "forma de olhar" que não equivalem a uma imposição ou "violação ativa", ${ }^{22}$ mas também não demandam que se ignore a retroatividade que reúne retroativamente a distância entre passado e presente em uma totalidade simultânea. ${ }^{229}$ O que está em jogo

\footnotetext{
${ }^{226}$ Dada a natureza deste trabalho, poderíamos manter esta tese mesmo que Ankersmit não concordasse com a leitura de Kellner, enquanto interpretação de sua obra, nem com sua força enquanto produto de filosofia da história. Mas cabe observar o comentário feito por ele, referindo-se não a este ponto mas ao artigo como um todo, em Reply to my Critics, que conclui a edição do Journal of the Philosophy of History dedicada à sua obra: "Tomando como sua pista a ideia 'Ankersmit como um Leitor', Kellner sucede em, muito engenhosamente, reunir em seu ensaio todos os temas que eu abordei nos últimos quarenta anos." (ANKERSMIT, 2018: 247)

${ }^{227}$ Uma hipótese, que deixo em nota pelo fato de que este trabalho não busca ser uma biografia intelectual de Ankersmit, e adicionalmente pela dificuldade de verificá-la, é de que foi a sua longa excursão pelos terrenos da experiência que culminou na produção de uma noção mais "experiencialista" de representação histórica no seu texto de 2012.

${ }^{228}$ Sobre isto, ver a discussão no capítulo 2.

${ }^{229}$ Como na versão de "compreensão" de Mink apresentada no capítulo 2 e na experiência nostálgica proposta por Ankersmit $(1994,2012)$. No caso de Mink, afirmei que também os elementos do presente são parte da "totalidade simultânea" produzida pela compreensão. No caso de Ankersmit, mantive suas reflexões sobre a relação entre presente e passado, mas questionando a fundacionalidade da nostalgia. É importante deixar claro que não estou argumentando simplesmente que a compreensão histórica estudada pelos narrativistas e a experiência histórica teorizada por Ankersmit são a mesma coisa: estou, sim, argumentando que a historiografia é histórica antes de ser historiográfica, e nunca deixa de sê-lo; e que, desse modo, é uma prática que elabora, de maneiras peculiares, a maneira compreensiva por meio da qual a realidade humana já se articula. A noção aparece em White, na tese Carr-Mink que propusemos no capítulo 2 (e certamente em cada autor separadamente), e agora também em Ankersmit, que parece chegar a ela por meio de Gadamer. O Ankersmit tardio, como Gadamer, compartilha com este uma afinidade com a filosofia de Heidegger. Não é à toa que a noção de aletheia, mobilizada inicialmente na discussão sobre experiência (nos capítulos 5 e 6 de Sublime, sobre Gadamer e Dewey) e mais adiante
} 
é a dinâmica entre atividade e passividade mais bem expressada pela noção de abertura, que pode ser descrita como uma receptividade ativa; esta, por sua vez, é possibilitada pelo cultivo erudito e pelo desejo intenso de estar em condições de ouvir os "chamados" do passado. O historiador muda a si mesmo até que tenha em si os preenchimentos capazes de fazerem o passado surgir como figura; quando e como isto ocorrerá não pode ser previsto pelo simples fato de que, até que o encontro ocorra, o que veio a ser figura não era ainda figura e o que veio a ser preenchimento não era ainda preenchimento. Assim, por ter se transformado previamente, o historiador é submetido - como resultado de sua atividade e de sua abertura igualmente ativa - a uma nova experiência transformadora, cujo conteúdo ele não poderia prever ou controlar.

\section{As nuvens e a tradição}

O sujeito, como já argumentamos no cap. 2, é feito também por tradições. Porque o que estamos afirmando não é que existe efetivamente este passado em si, perdido para sempre, de um lado, e o passado apresentado, acessível por meio de inferências, de outro, a tradição não precisa surgir necessariamente como uma "nuvem transcendental", mas como um conjunto de formas de desvelar o passado que se combinam com a materialidade em uma totalidade peculiarmente intensa. Se a tradição será ou não esta tela que mantém o historiador mais atento às suas abstrações do que às maneiras pelas quais elas se conectam com os "passageiros clandestinos" do passado - e quase sempre ela é, contingentemente - depende em grande medida de como se lida com ela. Estamos recusando a colocação da questão nestes termos transcendentalistas, tanto em sua variação linguística pós-modernista (como Ankersmit criticou em Rorty) quanto o indesejado transcendentalismo ankersmitiano.

De passagem, mencionamos a metáfora das "nuvens" que se abrem. No capítulo de Sublime sobre "experiência estética pragmatista", Ankersmit compara a possibilidade de uma experiência descontextualizada à visão da realidade por trás das "nuvens" do contexto por parte de alguém que se encontra em um avião. É possível imaginar uma imagem que sugira maior divisão entre sujeito e objeto do que esta, exceto talvez a de alienígenas em uma nave espacial? A metáfora do rio visto de cima, que Ankersmit considera transcendentalista demais, soa inteiramente aristotélica em comparação. A realidade não é algo atrás das nuvens: a realidade histórica passada são as tradições, em

naquelas sobre representação, possui afinidade eletiva com as demais reflexões narrativistas e se mostra como uma maneira hábil de preencher suas promessas. 
suas manifestações culturais diversas, em relação com a concretude do mundo abaixo, mas não menos irreal por isto. Como o passado não é algo que está "lá", não temos acesso às dimensões concretas do mundo, que se modificaram para sempre, como consequência do movimento constante de todas as coisas. Mas podem adquirir informações, fazer inferências, usar a imaginação, e podemos ver as nuvens a partir de dentro. Assim, rejeitamos a pertinência da imagem empregada, e afirmamos que toda experiência (presente e passada) faz surgir, na interface indivisível entre consciência incorporada e o mundo, a realidade apresentada. E os melhores argumentos de Sublime também seguem esta direção.

\subsection{Experiência histórica subjetiva}

Nas discussões sobre Guardi e sobre ornamentos rocoó em "Subjective Historical Experience", é possível destacar dois pontos principais que se conectam com temas da filosofia da história de Ankersmit, inclusive em sua fase narrativista: (a) a relação entre "realidade" e "representação"; e (b) a distância entre as perspectivas dos agentes e a meta-perspectiva dos observadores. Que estas discussões sejam conectadas com a discussão sobre experiência, a nosso ver, não surpreende: pois nossa tese diz respeito precisamente à conexão processual entre os níveis da representação, da realidade (representada) e da "presença" (ou realidade não-representada, quando pensada da perspectiva da representação). Estes dois exemplos, por sua vez, são explicados por Ankersmit por meio da noção de "humores e sentimentos" (moods and feelings) ou "atmosfera" (Stimmung), que será discutida na sequência.

\section{a) Guardi}

O primeiro exemplo de "experiência histórica subjetiva" oferecido por Ankersmit neste sétimo capítulo é o do capriccio de Francesco Guardi (1712-1793), Arcade with a Lantern, feito em algum momento após 1760. Embora Ankersmit proceda por meio de uma análise do quadro e não de um relato de experiência que ele ou alguém teve ao observá-lo, é o próprio Ankersmit - e não um observador abstrato quem considera poder acessar a "atmosfera" de fins do século XVIII representada nele.

O quadro mostra uma cena bastante comum na Veneza do período, a de pessoas brincando o carnaval vestidas de Pulcinellas. Dentre as várias características que Ankersmit enumera deste personagem, citemos algumas superficialmente e então destacaremos uma: ele é corcunda, barrigudo, usa fantasia branca, chapéu cônico e uma 
máscara com um nariz adunco, tem personalidade desagradável e maliciosa, tem as respostas na ponta da língua, é vulgar, egoísta, tem apetite insaciável. (266-7) O principal para os nossos propósitos: andando em grupos, os Pulcinellas estabelecem um contraste entre o mundo "normal" e o deles próprios, criando como que um mundo real para eles. Passando à análise do quadro propriamente dito, Ankersmit toma como chave interpretativa algo que, em muitos outros textos, ele considerou fornecer algo como uma chave para fornecer um acesso à realidade para além da prisão da linguagem: a ênfase nas fricções, tensões, paradoxos. Assim como em seus exames do "apelo de Hayden White aos historiadores" e da estratégia narrativa de Tocqueville, Ankersmit propõe que também este capriccio de Guardi propicia acesso à realidade por meio da produção de "fricções", que neste caso são tanto formais quanto semânticas.

No que diz respeito à forma da pintura, estas fricções são geradas por ela ser "ilógica". Eis, brevemente, as três inconsistências localizadas pela interpretação de Ankersmit. Primeiro, sua massa está concentrada no topo, de maneira que "sente-se vontade de virar a pintura de cabeça para baixo". Segundo, há uma "diferença entre a perspectiva da qual o espectador vê a arcada, de um lado, e como o espectador é posto no espaço que é sugerido pela pintura, por outro.” Terceiro, há na pintura a sugestão de um túnel, e "uma das peculiaridades paradoxais de um túnel é que eles sugerem uma grande distância ou profundidade, mas, ao mesmo tempo, parecem mover o ponto de fuga para perto de nós." No caso deste capriccio, "a distância entre a cúpula no fundo e a lâmpada na frente parece muito menor do que ela deve ser 'na realidade' - um efeito que é ainda mais notável por Guardi tê-los posto bastante perto uma da outra na pintura." (2005: 268-70) $)^{230}$

Quanto às fricções semânticas, ele cita duas. A "menos importante" ocorre na relação entre representação e realidade, que, no caso, se manifesta pela invasão gradual do teatro na realidade: se em um autor Gillot os atores se encontravam efetivamente em cena, nos seus sucessores somos convidados a ver "metaforicamente" a realidade como um teatro, e em Guardi a tensão é levada ao nível do paradoxo: a vida aparece como ambos, teatro e realidade. A outra tensão, que ele considera mais importante, vem do que é declaradamente uma experiência pessoal da pintura:

\footnotetext{
${ }^{230}$ Notar que os itens 2 e 3 remetem a temas importantes para a filosofia da história de Ankersmit: tensão entre perspectivas (e o que elas permitem ver na realidade), no item 2 , e a possibilidade das representações ou das experiências históricas serem como o "túnel" que ressalta (ou cancela momentaneamente, dependendo do texto) a distância entre presente e passado precisamente ao aproximálos, no 3. Ambos serão discutidos mais adiante.
} 
A sensação de tédio é provocada, em mim, pelo sol feroz do Mediterrâneo que é visto no plano de fundo e que ainda assim não sucede em penetrar a parte da frente, escura; isto me dá a sensação de ter sido fechado dentro do impasse estreito da arcada e de não conseguir alcançar o mundo livre e real por trás da arcada." (272)

Representação e "vida real”. A partir desta descrição geral do que é, simultaneamente, uma análise do quadro e uma descrição de como Ankersmit o experiencia, podemos partir para as discussões mais detalhadas de alguns pontos relevantes a este trabalho. Em primeiro lugar, sobre a interpenetração entre "teatro" e "vida real", que pode facilmente remeter à nossa discussão do capítulo 2 sobre relação entre "narrativa" e "vida real". Ankersmit especifica sobre como ela se manifesta no quadro:

\begin{abstract}
É nesta tensão entre "normalidade" e o mundo do Pulcinella que reside muito do segredo sobre o Pulcinella. O fundo duplo [double bottom] da sua aparência e comportamento é que eles são figuras cômicas tiradas da comedia dell'arte, mas, ao mesmo tempo, são bem sucedidas em ironizar a "normalidade"... Assim, o paradoxo é que o Pulcinella é uma figura tomada do palco, embora, precisamente, ele busca nos tornar conscientes da dimensão de palco na assim-chamada "vida normal." (267-8)
\end{abstract}

Estas reflexões evocam o problema da relação entre "representação" e "mundo real", que já surgiu em vários momentos do presente texto, e certamente são de grande interesse para o próprio Ankersmit.

Ele compara a atitude dos antecedentes de Guardi, como Watteau, à do próprio Guardi, acerca da relação entre teatro e realidade: aqueles, adotando a metáfora do theatrum mundi, convidavam os espectadores a "ver o mundo 'real' como se ele fosse um teatro"; já "Guardi não opta pela metáfora, mas pelo paradoxo: Há agora um choque direto e frontal entre o teatro e o mundo 'real."' Ankersmit especifica:

... não, ele quer nos inculcar a verdade de que a vida é ambos - a vida
real às vezes é o que ela parece ser, mas em outros momentos ela é
uma comédia dura [harsh] no sentido um tanto literal da palavra. E é a
tensão entre as duas, entre ela ser às vezes isto e às vezes aquilo, que
dá à mensagem sua pungência. Ou, em outros termos, o mundo do
teatro (e da representação) é no sentido mais literal parte da nossa
realidade diária - e então pode-se dizer que a representação invadiu o
mundo (ou o representado) em si. (2005: 272)

Comecemos pela observação de que a "experiência objetiva" foi sempre, antes de ter sido tornada objetivo pelo fechamento do que até então era aberto, uma "experiência subjetiva", que é tornada "objetiva" pelo fato de que, retroativamente, é 
verdade que as experiências do passado foram vividas de um certo certo e não é verdade que foram vividas de vários outros. Num caso como o que está em questão, enquanto a experiência foi vivida pelos agentes, ela foi vivida como uma comédia. Não há uma vida literal e então uma metaforização subsequente que a enreda como tragédia, mas a estruturação da própria ação (Carr), experiência (Dewey) ou compreensão (Mink) de um modo tal que ela própria existe enquanto representada. Estamos afirmando ser esta a maneira pela qual a "realidade humana" (incluindo a que aparece como "representado" em textos de história) se estrutura. A representação histórica, assim, preenche as figuras da representações prévias que, estruturando a relação entre agente e seu ambiente, foram a realidade histórica sobre a qual se busca falar verdades. O que fez de parte da vida passada uma comédia foi o enredamento atribuído pelos agentes à sua ação no mundo. Não se trata de dizer que um certo conjunto de enredos cuja existência é historicamente contingente dê conta de expressar todos os aspectos da realidade, mas que elementos da realidade humana se confundem com os enredos com referência aos quais são vividos, e, paralelamente, que os enredos efetivamente são adequados para expressar elementos (eg, cômicos ou trágicos) da experiência humana. Assim, como Carr aponta, viver e narrar (ou viver e representar, na atual discussão) são efetivamente entrelaçados. Neste sentido, é possível que a própria vida assuma a forma de comédia, sem que isto signifique nem que a experiência, no próprio momento de sua ocorrência, não pudesse ter sido estruturada de outra forma, nem que as atribuições de sentido retroativas não possam também significá-las de outra forma.

O que isto significa para a discussão acerca da sublimidade da história? Em que sentido é adequado - especialmente a um autor narrativista - dizer que a vida pode ser uma comédia? Ora, ao ser vivida como comédia, a história não perdeu sua sublimidade, e mesmo os agentes não se tornaram capazes de suprimir tal sublimidade em nome de um significado específico - embora a maneira pela qual eles de fato enredaram suas vidas, embora pudessem tê-la feito de outras formas, tenha se tornado em uma inevitabilidade histórica: é fato que eles experienciaram parte de suas vidas como uma comédia, não como tragédia ou romance. Na mesma linha, o historiador de gerações subsequentes não perde sua liberdade de atribuir significados outros que não aqueles atribuídos pelos agentes: não posso meramente dizer que o passado foi mesmo uma comédia sem escolher tomar para mim a perspectiva dos agentes; a experiência cômica dos agentes não me obriga a adotá-la. 
E, de fato, o capriccio de Guardi e os Pulcinellas representados nele simbolizando tédio e o esforo para superá-lo nos trazem bem ao coração da vida pública do século dezoito e sua fascinação com a metáfora do theatrum mundi e ao tédio que inevitavelmente resulta de viver de acordo com esta metáfora (2005: 274) ... O paradox de Guardi da combinação da vida normal com o teatro tinha se tornado uma realidade na véspera da Revolução Francesa. (275)

A distinção a ser desfeita aqui é entre "subjetividade" e "realidade": a "realidade humana" surge com a participação da consciência: ela é a relação entre o que poderíamos chamar de mundos objetivo e subjetivo, não havendo um predomínio de um sobre o outro (como nas perspectivas do realismo e do idealismo). Como as pessoas se sentiam no século XVIII é inseparável de como eles produziam sentido para si mesmos e para o mundo - aspectos inseparáveis e mediados pela experiência -, e esta é a realidade histórica do período: não é como se os tilojos, pregos, madeiras e metais são a realidade e as experiências são apenas experiências. Por isto, como estamos enfatizando, a "experiência histórica objetiva" existiu originalmente na forma do entrelaçamento de objetividade e subjetividade, na qual mentes incorporadas se relacionavam com seus mundos social e natural. Sua "objetividade" é retroativa, resultado da transformação de abertura para fechamento que a história produz sobre todas as coisas; mas os múltiplos eventos da história "como realmente foram" existiram na forma de experiências (inter)subjetivas do mundo.

Não é que não haja constrastes feitos entre os comportamentos que serão normais e aqueles que serão teatralizados. Trata-se de reconhecer que o normal torna-se normal convencionalmente - como as reflexões sobre "experiência histórica sublime" logo tornariam explícito. Assim, a conclusão a ser tirada nos parece um pouco mais radical do que "a vida real às vezes é o que parece ser, mas outras vezes é uma comédia dura no sentido um tanto literal do termo." Ela sempre é aquilo que os agentes intersubjetivamente - fazem dela (incluindo o que fazem com o que recebem do mundo), ao mesmo tempo em que, enquanto eles fazem, eles nunca podem perder a liberdade de fazê-la de outros jeitos (liberdade sendo outro nome para a impossibilidade de ontologizar um sentido único para o mundo). A ausência dessa distinção de uma vida "real” por trás da máscara é necessária para o projeto de superar uma concepção transcendentalista, que presume uma realidade atrás das representações, em proveito de uma concepção de experiência em que esta ocorre na "superfície" (2005: 112, 121, 184, respectivamente sobre Huizinga e Benjamin) 
Distância histórica e a contingência do "mundo real". O segundo ponto em que a discussão de Guardi pode ser conectada com preocupações filosóficas de Ankersmit diz respeito à distância de perspectivas entre os agentes, engastados em seus mundos, e o representador (artista ou historiador), que vê esta ação à distância e produz um sentido que não se resume à perspectiva dos agentes. $\mathrm{O}$ problema, assim, diz respeito à distância de perspectivas. Sobre isto, duas observações prévias. Primeiro, como se vê na análise das fricções, também a perspectiva de quem contempla as perspectivas dos vários agentes é condicionada por sua própria situação histórica, e não uma visão transcendente. Segundo, este problema não aparece apenas nas suas reflexões sobre representação: a experiência histórica sublime é precisamente a irrupção de uma perspectiva distanciada em relação ao passado, que portanto perde sua imediaticidade. E as "experiências subjetivas", relacionadas a figuras como Huizinga, Guardi e ao rococó, e em muitos de seus textos conectadas também à noção de nostalgia, envolvem precisamente "experiência da distância" entre o passado e o presente. ${ }^{231}$

Ao olhar para o capriccio, o que Ankersmit afirma ter produzido a "abertura das nuvens contextualistas" que o impediam de acessar a "atmosfera" da Veneza do século XVIII foi a oposição entre a serenidade da paisagem ampla, ${ }^{232}$ por um lado, e "a excitação ostensiva e agitada dos Pulcinellas no espaço estreito e confinado", por outro.

\footnotetext{
Isto é o que me impressionou tão fortemente quando eu vi o capriccio e onde ele obliterou, na minha experiência da pintura, as barreiras que me separavam do fim do século dezoito quando ela veio a ser e onde ele efetuou em mim a sensação paradoxal de um reconhecimento do que eu, de certa forma, sempre soube, mas havia esquecido, e de umaconfrontação com o que era ao mesmo tempo estranho e alheio [alien] a mim." (276)
}

Este trecho encaixa bem com a afirmação de que um conceito como o de “experiência histórica sublime" é a culminação das reflexões historicistas. Os Pulcinellas representam o estreitamento de foco típico dos seres incorporados e situados

\footnotetext{
${ }^{231}$ Assim, a questão da diferença de perspectivas é um ponto central da filosofia de Ankersmit, e sem dúvidas é uma questão marcadamente historicista que perpassa tanto suas reflexões sobre representação quanto aquelas sobre experiência.

${ }_{232}$ Note-se, inclusive, que Ankersmit caracteriza o sol como "feroz", mesmo termo que Huizinga considerou capaz de expressar o humor de uma atmosfera de fins da Idade Média e de explicar os potenciais sinestéticos da linguagem. (ANKERSMIT, 2012: 203-6). Ankersmit evidentemente é movido pelas mesmas figuras que moviam Huizinga - e ainda as experiencia por meio dos preenchimentos, tornados figuras, fornecidos pelos seus textos históricos e teóricos -, e a tentativa de acessar algo feroz, porém inacessível, parece se manifestar uma vez mais em sua experiência do quadro de Guardi e do aspecto da atmosfera do século XVIII veneziano que ela expressa.
} 
vivendo em suas circunstâncias históricas, com as urgências e emoções conectadas a uma forma específica de experienciar a temporalidade, enquanto a paisagem mais ampla fornece o contraste do que poderíamos chamar de uma abertura sempre disponível. Para quem vê a partir de outros pressupostos, incluindo os contemporâneos que se viviam a partir de outros referenciais, mas mais ainda os historiadores de outras épocas, o estreitamento de foco que parece natural e gera um "mundo" significa também que os agentes não viam coisas que, de agora são visíveis. Mas o inverso também é verdadeiro: podemos aprender sobre os próprios agentes e sobre o ambiente em que eles se situavam, mas ao mesmo tempo em que vemos mais que eles, também vemos menos o que eles viam em sua experiência de mundo. Assim, não surpreende que a experiência que Guardi expressa eu seu capriccio e a experiência que Ankersmit expressa com sua filosofia se relacionem de maneira figural, já que o primeiro expressa um insight passível de ser atingido por aquele que reflete prolongadamente a partir de uma fascinação pela história: este insight é uma espécie de visão dupla ou múltipla da história, que se manifesta simultaneamente desprovida de sentido inerente (sublime), por um lado, e significativamente construída por seres engastados em suas circunstâncias históricas, por outro. Amplidão e estreitamento não são duas coisas: é no espaço amplo que os Pulcinellas estreitam sua atenção e assim constroem em "mundo"; da mesma forma que não há a separação entre a liberdade, por um lado, e a condição de garçom adotada pelo ser livre, por outro, mas sim o uso da liberdade para a adoção de uma "máscara" específica que, porém, nunca aniquila a liberdade do exercício de outra ocupação. Guardi não expressa a perspectiva dos Pulcinellas, mas a tensão entre o mundo construido intersubjetivamente pelos agentes e o distanciamento de quem o vê de fora; a filosofia de Ankersmit, igualmente, insiste que a escrita e o conhecimento históricos não são uma mera reprodução da perspectiva dos agentes, mas a diferença ou distância entre estas perspectivas e a de quem vê de fora. O que se descobre por estas reflexões não é o olhar imparcial por meio do qual se pode descrever a realidade "tal como ela é", mas a própria combinação entre situacionalidade e liberdade da "forma de olhar": ao descobrir que os agentes do passado focavam em alguns aspectos do mundo mas não em outros, reconhecemos não haver inevitabilidade na maneira pela qual nós mesmos revelamos aspectos do mundo, da mesma forma que, como afirma White, não é necessária tropear ou enredar o mundo de uma única maneira. Ao mesmo tempo, não transcendemos a história, e aqui um comentário combinado com referências panorâmicas às várias lições da tradição narrativista podem ajudar a explicar o ponto: 
entender a condição histórica é entender precisamente a limitação do próprio olhar, tanto em relação a eventos futuros (como Danto lembrou) quanto às formas de significar os eventos já conhecidos (sob alguns, mas não outros, aspectos). Tais reflexões estimulam, por isso, uma atitude pluralista, que, novamente, não nos livra da história, mas produz um (apenas aparentemente paradoxal) "afastamento engastado", que mostra ser vantajoso reconhecer que os proponentes de diversas regras para os "jogos" sociais de modo geral e a prática historiográfica em particular podem ter méritos em suas propostas (como prescrevera Gallie, sendo seguido por White), já que nenhuma delas é natural. Ao fazer surgir múltiplos aspectos, e ao fazê-lo autoconscientemente, a combinação entre historiografia e reflexão teórica desvela uma complexidade do mundo que jamais seria possível com a adoção de uma única perspectiva. Mas isto não produz algo como a combinação de todas as perspectivas em uma única História Universal (como podemos afirmar se seguirmos, respectivamente, Ankersmit e Mink).

A experiência histórica sublime, nesses termos, permite a descoberta teórica de que o campo de significações possíveis presentes uma época não engloba a totalidade de possibilidades humanas, como se os Pulcinellas repentinamente pudessem reconhecer que as urgências de suas vidas - representadas pela imediaticidade de suas respostas às demandas corporais e emocionais, que expressam uma forma imediatista de experiência da temporalidade - não são "o mundo em si”, mas uma certa forma de prefigurar o mundo (com atenção, temporalidade, emoções, identidades, hierarquizações, etc.) que, no mesmo gesto em que desvela alguns de seus aspectos, oculta tantos outros. É evidente que, se pudessem realizar tais reflexões os Pulcinellas não seriam mais propriamente Pulcinellas: mas veremos que a experiência histórica sublime, ou trauma 2, envolve exatamente tal mudança de identidade, ou subsunção da identidade antiga em uma nova. Esta mudança pode ser gerada pela reflexão, quando oriunda da ação do sujeito; ou que pode gerar a reflexão, quando o sujeito é "movido" rumo a ela pelos fatores de presença do mundo (e aqui, aludindo às multiplicidade de movimentos possíveis elencadas por Runia, encerramos o breve panorama que conecta historicismo e sublimidade a partir de vários insights "narrativistas" e "experiencialistas").

É por isso que, como temos argumentado, as reflexões filosóficas sobre a história podem cumprir a tarefa de permitir que o estreitamento de foco não se cristalize em uma versão mais estreita do que é "a história" e de quais são os princípios metahistóricos adequados às suas pesquisa e escrita, mas que, em vez disto, ele seja feito sem a perda da amplitude de possibilidades sempre presentes. Assim como os 
Pulcinellas, ainda que vejam apenas o que estão habituados a ver e ajam apenas no campo de possíveis delimitado por tal visão, nunca perdem a possibilidade de olhar para a paisagem e de vestir outras fantasias, também os historiadores, por mais que sigam protocolos profissionais do que conta como a maneira correta de fazer história em sua comunidade, nunca perdem a possibilidade de praticá-la de outras maneiras. Esta capacidade de se engajar sem perder a liberdade, e de escolher como quer se engajar por reconhecer o caráter incontornável de liberdade, é o preenchimento de um ponto central da agenda whiteana para a filosofia da história.

Distância e figuralismo. O tópico da distância se conecta a outro - central para o nosso trabalho - que diz respeito às maneiras pelas quais seria possível, ou não, reduzila, de modo a produzir um "encontro" com o passado. Como vimos, o capriccio expressa tédio para Ankersmit precisamente pela seperação entre o mundo atrás dos grossos muros, do lado de lá, e o observador, que conhece o sol mas não é tocado e aquecido por ele, do lado de cá. Nos termos da introdução de Sublime, seu conhecimento daquela parte do mundo, portanto, é mais de natureza "visual" do que "tátil", mais cartesiana e kantiana do que aristotélica. Vimos que, conforme a caracterização de Ankersmit, o túnel aproxima a farol próxima de nós da cúpula distante. Explorando um pouco este comentário, diríamos que a experiência histórica no argumento de Ankersmit, produzida pela conexão figuralista no nosso, operaria de maneira similar ao "túnel”: "Composições com túneis confundem nossas intuições sobre o que está distante e o que está perto, e assim confundem a diferença entre o espaço tridimensional e o espaço bidimensional..." (2005: 269-70). De fato, e com maior relevância teórica: como as metáforas visuais não dão conta de expressar a plasticidade dos processos temporais que envolvem não duas coisas materiais que têm uma distância fixa, mas sim significados que se modificam mutuamente quanto justapostos (e que são sobre estas coisas fixas), os túneis figuralistas aproximam de fato a cúpula do passado e o farol do presente. (Isto é, na medida em que haja um observador capaz de ver uma coisa à luz da outra, e, ao fazê-lo, trazer o significado cuppola para o presente. Isto porque a cuppola significativa é capaz de ser "movida" e empregada no presente de uma maneira que a cuppola material não pode. Tal coisa seria uma aplicação histórica da filosofia aristotélica da mente mobilizada por Ankersmit: ela não pode reviver a materialidade do passado, muito menos seus agentes já mortos, mas pode "receber suas formas sem matéria" de forma a "animar" a matéria presente com estas 
formas. ${ }^{233}$ As circunstâncias para que isto seja feito são raras, mas possíveis: é necessários um observador capaz de dirigir sua atenção - ou tê-la atraída - de maneira tal que, concentrada sobre os objetos do passado e do presente da mesma maneira propiciada pelo túnel de Guardi, alguma conexão entre eles seja vista. Não se trata de produzir uma analogia simplificadora entre representações históricas e a pintura, dizendo, por exemplo, que a cúpula equivaleria ao passado e o farol ao presente (afinal, a que conclusão chegaríamos a partir daí?). ${ }^{234}$ Mas uma observação sobre este ponto ilumina o funcionamento do figuralismo: a relação é estabelecida de uma terceira perspectiva, que também é situada e não do "ponto de vista de Deus", e por meio dela vemos uma coisa à luz da outra - o que, no caso da história, são os eventos em t1 e t2. Note-se também que a perspectiva oferecida pelo historiador em $\mathrm{t} 3$ e a do leitor, talvez em $\mathrm{t} 4,{ }^{235}$ depende do posicionamento real daquilo que é justaposto: pode-se aproximar quaisquer duas coisas, mas, se queremos ver algo que nos permite ativar algo do passado para o nosso próprio presente, devemos encontrar as conexões efetivamente existentes no passado. Também aqui, ocorre uma dinâmica histórica entre atividade e passividade na produção de significados, e não um predomínio positivista de passividade ou um predomínio whiteano e pós-modernista de atividade.

\footnotetext{
${ }^{233}$ É neste sentido que não consideramos necessária a retratação de Ankersmit, que, como dissemos, recentemente desistiu de falar em um "encontro" entre presente e passado. Esta noção seria absurda caso se referisse à totalidade de cada experiência, envolvendo o corpo, aquilo que ele percebe e os significados e pensamentos atribuídos pela mente. Mas as formas podem efetivamente transitar pelo tempo - e, ao "animar" outros conteúdos, tanto a forma quanto os conteúdos são também modificados. Assim, tanto estamos afirmando que as formas se movem pelo tempo de uma forma que as matérias não se movem, quanto estamos historicizando as próprias formas, modificadas a cada "aplicação". O justificado temor de Ankersmit, de que a noção de "aplicação" seja tomada aprioristicamente, parece não se aplicar a estas observações. Como isto funcionaria no caso da tropologia de White? Ora, metáfora, metonímia, sinédoque e ironia não noções a-históricas, puramente formais, mas os enredos, formalismos explanatórios e implicações ideológicas nos quais eles se manifestam são sempre históricos e contingentes. Isto significa que, mesmo que possamos falar abstratamente em um dos quatro tropos, todos eles só se manifestam historicamente. Da mesma forma, podemos dizer que Alexandre ou Júlio César ou Napoleão só podiam mover seus exércitos para frente, para trás, para a esquerda ou para a direita, mas os movimentos específicos se formam na situação das batalhas em que eles se encontravam, e - ao menos se tomarmos o exemplo de Napoleão, que estudou detalhadamente os movimentos de seus predecessores se beneficiavam com o conhecimento de seus lances prévios. O mesmo acontece, segundo Certeau, no caso de lances linguísticos tal como os que a historiografia realiza. O exemplo militar e o acordo com Aristóteles parecem justificar a concepção histórica da formação de universais adotada por Gadamer: a de que eles se formam como soldados em fuga, parando um a um, até que uma coletividade se forma.

${ }^{234}$ Evidentemente não estamos argumentando que a pintura simboliza estas questões de filosofia da história, mas que (a) Ankersmit parece tê-la interpretado à luz das questões que mais o interessam, não só intelectual mas também existencialmente; este argumento será feito mais adiante, não como uma tese sobre Ankersmit, mas sobre também a filosofia manifestar "humores" de períodos históricos específicos; e (b) os temas da história da arte (envolvendo perspectiva, distância etc.) não são inteiramente alienígenas àquelas que surgem na filosofia da história, tanto em termos de continuidade histórica quanto em familiaridade temática, e isto provavelmente se relaciona pelo fato de que ambos produzem representações - cujas semelhanças Ankersmit sempre investigou.

${ }^{235}$ Precisamente como comentamos sobre a filosofia da história de Danto.
} 


\section{b) Ornamento}

O segundo exemplo mobilizado por Ankersmit para esclarecer a noção de "experiência histórica subjetiva" também não diz respeito tanto a uma experiência específica quanto a uma fascinação pessoal estendida temporalmente - como uma sequência de preenchimentos retroativos das figuras fornecidas por experiências anteriores. Segundo seu relato, ela se inicia na sua infância. Tendo ficado doente muitas vezes, ele passava longos tempos sem poder brincar com as demais crianças. Daí, diz ele, "[t]omado pelo tédio, eu frequentemente senti uma fascinação pelas padrões de flores nas cortinas do quarto dos meus pais.” (286) A conexão entre tédio e fascinação, segundo sua análise, ocorre porque a fascinação é "uma promessa tentadora de uma fusão entre sujeito e objeto na ausência da cumprimenro intensamente desejado desta promessa.” (287) “Apenas alguns anos mais tarde," ele afirma, complementando não saber se há ou não alguma conexão entre os eventos, "eu desenvolvi um verdadeiro amor pela decoração rococó." (297) Este conjunto de fascinações pelo ornamento fornecem a ocasião para novas reflexões sobre experiência histórica subjetviva, que examinaremos a partir da sequência de problemas sobre as quais discorremos.

Quanto à conexão entre "representação" e "realidade", nossa chave agora será a noção de imaginação, particularmente relevante em sua variação de "imaginação histórica" para as filosofias de Collingwood e de White. Ankersmit introduz o tópico da imaginação aqui por meio da afirmação de que, muitos anos depois, lendo um comentário de Roger Scruton sobre decoração, ele teve uma "revelação tardia" sobre a natureza de sua fascinação infantil. O argumento de Scruton é de que "podemos fazer ... duas coisas com ornamento vegetal: Ver as folhas ou flores estilizadas como representações da coisa real, ou vê-las como puros padrões de papel de parede, independente de o que o design representa ou ao que se refere." (287) Neste segundo caso: "a imaginação se livra de todos os padrões prévios: Nós não mais nos perguntamos a que o design parece [looks like]. A imaginação é deixada a si mesma, em um jogo livre tal como aquele que Kant atribuiu à imaginação quando não há conceito para guiar a cooperação entre a imaginação e o entendimento." (288) E ele especifica o significado disto de maneira que remete particularmente à sua afirmação, feita inicialmente em 1994, de que as filosofias de White e de Gadamer não forneciam recursos suficientes para a teorização de uma experiência histórica que não fique presa aos moldes do transcendentalismo kantiano. Ele afirma: 
... normalmente nós reconhecemos as coisas que nós vemos (como flores, como seres humanos, e por aí vai); nós distinguimos as coisas que nós vemos, primeiro, quanto ao tipo de coisa que elas são, e, segundo, quanto às propriedades que são específicas a este espécime individual que o diferencia de outros espécimes do mesmo tipo. $\mathrm{O}$ segredo do desenho pato/Coelho ou do teste Rorschach é que eles podem se resolver em dois ou mesmo em vários padrões familiares. Mas estes padrões já existem na mente de quem percebe - e o propósito dos testes Rorschach foi precisamente descobrir o que já existe na mente. Porém, no caso de uma quase fusão entre sujeito e objeto no design de papel de parede, nós estamos discutindo padrões familiares que são desenvolvidos e não aplicados." (2005: 288, grifos no original)

E a frase seguinte a este raciocínio, que remete aos temas de interesse de sua filosofia que o levaram das reflexões sobre "lógica narrativa" para aquelas sobre "experiência histórica", segue rumo ao que se consolidaria como a direção futura de suas reflexões sobre os temas, sintetizadas no livro de 2012:

\begin{abstract}
Isto, eu sugiro, é o mais perto que nós podemos chegar à experiência pura, à completa abertura ao que os sentidos nos apresentam, pois agora nem o mundo real nem a nossa percepção dele são mais forçados para caber em padrões pré-existentes. [Um dos motivos pelos quais] estes momentos de uma receptividade quasi-Heideggeriana à aletheia do mundo [não são explicáveis por leis psicológicas é que não há] apenas uma única maneira para ver a realidade e apenas um padrão para descobrir nela...
\end{abstract}

A conexão com a filosofia de Gadamer, lembremos, aparece na restrição feita por Ankersmit ao seu apoio na ética aristotélica, e não na variante de epistemologia que sua filosofia propiciada: pois o enfoque na ética invariavelmente propiciaria aplicações. A filosofia de White, por sua vez - ao menos ou especialmente aquela dos anos 1970 -, afirma exatamente que o texto histórico torna o passado significativo por meio da identificação dele com um tipo, o enredo. Lembremos ainda que, embora considerasse que a partir dos anos 1980 White deixou de se interessar pelos tropos, Ankersmit avaliava que ele permanecia preso ao transcendentalismo kantiano em suas reflexões sobre o sublime. Mas aqui, curiosamente, podemos ver que Ankersmit acaba por recorrer ao mesmo procedimento. E nossa interpretação é que seus comentários sobre a relação que nos interessa no momento, aquela entre representação e mundo real, são muito mais kantianos que aristotélicos. Vejamos:

Nós iremos concordar com Kant que o funcionamento de tais estruturas cognitivas não excluem, de maneira alguma, a possibilidade de conhecimento da realidade objetiva. Então, de uma perspectiva cognitiva, nós sempre naufragamos quando parecemos chegar o mais perto da nossa meta. Por um lado, liberdade da imaginação pode nos 
trazer o mais perto da realidade e para uma experiência direta dela, mas por outro lado ela também remove tudo que poderia fixá-lo ou segurar firme o objeto [give us a firm hold of the object]. A maior objetividade portanto dá lugar à maior subjetividade [...] E neste processo de tomada de consciência desta dialética angustiante [distressing] nós somos ainda mais afastados do objeto, quanto mais perto chegamos dele. Nós iremos nos afastar em tédio, pois como mais poderíamos reagir ao fato de que a realidade se esconde ao máximo quando está prestes a se revelar? Esta é a versão profunda ensinada a nós pela estória de Narciso... (289)

Ora, três observações interconectadas são cabidas aqui. Primeiro, sobre a relação entre a maior subjetividade e a maior objetividade. Em conexão também com a citação anterior a esta, registremos a diferença nada subestimável apontada na seção sobre Guardi: os padrões da escrita e da experiência histórica devem ser simultaneamente encontrados e produzidos livremente. Eles dizem respeito à capacidade da imaginação de produzir e comunicar formas de olhar para eventos cujas conexões efetivamente existiram. As conexões causais são sempre de altíssimo número, mas a experiência histórica seleciona-as, significa-as livremente - e a representação histórica, adicionalmente, deve combinar as ações anteriores com uma linguagem capaz de tornar intersubjetivamente acessível uma dada forma de olhar para o passado. No caso da historiografia, como o próprio Ankersmit já mostrou, a maior subjetividade em conexão com a realidade é precisamente o que propicia o aparecimento da maior objetividade. Mas isto nos conduz às observações seguintes, já que, como ele bem nota aqui, o objeto parece desaparecer enquanto algo conhecível quando visto de perto. ${ }^{236}$

Em segundo lugar, notemos que a noção de "realidade" adotada aqui diz respeito à percpeção. Ela não é o mesmo que "realidade humana", muito menos uma manifestação passada da realidade humana, e também não é a "realidade histórica" acessada por meio de - ou produzida por - um texto ou uma experiência. Mas lembremos que, segundo o argumento narrativista, a realidade não se manifesta perceptualmente já dotada de quaisquer significados. Assim, para que algo surja como um objeto, é necessário haver não apenas a relação entre a materialidade do mundo e os órgãos sensoriais, ${ }^{237}$ mas também uma conceitualização desta parte "individualizável”

\footnotetext{
${ }^{236}$ Deste prisma, as reflexões de Ankersmit sobre experiência histórica podem facilmente ser lidas como um aprofundamento da questão sobre como acessar ou ter contato com a realidade.

${ }^{237}$ E mesmo esta relação, conforme o próprio Aristóteles, em quem Ankersmit baseia parte de suas teorias sobre experiência, já não é unicamente objetivista. Como John Russon (1996: passim) explica, Aristóteles concebe que embora a sensação não seja uma atividade redutora do outro ao mesmo - como é a nutrição e sim uma atividade que se conforma ao objeto, mesmo ela deve ser feita também nos termos do próprio conhecedor. Por exemplo, o toque demanda que o objeto apareça de modo tátil, o cheiro demanda que o faça de modo olfativo, etc.
} 
do mundo como um objeto. Assim, adicionando agora a segunda observação, a conclusão que nos parece sustentável não é que "a realidade se esconde ao máximo quando está prestes a se revelar", uma realidade por trás daquilo que acessamos por meio dos órgãos sensoriais - digamos, fornecendo uma "substância" que possa nos dar uma compreensão do objeto, colocá-lo metaforicamente em nossas mãos [" $a$ firm hold of the object"]. Quando Ankersmit afirma que o tédio fornece acesso à "realidade", a conclusão me parece ser: sim, pois ele mostra precisamente que o mundo perceptível só se torna um mundo de objetos discerníveis com a participação da consciência. Este processo, em sua versão com maiores complexidades epistemológicas, é precisamente o que se manifesta quando tentamos escrever histórias: não há substâncias a serem acessadas por trás das "substâncias narrativas" (pois são precisamente as narrativas e representações que produzem as substâncias), ou, no caso do contato percpetual do mundo, com as "substancializações" ou produção de objetos. A "experiência direta" tida por Ankersmit parece falha exatamente porque ele esperava haver algo mais: um mundo de coisas em si. Mas longe de dizer que tratou-se de algo como uma experiência da impossibilidade de acessar a realidade, ele experienciou a sublimidade da realidade, que é precisamente uma tese negativa sobre como a realidade é. Ela é assim em todos os períodos históricos, indo desde pequenos objetos representados em ornamentos a processos históricos de longa duração, embora esta forma de dizer seja historicamente condicionada e não haja uma meta-linguagem para expressá-la de maneira unívoca. Complementaríamos ainda: se, como propôs Ankersmit, o tédio permite que se experiencie a realidade com o máximo de proximidade, por suspender nossas expectativas usuais em relação ao mundo, ${ }^{238}$ também é nítido que seu relato parece conter uma expectativa "transcendentalista", e que tal expectativa é o que (re)produz o tédio. $^{239}$

\footnotetext{
${ }^{238}$ Segundo Braver: "Para Heidegger, sair de nossas preocupações cotidianas e distraídas funciona como o que Derrida chama de pharmakon, tanto cura quanto veneno. Enquanto o desengajamento do envolvimento ativo tradicionalmente levou ao infeliz domínio da ontologia do ser simplesmente dado [no original: presence-at-hand, tradução para o termo Vorhandenheit de Heidegger. Recorro aqui ao termo empregado por Márcia Sá Cavalcante Schuback; ver HEIDEGGER, 2005: 32], quando cultivado em um atento e quase fenomenológico "ficar com as coisas" (BW 353) - como Heidegger faz em seus trabalhos tardios - isto produz insight sobre a natureza do próprio ser. ... A combinação de hermenêutica e fenomenologia feita por Heidegger significa que compreender fenômenos envolve interpretação. Ainda que isso nunca possa nos levar a rejeitar fenômenos a favor de algo noumenal escondido atrás deles ou algo substancial à espreita por baixo, nós também não somos forçados a tomar as coisas tal como elas aparecem inicialmente. As conclusões devem ser corroboradas pela experiência, amplamente concebida, e isso geralmente requer considerável esforço e paciência." (BRAVER: 2012: 46-7)

${ }^{239}$ Dizemos "(re)produz" porque, embora ele antes afirme que o próprio tédio estimulou o seu livre jogo da imaginação em relação aos padrões de flores, ele também afirma que o tédio resulta do que ele
} 
Assim, a discussão sobre a conexão entre representação e "vida real" do caso de Guardi reaparece aqui. Mas a mesma reflexão pode produzir não tédio, mas exatamente a revelação da sublimidade da realidade humana, perpassada por uma ficcionalidade para usarmos um termo caro a Vico e White - muito mais profunda do que o investigador inicialmente imaginara. Inseparável desta ficcionalidade é uma maleabilidade que abre espaço para o tipo de ação ética que é enfatizada de muitas formas e momentos na tradição narrativistas. Afinal, se se pudesse encontrar "ornamentos de flores" para além das categorias, e não a ausência de tal "ornamento" nos inputs sensoriais - quando examinado na busca pela realidade do ornamento na materialidade tal como experienciada por visão e eventualmente outros sentidos - então a mente que experiencia "ornamento" seria efetivamente um Espelho da Realidade. Nossa hipótese de trabalho é que, em vez disto, ela é co-construtora - incorporada, situada, com uso de categorias intersubjetivas que ela modifica performativamente, mas que criaram sua intersubjetividade antes que ela pudesse operar tais modificações - da "realidade humana". Se a materialidade por si só possui uma rigidez que contrasta com a maleabilidade das categorias com que lidamos com ela, a realidade humana caracterizada pela interação de mentes incorporadas com a facticidade do ambiente físico e social - se mostra muito mais maleável do que inicialmente poder-se-ia cogitar. Isto é, muito mais histórica, pois muito mais contingente.

Uma terceira observação segue. Se concebemos, como Dewey e como Ankersmit em seus momentos mais aristotélicos e menos kantianos, que a experiência ocorre precisamente na interação indivisível entre subjetividade e objetividade e que não há esta realidade se escondendo de nós, então a linguagem passa a ser algo que usamos para fazer coisas, e não algo que usamos para "espelhar" transcendentalmente a realidade. Esta é certamente a posição que Ankersmit deseja adotar, seguindo Rorty. Nesse caso, é necessário rever a seguinte posição: "A liberdade resulta," diz ele, "da nossa experiência da indiferença sublime da realidade às categorias e estruturas que nós projetamos nela, tão vorazmente e tão inutilmente." (2005: 289-90) A partir do momento em que usamos a linguagem autoconscientemente, então não se trata de inutilidade: pelo contrário, o critério para qual vocabulário usar passa a ser precisamente sua utilidade para os fins que desejamos adotá-los (cf. RORTY, 1994). Esta me parece uma afirmação muito mais adequada à "filosofia existencialista" de Ankersmit. 
Em vez disso, a impossibilidade de "agarrar" a realidade é o que se manifesta dentro dos pressupostos transcendentalistas e cientificistas que o capítulo em questão ainda manifesta.

Cabe apenas lembrarmos que isto é algo que $a$ arte pode fazer, mas que sua transposição para "a vida" - como quando produzimos sentido para o passado, realizando o lance histórico de modificar o próprio presente por meio da modificação do passado tal como o significamos - não pode esquecer que (para fazermos uma analogia com o ornamento) toda representação "orgânica" deixa de fora elementos que seguirão presentes e, mais cedo ou mais tarde, demandarão ser apresentados à consciência. Esta maneira peculiar de atividade (também) estética que é a historiografia está inserida no mundo da vida. O ornamento, embora seja feito em um suporte material também sujeito à ação do tempo, pode ser experienciado como se não pertencesse, mas tal abstração é menos possível e menos desejável no caso da historiografia. Menos possível porque uma história efetivamente capaz de se abstrair da vida logo se tornaria inteiramente irrelevante, e as várias formas de historiografia realmente existentes - pelo tipo de pacto contingentemente formado entre historiadores e (a) seus pares e (b) seu "público" tratam de assuntos que movem as pessoas, e com recursos retóricos que as movem. Isto é: elas efetivamente completam o ciclo de sair do mundo da vida e retornar a ele. Menos desejável porque, como textos históricos de caráter mais "prático" buscam fazer algo em relação ao passado, então toda produção "orgânica" só tem utilidade na medida em que for interpretada por alguém que seja capaz de mobilizá-lo para seus fins (incluindo o fim de repensar seus fins).

O mundo se adapta à ornamentação rococó, da perspectiva de quem aprecia tal ornamentação, mas dimensões inteiras do mundo não se adaptam à representação histórica da perspectiva de pessoas que querem agir de maneira eficaz em relação ao mundo. Na escrita da história entendida como uma etapa do processo "existencial" humano, sobre o qual reflete a "filosofia existencialista da história", trata-se tanto de conquistar quanto de ser conquistado, sem algoritmos capazes de definir a principal a medida ideal de cada um.

Note-se, evidentemente, que tais observações não são uma crítica à ornamentação rococó, mas uma comparação sobre como não se poderia transpor tais reflexões para a filosofia da história. Tal transposição resultaria em uma concepção cientificista da escrita da história, inseparável de "humores e sentimentos" igualmente cientificistas, ligados à noção iluminista de que se pode "conquistar espaço e tempo" 
(ANKERSMIT, 2005: 304). As reflexões sobre presença deixam claro: o destino de toda representação que produzimos, por ser erguida sobre pilares instáveis, é ser útil por um tempo, antes de ser "conquistada" pela realidade, que não se dobra aos sentidos produzidos por seres humanos que usam representações para lidar com ela, e portanto precisam encontrar novos meios de compreender (não espelhar) sua complexidade, irredutível às representações.

\section{c) Humores e sentimentos}

Antes de concluir o capítulo "Subjective Historical Experience", Ankersmit sintetiza os exemplos do capriccio de Guardi e do ornamento rococó com uma reflexão teórica sobre a noção de "humores e sentimentos" (moods and feelings), caracterizandoos como "o locus da experiência histórica." (2005: 306) Embora Heidegger empregue com grande importância a noção de Stimmung (que Ankersmit traduz como "mood") em Ser e Tempo, é principalmente com O. F. Bollnow que Sublime dialoga. Estes humores, para Bollnow, estão "no nível mais profundo de toda a nossa vida mental", e expressam “como nos sentimos sobre a vida em geral." Eles são "as maneiras mais elementares e básicas em que a vida humana - embora sempre já com um certo viés, tendência e atitude - pode se tornar consciente de si mesma". (citado por ANKERSMIT, 2005: 307)

Dentre as especificações e comentários que temos a fazer sobre a noção, a primeira diz respeito à compatibilidade com nossa afirmação de que tanto a experiência do passado quanto a representação histórica atuam com base no que Collingwood chamou de "segundo nível de consciência". Já dissemos várias vezes que isto não significa que representação e experiência sejam a mesma coisa, pois, ao caracterizar a "experiência histórica subjetiva", a atenção parece focar inteiramente (ou quase) neste nível mais básico, deixando de lado momentaneamente as atividades de terceiro e quarto nível reflexivo - em um aspecto de como seres humanos no passado experienciavam a si mesmos e ao seu mundo. Da mesma forma que no caso da imaginação, é evidente que esta construção e (não "ou”) desvelamento do mundo por meio da imaginação não é meramente abstrata e apriorística, mas sim conectada ao corpo (dotado de memórias, desejos, habitus etc., alguns dos quais têm afinidade com certas atmosferas do passado).

Assim, como no caso da escala de formas de Collingwood, também Bollnow “demanda que nós aceitemos o paradoxo de que nossos humores e sentimentos são, por um lado, a fundação de toda a nossa vida mental ... mas, ao mesmo tempo, o seu aspecto 
mais volátil e transitório." (2005: 307) É por ser assim que podemos afirmar, por meio da leitura que Braver faz de Heidegger e Wittgenstein, que os fundamentos da vida humana são "groundless grounds": desse modo, se a atmosfera é efetivamente um fundamento, o próprio fundamento é meramente contingente. As reflexões de Vico sobre a condição de possibilidade da comunicação também demandam um chão prévio, igualmente contingente: para ele, a possibilidade de falar sobre o mundo presume o estabelecimento de uma "tópica" prévia, que estabelece o consenso que possibilita a comunicação subsequente. Acordo não seria, assim, o que surge ao final da comunicação, mas também o que permite que ela se instaure. Dessa forma, o acesso a um mundo passado em sua dimensão mais básica demanda uma afinidade de "humores" comuns. Veremos ao longo do capítulo que isto ocorre nos vários exemplos de experiência histórica elencados por Ankersmit.

Em segundo lugar, tanto ao buscar apoio teórico na noção de "humores e sentimentos" quando em tomar dois exemplos de Stimmung do passado experienciáveis por meio da arte do período, Ankersmit formula sua explicação em termos que nos parecer fornecer evidências consideráveis quanto à nossa tese de que o contato com o passado se dá por meio de conexões figurais. Aqui, isto fica claro fato de que figura só se manifesta quando encontra o preenchimento, e vice-versa, de modo que nenhum dos polos é fixo: o encontro é o que faz com que eles se efetivem. Então não se trata de uma característica do sujeito no presente que, estando já pronta, permite ver algo no passado, ou vice-versa: a relação modifica ambos os polos. Ela evidentemente é retroativa: ocorre na dependência de uma consciência no presente, vivendo em relação com outras consciências. Mas, como vimos, isto não significa que sua posição seja transcendental, como no jargão pós-modernista que postula um sujeito significando livremente um passado que não pode reagir, responder, protestar. (E, claro, não estamos afirmando que "o passado" reage, mas que o contato com o passado modifica o próprio sujeito, e o significado surge na relação. A relação é retroativa e depende de uma consciência viva no presente, mas é não meramente "impositiva".)

Em terceiro lugar, e em íntima conexão com o segundo ponto, lembremos que Ankersmit afirma haver uma similaridade estrutural entre Stimmung e música. É possível falar (como Dewey ao tratar da experiência) em um "colorido" do mundo, mas Ankersmit considera ainda melhor falar no "tom" (key) pelo qual experienciamos o mundo. Ele especifica: "Stimmung é etimologicamente relacionada a Stimme ("voz") e é sugestivo da afinação de um instrumento, por exemplo, de um piano ou um violino, e do 
tom em que uma composição musical foi escrita.” O tom não é um conteúdo específíco da música, nem mesmo um estilo; da mesma forma, humores e sentimentos "não têm conteúdo e não têm nem mesmo a determinação da forma que nós associamos com estilo". (308) Eles são "perto de nada": em vez de ter origem em objetos emocionais, eles precedem tais objetos; são "a paisagem em que a nossa vida emocional irá acontecer." Elas têm, assim, uma "leveza", e é esta dimensão incrivelmente leve - em contraste com o "peso" de conteúdos, formas e estilos - que é acessada na experiência histórica:

A experiência histórica é a ressonância que a "música do passado", seus humores e sentimentos, pode ter no historiador cuja mente por acaso tenha sido composta no mesmo tom. E é a combinação sublime de uma leveza extrema com a toda-pervasividade que permitiu que os humores e sentimentos tenham esta ressonância ao longo dos séculos. Mais uma vez, como não admitar Huizinga por ter descoberto este relacionamento da experiência histórica com a música! (2005: 309)

Isto apoia outra de nossas teses: a de que, (a) sendo a estrutura mais básica das representações históricas uma expressão da atividade imaginativa, e (b) sendo a historiografia uma expressão particular da capacidade da faculdade de imaginação de criar mundos (i.e., articular elementos na relação sujeito-mundo), manifestada de modo mais geral na criação da realidade humana que, vista diacronicamente, é a história, então (c) a experiência do passado em sua dimensão mais básica contém em si muitos elementos que, afora as características peculiares da prática historiográfica, compõem também a representação histórica.

Basta vermos que, da mesma forma que o Stimmung se assemelha à música, também a representação histórica tal como os narrativistas a pensaram também possui tal característica. Seguido Mink, por exemplo:

[A forma narrativa] não pode ser "dita", mas deve ser "mostrada" - na narrativa como um todo. A situação não é diferente da estória apócrifa contada sobre muitos compositores, por exemplo de Schubert: quando perguntado sobre o "significado" da sonata que ele acabara de tocar, sua única resposta foi sentar e tocá-la de novo. (MINK, 1987: 187$8)^{240}$

\footnotetext{
${ }^{240}$ Mink enfatizava ainda uma diferença: o fato de que a representação histórica busca ser verdadeira, enquanto a música não. Quando faleceu, em 1983, ele ainda não considerava ter encontrado uma explicação satisfatória para o que seria uma "verdade narrativa". Pode-se dizer que a proposta formulada por Ankersmit em 2012, formulada em termos heideggerianos, preenche seu projeto. Podemos especular que que apenas a incursão nos níveis mais básicos da experiência humana - que o próprio Mink encontrou na escala de formas e sobre a qual realizou especulações teóricas, mas não explorou na forma de exemplos como fez Ankersmit - permitiu a Ankersmit adotar uma noção mais "experiencialista"ou "existencialista" de representação em seu livro de 2012.
} 
Em uma passagem d'A Invenção do Cotidiano, (v. 1, 1994: 155), Michel de Certeau faz comentário semelhante, mas atribuindo a história a Beethoven. O contexto da discussão é outro, mas - ou por isso mesmo - ele aponta para algo de valor. Ali, a forma musical é comparada às recitações orais na possibilidade de serem repetidas como um "gesto tático", que não pode ser dito de forma proposicional, mas sim mostrado pela sua repetição. Por ser um lance em um jogo, a repetição não é uma mera cópia, mas parte de uma prática: ela $f a z$ algo. Poderíamos dizer o mesmo sobre as tentativas de expressar atmosferas do passado por meio de textos históricos: ao mostrar (uma experiência do) passado que não pode ser dito(a), ela produz a novidade no gesto mesmo da repetição.

A comparação entre a forma narrativa e a música reaparece em outros pontos da tradição narrativista. Em Metahistory, White também compara a estrutura narrativa com a música, indicando que ambas produzem sentido mas não possuem valor de "verdade" - uma música não é "verdadeira" ou "falsa". Ele diz sobre a forma musical, comparando-a à narrativa, exatamente o que Ankersmit diria depois sobre ela, comparando-a à experiência: ela aspira à pura forma. Em Mind, History, and Dialectic, Mink - lendo Collingwood - afirma o mesmo sobre as metáforas: elas são condição de possibilidade para que a mente possa formular asserções verdadeiras ou falsas, mas não são elas próprias verdadeiras. Lembremos que, escrevendo sobre representação, Ankersmit dá grande centralidade à maneira "metafórica" pela qual ela se relaciona com o passado. Lembremos agora que, introduzindo a noção de experiência histórica sublime, ele a situa nesta "etapa que precede todas as questões de verdade e falsidade históricas." (2005: 15). Lembremos também que, ao tratar desta estapa em termos de sinestesia, Huizinga também considerou que as palavras capazes de expressá-las "eram formadas por uma 'formação lírica direta' ou 'pela metáfora lírica de uma palavra já existente para expressão sentimento ou sensação'."241 (idem, 129) E, da mesma forma que, de acordo com a escala de formas collingwoodiana, a "consciência histórica" só pode vir à tona após a reflexão sobre as experiências nestes níveis mais básicos, também aqui o interesse de Ankersmit é escrever "sobre o que é a natureza e a origem da consciência histórica." (idem, ibidem)

\footnotetext{
${ }^{241}$ Ankersmit cita aqui as palavras de Wessel Krul, biógrafo de Huizinga, no livro Historicus tegen de tijd (Groningen, 1990), p. 132.
} 
Em quarto lugar, e novamente em conexão com as discussões anteriores, há o problema da relação entre experiência - no caso dos moods and feelings, anterior à linguagem, situada no nível mais básico de contato com o mundo - e as atividades subsequentes da mente. O ponto preferencialmente enfatizado por Ankersmit é o da relação entre experiência e verdade. Na conclusão do sétimo capítulo de Sublime, Ankersmit comenta que, tanto no caso da experiência de uma obra de arte quanto no da experiência do passado, "nos é requerido que fiquemos 'na superfície', por assim dizer, e que evitemos a tentação de buscar por fundações mais profundas para o que nós vemos e experienciamos, seja no lado do sujeito, seja no lado do objeto.” (313) Por isso, ele considera que estas discussões sobre experiência não se aplicam às discussões sobre escrita da história. Pois a historiografia tem pretensões cognitivas, e a "experiência não tem função cognitiva a exercer aqui." (313) Mas imaginando um eventual interlocutor interessado na relação entre experiência e verdade, ele adiciona que "a experiência histórica não é a serva da verdade aqui, mas sim sua guia." (313) Ele formula uma analogia com a economia, na qual tanto é indesejável um excesso de planejamento, como no caso da economia soviética, quanto é indesejável um excesso de liberdade. Ele vê o mesmo no caso da escrita histórica, “onde nós também buscamos o juste milieu entre verdade e experiência e onde um excesso de uma delas às vezes precisa ser compensada por uma infusão extra da outra." (313)

O que isto pode significar? A meu ver, a melhor versão que se pode apresentar deste argumento afirma que é possível haver experiência direta dos moods and feelings, sem a presença da linguagem, mas que não é possível dizer verdades sobre o mundo (atividade de terceiro nível da consciência) sem tê-lo colorido de uma certa forma, ou atribuído um certo tom a ele. Uma representação autêntica, produtora de verdade estética e não apenas de verdade factual sobre o passado, saberia expressá-lo de modo a fazer jus a esta entonação do mundo passado, à sua dimensão experiencial básica que coloria as ações e pensamentos "de terceiro nível”, acessíveis por meios científicos ou hermenêuticos, e sobre as quais se podem falar verdades factuais. Assim, a atividade dos níveis mais abstratos da mente não é jamais separada da experiência dos níveis mais básicos, embora esta possa ocorrer - como Ankersmit afirma, contra Rorty et al - sem a presença da linguagem. Isto é precisamente o que se pode depreender do argumento de Oswald Spengler mencionado por Ankersmit, em que até mesmo a matemática aparece como expressão de moods and feelings: a matemática dos gregos, por exemplo, aparece em $O$ Declínio do Ocidente como a expressão de uma maneira de apresentar o mundo 
bastante conectada às experiências sensíveis, enquanto a matemática mais formal do século XVIII expressa uma mentalidade mais abstrata. ${ }^{242}$

Além disso, lembremos aos leitores nosso argumento que a eficácia de um dos níveis sobre o outro não se move apenas de baixo para cima. Em sua relação holística, há nitidamente um movimento "de cima para baixo", dos níveis mais abstratos de volta para o mais básico - a ruptura do qual sendo aquilo que, em breve, discutiremos como exemplo de uma "experiência histórica sublime". Nosso argumento do capítulo 2, segundo o qual o "ponto de vista" do autor é abduzido pela leitura de suas frases (que expressam atividades de terceiro e quarto nível da mente), expressa esta visão. Isto também explica como não basta o desejo de se conectar com o passado para a ocorrência de experiências históricas subjetivas: a erudição é uma marca característica daqueles que passam por ela. Assim, porque a experiência (da Stimmung) colore as demais atividades da mente, o que está em jogo opera sempre na interface entre sujeito e objeto. Isto nos leva a discordar de Ankersmit quando ele formula raciocínios situando "a verdade" em um dos lados, como no caso de Meaning, em que ele a situa "no lado do

\footnotetext{
${ }^{242}$ Em uma passagem de The Idea of History na qual discute o mesmo trabalho de Spengler, Collingwood cita-o no contexto de uma discussão sobre a relação entre passado e presente. Ele afirma: "A falácia comum a estas visões [de Spencer e Santayana, citadas no parágrafo anterior] é a confusão entre um processo natural, em que o passado morre ao ser substituído pelo presente, e um processo histórico, em que o passado, na medida em que ele é conhecido historicamente, sobrevive no presente. Oswald Spengler, realizando vividamente a diferença entre a matemática moderna e aquela dos gregos, e sabendo que cada uma é uma função de seu próprio período histórico, argumenta corretamente a partir desta falsa identificação de processos históricos com naturais que, para nós, a matemática grega deve ser não apenas estranha, mas também ininteligível. Mas, na verdade, não apenas nós entendemos a matemática grega com facilidade, ela também é, na verdade, a fundação da nossa própria. Ela não é o passado morto de um pensamento matemático feito por pessoas cujos nomes e datas nós podemos dar, ela é o passado vivo das nossas próprias investigações matemáticas presentes, um passado que, na medida em que nós nos interessemos por matemática, nós podemos ainda apreciar como algo que de fato possuímos. Porque o passado histórico, ao contrário do passado natural, é um passado vivo, mantido pelo pelo próprio ato do pensamento histórico, a mudança histórica de uma maneira de pensar para a outra não é a morte da primeira, mas a sua sobrevivência integrada em um novo contexto envolvendo o desenvolvimento e crítica das suas próprias ideias." (COLLINGWOOD, 1994: 225-6) Enquanto Ankersmit não poupa elogios a $O$ Declínio do Ocidente em Sublime, Collingwood considera-o "radicalmente inconsistente", um trabalho que marca um "relapso rumo ao naturalismo positivista" por parte de Spengler. (idem: 181) Creio que sua crítica pode ser aplicada a muitas concepções contemporâneas que, embora se pretendam profundamente distintas do positivismo, ainda recaem no que caracterizamos como uma concepção atomística de eventos ou da experiência, e como o que caracterizaremos como uma noção a-histórica de "período". Tenho em mente todas as teses (pós-modernistas, construtivistas, e em alguns de seus pressupostos também ankersmitianas) que meramente concebem o passado como algo que passou, em reconhecer uma diferença entre o passado natural e o histórico. Diz Collingwood sobre O Declínio: "Os fatos são concebidos positivisticamente como isolados uns dos outros, em vez de crescerem organicamente um a partir do outro; mas os fatos agora são grandes chunks de fato - fatos maiores e melhores, cada um com uma estrutura interna fixa, mas cada um relacionado não-historicamente aos outros. [...] Assim, a cada ponto, a ideia do processo histórico como um processo mental, no qual o passado é conservado no presente, é elaboradamente negado." (idem: 182) Em outro momento, ele faz uma observação que pode explicar o apreço de Ankersmit pelo livro de Spengler: neste, "o isolamento de várias culturas é tão completo quanto aquele mas mônadas leibnizianas." Deste modo, "não há qualquer relação positiva entre uma cultura e outra." (idem: 469)
} 
passado". A verdade é sempre a dimensão objetiva do mundo apresentada a partir de uma certa perspectiva sobre ela. E isto também nos leva a concordar com o argumento de White sobre os perigos da má-fé na historiografia e o de Collingwood sobre os perigos da "corrupção de consciência". Afinal, como argumenta Ankersmit com base em Spengler, mesmo as maneiras mais "distanciadas" de lidar com o mundo seguem sendo uma expressão de uma Stimmung particular, e deixar de reconhecer isto nos impediria (a) de descobrir e reconhecer os méritos de outras maneiras de fazer o mundo aparecer, e (b) de entender filosoficamente o processo pelo qual conhecemos (historicamente ou de outras formas) o mundo. Se vários níveis estão presentes e se organizam em uma totalidade experiencial, então é de nosso interesse prático reconhecer a presença de todos e poder produzir verdades de vários tipos, tanto as mais artísticas quanto as mais científicas, e é igualmente de nosso interesse refletir moralmente sobre as consequências das maneiras pelas quais articulamos passado, presente e futuro. Como o conhecimento científico em geral, ou o "passado histórico" em particular, dão conta de apenas uma dimensão, é necessário que produzamos e articulemos "passados práticos" e reflexões meta-históricas.

$\mathrm{Na}$ lógica da discussão sobre as representações históricas de que tratei no capítulo 2, é possível argumentar que os níveis superiores de atividade reflexiva da consciência apresentados textualmente "abduzem" uma Stimmung, pois os níveis da escala de formas se interpenetram, e os mais básicos são modificados pelos mais abstratos (assim como, para Ankersmit, a totalidade de frases permite individualizar a representação, mas esta é mais básica). Aqui, cabe lembrar que isso acontece não apenas na representação histórica, mas também na vida - inseparável das representações e aqui, até mais precisamente, por meio das narrativas, que delimitam o tipo de expectativas sobre o que pode ser encontrado no "mundo", expectativas inseparáveis da memória intelectual e corporal de experiências anteriores: o tipo de experiências que uma pessoa considera que pode ter abduz uma paisagem capaz de englobá-las, e vice-versa. Assim, por exemplo, uma criança por muito tempo confinada à cama por estar doente (como Ankersmit relata ter sido) não terá como produzir, com seu corpo e nas interações com outras pessoas, ações compatíveis com a sensação de conexão, como brincar na neve e jogar jogos. As circunstâncias econômicas e tecnológicas de um período também têm grande poder de moldar a Stimmung de um período: por exemplo, a presença massiva da virtualidade em nossos tempos e a estruturação dos centros urbanos favorecem a sensação de desconexão que Ankersmit experienciou por outros motivos, e, por outro 
lado, o excesso de estímulos dificulta a experiência do tédio (ou tentam suprimi-la exatamente por ela ser muito grande) - e, se a tese (dele e de Heidegger) de que o tédio permite um maior conhecimento do funcionamento da realidade está certa, a consequência é que o excesso de estímulos nos mantém presos a mundos construídos por "metáforas parciais" (cf. WHITE [1963] 2010) que a tomam como totalidade, da mesma forma que os Pulcinellas muito reativos às suas demandas por prazeres aparecem presos aos seus mundos particulares, insensíveis aos seus fellow human beings.

Façamos ainda uma quinta observação sobre a noção de "humores e sentimentos", utilizando-a agora para iluminar a filosofia do próprio Ankersmit. Suas observações auto-biográficas neste capítulo, revelando-se intimamente familiarizado com o humor do tédio, já oferecem os subsídios necessários para isto. A prática da filosofia se dá sempre como uma expressão de certos humores, que permitem que certos aspectos do mundo se revelem (KENAAN \& FERBER, 2011) - e, como mencionamos, o próprio Heidegger já caracterizara o tédio como o humor sem o qual a prática filosófica não pode se desenvolver. A filosofia de Ankersmit revela alguma "tonalidade" específica? Os exemplos dados, e a maneira pela qual os apresentamos, não deixam dúvidas que sim. Vista desse modo, tanto sua filosofia "narrativista" quanto sua filosofia "experiencialista" tratam dos dois aspectos envolvidos nesta dupla sensação de estar alienado em relação ao mundo e/ou ao passado, como quem vê o Sol por trás das pesadas paredes transcendentalistas e sequer consegue se aquecer com sua luz, mas ao mesmo tempo reconhece, é atraído pela, sua ferocidade, e se considera capaz de alcançá-la. Ankersmit afirma o ornamento rococó efetua "a transição do tédio para a participação no mundo", adicionando que consegue reconhecer esta mesma transição também em si mesmo, mas apenas após tê-la observado no passado - e viceversa. Este movimento é precisamente o movimento de interesses filosóficos "da narrativa para a experiência" (cf. DOMANSKA, 2009), que se revela, no final das contas, como duas expressões de uma mesma atitude básica em relação ao mundo. Se em Narrative Logic e em certos ensaios posteriores ele se encontrava do lado de cá da parede, mesmo naquele momento já não encontramos o pressuposto de que toda relação com o mundo se dá nestes moldes. Daí, History and Tropology como que atravessa o túnel transcendentalista e comporta uma tensão interna entre as sombras e a luz - tensão que Historical Representation busca harmonizar. Sublime Historical Experience já adota a perspectiva do outro lado, embora ocasionalmente ainda presuma que o único 
caminho seja por este túnel que passa por estas paredes grossas (mas presume que as paredes existem mesmo, i.e., mantém pressupostos transcendentalistas ao mesmo tempo em que busca rejeitá-los). As sínteses posteriores abordam diferentes aspectos da relação entre representação e experiência, mas as minhas favoritas, persistindo na analogia, são aquelas que, após caminhar, percebem que o olhar proposto por Guardi o acesso ao mundo bloqueado por altos muros transcendentalistas - são um tipo específico de relação dentre outros possíveis. É como se, ao andar por outros ambientes que não aqueles de Guardi, reconhecemos locais em que o sol nos aquece mais diretamente, sem paredes cientificistas, mas também sem pressupor que toquemos "o Sol em si”. 


\subsection{Questões gerais sobre experiência histórica em Ankersmit}

\subsubsection{Qual passado não pode ser experienciado, e qual pode?}

Em várias passagens ao longo de sua obra (1994: 19; 2005: 117; 2012: 175-7), Ankersmit cita a posição "construtivista" - de autores como Oakeshott, Meiland, Goldstein, Tucker - como exemplo de uma visão que tornaria insensata qualquer pretensão de experienciar o passado. Isto devido à "razão simples, mas decisiva, de que o passado não poderia possivelmente ser um objeto da experiência porque ele não existe mais. Nós só podemos experienciar, no sentido verdadeiro da palavra, o que nos é dado aqui e agora." (2005: 117) O passado mesmo ("past itself", grifo no original), para esta concepção, teria se perdido para sempre. (1994: 19)

Ele aponta, corretamente, um "interessante pressuposto escondido no argumento construtivista." Este pressuposto é o de que o conhecimento experiencial "sempre possui o que se poderia chamar de caráter atômico ou elementar." Assim, o "domínio da experiência" é "reduzido a estes blocos de construção [building blocks] de conhecimento atômicos e indivisíveis." (2005: 117) Uma consequência desta visão é que "não poderíamos jamais ter conhecimento experiencial de algo que é complexo, compreensivo, e avassalador [overwhelming]. Isto, é claro, é um dogma tipicamente positivista." (idem: 118) Dentre os contra-exemplos que Ankersmit fornece contra este “dogmatismo" está o de uma pessoa: "Não é verdade que uma pessoa é o mais complexo e compreensivo dos objetos?" Ele apresenta ainda como objeção ao positivista "nossa experiência da pintura, da música, da arte em geral." Desta forma, "exceto no caso dos experimentos científicos, a complexidade parece ser a regra, em vez da exceção, na nossa experiência do mundo.” (idem, ibidem)

Se o passado concebido atomisticamente não pode ser parte de uma experiência histórica, em que formas de concebê-lo ele pode ser?

Minha resposta envolve a afirmativa de que a dimensão mental da história e na historiografia não pode ser negligenciada, e, ligada a isto, busca explorar a dimensão dos significados (meanings) produzidos pelo "segundo nível de consciência" em sua relação com o mundo. Aqui se vê que proponha uma leitura do representacionalismo e do experiencialismo como muitos mais próximos do que usualmente se supõe.

Assim, o "passado" pode ser experienciado na medida em que se reconhece que toda experiência do mundo, passado ou presente, é vivenciada por uma mente incorporada, situada em um mundo social e natural. São os fenômenos mentais que, 
diferentemente da concepção atômica justamente criticada por Ankersmit, produzem uma interpenetração de passado, presente e futuro projetado. Não se trata de tomar "mental" como equivalente de "irreal" ou "imaginário", e como contraponto a "real": a realidade histórica é produzida por seres que têm mente, e, embora a compreensão histórica não se reduza a meramente produzir re-enactments dos pensamentos de agentes passados, não há outro lugar em que esteja "o passado" que não nos diversos "humores e sentimentos" ["moods and feelings"] - e todos os demais elementos de uma vida - das pessoas que viveram uma época. Também há uma forma de conceber os termos mente e presença que acaba por opô-los: o mental é concebido como o abstrato, enquanto aquilo que tem presença é associado a concretude, e esta a presença física. Mas isto não é correto. O passado que pode ser tornado presente é tornado presente pela mente - e como a mente é incorporada e se relaciona com o ambiente e com outras pessoas, então a presença física de monumentos, evidências, obras de arte e pessoas que nos interpelam - é um suporte para o evento mental em questão. Assim, não faz sentido conceber os termos dicotomicamente.

Ao tratar da "compreensão" (comprehension), Mink explicitamente a caracterizou como um ato mental (histórico, filosófico, científico); e este mesmo autor, ao estudar o pensamento de Collingwood, deu especial importância à sua filosofia da mente. A mente também tem papel central na obra de White; para exemplificar, basta lembrarmos do papel central que a tropologia ocupou por quase três décadas em sua obra. Se o foco de Mink é no conhecimento, a tropologia de White enfatiza a consciência humana como a produtora de significado para um mundo inteiramente nãosignificativo. Leiamos sua fala sobre a conexão entre consciência e significado:

\footnotetext{
Nós pós-modernistas somos sérios quanto à nossa necessidade de sentido [meaning], ainda que nós sejamos cientificamos irônicos sobre a possibilidade de encontrar sentido na congérie de coisas que chamamos de 'realidade'. Portanto, nós estamos na posição paradoxal, como sugere [Amy] Elias, de termos sido deixados como a nossa única fonte possível de significado uma história entendida como a nossa busca milenar e fracasso contínuo de encontrar sentido em qualquer outro lugar que não em nós mesmos. É este senso da história como o fracasso - especialmente no Ocidente - da religião, metafísica, ciência, e finalmente da própria história - o fracasso de encontrar sentido nas coisas e processos externos à consciência, que nos leva a pensar que a história - repensada, refigurada, re-imaginada - pode guardar o segredo de como e por que esta busca foi equivocada. (WHITE, 2005: 151-2)
} 
Esta consciência, não sendo desencarnada mas sim existindo holisticamente com o corpo e o ambiente (Aristóteles, Dewey), faz com que a realidade surja já significativa. É no segundo nível de consciência de Collingwood, ou na "atmosfera" de Ankersmit, ou na imaginação tropeadora de White, que podemos situar a dimensão mais básica a partir da qual os elementos do mundo se tornam individualizáveis e podem ser significados: a imaginação é "o local de nascimento do significado" (PETERS, 2013)

Dentre outras coisas, isto significa que conhecer a realidade histórica passada não é acessar algo localizável em um bloco temporal isolável, pois a realidade histórica não é algo para a qual o tempo é irrelevante. Sua temporalidade não é algo adicionado de fora, por historiadores, mas algo vivido em primeira pessoa antes de poder ser, se for, refigurado historiograficamente. Juntamente com uma certa vivência da temporalidade, e inseparável dela, está o fato de que seres humanos experienciam o mundo externo não como algo meramente objetivo, mas inseparavelmente de suas próprias emoções - nos termos de Dewey (1980), as emoções “colorem" as experiências de mundo. A "ferocidade" descrita por Huizinga (2010) em O Outono da Idade Média não existe independentemente das mentes incorporadas capazes de sentir medo, e o clima de latência descrito por Gumbrecht (2014) na Alemanha do pós-guerra não existe separadamente das memórias e das expectativas daqueles que viveram o período. Nem o tédio do Ancièn Regime (e de Ankersmit), nem o medo (não como um sentimento, mas como a experiência de um mundo ameaçador) dos primitivos de Vico. Os "humores e sentimentos" de uma época são uma experiência $e$ são a realidade histórica. Tais coisas não são incompatíveis: a história existe enquanto experienciada.

Uma representação histórica sobre estas representações/experiências passadas não é o texto (ou "produto"). Ela é a representação ou experiência que ocorre na mentecorpo do autor presente. As ações da parte "mente" deste composto possui uma peculiaridade que o corpo e, de modo geral, a matéria não possuem: como vimos com para Collingwood, pensamentos não são restritos ao tempo no sentido que os elementos materiais são; por isso, eles podem ser tornados presentes novamente. Ampliando um pouco mais o raciocínio, os significados produzidos por representações da vida cotidiana também são repetíveis - com diferença, como tudo na história, pois a repetição se dá em outro contexto e o significado é sempre contextual. Este aspecto da repetição com diferença não é diferente do que Ankersmit, muito justificadamente, buscava em History and Tropology por meio da experiência nostálgica. Ora, se podemos experienciar a representação que Huizinga fez de um período histórico com 
base no artefato onde ele expressou a forma pela qual ele experienciava o período, então a princípio podemos também experienciar a atmosfera que os próprios agentes experienciaram, se tivermos a erudição e habilidade historiográfica necessária para compreendermos: Huizinga é tão histórico quanto outros agentes históricos, que não escreviam livros. Mas para experienciar uma realidade passada não contamos com o apoio material de um livro, e portanto a "forma histórica" que o livro expressa deve ser produzida, o que só é feito com grandes esforços. Assim, como a realidade humana é experienciada na imbricação do organismo (que sente dor, dorme, precisa ser nutrido, envelhece, morre etc.) e de seu mundo material, por um lado, e dos significados (dele e de seu mundo intersubjetivo), por outro, então há algo destacável e repetível-comdiferença em toda experiência da realidade humana.

Não há polêmica quanto à destacabilidade de formulações abstratas, tais como as proposições científicas: todos concordam que elas são possíveis. Outras expressões, porém, são mais conectadas ao corpo e ao mundo imediato experienciado pelo corpo. Nesses casos, parece ser necessário que haja uma analogia figural entre o sujeito no presente e o sujeito no passado, que o permitam ou imaginar ou sentir como deve ter sido a experiência passada.

Os inputs sensoriais do passado estão perdidos para sempre, mas podem ser imaginados no presente. O processo evolutivo é lento o suficiente para que não haja diferenças substanciais entre os órgãos dos seres humanos do presente e do passado. Então, a distância radical entre nossa experiência e a deles não está na parte sensorial da experiência, mas na parte significativa. Porém, os significados tendem a penetrar muito "profundamente" (quase, mas não totalmente, all the way down - e mesmo quando vão bastante fundo, os esquemas linguísticos são instáveis e portanto deixam brechas, onde ocorrem "experiências históricas sublimes") nas experiências da realidade humana, de modo que a percepção já ocorre em uma totalidade na qual os significados que atribuímos ao mundo e a maneira pela qual o percebemos surgem inseparavelmente. Eles não são inseperáveis no sentido que estejamos condenados a operar automaticamente no processo. Eles são inseparáveis: (a) enquanto parte da "atitude natural" da maioria dos seres humanos que viveram até o momento; (b) no sentido que se articulam holisticamente na experiência; assim, se adoto referenciais diferentes no contato com o mundo, não experienciarei a "mesma" matéria: o foco de atenção 
espacial e temporal e o colorido produzido pela interpenetração de emoções e percepção - do mundo - serão outros. ${ }^{243}$

Ao afirmar haver um sentido em que a materialidade do mundo e os significados são separáveis, meu intuito é enfatizar a dupla tese do narrativismo whiteano sobre a sublimidade do mundo e a liberdade do sujeito. Mais especificamente, é afirmar que as reflexões filosóficas sobre esta relação sujeito-mundo, incluindo a variante historiadorpassado, é aumentar a margem de liberdade do sujeito. Isto não é fazer com que ele deixe de ser incorporado, situado, mas é permiti-lo reconhecer que a realidade humana que ele $f a z$ com seus pares não resulta de uma fatalidade, mas de sua participação, enquanto ser dotado de mente. Assim, se eu estivesse diante de Napoleão, o valor das reflexões filosóficas como as dos autores narrativistas seria me permitir reconhecer que, ao adotar diferentes "pontos de vista" diante dele, experienciaria diferentes aspectos da complexidade da pessoa (para retomarmos o exemplo de Ankersmit).

Se a experiência da pessoa é complexa, é mais realista que ela envolva o reconhecimento da particularidade desta experiência específica e envolve o que podemos chamar de "experiência da complexidade": abertura, curiosidade, reconhecimento de que há mais coisa a ver. Isto é realista. Além disso, eu deveria ver a participação de minhas próprias emoções no processo. Se sinto medo, por exemplo, vejo um certo aspecto dele (perigoso) que é inseparável do meu próprio projeto (mais imediatamente: de fuga; mais amplamente: de sobrevivência), sem que isso signifique que a característica que vejo nele seja uma mera projeção. Se sinto tédio, indiferença, rancor, nostalgia, desejo: tudo isto me revelará diferentes aspectos do representado, inseparáveis de meus próprios projetos.

Para encerrar esta seção, podemos aplicar o raciocínio recém formulado a uma das discussões do capítulo 2. Lá, vimos que o critério (implícito) de Mink para distinguir a "compreensão configuracional" de textos históricas de atividades compreensivas mais básicas é a complexidade daqueles, marcados por incontáveis redes de descrições sobrepostas. Mas agora podemos observar que, diante de textos ou diante do mundo, a experiência de simplicidade ou de complexidade depende da atitude que adotamos diante do mundo: se não pergunto pelo que não está imediatamente visível da pessoa na minha frente, ela pode parecer simples; se pergunto, uma complexidade - sem a qual toda ação ética se faz impossível - pode se manifestar. Da mesma forma o texto:

\footnotetext{
243 Ver os comentários de Braver (2012: 139-146) sobre “modelo perceptual de pensamento" em Heidegger e Wittgenstein.
} 
uma descrição pode ser interrogada na forma de representação, a ser investigada em suas partes, a ser vista em suas várias conexões.

\subsubsection{Uma experiência é ainda pressuposto atomístico. Contraste entre Greenberg (simultaneidade) e Dewey (movimento e simultaneidade)}

Como argumentamos, com Dewey, uma "experiência" é a culminação de um processo no qual as energias do sujeito e do mundo se encontram e são re-trabalhadas de alguma maneira rumo a um certo ajuste (ou tensão). Se a destacamos esta culminação do processo em que ela ocorre, estamos produzindo um "objeto teórico", que serve para alguns fins mas não para outros. O texto histórico é um tipo deste objeto, e sua utilidade é óbvia para muitos fins. Mas também a experiência pode ser teorizada de maneira que obscurece sua dimensão processual.

Se, ao teorizar, esquecemos a refiguração e a circulação de energias, significados, intenções - e, no caso da historiografia, informações -, interiorizadas pelo sujeito e novamente exteriorizadas para o mundo, ${ }^{244}$ então ainda não liberamos o suficiente o pressuposto atomístico: pois se há, como temos insistido, um movimento da atenção entre parte e todo, então a produção de uma unidade inseparável em partes menores - um “átomo" artístico -, por mais importante que seja em nossa experiência do mundo - e certamente mais ainda na arte do que na vida prática - é uma etapa de congelamento que não pode não se reintegrar ao movimento da vida. A arte, evidentemente, apresenta balizas e criptogramas mais claros do que os que usamos na vida prática para permitir-nos relacionar suas partes em uma totalidade; mas isto significa que ela acentua artificialmente uma das etapas da dinâmica entre totalização e disrupção. A indivisibilidade ou não-destacabilidade (undetachability [conferir grafia]) existe naquele momento, mas ele segue sendo um momento.

Isto fica nítido em um exemplo dado por Ankersmit, típico da produção de um "objeto teórico":

\footnotetext{
Há uma anedota instrutiva sobre Clement Greenberg. Quando ele desejava avaliar uma pintura, ele caminhava até ela com as suas mãos diante de seus olhos. Quando estava de pé bem na frente da pintura, ele soltava suas mãos e o impacto imediato que a pintura então tinha sobre ele seria decisivo para ele. Obviamente, o objetivo do procedimento era [to take in] a pintura como um todo e evitar a tentação de, de alguma maneira, de formá-la a partir das suas partes componentes. (2005: 119; grifos no original)
}

\footnotetext{
${ }^{244}$ Sobre esta dialética de interiorização e exteriorização, ver COLLINGWOOD: 1958, DEWEY, 1980, e RUNIA, 2014. Sua importância na filosofia da história de Sartre é apontada por FLYNN, 1997.
} 
Contra a concepção positivista de experiência, como vimos, Ankersmit propõe a complexidade como um dos critérios para a maioria dos tipos de experiência que podemos ter do mundo. Eu complementaria então afirmando que a complexidade da experiência de uma totalidade simultânea envolve exatamente a tensão entre partes e todo. Não porque a experiência da pintura ou do texto como totalidade seja irrelevante, ou que possa sim ser decomposta em suas partes enquanto ela ocorre; mas porque a memória da experiência das partes está presente na experiência do todo. A expectativa da totalização, por sua vez, está presente na experiência das partes, e a memória de totalizações anteriores afeta este processo em algum nível. De fato, no caso de uma leitura, uma eventual expectativa por reconhecer o enredo, subsumindo a narrativa particular ao seu tipo geral, produz uma alienação da experiência do texto e portanto também do passado apresentado sobre o qual ele fala. White pode ser lido como um teórico da inevitabilidade desta alienação ou como alguém que descreve sua formação como meio de denunciá-la e evitá-la. Ankersmit já interpretou White nos dois sentidos, mas é evidente que prefere o segundo. ${ }^{245}$ Ao tratar de experiência, ele busca maneiras ainda mais diretas do que o texto histórico de superar a alienação em relação ao passado; mas mesmo ele compreensivelmente oscila em sua confiança da possibilidade de que tal coisa ocorra.

O caso citado por Ankersmit, o de uma pintura, envolve um tipo de arte que é experienciado da maneira mais espacial do que temporal (mas não separemos exageradamente estes elementos, por motivos que veremos em breve). Ankersmit, Mink e White tendem a enfatizar o equivalente desta dimensão espacial da historiografia. Porém, seja primordialmente narrativa ou primordialmente argumentativa, ela também se desenvolve temporalmente: ${ }^{246}$ seja produzindo pequenas unidades espaciais de compreensão e, ao fim do processo, a compreensão enquanto totalidade, seja desenvolvendo sua tese e exemplificando-a. ${ }^{247}$ Mas mesmo a complexidade da compreensão de algo espacial demanda o processo temporal de compreensão: o

\footnotetext{
${ }^{245}$ Ver especialmente "Hayden White's Appeal to the Historians" (ANKERSMIT, 2001)

${ }^{246}$ Northrop Frye é o caso de alguém que - contrastando textos, não especificamente históricos, com pinturas - argumenta na direção da temporalidade dos textos, enquanto Mink e Ankersmit argumentam na direção da espacialidade deles. O que todos eles tendem a negligenciar é a interpenetração do espacial e do temporal nas experiências estéticas. Ver FRYE, 1963, e o capítulo 2 deste trabalho.

${ }^{247}$ Sobre pequenas unidades (motivos) e maiores (estórias, que particularizam enredos), ver "The Structure of Historical Narrative" (WHITE, 2010), a primeira tentativa publicada por White de formular a grade tropológica que viria a aparecer em Metahistory. Para sua tese de que nem sempre a historiografia narra, mas inevitavelmente "narrativiza", ver WHITE, 1980: 1-25. Sobre o caráter argumentativo da historiografia, ver KUUKKANEN, 2015; sobre exemplificação, ver VAN DEN AKKER, 2013.
} 
momento envolve a retensão da memória da ida às partes e da expectativa ou consumação da totalidade.

Assim, uma alternativa a este raciocínio que Ankersmit apresenta no capítulo 3 de Sublime é a concepção pragmatista sobre a qual o capítulo 6 trata. Mas aqui apresentaremos uma dimensão do pensamento de Dewey que aparece com menos ênfase lá: a processualidade.

"Nenhuma obra de arte," argumenta Dewey, "pode ser percebida instantaneamente porque, se assim o for, não há oportunidade para a conservação e aumento de tensão, e portanto também não há oportunidade para as liberações e desenvolvimentos que dão volume a uma obra de arte." E ele especifica: "O que é retido do passado é embutido dentro do que é agora percebido, e é embutido de uma forma que, pela sua compressão lá, ele força a mente a se esticar para a frente rumo ao que está por vir." (182) Assim, Dewey considera equivocado, "mais do que uma ingenuidade fora de lugar", “a divisão das artes em temporal e especial.” $(183)^{248}$

Para o caso da representação histórica: como ela é sobre o mundo e deve ser comparada com outras representações sobre o mundo, ela é menos conectada com o suporte da experiência - o "produto" de arte de Dewey - do que a experiência de um quadro. Além disso, a unidade da experiência está ao alcance da percepção no quadro, de um modo que apenas uma memória muito admirável conseguiria experienciar no caso de um livro: o "rio visto de cima" não é tão fiel ao livro quanto "o quadro visto de frente". As discussões de Ankersmit sobre representação recorrem fortemente à analogia com quadros, e estas diferenças não deveriam ser desconsideradas. Mas como o Ankersmit de Sublime se interessa sobretudo pelas experiências de atmosferas do passado, então sem dúvidas as artes visuais são muito mais propícias a produzir tais experiências, e a decisão de discutir a simultaneidade da experiência com o exemplo da experiência de um quadro é acertada. Sem dúvidas, tais atmosferas se expressam muito mais fortemente em pinturas do que em livros de história. No caso da experiência de atmosferas do passado, ela estaria produzindo a organização não só das energias do quadro, mas de uma imensa vastidão de conhecimentos e sensações que o experienciador já teve do passado, no lado objetivo, e um alto grau de investimento emocional, no lado subjetivo - os dois lados, lembremos, se interpenetram, e a

\footnotetext{
248 Para a discussão do capítulo 2, isto reforça nossa conclusão de que nem Gallie nem Mink, nem followability nem comprehension, fornecem algo como "a natureza" da compreensão histórica, mas dois aspectos que operam de maneira inseparável: dois aspectos de um processo.
} 
experiência ocorre na superfície: o elemento objetivo do mundo é acessado por meio da subjetividade. Daí se pode conceber o quão intensa pode ser a experiência possibilitada pelo contato com uma metáfora capaz de organizar todos estes elementos de uma só vez.

Notemos, adicionalmente: o caráter processual da experiência se mostra inclusive pela sua irrepetibilidade. A complexidade de uma pessoa, por exemplo, só será experienciada por meio da repetição da convivência com ela, e não pelo método de Greenberg. Uma conversa com ela, ainda que em algum momento produza uma síntese - “ah, agora entendi!" -, é também um processo, e esta síntese envolverá a memória de como ela foi obtida. A experiência mais realista de uma pessoa se dá sem os pressupostos filosóficos realistas: poderíamos chamá-la de "experiência de complexidade", aquela em que a consciência da parcialidade da experiência - a consciência de não estar experienciando "tudo que está ali”, mas apenas um aspecto - é parte da própria experiência. ${ }^{249}$ Esta é a diferença entre "ah, agora entendi!" e "ah, agora entendi tudo!". Também um quadro e um livro são influenciados por este reconhecimento, que tem afinidade eletiva com as virtudes epistêmicas de curiosidade, abertura, pluralismo e com posições éticas como a de Butler, que recusam a possibilidade de que uma única descrição ou representação possa esgotar o sujeito. ${ }^{250}$ Não se trata de uma posição que recuse a sugestão "olhe de uma vez", mas de uma que, caso assim se escolha olhar - com que base recomendar o caminho do todo às partes e não o das partes ao todo? - complementa: "e depois olhe de novo, e a partir de muitos outros pontos de vista". Forçando a analogia apenas um pouco mais, lembremos ainda que um conselho como: "olhe de novo, e de novo, e de novo" demandaria um limite: "bom, há muita coisa para olhar no mundo, então não perca a autonomia da sua atenção". Este problema também toca o escritor da obra: havendo uma infinitude de informações no mundo, qual recorte fazer na realidade e, dentro dela, como combinar a atenção aos detalhes com a atenção ao sentido? O espectador da obra, como o historiador, terá que focar em alguns aspectos do passado e não em outros, mas, se seu propósito é "contribuir à salvação da espécie humana, à qual é nosso dever, enquanto

\footnotetext{
${ }^{249}$ O jovem White (2010: 20-68) seguiu Croce em sua crítica da adoção de "metáforas parciais" como se fossem maneiras completas de representar realisticamente a realidade. Este raciocínio culmina na defesa, em Burden, de que é preferível multiplicar a quantidade de metáforas disponíveis, e a afirmação, em Metahistory, de que qualquer restrição a tal multiplicação é arbitrária. Este pluralismo é endossado pela filosofia da representação de Ankersmit $(2001,2012)$, para quem a multiplicação de "formas de olhar" enriquece nossa compreensão da parte do passado em questão.

${ }^{250}$ Ver BUTLER, 1993, 2003, e também SAFATLE, 2015.
} 
pensadores, servir" (como sugeriu White [2010: 152] em 1969), então sua atenção deverá retornar ao mundo em algum momento. O que significa que a discussão sobre o que fazer com a atenção - na pesquisa, na escrita e na recepção - é inseparável da discussão sobre o que se quer. Não há como avaliar o "melhor" texto separadamente da visão do "melhor" mundo. Não havendo algoritmos para o segundo - mas havendo possibilidade de avaliação racional das propostas, ${ }^{251}$ baseada nas consequências pragmáticas e em conhecimentos sobre causalidade, regularidades, retórica etc. - nem para os méritos para alcançá-lo, então não há algoritmos também que fundamentem como proceder a avaliação do texto.

Em qualquer um destes casos, não se trata de subestimar a importância do momento de culminação da experiência, mas de localizá-lo no mundo prático. $\mathrm{O}$ primeiro momento de experiência da totalidade (como no exemplo de Greenberg) ou o momento de reconhecimento do enredo em um texto histórico irão ressoar sobre todas as leituras de partes possíveis. Anteriormente, a expectativa de uma conclusão já terá também sido também um componente envolvido na experiência das partes. ${ }^{252}$ Assim, nosso ponto sobre a processualidade da experiência demanda que não se conceba atomisticamente a relação parte e todo: a parte é sempre experienciada como parte-deum-todo, e o todo é duplamente experienciado como síntese de partes e como parte de um mundo ou processo histórico mais amplos que existem em seu plano de fundo.

Contrastando com o exemplo de Greenberg, vejamos o relato feito pelo próprio Dewey acerca da percepção de um quadro, cujo nome ele não cita:

\footnotetext{
${ }^{251}$ Aqui, em acordo relativo com a argumentação de Ankersmit em "In Praise of Subjectivity", transfiro para a dimensão utópica ou política o termo "proposta" que ele usualmente aplica aos textos históricos. Trata-se de propostas exatamente porque, na escrita da história e na política, não há normas préestabelecidas que determinem o que deve ser feito. Quando elas se consolidam na prática historiográfica, passando a haver acordo sobre como usar a linguagem em relação ao mundo, então passamos ao nível da epistemologia, que Ankersmit reserva às sentenças singulares. Eu enfatizaria que a estética não deixa de operar, mas pode deixar de ser reconhecida. Se acordos não são necessariamente indesejáveis, naturalizálos - ou pressupor equivocadamente não se tratar de uma proposta estética - é, pois impede-nos de propor outras coisas. Como um texto é um ato de fala direcionado aos pares, e portanto faz algo no mundo, perder de vista a possibilidade de propor outras perspectivas é perder de vista a possibilidade de propor outro mundo. Assim, (a) nos dois níveis - o da escrita da história e o da política - não se deve perder de vista a "contestabilidade essencial" das formas de ver/fazer o mundo, que são propostas e não normas, ou, ainda, seguem sendo propostas mesmo quando se cristalizam em normas; e (b) mesmo se pensarmos em política com referência à forma contingente assumida pelo estado moderno, escrita da história e política não são duas dimensões inteiramente distintas, já que a profissionalização da historiografia, como vimos, se deu sob a tutela dos estados nacionais e tomou a nação como sujeito central. Porém, ampliando um pouco mais o termo para um sentido mais amplo, capaz de incluir tanto a relação representaçãorepresentado (da filosofia política de Ankersmit) quanto o sentido ético de atuação no mundo (enfatizado por White), a escrita (e leitura) da história atua em relação ao mundo social mais amplo no qual ela está inserida. Daí que a inexistência de algoritmos para pré-determinar "o que deve ser feito" em ambos os casos sempre remeta ao nível mais amplo, mas sem poder tomá-lo como fundamento.

${ }^{252}$ Como Gallie já enfatizava em Philosophy and the Historical Understanding, em 1964.
} 


\begin{abstract}
Olhando para este objeto particular que eu tenho em mente, a atenção é primeiro capturada pelos objetos em que as massas apontam para cima: a primeira impressão de aquela de movimento de baixo para cima. [Se analisar, o espectador] descobre que a primeira e dominante impressão é determinada por padrões assim constituídos por ritmos. No meio tempo, o olho também está se movendo pela pintura, embora o interesse permaneça nos padrões que surgem. Então há uma parada [a halt, an arrest], uma pausa pontuada enquanto a visão vem no canto inferior oposto sobre uma massa definida que, em vez de se encaixar nos padrões verticais, transfere a atenção para o peso das massas dispostas horizontalmente. (1980: 174)
\end{abstract}

Como a pintura é bem composta, a variação não é uma "quebra na experiência", mas "um redirecionamento da interesse e atenção, que deste modo expande a significância do objeto. Tal como é, o encerramento de uma fase ou ordem dá um novo início à expectativa e esta é cumprida enquanto a visão viaja de volta, por uma série de áreas coloridas dominantemente horizontais in character." Dewey segue descrevendo conclusões de fases de percepção, redirecionamentos de atenção (sugeridos pela pintura e não arbitrários), e conclusões em que algo que estava implícito, como a impressão de profundidade, é tornado explícito por uma certa ordem rítmica. Após fornecer detalhes adicionais, ele conclui: "O que foi dito pode parecer exagerar o aspecto temporal da percepção. Sem dúvidas, eu estendi elementos que são usualmente mais ou menos telescopados [telescoped]. Mas em nenhum caso pode haver percepção de um objeto exceto em um processo se desenvolvendo no tempo.."

Ele ainda adiciona um fator igualmente relevante para as discussões de Ankersmit e para as nossas: a conexão entre a experiência perceptual e o corpo. Sua observação aponta para a indesejabilidade de tomar um aspecto, tal como o visual ou o tátil, como referência única do que está envolvido na percepção, incluindo aí o caso particular em discussão, o da experiência de uma obra de arte: "A não ser que estas várias energias sensório-motoras estejam coordenadas umas com as outras, não há cena ou objeto percebidos. Mas igualmente não os há quando - por uma condição impossível to realizar de fato - um único sentido está operativo." (175) Então a dimensão anterior à individualização dos sentidos, presente na teoria da sinestesia de Huizinga, é acessada como que de marcha a ré por meio da experiência estética: na experiência dos elementos individuais, a atmosfera compartilhada por todos eles é abduzida e experienciada.

É a interpenetração temporal, da qual ela falara logo antes, que explica a presença de qualidades sensoriais diversas: Se o olho é o órgão primariamente ativo, então a qualidade da cor é afetada pelas qualidades dos outros sentidos abertamente ativos em experiências antecedentes. Desta maneira, ele é afetado com uma história; há 
um objeto com um passado. E a impulsão dos elementos motores que estão envolvidos efetua uma extensão rumo ao futuro, já que ela se apronta para o que está por vir e de certa maneira prevê o que irá acontecer." (175)

\subsubsection{A experiência subjetiva do passado é a experiência de uma representação (que desvela aspectos de representações)}

Se não há um "ponto de vista de Deus" ou "de lugar nenhum" que me permita experienciar "o passado", isto significa que, como toda experiência do mundo, ela é feita de um "ponto de vista" (nesse caso, é claro, humano). E vimos que, para Ankersmit, uma representação é precisamente a produção de um "ponto de vista". Já argumentamos também que a representação histórica contém a interpenetração da atividade imaginativa de segundo nível, das frases declarativas e de outros tipos mais, da perspectiva ética, etc. Tudo isto, combinado, permite a individualização de um ponto de vista. Agora falemos adicionalmente: quanto mais pontos de vista acessamos sobre uma parcela do passado, mais estamos em condição de reconhecer o espaço de possibilidades de onde aquela imensidão de informações e experiências se manifestaram. O elemento mais básico daquele mundo, que Ankersmit segue Bollnow em descrever como sua "atmosfera", pode então ser abduzido por um sujeito capaz de reconhecer tal atmosfera a partir das suas manifestações, da mesma forma que o leitor de um texto abduz sua substância narrativa a partir da leitura das várias frases. A atmosfera não é uma representação particular sobre algo, mas é a maneira pela qual o seu mundo era "apresentado" a eles: o campo de possibilidades compartilhados por muitos ou todos os seres de um período. A natureza desta "apresentação" é, como já argumentamos, a mesma que aparece na tradição narrativista sob o termo "representação" (que não é "representacionalista", embora isto ocasionalmente cause confusões).

Uma das formas possíveis de diferenciar o que pode significar "experienciar diretamente o passado" é a seguinte. Em uma, o experiencio diretamente na forma de re-enactment da experiência de outros agentes. Aqui, o foco não são os "humores e sentimentos", mas os pensamentos - mas lembremos que, para Collingwood, o que aqui chamamos de "humores e sentimentos" sobrevive nos pensamentos. Em outra, experiencio o passado na forma de substância narrativa produzida por mim no presente, que é, para sermos precisos, um preenchimento de várias experiências não automaticamente conectadas entre si e não apenas a repetição-com-diferença de uma 
única experiência tida por um único agente. Como se pode notar, a diferença entre os dois casos equivale à distância de dois tipos de perspectivas: as dos vários agentes e a do historiador - distância que, para Ankersmit, permite o ato estético de produção de sentido produzido em textos historiográficos.

Em seus textos sobre representação histórica, Ankersmit recusa enfaticamente que re-enactments sejam algo além de uma prática acessória para a historiografia: para ele, o mais relevante é que a historiografia inclui algo além das perspectivas dos agentes, que é a ordenação delas (e de outras coisas mais) em uma totalidade estética mais significativa que as partes. Esta totalidade organiza as perspectivas, e outras coisas mais, sob uma nova perspectiva, afastada temporalmente - mas sem produzir um mero cancelamento das demais, e sim uma subsunção delas em uma nova totalidade. Nos textos sobre experiências históricas, em momento algum elas parecem ser uma mera repetição de uma experiência individual, mas sim ser da "atmosfera" ou dos "humores e sentimentos" de um período. Assim, é deste segundo caso que ele trata em seu livro.

Esta conclusão leva a dois desdobramentos. Primeiro, se o que experienciamos são um certo tipo de "substância narrativa", as experiências do passado são menos e mais diretas do que se poderia supor. Elas são menos diretas do que ele parece crer que elas sejam, pois ocorrem por meio de uma produção de um representado. Nesse sentido, elas são sobre a realidade - da mesma forma que as representações históricas, embora mais intensas do que estas podem ser. Esta intensidade se manifesta no corpo por meio de emoções e por meio de percpeções sensoriais diretas. As emoções não são do passado, mas sim minhas: sobre o passado e também suficientemente semelhantes às do passado para que eu possa me atrair pela "atmosfera" que expressa aquelas emoções. Isto é: construí esta atmosfera a partir (a) das expressões de emoções de agentes do passado, com as quais as minhas se assemelham; e a partir (b) do que compreendo das atmosferas experienciadas pelos próprios agentes do passado, que, por sua vez, eram atmosferas que expressavam suas emoções. Já as percepções sensoriais são de artefatos que, para Ankersmit, são o próprio passado - the past itself - presente; e, para Runia, são uma presença metonímica do passado no presente. Prefiro a formulação de Runia, mais precisa. Estes artefatos se articulam holisticamente com todos os elementos estéticos (presentes nos demais tipos de representação) e intelectuais (mais fortemente presentes em livros de história). No caso das emoções, há uma intensidade emocional grande, mas é no segundo caso que podemos mais adequadamente dizer que, se por um lado a experiência da "substância narrativa" é menos direta do que Ankersmit 
pressupôs, por outro ela é certamente "direta". Isto porque ela é experienciada "de dentro" e não pode sê-lo de nenhuma outra forma que não desta. Trata-se de uma experiência simultaneamente criada e direta, portanto, como toda experiência da "realidade humana".

Isto significa que não é adequado produzirmos uma dicotomia que trata as representações históricas como indiretas e as experiências como em certo sentido diretas. Isto seria tratar as representações de uma perspectiva transcendentalista e então, contraditoriamente, buscar brechas em um mundo cuja própria concepção não permite brechas. Tanto as experiências quanto as representações históricas são uma expressão do "segundo nível de consciência"; uma é mais direta, potencialmente pré-linguística, às vezes tão "leve" a ponto de envolver apenas "humores e sentimentos", e a outra é uma formulação linguística de elementos pré-linguísticos, mas já produtores de uma apresentação do mundo e retroativamente afetados pela atuação reflexiva da linguagem e de outros fatores. Por compartilharem este nível, e por ele ser em algum nível destacável, as representações podem ter uma afinidade estrutural com o passado representado, e, portanto, podem estabelecer uma relação figural com o passado, preenchendo-o. Pois, da mesma forma que White (1999: 66-86) considera que os "eventos modernistas" demandam formas peculiarmente modernistas de representação, a experiência do passado tida pelo historiador no presente ocorre na medida em que ele possui recursos prefigurativos que o permitem produzir para si uma "substância (pré)narrativa" do que era "a atmosfera" do passado e então experienciá-la.

Nosso argumento, em síntese, considera que (a) as experiências da realidade não são compostas apenas por aquilo que está onde a linguagem - e as representações - não estão, (b) nem sempre as atmosferas e representações do mundo passado são diferentes do que se encontra na experiência de algumas pessoas do presente a ponto de serem incompreensíveis, (c) tais representações são significativas e não materiais, portanto acessíveis em outras épocas, e parcialmente "destacáveis" da matéria biológica e física na relação com a qual ela é produzida. Assim, a presença de um artefato do passado pode permitir a alguém experiencie uma "compreensão" dotada de altíssima intensidade, pela concentração de energia que ela carrega para aquele que tem em si os imãs capazes de atraí-la - ou melhor, que é feito por tais ímãs.

Assim, em nossa visão, não deve-se postular uma distinção rígida a experiência e a substância narrativa da mesma forma que Ankersmit afirma - embora haja uma diferença entre duas variantes delas, a experiência histórica sublime e a representação 
linguística. Assim, em vez de dizer que "a experiência está onde a linguagem não está" (2005, 79), a experiência do passado está onde a representação está. Preferencialmente se ela se articula holisticamente com os elementos do corpo e do ambiente que preenchem figuralmente ou apresentam metonimicamente o passado, pois corpo e mente se articulam na totalidade da experiência.

Onde estava a atmosfera do passado, se não nas múltiplas experiências dos agentes? Ora, não há, digamos, um século XVIII cuja "atmosfera" existisse por igual para todos os seres, ou uma aura de tédio padrão que cada ser experienciava a partir de suas variações subjetivas. A noção de "período" pode até incluir elementos "objetivos" como marcadores de seus inícios e fins, mas atmosferas não podem ser senão subjetivas - não desconectadas do mundo "objetivo", mas uma perspectiva de um sujeito incorporado em relação com o ambiente. Daí a importância de enfatizar que, na classificação proposta por Ankersmit dos três tipos de experiência, o que a "experiência histórica objetiva" tem de "objetiva" é o fato de que ela é parte de um passado agora "fechado" (e que, mesmo assim, nunca perderá sua condição de ter-sido-aberto) - mas sua existência foi a da interpenetração entre objetividade e subjetividade, como toda experiência. Assim, ou experiencio a "atmosfera" ao fazer re-enactment de uma ou muitas experiências que algum agente do período teve, preenchendo-a(s) com a minha própria experiência, $o u$ experiencio a atmosfera ao produzir um gesto de "compreensão" em que inúmeros elementos de experiências passadas - digamos, o que elas tinham em comum, tal como expressões particulares de ferocidade, tédio ou de latência - são transformados em figuras que preencho ao reuni-las em uma totalidade. Neste caso, que parece ser o que Ankersmit tem em mente, o que ocorre é o preenchimento retroativo do que existiu na multiplicidade de experiências de inúmeros agentes, sempre em conexão com o mundo no qual estavam inseridos. Preencho a partir de minha subjetividade presente. Assim, ter uma experiência do passado é inseparável de representá-las, embora não na forma de um texto histórico. O passado que experiencio não é um passado que qualquer outra pessoa já experienciou, embora - ou exatamente porque - eu o faça a partir do que consigo compreender das experiências de muitas outras pessoas e de condições objetivas e informações que eles próprios não tiveram acesso.

Reconhecer isto é o mais coerente com as posições de Ankersmit, que afirma claramente que a "ideia histórica" não está no período, mas na perspectiva do historiador. Ao que adicionamos que o objeto da representação "período X" 
(Renascimento, Iluminismo, Outono da Idade Média) é, sobretudo, uma multiplicidade de perspectivas. Como poderia haver essa Stimmung existente em si mesma? Stimmung é algo que se experiencia $e$ é a maneira pela qual o mundo é apresentado - isto é, é dimensão mais básica da maneira pela qual um agente no passado faz surgir representando e experienciando - este mundo, e é também uma fração do que um erudito no presente pode representar para si mesmo daquele mundo. Pois, em se tratando da realidade humana, o representar é inseparável do viver, embora evidentemente haja vida anteriormente à representação e às experiências mais básicas e instintivas. Todos os suportes materiais e intersubjetivos estão disponíveis e são constantes no caso do agente no passado e são muito raros no do erudito no presente.

Vimos que, para Ankersmit, é fundamental preservar as conquistas do historicismo. A inexistência de um ponto de vista transcendental, constituinte da atmosfera de um período, para além das experiências dos agentes e das experiências ("subjetivas" ou de caráter mais epistemológico) que historiadores possam ter de um período é incontornável para atender esta demanda. Como LaCapra afirmou em relação as contextos, eles não são pontos de referência estáveis a partir das quais se possa compreender os textos - e o mesmo vale para a relação entre agentes do passado e seu milieu. Como afirmou White em sua leitura de Auerbach, uma experiência já é uma figura a ser preenchida por um texto (ou uma "experiência histórica", podemos adicionar), e este preenchimento é uma figura para interpretações ou experiências subsequentes. Podemos adicionar: como as experiências da realidade já consistem em interpretações das possibilidades de produção de sentido que o agente recebe, e performatiza, de sua coletividade, elas são também preenchimentos de figuras recebidas. Pois elas também são históricas. Assim, da mesma forma que a literatura modernista dissolve a existência de pontos de vista externos às experiências, o "historicismo modernista" de Auerbach - que White considera ser uma abordagem ainda mais radical da história, e não, como Jameson ao tratar do modernismo de modo geral, seu abandono - também concebe assim a relação entre os agentes e os "períodos" (WHITE, 1999: 99-100). E o abandono de tais ponto de vista estáveis e coerentes - o que significa, também, a-históricos - é precisamente o que Ankersmit (1994: 1-30) demanda de Mink e de White.

\subsubsection{Tédio e a contestabilidade essencial da "realidade humana"}


No sétimo capítulo de Sublime, Ankersmit relata que, na infância, ficava doente com frequência. "Este confinamente regular à cama tendeu a me colocar fora de contato com as coisas..." Ainda assim, ele afirma, "eu era uma criança bastante ativa". "Esta dolorosa consciência de estudar excluído dos jogos dos meus amigos da escolar estimulou em mim um sentiment intense de tédio", que é, em sua concepção, "o sentimento que nos coloca mais perto da natureza das coisas." O motive é que, no tédio, "as interações entre nós e o mundo são temporariamente suspensas; e esta suspensão convida a realidade a manifestar sua verdadeira natureza, sem estar contaminada e distorcida pelos nossos interesses e preocupações." (2005: 286)

O que eram as coisas das quais Ankersmit relata estar afastado? Das relações intersubjetivas, nas quais se manifestam as dinâmicas de reconhecimento e permitem, portanto, que a pessoa "exista" socialmente. Isto é digno de nota porque a intersubjetividade tanto é parte central do que chamamos de "mundo" - o mundo social - quanto é um pré-requisito para que possamos estar em contato com os demais aspectos do mundo: pense no quanto os discursos da geografia, física, química, história ou das artes nos permitem revelar, de maneiras tão profundamentes diferentes entre si, muito além do que nossos sentidos individuais poderiam permitir. Assim, a noção de contato aqui remete a algo não localizável, não passível de descrição nos moldes tradicionais da presença. Da mesma forma que, na filosofia da arte de Danto, não é apenas a materialidade de um objeto que permite dizer se ele é ou não arte.

Lembremos ainda que, como temos argumentado, o "mundo" é construído em relações intersubjetivas e materiais. Assim, ele depende de uma re-criação constante para ser sustentado. Dessa forma, efetivamente, estar alheio ao movimento da circulação intersubjetiva (incorporada, situada) de significados efetivamente des-naturaliza "o mundo". Assim como andar de bicicleta, é este constante movimento que faz com que não se veja sua convencionalidade; assim, de fato, o tédio propicia um insight sobre a natureza do mundo social.

Para que sigamos explorando este ponto da relação sujeito e mundo, notemos a menção ao jogo feita neste trecho. Embora incidental, ela permite-nos observar algo que vai muito além de brincadeiras de criança. Gadamer e Gallie, ao menos em algum grau seguindo Wittgenstein, pensaram a vida social por meio da analogia com o jogo. Ao não estar imerso no jogo - observando-o com distanciamento intelectual, elemento que presumo não estar presente na infância de Ankersmit - torna-se mais fácil que ele se revela como um jogo, e não como o modo natural de como as coisas são. Suas regras se 
mostram com a contingência que elas efetivamente possuem - da mesma forma que as "regras de tradução" ou de "prefiguração" da realidade histórica para a sua representação, em White e em Ankersmit, dependem do estabelecimento de regras ou protocolos de tradução que não têm fundamentação última: "no grounds", como diria White. No jogo, as codificações de regras e táticas limitam a infinitude de movimentos a princípios possíveis a alguns poucos. Ao parar de jogar, porém, os jogadores estão livres para pegar a bola com as mãos, a não mais buscar marcar gols, e sair do espaço determinado. O goleiro é goleiro apenas nos limites do jogo, mas sua condição jamais se consolida eternamente como a de um goleiro; de fato, se sua sociedade conhecesse outros jogos mas não o futebol, ele nunca surgiria como goleiro, e talvez pudesse surgir como alguma outra coisa. Analogamente - e não sem familiaridade com Wittgenstein ao descrever os protocolos historiográficos utilizados pela historiografia do século XIX, White não presume que eles sejam uma prisão, mas sim um conjunto de regras contingentes, que, se não podem ser ignoradas, podem ser performativamente renegociadas. Como pressuposto destas reflexões, depois trazido à tona, ele aponta a ausência de significação inerente do passado, que pode surgir sob outras "máscaras de significado", da mesma forma que o goleiro (no exemplo atual) e o garçom (no exemplo de outrora) também nunca podem transformar suas máscaras em seus rostos. Se os ossos que compõem os rostos fossem tão maleáveis quanto os significados - e se, em contraponto, houvessem limitações econômicas, culturais e intersubjetivas que condicionassem a modificação de rostos/máscaras a todo tempo - poderíamos dizer que a própria distinção entre rostos e máscaras se tornaria questionável: e assim o é com a construção de significados nas sociedades.

O objeto do que agora enredamos como "passado" também existiu na forma de jogos que, vistos à distância, se revelam como tais; isto significa dizer que a ausência de significação inerente se revela mais facilmente uma vez que a imersão ou reatividade é substituída pelo distanciamento. Para fazer isto, o historiador deve também não estar reativo ou exageradamente identificado com seus próprios "elementos prefigurativos" do presente. Feito isto, a verdade que se revela não é apenas como o passado era, mas também a sublimidade da história, inclusive deste passado particular. O jogo visto de fora, assim como a atividade dos Pulcinellas vista de fora do campo de interação deles próprios, se mostra mais facilmente como convencional.

Esta habilidade de estar inteiramente presente, mas também "distanciado", foi e será apontado em diversos pontos deste trabalho, inclusive em relação com Ankersmit. 
Ela envolve uma dinâmica entre passividade e atividade em que os termos não se anulam, mas sim se equilibram: pois, como o sujeito é inseparável de seu meio social, não há contradição entre estar simultaneamente ativo e receptivo a ele. O exemplo do jogo ilustra bem este ponto. Imaginemos um grande atleta de esportes coletivos, cuja atividade é inseparável da responsividade - abertura - em relação a tudo que ocorre no campo de jogo. A natureza de sua atividade seria muito mal explicada pela metáfora da "violência" que, como vimos, às vezes é empregada para explicar como se dá a atividade de significação do passado. Quando mais ativo em relação ao jogo, menos ele decidirá dar um drible para uma direção inútil, ou dar uma bicicleta estando no campo de defesa: sua atividade será inseparável de sua atenção à situação e à capacidade de respondê-la. Ele deverá portanto se harmonizar com o jogo, em vez de impor sua vontade aprioristicamente. E no entanto, é nesta harmonização que ele poderá reconhecer as possibilidades que um jogador menos atento e hábil não reconheria nem executaria, e criar jogadas inesperadas. Assim também ocorre se empregarmos para a historiografia a concepção de "significado" em Dewey, em contraposição com a pósmodernista: para aquele, o significado surge na relação; para estes, é violentamente imposto. O que há em comum é o reconhecimento de que o significado não está pronto e é criado pela consciência do "jogador" (metáfora apropriada para a historiografia), mas precisamente porque ele está aberto para receber e dar vazão aos processos que ocorrem em todo o campo de jogo. ${ }^{253}$

\subsubsection{Compreensão e autenticidade}

O conceito de compreensão configuracional de Mink é muito mais amplo que o de experiência estética de Dewey, que é, como veremos, muito mais amplo que Ankersmit chama de "tipo-Huizinga de experiência" do passado - ainda que Ankersmit enfatize as semelhanças entre Dewey e Huizinga e não aponte explicitamente esta diferença. Ora, o tipo de compreensão produzido pela historiografia profissional tradicionalmente buscou tratar seu objeto com "distanciamento". Uma forma de produzir distanciamento consiste em focar a atenção mais nas atividades de "terceiro nível de consciência", que produz descrições factuais passíveis de verificação, do que nas do segundo ou do quarto, respectivamente mais artísticas e mais filosóficas. Um

${ }^{253}$ Sobre a relação entre atividade e passividade, ver a discussão sobre experiência em Dewey; aquela sobre "sensação histórica" em Huizinga e a leitura feita por Ankersmit; e o relato de Runia sobre a maneira peculiar pela qual Lênin respondia ao processo da Revolução Russa. (Dedico esta seção ao amigo Daniel Cunha, zagueiro habilidoso, mas demasiadamente fixado na ideia de dar "rolinhos".) 
texto distanciado pode tratar de arte, filosofia, história, mesmo de emoções e desejos do passado, mas não os aborda explicitamente de maneira artística - buscando expressar a atmosfera do passado, ou expressar a própria experiência presente de tal atmosfera - ou filosófica. É assim que White frequentemente historiciza a profissionalização da historiografia: ela se deu por meio da tentativa de se distinguir da retórica e das filosofias da história. No primeiro caso, pressupõe-se, dentre outras coisas, que não é subjetividade do historiador que fornece acesso às verdades do passado ${ }^{254}$, de modo que uma linguagem descritiva dos elementos compreensíveis em terceira pessoa são tudo que deve ser dito pela historiografia, e que a pesquisa determina a escrita (e não, como consideramos aqui, que ambas se co-determinam processualmente). Já ao se distinguir das filosofias da história, a historiografia evita propor um significado para o processo histórico como um todo, evitando abordagens apriorísticas.

A historiografia profissional, porém, não pode escrever textos sobre o passado sem que eles sejam informados por desejos (primeiro nível), tropeamentos e enredamentos (segundo nível), pressupostos (em todos os níveis ${ }^{255}$ ). O que ela pode é negligenciar tais níveis, ou negando que efetivamente empregue a imaginação antes de dizer verdades, ou buscando disciplinar a própria imaginação. O primeiro caso configura a variante collingwoodiana da má-fé: "corrupção de consciência". Assim, podemos apontar um interessante paralelo entre as filosofias da experiência em Ankersmit com a filosofia da representação de White: enquanto Ankersmit enfatiza que as experiências de Dewey e Huizinga são autênticas, White acusa os historiadores profissionais de má-fé, ou seja, de inautenticidade - o que também implica que, em sua fase propositiva, ele proponha abordagens de boa-fé. Nestas, a presença da própria subjetividade não é negada ou reprimida.

White demanda que percebamos como a consciência, no presente, molda o passado. Ankersmit demanda que haja simultaneidade do passado e do presente. Kuukkanen deseja que compreendamos o texto historiográfico como um ato de fala direcionado aos pares. A noção de compreensão pode ser ampliada para englobar todas estas dimensões (incluindo os eixos vertical e horizontal de relações que se estabelecem na produção de um ato de fala sobre o passado): para isso, ela deve ser concebida de modo que não mais inclua apenas a "rede de descrições sobrepostas" que, embora feitas no presente, são sobre os eventos no passado. A compreensão é também dos desejos

\footnotetext{
${ }^{254}$ Tese que Ankersmit defende detalhadamente em "In Praise of Subjectivity" (2001: 75-103).

${ }^{255}$ Que é como Mink afirmou que operam as "pressuposições absolutas” em sua leitura de Collingwood.
} 
envolvidos na relação com o passado, das sensações no corpo de quem escreve ou lê o texto (e não o experienciaria igualmente se fosse apenas um cérebro ou um espírito imaterial), dos recursos estéticos mobilizados ou produzidos para a tarefa, dos eventos que foram experienciados existencial e cognitivamente no processos de pesquisa, escrita e leitura, da ação que é feita por meio da publicação do livro, dos princípios filosóficos que geram também uma experiência particular desta totalidade dos eventos. Um dos argumentos que defendemos na presente tese é esta forma consideravelmente ampliada de holismo, que faz com que toda representação do passado seja experienciada sempre pela primeira e única vez (como "representação" ou como "experiência"), mas com componentes repetíveis, nunca inteiramente novos.

Assim, é louvável a tentativa da historiografia profissional de enfatizar a necessidade do tipo mais científico ou metódico de experiência para a produção da experiência total que culmina no produto, o texto historiográfico, e na experiência, oriunda de sua leitura. Porém, a ênfase unidimensional na pesquisa obscureceu o movimento entre pesquisa e escrita feita por um historiador incorporado e situado. Por outro lado, se White mostrou o quanto segue havendo uma dimensão não-reconhecida de filosofia da história implícita na produção de escrita, por outro suas ocasionais tendências apriorísticas efetivamente impediriam a formulação de uma escrita autêntica: o historiador não poderia ver senão a si mesmo ao significar o passado, e a pesquisa seria irrelevante exceto como fonte de dados a serem moldados livremente. O pressuposto a ser abandonado diante deste apriorismo é aquele que imagina o presente como radicalmente separado do passado - não afirmo nem nego que ele possa ser radicalmente distinto do passado -, uma entidade "presente" em contraposição a um passado "ausente", perdido para sempre. Mesmo Ankersmit, que em seus momentos mais românticos sonha com o encontro com o passado, o manifesta. Ele é análogo ao pressuposto cartesiano que concebe o sujeito como radicalmente separado de seu mundo - pressuposto que, como estamos vendo, Dewey considera oriundo de uma concepção equivocada da experiência humana. Nos termos de Rorty, ele nem precisa resolver o problema: ele o dilui.

Poderiam outros tipos de escrita da história produzir experiencialidade da atmosfera passada? Ora, embora White não fale nestes termos, isto é pressuposto em suas reflexões sobre a necessidade de produzir novas representações capazes de expressar os "eventos modernistas". Mas Ankersmit não fala de textos de história capazes de produzir tal efeito, apenas de tentativas de expressar experiências já 
ocorridas, como O Outono da Idade Média. Para ele, objetos despretensiosos e obras de arte são muito mais potentes na produção de experiências-Huizinga. Ainda assim, é nítido que os eruditos que tiveram experiências Huizinga tiveram um número considerável de experiências do - ou sobre (about) o - passado fornecidos pelos tipos descritos por Mink e por Dewey, antes de virem a ter a variante mais intensa de todas. Parece ser o caso que compreensões produzidas por representações históricas e artísticas são pré-condição para as experiências ankersmitianas, mas não são o meio mais apto a culminar em experiências tão particularmente intensas. 


\section{Capítulo 4 - Experiência histórica sublime}

Como Ankersmit elabora muitas definições dos vários tipos de experiência apresentados em sua obra ao longo de mais de duas décadas, compará-los não é questão de uma mera justaposição: há várias nuances interpretativas em jogo. Aqui, propomos uma comparação entre os dois principais tipos nos seguintes termos. Em primeiro lugar, a experiência histórica "sublime" (2005) ou "coletivista" (2012) se diferencia da "coletivista" (2005), "Huizinga" ou "individualista" (2012), analisada na maior parte dos capítulos de Sublime Historical Experience, por ocorrer na experiência dos próprios agentes históricos, e não na atividade reflexiva dos historiadores que tomam as experiências destes agentes como objeto. Em segundo lugar, e agora enfatizando a variante "sublime": dentre as várias experiências possíveis de agentes, ela trata de uma bastante específica, e sem dúvidas bastante rara: aquela em que o corte entre passado e presente vem a ser, quando outrora ele inexistia. Além da noção de ruptura já conter em sua própria definição uma temporalidade narrativa implícita (remetendo ao que havia antes e ao que vem depois), ao menos um segundo elemento temporal está envolvido na noção: o momento subsequente da produção da nova identidade. Ankersmit se detém sobretudo no segundo, pois também ele deve possuir uma natureza específica para que o evento possa ser descrito como uma "experiência histórica sublime": como o trauma não pode ser normalizado por meio de uma narrativização, é produzida uma nova identidade, que toma a antiga como referencial. Desse modo, a sociedade em questão passa a "ser o que não é mais". O que está em jogo no primeiro momento da experiência não é menos relevante: ali, os agentes experienciam o mundo sem as estruturações narrativas usuais. A meu ver, é ali que precisamente se situa o "sublime" da experiência: algo sobre o mundo é revelado, algo que pode ser redescoberto em reflexões filosóficas posteriores: sua não-conformidade aos esquemas cognitivos que, sem serem percebidos, usualmente participam da construção do mundo. Parece ocorrer no mundo histórico, conforme a descrição de Ankersmit, o tipo de "disrupção momentânea dos nossos aparatos cognitivos" que, em um autor como Burke (1993: 45-6), ocorre quando da experiência que combina terror e deleite, e que ele chama de sublime. ${ }^{256}$

\footnotetext{
${ }^{256}$ A historiografia toma processos históricos como objeto, refletindo sobre ele, mas também é parte da história. Assim, as distinções entre o que é apenas histórico e o que é tanto histórico quanto historiográfico não podem ser muito rígidas. O motivo é que não há existência histórica que não seja, ao menos em algum grau, reflexiva. A "consciência histórica" que pode surgir na sequência de "experiências históricas sublimes" é um tipo mais complexo de reflexão, mas não toma como objeto um passado
} 
No oitavo capítulo de Sublime, Ankersmit introduz o conceito por uma via dupla, focada na noção de "esquecimento". Primeiro, descrevendo "quatro tipos" de esquecimento, o quarto dos quais sendo o que encontramos em uma sociedade que passou por uma "experiência histórica sublime". Segundo, comparando como o historicismo, Nietzsche e Hegel concebem a relação entre identidade e esquecimento, e preferindo a solução hegeliana sobre as demais. Nela, reencontramos o tipo de esquecimento que ocorre nas experiências históricas sublimes. Discutiremos os dois casos na sequência.

Os quatro tipos de esquecimento. O primeiro tipo da classificação de Ankersmit (321-4) é aquele que ocorre porque o que foi esquecido simplesmente não tinha relevância para as identidades presente e futura. Observemos (por isto ser revelante para o argumento que faremos em breve) que Ankersmit não apenas especifica se tratar de "identidade presente ou futura" (grifo adicionado), mas também observa que "o que inicialmente era irrelevante pode adquirir uma relevância inesperada de uma perspectiva posterior." O segundo tipo diz respeito a algo que, embora seja relevante, é esquecido por ignorância. Nem sempre reconhecemos "a significação de certos fatores causais."

Ao introduzir o terceiro tipo, entramos no terreno do trauma, no qual permaneceremos no quarto. No terceiro caso, "nós podemos ter razões excelentes para esquecer uma parte ou aspecto do nosso passado - por exemplo, quando a memória dela é muito dolorosa para ser admitida na nossa consciência coletiva.” Nestes casos, ela é "simultaneamente esquecida e lembrada": ocorre uma dissociação do self entre consciente e inconsciente; a memória é expelida do consciente mas é retida na forma de uma memória inconsciente. Mesmo estanto esquecida neste sentido específico do termo,

inteiramente mergulhado na imediaticidade, como Ankersmit muitas vezes parece supor. Um exemplo da inexistência de distinções rígidas entre experiências históricas situadas apenas no lado dos historiadores e outra tida pelos agentes é Alexis de Tocqueville, que, na leitura de Ankersmit, tanto passa por uma experiência histórica sublime quanto a usa como fonte de insight para a sua própria escrita histórica (ANKERSMIT, 2018). Já alguém como Huizinga, escrevendo sobre um objeto do qual estava afastado cronologicamente - e próximo afetivamente - fica mais seguramente situado no lado da história-escrita (sobre a possibilidade de distinguir diferentes tipos de distância, e portanto também de presença, ver PHILLIPS, 2013). Ariès, outro exemplo mobilizado por Ankersmit (1994, 2012, 2018), mais ainda. Mas mesmo nos casos de Huizinga e Ariès, a tomada de consciência da distância em relação ao passado por parte de um historiador é parte do processo histórica e faz com que ao menos uma das perspectivas do presente sobre si mesmo - a desse sujeito vivo, como parte de uma coletividade - se transforme. Como na metáfora que será discutida adiante, este ganho de consciência é como uma "mutação" e um historiador é como uma pequena terminação nervosa em um monstrengo que é sua sociedade. Esta descoberta da distância não é idêntica à produção desta distância no caso das experiências históricas sublimes, ao menos como elas aparecem no livro de 2005. Por enquanto, notemos apenas que a experiência de descobrir a distância entre si mesmo e o passado ocorre tanto no caso sublime quanto das experiências subjetivas (sobre este último caso, ver ANKERSMIT, 2012: 188). 
“o sujeito da experiência traumática será seriamente prejudicado por ela” (322), e portanto ela também tem um tipo de presença.

O quarto tipo de esquecimento é o da experiência histórica sublime. Ele pode ser introduzido com uma comparação com o terceiro tipo: naquele "a resolução do trauma é possível, enquanto ela permanece uma presença constante e permanente no quarto tipo." Se compararmos os casos traumáticos de esquecimento, a visão de Ankersmit é que os diferentes níveis - a experiência passada e a narrativa presente, que produzem no presente os elementos de presença e de sentido - podem ser harmonizadas no terceiro tipo de esquecimento, mas não no quarto. Isto gera "sentimentos de uma perda profunda e irreparável, de desespero cultural, de desorientação desesperançosa." Trata-se então de um tipo de trauma "muito mais dramático", "pois aqui a pessoa realmente perde a si mesma, aqui uma identidade antiga é irrevogavelmente perdida para sempre e substituída por uma nova identidade histórica ou cultural." (324)

Ele especifica o significado da noção de experiência histórica sublime a partir da distinção entre dois tipos de trauma. O "trauma 1", para Ankersmit, é um subtipo do terceiro tipo de esquecimento (que também engloba vários outros tipos de traumas); o “trauma 2" é o produto da experiência histórica sublime. Eles são ligados, por sua vez, a dois tipos de reação a eventos traumáticos. Ankersmit exemplifica-os com os casos dos reacionários e conservadores no pós-Revolução Francesa, que desejavam “ser” o passado em um caso e "conhecer" o passado em outro, respectivamente. Os reacionários eram aqueles que pensavam que identidade pré-revolucionária podia ser recapturada, e portanto tomavam o passado como objeto de um "desejo de ser". Já os conservadores reconheciam a impossibilidade de "ser" novamente este passado, e portanto sublimaram este desejo, transformando-o em "desejo de conhecer". (2005, 327) Porém, esta tentativa apenas afastava-os cada vez mais deste passado:

A busca histórica para a nossa antiga identidade é motivada pelo desejo de nos tornarmos esta identidade de novo; mas a cada vez que parte da identidade passada foi, de fato, recapturada, uma nova dimensão foi (sem intenção) adicionada à diferença entre a identidade antiga e a presente. (328-9)

A citação deixa entrever a identificação de Ankersmit com o grupo: um nímero restrito de membros da sociedade é, aqui, transformado não só na totalidade de sua própria sociedade, mas ainda por cima referido universalmente como "nós".

Vimos que, para Ankersmit, no terceiro tipo de esquecimento é possível produzir, ainda que a duras penas, alguma harmonia entre identidade e a experiência 
traumática, mas não no quarto. Parece haver um paralelo em como ele descreve a relação entre os níveis do consciente e do inconsciente: ${ }^{257}$ eles são harmonizáveis no trauma do terceiro tipo de esquecimento, mas não na experiência histórica sublime; e, neste caso, ele conclui que a dor deste trauma será carregada pela sociedade para todo o sempre. Não é uma afirmação que podemos trivializar, se pretendemos compreendê-la em toda sua pretensão:

\begin{abstract}
Este, então, é o tipo de trauma que nós sempre iremos carregar conosco, mesmo depois que a História nos tenha forçado a confrontá-lo; ele é um trauma para o qual não há cura. A nova identidade é constituída principalmente pelo trauma da perda de uma identidade antiga - precisamente este é o seu conteúdo principal, e esta é a verdade inelutável que se anuncia na realização (agoniada, resignada, ou de algum outro tipo) de que esta perda é permanente e nunca poderá ser desfeita. (324) ... a nossa identidade coletiva é, em grande medida, a soma de todas as cicatrizes na nossa alma coletiva, cicatrizes que foram ocasionadas pelo abandono forçados que fizemos de nossas identidades antigas, cicatrizes que nunca irão desvanecer totalmente e que irão causar em nós uma dor contínua e duradoura. (324)
\end{abstract}

Não será difícil notar o quanto esta passagem destoa de todas as reflexões narrativistas, inclusive as do próprio Ankersmit, sobre como uma coletividade constrói sua identidade. Destoa também da pretensão whiteana de considerar possível e desejável a liberdade diante do "fardo da história". A proposta de lermos o experiencialismo de Ankersmit à luz do narrativismo permite-nos então colocar um conjunto de questões nada irrelevante.

O trecho, a meu ver, opera um non sequitur entre um tipo de reação de certos grupos a um evento particular para uma afirmação transhistórica sobre qualquer identidade de qualquer sociedade. Assim, a experiência sublime é, por um lado, apresentada como um tipo particular de experiência, mas, por outro, presumida como constitutiva das identidades de qualquer sociedade. Mais adiante, Ankersmit especificará um pouco: ela é um fenômeno ocidental, resultante da "incapacidade de sofrer" que a certa altura começou a se manifestar por estas terras. Mas argumentaríamos então: se começou, não é eterna, e portanto pode parar, não? Também não é imaginável que ocorra na sociedade inteira por igual, certo? O que é irrevogável é a perda, mas que a melancolia que segue também seja incontornável não me parece justificável em nenhuma base. Não seria o caso então de distinguirmos a "reação" de alguns grupos da possibilidade do que poderíamos chamar de uma "resposta", como

\footnotetext{
${ }^{257}$ Também Runia, ao distinguir níveis, aproxima o consciente dos significados "representacionalistas" e o inconsciente da presença (Ankersmit fala em "experiência", para sermos mais precisos).
} 
White considera possível ao menos por parte de elites intelectuais? Ademais, nenhuma construção de identidades pode jamais ser uma questão de "soma" - a "soma de todas as cicatrizes na nossa alma coletiva" - pois ela envolve sempre a criatividade humana de fazer algo com o evento: se a nova identidade é assumida de maneira rígida, sem o reconhecimento tipicamente narrativista de que sujeitos participam de suas criações, então não há espaço para a produção de uma harmonia entre os níveis, pois o passado também não mudará e as memórias seguirão dolorosas. Mas é impossível mudá-la de modo a produzir uma nova relação com a memória passada? Uma resposta ankersmitiana poderia reconhecer a liberdade de produção de significados, mas afirmar que o evento passado segue como uma "cicatriz". Mas o que poderia fazer com que certos eventos fossem sempre e incontornavelmente "cicatrizes"? A mudança geracional e a maleabilidade das fronteiras do que conta como uma sociedade não modificariam a condição do evento?

Estas questões informação nossa discussão ao longo do capítulo.

\subsection{Esquecimento e identidade: historicismo, Nietzsche e Hegel}

A comparação de como os historicistas, Nietzsche e Hegel abordaram a relação entre o passado e a construção ou formação de identidades é a segunda entrada de Ankersmit rumo à definição do que é uma "experiência histórica sublime". Passemos então à discussão.

Ele principia por uma comparação entre o historicismo e Nietzsche: o historicismo, em sua descrição, fornece a "convincente" descrição de que "a nossa identidade reside em nosso passado." (318) Como já mencionamos em outros momentos, Ankersmit $(1983,2012)$ abraça a tese historicista, realizando uma mudança que, ao menos recentemente, formulou como se mantivesse a tese historicista quase intacta: transpondo a "ideia histórica" da realidade para a linguagem. Aqui ele a cita para mostrar que, ao menos no caso das experiências históricas sublimes, ela requer ajustes adicionais. A comparação - fornecedora da antítese a ser igualmente superada por Hegel - é feita com recurso a Nietzsche. A Segunda Consideração Intemprestiva, como é bem sabido, afirma haver momentos em que o esquecimento ativo do passado é necessário para a ação. $\mathrm{O}$ hábito cientificista de consumir o passado sem fome provoca uma espécie de indigestão cultural paralisante, que impossibilita a produção de rupturas com o passado. (319-20) 
Ankersmit avalia, porém, que ao tentar valorizar o esquecimento, Nietzsche "pressupõe a existência de um indivíduo transhistórico, de um indivíduo equipado com uma identidade logicamente anterior à história deste indivíduo.” Já o historicismo, a seu ver, "é, na verdade, muito mais consistente e radical do que o usualmente tão radicalista Nietzsche." (320) Antes de passarmos a Hegel, anunciemos dois breves comentários sobre estas afirmações que aparecerão mais adiante no texto. Primeiro, a ideia de que a identidade do sujeito reside em seu passado é muito afetada pela transposição da noção de identidade da realidade para a linguagem (que reincide sobre a realidade, mas não a mimetiza). Ankersmit é, nesse sentido, bastante humilde quanto à novidade de sua crítica ao historicismo; e Sublime perde algo de muito relevante neste processo, que é o reconhecimento de que as "identidades" não são algo fixo residente no passado, mas, como bem perceberam os autores narrativistas, uma construção retroativa em que alguns dentre muitos elementos do passado são selecionados, ressignificados e rearticulados. Esta maleabilidade modifica todo o tom de inevitabilidade e o estranho pressuposto de sofrimento eterno irremediável que Ankersmit atribui à experiência histórica sublime. Quanto ao transcendentalismo nietzscheano, apontemos que se "identidade" for identidade no sentido do que Crowell chama de "identidade existencial", então não é impossível conceber que, efetivamente, é possível possuir uma "identidade" (no sentido de uma continuidade existencial) sem presumi-la transcendental, mas também sem confundi-la com os conteúdos históricos da "identidade temporal". Esta última identidade é aquela que escapa tipificação, e portanto também a narrativização. ${ }^{258}$

Hegel, para Ankersmit, conseguir conciliar "a total historicização do sujeito cognoscente com a possibilidade de dissociação do passado, portanto com o esquecimento de Nietzsche...". Ele fez isto, em sua visão, “envolvendo a identidade nas vicissitudes da história"; viu que "às vezes a nossa identidade pode ser definida pelo que nós não somos mais, pelo que nós esquecemos e repudiamos." (340) Isto se manifesta, em sua leitura, no exemplo da execução de Sócrates pelo estado ateniense. A narrativa diz que, com Sócrates, a mente deu o primeiro passo da mente ao reconhecimento de si mesma: a liberação da necessidade natural e objetiva. A moralidade do estado ateniense pertencia à mente objetiva. (331-2) Ao condenar

\footnotetext{
${ }^{258}$ E afirmar a existência desta identidade existencial é compatível com o projeto de Ankersmit, pois, como propõe Crowell: “... a recuperação da identidade existencial se dá precisamente como o registro afetivo de uma 'diferença entre o passado e o presente' (Ankersmit) que tem menos a ver com o mundo que se foi do que com aquela deliciosa vida do eu que elude a representação narrativa do tempo." A nostalgia "figura a história espectral da identidade existencial." (1999: 91)
} 
Sócrates à morte, o estado ateniense também condenou a si mesmo, pois reconheceu e aceitou a revolução efetivada por Sócrates: caso contrário, ele sequer seria reconhecido como uma figura perigosa, mas apenas como um tolo. Com Sócrates, porém, entra em vigor o princípio da subjetividade. (331-2) Ankersmit lança então a pergunta: neste relato, a identidade é ou não o passado?

Por um lado, responde ele, não é este o caso, na medida em que o passado, a fase de objetividade, foi efetivamente expelida da identidade coletiva..." (332) Mas "parte da visão historicista é guardada, no final das contas", e há um sentido em que "a antiga identidade é mantida": "a descoberta de não ser mais parte do mundo da objetividade é uma parte integral da identidade recém adquirida da subjetividade.” (333)

Tanto no caso da maneira historicista de conceber identidades - que Ankersmit em muitos locais cita com aprovação - quanto no caso exemplificado com apoio em Hegel, Sublime apresenta uma concepção estática do que significa "ser" uma identidade. Na sua descrição do historicismo é mais fácil notar isto, pois, a partir do momento em que levamos em conta a conexão do passado com a liberdade ou o espaço estético no presente e a orientação futura do ser (que por ser histórico é também aberto), é inevitável concluir por meio que este passado assume configurações (hierarquizações, ênfases, significados) inteiramente específicas, que não estão meramente no passado. Mas no caso em que "somos o que não somos mais" a rigidez se mantém, apenas mais complexa, já que uma negação é inserida. Ainda assim, esta análise ainda presume que "somos" esta combinação entre o que afirmamos e o que negamos.

Em seguida, vejamos discussão de Ankersmit sobre o trauma 1, o terceiro tipo de esquecimento. Nele, Ankersmit afirma, pode haver uma reconciliação entre a identidade e a experiência, e o sujeito mantém a "mesma" identidade. Ora, o simples fato de que houve uma negociação indica que estamos no campo da significação, da produção de uma narrativa para a própria vida. Assim, o que era uma descontinuidade foi retroativamente produzido de modo que se produzisse uma sensação de continuidade. O sujeito pode ou não ter sucesso nessa tentativa: se tem sucesso, temos um trauma 1; se não tem, temos o trauma 2. Mas a simples existência desta possibilidade indica que qualquer continuidade nas narrativas individuais é produzida, não é natural, e portanto é inseparável da fluidez típica das identidades coletivas. A diferença entre individual e coletivo reside na imensa fluidez do substrato que tomamos como base para a atribuição de significados: o indivíduo é invariavelmente significado com referência à continuidade de seu corpo, que o individualiza, enquanto a base do que 
conta como parte da França, Inglaterra, elite ou torcida do Flamengo está em contínua mudança. Mas não há motivo para, em toda essa discussão, individualização e identidade serem assimilados dessa forma. Afinal, coletividades que não mudaram de território também : é evidente que o que está em jogo é sempre o campo da significação, da narrativização de experiências prévias.

Adotar tal posição equivaleria a acreditar ser possível efetivamente "ser" uma identidade significativa - portanto adotada pelo indivíduo como membro de uma comunidade e com os recursos de produção de significado compartilhados pela comunidade. Mas este "ser" não pode jamais se ontologizar. Isto significa que, filosificamente, por assim dizer, o erro do reacionário não é apenas o que acreditar poder ser novamente o que ele era; é também, ao lado do conservador e de quase todos nós, o de crer na possibilidade de ontologizar substâncias narrativas.

Termos como "se tornar o passado novamente" parecem presumir que alguma vez fomos, e que agora somos uma outra identidade - quando apenas estamos operando com ela, talvez sob a "ilusão de substância" que mesmo um autor como White considera que precisamos. Ele faz sentido como descrição de uma certa visão de mundo, mas não como uma tese de filosofia da história. Ou seja, o reacionário cai em um erro grotesco, mas o conservador - e mais a imensidão de seres vivendo com suas atitudes naturais cai ainda em um erro sutil, e que produz retroalimenta seu sofrimento com a perda de sua identidade prévia: acreditam na "ilusão de substância". A noção de "experiência histórica sublime" também reproduz este equívoco, e precisa ser corrigida neste ponto.

Ankersmit afirma: "Deste modo, uma dor prometéica e nosso desejo de amenizar essa dor mantém um ao outro em movimento, em um perpetuum mobile permanente - e não haverá espaço para a calma temporária da repressão ou para a dissolução do trauma que o trauma 1 pode causar." (329) Mas aí estamos efetivamente condenados ao fardo do passado, de uma maneira ou outra. Por exemplo, Ankersmit iniciara o capítulo com uma anedota sobre Kant. Após ter algo de sua casa roubado por um empregado de longa data, Lampe, Kant escreveu uma notinha e afixou-a sobre sua escrivaninha: "esqueça de Lampe". Um pouco mais adiante no capítulo, falando sobre a dissociação do self entre consciente e inconsciente, Ankersmit de passagem traz este caso à tona como um exemplo:

O problema de Kant com Lampe foi, por assim dizer, que ele não teve sucesso em transformar uma memória consciente em uma memória inconsciente. E a explicação é, provavelmente, que toda a situação com Lampe, por mais dolorosa que possa ter sido, foi insuficiente traumática para Kant. (322-3) 
Ora, uma visão alternativa é de que o problema é que Kant não se reconciliou com a realidade do ocorrido. Transformar o evento em uma memória inconsciente seria apenas produzir mais um caso do que, como o próprio Ankersmit reconhece, poderia “debilitar seriamente" (322) o agente. ${ }^{259}$

Levando em conta este fator intersubjetivo e significativo do tipo de identidades e, inseparáveis delas, mundos que "se perdem para sempre", nossa tese é a seguinte: O "não vai voltar mais" não significa uma inacessibilidade individual, mas a impossiblidade de compartilhar intersubjetivamente aquela atmosfera.

Segundo Jacques Bos, a edição holandesa de Sublime enfatiza mais claramente, em seu epílogo, a dimensão política da experiência. (2018: 469) No nível individual, por exemplo, um conservador tem mais chances de experienciar a distância entre o passado e o presente. Ora, ser um conservador político é exatamente propor aos demais membros da sociedade que adotem um tal passado. A dimensão política da experiência nos remete portanto à direção em que se deseja afetar a intersubjetividade dos pares - e, ocasionalmente, à lamentação de que tais desejos são infactíveis. Assim, curiosamente, trata-se menos de um desejo de voltar ao passado, mas do desejo de viver em um mundo intersubjetivo tal como ele foi configurado no presente. Não há algo como uma impossibilidade física em moldes construtivistas - não ser possível voltar a um mundo que não existe - há apenas o fato de que os demais membros da sociedade constróem o mundo de outra forma. Não se trata também, é evidente, de desconectar tais dimensões sutis das relações materiais em que elas estão inseridas.

\subsection{A reação melancólica do trauma 2 é inevitável e será permanente?}

Explorarei esta questão por dois caminhos, indicadas pela própria duplicidade da pergunta, mas ainda assim signos de investigação em separado. Em ambos, a resposta se mostra negativa: a reação melancólica descrita em termos de trauma 2 não é inevitável, e isto também significa que há uma inversão na relação entre a nomeação "trauma 2" e a natureza do evento: tal como o vemos, não é que o trauma 2 seja um evento a permanecer como uma cicatriz que dói por todo o sempre: o que ocorre, inversamente, é que os eventos que seguem ocupando esta condição são retroativamente identificados

\footnotetext{
${ }^{259}$ Como afirma Elshtain a respeito da psicanálise freudiana: "Os histéricos e os neuróticos sofrem de reminiscências, de contar histórias inapropriadas, falsas ou obsessivas. A verdade liberta, sim, a pessoa, mas não pode ser uma construção antiga - ela deve 'pegar'; deve ser uma construção que leve a uma recolecção que convida a um 'sim', um 'sim' libertador por parte do analisando." (GUIGNON \& HILEY, 2003: 150)
} 
como "trauma 2". Nada obriga as gerações seguintes a de identificarem com a "mesma" substância - e.g., a elite francesa de uma sociedade aristocrática - e, não havendo uma substância contínua a sustentar o trauma, não há base para que o evento permaneça na mesma posição no futuro.

\section{(a) Reação melancólica inevitável ou uma resposta dentre outras possíveis?}

Esta rigidez de como Ankersmit emprega a noção de identidade em Sublime se conecta com o privilégio da melancolia sobre o luto: parece não haver margem para o estabelecimento de novas "relações com o passado". Assim, em vez de enfatizar tratarse de um caso em que o passado possui um "poder de tração" especialmente forte sobre o presente, o capítulo 8 vai além e toma este poder de tração como incontornável. É este "passo além" - sem negar a força do passado e de suas cicatrizes - que rejeitamos. Expliquemos melhor o motivo.

Ankersmit enfatiza que a condenação de Sócrates foi uma perda traumática para os atenienses, pois, com ela, estes perderam sua identidade prévia. Em reação a isto, eles adotaram uma propensão à auto-acusação que, como nota Ankersmit, é típica da reação melancólica à perda traumática:

Este tipo de reação é, como Freud argumentou, típico da reação melancólia à perda traumática, isto é, o tipo de reação que impede que uma pessoa supere a perda (que é a maneira "normal" ou saudável de reagir à perda e que Freud associa com o Trauer). A explicação é, de acordo com Freud, que o que é criticado no objeto perdido é transformado emu ma crítica do self. (341)

Após citar Freud, Ankersmit segue com o seguinte comentário:

Assim, o objeto perdido é, primeiro, puxado para dentro do sujeito de modo a ser, em seguida, repelido novamente como um objeto criticado - enquanto ele irá, por fim, permanecer para sempre como parte do sujeito neste disfarce. E este é, resumido em uma frase, todo o mecanismo que eu estou descrevendo neste capítulo (e, ainda mais sucintamente, encapsulado no poema de Emily Dickinson que eu usei como sua epígrafe). (341)

O poema de Dickinson diz: "The heart cannot forget / Unless it contemplate / What it declines." 260

Uma primeira observação é que a duração "para sempre" da reação melancólica é uma extensão indevida, rumo à vida social, de uma ocorrência psicológica que ocorre em indivíduos ou grupos destinados a morrer, e que experienciaram diretamente a

\footnotetext{
260 "O coração não pode esquecer / A não ser que ele contemple / O que ele declina.”
} 
perda. No caso de coletividades, o investimento emocional nos eventos passados evidentemente não é o mesmo por parte de quem viveu pessoalmente alguma perda e de quem não a viveu.

Em segundo lugar, e mais importante. Ankersmit narra o processo de "contemplar o que se declina" no caso ateniense da seguinte forma: o elo com a identidade antiga já estava fraco, e Sócrates apenas tornou os gregos conscientes do novo, que já havia surgido; porém, a catexia [object cathexis] ainda não estava disponível para ser projetada no novo mundo, que ainda não havia se manifestado. Antes disso, "a ruptura com o velho mundo primeiro teria que ser final e definitiva." (342) Ankersmit interpreta em Hegel a tese de que "nós podemos entrar em um novo mundo apenas após ter ganho um insight completo e adequado sobre que deve ser abandonado." (342; grifo no original) E portanto a trajetória a ser seguida seria a seguinte: "O passado primeiro tem que ser plenamente admitido à nossa identidade, ser reconhecido como o mundo que nós deixamos para trás, e apenas então ele pode ser descartado e dar lugar a uma nova identidade." (343) Ankersmit recorre aqui ao comentário de White - parecido com o que temos trazido à tona nesta discussão, embora situado em uma discussão de Metahistory e não em "What is a Historical System?" - de que as mortes de civilizações se parecem mais com "suicídios" do que com mortes naturais. Assim, a entrada em um novo mundo no caso do "quarto tipo de esquecimento" "realmente é e também requer um ato de violência, de fato nada menos que um ato de suicídio - daí também a hostilidade que Freud reconheceu na nossa atitude para com o objeto perdido depois que o internalizamos e o transformamos em parte da nossa própria identidade.” (343)

Mas o argumento aqui me parece novamente misturar dois tipos de "aceitação". O "suicídio" típico das civilizações é a escolha ativa por não mais adotar uma certa identidade, e certamente é o caso que, para que ele ocorra, realidades que pareciam naturais devem ser desveladas como convencionais. Não à toa, os momentos utilizados por White em seus textos para exemplificar os momentos em que sociedades cometem "suicídios" e escolhem novos passados são sempre os momentos subsequentes a "experiências históricas sublimes" (embora ele não use o termo): os romanos entre os séculos III e VIII em "What is a Historical System?" e The Greco-Roman Tradition, não mais confiantes na capacidade de sua cultura mediterrânea de fornecer orientação para suas existências; e os historiadores e filósofos da história da "época da ouro" da historiografia do século XIX, que buscam desesperadamente produzir sentido para o 
evento disruptivo da Revolução Francesa ou para o mundo que ela trouxe à tona. Mas os suicídios de White não são reações melancólicas. Se há "destruição" ou "violência", ela é direcionada aos próprios sistemas representativos, abandonados em busca de outros. Não há nada como a internalização de uma outra identidade como parte de si, nem a adoção de posturas auto-acusatórias por parte desta outra identidade em um eu duplicado. Então a aproximação entre o "suicídio" de White e a "hostilidade" descrita por Freud para o caso específico da melancolia possui apenas uma semelhança superficial (i.e., a palavra suicídio remete a um tipo de hostilidade). Seria inteiramente concebível afirmar que é no luto que se obtém um insight sobre o que se perdeu: o luto aceita a perda e pode, a partir daí, mover a energia libidinal em outras direções (fazer surgir um novo mundo, na linguagem de Ankersmit). A melancolia bloqueia este processo e portanto não permite que o possado, após ser narrativizado, "possa ser repudiado" (344): pois quem é repudiado na duplicação melancólica do self é o próprio agente, não o objeto perdido. A auto-acusação e a agressividade não são um "insight adequado", mas uma manifestação de um luto incompleto. Não há auto-acusação "adequada" em um caso de transformação histórica inevitável.

Além disso, a descoberta de que a própria identidade é convencional faz com precisamente que, ao destrui-la, o agente não esteja de fato se atacando. Adicionalmente, quando reflexões filosóficas como a do narrativismo ou da negatividade vêm à tona (teorizado por ninguém menos que o próprio Hegel, e mobilizado para temas próximos ao nosso por autores como Butler e Safatle), este insight é como que explicitado e pode ser posto à vida: de fato, ao desfazer (com "hostilidade" ou "violência") uma certa forma de conceitualizar o mundo, não se está de fato violentando a si mesmo, pois um sujeito não se esgota nos seus predicados. Quando Runia teoriza sobre a possibilidade de seres humanos produzirem mudanças históricas, sendo "seus próprios piores inimigos", ele está falando deste gesto disruptivo, que não mantém agentes presos ao passado da mesma forma de conservadores e reacionários ficaram presos. E da mesma forma que com os termos violência e suicídio, a frase pode ser reformulada em outros termos: pois modificar o ambiente de modo a afetar o próprio processo evolutivo, se por um lado produz disrupção nas identidades que já não nos esgotavam, por outro permitem que contactemos aspectos do mundo que permaneceriam acessíveis. Então podemos dizer também que somos verdadeiramente nossos inimigos não quando produzimos tais disrupções, mas quando perdemos de vista a convencionalidade - e portanto a liberdade - dos sistemas culturais e passamos a tratá- 
los como naturais. Ao rompê-los, podemos estar sendo "nossos melhores amigos". Pois a lição de Butler é que já não somos tais sistemas - eles produzem uma aparência fundacionais, mas, ao fazê-lo, obscurecem os processos que os geraram -, e que tais sistemas frequentemente nos fazem sofrer. ${ }^{261}$

$\mathrm{O}$ raciocínio apresentado aqui não afirma que as identificações do ego com o objeto perdido ocorrem apenas na melancolia. Em "O Eu e o Id", de 1923, Freud retoma as reflexões desenvolvidas seis anos antes em "Luto e Melancolia", e enfatiza que também no processo de luto parece necessário ocorrer uma internalização do objeto perdido. ${ }^{262}$ As discussões de filosofia da história que envolvem os mecanismos psicanalíticos envolvidos na discussão de Ankersmit cairiam dificuldades metodológicas que não devemos ignorar caso presupuséssemos a aplicabilidade $a$ apriori de categorias psicanalíticas aos fenômenos coletivos em questão, pois as observações têm origem em outros âmbitos: por exemplo, a observação de Freud se refere a um mecanismo individual, cuja aplicabilidade às dimensões mais amplas no espaço e no tempo, no caso dos fenômenos culturais, não é inteiramente clara. Em 1923, Freud ainda hesitava sobre o seu alcance preciso. A discussão de Butler sobre o papel do mesmo mecanismo na formação das identidades de gênero também não pode ser automaticamente transposta para a nossa, pois o objeto amado em questão no caso é a figura de um dos pais, e o mecanismo produtor da perda é a proibição internalizada a partir de fora (BUTLER, 2010: 87); o caso da perda de uma identidade coletiva, que se manfiesta a partir de um evento disruptivo e depois é atualizada em interações cotidianas, mudanças locais e estruturais na economia, cultura, materialidade do espaço e tantas outras, tem portanto uma série de peculiaridades.

Em 1923, Freud hesitava em delimitar inequivocamente a maneira pela qual o objeto perdido deve ser internalizado: "Talvez, com essa introjeção que é uma espécie de regressão ao mecanismo da fase oral, o Eu facilite ou permita o abandono do objeto. Talvez essa identificação seja absolutamente a condição sob a qual o Eu abandona seus objetos." (idem, 26) Mas um ponto parece poder ser demarcado de maneira bastante compatível com o que temos afirmado neste capítulo. Ele seguia afirmando:

\footnotetext{
${ }^{261}$ Ver as discussões em RUNIA, 2015: 179-202 e BUTLER, 2010.

262 "Foi-nos dado esclarecer o doloroso infortúnio da melancolia, através da suposição de que um objeto perdido é novamente estabelecido no $\mathrm{Eu}$, ou seja, um investimento objetal é substituído por uma identificação. Mas ainda não reconhecíamos, então, todo o significado deste processo, e não sabíamos como ele é típico e frequente. Desde então compreendemos que tal substituição participa enormemente na configuração do Eu e contribui de modo essencial para formar o que se denomina seu caráter." (FREUD, 2011: 25-26; grifo no original).
} 


\begin{abstract}
De todo modo, o processo é muito frequente, sobretudo nas primeiras fases do desenvolvimento, e pode possibilitar a concepção de que o caráter do Eu é um precipitado dos investimentos objetais abandonados, de que contém a história dessas escolhas de objeto. Desde logo há que se conceder, naturalmente, uma gradação da capacidade de resistência, até que ponto o caráter de uma pessoa rejeita ou acolhe estas influências da história de suas escolhas eróticas de objeto. (idem, ibidem)
\end{abstract}

Assim, um ponto sobre a relação entre luto e melancolia, e sobre não ser necessário reagir melancolicamente às perdas históricas mesmo quando a identificação é necessária, pode ser feito sem maiores riscos. Como as reflexões filosóficas surgem posteriormente ao acúmulo de experiências coletivas, elas não se encontram no que eventualmente seria o análogo cultural das "primeiras fases do desenvolvimento" - a ironia é precisamente uma fase tardia. É desejável que ela busque localizar então os fatores capazes de ampliar sua "capacidade de resistência", que Freud reconhece existir em uma gradação de maiores ou menores graus. Assim, ela pode reconhecer mecanismos que produzem uma "identificação" ou "aceitação" do passado de modo que o "fardo da história" se torna mais pesado, e outros que produzem tal "identificação" ou “aceitação" sem o recaimento em um "desejo de ser" (nem mesmo sublimado no desejo de conhecer) o passado.

Esta contradiscurso está presente também no capítulo 8 de Sublime, e consideroo fornecer muito mais potencialidades para a produção de um discurso filosófico pragmaticamente relevante.

Como vimos em sua discussão sobre aceitar o Holocausto - que, como argumentamos, deve ser lida com vistas a dois sentidos diferentes do termo aceitação Ankersmit considera que: "não há, como esperaríamos, uma correspondência direta entre os horrores passados por uma sociedade humana e sua propensão ao trauma." (352) Em sua interpretação, há uma peculiaridade ocidental na propensão ao tipo de trauma discutido em Sublime. Ele pergunta então: "Então por que e como surgiu no Ocidente esta capacidade única para o trauma coletivo? (353)

Ao lermos sua resposta, tenhamos em mente que a discussão sobre dissociação até aqui tratou do que era necessário para se dissociar do passado, mas que, aqui, a dissociação é outra: a dissociação da própria dor, manifestada no presente.

Eu creio que a explicação é, na verdade, que no ocidente uma mudança pode ser observada da dor coletiva para uma consciência desta dor e foi assim que a capacidade peculiar do Ocidente para sofrer trauma coletivo veio a existir. (353) ... o que é típico do trauma é precisamente uma incapacidade de sofrer ou de assimilar a experiência traumática na própria história de vida. O que vem 
a ser com o trauma não é tanto uma abertura ao sofrimento, mas um certo torpor... (353) Dessa forma, uma dissociação veio à existência entre o sofrimento e a consciência deste sofrimento; embora ambos sempre e inevitavelmente andem juntos, aqui é como se, ao sentir dor, eu experiencie minha dor como sendo um mero, embora absolutamente confiável, signo de que alguém (isto é, eu) está sentindo dor, ao mesmo tempo em que não sinto a dor mesmo [the pain itself]. (353)

Esse processo é precisamente o se perder nas abstrações das histórias e se desconectar das sensações, desejos e emoções mais imediatos - risco que, como vimos, Vico e Collingwood temeram, e que, em outros contextos, também pode ser lido em Sartre e em White. Eu apontaria ainda que a narrativização produz um segundo grau de reflexividade, para além da consciência da dor. Quando a conexão entre a sensação e sua expressão narrativa não se perde, temos uma experiência no sentido descrito por Dewey: a experiência é precisamente o estabelecimento da conexão, modificando os vários polos até que um novo arranjo se produza. A não-aceitação de uma perda inevitável impede o processo, mas nada obriga os agentes a procederem desta maneira. Isto significaria que a "aceitação" dos conservadores é apenas parcial, pois, como mencionamos, eles desejam algo impossível, que é o retorno à uma condição onde a convencionalidade de uma certa estrutura social ainda não havia sido descoberta.

Esta capacidade de conectar a dor com as atividades de consciência de nível mais elevado não implicam a possibilidade de esgotar, por meio de conhecimento ou arte, os significados do evento. De acordo com a teoria da arte como expressão apresentada por Collingwood em The Principles of Art, a expressão de um sentimento modifica o próprio sentimento, da mesma forma que a expressão escrita de um pensamento não apenas copia o pensamento de dentro para fora, mas é ela própria uma atividade que modifica o pensamento. Esta alienação da própria dor é o equivalente de um processo de experiência (deweyana) não realizada, ou da má-fé sartreana. Também não é o caso de produzir uma harmonia por meio da qual o passado fique domesticado: trata-se de ampliar os próprios referenciais subjetivos para que eles se tornem capazes de incluir elementos da realidade outrora indesejáveis. O trabalho é de despossessão. ${ }^{263}$

\footnotetext{
${ }^{263}$ Pensemos, novamente, em como os negacionistas prefeririam rejeitar a realidade do Holocausto e das torturas na ditadura, produzindo sentido para o mundo apenas no nível mais abstrato das narrativas. Se nenhuma construção de identidades se harmoniza com a realidade (como se a linguagem fosse esgotar o mundo, produzindo "o" seu sentido), por outro é possível construir identidades em desarmonia com ela (identidades que só se sustentam à custa de narrativas cujos eventos são comprovadamente falsos). Em última instância, qualquer substancialização produz tal desarmonia, pois sempre nega a complexidade ou sublimidade da história em prol da decisão de tomar uma parte dela como sua totalidade. E isto mesmo que sua parte seja verdadeira: pois ela pode ser verdadeira, mas verdade enquanto parte e não enquanto todo. Especifiquemos ainda: substancializações negam a instabilidade constitutiva de todas as coisas
} 
Como promover esta conexão entre as abstrações da linguagem e as várias formas de experiência, se não temos acesso à realidade "em si"? Alguns exemplos são (a) o recurso às evidências na prática historiográfica: as evidências não nos obrigam a descrevê-las de uma única maneira, mas permitem-nos dizer verdades factuais intersubjetivamente verificáveis uma vez que tenhamos estabelecido esteticamente quais formas de falar são consideradas como válidas; (b) a conexão com as sensações no próprio corpo, em contraponto com a abstração das histórias, evitam que as histórias se tornem recursos de percetuação de má-fé; (c) a conexão entre as próprias aspirações éticas e as consequências imagináveis ou previsíveis da adoção de certos estilos historiográficos permite o exercício de responsabilidade ética situada, ao mesmo tempo em que reconhece a cegueira incontornável da existência histórica; (d) a atenção ao fato de que os seres sofrem e desejam felicidade, especialmente se combinada com a atenção aos elementos anteriores, é pré-requisito para uma historiografia intencionada a interferir positivamente no mundo em que está inserida.

O que está em jogo, portanto, não é uma espécie de realismo, mas precisamente a capacidade de julgamento prático defendida por um autor como Mink. A "compreensão" não precisa envolver apenas ver o início da narrativa à luz de seu fim, mas ver os eventos à luz da totalidade, dos desejos que produziram uma certa forma de se relacionar com o passado, do tipo de consequência que se deseja produzir no presente, e, muito importante, do efeito que a ação poderá ter sobre os demais seres vivos. Nenhum remédio para a sensação de separação do mundo pode ser eficaz se ignora a interconexão entre quem escreve e todos os demais seres que vivem, desejam, sofrem.

Lembremos que Ankersmit afirmou desejar um ambiente cultural onde a atividade de abstração (artística, histórica, filosófica) não seja desconectada da experiência desta maneira. Para isto, a tarefa da filosofia da história há de ser a da retomada desta capacidade de sofrer contingentemente perdida - portanto recuperável no Ocidente desde o início da modernidade.

Isto nos traz de volta à discussão sobre nostalgia. Segundo Boym: “A nostalgia moderna é o luto pela impossibilidade do retorno mítico, pela perda de um "mundo encantado" com limites e valores claros." (158) Se uma resposta possível a esta perda é

históricas, e portanto obscurecem fatores como o envelhecimento e a morte, incontornáveis de toda existência humana. 
o desejo pelo "retorno para onde nunca estivemos"264 - pois, como Ankersmit aponta, o passado mítico surge após a produção da divisão entre passado e presente - outra resposta possível é abraçar o desamparo e o antifundacionalismo. A filosofia de Ankersmit tende a rejeitar o desamparo, mas se pretende antifundacionalista, e portanto não é bem atendida pelo tipo de aspiração melancólica pelo retorno a um passado onde as categorias eram estáveis. É importante que pensemos, então, nas condições de possibilidade para a realização deste luto. Rorty e Lakoff apontam, com razão, que produzir novos vocabulários é mais vantajoso do que operar no interior dos antigos. Nossa visão, nessa linha, é de que o luto de identidades construídas nos moldes da ideia de nação pode ser imensamente facilitada pela produção de outros vocabulários. Não se trataria tanto de rejeitar a organização ao redor da nação, mas da produção de solidariedades por outros meios, tanto em grupos de menor escala quanto por meio da universalidade negativa pautada no reconhecimento não pautada nos predicados dos sujeitos. É questionável, em suma, se este trabalho coletivo de luto e escuta seja melhor atendido por aquele que é o principal sujeito melancólico, precisamente, o estado-nação. A dúvida existe na proporcionalidade em que o estado, não abstratamente mas sim tal como se constituiu nos últimos séculos, legitima violências e a manutenção de desigualdades contra as minorias em seu interior - a maneira precisa pela qual isto ocorre varia de um local para outro, mas a descrição geral é suficientemente justa -, bloqueando mais do que estimulando o tipo de laços solidários necessários para que as dores do passado, que doem por serem conectadas processualmente com as dores do presente, passem.

Além disso, o sofrimento se manifesta em conexão com certos pressupostos culturais que, como tudo na cultura, não é natural e imutável. Ankersmit especula sobre por que Guicciardini estava sujeito ao sofrimento ocasionado pela descoberta da consequência não intencionada de suas ações, enquanto alguém como Filipe, o Bom "olhou com completa equanimidade a destruição wrought on France devido à sua selfserving aliança com a Inglaterra da Guerra dos Cem Anos” (2005: 359). Ele levanta a hipótese de que Guicciardini tinha um conceito de ação política moderno que Filipe, vivendo em outro mundo, não podia ter. Assim, enquanto Guicciardini se sentiria responsável diante do mundo, ou da Itália, Filipe não poderia conceber que suas ações fossem capazes de afetar as profundezas de uma realidade ordenada por Deus. (2005:

\footnotetext{
${ }^{264}$ Parafraseio a expressão muito apropriada que Kleinberg empregou em outro contexto: KLEINBERG, 2012.
} 
360) Filipe estava sujeito à sensação privada da vergonha, enquanto Guicciardini estava sujeito à culpa, "que sempre tem a ver com um débito que temos com o mundo." Ankersmit descreve, adicionalmente, como a noção moderna se diferencia da medieval por conceber que os seres humanos deixaram de se ver e ser vistos como imersos no mundo "e ficaram cativados pela ideia de que, deste ponto de vista de fora da realidade", nós podemos alterá-la. Ele traça o paralelo ainda com a revolução científica, que, da mesma forma que a consciência histórica, criou ou presumiu um "ego transcendental" que era "o produto e resultado de um movimento de anachoorèsis, de uma retirada do self do mundo mesmo para dentro de um santuário cognitivo interno que decide sobre a confiabilidade dos dados da experiência." (362) Trata-se, para Ankersmit, de um reculer pour mieux sauter: a partir deste "ponto de vista arquimediano fora da realidade mesma," caracteriza ele, e prossegue, "apenas após ter adotado esta estratégia paradoxal - a mente ocidental poderia ganhar uma ascendência sobre a realidade histórica e natural que nunca antes ela havia possuído.” (362)

Porém, podemos adicionar que não há nada nesta postura de não-reatividade que necessariamente envolva pressupostos cientificistas e que demande a centralidade da culpa como forma de assunção de responsabilidade pelas ações políticas. Os dois primeiros argumentos que tenho sobre este ponto envolvem a necessidade, fortemente valorizada por Ankersmit, de historicizar a história e a filosofia da história. Em primeiro lugar, não cabe a uma reflexão teórica precisamente histórica o reconhecimento de que não há nada necessário quanto à configuração assumida a partir do período moderno? Adicionalmente, uma atividade reflexiva - como a da crítica ou da filosofia da história - interessada em apoiar a produção de passados práticos não estimularia a produção de artefatos culturais pautadas por outros afetos que não o da culpa? Em segundo lugar, se a reflexão - inacessível a Guicciardini, que, embora tenha refletido sobre as próprias, não ocupa a mesma condição histórica de Ankersmit, que reflete sobre as reflexões de Guicciardini sobre as próprias ações - permite a conclusão de que agir historicamente é não ter acesso a todas as consequências das próprias ações, então a categoria de culpa se mostra inútil em relação a todo um espectro de consequências (embora talvez não a todo ele). Reconhecer isto nos libera para agir em relação à cultura de nossa contemporaneidade de modo a produzir outras formas de responsabilização individual, nos casos em que isto pareça pragmaticamente vantajoso. É compreensível que Guicciardini tenha sentido culpa, mas, uma vez que 
compreensamos como este cenário se formou, não estamos condenados a repeti-lo - se estivéssemos, para que teorizar?

Em terceiro lugar, cabe questionar a afirmação de Ankersmit sobre a maestria do passado produzida em um caso como este. Uma crítica na linha de Nietzsche, Collingwood e White poderia afirmar precisamente o oposto, que esta maestria meramente intelectual teve a consequência de produzir uma maestria do passado sobre o presente, do mundo histórico sobre aqueles que desejam conhecê-lo. O conhecimento histórico surge na interface entre o polo "objetivo" da realidade histórico e o polo "subjetivo" da perspectiva oferecida pelo historiador. Isto significa que, ainda que o passado em certo sentido seja fechado, o conhecimento histórico é sempre aberto, pois surge na totalidade produzida por uma dimensão fechada e uma aberta - e portanto o resultado da combinação está sempre em aberto. Assim, não há maestria sobre o passado que não envolva o reconhecimento da liberdade presente na dimensão subjetiva, por parte dos sujeitos incorporados e conscientes que estabelecem relações com o passado. E isto deve incluir o tipo de autonomia sobre o próprio desejo possibilitado pela reflexão ética, que não apenas produz liberdade sobre desejos imutáveis, mas também modifica os desejos - dado que a reflexão não ocupa uma posição transcendental sobre aquilo que toma como objeto. Não se trata de repressão, mas de autonomia da atenção. Para adiantar um exemplo, direcionar a atenção às aspirações e ao sofrimento dos demais seres vivos tende a fortalecer os sentimentos ligados à solidariedade; inversamente, é inteiramente concebível que a produção de imagens desumanizadoras do "outro" estimule desejos de aniquilação - se os exemplos do século XX já são tristemente abundantes, lembremos ainda de imagens como a do "bandido" nos programas policialescos contemporâneos. Assim, se por um lado os desejos - e, mais superficialmente, os sentimentos - estimulam a produção de imagens ou mais complefixicantes dos seres, ou mais simplificadoras do "outro", por outro lado o movimento inverso também ocorre: uma certa construção do "mundo" e dos seres que os ocupam reincidem sobre os desejos. Afirmar isto é levar a sério a conclusão de autores como Wittgenstein e Heidegger que nenhum fundamento das práticas humanas é sólido, mas sim contingente.

Em quarto lugar, e como complemento importante ao item anterior, cabe reconhecer que a abordagem científica - acompanhada do ego transcendental que ela pressupõe- não é a única maneira de lidar com o mundo e com o passado: também a arte e as reflexões éticas participam da "conversa" humana sobre o mundo de maneiras 
que envolvem um "afastamento engajado". De fato, como a realidade humana é composta por atividades materiais e mentais, de outros seres e de nós mesmos, combinadas holisticamente de maneiras diversas, o tipo de engastamento descritos por Ankersmit em termos de "compulsão" também tem como consequência a desconexão do sujeito com todas as dimensões complexas do mundo. A alternativa à ela não precisa ser necessariamente pensada em termos das "doenças de reflexão" como a desrealização ou despersonalização, que se manifestam no tipo peculiar de experiência que Ankersmit chama de "histórica sublime" (ANKERSMIT, 2005: 354-5). Por que não precisam? Porque os elementos mais concretos do mundo, desvelados por um contato empírico mais imediatista, podem ser integrados a tudo que pode ser desvelado por meio de atividades mais abstratas como a arte, a ciência e a filosofia - ou a historiografia, que envolve todas elas. Como Ankersmit não é, ou parece não desejar ser, transcendentalista, creio estar harmonizado com seus interesses ao insistir que, ao contrário do que sua afirmação dá a entender, não precisamos conceber a reflexão como algo "fora da realidade": pois a "realidade humana" se desenrola de modo temporal, e a reflexão cria um espaço a partir do qual se pode ativar diferentes potencialidades, presentes historicamente (por exemplo na forma de "passageiros clandestinos") mas não imediatamente visíveis. A consciência que efetua estas escolhas, com maior ou menor grau de autonomia dependendo das condições históricas em que ela atua, bem como tudo aquilo que só pode ser desvelado com maior grau de reflexão, é tão real quanto aquilo que é imediato.

(b) O trauma 2 é insuperável ou chamamos de trauma 2 aqueles contingentemente não superados?

Ankersmit caracteriza o processo que culmina no trauma 2, com razão, como marcado por uma cisão irreparável, a partir da qual surgem passado e presente. (2012: 180) Esta é a separação ocasionada pela reflexividade, e para caracterizá-la o exemplo de Sócrates é muito preciso: uma vez feita a reflexão sobre si mesmo em uma condição “objetivista”, não se pode escolher perder tal condição. Isto não deveria significar, porém, que (a) ao longo do processo histórico, as condições que produziram a reflexividade não podem ser perdidas. Afinal, como a consciência se sustenta em corpos, e estes estão em ambientes físicos, é concebível que fatores externos produzam. Este insight apareceu em vários trechos do presente trabalho: no receio que Vico e Collingwood possuíam do retorno do "barbarismo", e na afirmação deste último de que 
a consciência histórica se encontrava em risco na primeira metade do século $\mathrm{XX}$; na concepção de Elias segundo a qual as condições de "distanciamento" podem ser perdidas; na visão whiteana de que a lógica interna dos tropos pode ser afetada por processos causais externos. Adicionalmente, (b) a impossibilidade de esquecer voluntariamente da reflexividade é um pouco diferente do que concluir que, então, tal perda provocará dor para todo o sempre. Pois, sim, tudo que é histórico fica "em aberto": esta é a lição de Danto, especialmente se lida a partir da perspectiva figuralista. Então o evento disruptivo sempre poderá ser reativado em conexão figurais posteriores, e em algumas delas de maneira dolorosa; em outros momentos, porém, a atenção dos agentes se direcionará ou será atraída para outros pontos da "cidade".

No terceiro tipo de trauma, o sujeito se sente "o mesmo" e sente que o mundo é "o mesmo". No quarto, houve uma mudança grande a ponto de o mundo ser experienciado como "outro", mas é nítido que o sujeito gostaria ainda de permanecer como o "mesmo", vivendo no mesmo mundo. Parece-me justo distinguir um tipo de esquecimento no qual o mundo mudou e outro no qual isto não ocorreu, mas disto não me parece seguir que os sujeitos estão condenados a carregar o trauma para sempre. Isto porque a nova identidade não é fixa, produzida de modo meramente causal: precisamente porque, como o próprio Ankersmit avalia, o evento da perda é um fator causal para a produção de uma nova identidade - como um tiro ${ }^{265}$ - a configuração específica a ser assumida pela nova identidade não é dada, mas sim produzida performativamente e negociada intersubjetivamente, por meio de recursos estéticos.

O problema, então, parece ser o da nomeação: como sabemos antes do trabalho com o trauma, tomando como critério sua superabilidade, se ele era do terceiro ou do quarto tipo? Um trauma não superado, oriundo de uma mudança histórica, pode ser descrito como de quarto tipo; mas e se ele for harmonizado com uma nova identidade coletiva, ele passará a ser de terceiro? Como afirmar que, de uma dada mudança histórica, já se possa saber a priori que era impossível superar um trauma - destinado que estava a ser "constante e permanente"? Como saberemos se a identidade coletiva posteriormente dominante em algum dado momento (e qualquer predomínio é temporário, contingente e parcial, pois identidades estão sempre em disputa e nenhuma se estabelece incontestavelmente) tomará como referência a experiência das elites traumatizadas e não, quando for o caso, de eventuais grupos emancipados? Ora, o que

\footnotetext{
${ }^{265}$ Metáfora muito adequada empregada em Meaning para afirmar exatamente que a experiência causa a produção de uma nova identidade, mas não determina como ela será.
} 
me parece ocorrer quando descobrimos um exemplo traumático como sendo do tipo 2 é evidentemente uma categorização a posteriori, uma contingência retroativamente tomada como necessidade: chamaremos de trauma 2 aqueles que, ao seguirem ao tipo de rupturas que ocorrem em uma das etapas de uma experiência histórica sublime, se mantiveram "constantes e permanentes", sem ser inevitável que isto ocorresse.

Conservadores e reacionários eram em sua maioria aristocratas no préRevolução Francesa. Desta forma, não foi sua posição social que determinou quais identidades eles assumiriam no pós-Revolução, pois ao menos duas respostas foram possíveis (i.e., isto indica que havia margem de resposta, não meramente reação); mas sua posição social foi fator de alta relevância para o tipo de experiência que eles tiveram do evento. Quem desejasse tomar um caminho behaviorista ou fatalista poderia especular por causas em suas constituições psicológicas, mas me parece haver uma direção muito mais adequada: a assunção destas identidades foi como eles se fizeram em resposta ao evento traumático. Ankersmit fala de um tipo de "reação", mas em circunstâncias históricas específicas - e cuja manutenção pode ser desejada por agentes históricos no presente - é igualmente possível produzir "resposta". E diferentes respostas são sempre possíveis a princípio. Dito isto, como temos dito ao longo do trabalho, a margem de liberdade que permite a indivíduos e grupos responder (em vez de meramente reagir) aos eventos não é efetivada por igual em todas as circunstâncias, e em muitos casos simplesmente não é. Devido à maneira pela qual os membros de tais grupos foram educados e pelas experiências de vida que eles tiveram, é provável que eles não soubessem reconhecê-la e assim se vissem condenados a "reagir" ao fardo de seus passados (assim como os primitivos de Vico estavam condenados à reação e só com muito esforço passaram a poder responder; o mesmo para todos que tropologizam o mundo de maneira não-irônica em White). Nosso ponto é que a reflexão teórica posterior mostra a presença desta margem de liberdade, na medida em que descobre que identidades não são fixas, dadas, naturais, e que os sujeitos individuais e coletivos participam de suas construções. O quão capazes os sujeitos do presente e do futuro estarão para lidar com seus respectivos passados é uma questão em aberto, e a reflexão teórica é parte do processo que garante a presença desta margem, mas nunca o todo pois é efetivamente no nível de desejos, afetos e emoções que a reflexão reincide em mudanças de comportamento. Por saber suas limitações, o poder da reflexão deve se 
combinar com a estética para ser efetiva na prática. Não é outro o projeto de um autor como White, que escreve teoria mas aposta na sensibilidade. ${ }^{266}$

Há algo em comum nas reflexões de White sobre prefiguração e de Ankersmit sobre o caminho entre a experiência e sua expressão historiográfica: elas têm no desejo um papel fundacional. Esta fundação, porém, é um groundless ground. Além disso, Ankersmit enfatiza o insight historicizante de Louis Mink sobre o pressuposto - a ser abandonado - sobre a História Universal: mesmo uma meta-perspectiva sobre a história é histórica. Se examinarmos a própria filosofia de Ankersmit à luz deste princípio, um ponto importante se revela: a perspectiva dos reacionários e conservadores no pósRevolução, incluindo os historiadores, não é a mesma perspectiva do teórico escrevendo dois séculos depois. A mudança não é apenas a ocorrência de novos eventos, mas também o grau de reflexividade. Ankersmit produz uma reflexão teórica, e, conforme a descrição de Collingwood, o desejo não inteiramente esclarecido para os próprios agentes é trazido à tona no nível da teoria. Pois bem: o desejo não é um fundamento que, mesmo quando observado, se mantém inerte. Historicizar até as próprias fundações relativas da atividade historiográfica inclui reconhecer que (a) quando vistas à luz de suas consequências pragmáticas, (b) quando justapostas a outras consequências aparentemente mais desejáveis, e quando estas duas ações são (c) feitas à luz da reflexão moral - qualquer uma destas atividades influencia o desejo, o que, por tabela, influencia todas as atividades dos níveis mais abstratos que se pautam por eles.

Assim, por um lado Ankersmit está mais que justificado em rejeitar a concepção de filosofia tão criticada por Rorty, a de uma árbitra transcendental das demais disciplinas, e por isso tem bons motivos para pretender atuar descritivamente, e não prescritivamente, em relação à historiografia. Por outro, em questões humanas, e precisamente por não haver uma posição transcendental, é impossível refletir sem afetar aquilo sobre o qual se reflete.

Um ponto chave aqui, a meu ver, está no fato de que a relação com o passado segue dolorosa - de maneiras diferentes, para diferentes grupos dentro de uma sociedade - na dependência das circunstâncias presentes e da confiança que seus membros têm nos arcos narrativos futuros das diferentes significações negociadas para seu "nós" coletivo. As circunstâncias em que os agentes se encontram e as narrativas

\footnotetext{
${ }^{266}$ E também o de Rorty, embora este adote um discurso anti-teórico. As críticas de Bernstein em "Rorty's Inspirational Liberalism" são precisas sobre a necessidade da reflexão teórica para a ação; ver GUIGNON \& HILEY, 2003: 124-139.
} 
que constróem podem ser lidados com a liberdade situada que White ([1967] 2010) descreveu como típica dos "sistemas históricos", em contraposição aos "biológicos". Por exemplo, em todos os casos de "relações com o passado" de violência estatal estudados por Bevernage, bem como na relação da sociedade brasileira com o passado da escravidão e da ditadura, (a) não há ou havia indícios no presente de que as consequências daquele passado estavam sendo adequadamente abordadas e (b) não há ou havia escuta das perspectivas dos grupos vitimizados no passado. Assim, o fato de que certos eventos seguem dolorosos para uma sociedade não está ligado a nenhuma característica inata dos próprios eventos, mas precisamente ao fato de que eles não passaram - a escravidão pode ser redescrita como parte de um processo amplo de dominação racial plenamente em atividade, a ditadura pode ser redescrita como parte de um processo de autoritarismo que remete à escravidão e segue presente na atuação de instituições como a polícia militar, etc. Isto significaria também que um critério para a "cura" efetiva do passado, para uma abordagem produtora de luto e não de melancolia, é inseparável de uma visão de sociedade marcada por princípios inclusivos como solidariedade e compaixão - entendidos como uma proposta de direção coletiva para o futuro que ressignifica o passado de maneira reconhecida como justa pelos vários membros. Não é factível que este processo ocorra se não com o embasamento em práticas presentes concretas, pois, como vimos, significados não flutuam em um céu de abstrações, mas circulam entre corpos convivendo entre estruturações de todo tipo. Não é difícil ver que o sofrimento dos conservadores e reacionários pós-revolução envolve uma visão de mundo muito menos inclusiva, dependendo que era de uma estrutura social que dominava os mesmos membros dos quais eles demandavam reconhecimento. O desejo de "ser" aquele passado - literal ou sublimado no desejo de conhecer - é inseparável da aspiração por uma sociedade desigual. Retomaremos este tópico mais adiante, ao discutir o pressuposto de que o (real ou suposto) "imediatismo" do passado que se perdeu é naturalmente preferível à reflexividade da "sociedade civil" formada na sequência. Em Sublime, com sua entonação abertamente rousseauniana, isto é o caso. Mas não vejo como sustentá-lo: a desejabilidade de algo depende da natureza precisa do que foi perdido, do mundo que entrou em vigor em seu lugar, e dos desejos daquele que conecta narrativamente estes dois períodos. Em vez de presumir que toda uma sociedade se move pelo desejo por aquele passado, seria o caso de nos perguntarmos: quem o deseja, e por quê? O simples colocar da pergunta, especialmente se feita da 
perspectiva de uma perspectiva utópica que pode se mostrar como desejável, desnaturaliza a suposta condição (pressuposta como) fixa do desejo pelo passado.

A diferença entre esta visão e a tese apresentada no capítulo 8 de Sublime, a diferença é que ela leva em conta (a) a maleabilidade das identidades, (b) a dimensão temporal das significações, não resumidas ao passado - como na visão historicista -, mas sim inseparáveis das perspectivas utópicas dos diversos grupos, e (c) a dependência da "cura" do fardo da história de uma perspectiva compassiva e inclusiva presente na intersubjetividade presente. Para os grupos que sofreram e sofrem no passado devido a injustiças históricas, isto é pré-requisito para a cura de traumas 1. Para grupos que outrora foram dominantes e não são mais, nosso argumento é que isto está envolvido na cura para o trauma 2. Especialmente, seus descendentes não estão condenados a desejar “ser" tais grupos porque, como afirmou White, a ancestralidade histórica é escolhida retroativamente. O interesse excessivo por si mesmo no passado é o outro lado da moeda do desinteresse em ser parte da coletividade presente - o que produz sofrimento, assim como a marginalização forçada de outros grupos produz sofrimento para eles. Se uma solução será buscada com apoio no conhecimento sobre o passado, é menos relevante que o quão solidária ou excludente é a motivação para a investigação: pois é nas dinâmicas de reconhecimento no presente que se está interferindo quando da produção de atos de fala historiográficos, e não é factível que o reconhecimento de um dominado fosse satisfatório - no caso improvável de uma configuração social passada ser restaurável. Não bastasse, há o problema adicional de que não é efetivamente possível "ser" uma identidade.

Em relação ao quarto tipo de esquecimento, isto significa: na relação entre os níveis consciente e inconsciente, incluindo entre a identidade assumida no presente e as memórias dolorosas, o sujeito está ativamente escolhendo se construir com uma identidade presumidamente fixa - e Sublime está equivocadamente tomando esta reação psicológica, ignorante das próprias circunstâncias históricas, como um dado filosófico: algo insustentável diante das pretensões antifundacionalistas de Ankersmit. Não é que ela "não pode ser narrativizada" (323): é que a fixação a uma certa identidade não abre o campo de possibilidades, que, porém, segue "presente". O processo descrito em Sublime é mais melancólico do que de luto: a energia libidinal não se libera em novas direções porque o sujeito não aceita plenamente que não pode ser o que (acredita que) era. 
Há espaço para este ajuste em Sublime, pois Ankersmit compara dessa forma o trauma 2 aos eventos - frequentemente muito mais violentos e produtores de muito mais sofrimento - envolvidos no trauma 1 :

[O trauma 2 de conservadores] foi precisamente seu reconhecimento de que eles tinham que aceitar o que eles so much abominavam. Mas isto é completamente diferente com o Holocausto. O que Hitler e seus capangas legaram à posteridade é algo que deve ser evitado para todo o sempre e que em nenhuma circunstância poderia ser uma parte legítima do nosso presente e do nosso futuro. Então há ocasião para tristeza, desespero e indignação moral sobre os crimes indizíveis que foram cometidos pelos nazis - mas não há ocasião aqui para um trauma coletivo. Para dizer provocativamente, seria até mesmo uma infâmia moral se o Holocausto tivesse desencadeado um trauma histórico, como eu entendo esta noção, pois isto sugeriria que nós aceitamos o legado de Hitler de alguma forma. (351-2)

Notemos que o trecho mistura dois sentidos do termo "aceitar": os conservadores tinham que "aceitar" um acontecimento que produziu uma mudança (para eles) insedejável, já os europeus não podem "aceitar" o legado do Holocausto. O primeiro caso é o de conformar o intelecto à realidade, aceitando que algo ocorreu, por mais que o grupo não o desejasse. Nesse sentido, como não somos negacionistas, aceitamos quase todos que o Holocausto ocorreu - como também deveríamos aceitar que houve uma ditadura militar no Brasil, que praticou torturas mais do que suficientemente documentadas. Como Ankersmit aponta, o sentido em que não se deve "aceitar" o Holocausto é o de tomarmos para nós seu legado, fazermos dele parte da nossa ancestralidade. No primeiro caso de "aceitação", falamos do aspecto "fechado" do passado; no segundo caso é que se encontra a liberdade teorizada por White: nele o passado é aberto, e o Holocausto europeu, bem como o autoritarismo brasileiro, podem ou não ser aceitos. ${ }^{267}$

\footnotetext{
${ }^{267}$ Em certo sentido, se lembrarmos do que Gumbrecht comenta em Após 1945, é a Primeira Guerra Mundial que fez com que os europeus perdessem para sempre o mundo que parecia ter se naturalizado, aquele narrativizado pelo mito do progresso e pelas esperanças de uma paz duradoura (ver HOBSBAWM, 1989: 302-340). A guerra foi sem dúvidas indesejável, mas o quão limitadas teriam que ser nossas aspirações utópicas para que, só por rejeitá-la, nos sentíssemos compelidos a desejar o passado do império? Depende para onde direcionaremos a atenção: para o mito do progresso ou para a experiência concreta dos seres humanos subjugados pelos impérios europeus ao redor do mundo. Como o projeto de Ankersmit deseja ampliar o contato com a realidade e não ficar preso nas abstrações (2003: 419), ele é muito melhor atendido pela atenção às experiências subjetivas dos agentes no passado (que ele categoriza como "experiência histórica objetiva"). Estamos condenados a desejar aquele passado? A maneira pela qual direcionamos a atenção a ele não afeta o quão desejável ele nos soa? Um segundo elemento que temos apontado como capaz de influenciar a desejabilidade de certos passados é o foco nas consequências pragmáticas da adoção de identidades estreitas em contraste com as consequências de compaixão, solidariedade, "unselfing". Formulações filosóficas gerais podem ser fornecidas, mas não é possível fornecer normas de nenhum tipo e portanto os exemplos concretos são o melhor recursos; além disso, como Rorty bem sabia, são os exemplos concretos que mobilizam o desejo.
} 
Isto permite-nos levantar a questão ética: em que circunstâncias devemos oferecer reconhecimento às demandas identitárias de outros grupos, e em quais ela é eticamente questionável? Notemos que, como já observado, o sofrimento parece surgir tanto em casos como o de grupos (outrora) dominantes, que não são mais reconhecidos da maneira que gostariam, quanto de grupos marginalizados, que não são escutados e não têm acesso aos meios econômicos e tecnológicos que possibilitariam, se não a escuta, ao menos uma ação capaz de modificar as circunstâncias de escuta. O tipo de demanda ética não é idêntico em ambos os casos.

Em qualquer circunstância na qual está presente a demanda pelo reconhecimento de uma identidade - construída pela narrativização do passado -, temos ao menos três dimensões envolvidas: (a) o passado, (b) um sujeito coletivo (parte de uma coletividade maior) buscando ser reconhecido a partir de uma certa narrativização de si mesmo que o conecta a este passado (e vice-versa) de uma maneira específica, e (c) os demais grupos, que oferecem este reconhecimento de formas variadas e se constróem e buscam reconhecimento a partir de outras relações com o passado. Ao contrário do que Sublime pressupõe, nenhum destes três elementos é fixo, e o sofrimento surge em uma certa combinação entre os três. Além disso, a dinâmica entre os grupos não aparece na discussão de Sublime: o foco aparece unicamente nos grupos de elite ${ }^{268} \mathrm{e}$ frequentemente a sociedade é pressuposta ser uma unidade monolítica, sem tensões internas, que se modifica por inteiro de uma vez só. ${ }^{269}$ Perde-se de vista, assim, as dinâmicas de reconhecimento pelas quais identidades são negociadas.

De uma perspectiva pragmática, uma visão que considero desejável de sociedade é aquela capaz de reconhecer o sofrimento de seus membros e modificar os elementos que se harmonizam com uma visão não excludente: a recusa ao reconhecimento de uma subjetividade que constrói com base no desejo por uma sociedade excludente é justificável em critérios pragmáticos, enquanto a recusa a reconhecer que as causas de sofrimentos passados seguem operando no presente - e portanto não podem ser adequadamente narrativizados como "passado" sem produzirem a consequência indesejável de perpetuar tal sofrimento - é indesejável. É necessário inserir esta visão das dinâmicas de reconhecimento, e infelizmente também de dominação, na

\footnotetext{
${ }^{268}$ O que permite a Froeyman (2012), por exemplo, caracterizar a noção de "experiência histórica sublime" como "elitista".

${ }^{269}$ Embora a analogia entre sociedade e um "monstrengo", presente no capítulo 5, escape a este equívoco e apresente uma perspectiva mais interessante sobre o tipo de experiência histórica que uma coletividade pode ter. Falaremos sobre isto mais adiante.
} 
caracterização das "experiências históricas sublimes". Ankersmit operou como uma noção exageradamente monolítica de sociedade, no espaço (e de período, no tempo). Não à toa, ele cita vários exemplos de como "o homem ocidental" "entrou em um mundo inteiramente novo", e "ele só pode fazê-lo na condição de esquecer um mundo prévio e perder uma identidade antiga." (323) Se este pressuposto não-notado por Ankersmit reforça uma certa concepção eurocêntrica e androcêntrica, ainda assim não se trata de produzir uma reprovação moral ao autor, que seria inteiramente descabida, mas meramente de ampliar sua proposta de modo a incluir uma multiplicidade maior de relações sociais. A riqueza da "conversa" filosófica - para falarmos como Rorty - reside precisamente na possibilidade de uns (DOMANSKA; FROEYMAN; ICKE, 2011; JAY, 2018) verem o que passou despercebido para outros. A tinta no papel pode produzir uma rigidez que falseia o movimento do diálogo necessário para enriquecer qualquer teoria. Como ele comentou em 2018: "Jay me critica acertadamente quando eu (nãointencionalmente) sugeri que o desejo de restaurar uma ordem passada política e moralmente injusta possa ser parte da experiência histórica. A experiência histórica é essencialmente diferente da nostalgia e sua política não é reacionária. Muito pelo contrário."270 (2018: 486) Isto significaria que os emigrés reacionários não tiveram “experiência histórica” da Revolução Francesa, enquanto Tocqueville sim, o que se mostra no fato de que este teve insights sobre o que se perdeu e sobre as consequências da entrada no novo período que os primeiros não tiveram. ${ }^{271}$ Isto parece envolver tanto a aceitação de Tocqueville da inevitabilidade da mudança, quanto o desejo dos primeiros de manter uma ordem injusta - mas como isto se dá não está claro: Ankersmit cita os dois pontos, a aceitação da mudança e a dimensão moral da ordem desejada, mas apenas de passagem.

A maleabilidade das identidades e da relação com o passado, que no cap. 2 vimos estar presente em White e que aqui buscamos articular com os esquecimentos traumáticos descritos por Ankersmit, também deveria aparecer na maneira pela qual Ankersmit descreve os dois primeiros tipos de esquecimento.

Os casos de não aceitação em relação às verdades sobre o passado - incluindo os negocionismos - inevitavelmente produzem sofrimento, pois quando se manifestam na

\footnotetext{
${ }^{270}$ Mas esta negação enfática, "rather the opposite", ainda carece de um esclarecimento nos textos de Ankersmit ou na bibliografia ao redor deles.

${ }^{271}$ Lembremos do comentário de Orwell, segundo o qual aqueles que melhor compreenderam o fascismo foram os que tinham algo do fascismo dentro de si mesmos. Rorty comenta o fato de que, segundo biógrafos, o próprio Orwell tinha algo de sádico em seu comportamento (RORTY, 1989: 180, n12).
} 
própria consciência do agente, na forma de má-fé, o impedem de reconhecer fatores causais ainda operativos no presente, e, quando envolvem a tentativa de reconhecimento social de uma narrativa cujos fatos não são conformes com a realidade, demandam ou ignorância na melhor hipótese ou são impostas à força na pior. Má-fé ou dominação autoritária são os correlatos inseparáveis - e ambos são péssimas estratégias para a superação do sofrimento de um dado grupo, visto que apenas faz com que o restante da sociedade sofra, o que, além de não resolver o próprio sofrimento, ainda por cima o amplia. Exemplos históricos são óbvios a ponto de nos autorizarem esta afirmação sem dúvidas geral demais: não me consta um único negacionismo dos campos de concentração ou da ditadura brasileira, incluindo membros do atual governo, que não tenham (a) sido aparentemente motivadas por um sofrimento prévio, que começou a se manifestar quando as circunstâncias que lhes permitiam controlar as narrativas públicas se modificaram, e que não tenham (b) ampliado ainda mais o sofrimento e causando danos à comunidade comunicativa (pré-condição para a comunicação, e não apenas seu resultado) ao atacar a própria noção de verdade intersubjetiva. ${ }^{272} \mathrm{~A}$ isto cabe adicionar, (c) enquanto as violências ocorriam, os membros de tais grupos já não eram felizes. $\mathrm{E}$ rejeito inteiramente a possibilidade de felicidade e sofrimento serem tratados como questões filosoficamente irrelevantes, pois, do fato de que textos e experiências históricas são tidas por seres humanos em corpos de carne e osso e em relações intersubjetivas, é neste campo que efetivamente encontramos os motivos pelos quais movemos o passado e pelos quais o passado nos move. E é evidente que o tema do sofrimento tem centralidade também no próprio Sublime. Assim sendo, especifiquemos esta última afirmação. Em sua excelente discussão sobre os limites do liberalismo rortyano para efetivamente produzir uma alternativa à crueldade, Jean Bethke Elshtain cita Jonathan Lear:

De tudo que sabemos sobre crueldade, ela não é amorosamente instilada. É a crueldade que gera crueldade: e assim a possibilidade de uma alma cruel e harmoniosa, relativamente livre de conflitos internos e suficientemente diferenciada do ambiente cruel, começa a parecer ficção científica." Lear prossegue em uma nota de rodapé, para escrever desimpedidamente, da formação da alma como sendo "dependente de um certo tipo de responsividade. A sanidade é uma condição constitutiva de uma alma

\footnotetext{
${ }^{272}$ Uma diferenciação importante: a historiografia debate (dentre outras coisas) quais verdades devem ser intersubjetivamente aceitas precisamente porque os membros da comunidade historiográfica vêem uns nos outros a capacidade e a boa-fé de reconhecer no passado as verdades que eles também reconhecem. Quanto às verdades é possível produzir consenso, quanto aos significados não. Mas idealmente os membros da comunidade historiográfica reconhecem que (a) representado a partir de certas perspectivas, o passado assume significados diferentes, (b) esperam boa-fé na produção de significado por parte de seus pares, e (c) entendem a pluralidade de perspectivas como uma riqueza e não um obstáculo.
} 
plenamente formada. A experiência clínica sugere que o exemplo mais próximo de um torturador feliz é um torturador que está mais feliz do que ele normalmente está quando ele está torturando. Tais pessoas não são seres humanos razoavelmente felizes ou bem integrados. No geral, é uma vida difícil ser um torturador. (GUIGNON \& HILEY, 2003: 150)

Um esclarecimento filosófico me parece ter sido adequadamente produzido por Vico e Gadamer, que condicionaram, cada um a sua maneira, a possibilidade de comunicação ao reconhecimento de um mundo comum prévio. Em relação à argumentação da presente tese, cabe notar como o sofrimento produz movimento: a tentativa de ressignificar o passado, e/ou a si mesmo, e de convencer os demais membros da sociedade é uma busca por atenuá-lo. Este movimento, cabe observar ainda, enfatiza tanto os elementos de presença quanto os de significado, e trata sempre do estabelecimento de uma certa relação entre eles. Daqui que, como estamos defendendo, eles não possam ser adequadamente compreendidos se tomados como “objetos teóricos" isolados.

\subsection{As mutações do monstrengo}

Ainda sobre a atividade reflexiva, Ankersmit caracteriza eventos como o da manifestação da consciência histórica em Maquiavel e Guicciardini como uma "mutação". Aqui, o exemplo tem o mérito de não pressupor estes blocos temporais - os "períodos" em que uma sociedade deixa de ser uma coisa e passa a ser outra coisa:

\footnotetext{
... a realidade histórica, como tal, não foi afetado por ela; ela não foi bem mesmo uma mutação na própria realidade histórica [historical reality itself]. Em vez disso, foi uma mudança em como os homens ocidentais decidiram olhar para a realidade histórica; foi uma mudança em perspectiva, enquanto tudo sobre o qual ela é uma perspectiva permaneceu do jeito que sempre havia sido. Ainda assim, essas mudanças pequenas e imateriais podem se tornar irreversíveis e determinar o destino da humanidade. Elas são como uma mutação...
}

O problema da descrição é dar a entender que o modo de olhar - exatamente como Ankersmit caracteriza as representações - não é parte da realidade histórica. Isto não é correto, nem para descrever a história-processo nem para a história-escrita: a história é feita do material e do imaterial, e ambos se afetam mutuamente. Mas ela é muito rica ao reconhecer a existência de múltiplas temporalidades no interior de um mesmo período - i.e., do que pode ser representado, por agentes ou historiadores, como um período - e ao descobrir que, por períodos muito longos, processos que assumirão 
grande importância podem se desenrolar sem serem notados por aqueles que ainda não conseguem adotar a perspectiva que os próprios processos tornarão possível no futuro.

Outra analogia presente em Sublime também embasa esta leitura. No início do seu capítulo sobre Gadamer, ele pede que imaginemos

uma civilização, uma cultura, ou uma época histórica como se ela fosse uma criatura estranha e híbrida, uma criatura reminiscente do que Schopenhauer tinha em mente com a sua noção de uma Vontade precedendo o estágio em que o principium individuationis havia começado a operar.

Esta criatura inclui todos os membros da sociedade, mas "seu nível de autoconsciência é muito menos desenvolvido e muito menos articulado do que usualmente é o caso com nós, como indivíduos humanos normais, acordados.” Ele prossegue:

\begin{abstract}
Sobretudo, pense sobre esta estranha criatura como consistindo em nada que não estas sensações, humores e sentimentos vagos e inarticulados. Ela carece de um "self" unindo-os. Estas criaturas são apenas estas conjuntos fleeting de sensações, humores e sentimentos. Dessa maneira, estas criaturas são conjuntos de experiências sem que haja um sujeito de experiência. (196)
\end{abstract}

Mesmo sem um "Eu", Ankersmit especula, esta criatura poderia se tornar consciente de si mesma:

O paradoxo de um auto-consciência sem auto-consciência poderia então ser resolvido dizendo que a presença destas dores e sensações se articula apenas na mente de alguns gratos poetas, romancistas e historiadores vivendo e escrevendo em uma certa civilização ou cultura.

As escritas destes "poetas, romancistas e historiadores" deveriam ser vistas como produtoras de um discurso que não se submete ao estatuto de verdadeiro ou falso, mas como "os gemidos desta civilização" (196-7). Gemidos estes que não são sem significado (meaning), "longe disso!” (197), mas que não visam ser verdadeiros: "estes gemidos são essencialmente poéticos; assim como um poema, eles não almejam a verdade, mas a fazer a experiência falar.” (197; o original está em itálico).

O contexto desta analogia foi estabelecido com apoio na discussão de Wittgenstein sobre o que significa dizer "eu sei que estou com dor". A frase "eu sei” só faz sentido quando há algum espaço para dúvida, e, no caso da experiência privada de dor, tal espaço inexiste. Ankersmit argumenta, portanto, que ela equivale a um gemido, que expressa uma dor mas não se conforma ao estatudo dos discursos passíveis de serem verdadeiros ou falsos. Ankersmit avalia em seguida que o filósofo da história que mais chegou perto do que a imagem do monstrengo insinua foi Gadamer. Para ele, 
Gadamer teve o mérito de, seguindo Heidegger, "pensar sobre os historiadores e seus escritos não em termos epistemológicos, mas ontológicos." (197) Desse modo, o historiador e seu objeto compartilham um mesmo status ontológico. (198)

Há ao menos um demérito e um mérito na analogia do monstrengo. $\mathrm{O}$ demérito surge na sequência do raciocínio recém delineado, com base no qual Ankersmit afirma:

Auto-evidentemente, isto está de acordo com a minha imagem wittgensteiniana
de historiadores expressando as dores, humores e sentimentos de sua
civilização e seu passado, e portanto com uma explicação da escrita histórica
em que o elo entre experiência e Verdade foram impiedosamente cortados. A
verdade é o inimigo implacável da contiguidade e de uma negociação
ontológica das reivindicações do sujeito e do objeto. (198)

Mas notemos: experiência e Verdade nesse caso são, especificamente, experiência não-linguística e verdade epistemológica. O problema é que apenas a "experiência histórica sublime", de todas as formas de experiência histórica analisadas no livro - e certamente incluindo tantas outras não analisadas - é não-linguística (ou, mais precisamente, contém um momento não-linguístico). (E toda vida humana evidentemente, ao menos se pode argumentar, é perpassada de outros momentos em que a linguagem não tem papel central.) Em uma civilização, porém, estão presentes os tipos linguísticos de experiência, juntamente com os não linguísticos. A imagem do monstrengo dá a entender que apenas o nível mais básico da experiência está presente para a maioria dos seres, e presume a mesma imagem da imediaticidade da infância, do rebanho nietzscheano, do estado da natureza, etc. No que diz respeito a toda experiência da história desde que a humanidade formou o que chamamos de cultura, tal estado de imediaticidade não existe, e portanto o que presumimos acontecer no monstrengo deve ser complexificado. É sem dúvidas justificado dizer que as mentes mais sensíveis articulam os gemidos de dor da civilização, mas devemos reconhecer que muito do que se passa nas experiências do monstrengo envolve a circulação e reprodução destes significados, e não uma pura imediaticidade.

Nossa visão é que a filosofia de Ankersmit seria melhor atendida pelo abandono de distinções rígidas que perdem de vista a interprenetração do nível epistemológico pelo estético, mais básico, que o constitui. Assim, podemos reconhecer que o nível mais básico de experiência humana é melhor expressado pela linguagem poética, e esta cria o campo de possibilidades de expressão proposicional de verdades ou mentiras. Não se trata tanto de "cortar sem piedade" os elos quanto de reconhecer que a verdade é perpassada de estética, mas esta antecede o discurso de verdade. Assim também nas 
discussões sobre representação histórica: o nível da representação e o das descrições são uma distinção analítica útil, mas na prática a descrição epistemológica é também de natureza representativa - uma representação cristalizada, quando há acordo intersubjetivo temporário sobre como descrever um evento -, inseparável da representação que forma e ajuda a formar. E isto significa, no caso da analogia do monstrengo, que nem só de gemidos ele vive: ele geme, mas também diz verdades (ou mentiras), e, ao dizer verdades, o como ele diz segue a lógica do gemido ao mesmo tempo em que o que ele diz pode ser avaliado por critérios epistemológicos. Este nível mais básico de cada ato de fala é uma expressão direta dos "humores e sentimentos" predominantes em um período, mas tais humores constituem o campo a partir do qual as verdades e a reflexividade também atuam.

Feito este ajuste, então a metáfora do monstrengo - cheio de imediatismos, mas também de reflexividade nas várias partes de seu corpo (com uma proporcionalidade historicamente contingente) - passa a ser bastante promissora. Pois como os demais membros da sociedade não são uma massa amorfa imediatista nem um mero rebanho, o que surge como "mutação" em uma parte do monstrengo pode se espalhar para as demais partes, e o faz de maneira desigual, dependendo do tipo de "conexão nervosa" disponível. Para que possa ocorrer a comunicação entre diferentes partes do monstengo, que - para emprestarmos uma analogia a mais, agora a de Eelco Runia - é como uma "cidade" cheia de partes que se "comunicam" entre si por meios mais ou menos eficientes, e que portanto não podem nunca ser homogeneamente situadas em um único "período", é indispensável que a "eficácia" da comunicação seja levada em conta. Um texto produzido apenas para os pares tem o mérito de, por meio da comunicação entre eles, refinar o conhecimento sobre o passado, na medida em que produz mais perspectivas sobre ele; porém, para que chegue a outros lugares da cidade - ou do monstrengo - a situação da comunicação deve ser levada em conta.

Em seu argumento sobre a experiência histórica sublime provocada pela Revolução Francesa, Ankersmit precisa precisar uma ruptura não só muito mais drástica do que ela foi, mas também que tenha se produzido coletivamente de modo que todo o "período" mudou. Assim, ele deixa pouco espaço para a concepção de Runia, que concebe o "presente" - e portanto os "períodos" - como análogos a uma cidade, cheios de descontinuidades e manifestações de temporalidades múltiplas. Esta analogia com a cidade aparece nos dois principais teóricos com os quais Ankersmit dialoga para 
formular a noção de experiência histórica sublime neste capítulo 8: Hegel e Freud. Segundo Rebecca Comay:

\begin{abstract}
A paisagem da Fenomenologia está repleta de cadáveres que, como Polinices, não vai embora - um monte de estruturas defuntas persistindo muito depois que sua autoridade, legitimidade, utilidade, fator de prazer, e mesmo sua pitorescidade antiquária desapareceram. Há uma desordem quase barroca na encenação de Hegel (estou pensando na descrição de Benjamin dos cenários desolados do Trauerspiel alemão). Mesmo enquanto a cena continua mudando, o palco nunca é totalmente liberado, os antigos adereços e fantasias se acumulando muito além de sua data de expiração, atitudes abandonadas constantemente retornando, argumentos refutados continuamente se reavivando, desejos abandonados ressurgindo, tudo amontoado em algum tipo de simultaneidade impossível. A coisa toda tem elementos de um capriccio do século XVIII (Hegel deve tê-los visto $)^{273}$ — uma daquelas fantasias arquitetônicas, às vezes vendidas como souvenirs, nas quais todos os marcos estão amontoados sem levar em conta a geografia, a cronologia ou a lógica, as ruínas do Coliseu bem ao lado do Panteão, a Villa Borghese no mesmo quarteirão da Domus Aurea. (Isto é, é claro, precisamente como Freud descreverá a "cidade eterna" do inconsciente em O Mal-Estar na Civilização: uma confusão de relíquias dispostas juntas numa fantasmagoria impossível de espaço e tempo.)

Ainda mais notável do que a profusão do material é a prodigiosa ineficiência da narrativa: as estagnações e retrocessos incessantes, a sinuosidade e a repetição, o esquecimento teimoso, a autocensura e os constantes apagões. A consciência revela-se um virtuoso em esquecer o que ela aprende...
\end{abstract}

Esta citação indica que, ao mesmo tempo em que a melancolia eterna não é necessária, a consciência efetivamente estabelece múltiplas formas "relações com o passado", incluindo todos os quatro tipos de esquecimento (ou a contrapartida de lembrança que cada um carrega consigo), e portanto também a variação teorizada por Ankersmit. E indica, ao mesmo tempo, que não é em uma concepção monolítica do que seria a sociedade presente em sua relação com o passado, mas no reconhecimento da plenitude de "mutações" passíveis de serem ativadas e difundidas, na coexistência entre passados e presentes, entre o velho e o novo, que a noção de experiência histórica sublime melhor encontra seu lugar. Assim, em comparação com sua discussão sobre conservadores e reacionários do pós-Revolução, os seus exemplos de Sócrates, Maquiavel e Guicciardini ilustram melhor que, as mudanças de consciência, especialmente quando envolvem reflexão, adetram a sociedade como que em "mutações" de alguns de seus membros antes de se difundir, de maneiras desiguais, às vezes por períodos muito prolongados, e não necessariamente chegando a se difundir

\footnotetext{
${ }^{273}$ E Ankersmit certamente os viu!
} 
por completo. Em alguns momentos históricos, as novas significações e/ou as mutações se espalham mais rapidamente que outras. Mas elas nunca são instantâneas ou homogêneas: dependem das condições técnicas e de todos os elementos infraestruturais e superestruturais. ${ }^{274}$ Além disso, sempre haverá disputas entre diferentes grupos sociais, especialmente quando se tratar de histórias (que não são verdadeiras ou falsas), mas também quando da descoberta de como a realidade surge inseparavelmente da consciência (uma verdade), pois ela demanda uma não-reatividade que nem todos têm condições de aceitar ou compreender. As metáforas da cidade e do monstrengo são mais adequadas que o "período" e a "identidade" supostamente homogêneos para dar conta das possibilidades complexas das "relações com o passado" que a "filosofia existencialista da história" busca dar conta.

E se ainda não estava claro o suficiente por meio das alusões implícitas ao figuralismo de White e da tópica de Vico mobilizada por Runia (como vimos no capítulo 2 e como veremos no próximo), podemos ler, nas palavras de Kellner, como a potência da concepção de mutação se harmoniza particularmente bem com o figuralismo whiteano (DORAN, 2013: 162):

O que eu estou sugerindo aqui é que a noção de figuralismo que é a base da compreensão narrativa e do pensamento histórico [historical reasoning], como White a descreve, tem uma antecipação messiânica em seu coração. Como o desejo judaico na Páscoa — "Ao que vem em Jerusalém" - há uma esperança, um ato de fala que busca um cumprimento que pode ou não vir. Este é um "monstro esperançoso" [hopeful monster], uma figura não-preenchida. (Eu pego a frase "monstros esperançosos" emprestada da genética, onde ela já descreveu um mutante que sobrevive e pode levar a uma nova espécie..)

E assim também em Ankersmit, por exemplo ao tratar da "consciência histórica": ela "foi uma mudança em como o homem Ocidental decidiu olhar para a realidade histórica; é uma mudança de perspectiva, enquanto tudo sobre o que ele olha continuou da maneira como sempre foi. Ainda assim, estas mudanças pequenas e imateriais podem se tornar irreversíveis e determinar o destino futuro da humanidade. Elas são como mutações..." E isto porque o modo de olhar - exatamente como Ankersmit caracteriza as representações - é parte da realidade histórica, tanto na história-processo quanto na história-escrita. A história é feita do material e do imaterial.

\footnotetext{
${ }^{274}$ Pensemos em como algumas narrativas atingem um número alto de pessoas instantaneamente com o advento da internet, em contraposição ao isolamento geográfico comparativamente muito maior dos povos da Antiguidade.
} 
Se levarmos a recusa do transcendentalismo a sério, no que diz respeito às questões humanas, faz sentido que aquilo que é olhado também se modifique devido à maneira pela qual é olhado, e modifique aquele que olha: assim o é quando figuras do passado são retroativamente ativadas no presente.

\section{4. É difícil, mas não impossível, ver nossas representações}

A a-historicidade da abordagem de Sublime que eu critico neste capítulo equivale a descartar, em termos tropológicos, a possibilidade de ganho de liberdade em relação às próprias representações do mundo que se manifestam no tropo da ironia. De fato, o conceito proposto por Ankersmit envolve pressupostos incompatíveis: por um lado, a cada experiência sublime, ganha-se reflexividade e a imediaticidade se perde para outro; por outro, o conceito concebe que uma nova imediaticidade se perde, e isto significa que ou a reflexividade se perdeu, ou que ela se resume a registrar perdas, mas sem ganhar autonomia diante do processo por meio da compreensão de como ele ocorre. (A imediaticidade perdida nos casos como a da França pré-revolucionária, dos gregos, de Maquiavel e Guicciardini envolviam ignorância "fillosófica" sobre a própria condição no mundo.)

Ankersmit expressa essa visão determinista com apoio na filosofia da representação de Danto. Ele explica que o tipo de transição examinado no capítulo "nos apresenta com a a situação desconcertante em que é como se alguém repentinamente se tornasse uma outra pessoa - o que requeriria que ele veja seu antigo self como o self de uma outra pessoa." (344-5) Para explicar o que ocorre nestas transições, ele recorre a um argumento de Arthur Danto sobre representações, segundo o qual "representamos o mundo, não as nossas representações do mundo" (345). Assim, nossa maneira de ver o mundo apareceria como simplesmente o próprio mundo, enquanto as representações dos outros aparecem como representações.

Mas isto será inevitável? Nas últimas páginas de A Transfiguração do LugarComum, lemos Danto afirmar que não: "É preciso um esforço especial," diz ele, "para que eu alcance uma espécie de consciência de minhas representações, e isso exige um ato de identificação complexo para que eu aceite essas representações como minhas. Suponho que é a complexidade dessa identificação que torna a psicanálise tão complexa do ponto de vista filosófico.” A filosofia da história não teria uma tarefa comparável à da psicanálise, por exemplo no sentido de contribuir para o tratamento de uma relação melancólica (individual ou coletiva) com o passado, de modo que ela poderia receber 
precisamente a tarefa de não reproduzir a atitude usual de ingenuidade representativa aqui descrita por Danto? Nossa resposta é afirmativa.

Além de uma dimensão filosófica, a historiografia envolve também a dimensão artística, enfatizada por alguém como White. E como a arte entra neste raciocínio de Danto? "O que é interessante e essencial na arte", afirma ele, "é a capacidade espontânea do artista de nos fazer ver seu modo de ver o mundo.” Em última instância, Danto afirma que a consciência efetivamente pode ser flagrada por meio de uma exteriorização artística. É o que a caixa de Brillo, ao ser transfigurada em uma obra de arte, fez com consciência das estruturas da arte de seu tempo (DANTO, 2011: 297). A produção de distanciamento, seja o artístico, o científico ou o histórico-filosófico (como reconheceram, respectivamente, Danto, Elias e Collingwood, dentre os autores citados neste trabalho), é efetivamente resultado de um grande esforço. Mas não haveria sentido em, uma vez ele tendo sido realizado ou demonstrado ser possível, fazermos análises de filosofia da história que descartam sua existência ou viabilidade, e meramente se contentam em reafirmar a atitude natural da maioria dos grupos humanos como - e um tanto a-historicamente - a maneira pela qual as coisas são. Da mesma forma, adicionando o ponto moral relevante para o argumento deste trabalho, também o etnocentrismo é incrivelmente predominante e só pode ser superado a grandes esforços. No entanto, não presumiríamos que estamos condenados a ele: o trabalho da filosofia é, dentre outras coisas - e certamente o trabalho de uma filosofia da história whiteana - a dificílima, porém demonstradamente possível, ampliação da margem de liberdade disponível a seres humanos, não condenados a representar ingenuamente o mundo, a não reconhecer a historicidade de sua existência, a serem etnocêntricos.

Se fosse naturalmente impossível experienciar o mundo conscientes de que nossas representações são representações e não o mundo em si, estaríamos condenados a jamais experienciar o insight historicista (ou do "historicismo modernista", para White) que Ankersmit tão enfaticamente, e com razão, demanda que seja levado à sério pelos filósofos: aquele segundo o qual também o ponto de vista presente é histórico, e não transcendental. E isto condenaria o exercício filosófico à inutilidade. Felizmente, porém, seres humanos têm o potencial de aprender, ainda que a duras penas, que a partir de outros conjuntos de referenciais, um mesmo evento externo se manifesta de maneira diferente na experiência. A possibilidade de entender os referenciais de outros agentes, no presente e no passado, só se justifica diante da possibilidade de mobilizá-los para a vida, e na vida - não apenas no isolamento das bibliotecas. Havendo a margem para 
escolher entre mais de um conjunto de referenciais (como White afirmou haver, repetidas vezes), automaticamente isto significa que há alguma liberdade diante das próprias representações do mundo. A margem estética não existe apenas ao representarmos experiências do passado: assim como elas sempre podem ser apresentadas de outro jeito, o próprio mundo já sempre pode ser experienciado de múltiplas maneiras. Afinal, assim como não há nem "descrição padrão" nem "representação padrão", não há também uma maneira padrão, objetiva, de experienciar o mundo.

\title{
4.5. Mito como groundless ground, não como fundamento natural
}

Ankersmit afirma que tanto no caso do "sublime histórico de Hegel" quanto no de um evento como a Revolução Francesa:

\begin{abstract}
Em ambos os casos, estes eventos geraram uma tempestade de historicização que atingiu tudo que poderia possivelmente ser historicizado - e no vazio ou vácuo histórico assim criado, um passado idílico, pré-histórico, quase-eterno e quase-natural veio à existência. Hence, um passado veio à existência que era perfeito para idealização, um passado pelo qual gostamos de anseiar nostalgicamente e sonhar sobre para momentaneamente esquecer o mundo histórico feio e não natural da modernidade. É um passado ahistórico, que está além do tempo ou o precede, como nós vimos, e a este respeito é o tipo de passado do qual, de acordo com Freud, o melancólico nunca sucede em se livrar e que é, deste maneira, não mais parte da sua história mas em vez disso parte da sua natureza. Desta maneira, a história pode criar a natureza (e o mito). (366)
\end{abstract}

Mas há uma diferença que não considero negligenciável. Na passagem da "mente objetiva" para a "mente subjetiva", produzida pelo assassinato de Sócrates segundo a descrição de Hegel, temos efetivamente a saída de um estado da natureza para a história. É evidente que o "estado natural" pode ser fantasiado, mas ele de fato possui a imediaticidade que lhe é atribuída. Os passados criados pelas rupturas dos processos históricos são diferentes: o quão capaz de (a) reter a memória dos processos anteriores e de (b) operar mais reflexivamente sobre esta memória do que apenas reativamente em relação aos acontecimentos imediatos, sem jamais vê-los em perspectiva, é inteiramente contingente.

Ainda assim, a descrição das rupturas históricas não deve ignorar que, ao menos a princípio, uma vez que o princípio da subjetividade ou a consciência histórica tenham se manifestado, elas não são estão condenadas a repetir os processos anteriores, em ciclos de esquecimento produtores de "má-infinitude". A descrição fornecida por 
Ankersmit pressupõe este ciclo de esquecimentos: "o mito e o sublime histórico nos acompanham como uma sombra sempre-presente no nosso caminho rumo à modernidade. A cada vez que a humanidade ou uma civilização entram em uma fase verdadeiramente nova em sua história, um novo sublime mítico surge como o coração frio e fossilizado desta civilização que será para sempre passado adiante àqueles que viverão em todas as suas fases posteriores.” (366)

Seria uma condição muito próximo da "prisão do ironista": após a ascensão da consciência histórica, poderíamos finalmente teorizar sobre como uma ruptura significou como um passado mítico o que outrora era um processo histórico vivo, mas jamais poderíamos fazer outra coisa que não reagir melancolicamente a cada nova ruptura e presumir como natural um ponto de referência que foi meramente construído.

Isto significa que a filosofia da história deva prescrever o abandono do mito? Não, mas significa que os novos começos podem se beneficiar da memória histórica dos começos anteriores, e reconhecer nos mitos as contingências que eles têm. Tomar como natureza o que é cultura. Não é possível adotar práticas senão com a adoção de algum chão provisório sob os pés. Saber disso não nos torna capazes de voar, mas nos permite reconhecer que o que parece o fundamento último é na verdade um groundless ground. Reconhecer sua contingência - pensemos na distinção aparentemente natural entre os gêneros, descrita por Butler como uma fonte de sofrimento para aqueles cujas formas de desejar não são reconhecidas como válidas no interior de muitas sociedades - é também reconhecer sua maleabilidade. O resultado pragmático é termos condições de evitar sofrimentos desnecessários, se assim o desejarmos. Não é possível naturalizar o que não é natural sem violentar tudo aquilo que não se conforma aos enredamentos, esquemas conceituais e representacionais dominantes.

"Mitos," diz Ankersmit, "são aquelas partes do nosso passado coletivo que nós nos recusamos a historicizar: um passado mítico é retirado do curso da história e tornado imune à (re)interpretação histórica.” (368) A teorização sobre como isto se dá, seja no momento da ruptura (Ankersmit), seja no momento da produção de sentido (Mink, White, Ankersmit), está a serviço dos seres quando leva a sério sua conclusão de que, ao contrário do que se pensou anteriormente à reflexão teórica, nada precisa estar efetivamente "imune à (re)interpretação histórica" - especialmente aquilo cujas consequências pragmáticas são o silenciamento daqueles que sofrem e o exercício de uma autoridade infundada sobre eles. O que pode ser ganho de maestria sobre o processo histórico é a ampliação máximo de possibilidades de estabelecimento de 
relações com o passado, o que torna preferencial o reconhecimento - que é também adequado teoricamente - de que as identidades presentes e seus passados correspondentes são contingentes, e que portanto podem ser modificadas performativamente. Se a conclusão de Sublime Historical Experience afirma que a identidade perdida assume a condição mítica de "o coração gelado da civilização" (367), este ganho de maestria envolve a capacidade "xamânica" - atingível por meios estéticos mais que meramente cognitivos ou filosóficos - de aquecer novamente os corações, e isto pode ser feito precisamente porque, parafraseando o jovem White, estamos falando de corações históricos e não meramente naturais (e vimos, claro, que "histórico" inclui também os corpos dos seres) - mas mesmo isto só pode ser feito por meio de artefatos culturais (incluindo textos historiográficos) capazes de aquecer corações de corpos reais em relação. A margem de liberdade que permite fazer isto só pode ser ampliada a duras penas e pode facilmente ser perdida - mas nossa leitura de tradição narrativista considera encontrar nela a afirmação bem fundamentada de que ela existe.

Concluamos a seção com duas reflexões adicionais sobre a reflexividade - que tanto pode produzir quanto pode resultar da experiência de perda discutida em Sublime.

Primeiro: ao trazer ativamente à consciência o que era uma "pressuposição absoluta" de seu período (eg., Sócrates), ou ao fazer este movimento reflexivo como resposta à experiência de perda (eg., reacionários e conservadores da França pósRevolução), Ankersmit considera o(s) sujeito(s) entram em um novo período histórico, e o antigo se perdeu para sempre. Isto significa que naquela época era impossível ver certas coisas, e que agora é possível? Não, significa que chamamos de época passada $X$ o momento em que tal pressuposto não era visto, e que, como o reconhecimento do pressuposto agora foi realizado (o que indica que ela poderia sê-lo), uma mudança drástica aconteceu e portanto chamamos o novo período de Y.

Assim sendo, a experiência histórica sublime envolve tanto o momento de perda (não qual não há linguagem ou reflexão envolvida) quanto a reflexão sobre a perda. Adicionalmente, a noção envolve uma reação mais melancólica do que de luto ao acontecimento, e naturaliza uma das reações possíveis como a única possível nestes casos. Novamente temos uma questão de nomeação: nenhuma sociedade está condenada a, nem proibida de, "ser o que não é mais". O que ocorre é que Ankersmit dá o nome "experiência histórica sublime" aos momentos em que as sociedades (ou grupos 
particulares dentro delas), ainda que a princípio possam se construir de outras formas, se constróem como sendo o que não são mais.

Por que a especificação "a princípio"? Porque o não-reconhecimento de outras possibilidades e a fixação em uma certa identidade - ainda que filosoficamente Ankersmit, e todos os demais narrativistas, reconheçam a inexistência objetiva de tais "pontos fixos" (ver 2.1), ainda mais quando estamos tratando de significados impedem a efetivação de fato desta possibilidade. Assim sendo, a própria reflexão teórica sobre o que é uma experiência histórica sublime modifica o fenômeno: ao saber que os grupos do passado poderiam ter construído a si mesmos por meio de outras relações com os eventos passados se tivessem consciência disto, os novos grupos passam a estar conscientes disto, e portanto ampliam seu leque de opções.

Uma interpretação possível dos vários exemplos de experiências históricas sublimes oriundos da história, psicanálise, filosofia e literatura mobilizados por Ankersmit é a seguinte: o que há de comum em todos os eventos é a introdução da reflexão e a perda da imediaticidade. Esta leitura se harmoniza particularmente bem com as preocupações intelectuais e existenciais que Ankersmit manifestou desde sempre, que envolvem uma fascinação pelo fato de que - como as crianças com as quais ele não podia brincar - a impressão de imediaticidade e naturalidade está fadada a se perder. Em segundo lugar, então, notemos que o elemento reflexivo surge em sua filosofia como essencialmente negativo, alienante. Mas confesso achar necessário não nos perdermos exageradamente em abstrações filosóficas e perguntar, de maneira talvez um pouco esdrúxula: a entrada na sociedade civil (se vamos falar nestes termos) é tão ruim assim? A situação dos bebês antes da saída do útero e dos animais é tão invejável assim? Creio que Ankersmit não tenha qualquer intenção de fantasiar sobre tais coisas, mas que o jogo de linguagem filosófico possa se auto-perpetuar sem referentes claros em casos assim. Ora, a linguagem nos separa, mas a capacidade de planejamento, de ação moral, de manifestação de amor em formas mais profundas que não as meramente imediatas, tudo isto depende da reflexão para ocorrer (ver 2.6). E se até que saibamos que o mito é a criação de uma natureza, e não uma natureza de fato, possamos desejar (reflexiva ou restauradoramente) este suposto passado, a partir do mito em que entendemos que o mito, como o gênero e as identidades culturais, nada têm de natural ou fundacional, então novas possibilidades se abrem: por exemplo, a possibilidade de visões utópicas de sociedade em que não uma pequena parcela de formas de desejar é reconhecida como legítima, e em que na qual aqueles que não se adequam a sistemas de 
representação supostamente "naturais" têm de lidar com as consequências da violência discursiva que sofrem.

Como ensinou Butler, as representações e narrativas nos separam, mas a negatividade básica é comum a todos. Mesmo quando produzimos sentido e construimos identidade, podemos reconhecer que os sujeitos não se esgotam nas propriedades de suas narrativas, e nos reconhecer não com referência aos conteúdos narrativos, mas a esta base mais comum. Isto significa que podemos, sim, adentrar a sociedade civil sem perder de vista uma forma de "unidade antes da queda" (i.e., da "queda" na linguagem). A união a ser valorizada não é necessariamente a do sujeito consigo mesmo, em um estado natural no qual a linguagem não traz à tona tal impossibilidade. Feito o reconhecimento do não-esgotamento do sujeito na linguagem, a união a ser valorizada é a da interconexão entre tudo que é vivo. Desta alienação é possível escapar, pois ela repousa no engano de conceber indivíduos como átomos isolados e autossuficientes: como identidades plenas.

\subsection{Sem linguagem e historicidade, há apenas um estado em branco?}

Afirmar a anterioridade da consciência ou atenção à constituição do sujeito histórico e do mundo histórico, como fizemos no início da discussão sobre experiência histórica em Ankersmit, equivale a recusar o pressuposto de que conceber a possibilidade de que o sujeito se veja incapacitado de significar a si mesmo e ao mundo demandaria o pressuposto de que, nestes casos, surge algo como um "estado em branco" ["blank state"]. Icke presume isto:

\footnotetext{
Neste entendimento, ao pôr de lado o contexto/identidade literalmente o esvaziamento do sujeito experienciador - reduz esse assunto a um "estado em branco" ou a um ser pré-natal, não-formado, sem a auto-identidade necessariamente requerida para registrar o sublime histórico ou se lembrar de uma identidade prévia, ou, por falar nisso, qualquer coisa. ” (ICKE, 2012: 137)
}

$\mathrm{Na}$ leitura que estou propondo aqui, o que se rompe é a "substância narrativa" por meio de qual o sujeito se compreende. Deixando de ser capaz de organizar as “energias” em ação (emoções, desejos, estímulos do ambiente, incluindo aqueles que remetem metonimicamente ao passado, etc.), ele precisa encontrar e negociar com os pares novas maneiras de fazê-lo. A ruptura pode partir, como Runia explicou corretamente, tanto do lado da história-processo quanto da história-escrita - ou, um pouco mais amplamente, de qualquer produção de sentido feita retroativamente para a 
história-processo, o que é sempre feito por alguém formado também na e pela históriaprocesso; e, em cada um dos dois casos, pode ser regressiva ou revolucionária. Assim sendo, não é que o sujeito "perde" suas memórias, mas que perde seu princípio organizador, que é histórico, abrindo espaço para outras memórias, incompatíveis com a substância narrativa anteriormente em voga, virem à tona.

Uma afirmação com esta, acerca do blank state, a mim parece nada mais que um dogma. Ela tem o mérito: o de reconhecer que o mundo contingente que se forma cria também seus próprios limites, e dificulta que se pense a partir de outros referenciais. Porém, como paradigmas e epistemes se rompem - e "experiências históricas sublimes" surgem precisamente nestes momentos -, e (ao menos se pode argumentar) a atividade "normal" e os esforços hermenêuticos para ampliar os limites do compreensível estimulam tais rupturas, não é um dado auto-evidente que o auto-enclausuramento destes sistemas (desprovidos de um "fora") seja total. Como afirma Evan Thompson, para dar um exemplo dentre tantos possíveis, outras tradições afirmam precisamente o oposto do que o dogma de que, fora da linguagem - que iria all the way down - só pode haver a noção absurda de um blank state: "De acordo com a filosofia indiana e do budismo tibetano, a definição de consciência é aquilo que é luminoso e cognoscente. Luminosidade significa a habilidade da consciência de revelar ou desvelar [reveal or disclose]." (2015: xxi) ${ }^{275}$ Esta hipótese se articula muito melhor com as filosofias da experiência e da representação de Ankersmit, que atribuem à consciência esta capacidade de disclosure. O caso de uma experiência histórica sublime é apenas a ausência de uma maneira de organizar as próprias experiências na articulação com uma história coletiva reconhecida como válida, mas não a ausência de consciência.

É a ausência de uma noção como consciência que mantém Rorty preso a um transcendentalismo linguístico do qual Ankersmit quer escapar, e adicionalmente

\footnotetext{
${ }^{275}$ Notemos que Jonardon Ganeri, citado em nota no início do capítulo, também argumenta sobre a prioridade da atenção sobre o self amplamente com base na filosofia budista, sobretudo na obra de Buddhaghosa, que viveu no Sri Lanka por volta do século V - ao mesmo tempo em que estabelece diálogo com a ciência cognitiva contemporânea. Da minha parte, considero questionável que o método filosófico, que opera unicamente no nível linguístico mas não produz nenhuma observação empírica em primeira pessoa da mente, possa dar conta das questões que ocupam autores como Rorty ou o Ankersmit de Sublime. Também por isso, a acusação de que Ankersmit recai em "misticismo" é parcialmente acertada, mas usualmente feita em tom pejorativo, o que a torna um tanto injusta. Todo o debate efetivamente vai "all the way down", e (como bem sabem os filósofos) não é uma tarefa fácil falar ou teorizar as atividades da consciência na dimensão pré-linguística da experiência humana. Mas isto significa que devamos examinar apenas o "dentro" da linguagem? Excluir objetos difíceis, ainda que eles sejam efetivamente parte da existência humana, seria se condenar a uma compreensão limitada do que é (para citar o caso da filosofia ankersmitiana) existir historicamente. Não consigo pensar em nenhuma defesa pragmática convincente para a falta de ousadia intelectual - por isso, como já disse, acho ótimo que Ankersmit não tenha se intimidado em explorar novos terrenos.
} 
também a um behaviorismo no qual o pressuposto da possibilidade de escolher entre diferentes vocabulários já parece equivaler à equivocada presunção de estar em um meta-vocabulário fora da história. Esta consciência que vive mesmo quando os vocabulários históricos se rompem não possui um meta vocabulário transcendental, mas pode escolher dentre os vocabulários que conhece e modificá-los performativamente. ${ }^{276}$

Os pós-modernistas em geral, e Icke em particular, manifestam respeito pelas reflexões de White sobre como a linguagem produz significado para um mundo nãoinerentemente significativo. Efetivamente, isto significa que a linguagem produz o mundo, que mundo e sujeito surgem inseparavelmente na experiência de consciências incorporadas. Rejeitar as brechas - e a possibilidade de se experienciar, desorientadamente, as brechas - é contraditório, pois trata o "mundo" como uma realidade dada, independente da mente. Se a consciência produz produz o mundo com apoio da linguagem, e se ela sobrevive às brechas entre um outro sistema conteitual ou significativo, então por isso mesmo há experiência do que não é linguístico. Icke busca argumentar, contra Ankersmit, que vivemos em um mundo retórico. Mas isto é inteiramente compatível com reconhecer que a confusão se instaura entre a troca "revolucionária" de um para outro paradigma retórico.

Uma afirmação que Icke formula em seguida, portanto, não pode ser senão um non sequitur: "Qualquer coisa que resida for a da nossa capacidade para sua descrição linguística não poderia ser relacionado linguisticamente com outras coisas e portanto não poderíamos (como nós vimos Richard Rorty argumentar) falar ou pensar sobre ela. Pois dar um passo for a da linguagem da descrição é dar um passo rumo ao vazio inefável.” (2012: 139) Nada do raciocínio anterior autoriza a última conclusão, que

\footnotetext{
${ }^{276}$ Gorman comenta como Metahistory destoava das publicações de filosofia analítica da história na época da sua publicação, em 1973: "Na época, muitos filósofos analíticos eschewed as palavras 'consciência', 'pensamento' e seus cognatos, considerando todas elas como partes do lado 'fantasma' no 'fantasma na máquina' de Gilbert Ryle (1949). Portanto apenas alguns poucos filósofos analíticos desejavam, na época, reconhecer que, ao fazer filosofia da linguagem, eles também estavam fazendo filosofia da mente." Hoje, complementa ele, o cenário não é mais o mesmo, e tal reconhecimento já existe. (GORMAN, 2013: 17) Caberia enfatizar nosso ponto adicional de que, ainda que na "realidade humana" a consciência opere quase inteiramente aderida a vocabulários, concordamos com Ankersmit que experiência não precisa ser identificada com eles em todos os momentos: como vocabulários são construídos, há brechas entre eles. Uma experiência histórica sublime é um caso raro diante da presença constante de simbolizações em nossas experiências mais cotidianas, mas (cf. COLLINGWOOD, 1958: 185) é certamente o caso que exceções às regras são instrutivas sobre o mundo, inclusive sobre as próprias regras, e devem ser levadas à sério. Por fim, notemos ainda que a ênfase neste elemento da consciência e de sua potencialidade de escolher vocabulários é mais presente em White do que em Ankersmit e em Rorty, e parte do que propomos neste capítulo é enriquecer o conceito de "experiência histórica sublime" com elementos da filosofia de White, e vice-versa.
} 
parte de uma descrição de como a linguagem opera para uma conclusão não apenas sobre como a mente operaria nos momentos em que a linguagem não está presente.

Também as teses pós-modernistas precisam seguir a prescrição de Mink de levar a temporalidade a sério. Como Runia mostra, há ao menos alguns casos em que primeiros os seres humanos agem, e depois produzem significado para a ação. É evidente que a significação é sempre retroativa, mas Runia enfatiza os casos em que o objetivo primordial da ação não era produir um significado, mas romper um sistema significativo, e que o objetivo da significação que sucede é, acima de tudo, a redução de dissonâncias. O significado sucede ao evento. (Mas temos argumentado que, da perspectiva da ironia, é possível que, ainda que a retroatividade da significação seja inevitável, é possível evitar a busca por redução de dissonâncias. Tal coisa pode ser buscada, por exemplo, por meio do recurso linguístico do paradoxo, tão valorizado por Ankersmit.) Então, que o evento seja inefável, não segue que posteriormente não se poderá buscar significá-lo. Por outro lado, mas não em contradição com esta afirmação, a significação jamais esgotará o evento. Por que não há contradição? Porque isto significa que, mesmo quando um certo vocabulário está estabelecido, a linguagem não dá conta jamais de esgotar a riqueza da experiência.

Disto segue o próximo ponto. Os seres e sociedades têm diversos níveis, e a negociação entre um e outro nível é temporal, pois envolve um movimento constante entre um e outro: abaixo dos significados produidos pelos vocabulários, enredos etc., há vários componentes tanto de presença quanto de significado, que remetem a outros vocabulários e enredos ou a nada em particular. Muito do que se encontra marginalizado no "mundo" que surge no presente efetivamente não pode ser redescrito nos termos do vocabulário dominante, mas ainda assim - e por isso mesmo - atrai a atenção dos agentes, e estimula atividades de arte, pesquisa e reflexão teórica. Os vocabulários e aquilo que tentamos descrever com eles estão em constante mudança (horizontal e verticalmente: no primeiro caso, a linguagem muda, as ruínas envelhecem, aquilo que não foi arquivado perece; no segundo, os níveis de presença demandam manifestação linguística, a linguagem é reinventada para dar conta de novas demandas, etc.), e nunca se harmonizam plenamente. É dessa desarmonia que surge o novo.

$\mathrm{O}$ que nos conduz às reflexões de Eelco Runia a serem desenvolvidas no próximo capítulo. 


\section{Capítulo 5 - "Presença" em Eelco Runia}

Enquanto Ankersmit apresentou suas reflexões sobre experiência histórica como marcadamente distintas daquelas sobre representação, Eelco Runia formulou a noção de "presença" de maneira mais próxima de como pensamos, neste trabalho, todo o

conjunto de reflexões "experiencialistas": como complementares ao "representacionalismo whiteano" (RUNIA, 2014). (Ainda que, por necessidades retóricas, seu tom frequentemente assuma caráter oposicional em relação a este movimento.) Ankersmit, é claro, considera que precisamos dos dos tipos de filosofia da história - que, neste sentido, também se complementam. Mas a tese do presente trabalho é que os dois tipos só podem selecionar seus objetos como marcadamente distintos do outro - sem interpenetração processual - se os construírem como "objetos teóricos", desconectando-os do processo dialético no qual ocorrem e sem o qual não fazem sentido. Runia concebe a relação entre representação e presença de um modo que consideramos mais adequado: como vimos, como uma dialética de continuidade e descontinuidade, conotação e denotação.

Passo então a uma exposição crítica do conceito central de sua obra, o de "presença", que é mobilizado para responder sua pergunta mais recorrente, "como somos movidos pelo passado?", focando nos pontos em que suas preocupações interseccionam com a minha.

\subsection{Presença, em relação à representação}

Como vimos no capítulo 2, ao buscar oferecer um complemento ao "representacionalismo whiteano", Runia caracteriza a função desta corrente como “essencialmente negativa": White e pensadores afins, a seu ver, mostram que a narrativa produz continuidade sobre processos históricos descontínuos (WHITE, 1978), caóticos, “sublimes" (WHITE, 1987: 58-82). Por sua vez, Runia busca a parte "positiva" da empreitada, para a qual considera o representacionalismo inadequado. Pois, a seu ver, resta a questão de como a descontinuidade histórica vem à tona. O leitor deve lembrar nosso argumento no capítulo 2, segundo o qual o projeto de White não negava a descontinuidade, muito pelo contrário. Assim, delinear a maneira pela qual as representações produziam falsas continuidades era inseparável de propor maneiras pelas quais a descontinuidade poderia ser expressada linguisticamente, na mais otimista das hipóteses, ou ao menos no reconhecimento de que a produção de continuidades era 
artificial e portanto uma base questionável para argumentos de autoridade e exercício de poder, na mais pessimista. Este programa "positivo" sem dúvidas demandava complementos e ajustes, alguns dos quais vieram a ser o esclarecimento filosófico da relação entre a representação e o representado, levada a cabo por Ankersmit, e, agora, um exame de como a descontinuidade se produz, rompendo as continuidades construídas.

Em outro ponto, talvez o maior ponto cego da obra de White, Runia de fato fornece-nos mais uma correção do que um complemento: aquele indicado pelo título de seu livro, Moved by the Past. White - e, na sua esteira, os pós-modernistas -, antecedido por Mink e sucedido por Ankersmit, está certo em apontar que a construção de sentido é retroativa. O sentido não é produzido pelos mortos - que produziam sentido enquanto estavam vivos -, só se pode produzi-lo com uma consciência viva, partindo do presente rumo ao passado. Assim, ao afirmar que os eventos são constituídos por um ato poético no momento em que um historiador escreve os resultados de sua pesquisa, White de fato se permite ler como atribuindo ao historiador o poder de mover o passado, marginalizando (na melhor hipótese) ou subestimando (na pior) a força motora do próprio passado sobre uma consciência viva no presente. É portanto muito bem vinda a decisão de teóricos como Runia de pensar o caminho oposto, perguntando: Não haveria momentos em o mundo (ou o passado, ou o real) nos força a reescrever nossas estórias? Não haveria situações em que é o passado que move o presente? Ainda mais importante, não haveria momentos em que o passado pode ser concebido não como ausente e portanto passivo, mas como dotado de "presença", e, portanto, de resistência e mesmo de atividade? Não haveria denotação metonímica juntamente com a conotação metafórica?

A resposta de Runia a todas estas perguntas é afirmativa, devido ao fenônemo (ou ao conjunto de fenômenos) que ele chama de "presença". Vejamos como ele o definiu no ensaio "Presence", de 2006:

\footnotetext{
"Presença," na minha visão, é "estar em contato" ("being in touch") seja literal, seja figurativamente - com pessoas, coisas, eventos, e sentimentos que fizeram de você a pessoa que você é”. É respirar um suspiro de vida e realidade no que se tornou rotina e clichê - é realizar plenamente as coisas em vez de apenas tomá-las como já conhecidas [taking them for granted]. Por "presença" eu não me refiro à realização de um desejo de parar o tempo e preservar, respeitar e honrar o que você eventualmente possua. [...] Ela é um desejo de participar da realidade maravilhosa de coisas, pessoas, eventos e sensações, combinada com um impulso vertiginoso de saborear o fato de que pessoas, coisas, eventos e sensações maravilhosamente reais
} 
podem maravilhosa e repentinamente deixar de existir. [...] Presença - estar em contato com a realidade - é, eu acredito, tão básica quanto significado. Enquanto pode-se dizer que o significado é o lado conotativo da arte, da consciência, da vida, presença é o lado denotativo. (RUNIA, 2014: 53- 54)

Quatro anos depois, em "Inventing the New from the Old: From White's Tropics to Vico's Topics”, Runia forneceu outra definição:

Eu chamei esta persistência subconsciente de um passado nãoreconhecido de "presença" - e o defini como "a maneira não representada pela qual o passado está presente no aqui e agora." Presença é o que não está incluído na nossa estória sobre nós mesmos - e é o que nos leva a fazer coisas em desacordo com a nossa identidade, e, como tal, tem menos a ver com "figuração" que com prefiguração. Se "cultura" é - como eu penso que é - o conjunto de coisas sobre as quais não precisamos falar, isto é, o conjunto de coisas que não precisam e não podem ser representadas, então nossa cultura é feira de "presenças" - de conhecimento comum que é tão comum que nem é mais conhecimento, de coisas que são tão sutis que não podem ser forçadas pela garganta de imigrantes que querem uma autorização de residência, de, em suma, os mitos subrepitícios e onipresentes que nos distinguem dos bárbaros." (idem: 147; grifos no original)

Estas duas definições já fornecem uma grande quantidade de elementos a explorar. Primeiro, notemos que os trechos indicam a necessidade de não pensar dicotomicamente as noções de presença e ausência, presente e passado, experiência e representação. Pelas definições apresentadas nos dois trechos, bastante representativas do argumento de Runia tomado em conjunto, "presença” não é meramente a ausência de intermediários linguísticos, nem é algo como a numinosidade da história. Nos termos do presente trabalho, presença é a parte "não-representada" da cultura processualmente ligada com aquilo que é representado: o primeiro trecho cita a identidade; o segundo cita como "não representados" elementos que são mais precisamente prefiguradores de representações: a cultura, o conhecimento comum e os mitos, no segundo. Isto não equivale a dizer que a presença é determinada pela representação, pois, se a maneira pela qual me represento me torna suscetível a ser atraído - por desejo ou por temor por certos elementos do mundo, os desejos também estimulam certas formas de expressão narrativa, nem sempre conscientes, ${ }^{277}$ e também estimulam a atenção rumo a outros elementos de presença do mundo, sem mediação representacional. Quanto ao primeiro trecho, cabe observar que, assim como no Sublime Historical Experience de Ankersmit, em Moved by the Past a relação entre presença e identidade é especialmente

\footnotetext{
${ }^{277}$ Como White aponta nas perguntas que encerram, de modo aberto, "The Value of Narrativity in the Representation of Reality" (WHITE, 1987: 1-25).
} 
enfatizada. ${ }^{278}$ No mínimo, isto já indica que a melhor abordagem para o conceito de Runia só pode ser a relação entre presença e representação. Pois, como Ankersmit apontou em outro contexto (1983), "Eu” (e, por extensão, também “Nós”) é um tipo de "substância narrativa", portanto uma representação. Mas a recíproca deve ser verdadeira: da mesma forma que sou atraído pela presença (ou pelos elementos nãorepresentados) daquilo que rodeia e assombra o que represento como minha identidade, também a construção de identidades mantém implícita uma série de elementos nãorepresentados. Isto não inclui apenas o que reforça tais identidades, mas também todos os espectros que as ameaçam. Se a substância narrativa é leibnizianamente composta pelos seus predicados, cabe lembrar que a pessoa, a sociedade, o período histórico são sempre irredutíveis a eles.

Por isso, o que a presença não faz é "preservar, respeitar e honrar o que quer você eventualmente possua". Não à toa, em "Spots of Time", publicado meses depois de "Presence" na mesma History and Theory, Runia fala não mais na contestação presencial de "quem você é" (ou "quem você é"), mas sim em "quem eu penso que sou": "Flutuando pelo aqui e agora, esta presence do passado também me faz sentir coisas, pensar coisas, e fazer coisas que não são compatíveis com quem eu penso que eu sou - e portanto me força a reescrever minha estória sobre mim.” (RUNIA, 2014: 99) Assim, ao despossuir o sujeito de sua representação de si mesmo e do mundo, ela produz uma abertura que permite tanto o estabelecimento de relação, mas também o conhecimento de outros aspectos outroras invisíveis, e portanto de um campo de possibilidade de ações a princípio irralizáveis. Eu argumentaria que toda abertura a "tudo que está á" produz uma ampliação do conhecimento de si mesmo e das possibilidades da humanidade (ou da vida) como um todo: se o que eu considerava ser me impedia de ver algumas - a imensa maioria - das potencialidades, então o que precisamente significa dizer que eu "era" aquilo? Este "ser" se refere a uma dinâmica intersubjetiva de reconhecimento, a um jogo de "máscaras de significado" que, como toda significação, simultaneamente revelam e obscurecem. Desvelar a própria dinâmica de desvelamento, neste sentido, permite que se veja, ou ao menos que se queira ver, o que outrora estava obscurecido - e permite também que se veja a impossibilidade de ver

\footnotetext{
${ }^{278}$ Anton Froeyman percebe isto bem. Ele aponta que tanto Ankersmit quanto Runia tratam apenas de situações em que o passado presente ou a experiência histórica são ligados à identidade daquele que presencia ou experimenta, eliminando a alteridade de suas propostas. Grupos minoritários, por exemplo, não estariam aptos a "perder" uma identidade com a qual nunca se identificaram.
} 
"tudo" (ou apresentar uma síntese de tudo), como que fazendo com que a linguagem espelhe o mundo.

Sobre a noção de "ser", e retomando as discussões sobre identidade em Sublime, cabe também aqui a pergunta: $O$ que faz de mim o que sou, a presença ou a identidade? Um sujeito ligado a um mundo (apresentado à, e por, sua mente) tem urgências, emoções, desejos e todos os demais elementos envolvidos na prefiguração. $\mathrm{O}$ que o move mais, sua identidade construída com estórias ou aquilo incompatível com a identidade? Como nos casos anteriores, isto depende de sobre qual momento do processo estamos teorizando.

Uma identidade, e seu mundo correspondente, existem na dependência de desejos, de suportes materiais, de sistemas representativos que canalizam ou limitam a expressão de tais desejos, de intersubjetividade. Todos estes fatores mudam constantemente. Sua satisfação com a própria identidade também muda, pois a experiência do que é "próprio" ao sujeito pode ter alguma novidade inicialmente, mas em seguida não mais produz as mesmas sensações, e isto pode motivá-lo a se perguntar por outras fontes de satisfação.

Mesmo no caso de identidades que por um tempo parecem satisfatórias, a impermanência de seus suportes age, e tudo aquilo que lhe é excluído se faz ver. Então não é que necessariamente a presença é o que faz o sujeito aquilo que ele realmente é, pois o que ele "é" (tanto no sentido de uma identidade, quanto no sentido de presença, e ainda no sentido da combinação entre identidades e presenças) se modifica constantemente. Como o figuralismo nos ensina, o que é menos importante em um momento pode se tornar mais importante no outro, o que foi registrado implicitamente pela consciência pode ser explicitado em momentos posteriores, às vezes muito posteriores. Então tais elementos não fundamentam "quem eu realmente sou", pois a importância deles é contingente. Por motivos práticos, é possível incluir os significados e a presença como parte de tudo que compõe a pessoa em um dado momento - e, sobretudo, reconhecer que se trata de uma multiplicidade em constante movimento.

Esta conexão entre presença e representação, por um lado, e a irredutibilidade do que é representado às suas propriedades, por outro, aparece nitidamente no trecho intermediário da primeira citação: "é realizar plenamente as coisas em vez de apenas tomá-las como já conhecidas [taking them for granted]. Por "presença" eu não me refiro à realização de um desejo de parar o tempo e preservar, respeitar e honrar o que você eventualmente possua." Por isso, a leitura que propomos dos narrativistas conecta a 
capacidade das representações de desvelar aspectos do mundo com a necessidade de uma posição pluralista, que resista ao impulso de não mais realizar "experiências" e apenas "take for granted" um certo aspecto de uma pessoa ou evento como sendo capaz de esgotá-la. O oposto disso é o que propõe Runia: "realizar as coisas plenamente". 279 Como as coisas são infinitamente complexas - todos os eventos se interpenetram - o movimento não é nunca esgotável. Isto não significa que devamos andar na esteira de descobrir "tudo que está ali" como quem consome um saber sem fome, mas que devemos evitar a atitude de tomar "metáforas parciais" (cf. White) como a mimese perfeita dos eventos tal como eles aconteceram, ou, em outros termos, de tomar desvelamentos de aspectos (cf. Ankersmit) como desvelamento da realidade em sua plenitude. "Realizar as coisas plenamente", assim, é realizar a impossibilidade de domesticar as coisas plenamente por meio de gestos significativos. Como isto demanda o reconhecimento de que todo evento pode ser significado de múltiplas perspectivas, nossa leitura de Mink no capítulo 2 sobre a provisoriedade do "cancelamento do tempo" se articula com a proposta de Runia de que presença não é a realização do desejo de "parar o tempo". E isto se conecta com o reconhecimento da impermanência de todas as coisas, inclusive daquelas que nos compõem: "Ela é um desejo de participar da realidade maravilhosa de coisas, pessoas, eventos e sensações, combinada com um impulso vertiginoso de saborear o fato de que pessoas, coisas, eventos e sensações maravilhosamente reais podem maravilhosa e repentinamente deixar de existir." Mais ainda, como afirmamos existir inevitavelmente - e ser desejável praticar ativamente - a oscilação da atenção entre significação e presença, concordamos com Gumbrecht que também a presença produz revelação ou desvelamento do mundo, e que (como Runia também considera) tais modalidades são complementares.

Ao longo de todo o trabalho, enfatizamos o fato de que a realidade humana se compõe de níveis diferentes, e que a temporalidade opera na brecha estética entre a representação e aquilo que ela representa. A "compreensão" que reúne a estaticidade da linguagem e o movimento das coisas permite ver, por um contraste não muito diferente de como Ankersmit caracterizou a experiência nostálgica, a vulnerabilidade da condição humana. O contraste entre a concretude em movimento do mundo e a aparente permanência das abstrações também pode produzir tal efeito. A combinação entre estes dois fatores se mostra de maneira particularmente reveladora em um caso de "presença"

\footnotetext{
${ }^{279}$ Ver, respectivamente, o exemplo da conexão entre ódio e representações no capítulo 2, e a discussão sobre ver a complexidade das pessoas no capítulo 3 .
} 
citado por Adam Bencard (2014): a dos “ossos patológicos” que um museu, o Medical Museion, colecionava e exporia em breve. Vimos como Ankersmit enfatiza o fato de que vários dos elementos produtores de presença são "insignificantes". Ossos, e mais ainda ossos que indiciam patologias, não são "insignificantes" no sentido em que um objeto velho pode ser, mas elas têm algo em comum: a resistência às significações imediatas, isto é, sua não-representabilidade. Assim, eles nos ajudam a esclarecer o que está em jogo na relação entre objetos "insignificantes" e representações "significantes": no caso deles, a ausência de atribuição de significados não se deve ao fato de eles exercerem pouca tração sobre o interesse dos seres vivos quando de sua produção original, mas de produzirem temor, incômodo e/ou estranhamento em seres com um certo conjunto de pressupostos e expectativas que envolvam o temor da morte ou a incapacidade de lidar com ela. (Todo foco em representações que não é redirecionado depois a dimensões mais concretas produzirá isto, já que a linguagem é estática, enquanto aquilo sobre o qual ela fala está em constante movimento.) Assim, eles escapam à significação porque, ao serem mantidos em mente, eles desestabilizam qualquer expectativa de significação que dependa de esquecer as condições básicas de toda vida humana - e o argumento deste trabalho envolve, ao menos implicitamente, a afirmação de que é necessário lembrá-las para fazer boa filosofia da história e para fazer uma historiografia eticamente responsável. Os ossos são parte da infra-estrutura necessária para que seres humanos produzam sentidos, e apontam ainda para aspectos que podem passar desapercebidos por um foco abstrato e temporal na significação, como a fragilidade da vida, a arbitrariedade das noções de normalidade e, e última instância, a inevitabilidade da mudança e da morte. É por isso que eles têm "presença". ${ }^{280}$ Esta resistência à significação, como temos visto, é central para a noção de "sublime" - e temos argumentado também que tudo resiste à significação se for examinado o suficiente, sem que isto impeça seres humanos de usarem significações para iluminar aspectos particulares de eventos, pessoas e objetos, e de as usarem melhor quando o fazem autoconscientemente.

\subsection{Metonímia}

\footnotetext{
${ }^{280}$ Basta lembrarmos que os fenômenos de presença se manifestam muito frequentemente no caso de experiências dolorosas. As várias experiências subjetivas e sublimes discutidas por Ankersmit são manifestações de alguma forma de lidar com experiências de perda. Outro exemplo é a experiência de Barthes com o punctum de uma fotografia de sua mãe recém-falecida, que estimula as reflexões de $A$ Câmara Clara.
} 
A primeira das definiç̧ões de "presença" que destacamos fala em sua capacidade de produzir "contato" com o passado. Seria então o caso de perguntarmos: em que sentido ele é "literal", e em que sentido é "figurativo"? Quais são os exemplos de cada caso? Seria necessário especificar o tipo de "contato" possível em cada caso, mas, como Ankersmit, Runia é vago em seu uso do termo. É notável que muitos dos exemplos envolvem diretamente contato sensorial com objetos do passado, e portanto enfatizam a dimensão material que compõe um dos aspectos em relação aos quais a "realidade humana" se forma holisticamente. Nisso, os objetos produtores do efeito de presença tem algo em comum com a sensação histórica de Huizinga, à qual ele também alude em alguns momentos de Moved by the Past. Mas um caminho whiteano também proveitoso (inclusive para usar contra o próprio White, em outros momentos) passa por perguntar: em que sentido o conceito e seus exemplos desnaturalizam a própria distinção entre literalismo e figuralidade, ainda que sem necessariamente impossibilitar o uso convencional da distinção?

Comecemos observando que, para Runia, a metonímia é o instrumento preferencial tanto para explicar o fenômeno de presença quanto para produzi-lo. Mesmo o contato que poderíamos chamar de literal - digamos, com um objeto - produz a experiência de presença do passado por apontar metonimicamente, por meio do que está presente, para algo que está ausente. Porém, isto não nos leva diretamente à conclusão de que são as figuras de linguagem que produzem tais efeitos. Afinal, como Ankersmit com suas representações metafóricas, Runia considera que nem toda metonímia é linguística. A tropologia de White, se por um lado pode ser lida como um transcendentalismo linguístico, por outro também pode ser lida nestes moldes, na medida em que ela produz a transição do inconsciente para a consciência, e, portanto, produz metáforas e metonímias linguísticas por meio de atos mentais pré-linguísticos justamente caracterizáveis como metafóricos, metonímicos - e sinedóquicos, e irônicos.

Para Runia, "metonímia é uma metáfora para a simultaneidade de continuidade e descontinuidade". Fundamental para este conceito é o contexto: "A metonímia pode ser descrita como a transposição propositalmente inapropriada de uma palavra que pertence ao contexto 1 (por exemplo, o domínio de nomes próprios: DeLillo) para o contexto 2 (o domínio dos livros), onde ela subsequentemente se destaca como levemente 'deslocada' [out of place]'. Feito isto, acrescenta ele, uma metonímia pode ter duas carreiras: quase sempre ela é gradualmente absorvida pela contexto em que está colocada; porém, "às vezes alguma é tão forte que ela infecta o contexto em que está 
colocado e transforma o seu cenário “em sua própria imagem”” (RUNIA, 2014: 66-70). Os eventos em que seres humanos produzem descontinuidade histórica ao serem "movidos pelo passado" estão neste segundo caso.

Além disto, Runia considera que "metonímia não é um fenômeno exclusivamente linguístico": coisas também podem ser removidas para outro contexto. Eis um de seus exemplos: “As ilustrações de Sebald são uma espécie de 'vazamento' no tempo por meio do qual a 'presença' emerge do passado para o presente.” (67) Ele então especifica que, sendo obcecado com "presença”, Sebald é especialmente cuidadoso em maximizar a condição deslocada das ilustrações de seus textos. Estas ilustrações, acrescenta ele, além de não serem necessariamente linguísticas, também "não possuem significado".

É evidente que nada possui significado por si. O fenômeno descrito por Runia evidencia casos em que, pela habilidade artística de um Sebald ou pelas circunstâncias históricas de um pós-Revolução Francesa, seres humanos não conseguem significar ou contextualizar - coisas e eventos. Também no caso de Sebald, o que ocorre é que o efeito de presença surge em contraste com o significado. Daí que um imagem produza efeito de presença quando inserida no texto, ou que um monumento faça o mesmo situado em uma praça ou museu. Uma imagem ou um objeto parecem fora de lugar quando possuímos expectativas acerca da "adequação" de um lugar, e isto nos traz de volta ao campo da representação - embora não necessariamente ao da linguagem, mas ao das representações não-linguísticas, das apresentações mais básicas do mundo à mente.

O efeito de presença, proponho então, é também o efeito de disrupção de significados - efeito este que, em outros termos, as obras de White e de Runia se apressam em celebrar. Se White subestimou a forma pela qual o mundo (especialmente o mundo narrativamente estruturado da "realidade humana" de Carr) oferece resistência à produção de significados, Runia ocasionalmente subestima a relação entre presença e representação. Minha insistência na existência de tal relação me parece mais compatível com a afirmação do próprio Runia de que toda obra de arte combina denotação metonímica e conotação metafórica (2014: 68) - e, mais ainda, com sua asserção de que “enquanto a metáfora 'dá' significado, metonímia insinua que há uma necessidade urgente por significado." (idem: 71) Não é diferente da conexão feita por White entre atividades volitivas e sua manifestação simbólica, tanto em condições despertas quanto em sonhos. 
Quando um evento não pode ser significado, não se está descrevendo apenas uma característica do evento, da dimensão objetiva do mundo. A significação é atribuída por sujeitos, e, portanto, a impossibilidade de significar um certo conjunto de eventos envolve sempre a relação que tais sujeitos estabelecem com o objeto ou evento. Portanto, a impossibilidade de significar um evento diz respeito também, em primeiro lugar, aos recursos intersubjetivos de produção de sentido, que podem ser limitados internamente (pelas limitações da tradição ou da criatividade dos sujeitos) ou por coibições externas (institucionais, econômicas, ausência de liberdade de expressão, etc.). Em segundo lugar, ela diz respeito à identidade do sujeito, tópico que Runia corretamente enfatiza. Isto envolve suas memórias e conexões pessoais com o evento, inclusive quando ele não envolveu diretamente o sujeito, incluindo aí os casos de eventos traumáticos. E em terceiro lugar, a impossibilidade envolve também também os vários desejos e aspirações práticas que excedem tais identidades: isto é, outros "passageiros clandestinos", que disputam a atenção do sujeito em direções nem sempre coerentes.

Uma observação adicional. Ao discutir Sublime, afirmei - inspirado pela recorrência do tema da "unidade anterior à queda" em Ankersmit - que há um tipo de "unidade" - melhor descita como "comunidade" - entre os seres viventes, que antecede nossa separação em identidades produzidas pela representação e pela linguagem. Aqui, ela pode ser articulada com uma discussão feita por Runia sobre como os nomes "perfuram" as bolhas de seus períodos históricos. Em "Spots of Time", ele fala da estratégia de alguns museus de produzirem o efeito de "presença" por meio da citação dos nomes daqueles que estavam ausentes. A meu ver, a capacidade dos nomes é a de apontar para o fato de que os seres nomeados eram pessoas reais: seres que experienciavam o mundo em primeira pessoa, em um mundo que lhes parecia real e instável, mas que se desfez. Sinto este efeito quando visito cemitérios: ao ver os nomes e datas, é a consciência de minha própria condição transitória também se acentua, e portanto também a consciência desta dimensão comum entre eles e eu: antes de sermos "brasileiros" ou "canadenses", somos pessoas mortais que não desejam sofrer, que viveram ou vivem em "mundos" que se desfarão. ${ }^{281}$ Creio que algo da sensação de "separação" em relação ao mundo real - um verdadeiro contato com a realidade - se

\footnotetext{
${ }^{281}$ Sobre a transitoriedade de tudo que apoia os significados, incluindo os corpos, ver 1.6.
} 
manifesta aqui: não é um contato com qualquer realidade, mas o reconhecimento da própria senciência dos demais seres, tão reais quanto eu.

\subsection{Agência produtora de descontinuidades, agência inventora de continuidades}

Se uma vez mais retomarmos o exame das definições de presença fornecidas no início do capítulo, podemos perceber também que, neles, a agência é atribuída às coisas: elas "fizeram de você a pessoa que você é". Não se escolhe o que se é no tipo de situação examinada por Runia; mesmo quando agimos para construir uma identidade, não temos controle sobre os resultados do processo; há necessariamente um elemento de passividade (que também pode ser o que chamei de "abertura ativa") nas mudanças históricas. Ligado a isto, o segundo trecho - não mais falando do que se é, mas do que está presente sem que saibamos - destaca o caráter subconsciente da presença.

Runia aborda duas modalidades por meio das quais o passado pode nos mover no presente: a primeira, "regressiva", a segunda, "revolucionária". Um exemplo do primeiro caso é o fenômeno de paralell processing, ilustrado pelo caso do Srebrenica Report: um estudo feito por um órgão do governo holandês (NIOD, Netherlands Institute for War Documentation) com o intuito de investigar a possível responsabilidade de "políticos, militares, funcionários públicos e da força de paz holandeses" no Massacre de Srebrenica, ocorrido em 1995. Segundo a análise de Runia, os autores do relatório "replicaram vários dos aspectos importantes dos eventos que estudaram" (2014: 19). Sem que tivessem consciência, o passado se fez presente e "determinou" a pesquisa, em direção contrária ao tipo de interação "kantiana" que normalmente se supõe ocorrer na historiografia (idem: 48). Para Runia, o paralell processing pode ser descrito como uma variação do re-enactment collingwoodiano, com duas diferenças: primeiro, trata-se de uma forma especificamente subconsciente do processo, e, segundo, as interações entre os agentes não são "representações in vitro, mas a interações reais - in vivo".

Outro exemplo de modo "regressivo" em que somos "movidos pelo passado" é a série de torturas praticadas por militares estadunidenses em Abu Ghraib, no Iraque: "Nas celas e corredores de Abu Ghraib, as práticas passadas de tortura de Saddam Hussein estavam presentes da mesma maneira que uma palavra permeia a consciência por uma proibição de se pensar nela." E adiante: "O caso de Abu Ghraib sugere que o passado opera como um tipo de locus genii - que ele pode ter um poder tão irresistível que ele é capaz de se expressar no que de fato acontece no mundo real. Ele abre uma 
perspectiva que é quase perturbadora demais para aceitar: de que o passado pode ter uma presença que é tão poderosa que pode usar a nós, humanos, como seu material." De passagem, noto que este emprego do termo "presença" não se articula tão bem com aquele fornecido no ensaio "Presence", embora tenha sido redigido no mesmo ano (ver "Spots of Time": RUNIA, 2014: 88). Que conexão haveria entre esta repetição e a identidade dos soldados norte-americanos? Não parece ser o caso de entrar em contato com algo que os fez, pois se a Guerra do Iraque hoje já é parte da identidade coletiva estadunidense, as torturas de seus primeiros anos foram motivadas por espaços que ainda não eram parte dela. Também não parece ser o caso de uma ação na modalidade "revolucionária" de destruição de identidades, pois é provável que os militares invasores desejassem manter o contraste entre os norte-americanos salvadores e os "terroristas" do "Eixo do Mal”. A conexão entre a própria identidade e a ação parece existir, mas por outro motivo: por ela legitimar a crueldade em relação ao Outro. Mas o raciocínio de Runia é inadequado neste caso, pois ainda atribui a agência ao Outro, de modo que naturaliza a própria distinção que, se minha hipótese está correta, estimulou (em algum grau difícil de estabelecer aprioristicamente) o impulso de repetição em primeiro lugar.

Discutindo o problema da agência na teoria da Runia, Kleinberg afirma que a discussão dele "sobre as maneiras pelas quais o passado de Abu Ghraib condicionou as ações dos indivíduos no presente absolve estes atores de agência e, de fato, cede agência e responsabilidade para um passado que estamos condenados a repetir." (KLEINBERG \& GHOSH, 2013: 24) Parece-me possível levar todas as posições em conta na análise de casos particulares, de modo que não esqueçamos nem da força da "presença" (dos locais, do passado, etc.) nem da responsabilidade ética dos agentes. A chave está no fato de que a capacidade de exercer responsabilidade ética não é um atributo fixo, mas algo que surge no processo histórico e pode ser ampliada ou reduzida, dependendo do quanto a cultura que forma os sujeitos - que re-formarão a cultura - os capacita a capacidade de refletir sobre os elementos de presença em vez de meramente responder a eles, a atenção ao sofrimento dos outros, a capacidade de reconstruir os próprios instrumentos de produção de significado quando eles se mostram incapazes de agir de maneira que leva em conta tal sofrimento, etc. Esta ampliação da capacidade de agência eticamente responsável, que primeiro mencionamos no caso da historiografia com apoio em Vico, Collingwood, Butler e White, também se aplicam à agência na história-processo. Assim, a descrição dos fenômenos de presença pode não permitir, mas precisamente evitar o esvaziamento ético temido por Kleinberg, se o tomarmos como uma forma de, ao 
explicitar as várias forças atuantes no processo histórico, produzir ampliação da autonomia relativa que se tem diante delas.

Nosso argumento é de que o problema ético não surge da abordagem presencialista, mas da perda de vista da relação entre presença e representação. De fato, é vantajoso levar em conta que as decisões éticas se dão em situações nas quais forças alheias à identidade dos sujeitos também condicionam seu movimento. Tendo em conta a dinâmica, é certament útil (não contrapor, mas) justapor a visão de Runia à de Butler, para quem: "A tortura não foi meramente um esforço de envergonhar os prisioneiros de Abu Ghraib e Guantánamo com base em sua formação cultural presumptive. A tortura foi também uma maneira de coercivamente produzir o sujeito árabe e a mente árabe." (BUTLER, 2009a: 126).

Além deste modo "regressivo", vimos que, para Runia, a metonímia pode servir a uma função "revolucionária" quando, ao ser posta "fora de lugar", em vez de ser modificada pelo contexto, o modifica. Isto também vale para ações humanas. Desta forma, agentes históricos forçam a mudança de si mesmos e de suas sociedades por meio de ações "deslocadas", incompatíveis com suas identidades prévias, e apenas retroativamente eles próprios e os historiadores justificam suas ações, produzindo uma "redução de dissonância". Aqui, o caráter da agência se torna mais ambíguo: por um lado, são indivíduos que as realizam; por outro, há pouco ou nenhum espaço para escolhas conscientes (ainda que oscilantes ou passíveis de modificações posteriores) no que diz respeito às direções de suas ações. Neste ponto, Runia formula um equivalente positivo do que Ankersmit, seguindo Danto, chama de "tragédia da existência humana"; eles enfatizam a impossibilidade do agente histórico conhecer as consequências futuras de suas ações. Há algum grau em que este argumento pode ser equilibrado com a perspectiva oferecida por Carr contra o mesmo "representacionalismo" que Runia busca criticar: como as ações são estruturadas narrativamente, elas não apenas recorrem a um passado, mas também projetam um futuro. Isto envolve vários momentos em que a direção da ação é re-calculada ou inteiramente recriada, para internalizar as novidades imprevistas antes de seguir externalizando o projeto.

Porém, o modo "progressivo" de Runia dá espaço a um fator importante a todo pensador interessado nas consequências do historicismo. Enquanto Carr atribui uma certa constância ao sujeito individual e coletivo de suas teses, em Runia há a possibilidade de o sujeito passar pelo que a filósofa L.A. Paul chama de "experiência transformadora". Estas experiências são aquelas em que a escolha de modificar a si 
mesmo é feita em circunstâncias nas quais não se sabe como serão os critérios e a experiência de mundo do ser que surgirá como resultado da experiência. Assim, a decisão é de se transformar, mas não se sabe previamente - por não haver "regras de tradução" (Ankersmit) ou transcendência à "situação" (White) - como será a perspectiva futura. $^{282}$

A formulação de Paul permite-nos ver que também Runia, como Ankersmit e White, se ocupa da perspectiva da autenticidade. Isto se mostra pela inseparabilidade, que temos trazido repetidamente à tona, entre sujeito e mundo. Ao ser uma mesma pessoa, só se pode desvelar ou revelar o mundo de perspectivas específicas. Assim, a produção de disrupção na própria identidade é também a adoção de uma postura de abertura, de modo que se pode conhecer o mundo de formas até então inauditas. A autenticidade da experiência não deve ser entendida, portanto, como a busca da realização das "próprias" preferências, mas da recusa à alienação do mundo produzida pelo fechamento no modo de representação que produz este "próprio". Neste processo, o que aparecia como próprio revela-se altamente contingente: experiências transformadoras modificam de maneiras imprevisíveis aqueles que passam por elas. E elas os abrem para um tipo de "contato" valorizado por Runia: aquele de encontrar "tudo que está aí" no mundo. Então, além de dizer que a presença permite encontrar tudo que fez de mim quem sou, a modalidade revolucionária é permitir-se ser feito por outras coisas. A disrupção dos mecanismos linguísticos que empregamos como se fossem transcendentais não ocorre no contato com um quadro ou um artefato (Ankersmit): pode também ser produzida por ações (Runia).

Deste modo, por mais que as narrativas atuem como redutoras retroativas de dissonância por meio das quais identidades são construídas, como apontam tanto White quanto Runia, elas não são apenas isto. As narrativas das identidades coletivas e da historiografia precisam ressignificar ações que, por seu caráter intencional, visavam futuros específicos, com variados graus de especificidade - e também variados graus de sucesso. Não negaríamos a existência do salto no abismo, mas apontaríamos a possibilidade de algo como um abraço no abismo: a manutenção de uma abertura constante àquilo que despossui o sujeito de si mesmo, incluindo a imprevisibilidade das

\footnotetext{
${ }^{282}$ A dialética collingwoodiana concebe a possibilidade de que o sujeito do futuro poderá conhecer o do passado de uma maneira pela qual o sujeito do passado não poderia conhecer o do futuro, já que o do futuro transcendeu dialeticamente o do passado, de modo que ele é efetivamente feito de passado (mais reflexão, ação, etc.). Mas a perspectiva de Runia é radicalmente histórica neste ponto, e, com ele, podemos conceber que não se possa a princípio prever se o resultado da mudança revolucionária fará de mim alguém capaz ou incapaz de estabelecer esta relação dialética com o passado.
} 
consequências das próprias ações. Ela não significa, afinal de contas, que um tipo de "prudência" é impossível, e que existir historicamente incapacite inteiramente os sujeitos de avaliarem os melhores rumos para suas ações.

Este ponto não é irrelevante. Ao longo do capítulo 2, argumentamos haver uma conexão entre as condições de prefiguração e o resultado de tais condições, e também que os vocabulários efetivamente adotados as retroalimentam. ${ }^{283}$ Isto vale também para as consequências das ações dos agentes históricos para além de seus ambientes imediatos, e para além do contexto em que eles própriam podem "cometer história". Não é possível prever as consequências futuras dos próprios atos, mas os novos "ambientes" em que os seres humanos viverão não surgem de maneira inteiramente aleatória. Eles surgem (e simultaneamente são criados) por meio da energia dos processos passados (sem dúvidas alheias ao controle de um único indivíduo, grupo ou mesmo geração), tanto em sua força enquanto dotados de "presença" quanto pela retroatividade dos agentes em busca por modelos de como viver. São os fatores de prefiguração efetivamente disponíveis no acervo da humanidade que gerarão o novo mundo: maneiras de desejar, de afefar, de se emocionar, de narrar, de refletir, etc. É precisamente porque não há controle sobre como serão os mundos futuros, que a responsabilidade ética dos agentes históricos passa também pelo tipo de figura que eles legam às gerações futuras - cuja forma de cumprimento os escapa. Pois, novamente: o preenchimento não é determinado pela figura, mas depende das figuras efetivamente disponíveis.

Lembremos que, em Rorty, as configurações dos novos vocabulários também não são influenciadas pela escolha ética dos agentes. Como em Runia, portanto, caímos no problema ético de que o ambiente evolucionário (Runia) ou o vocabulário (Rorty) que irá nos determinar não pode ser ativamente criado em seu conteúdo: tudo que nos restaria de potencialidade, especialmente no caso de Runia, seria a disrupção dos vocabulários antigos. E mesmo a motivação para fazê-lo, no relato de Runia, envolve mais o tédio com as representações conscientes e o impulso de responder às forças do inconsciente do que qualquer interesse pelo bem estar dos demais seres, qualquer perspectiva coletiva. Não há qualquer problema no interesse de Runia em teorizar sobre estes pontos, que efetivamente compõem parte da existência humana, mas insisto que ele não esgota as nossas possibilidades e que portanto é importante articulá-los com a

\footnotetext{
${ }^{283}$ De maneira parecida com o que Roth afirma ter sido adotada por Foucault na sua transição de interesses "do discurso para o estilo" (ROTH, 1995: 85).
} 
possibilidade da ação ética, solidária, compassiva. Mais ainda: não só com a possibilidade de tais ações "normais", no interior de um vocabulário contingente, mas também no processo "revolucionário" de disrupção e criação de novos vocabulários e ambientes. Jean Bethke Elshtain comenta muito acertadamente o problema desta abordagem no caso de Rorty, e proponho que o mesmo vale como complemento para as reflexões de Runia:

O desenvolvimento do indivíduo, é claro, é contingente em muitas maneiras: ninguém seleciona seus pais, local ou cultura de nascimento, etc., mas ele não é arbitrário. O desenvolvimento tem um thrust teleológico; ele carrega dentro dele as sementes de possibilidade. Tal possibilidade é mais bem compreendida como uma tentativa de work out o que significa ser livre e ser responsável à luz de predeterminações de um tipo encorporado e determinações de um tipo cultural. (GUIGNON \& HILEY, 2003: 150)

... Com a razão não-seja-cruel em mente, ele [Rorty] coloca alternativas que, eu temo, nos toma como mais tolos do que nós temos qualquer direito de ser neste estágio tardio. "Apenas aconteceu" que sociedades liberais condenaram a tortura porque os liberais querem ser razoáveis, e eles querem isto porque as contingências calharam desta maneira. Mas não é que simplesmente aconteceu. A sociedade liberal e a possibilidade democrática são herdeiros de um relato muito forte uma estória cristã-hebraica - a de por que a crueldade é pecaminosa e deve ser parada, começando com os jogos romanos e a exposição de crianças. Estas foram as primeiras crueldades que o cristianismo proibiu. Você não tortura as pessoas porque é uma violação, e é uma violação porque nós somos todos filhos de Deus. (idem: 151-2)

[Isto porque, como Elshtain dissera um pouco antes:] Para não sermos cruéis nós devemos aprender que a crueldade machuca e fere, e nós aprendemos isto porque a ético-política do aprendizado moral eroticizado foram trabalhadas: nós podemos nos identificar com o outro. (idem: 151)

E a possibilidade do exercício de agência na produção dos novos vocabulários e não meramente na destruição dos antigos - tem uma urgência especial no atual contexto de catástrofe climática do planeta. Como Joanna Macy e Molly Young Brown (2014: 51) afirmam:

Enquanto a revolução agrícola levou séculos e a revolução industrial levou gerações, esta revolução ecológica tem que acontecer em uma questão de anos. Ela também tem que ser consciente - envolvendo não apenas a economia política, mas os hábitos, valores e entendimentos que a promovem.

Elas prosseguem o raciocínio apontando a importância de escolhermos "nossa estória", pelo que elas entendem "a lente pela qual nós vemos e compreendemos o que está acontecendo agora no nosso mundo". Enquanto as estórias usuais na mídia têm 
como enredo central a perspectiva do crescimento econômico, e as estórias dos que percebem o impacto destas no mundo envolvem um "relato embasado em evidências" sobre sua insustentabilidade, elas apontam a necessidade da promoção de uma estória cujo "enredo central é sobre reunir as forças em prol da vida conjunta na Terra" (idem: 52). Como Ankersmit - que exemplifica sua proposta sobre como avaliar representações precisamente com as implicações ecológicas de diferentes metáforas acerca do que é a Terra - elas reconhecem que diferentes narrativas desvelam diferentes aspectos do mundo; como White, elas sabem que elencar evidências não basta para produzir uma narrativa eficaz, capaz de produzir engajamento coletivo em uma açãoorientada para o futuro. $^{284}$ Isto não demanda que abandonemos o ponto de Danto, Ankersmit e Runia sobre a imprevisibilidade do futuro, mas que não percamos de vista a possibilidade humana de influenciá-lo.

\subsection{Cultura como locus da presença}

O que o raciocínio acima delineado indica é que, a curto prazo, o agente pode modificar sua relação com a cultura, de modo a afetar os resultados do seu "salto no abismo"; e que, portanto, não apenas ele recorre ao conjunto de exemplos e potencialidades disponíveis, mas também afeta este estoque. Mesmo quando não tem escolha sobre o que as gerações futuras farão, isto não elimina a utilidade do conceito de escolha, pois as pessoas do futuro exercerão também escolhas (situadas). E isto significa que o que surgirá como presença do passado no futuro é parcialmente resultado de ações feitas no presente, que é o passado do futuro.

Mas cabe examinar um pouco melhor a relação entre presença e cultura. Se retornarmos à segunda definição de presença do início do capítulo, a de 2010, podemos notar que ela enfatiza esta conexão. Runia assimila presença e cultura por meio da afirmação de que a presença se manifesta na forma de "segredos públicos", e manifestei meu acordo parcial ao dizer que, de fato, a presença é parte da cultura. Mas confesso sentir um estranhamento com a formulação de Runia: minha hipótese a de que a cultura é a combinação do conjunto de possibilidades de conotação e de denotação, em vez do que Runia afirma ocorrer, na qual ela envolve apenas um dos polos. Como ele afirmou, presença...

\footnotetext{
${ }^{284}$ Este último argumento também é apoiado pela ênfase de Carr na função prática das narrativas, especialmente tal como ele avança em sua contribuição ao livro Re-Figuring Hayden White (ANKERSMIT, DOMANSKA \& KELLNER, 2009: 15-33).
} 
tem menos a ver com 'figuração' que com prefiguração. Se ‘cultura' é - como eu penso que é - o conjunto de coisas sobre as quais não precisamos falar, isto é, o conjunto de coisas que não precisam e não podem ser representadas, então nossa cultura é feira de 'presenças'...

Mas, como vimos por meio da noção da escala de formas e por meio da concepção whiteana segundo a qual a tropologia media entre o inconsciente e o consciente, entre desejos e racionalidade, etc., então não seria justificável eliminar as representações do campo cultural. A ideia de que há coisas "sobre as quais não precisamos falar" não significa que elas não sejam faladas, mas sim que são naturalizadas; por exemplo, as categorias de gênero por meio das quais o desejo sexual é constrangido rumo a manifestações específicas.

Nosso trabalho tem enfatizado o caráter processual da relação entre representação e aquilo que a excede, baseado no reconhecimento da impermanência das condições que produzem um conjunto de representações: seus suportes, incluindo a materialidade do mundo e as circunstâncias estruturais, conjunturais e imediatas da sociedade; e também os fatores envolvidos na prefiguração, incluindo desejos, emoções, pressupostos filosóficos e temporalidade. Levando a processualidade da relação em conta, podemos dizer que em alguns momentos a representação produzida poderá parecer satisfatória, mas como ela existe para mediar a relação com um mundo que está em constante mudança, em algum momento a insatisfatoriedade se instalará. E nesses momentos, o que antes surgia como-que-naturalmente na forma de "quem eu sou", na forma de uma identidade estável, será posto em questão por parte do que excede o sistema representativo, que demanda atenção, reconhecimento e expressão. Minha visão é que Runia está examinando este momento da relação entre representação e "presença". Neste momento ocorre o que ele descreve nestes termos: "Flutuando pelo aqui e agora, esta presença do passado também faz com que eu sinta coisas, pense coisas, e faça coisas que estão em desacordo com quem eu penso que sou - e portanto me força a reescrever minha estória sobre mim mesmo.” (2014: 99)

Se tomarmos o fato básico de que seres humanos sofrem (simbólica e fisicamente) e não desejam sofrer, isto explica o poder que os fenômenos de presença têm sobre eles: quando os sistemas de representações não desvelam aspectos (cf. Ankersmit) do mundo de maneira adequada (i.e., dentro do que o sujeito sente como adequado, simbólica e fisicamente), eles se tornam ineficazes (cf. White) para sua ação em relação aos mundos social e natural, e motivados por isto os seres humanos 
modificam um dos polos envolvidos na relação entre (a) seu corpo, seus desejos e tudo mais que está presente mas não "representado", (b) sua identidade representada, (c) o mundo social. Então uma das possibilidades quando surge este sofrimento, ou a promessa de um cenário mais satisfatório no futuro, é a reescrita das estórias sobre quem somos.

E isto também significa que há agência, mas é a agência de um sujeito situado, incorporado (cf. Dewey, Collingwood), passível de sofrimentos diversos, e cujo grau de autonomia em relação ao mundo é contingente (cf. White, Collingwood). Por exemplo, mesmo em relação à prisão de Abu Ghraib, Runia deveria reconhecer a possibilidade de não se ceder às forças do ambiente e das próprias circunstâncias psicológicas - ou de ambos em relação. Ele faz isto insatisfatoriamente, já que só reconhece tal possibilidade por meio de uma coerção externa:

... nas celas e corredores de Abu Ghraib, as práticas de tortura passadas de o passado Saddam Hussein estavam presentes da mesma maneira que uma palavra permeia a consciência quando se proíbe de pensar nela. Os guardas americanos em Abu Ghraib teriam que ser mantidos sob viligância/controle [in check] muito cuidadosamente para prevenir que eles cedessem ao que pairava tão amplamente [to what loomed so large] - e, como nós sabemos agora, eles não foram.. (88)

Quem teria vigilado os vigilantes? Quem manteria os vigilantes dos vigilantes sob controle? Os próprios guardas poderiam desejar ser mantidos sob controle? Não há formas de auto-regulação ou de "cuidado de si" capazes de contribuir para que a própria pessoa exiba ou cultive algum grau de agência em casos assim? ${ }^{285}$ Nossa visão é que, sendo uma potencializadora da ação moral consciente (não por não possuir opacidades para si mesma, mas por assumir a responsabilidade pelo exercício do juízo situado, condicionado, historicamente limitado), a ação da consciência típica da ironia equivale precisamente à capacidade de manter a si mesmo "in check", não por controlar todos os

\footnotetext{
${ }^{285}$ Ver, sobre esta possibilidade: HADOT, 1995, GANERI, 2013, DORAN, 2017: passim; ROTH, 1995: 71-95. Runia concebe esta possibilidade de auto-regulação de maneira particularmente explícita no último capítulo de Moved by the Past, "Our Own Best Enemy: how humans energize their evolution". Mas, na dinâmica entre internalização e externalização, o movimento enfatizado por ele é aquele pelo qual seres humanos modificam o ambiente, para então terem que se adaptar a ele. A agência em Runia envolve mais o movimento de adaptação ao ambiente, que, como no exemplo de Abu Ghraib, segue sendo visto preferencialmente como o agente. Mas, claro, uma visão panorâmica do processo invariavelmente mostrará que poder escolher o ambiente é também uma forma de agência. Mas segue sendo verdade que há algo como um poder de decisão mesmo que a situação não mude: a decisão de torturar não veio apenas da presença do passado iraquiano, mas da presença do passado norte-americano nos corpos, linguagem, narrativas e memórias que eles levaram para lá. E mesmo diante desta, como a cultura não é unitária, há agência possível: há outras figuras a serem ativadas.
} 
impulsos que surgem, mas por poder responder em vez de reagir. ${ }^{286}$ Ele está afirmando que no caso de Abu Ghraib a força da presença era maior do que a possibilidade de escolha ética (algo concebível, embora talvez não neste exemplo)? Ou está decidindo chamar de fenômenos de presença apenas aqueles que são inteiramente irresistíveis? Se sim, há um espectro de possibilidades, de modo que poderíamos conceber fenômenos parcialmente resistíveis? Não vejo como não responder afirmativamente a esta última pergunta, já que não faria sentido dividirmos o mundo entre fenômenos sobre o qual o sujeito tem total controle e aqueles em que o mundo tem total controle sobre ele: entre os casos extremos, o que há é uma vasta gama de desequilíbrios relativos, ora com maior atividade e ora com maior passividade do sujeito em relação ao ambiente (cf. Dewey). E mesmo em casos extremos, há algum tipo de agência: alguém viciado que pede ajuda aos demais, por exemplo, ainda está exercendo-a, ao reconhecer seus limites em uma dada circunstância. E certamente algo assim seria possível em Abu Ghraib, embora isto direcione nossa atenção à estrutura militar mais ampla do exército norteamericano e as conexões deste com a política, a cultura e a economia do país de modo mais amplo, e devamos dizer então que uma ação não brota de um indivíduo tomado isoladamente, mas (como dissemos no capítulo 1) do indivíduo enquanto particularização do encontro de estruturas e processos muito diversos e não-inteiramente conhecidos por ele próprio.

Ainda assim, certamente não foram todos os militares que agiram de maneira igual em Abu Ghraib: como o exemplo do nazismo nos mostra bem, ninguém é obrigado a ser sádico, então em algum nível há escolha. Assim, há a princípio mais liberdade do que Runia reconhece. Compartilhando da preocupação de Kleinberg, eu argumentaria que a condição de ironia ou autoconsciência, de resposta mais do que reação, é o que possibilita o exercício desta liberdade. ${ }^{287}$ Nos termos da escala de formas, o impulso à repetição teria sido mais facilmente resistido (e não descartemos a possibilidade de sequer ter surgido) por meio de uma atividade de segundo nível de consciência em que a objetificação do outro não fosse tão comum, e de reflexões morais do quarto nível de consciência que modificassem o campo de ações possíveis.

\footnotetext{
${ }^{286} \mathrm{O}$ simples fato que inúmeras configurações sociais humanas responderam (ou reagiram) às suas circunstâncias de maneiras variadas mostra que não há a menor sustentação para uma visão dos seres humanos na qual tal capacidade de resposta - ou no mínimo a capacidade de desenvolver tal capacidade inexista. Não se trata de negar a compulsão à repetição, mas de lembrar que toda repetição é ou pode ser também uma repetição com diferença.

${ }^{287}$ Para a leitura de Kleinberg sobre a obra de White na qual a perspectiva irônica e a importância da autoconsciência são enfatizados, ver sua homenagem póstuma em KLEINBERG, 2018.
} 
Lembremos, especialmente, que as atividades de nível superior reincidem sobre as demais, incluindo as verdades que se diz sobre o mundo, a maneira pela qual ele é imaginado e o tipo de desejo que se tem em relação a ele. Assim, com sua repetição ao longo do tempo, os resultados da reflexão passam a compor o que Runia está chamando de "cultura". Da mesma forma que "o passado das práticas de tortura de Saddam Hussein" estava presente em Abu Ghraib, o resultado de pensamentos e ações passadas de militares criados na cultura norte-americana estava presente em seus corpos e mentes. A presença do passado, então, se encontra nos lados da moeda, o do sujeito e o do ambiente em que ele se encontra - e a consciência media entre eles, com maior ou menor grau de eficiência.

Outra questão que surge com a aproximação dos conceitos de presença e cultura é o da relação entre consciência e inconsciência. Vimos que Runia também aproxima presença de prefiguração, e isto certamente se harmoniza com nossa afirmação do capítulo 2 sobre os vários elementos de prefiguração, e, adicionalmente, com a tese de que a prefiguração efetua a transição entre os elementos inconscientes e aqueles conscientes. Para esclarecer como isto se ocorre de maneira compatível com o conceito de presença, creio que a filosofia de Collingwood fornece a perspectiva mais adequada. Vejamos.

Runia usualmente conecta as noções de representação e consciência, por um lado, e de presença e inconsciência, por outro. Cultura, mitos e conhecimento comum não são necessariamente sinônimos de "inconsciente" em nenhum sentido psicanalítico óbvio - embora se relacionem com ele -, mas sem dúvidas indicam a dimensão tácita que fica nas franjas daquilo que é apresentado à consciência em representações linguísticas ou não-linguísticas. Como ele fala em prefiguração, outra forma de dizê-lo é que, como a faculdade da imaginação do segundo nível de consciência, estes elementos são os recursos coletivos de produção de sentido, que selecionam o (pouco) que será apresentado à consciência do (muito) que não será. White, como vimos, é mesmo explícito em considerar que a tropologia explica a transição do inconsciente para o consciente.

Este não-dito, para Collingwood, não é algo que está ausente da consciência, mas sim que não foi explicitado por ela a partir da atividade reflexiva. Como em Runia, portanto, tal dimensão é não-ausente, e neste sentido "presente”, mas implícita. Ela é parcialmente consciente, pois adentra a experiência, mas não de maneira "clarificada". Esta condição implícita dos fenômenos de presença mostra que, em outra terminologia, 
seria adequado caracterizá-los para além da dicotomia entre presença e ausência, e é esta leitura que propomos neste trabalho. Ela é corroborada, como veremos, pela conexão feita por Runia entre presença e metonímia. Ao mesmo tempo, cabe reconhecer que o termo "presença" tem uma força retórica considerável em um contexto intelectual em que os não-representados, dehors texte, tendem a ser tratados como simplesmente ausentes - um equívoco que, por também pressupor ou presença ou ausência, não dá conta da interpenetração espacial e temporal de todos os eventos do processo histórico.

\subsection{Presença e figuralismo}

No capítulo 2, ao propor uma leitura antifundacionalista do narrativismo - que destaca a ausência de "pontos fixos" na relação entre dois eventos afastados temporalmente - o presente trabalho afirmou que também tipos de eventos ligados ao paradigma da presença, especialmente eventos traumáticos, assumem forma figural. Cabe agora detalhar como tal relação ocorre nas formulações específicas que assumem na obra de Runia. Não deve ter escapado ao leitor que as reflexões sobre a possibilidade de agência ética mesmo no caso de "experiências transformadoras" ou "saltos no abismo" também assumiram moldes da relação não fundamentada nem fundamentável entre eventos afastados temporalmente.

O figuralismo tradicionalmente teorizado por White segue na direção oposta do paralell processing: nele, um evento tardio projeta sentido sobre o anterior, em vez de reproduzi-lo em sua mente. Já nestes, o evento antecedente é que exerce poder de tração sobre o ser vivo no presente, nesse caso à revelia ao menos parcial de sua consciência.

Aqui, Runia e White se complementam aqui de maneiras interessantes. Percebamos, acima de tudo, como os autores falam de diferentes momentos de um processo que, para ser adequadamente compreendido, precisa ser visto como uma totalidade. Para os teóricos da história, deve estar claro que a escolha entre "narrativismo", de um lado, e (digamos) "experiencialismo" ou "presencialismo", de outro, é equivocada. Na complexidade do mundo, há presença, há experiência, há representações, ainda que se possa discutir como, quando, como e por que a "história" (que não é meramente "o passado") é marcada por uns ou outros. Tomados em conjunto, o trabalhos de Runia e White mostram como há momentos em que as identidades coletivas são rompidas (de modo regressivo ou revolucionário) e momentos em que são reconstruídas (por meio do preenchimento de figuras). Um processo requer 
o outro. O mesmo ocorre na relação entre representações coletivas e "experiências históricas", tal como Ankersmit as analisa.

Exploremos um pouco mais as diferenças em relação aos dois momentos. Em relação ao paralell processing, Runia afirmou (como vimos) tratar-se não de "representações in vitro, mas [de] interações reais - in vivo". Há algo de curioso nesta afirmação: levando em conta que, ao proferi-la, Runia tratava de um texto historiográfico (ou ao menos pretendia fazê-1o ${ }^{288}$ ) o que poderia significar o termo "reais"? É válido e importante ressaltar as peculiaridades das interações ocorridas no mesmo ambiente, mas, quando se trata de mentes humanas, interações fisicamente afastadas não são "irreais". Esta observação seria menos relevante se o próprio Runia não situasse sua análise na intersecção entre história-processo e história-escrita. Ora, o tipo de relação entre os historiadores do NIOD e os militares holandeses é um exemplo: o incidente ocorreu em 1993, e a pesquisa sobre ele foi iniciada em 1996. "Sujeito" e "objeto" da pesquisa não se conheciam diretamente, e os elos identitários entre eles eram de natureza especificamente representativa: afinal, o que é "Holanda" senão uma identidade - uma "substância narrativa", um "sujeito coletivo"- compartilhada por um certo grupo de pessoas, e amparado nos suportes que discutimos brevemente no primeiro capítulo? Elas são representações $e$ são reais.

O figuralismo de White enfatiza a relação entre dois eventos afastados temporalmente. Isto nos traz a possibilidade de que, em alguns (não todos os) momentos, a conexão entre eventos do passado e do presente opere nos moldes do que White chamou de "causalidade figural", e, assim, eventos já longamente sem "presença" possam "retornar" e retomar sua efetividade no presente. (E lembremos que White certamente resistiria ao termo "presença" neste contexto.) Runia utiliza a interessante metáfora do "passageiro clandestino" para ilustrar a noção de presença do passado; mas Collingwood e, neste caso involuntariamente, White, nos lembram que, quando tratamos de mentes humanas, há casos em que um passageiro pode estar

\footnotetext{
${ }^{288}$ No evento intitulado Tears in the Fabric of the Past: New theories of narrative and History, ocorrido em 30 de outubro de 2014, White, Harootunian, Kleinberg e Jay debateram com Runia o livro Moved by the Past. Em sua fala, White contesta que o relatório o NIOD seja um texto historiográfico. De modo geral, o tom de White foi bastante crítico em relação à noção de "presença", embora eu o tenha considerado mais amigável em relação ao trabalho de Runia do que o próprio Runia parece tê-lo. Neste evento, Jay relata sua "experiência histórica" que discutimos anteriormente. Disponível em: <https://www.youtube.com/watch?v=Mr5DgDv1two>. Acesso em jan. 15, 2015.
} 
ausente por várias estações e, então, ser trazido de volta, pela força que o preenchimento confere à figura. $^{289}$

E isto exatamente pela conexão enfatizada por Runia entre presença e identidade: afinal, é porque as identidades são maleáveis que elas podem não só condicionar o direcionamento da atenção para diferentes aspectos da realidade, mas também deixar o sujeito suscetível a ter sua ação tragada por eles. Assim, algo que em um momento não gerava maior interesse em outro pode passar a fazê-lo. A perspectiva de Carr, por sua vez, traz à tona a conexão entre identidade e temporalidade: é porque o sujeito se vê, individual e coletivamente, como agente com vistas à produção de um futuro específico, que os diferentes aspectos do evento se tornam ou não relevantes para ele.

Porque as identidades não são produzidas necessariamente por um causalidade histórica linear, mas por retoração figurativas, que não há um conjunto de coisas que "fizeram de mim quem eu sou". Quando, sendo tendo uma certa identidade em t1, me conecto retroativamente a outra tradição que até então não havia me formado nem informado meu contato com o mundo, faço com que outras coisas façam de mim o que passo a ser em t2, incluindo elementos de presença, isto é, coisas que a princípio não escolhi ser afetado por. Não há, a princípio, um conjunto de eventos passados que me fizeram, e outro conjunto dos que não me fizeram. Como seria possível isto se, como afirma Anders Schinkel, ${ }^{290}$ "nada existe em isolamento", "não há nada que não esteja de alguma forma relacionado a alguma outra coisa"? (2004: 49) Todos os eventos me fizeram, o que muda é a hierarquização de relevância que eles adquirem à luz de como os trago à consciência ao produzir um significado - invariavelmente relacional - sobre "quem eu sou". Esta questão me parece envolver três níveis. O primeiro e o segundo se interpenetram no processo histórico passado. O primeiro envolve o que poderíamos chamar de uma causalidade natural. Não discutiremos se ela é melhor vista por um modelo mecânico ou se já nela (como considerava Whitehead, por exemplo) os eventos já são "subjetivos" - ou ainda "experienciais" -, no sentido de que organizam o passado relevante ao processo que se desenrola em um dado momento. Para o nosso

\footnotetext{
${ }^{289}$ Em algumas aulas de seu curso sobre "Dialética hegeliana, dialética marxista, dialética negativa", no Departamento de Filosofia da USP, o professor Vladimir Safatle fez observações semelhantes (embora em contextos consideravelmente diferentes), especialmente em sua leitura de Marx. Ver SAFATLE, 2015. Um elo óbvio entre Auerbach, White e Marx se encontra em Hegel.

${ }^{290}$ Schinkel contrapõe às teses propostas por Ankersmit em "The Sublime Dissociation of the Past: or How to be(come) what one is no longer" (artigo de 2001, que viria a ser republicado como o oitavo capítulo de Sublime Historical Experience) uma abordagem "processual" baseada na filosofia de A. N. Whitehead. Seu artigo tem portanto uma afinidade básica com o argumento central de nossa tese.
} 
propósito, o importante é considerar sua relação com o segundo nível, o da subjetivização deste mundo objetivo pelos agentes que nele viviam. Assim, em relação holística com estes processo físicos, a história passada foi composta por incontáveis ações de múltiplas perspectivas, cada uma das quais hierarquizando sincrônica e diacronicamente o mundo. O terceiro nível é a perspectiva temporalmente afastada daqueles - historiadores e outros agentes históricos - que preenchem figuralmente este passado a partir de seus próprios interesses. Eles devem simultaneamente (a) entender os interesses dos seres do passado, e ver como tais interesses os permitiam ver alguns aspectos do mundo e não ver outros, e (b) ver o os múltiplos interesses, bem como seus mundos correspondentes, com diferentes passados e presentes relevantes, à luz dos próprios interesses. Dependendo de "quem eu sou", todo esse mundo se reordena. Para meus projetos, como eles ocorrem no mundo, tanto preciso me harmonizar às leis físicas e biológicas tal como elas operam, quanto também entender o funcionamento de minha sociedade, da psicologia em geral e da minha psicologia em particular, etc. A lição de Runia sobre os elementos de "presença", porém, indica que a definição de "quem eu sou" não envolve apenas um significado produzido no vácuo, mas a negociação entre memórias, habitus, demandas intersubjetivas, corpos, desejos, verdades consensualmente estabelecidas - formas processuais pelas quais o passado interpenetra no presente -, tudo isto em relação com um mundo físico, biológico e social, também marcados por dialéticas de mudança e permanência de todo tipo. A atenção não é nunca uma transcendência pura em relação a todos estes condicionantes, mas é sempre capaz de significá-los de modo a produzir um futuro específico dentro da margem de manobra que ela dispõe.

Envolvido no processo não estão apenas suas esperanças, mas também seus medos; assim, o passado surge não só como uma fonte de recursos, mas também como ameaça, na forma de memórias a serem reprimidas, espectros, e, dependendo das inclinações éticas do agente, verdades factuais a serem obscurecidas, na melhor das hipóteses, e negadas, na pior. Quanto mais rígida a adesão a uma identidade, menos o sujeito pode se relacionar com os elementos do passado que a põem em cheque $-\mathrm{e}$ como temos argumentado, toda adoção não-irônica de identidades se põe na indesejável condição de ter que rejeitar aspectos do passado. A perspectiva de Collingwood, como a de Dewey, tem outro componente relevante: situa a identidade na conexão com elementos a princípio extra-significativos, incluindo os internos ao corpo e aqueles percebidos por ele no ambiente. Dessa forma, um sistema de 
representações não pode jamais na prática ser fechado em si mesmo, pois deverá significar elementos do ambiente e da relação com outros seres que não podem ser satisfatoriamente imbuídos de coerência temporária sem um longo processo de experiência - e o fenômeno da presença consiste exatamente no início deste processo.

(O que também equivale a dizer que, para uma metáfora adequada acerca da complexidade de relações possíveis entre passado e presente, o passageiro clandestino não poderia estar em um trem, que viaja em linha reta, mas em algum meio de transporte que ocasionalmente visite locais inesperados, sem que possamos prever com antecedência sua trajetória, já que diferentes motoristas podem assumir o comando, atalhos desconhecidos podem estar disponíveis, etc. Como já mencionei algumas vezes, o próprio Runia nos fornece o que é, a meu ver, o complemento ideal para a metáfora: uma cidade - para a qual podemos buscar em Michel de Certeau o complemento da figura do caminhante, e reconhecer a possibilidade de se inventar o novo a partir de materiais oriundos de diferentes momentos e criados para diferentes finalidades. ${ }^{291}$ Para Runia, uma cidade representa adequadamente tanto a realidade quanto a historiografia porque é "uma maravilha da continuidade e também uma orgia de descontinuidade", com partes novas ao lado de outras antigas, partes bem conservadas ao lado de outras danificadas, etc. [RUNIA, 2014: 59]. Em suma: há casos em que o passageiro clandestino segue viagem o tempo todo, tal como Runia e Gumbrecht [2013] o descreveram; mas há outros em que ele embarca inesperadamente após ter estado ausente.)

(Notemos ainda que a relação entre representações e passageiros clandestino têm uma plasticidade, na qual nem linguagem nem seu fora são pontos fixos. Aparentemente, chegamos ao limite da metáfora: teríamos que falar em trens que mudam de tamanho e de trechos de ferroviárias que vão sendo construídos juntamente com o avanço do trem. O sujeito-na-mudança não é uma substância imutável, mas uma sequência de substâncias narrativas alinhadas retroativamente, que se modificou inclusive de território e membros, qualquer que seja essa substância - várias vezes ao longo do tempo. Mesmo quando a contingência histórica permite que ela persista por um longo tempo, os agentes históricos sempre poderiam ter feito diferente. $\mathrm{O}$

\footnotetext{
${ }^{291}$ Em texto recente, João Ohara (2019) aponta a complementaridade da abordagem de Certeau acerca dos textos historiográficos com aquela que, escrita inicialmente com vistas a tópicos mais amplos do que a historiografia, trata da criatividade do leitor (que encontramos, respectivamente, em A Escrita da História e em A Invenção do Cotidiano). Isto permite-nos dizer que o próprio Ohara "caminha" pelos textos de Certeau para propor tal interpretação. Esta interpretação certeauniana de Certeau faz com que ele passe pelo "teste de Danto", que demanda das teorias que elas sejam capazes de explicar a si próprias.
} 
fechamento ocorrido quando um certo período se torna passado não apaga seu ter-sidoaberto: portanto, não se trata de uma substância que esteve pronta ao longo de sua trajetória.)

Com Runia, por sua vez, podemos complementar o figuralismo de White atribuindo maior poder disruptivo ao passado. Ao longo de sua trajetória, White enfatizou a forma retroativa pela qual o evento posterior projeta sentido no anterior. É como se o ato de representar posteriormente (articulando eventos) sempre tivesse mais força que qualquer parte daquilo que é representado, no que diz respeito ao processo de produção do significado. Mas este posicionamento sempre foi problemático dentro das formulações do próprio White: de sua ideia de que os "eventos modernistas" requerem estilos modernistas de representação, por exemplo, podemos concluir a existência de uma correspondência entre o tipo de evento e a forma de representá-lo, o que, por sua vez, indica que a natureza da experiência vivida influencia as "condições de expressividade" da representação tardia.

White superestima o caráter "livre" da construção retroativa de identidades, e Runia traz à tona casos em que é "o passado" quem age sobre nós. A questão que ele traz à tona mais forçosamente que White, a meu ver, é a questão das condições de performatividade da "escolha do passado". É como se, paradoxalmente, o corte entre passado e presente fosse performativo, mas se tratasse de uma performance que ninguém especificamente pode escolher fazer, sob pena de não ser convincente. Ao menos dois estudos recentes, de Berber Bevernage (History, Memory and StateSponsored Violence) e de Carlos Fico ("Violência, trauma e frustração no Brasil e na Argentina"), mostram que setores das sociedades ou dos governos da Argentina, da África do Sul e de Serra Leoa, no primeiro caso, e do Brasil, no segundo, manifestaram a expectativa de que a verdade histórica pudesse atuar performativamente na transformação do presente em passado, com resultados de modo geral pouco satisfatórios: em certos casos de violência governamental (Bevernage) ou de ressentimento (Fico), somos (como indica o título do livro de Runia) "movidos pelo passado". O que me parece ocorrer aqui pode servir como complemento às teses representacionalistas: o corte entre passado e presente não possui existência ontológica (White), pois é resultado de um corte performativo, ${ }^{292}$ mas ele só possui eficácia interpretativa se ressoar com as emoções dos leitores. O mesmo vale para os sentidos

\footnotetext{
${ }^{292}$ Michel de Certeau desenvolveu este argumento já na década de 1970; ver CERTEAU, 2002.
} 
específicos que se pode querer atribuir aos processos com os quais estas temporalidades se articulam. Os leitores devem sentir, ou devem ser convencidos a passar a sentir, a desejabilidade de um investimento emocional na narrativa proposta para os sujeitos coletivos que eles tomam por parte de sua identidade. Ora, inúmeras formas de "presença" influenciam nisto, inclusive em sentidos diferentes daquele empregado por Runia: o lugar em que se vive, as relações entre enunciador e receptor(es), as memórias de indivíduos em diferentes "posição de sujeito" em relação ao que é narrado, etc. A investigação detalhada da interrelação entre presença e significado, preferencialmente com casos empíricos como o estudado por Bevernage, é parte indispensável de qualquer tentativa de responder a questão que White pôs na mesa em 1982: o que torna uma narrativa “eficaz"? (WHITE, 1987) Por exemplo, Bevernage mostra como as Madres de Plaza de Mayo resistiram narrativamente à tentativa de fechamento narrativo promovida pelo governo argentino. Mas parte do que contribuiu para a eficácia de sua narrativa é a ocupação do ambiente físico da Plaza de Mayo, e outra parte é a maneira pela qual mobilizaram os fatores de "presença", não desprovidos de significado mas pouco propícios às "domesticações" narrativas tal como a proposta oficial. ${ }^{293}$ A questão, portanto, realmente vai muito além da enunciação de verdades - embora elas não sejam irrelevantes -, adentrando o campo de o que fazer com a identidade coletiva, inseparável de uma narrativa de eventos, tanto no que ela domestica quanto no que ela não pode ou não deseja domesticar.

Se em casos como os estudados por Bevernage a ruptura entre passado e presente é performativa, o que dizer das "experiências históricas sublimes" de Ankersmit? Não parece ser o caso que, nelas, o passado foi "perdido" em vez de a ruptura ter sido "produzida"? A diferença me parece estar no acordo intersubjetivo. Para os perdedores do pós-Revolução Francesa, o passado foi perdido porque os demais não mais desejavam viver naquela sociedade. Há uma dimensão de perda, que diz respeito à descoberta de que as convenções sociais não eram dadas, e que, portanto, a sociedade poderia ser feita de outra forma. Este parece ser o caso da saída do que Ankersmit chama, talvez enganosamente, de "presente eterno", rumo a uma condição auto-consciente que, se por um lado está sempre sob o risco de ser perdida (cf.

\footnotetext{
${ }^{293}$ Em texto de 2006, Ewa Domanska também discutiu este caso. Sua conclusão antecipa a de Bevernage: "A liminalidade e monstruosidade dos desaparecidos, de quem nós não sabemos se estão mortos ou vivos, previce o trauma da perda de ser curado por meio de rituais. O status ambivalente dos desaparecidos, sua natureza quase sobrenatural [unearthly], os dá um grande poder. As Mães, que buscavam justiça, utilizaram este poder [...]" (DOMANSKA, 2006: 343).
} 
Collingwood), por outro não se pode escolher esquecer (cf. Mink e Ankersmit). Mas, instalada esta condição auto-consciente, os revolucionários franceses efetivamente "saltaram no abismo", produzindo uma ruptura com o passado. A perda dos conservadores e reacionários reside no campo intersubjetivo: o mundo que seus contemporâneos produziam não era o mundo que eles gostariam que eles produzissem. Já casos como os das disputas pelo passado estudados por Bevernage parecem tratar de um passado em disputa. Para os perdedores da Revolução Francesa, perder a disputa foi inseparável de perder o passado.

A objeção acerca da importância de pensar nossas relações com o passado pode ser feita em outro contexto, dessa vez mais voltada para Runia. Ele tende a conceber a narrativa como, primordialmente, um meio de "redução de dissonâncias". Em crítica a ele (mas que, ao menos quando comenta do tipo de narrativa produzido por historiadores, também poderia ser estendida a White), Jonas Grethlein insiste na possibilidade de se narrar de modo que o caráter outrora aberto dos eventos passados não seja perdido de vista: “O passado está de fato presente: ele está tangível em rélicas materiais, ele dá forma a identidades, e ele se sedimenta em costumes. Ao mesmo tempo, porém, o passado é narrado. Em narrativas historiográficas, ele não está simplesmente presente, mas visto de uma perspectiva que entrelaça passado e futuro." (GRETHLEIN, 2014: 328) Se Runia tem razão com conceber a narrativa como redutora de dissonâncias, é concebível pensar o narrativismo como parte de um projeto ético direcionado a educar para a dissonância. Quando Ankersmit exibe a "dialética do historicismo narrativista", ele mostra ser essa a consequência inevitável de todo programa que estimule simultaneamente a produção de coerência narrativa e o contato com o passado tal como ele foi - como foi o caso do historicismo. (ANKERSMIT, 2001). Mas o narrativismo é algo mais: é uma reflexão sobre o historicismo - e, no caso de Ankersmit, da relação dele com as produções historiográficas que buscam "contato com o passado" e (como Runia) com as experiências históricas que envolvem tal contato. Assim, trazer à consciência o fato de que a narrativa frequentemente atuou como redutora de dissonâncias produz liberdade performativa - da mesma forma que reconhecer os elementos de presença pode fazê-lo - para que se busque a difícil tarefa de oscilar o movimento da atenção entre a coerência e o detalhe, entre a representação e a presença.

White certamente tem razão na base filosófica de seu argumento: como o processo histórico não possui sentido inerente, é possível construir tal sentido por meio 
dos recursos representativos disponíveis em nossa cultura. Mas essa possibilidade $a$ princípio existente se choca com a facticidade ou o prático-inerte da existência humana, cujas escolhas são feitas por serem que possuem corpos (como insistiu, por exemplo, Gumbrecht), pelo habitus (Bourdieu), pela técnica e pelo lugar social (Certeau)... e pela psicologia (Runia). Diferentemente de aderentes do pós-modernismo, que não vêem complementariedade entre os movimentos, o narrativismo em geral, e White em particular, não negam nada disto: apenas adotam outro enfoque. $\mathrm{O}$ desafio teórico em aberto consiste em articular os movimentos e manter viva a memória disciplinar da dialética em questão, sem a qual o destino é a má infinitude e não a ampliação da margem de liberdade buscada por Collingwood, Mink e White.

O que Runia busca mostrar é algo ausente das reflexões de White: como vêm à tona as rupturas de identidades coletivas e do conhecimento historiográfico? White se restringe à lógica interna dos tropos, segundo a qual o pensamento metafórico conduz ao metonímico, que conduz ao sinedóquico, que estimula a atitude irônica, e ao relacionamento entre figuras e preenchimentos. Isto talvez esteja correto, mas, como White reconheceu explicitamente em relação ao primeiro caso (e certamente também o faria em relação ao segundo), este movimento pode ser interrompido por qualquer fator externo que intervenha no processo, e cada produto textual resultante dele retorna ao mundo na forma de um "ato de fala" (WHITE, 2014) potencialmente produtor de “implicações ideológicas” específicas (WHITE, 1973). Isto não invalidaria sua análise tropológica, da mesma forma que "a morte de uma pessoa antes da puberdade não invalida as 'leis fisiológicas do desenvolvimento orgânico' que regem a fase pubertária” (WHITE, 1978: 250). Mas isto também equivale ao reconhecimento de que os elementos extradiscursivos que interferem no discurso, mesmo aqueles que não chegam a ser ditos.

\subsection{Estamos mesmo condenados à ingenuidade? Ironia e presencialismo}

Em sua caracterização dos tropos, White observa que metáfora, metonímia e sinédoque, diferentemente da ironia, são tropos "ingênuos". A relação entre ironia e os demais tropos é mais ou menos parecida com a relação entre um período visto de fora e um visto de dentro na teorizações de Danto e Ankersmit. Buscarei mostrar agora que há um padrão parecido em Runia, e, como nas discussões anteriores, argumentarei que a atitude natural e imersa descrita por ele não é algo a que estamos eternamente 
condenados a repetir. Esta argumentação anti-determinismo aparece em ao menos dois exemplos.

\section{Pensar impulsivamente é mesmo inevitável?}

Além da ideia de que estamos condenados a construir identidades "substanciais", de que inclusive "precisamos da ilusão de substância", da possível inevitabilidade do narcisismo, etc., surge nos debates narrativistas e experiencialista outro princípio frequentemente tomado como inevitável, como algo sobre o qual não há nada que possa ser feito: o da tendência humana de pensar de produzir associações de maneira mais ou menos imediatas e de não apenas pensar associativamente, mas "comprar" - nãoironicamente - os resultados das associações.

Runia descreve, com justiça, a maneira usual pela qual a maioria de nós, seres humanos, lidamos com o hábito de pensar:

\footnotetext{
Musil e Conrad se referem ao que se poderia chamar de 'o mito do pensamento': fala-se muito sobre pensamento, mas, na prática de fato, o pensamento, como um esforço sustained de passar de premissas a conclusão, é extremamente raro. O que nós chamamos 'pensamento' frequentemente é um tipo de pathos, interrompido por acessos involuntários de associação e um flash ocasional de inspiração. Quando nós dizemos 'vou pensar sobre isto', o que realmente queremos dizer é 'vou esperar até que alguma coisa me ocorra.' $\mathrm{Na}$ maior parte do tempo, o que nós chamamos de 'pensamento' apenas nos 'acontece', ou, como Musil disse, 'é a vida que faz o pensamento ao nosso redor.' (2014: 127-8)
}

E isto indica, para ele, o quão usual é que as ações ocorrem anteriormente às explicações. E isto está perfeitamente correto, especialmente se levarmos em conta a assimetria sobre a qual Danto e Ankersmit tanto esclareceram: como a previsão histórica é impossível, não seria justificado esperar que uma ação - especialmente uma ação "revolucionária" sobre a qual Danto fala - já contivesse em si a perspectiva posterior. Como Mink e Collingwood argumentam, a perspectiva posterior pode englobar a anterior, mas o inverso não é verdadeiro. Ainda assim, como argumentei anteriormente, isto não significa que a construção das novas configurações históricas seja inteiramente aleatórias; também não significa que não se possa tratar as próprias representações com ironia, de maneira não-ingênua. E, argumento agora, não significa que a ação não possa ser feita a partir da perspectiva da consciência de quarto grau, retroagindo sobre as atividades de níveis mais básicos. Se filósofos (inclusive os da história) já reconheceram que o cultivo de capacidades atencionais adequadas 
(DEWEY, 1980), de solidariedade (RORTY, 1989), compaixão (GILBERT, 2019) etc. são possíveis, então - da mesma forma que os soldados do exemplo de Danto, citado no capítulo 1 - a facticidade que nos obstaculiza no processo de produção de modificações institucionais e estruturais que permitam e estimulem estas qualidades, e não seus opostos (distração, crueldade, indiferença, etc.), nunca domina tão inteiramente nosso ser a ponto de, como aquele soldado imaginário, sequer podemos mover nossas pernas.

Assim, como já argumentamos, é desejável inserir um grau de liberdade diante dos vocabulários na argumentação de Ankersmit (ele próprio tão insatisfeito com o transcendentalismo linguístico de Rorty), algo concebível a partir da noção de ironia em White. Ali, dissemos: sim, da atitude natural é muito difícil de escapar; a autenticidade, a ironia e a consciência histórica são conquistas que podemos manter apenas com grandes esforços; a literatura modernista é extremamente exigente; a experiência estética e a capacidade de juízo prático são de difícil realização; o etnocentrismo é extremamente fácil e tentador. Mas meramente caracterizar algo como raro ou difícil como feito por Runia neste trecho - não significa que, devido a isto, elas não possam ser mobilizáveis "para a vida". Mas a pesquisa e a filosofia da história não são parte destas empreitadas altamente reflexivas e de difícil realização, no final das contas?

Há uma grande dificuldade de abrir margens de manobra em espaços como museus e escolas, já que eles são ligados a instituições e ao estado, e portanto submetidos a todo tipo de relações de poder, mas dificuldade não é impossibilidade. Desde seu princípio, o narrativismo está ligado à perspectiva de ampliação de liberdade dos seres humanos. Se teorizar sobre a história não puder abrir esta margem em nenhum grau - e com uma justificativa estranhamente a-histórica de que os seres humanos são assim mesmo - para que teorizar?

Estamos condenados a uma circularidade eterna entre produzir descontinuidade $e$ reduzir dissonâncias?

Um segundo tópico no qual rejeitamos os pressupostos deterministas e enfatizamos a possibilidade de manutenção e ampliação da liberdade situada de ação aparece na leitura que Maren Lytje (2019) faz de um aspecto do pensamento de Runia. O holandês, para ela, tem uma visão determinista do processo entre o impulso por produzir descontinuidades e o impulso subsequente de narrar para produzir continuidades. Comparando a abordagem de Runia com a de Freud, Lytje (idem: 65) observa que Freud permite a possibilidade de uma "história progressiva", enquanto 
Runia a nega: “O evento traumático sempre irá nos puxar com sua 'gravidade narrativa' rumo à órbita da historiografia revisionista, e a possibilidade de uma história progressiva é para Runia um engodo."

No capítulo anterior, afirmei haver um determinismo deste tipo Ankersmit, mas não o encontro tão acentuado em Runia - embora também não encontre uma afirmação da existência de uma margem (ampliável) de liberdade diante do processo, como afirmo existir em White e com referência à qual leio o próprio Runia. O que efetivamente há em seu texto é uma rejeição da inevitabilidade do progresso, mas ela não leva automaticamente - ao menos não deveria - a uma afirmação de sua impossibilidade.

Lytje caracteriza o processo assim:

Incapazes de crescer, seres humanos estão condenados a errar pelo plano de tempo. Ao longo de suas errâncias, eles criam estórias a partir dos rastros que o passado deixou armazenados, enganando a si mesmos que eles possam verdadeiramente chegar ao coração de quem eles são, até que o fardo das suas estórias pesa tanto sobre eles que eles só podem ser liberados por um ato transgressivo de violência. (65)

Como no caso de Ankersmit, também aqui proponho que a chave para a produção de um progresso relativo - que sempre pode ser perdido - é a manutenção da memória do processo, de modo que a segunda experiência disruptiva não precisa ser idêntica à primeira, como se nenhuma lição tivesse sido aprendida - por exemplo, por meio de livros como Sublime Historical Experience, que, a partir desta perspectiva ahistórica, seriam incapazes de causar qualquer impacto no leitor. A mente, dentro deste pressuposto, não tem qualquer analogia com o toque: ela parece tão longe da história quanto o topo da montanha ou o avião em pleno vôo.

Se houvesse apenas uma circularidade entre descontinuidade e continuidade, estaríamos condenados à má-infinitudade. Porém, seres humanos são capazes de, sem precisar "sair da história" e assumir uma posição transcendental, guardar memória dos processos anteriores, identificar seus padrões e agir de modo a usá-los favoravelmente. O tipo de imersão na história descrito por Runia e Ankersmit é suspenso no exato momento em que eles refletem sobre o processo e os descrevem para os leitores de seus livros. Notemos também que, na descrição de Lytje, há uma descrição compatível com o movimento da tropologia, mas no qual a posição autoconsciente da ironia se perde no ricorso. Mas em Vico, felizmente, o ricorso não é idêntico ao corso, e, da mesma forma, em White o retorno irônico à metáfora não é idêntico ao primeiro uso da metáfora. Assim, como argumentamos, em Ankersmit o ciclo uma experiência sublime seguida da 
adoção de uma nova identidade não precisa ser idêntico ao anterior. Da mesma forma, em Runia o ciclo pelo qual ato de "cometer história" e "saltar no abismo", destruindo a própria identidade por meio de uma mudança no ambiente, é seguido da narrativização do processo, não precisa resultar na construção não-irônica, substancialista, de uma nova identidade: a nova construção pode ser feita a partir de pressupostos filosóficos mais razoáveis. Runia e Ankersmit descrevem atos imersos nos foram feitos a construção de uma nova identidade e a narrativização que reduz dissonâncias. Mas aquele que descreve os atos já não está imerso.

Em suma:

(a) Por estarmos na história, não sabemos como seremos vistos a partir de uma posição futura inacessível a nós, mas sabemos que nossa perspectiva é contingente. Presumir que a condição de quem não refletiu sobre o processo, pois não possuía acesso à memória de sua própria ação, e a de quem refletiu e possui tal memória, é idêntica, é negar a historicidade da própria história, e presumir a existência de um mecanismo ahistórico conduzindo a história. Porém, por outro lado...

(b) Isto não significa que a reflexão automaticamente nos dê liberdade total de ação, ou que vá culminar em um ponto final: em vez de alcançar o ponto fixo a partir do qual podemos nos predicar, o processo resulta no reconhecimento da ausência dos pontos fixos (ou da inexistência de História Universal, ou da sublimidade do processo histórico). As reflexões "presencialistas" sobre os mecanismos psicológicos que agem à revelia dos agentes, combinadas com os fatores que produzem o retorno do barbarismo para Vico e Collingwood, e com os vários elementos de facticidade presentes na filosofia de Sartre (e daí legíveis na de White) indicam precisamente que a margem de autonomia histórica só surge a duras penas, em circunstâncias muito específicas, e não possuem qualquer garantia de progresso inexorável. De fato, pelo contrário, permitem descobrir que não há tal coisa como progresso inexorável. Ainda assim...

(c) Se pudéssemos descobrir que as narrativizações retroativas reduzem dissonância, mas fôssemos incapazes de produzir narrativas senão para este fim, de que adiantaria descrever o processo? Runia e Ankersmit se veriam de volta à "prisão do ironista" dos pós-modernistas, da qual tão forçosamente tentaram escapar.

Mas o grande mérito de suas reflexões foi mostrar que a prisão tem rachaduras. Em conjunto com o narrativismo whiteano, elas compõem uma filosofia da liberdade em situação. 


\section{Considerações finais}

Este trabalho buscou ler as tradições narrativista e experiencialista de modo a enfatizar sua preocupação básica com as "relações com o passado" - ou com como lidar com "o fardo da história" - ora enfatizando o lado da liberdade, ora o das limitações situacionais em que a liberdade é exercida, quando o é. E se é que pode sê-la: contra algumas tendências manifestadas nos últimos anos por experiencialistas e presencialistas, o presente trabalho afirma que sim.

O primeiro capítulo estabeleceu as linhas gerais daquilo que deveria ser mantido do pensamento narrativista, agora que o campo já se direcionou irreversivelmente para novas direções. Ele aponta a existência de uma ontologia comum que perpassa ambos os movimentos, embora não tenha ainda tido suas implicações plenamente levada a sério por nenhum deles: aquela na qual a própria realidade humana, que é o representado das representações históricas, já comparta em si mesma esta "dobra" ou reflexividade - já é perpassada por representações. Ambos os movimentos também foram lidos a partir da perspectiva anti-fundacionalista, com o reconhecimento de que não há "pontos fixos" a partir dos quais se possa conhecer ou significar o passado, e de que, portanto, a relação - estabelecida retroativamente - entre consciências vivas no presente e acontecimentos ou tradições do passado, cria um sistema totalizante, em que passado e presente se constituem simultaneamente, nos moldes de uma "causação mútua”. Deste ponto central, decorre outro igualmente importante, segundo o qual os critérios práticos e a atenção à situação em que o agente se encontra são o que nos resta em um mundo sem fundamentos.

A isto, adicionei um terceiro ponto, que esteve presente no plano de fundo de todas as discussões subsequentes deste texto: segundo ele, as situações não envolvem meramente decisões individuais, nem lidam com um mundo de objetos inertes, mas afetam toda a cadeia interconectada de seres. Veja-se ou não o impacto das próprias escolhas sobre os demais seres, elas existem. A atenção para além das próprias identidades aparece portanto como eticamente desejável, no meu argumento, e também como a posição mais sustentável por motivos tanto práticos quanto filosóficos. No primeiro caso, pelo argumento hegeliano segundo o qual toda tentativa de estabelecer relações de reconhecimento com seres que dominamos está condenada a ser insuficiente (ao que complemento, no mínimo com evidências anedóticas, que relações entre iguais 
são incomparavelmente mais satisfatórias.) No segundo, pelo fato de que, se as identidades são produzidas de maneira performativa e nunca esgotam os predicados dos sujeitos que as adotam, então toda auto-construção baseada em pressupostos etnocêntricos é tanto equivocada quanto desnecessária: é preferível o complemento feito por Butler e Safatle na esteira de Hegel, por meio do qual eles propõem dinâmicas de reconhecimento "anti-predicativas".

O segundo capítulo explorou esta argumentação por um caminho duplo, correspondente ao duplo sentido do termo "história", que se aplica tanto à escrita quanto ao processo. Dando sequência ao argumento do primeiro capítulo, argumentei que, se a "realidade humana" é feita por meio de representações ou apresentações (no sentido não-representacionalista do termo), i.e., por gestos que são antes estéticos e práticos e só depois podem ser cognitivos, e que se a historiografia também produz representações, então a teorização sobre textos historiográficos deve levar em conta o que Martin Jay certa vez chamou de tensões de ordens narrativas. Entendendo as representações como, sobretudo, instrumentos para direcionar a atenção para certos aspectos da realidade, enfatizei a importância prática da capacidade de movimentar a atenção: por exemplo, direcionando-a das partes do texto para o todo, e vice-versa, ou do texto para a contemplação de suas consequências práticas, e vice-versa. Por meio deste procedimento, as formas de produzir sentido para o mundo revelam suas fraturas, impedindo que pressupostos realistas - e, por tabela, não pluralistas - se instalem.

O terceiro capítulo discutiu as várias manifestações do conceito de "experiência histórica subjetiva" em Ankersmit, incluindo suas primeiras discussões sobre experiência nostálgica até os relatos mais precisos apresentados em Sublime Historical Experience sobre Huizinga e as do próprio Ankersmit, culminando em uma discussão sobre a noção de "humores e sentimentos". Aqui, minha leitura é que o projeto antitranscendentalista de Ankersmit poderia ir ainda mais longe do que ele avaliou: pois, ao discutir a possibilidade de "contato com o passado", ele ocasionalmente presume que a realidade é algo que está "atrás" dos nossos esquemas transcendentais, como o mundo por trás das nuvens. Porém, argumentamos e exemplificamos de várias maneiras a proposta de que tradição não é o que bloqueia que vejamos a realidade, mas o que permite que ela surja de maneiras particulares. Seres humanos são feitos de tradição e cultura, de modo que acessar tradições e culturas (e acontecimentos e atmosferas) passados não é ver atrás delas, mas vê-las a partir de dentro, em primeira pessoa. Como esta primeira pessoa é uma consciência incorporada no presente e como a materialidade 
e as relações intersubjetivas do passado já se perderam, isto significa que efetivamente temos o que Ankersmit desejava: (a) uma forma de conceitualizar as relações com o passado em que não há nem total identidade, nem total estranhamento, mas experiênciacom-diferença; (b) uma concepção tanto de representção quanto de experiência em que não há nem realismo nem transcendentalismo, mas o encontro "na superfície" entre ambos; (c) a inexistência de um ponto de vista transcendentalista, que perde o insight historicista sobre como o "rio visto de cima" não é a mesma coisa que o rio visto "de lugar nenhum" ou do "ponto de vista de Deus". Este último ponto se harmoniza com o "historicismo modernista" que White afirmou ser praticado por Erich Auerbach em Mimesis: como em nossa leitura da experiências históricas "objetiva" (no passado) e "subjetiva" (no presente, sobre o passado), não há - para falar propositalmente de modo redundante - um ponto de vista não-experiencial a partir do qual a experiência possa ocorrer. E, assim, as atmosferas do passado são objetivas não no sentido que datas, preços, objetos e assassinatos são objetivos, mas no sentido de que efetivamente foram experienciados por seres humanos situados no passado, e são experienciados com diferença - i.e., com o desvelamento de outros aspectos - pelos seres humanos no presente - que, por serem pessoas diferentes, com diferentes perspectivas históricas, automaticamente desvelam outros aspectos - que, na condição de aspectos, são tão reais quanto as experiências históricas do passado e do presente podem sê-lo.

O quarto capítulo discute o conceito de "experiência histórica sublime". Enfatizo a distinção (nem sempre feita por Ankersmit) entre experienciar o passado (com diferença) e experienciar a sublimidade da história. Este último caso é bem ilustrado em várias discussões do capítulo 8 de Sublime Historical Experience, nos quais os agentes históricos se vêem desprovidos dos esquemas e representações com os quais usualmente produziam sentido para o mundo. Contesto duas teses apresentadas por Ankersmit. Primeiro, diante de sua afirmação de que o trauma 2 é insuperável e será insuperável para uma dada sociedade enquanto ela existir, proponho que, ao reconhecer a maleabilidade e a retroatividade do que White chamou de sistemas históricos, não há como impedir as pessoas que nascerão no futuro de escolherem outra identidade. Até mesmo a questão de se elas pertencem à "mesma" sociedade depende, em última instância, de uma nomeação arbitrária. Se o trauma 2 é entendido como uma reação melancólica à perda, então defendo que não há nada em sua natureza que impeça um trabalho de luto eventual. Nos exemplos fornecidos por Ankersmit, o elemento comum é a fixação de membros de certos grupos (sobretudo grupos de elite) às suas identidades, 
que, por sua vez, dependem da manutenção de hierarquias (que caracterizo como) indesejáveis e (que afirmo serem, mesmo para eles) insatisfatórias. Em segundo lugar, e na sequência disto, aponto como Ankersmit foca excessivamente na dimensão vertical da relação entre a identidade de certos grupos no presente e o passado que eles desejam conhecer, mas não contempla o terceiro fator envolvido nesta relação: a intersubjetividade. Levar esta variável em conta é reinserir a dimensão utópica do narrativismo whiteano, afirmando que nada obriga nenhum grupo a desejar o passado de uma maneira específica.

O último capítulo também mantém a rejeição a determinismos e algumas tendências behavioristas do experiencialismo e do presencialismo, ao mesmo tempo em que reconhece os amplos méritos destas correntes em fazer reconhecer a facticidade que impede a produção livre de sentido para o passado. Em discussão neste último caso esteve o conceito de "presença", de Eelco Runia. Dentre os méritos da abordagem de Runia, um a ser mantido para a filosofia da história do futuro e retroativamente articulado com a do passado é a espacialização do tempo, de modo que os enredamentos whiteanos e os períodos ankersmitianos trazem consigo "passageiros clandestinos" e temporalidades múltiplas. Em vez de uma metrópole que varre o passado para sempre, estabelecer relações com passado nos termos de Runia é mais próximo de andar por uma cidade onde construções, vielas e pessoas de todos os tipos se encontram e se afetam. Equivalentes desta metáfora da cidade em Ankersmit são o monstrengo e as mutações: nelas, se reconhece o fato de que potencialidades pouco notadas por parte dos seus contemporâneos podem ter grande força causal sobre, ou potencialidade figural para, os seres do futuro.

Vimos, em suma, que a reflexão narrativista sobre liberdade de produção de significados demanda como contrapartida o exame da facticidade que limita o processo. A produção e a ruptura das continuidades, por um lado, e a negociação com as descontinuidades, por outro, se relacionam processualmente em um mundo onde tudo caminha rumo à inevitável transformação. Sofrendo e agindo neste processo, com graus limitados, porém ampliáveis, de autonomia, estão os seres humanos. Em 2019, parece especialmente importante lembrarmos que, como afirmou Collingwood após o fim da Primeira Guerra Mundial, as circunstâncias que permitem que a mente exerça a capacidade de conhecer a si mesma - que, para ele, é nada menos que a própria atividade histórica - são um ganho sempre passível de ser perdido. Mas tal capacidade também pode, felizmente, ser ampliada, como também a de reduzir o etnocentrismo e 
efetivamente ampliar o círculo de solidariedade pelos seres que vivem. Que assim façamos. 


\section{Referências}

\section{Livros}

ANDERSON, Benedict. Imagined Communities: Reflections on the Origin and Spread of Nationalism. London: Verso, 2006.

ANKERSMIT, Frank. A Escrita da História: a natureza da representação histórica. Trad. Jonathan Menezes et. al. Londrina: EdUEL, 2012b. Aesthetic Politics: Political philosophy beyond fact and value. Stanford: Stanford University Press, 1996. \& KELLNER, Hans (Orgs.). A New Philosophy of History. Chicago: Chicago University Press, 1995.

. A Plea for a Cognitive Approach to White's Tropology. In: DORAN, Robert (Org.). Philosophy of History After Hayden White. London: Bloomsbury, 2013, pp. 4765.

. Can We Experience the Past? In: TORSTENDAHL, R.; VEIT-BRAUSE, I. (Ed.). History-Making: The Intellectual and Social Formation of a Discipline. Stockholm: Amquist \& Wiksell International, 1996, pp. 47-76.

Danto's Philosophy of History in Retrospective. In: DANTO, Arthur. Narration and Knowledge. New York, Columbia University Press, 2007, pp. 364-393. . Historical Representation. Stanford: Stanford University Press, 2001. History and Tropology: The rise and fall of the metaphor. Berkeley: University of California Press, 1994.

\& MOOIJ, J.J.A. (Orgs.). Knowledge and Language, vol. III: Metaphor and Knowledge. Dordrecht: Kluwer Academic Publishers, 1993.

. Language and Historical Experience. In: RÜSEN, Jörn (Org.). Meaning and Representation in History. New York: Berghahn Books, 2006, pp. 137-152.

Manifesto for an Analytical Political History. In: JENKINS, Keith; MORGAN, Sue \& MUNSLOW, Alun. (Orgs.) Manifestos for History. London: Routledge, 2007, pp. 179-193.

Meaning, Truth, and Reference in Historical Representation. Cornell: Cornell University Press, 2012.

Narrative and Interpretation. In: TUCKER, Aviezer (Org.). A Companion to the Philosophy of History and Historiography. Chichester: Blackwell, 2009, pp. 199208.

. Narrative Logic: A Semantic Analysis of the Historian's Language. The Hague: Martinus Nijhoff, 1983.

. Political Representation. Stanford: Stanford University Press, 2002.

DOMANSKA, Ewa \& KELLNER, Hans (Orgs.). Re-Figuring Hayden White. Stanford: Stanford University Press, 2009.

, Representation in Retrospect. In ARBEIT, Marcel \& CHRISTIE, Ian (Eds.). Where is History Today? New ways of representing the past. 2017. . Sublime Historical Experience. Stanford: Stanford University Press, 2005.

. The Three Levels of 'Sinnbildung' in Historical Writing. In: RÜSEN, Jörn (Org.). Meaning and Representation in History. New York: Berghahn Books, 2006, pp. 108-122.

APPLEBY, Joyce; HUNT, Lynn \& JACOB, Margaret. Telling the Truth About History. New York, W.W. Norton, 1995.

ARISTÓTELES. De Anima. Livros I, II e III. Apresentação, tradução e notas de Maria Cecília Gomes dos Reis. São Paulo: Editora 34, 2006. 
AUERBACH, Erich. Figura. São Paulo: Ática, 1997.

Mimesis: a representação da realidade na literatura ocidental São Paulo:

Perspectiva, 2007.

AUSTIN, J. L. How to Do Things with Words. Oxford: Clarendon Press, 1975.

BARBOSA, Alexandre de Moura. Ciência e Experiência: um ensaio sobre a Fenomenologia do Espírito de Hegel. Porto Alegre: EdiPUCRS, 2010.

BARTHES, Roland. A Câmara Clara. Lisboa: Edições 70, 1989.

. O Discurso da História. In: O Rumor da Língua. São Paulo: Martins Fontes, 2004, pp. 163-180.

BERGSON, Henri. A Evolução Criadora. São Paulo: Martins Fontes, 2005.

. Ensaio Sobre os Dados Imediatos da Consciência. Tradução de João Silva

da Gama. Lisboa: Edições 70, 1988.

BEISER, Frederick. Hegel. New York: Routledge, 2005.

Hegel and Ranke: A Re-examination. In: HOULGATE, Stephen \& BAUR,

Michael (Eds.). A Companion to Hegel. Oxford: Blackwell, 2011.

BENTIVOGLIO, Julio \& TOZZI, Verónica (Orgs.). Do Passado Histórico ao Passado

Prático: 40 anos de Meta-História. Serra: Milfontes, 2017.

BERNSTEIN, Richard J. Beyond Objectivism and Relativism: Science, Hermeneutics, and Praxis. Philadelphia: University of Pennsylvania Press, 1983.

BEVERNAGE, Berber. History, Memory, and State-Sponsored Violence: Time and Justice. New York/London: Routledge, 2012.

\& LORENZ, Chris (Orgs.). Breaking Up Time. Göttingen: Vandenhoeck \&

Ruprecht, 2013.

BOURDIEU, Pierre. Meditações Pascalianas. Rio de Janeiro: Bertrand, 2001.

. Outline of a Theory of Practice. Cambridge: Cambridge University Press, 1977.

1998.

. Les Règles de l'Art : Genèse et structure du champ littéraire. Paris, Seuil,

. Meditações Pascalianas. Rio de Janeiro: Bertrand, 2001.

. Razões Práticas: sobre a teoria da ação. Campinas: Papirus, 1996.

BRAVER, Lee. Groundless Grounds: A Study of Wittgenstein and Heidegger. Cambridge e Londres: The MIT Press, 2012.

BRZECHCZYN, Krzysztof. 2017. Towards a Revival of Analytical Philosophy of History: Around Paul A. Roth's Vision of Historical Sciences. Leiden/Boston: Brill/Rodopi, 2017.

BURKE, Edmund. Uma investigação filosófica sobre a origem de nossas idéias do sublime e do belo. Campinas: Papirus, 1993.

BURKE, Kenneth. A Grammar of Motives. New York: Prentice Hall, 1945.

BURKE, Peter (Org.). New Perspectives on Historical Writing. University Park: Pennsylvania State University Press, 2001.

BUTLER, Judith. Bodies That Matter: On the discursive limits of 'sex'. New York: Routledge, 2011.

Giving an Account of Oneself. New York: Fordham University Press, 2005.

. Frames of War: when is life grievable? Londres: Verso, 2009a.

Routledge, 2010.

Gender Trouble: Feminism and the Subversion of Identity. New York:

. Primo Levi for the Present. In: ANKERSMIT, Frank, DOMANSKA, Ewa

\& KELLNER, Hans (Orgs.). Re-Figuring Hayden White. Stanford: Stanford University Press, 2009b, pp. 282-303. 
. Subjects of Desire: Hegelian Reflections in Twentieth-Century France. New York: Columbia University Press, 1987.

CARDOSO, Ciro. História e Paradigmas Rivais. In: CARDOSO, Ciro \& VAINFAS, Ronaldo (Orgs.). Domínios da História. Rio de Janeiro: Campus, 1997, pp. 1-23.

. Um Historiador Fala de Teoria e Metodologia. Bauru: EDUSC, 2005.

CARR, David. Experience and History: Phenomenological Perspectives on the Historical World. Oxford: Oxford University Press, 2014.

Phenomenology and the Problem of History: A Study of Husserl's

Transcendental Philosophy. Evanston: Northwestern University Press, 1980. . The Paradox of Subjectivity. Oxford: Oxford University Press, 1999.

. Time, Narrative, and History. Bloomington: Indiana University Press,

1991.

CARRARD, Philippe. Poetics of the New History: French Historical Discourse form Braudel to Chartier. Baltimore: John Hopkins University Press, 1992.

CERTEAU, Michel de. A Escrita da História. Rio de Janeiro: Forense, 1982. . A Invenção do Cotidiano, 1: Artes de fazer. Petrópolis: Vozes, 1994a.

. A Invenção do Cotidiano, 2. Morar, cozinhar. Petrópolis: Vozes, 1994b.

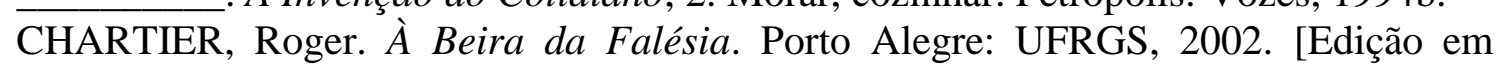
inglês: On the Edge of the Cliff: History, Language, and Practices. Baltimore: The Johns Hopkins University Press, 1997.] . A História Cultural: entre práticas e representações. Lisboa: DIFEL, 1990.

CLARK, Elizabeth. History, Theory, Text: Historians and the Linguistic Turn. Cambridge and London: Harvard University Press, 2004.

COLLINGWOOD, R. G. An Autobiography. Oxford: Clarendon Press, 1978. . An Essay on Metaphysics. Oxford: Oxford University Press, 1998.

. An Essay on Philosophical Method. Oxford: Clarendon Press, 2005. . Essays in Political Philosophy. Oxford: Clarendon Press, 1995.

1970. Speculum Mentis, or, The Map of Knowledge. Oxford: Clarendon Press, . The Idea of History. Oxford, Oxford University Press, 1993.

The New Leviathan. Oxford: Clarendon Press, 1992.

The Principles of Art. London: Oxford University Press, 1958.

COMAY, Rebecca. Mourning Sickness: Hegel and the French Revolution. Stanford: Stanford University Press, 2011.

CRAIB, Ian. Narratives as Bad Faith. In: ANDREWS, Molly et al (Eds.). Lines of Narrative: psychosocial perspectives. London: Routledge, 2000.

DANTO, Arthur C. A Transfiguração do Lugar-Comum: uma filosofia da arte. Trad. Vera Pereira. São Paulo: Cosac \& Naify, 2011.

Narration and Knowledge, including the integral text of Analytical

Philosophy of History. New York: Columbia University Press, 2007.

. Nietzsche as Philosopher. New York: Columbia University Press, 2005. . Sartre. London: Fontana/Collins, 1975.

. The Decline and Fall of the Analytical Philosophy of History. In:

ANKERSMIT, Frank \& KELLNER, Hans (Orgs.). A New Philosophy of History. Chicago: Chicago University Press, 1995.

DAVIDSON, Donald. Inquiries into Truth and Interpretation. Oxford: Clarendon Press, 1984.

DERRIDA, Jacques. Specters of Marx: The State of the Debt, the Work of Mourning and the New International. New York: Routledge, 2006.

DEWEY, John. Art as Experience. New York: Perigee, 1980 [1934]. 
DIDEROT, Denis. Selected Writings. London: Macmillan, 1966.

DOMANSKA, Ewa. Encounters: Philosophy of History After Postmodernism. Charlottesville: University Press of Virginia, 1998a.

DORAN, Robert. The Ethics of Theory: Philosophy, History, Literature. London: Bloomsbury, 2017.

2013.

(Org.). Philosophy of History After Hayden White. London: Bloomsbury,

D'ORO, Giuseppina. Collingwood and the Metaphysics of Experience. London and New York: Routlegde, 2002.

DOSTAL, Robert J. (Org.). The Cambridge Companion to Gadamer. Cambridge: Cambridge University Press, 2002.

DRAY, William. Laws and Explanation in History. London: Oxford University Press, 1957. On History and Philosophers of History. New York: Brill, 1989. (Org.). Philosophical Analysis and History. New York: Harper \& Row,

1966.

ELIAS, Norbert. Envolvimento e Distanciamento. Lisboa: Dom Quixote, 1997.

FAIN, Haskell. Between Philosophy and History. Princeton: Princeton University Press, 1970.

FEBVRE, Lucien. Combates por la Historia. Barcelona: Ariel, 1982.

FLYNN, Thomas. Sartre, Foucault, and Historical Reason. Volume 1: Toward an Existentialist Theory of History. Chicago: University of Chicago Press, 1997.

Sartre, Foucault and Historical Reason, Volume 2: A Poststructuralist

Mapping of History, University of Chicago Press, 2005.

FOGU, Claudio, KANSTEINER, Wulf \& PRESNER, Todd (Orgs.). Probing the Ethics of Holocaust Culture. Harvard University Press, 2016.

FRIED, Michael. Absorption and Theatricality: Painting and beholder in the age of Diderot. Chicago: The University of Chicago Press, 1980.

FRITZSCHE, Peter. Life and Death in the Third Reich. Cambridge: Harvard University Press, 2008.

FRIEDLÄNDER, Saul. The Years of Extermination: Nazi Germany and the Jews, v. 2, 1939-1945. New York: HarperCollins, 2007.

. The Years of Persecution: Nazi Germany and the Jews, v. 1, 1933-1939.

New York: HarperCollins, 1997.

(Org.). Probing the Limits of Representation: Nazism and the "Final Solution". Cambridge: Cambridge University Press, 1996.

- Trauma, Memory, and Transference. In: HARTMAN, Geoffrey (Org.).

Holocaust Remembrance: the shapes of memory. Oxford: 1994, p. 252-63.

FRYE, Northrop. Anatomia da Crítica. São Paulo: Cultrix, 1973.

Fables of Identity: Studies in Poetic Mythology. New York: Harcourt,

Brace \& World, 1963.

FREUD, Sigmund. Obras Completas, v. 16. O Eu e o Id, "Autobiografia" e outros textos. Tradução de Paulo César de Souza. São Paulo: Companhia das Letras, 2011.

O Infamiliar [Das Unheimliche] - Edição comemorativa bilíngue (1919-

2019): Seguido de O homem da areia de E. T. A. Hoffmann. Formato kindle. Autêntica, 2019.

GADAMER, Hans-Georg. A Century of Philosophy: Hans-Georg Gadamer in Conversation with Riccardo Dottori. Londres: Continuum, 2006.

Verdade e Método I: Traços fundamentais de uma hermenêutica filosófica.

Petrópolis: Vozes, 1999. 
. Verdade e Método II: Complementos e índice. Petrópolis: Vozes, 2002.

GANERI, Jonardon. Attention, Not Self. New York: Oxford University Press, 2017.

Philosophy as a Way of Life: Spiritual Exercises from the Buddha to Tagore.

In: CHASE, Michael, CLARK, Stephen \& McGHEE, Michael (Orgs.). Philosophy as a Way of Life: Ancient and Modern Essays in honor of Pierre Hadot. Malden: WileyBlackwell, 2013, pp. 116-131.

GEUSS, Raymond. Richard Rorty at Princeton: Personal Recollections. In: Politics and the Imagination. New Jersey: Princeton University Press, 2010, pp. 151-164.

GILBERT, Bennett. A Personalist Philosophy of History. Londres: Routledge, 2019.

GINZBURG, Carlo. Mitos, Emblemas, Sinais: morfologia e história. São Paulo:

Companhia das Letras, 1989.

Letras, 2002.

Relações de Força: história, retórica, prova. São Paulo: Companhia das

Letras, 2007.

. O Fio e os Rastros: verdadeiro, falso, fictício. São Paulo: Companhia das

GORMAN, Jonathan. Ethics and the Writing of Historiography. In: TUCKER, Aziever (Org.). A Companion to the Philosophy of History and Historiography. Oxford: WileyBlackwell, 2008, pp. 253-261.

GUIGNON, Charles \& HILEY, David R. (Orgs.). Richard Rorty. Cambridge: Cambridge University Press, 2003.

GULDI, Jo \& ARMITAGE, John. The History Manifesto. Cambridge: Cambridge University Press, 2014.

GUMBRECHT, Hans Ulrich. Atmosphere, Mood, Stimmung: on a hidden potential of literature. Stanford: Stanford University Press, 2012. . Depois de 1945. São Paulo: EdUnesp, 2014.

. Produção de Presença: o que o sentido não consegue transmitir. Rio de

Janeiro: Contraponto, PUC-Rio, 2010.

HADOT, Pierre. Philosophy as a Way of Life: Spiritual Exercises from Socrates to Foucault. London: Blackwell, 1995.

HAMMER, Espen. Philosophy and Temporality from Kant to Critical Theory. Cambridge: Cambridge University Press, 2011.

HARI, Johann. Lost Connections: Uncovering the real causes of depression - and the unexpected solutions. London: Bloomsbury, 2018.

HARTOG, François. A Arte da Narrativa Histórica. In: BOUTIER, Jean \& JULIA, Dominique (Orgs.). Passados Recompostos: campos e canteiros da História. Rio de Janeiro: Editora UFRJ: Editora FGV, 1998, p. 193-202.

Regimes de Historicidade: Presentismo e Experiências do Tempo. Belo

Horizonte: Autêntica, 2013.

HEGEL, W. G. F. Fenomenologia do Espírito. Petrópolis: Vozes, 1992.

HEIDEGGER, Martin. Ser e Tempo, Parte I. Petrópolis: Vozes, 2005.

. Ser e Tempo, Parte II. Petrópolis: Vozes, 2005.

HELFER, Martha B. The Retreat of Representation: the concept of Darstellung in German critical discourse. Albany: State University of New York Press, 1996.

HERWITZ, Daniel \& KELLY, Michael (Orgs.). Action, Art, History: Engagements with Arthur C. Danto. New York: Columbia University Press, 2007.

HOBSBAWM, Erich. The Age of Empire. New York: Vintage Books, 1989.

HÖSLE, Vittorio. Vico's New Science of the Intersubjective World. Indiana: University of Notre Dame Press, 2016.

HOY, David Couzens. The Time of Our Lives: A Critical History of Temporality. Cambridge: The MIT Press, 2009. 
HUIZINGA, Johan. El Concepto de la Historia y Otros Ensayos. México: Fondo de Cultura Económica, 1980.

O Declínio da Idade Média. Lisboa: Ulisseia, s/d.

HUSSERL, Edmund. A Crise da Humanidade Europeia e a Filosofia. Trad. Urbano Zilles. Porto Alegre: EDIPUCRS, 2008.

. The Crisis of European Sciences and Transcendental Phenomenology. An

Introduction to Phenomenology. Tradução de David Carr. Evanston: Northwestern University Press, 1970.

HUTCHEON, Linda. Irony's Edge: the theory and politics of irony. Routledge: London and New York, 1994.

. Poética do pós-modernismo: história, teoria, ficção. Rio de Janeiro: Imago,

1991.

ICKE, Peter. Frank Ankersmit's Lost Historical Cause: A Journey from Language to Experience. London: Routledge, 2011.

IGGERS, Georg. Historiography in the Twentieth Century: From scientific objectivity to the postmodern challange. Middletown: Wesleyan University Press, 2005.

INGLIS, Fred. History Man: The Life of R. G. Collingwood. Princeton: Princeton University Press, 2009.

JANACK, Marianne. What we Mean by Experience? Stanford University Press, 2012. JAY, Martin. Cultural Semantics: Keywords of Our Time. Amherst: University of Massachusetts Press, 1998.

Press, 2005.

. Songs of Experience. Berkeley and Los Angeles: University of California

JENKINS, Keith. A História Repensada. São Paulo: Contexto, 2005.

Routledge, 1999.

Why History? Ethics and Postmodernity. London and New York:

. On "What is History?" From Carr and Elton to Rorty and White. London and New York: Routledge, 1995.

KANT, Immanuel. Crítica da Faculdade do Juízo. Rio de Janeiro: Forense Universitária, 2008.

. Crítica da Razão Pura. Lisboa: Fundação Calouste Gulbenkian, 1989.

Crítica da Razão Prática. São Paulo: Martins Fontes, 2003.

KELLNER, Hans. Hayden White and the Kantian Discourse: Freedom, Narrative, History. In: SILLS, Chip \& JENSEN, George (Orgs.). The Philosophy of Discourse, v. II. Portsmouth: Boynton/Cook, 1992.

KENAAN, Hagi \& FERBER, Ilit (Eds.). Philosophy's Moods: The affective grounds of thinking. Dordrecht: Springer, 2011.

KERMODE, Frank. The Sense of an Ending. Oxford: Oxford University Press, 2000.

KING, Preston. Thinking Past a Problem: Essays on the History of Ideas. London, Frank Cass, 2000.

KLEINBERG, Ethan. Haunting History: For a deconstructive approach to the past. Stanford: Stanford University Press, 2017.

\& GHOSH, Ranjan (Orgs.). Presence. Ithaca: Cornell University Press,

2013.

KORHONEN, Kuisma (Org.). Tropes for the Past: Hayden White and the History/Literature Debate. Amsterdan - New York, NY: Rodopi, 2006.

KLEIN, Kerwin Lee. From History to Theory. Berkeley: University of California Press, 2011.

KLEIN, Naomi. No Is Not Enough: resisting Trump's shock politics and winning the world we need. Chicago: Haymarket Books, 2017. 
KUHN, Thomas. A Estrutura das Revoluções Científicas. São Paulo: Perspectiva, 1973. KUUKKANEN, Jouni-Matti. Postnarrativist Philosophy of Historiography. Palgrave Macmillan, 2015.

LaCAPRA, Dominick. History and Criticism. Ithaca: Cornell University Press, 1985. . History and Memory After Auschwitz. Ithaca and London: Cornell University Press, 1998.

. History in Transit: Experience, Identity, Critical Theory. Ithaca: Cornell University Press, 2004.

. History, Literature, Critical Theory. Ithaca: Cornell University Press, 2016. . Representing the Holocaust: History, Theory, Trauma. Ithaca and London: Cornell University Press, 1994.

Rethinking Intellectual History: Texts, Contexts, Language. Ithaca and London: Cornell University Press, 1983.

LA GRECA, Maria Inés. Historia, figuración y performatividad: Crítica y persistencia de la narración en la Nueva Filosofía de la Historia. Tese de doutorado. Buenos Aires: Universidad de Buenos Aires, 2013.

LAKOFF, George. Don't Think of an Elephant!: Know your values and frame the debate. Vermont: Chelsea Green Publishing, 2004.

LEAR, Jonathan. A Case for Irony. Cambridge: Harvard University Press, 2011.

Press, 1988. Aristotle: The desire to understand. Cambridge: Cambridge University

Freud. London: Routledge, 2015.

LEOPOLDO E SILVA, Franklin. Bergson: Intuição e Discurso Filosófico. São Paulo: Loyola, 1994.

LERER, Seth (Org.). Literary History and the Challenge of Philology. Stanford: Stanford University Press, 1996.

LEVI, Primo. É Isto um Homem? Rio de Janeiro: Rocco, 1988.

LINGPA, Düdjom. O Darma Tolo de um Idiota Vestido de Barro e Penas. Porto Alegre: CEBB, 2016.

LOPES, Fábio Henrique. A História em xeque: Michel Foucault e Hayden White. In: RAGO, Margareth \& GIMENES, Renato Aloizio de Oliveira (Orgs.). Narrar o Passado, Repensar a História. Campinas: UNICAMP, 2000.

LORENZ, Chris. Unstuck in time. Or: the sudden presence of the past. In: TILMANS, Karin, VAN VREE, Frank \& WINTER, Jay (Eds.). Performing the Past: Memory, History, and Identity in Modern Europe. Amsterdam: Amsterdam University Press, 2010, pp. 69-103.

LOVEJOY, Arthur O. The Revolt Against Dualism: An Inquiry Concerning the Existence of Ideas. La Salle: Open Court, 1955.

LYOTARD, Jean-François. O Pós-Moderno. Rio de Janeiro: José Olympio, 1988.

MACY, Joanna. Mutual Causality in Buddhism and General Systems Theory. Albany: State University of New York Press, 1991.

\& BROWN, Molly Young. Coming Back to Life: The Updated Guide to the

Work that Reconnects. Gabriola Island: New Society Publishers, 2014.

\& JOHNSTONE, Chris. Active Hope: How to Face the Mess We're in

Without Going Crazy. Novato: New World Library, 2012.

MAKKREEL, Rudolf A. Imagination and Interpretation in Kant: The Hermeneutical Import of the Critique of Judgment. Chicago: University of Chicago Press, 1990.

MALPAS, Jeff. Place and Experience: A Philosophical Topography. Cambridge: Cambridge University Press, 1999. 
MEGILL, Allan. Prophets of Extremity: Nietzsche, Heidegger, Foucault, Derrida. Berkeley: University of California Press, 1985.

MENEZES, Jonathan. Frank Ankersmit: A metamorfose do historicismo. Tese de doutorado. Assis: UNESP, 2018.

MINK, Louis O. Knowledge of the Past: A Critique of Epistemological Theories With Respect to Their Consequences for Knowledge of the Past. Tese de doutorado. Yale University, 1952.

Mind, History, and Dialectic: The Philosophy of R. G. Collingwood. Bloomington, Indiana University Press, 1967.

GOLOB, Eugene, FAY, Brian \& VANN, Richard (Orgs.). Historical Understanding. Ithaca: Cornell University Press, 1987.

Philosophy and Theory of History. In: IGGERS, Georg G. \& PARKER, Harold (Orgs.). International Handbook of Historical Studies. Westport: Greenwood Press, 1979.

The Theory of Practice: Hexter's Historiography. In: MALAMENT, Barbara (org.). After the Reformation: essays in honor of J. H. Hexter. Philadelphia: University of Pennsylvania Press, 1980.

MUNSLOW, Alun. Desconstruindo a História. Petrópolis: Vozes, 2009.

MUSZYNSKI, Lisa. Unmaking History-as-Fiction: Decoupling the Two Incompatible Principles of Language in Hayden White's Linguistic Turn, 1970s-2000s. Tese de doutorado. University of Helsinki, 2017.

NIETZSCHE, Friedrich. Segunda Consideração Intempestiva: da utilidade e desvantagem da história para a vida. Rio de Janeiro: Relume Dumará, 2003.

OAKESHOTT, Michael. Experience and Its Modes. Cambridge: Cambridge University Press, 1966.

ODENSTEDT, Anders. Gadamer on Tradition: Historical Context and the Limits of Reflection. Springer, 2017.

PARTNER, Nancy \& FOOT, Sarah (Orgs.). The SAGE Handbook of Historical Theory. London: SAGE Publications, 2013.

PAUL, Herman. Hayden White: The Historical Imagination. Cambridge: Polity, 2011.

PAUL, L.A. Transformative Experience. New York: Oxford University Press, 2014.

PETERS, Rik. History as Thought and Action: The Philosophies of Croce, Gentile, de Ruggiero and Collingwood. Exeter: Imprint Academic, 2013.

POPPER, Karl. The Poverty of Historicism. Boston: The Beacon Press, 1957.

PHILLIPS, Mark Salber. On Historical Distance. New Haven: Yale University Press, 2013.

REVEL, Jacques (Org.). Jogos de Escalas: a experiência da microanálise. Rio de Janeiro: Editora Fundação Getúlio Vargas, 1998.

RICOEUR, Paul. A Memória, a História, o Esquecimento. Campinas: EdUNICAMP, 2007.

La Métaphore Vive. Paris: Seuil, 1975.

Tempo e Narrativa, 3 vols. Campinas: Papirus, 1994.

RIEDEL, Dirce Côrtes (Org.). Narrativa: Ficção \& História. Rio de Janeiro: Imago, 1988.

RORTY, Amélie Oksenberg \& NUSSBAUM, Martha C. Essays on Aristotle's De Anima. Oxford: Oxford University Press, 1995.

RORTY, Richard. A Filosofia e o Espelho da Natureza. Rio de Janeiro: Relume Dumará, 1994.

Contingency, Irony, Solidarity. Cambridge: Cambridge University Press, 
Essays on Heidegger and Others: Philosophical Papers, Volume 2. Cambridge: Cambridge University Press, 1991.

. Consequences of Pragmatism: Essays, 1972-1980. Minneapolis: University of Minnesota Press, 1982.

ROTH, Michael S. The Ironist's Cage: Memory, trauma, and the construction of history. New York: Columbia University Press, 1995.

Trauma: A Dystopia of the Spirit. In: RÜSEN, Jörn, FEHR, Michael \&

RIEGER, Thomas W. (Orgs.). Thinking Utopia: Steps into Other Worlds. New York \& Oxford: Berghahn Books, 2007, p. 230-246.

RÜSEN, Jörn (Org.). Meaning \& Representation in History. New York: Berghahn Books, 2006.

. Teoria da História. 3 v. Brasília: EdUNB, 2001, 2007 e 2007.

(Org.). Western Historical Thinking: An Intercultural Debate. New York:

Berghahn Books, 2008.

RUNIA, Eelco. Moved by the Past. New York: Columbia University Press, 2014.

SAUSSURE, Ferdinand de. Curso de Lingüística General. Buenos Aires: Losada, 1945.

SAFATLE, Vladimir. Grande Hotel Abismo: por uma reconstrução da teoria do reconhecimento. São Paulo: Martins Fontes, 2012.

SAFATLE, Vladimir. O Circuito dos Afetos: Corpos políticos, desamparo e o fim do indivíduo. São Paulo: Cosac \& Naify, 2015.

SAGAN, Carl. O Mundo Assombrado Pelos Demônios. São Paulo: Companhia das Letras, 1996.

SARTRE, Jean-Paul. La Nausée. Paris: Gallimard, 1938.

O Ser e o Nada: Ensaio de Ontologia Fenomenológica. Trad. Paulo

Perdigão. 20a ed. Petrópolis: Vozes, 2011.

THOMPSON, Evan. Waking, Dreaming, Being: Self and consciousness in neuroscience, meditation, and philosophy. New York: Columbia University Press, 2015. WALSH, W. H. Introdução à Filosofia da História. Rio de Janeiro: Zahar, 1978.

WINDSCHUTTLE, Keith. The Killing of History: How Literary Critics and Social Theorists Are Murdering Our Past. San Francisco: Encounter Books, 1995.

WITTGENSTEIN, Ludwig. Investigações Filosóficas. São Paulo: Nova Cultural, 1999. WOOD, Ellen Meiksins \& FOSTER, John Bellamy. Em Defesa da História: Marxismo e Pós-Modernismo. Rio de Janeiro: Zahar, 1999.

UNDERWOOD, Ted. Why Literary Periods Mattered: Historical Contrast and the Prestige of English Studies. Stanford: Stanford University Press, 2013.

VASCONCELOS, José Antonio. Quem Tem Medo de Teoria? A ameaça do pósmodernismo na historiografia norte-americana. São Paulo: Annablume; Fapesp, 2005.

VAN DER DUSSEN, Jan. History as a Science: The Philosophy of R.G. Collingwood. New York : Springer, 2012.

2016. . Studies on Collingwood, History and Civilization. Dordrecht: Springer,

VERENE, Donald Philip. Vico's Science of Imagination. Ithaca: Cornell University Press, 1981.

VEYNE, Paul. Como se Escreve a História. Foucault Revoluciona a História. Brasília: EdUNB, 1998.

VICO, Giambattista. The New Science. $3^{\mathrm{a}}$ edição, de 1744. Traduzido por Thomas Goddard Bergin e Max Harold Fisch. Ithaca: Cornell University Press, 1948.

WHITE, Hayden. Afterword. In: DORAN, Robert (Org.). Philosophy of History After Hayden White. London \& New York: Bloomsbury, 2013. 
Afterword: Manifesto Time. In: JENKINS Keith, MORGAN, Sue \& MUNSLOW, Alun (Orgs.). Manifestos for History. London: Routledge, 2007. Bodies and Their Plots. In: In: FOSTER, Susan Leigh (Org.). Choreographing History. Bloomington: Indiana University Press, 1995b, pp. 229-234.

. El Contenido de la Forma: Narrativa, Discurso y Representación Histórica.

Barcelona: Paidós Básica, 1992.

. Figural Realism: Studies in the Mimesis Effect. Baltimore \& London: The Johns Hopkins University Press, 1999.

Metahistory: the historical imagination in nineteenth-century Europe. Baltimore: The Johns Hopkins University Press, 1973. [Edição em português: MetaHistória: A Imaginação Histórica do Século XIX. São Paulo: EdUSP, 1995.]

Michel Foucault. In: STURROCK, John (Org.). Structuralism and Since: From Lévi-Strauss to Derrida. Oxford and New York: Oxford University Press, 1979, pp. 81-115.

\& TAGLIACOZZO, Giorgio (Orgs.). Giambattista Vico: An International Symposium. Baltimore and London: Johns Hopkins University Press, 1969. . The Greco-Roman Tradition. New York: Harper \& Row, 1973.

The Practical Past. Evanston: Northwestern University Press, 2014.

The Westernization of World History. In: RÜSEN, Jörn (Org.). Western

Historical Thinking: an intercultural debate. New York: Berghahn Books, 2002.

EdUSP, 1994.

Trópicos do Discurso: Ensaios Sobre a Crítica da Cultura. São Paulo:

\& DORAN, Robert (Org.). The Fiction of Narrative. Baltimore: The Johns Hopkins University Press, 2010.

\& VANDERSCOFF, Cameron. Hayden White: Frontiers of Consciousness at UCSC. Disponível em: <http://www.escholarship.org/uc/item/20b91099>. Acesso em 12 ago. 2015.

\section{Artigos}

AHLSKOG, Jonas. Michael Oakeshott and Hayden White on the practical and the historical past. Rethinking History, 2016, pp. 1-21.

R. G. Collingwood and the Presence of the Past. Journal of the Philosophy of History, v. 11, 2017, pp. 289-305.

ANKERSMIT, Frank. A Dialogue with Jouni-Matti Kuukkanen. Journal of the Philosophy of History, v. 11, n. 1 2017, pp. 38-58.

A Proposal for How to Look at the Past: Interview by Frode Molven, December, 2007. Disponível em: 〈http://www.culturahistorica.es>. Acesso em $11 \mathrm{de}$ agosto de 2016.

Introduction: Forum Debate on Jouni-Matti Kuukkanen's Postnarrativist Philosophy of Historiography. Journal of the Philosophy of History, v. 11, n. 1, 2017, pp. 1-10.

\& MENEZES, Jonathan. Historical Experience Interrogated: A conversation. Journal of the Philosophy of History, v. 11, n. 2, 2017, pp. 247-273.

. History as the Science of the Individual. Journal of the Philosophy of

History, v. 7, n. 3, 2013, pp. 396-425.

Invitation to Historians. Rethinking History, v. 7, n. 3, 2003, pp. 413-437.

\& TAMM, Marek. Leibnizian Philosophy of History: A conversation.

Rethinking History, v. 20, n. 4, 2016, pp. 491-511. 
Political Representation and Experience: an essay on political psychology. Redescriptions, v. 11, 2007, pp. 21-45.

Postmodernism and the Humanities. Groniek, n. 157, 2002, pp. 483-506.

. Reply to My Critics. Journal of the Philosophy of History, v. 12, n. 3, 2018, pp. 472-490.

Reply to Professor Saari. Rethinking History, v. 9, n. 1, 2005, pp. 23-35.

Reply to Professor Zagorin. History and Theory, v. 29, n. 3, 1990, pp. 275-

296.

Representation as a Cognitive Instrument. History and Theory, v. 52, n. 2, 2013, pp. 171-193.

. Representation as Representation of Experience. In: Metaphilosophy, v. 31, n. 1-2, 2000, pp. 147-168.

Reply to Professor Roth: on how antidogmatism bred dogmatism. Rethinking History, v. 17, n. 4, 2013, pp. 570-585.

Rorty and History. New Literary History, v. 39, n. 1 (Remembering Richard Rorty), 2008, pp. 79-100.

. The Necessity of Historicism. Journal of the Philosophy of History, v. 4, n. 2, 2010, pp. 226-240.

The Transfiguration of Distance into Function. History and Theory, v. 50, n. 4, 2011, pp. 136-149.

Truth in History and Literature. Narrative, v. 18, n. 1, 2010, pp. 29-50.

ASDAL, Kristin \& JORDHEIM, Helge. Texts on the Move: Textuality and Historicity Revisited. History and Theory, v. 57, n. 1, 2018, pp. 56-74.

AUBERT, Eduardo Henrik. Planos ontológicos e processualidade em O Outono da Idade Média, de Johan Huizinga. Revista USP, v. 90, junho/agosto de 2011, pp. 218229.

BECKER, Tobias. The Meanings of Nostalgia: Genealogy and critique. History and Theory, v. 57, n. 2, 2018, pp. 234-250.

BENCARD, Adam. Presence in the Museum: On metonymies, discontinuity and history without stories. Museum \& Society, v. 12, n. 1, 2014: 29-43.

BENTLEY, Michael. Past and "Presence": revisiting historical ontology. History and Theory, v. 45, n. 3, 2006, pp. 349-361.

BERGER, Stefan \& LORENZ, Chris. National Narratives and their 'Others' Ethnicity, Class, Religion and the Gendering of National Histories. Storia della Storiografia, v. 50, 2006, pp. 59-98.

BERGER, Peter \& PULLBERG, Stanley. Reification and the Sociological Critique of Consciousness. History and Theory, v. 4, n. 2, 1965, pp. 196-211.

BEVERNAGE, Berber, DELANOTE, Broos, FROEYMAN, Anton \& VAN DE MIEROOP, Kenan. Introduction: The Future of the Theory and Philosophy of History. Journal of the Philosophy of History, v. 8, n. 3, 2014, pp. 141-148.

BEVERNAGE, Berber. Tales of pastness and contemporaneity: on the politics of time in history and anthropology, Rethinking History, 2016, pp. 1-23.

Time, Presence, and Historical Injustice. History and Theory, v. 47, n. 2, 2008, pp. 149-167.

BEVIR, Mark \& ANKERSMIT, Frank. Exchanging Ideas. Rethinking History, v. 4, n. 3, 2000, pp. 351-372.

BOYM, Svetlana. Mal-estar na nostalgia. Trad. Marcelo Santos de Abreu e André de Lemos Freixo. História da Historiografia, n. 23, v. 1, 2017, pp. 153-165.

BORN, Georgina. 2015. Making Time. Temporality, History, and the Cultural Object. New Literary History, v. 46, n. 3, 2015, pp. 361-386. 
BOS, Jacques. Ankersmit's Dutch Writings and Their Audience. Journal of the Philosophy of History, v. 12, n. 3, 2018, pp. 450-471.

BOUCHER, David. Human Conduct, History, and Social Science in the Works of R. G. Collingwood and Michael Oakeshott. New Literary History, v. 24, n. 3, 1993, pp. 697717.

BOURG, Julian. Nature and the Irruptive Violence of History. History and Theory, v. 54, n. 4, 2016, pp. 93-111.

BURKE, Peter. Metahistory: before and after. Rethinking History, v. 17, n. 4, 2013, pp. 437-447.

CARDOSO Jr., Hélio Rebello. Peirce and Foucault on Time and History: The Tasks of (Dis)continuity. History and Theory, v. 55, n. 1, 2016, pp. 25-38.

CARR, David. Narrative and the Real World: An Argument for Continuity. History and Theory, v. 25, n. 2, 1986, pp. 117-131.

. Narrative Explanation and its Malcontents. History and Theory, v. 47, n. 1, 2008, pp. 19-30.

. Place and Time: On the interplay of historical points of view. History and Theory. v. 40, n. 4, 2001, p. 153-167.

. Reflections on Temporal Perspective: The Use and Abuse of Hindsight.

History and Theory, Theme Issue 56, dezembro de 2018, pp. 71-80.

Response to Casey, Crowell and Kearney. Human Studies, v. 29, 2007.

CARRARD, Philippe. 2018. Hayden White and-in France. Receptions, translations, questions. Rethining History, 2018, pp. 1-18. Ahead of print.

CARROLL, David. On Tropology: The Forms of History. Diacritics, 1976, pp. 58-64.

CARTER, Jonathan A. Telling Times: History, Emplotment, and Truth. History and Theory, v. 42, n. 1, 2003, pp. 1-27.

CALDAS, Pedro Spínola Pereira. Hans Georg Gadamer e a Teoria da História. Dimensões, v. 24, 2010, p. 55-74.

CHARBEL, Felipe. Uma filosofia inquietante da história: sobre Austerlitz, de W. G. Sebald. História da Historiografia, v. 8, n. 19, jun. 2016, pp. 124-141.

CHAKRABARTY, Dipesh: Anthropocene Time. History and Theory, v. 57, n. 1, 2018, pp. 5-32.

197-222.

The Climate of History: Four Theses. Critical Inquiry, v. 35, n. 2, 2009, pp.

CHORELL, Torbjörn Gustafsson. Desire for the past? Rethinking History, 2015.

F. R. Ankersmit and the historical sublime. History of the Human

Sciences, v. 19, n. 4, 2006, pp. 91-102.

. History and identity in Hayden White's The Practical Past. History of the

Human Sciences, v. 29, n. 1, 2016, pp. 128-135.

Incomplete Secularization of History: Ethan Kleinberg and Hayden White.

Journal of the Philosophy of History, 2019, pp. 1-20. Ahead of print.

COHEN, Sande. On intellecticide or university driven politics of history. Rethinking History, v. 17, n. 4, 2013, pp. 528-547.

CLARK, Jonathan Owen. Aesthetic Experience, Subjective Historical Experience and the Problem of Constructivism. Journal of the Philosophy of History, v. 7, n. 1, 2013, pp. 57-81.

COLLINGWOOD, R. G. Some Perplexities About Time: With an Attempted Solution. Proceedings of the Aristotelian Society, v. 26, 1925-1926, pp. 135-150.

COLAPIETRO, Vincent. Situation, Meaning, and Improvisation: An Aesthetics of Existence in Dewey and Foucault. Foucault Studies, n. 11, v. 1, 2011, pp. 20-40. 
COMAY, Rebecca. Resistance and Repetition: Freud and Hegel. Research in Phenomenology, v. 45, 2015, pp. 237-266.

CROWELL, Steven. Experiencing History: David Carr's Philosophy of History. Research in Phenomenology, v. 46, n. 3, 2016, pp. 441-455.

. Spectral History. Narrative, Nostalgia, and the Time of the I. Research in.

Phenomenology, v. 29, n. 1, 1999, pp. 83-104.

D'ALESSIO, Márcia Mansor. Memória e Historiografia: limites e possibilidades de uma aproximação. História Oral, v. 4, 2001, p. 55-71.

DÍAZ-MALDONADO, Rodrigo. Historical Experience as a Mode of Comprehension. Journal of the Philosophy of History, 2016, pp. 1-21. Ahead of print.

DE BOLLA, Peter. Toward the Materality of Aesthetic Experience. Diacritics, v. 32, n. 1, 2002, pp. 19-37.

. Disfiguring History. Diacritics, 1986, pp. 49-58.

DEN HOLLANDER, Jaap. Contemporary History and the Art of Self-distancing. History and Theory, v. 50, n. 4, 2011, pp. 51-67.

DOMANSKA, Ewa. Frank Ankersmit: From Narrative to Experience. Rethinking History, vol. 13, n. 2, 2009, pp. 175-196.

173-181.

Hayden White: Beyond Irony. History and Theory, v. 37, n. 2, 1998b, pp.

Spring 1994, pp. 91-100.

pp. 337-348.

The Material Presence of the Past. History and Theory, v. 45, n. 3, 2006,

DONIZETTI DA SILVA, Luciano. Tempo e temporalidade na filosofia de Sartre.

Princípios, v. 15, n. 24, 2008, pp. 225-248.

EDWARDS, Elizabeth. Photography and the Material Performance of the Past. History and Theory, v. 48, n. 4, 2009, pp. 130-150.

ELIAS, Amy. The Voices of Hayden White. L.A. Review of Books, apr. 22, 2018. Disponível em: <https://lareviewofbooks.org/article/the-voices-of-hayden-white/\#!> Acesso em 05 jun. 2018.

ERKKILÄ, Ville. Time, identity, and history: on the cognitive psychology and figural practice of historiography. Rethinking History, v. 19, n. 4, 2015.

FAIRBROTHER, Daniel. Ankersmit's Leibnizism. Journal of the Philosophy of History, v. 12, n. 3, 2018, pp. 391-409.

Leibniz and the Philosophical Criticism of Historiography. Journal of the

Philosophy of History, v. 11, n. 1, 2017, pp. 59-82.

2018, pp. 1-24.

The Soul of Historiography. Journal of the Philosophy of History, v. 12,

FARELD, Victoria. (In) Between the Living and the Dead: New Perspectives on Time in History. History Compass, v. 14, n. 9, 2016, pp. 430-440.

FELIPPE, Eduardo Ferraz. Renovar votos com o futuro: Nostalgia e escrita da história. História da Historiografia, n. 25, dez. 2017, pp. 117-134.

FICO, Carlos. Violência, trauma e frustração no Brasil e na Argentina: o papel do historiador. Topoi, v. 14, n. 27, 2013, pp. 239-284.

FORD, Thomas H. The Natural History of Aesthetics. Journal of the Philosophy of History, v. 9, n. 2, The Aesthetics of Scale, 2015, pp. 220-239.

FRANÇA, Luara. A Presença Sentida do Passado: Arquitetura, Preservação e Cronótopos. Redescrições, v. 3, n. 4, 2012, pp. 72-79.

FRIEDLÄNDER, Saul. History, Memory, and the Historian: Dilemmas and Responsibilities. New German Critique, n. 80, Special Issue on the Holocaust, 2000, p. 
3-15.

FROEYMAN, Anton. Frank Ankersmit and Eelco Runia: the presence and the otherness of the past. Rethinking History, vol. 16, n. 3, 2012, pp. 393-415.

Never the Twain Shall Meet? How Narrativism and Experience can be

Reconciled by Dialogical Ethics. History and Theory, v. 54, n. 2 2015, pp. 162-177.

GABRIEL, Gottfried. Sobre o Significado na Literatura e o Valor Cognitivo da Ficção. O que nos faz pensar?, n. 7, maio de 1993, pp. 63-73.

GAFIJCZUK, Dariusz. Dwelling Within: The Inhabited Ruins of History. History and Theory, v. 52, n. 2, maio de 2013, pp. 149-170.

GAY, Eugenia. Para um conceito moderno de imaginação: a imaginação do ponto de vista kantiano. História da Historiografia, n. 18, agosto de 2015, pp. 75-92.

GENEL, Katia. La Lettre sur les aveugles de Diderot : l'expérience esthétique comme expérience critique. Le Philosophoire, n. 21, v. 3, 2003, pp. 87-112.

GHOSH, Ranjan. Interdisciplinarity and the 'Doing' of History: A Dialogue Between F. R. Ankersmit and Ranjan Ghosh. Rethinking History, v. 11, n. 2, 2007, pp. 225-249.

GILBERT, Bennett. Simone Weil's Philosophy of History. Journal of the Philosophy of History, 2017, pp. 1-20. Ahead of print.

GOLOB, Eugene. The Irony of Nihilism. History and Theory, v. 19, n. 4, Beiheft 19: Metahistory: Six Critiques, 1980, pp. 55-65.

GRETHLEIN, Jonas. Experientiality and 'Narrative Reference,' with Thanks to Thucydides. History and Theory v. 49, n. 3, 2010, pp. 315-335.

"Future Past": Time and Teleology in (Ancient) Historiography. History and Theory, v. 53, n. 3, 2014, pp. 309-330.

More than Minds: Experience, Narrative, and Plot. Partial Answers: Journal of Literature and the History of Ideas, v. 16, n. 2, 2018, pp. 279-290.

- Experience and History: the reach and limits of phenomenological approaches to history. History and Theory, v. 58, n. 2, 2019, pp. 302-312.

GORMAN, Jonathan. Discontinuity Pragmatically Framed. Journal of the Philosophy of History, 2016, pp. 1-22.

. Hayden White as Analytical Philosopher of Mind. Rethinking History, v. 17, n. 4, 2013, pp. 471-491.

Philosophical Fascination with Whole Historical Texts. History and Theory, v. 36, n. 3, 1997, pp. 406-415.

. Reality and Irony in History. Storia della Storiografia, v. 24, 1993, pp. 59-

69.

GRIGORIEV, Serge. Dewey: A Pragmatist View of History. Journal of the Philosophy of History, v. 6, 2012, pp. 173-194.

GROSSMAN, Marshall. Hayden White and Literary Criticism: The Tropology of Discourse. Papers on Language and Literature, v. 17, n. 4, 1981, pp. 424-445.

GUIDI, Lucilla. Moods as Groundlessness of the Human Experience. Heidegger and Wittgenstein on Stimmung. Philosophia, v. 45, n. 4, 2017, pp. 1599-1611.

GUYER, Paul. 2017. Re-enactment, reconstruction and the freedom of the imagination. Collingwood on history and art. British Journal for the History of Philosophy, 2017, pp. 1-21. Ahead of print.

HARLAN, David. Intellectual History and the Return of Literature. American Historical Review, v. 94, n. 3, 1989, pp. 581-609.

HESKETH, Ian. The Recurrence of the Evolutionary Epic. Journal of the Philosophy of History, v. 9, n. 2, The Aesthetics of Scale, 2015, pp. 196-219.

\& PEDEN, Knox. The Aesthetics of Scale. Journal of the Philosophy of History, v. 9, n. 2, The Aesthetics of Scale, 2015, pp. 169-175. 
HIRSCH, Marianne \& SPITZER, Leo. Incongruous Images: 'Before, During, and After' the Holocaust. History and Theory, v. 48, n. 4, 2009, pp. 9-25.

HOWIE, Gillian. Nonidentity, Negative Experience and the Pre-Reflective Cogito. European Journal of Philosophy, v. 23, n. 3, 2015, pp. 589-607.

IGGERS, Georg G. Desafios do século XXI à historiografia. História da Historiografia, n. 04, mar. 2010, pp. 105-124.

Historiography between Scholarship and Poetry: Reflections on Hayden White's Approach to Historiography. Rethinking History, v. 4, n. 3, 2000, pp. 373-390. HUNTER, Ian. Hayden White's Philosophical History. New Literary History, v. 45, n. 3, 2014, pp. 331-358.

ICKE, Peter. Frank Ankersmit's Narrative Substance: A Legacy to Historians. Rethinking History, v. 14. n. 4, 2010, pp. 551-567.

IGGERS, Georg. Resenha de Meaning, Truth and Reference in Historical Representation. American Historical Review, v. 118, n. 2, 2013, pp. 472-474.

Comments on F. R. Ankersmit's paper "Historicism: An Attempt at Synthesis". History and Theory, v. 34, n. 3, 1995, pp. 162-167.

JAY, Martin. Intention and Irony: The Missed Encounter between Hayden White and Quentin Skinner. History and Theory, v. 52, n. 1, 2013, pp. 32-48.

. Resenha de David Carr, Experience and History. Journal of the Philosophy of History, v. 10, n. 2 2016, pp. 328-329.

. Sublime Historical Experience, Real Presence, and Photography. Journal of the Philosophy of History, v. 12, n. 3, 2018, pp. 432-449.

JAMES, Samuel, Louis Mink, 'Postmodernism,' and the Vocation of Historiography. Modern Intellectual History, v. 7, 2010, pp. 151-84.

JAMESON, Fredric. Figural Relativism, or the Poetics of Historiography. Diacritics, v. 6, n. 1, 1976, p. 2-9.

JANSEN, Harry. In Search of New Times: Temporality in the Enlightenment and Counter-Enlightenment. History and Theory, v. 55, n. 1, 2016.

. Research, Narrative, and Representation: A postnarrative approach. History and Theory, v. 58, n. 1, 2019, pp. 67-88.

Rethinking Burckhardt and Huizinga. A Transformation of Temporal Images. Storia della Storiografia, v. 70, n. 2, 2016, pp. 95-113.

Time, Narrative, and Fiction. The uneasy relationship between Ricoeur and a heterogeneous temporality. History and Theory, v. 54, n. 1, 2015, pp. 1-24.

JORDHEIM, Helge. Against Periodization. Koselleck's theory of multiple temporalities. History and Theory, v. 51, n. 2, 2012, pp. 151-171.

JENKINS, Keith. 1998. A conversation with Hayden White. Literature \& History, v. 7, n. 1, 1998, pp. 68-82.

2000, p. 181-200.

A Postmodern Reply to Perez Zagorin. History and Theory, v. 39, n. 2, . Cohen contra Ankersmit. Rethinking History, v. 12, n. 4, 2008, pp. 537555.

Inventing the New From the Old - From White's 'Tropics' to Vico's

'Topics' (Referee's Report). Rethinking History, v. 14, n. 2, 2010, pp. 243-248.

Why Bother with the Past? Engaging with some issues raised by the possible 'end of history as we have known it', Rethinking History, v. 1, n. 1, 1997, pp. 56-66.

KANSTEINER, Wulf, Hayden White's Critique of the Writing of History. History and Theory, v. 32, n. 3, 1993, pp. 273-295. 
. Success, Truth, and Modernism in Holocaust Historiography: Reading Saul Friedländer Thirty-Five Years after the Publication of Metahistory. History and Theory, v. 48, n. 2, 2009, pp. 25-53.

KELLNER, Hans. A Bedrock of Order: Hayden White's Linguistic Humanism. History and Theory, v. 19, n. 4, Beiheft 19: Metahistory: Six Critiques, 1980, pp. 1-29.

A Dutchman Views the World - Ankersmit as a Reader. Journal of the Philosophy of History, v. 12, n. 3, 2018, pp. 371-390.

Beyond the Horizon: Chronoschisms and Historical Distance. History and Theory, v. 50, n. 4, 2011, pp. 38-50.

. However Imperceptibly: from the historical to the sublime. PMLA, v. 118, n. 3, Special Topic: Imagining History, maio de 2003, pp. 591-596.

Narrativity and dialectics revisited. Rethinking History, 2016, pp. 1-15.

The Inflatable Trope as Narrative Theory: Structure or Allegory? Diacritics, v. 11, n. 1, 1981, pp. 14-28.

. The Practical Turn. Journal of the Philosophy of History, 2016, pp. 1-8.

KENT, James. Vico, Collingwood, and the Materiality of the Past. Journal of the Philosophy of History, 2016, pp. 1-24. Ahead of print.

KERN, Daniela. Hayden White e o pluralismo histórico. História, v. 29, n. 1, 2010, pp. 278-288.

KLEINBERG, Ethan. Back to Where We've Never Been: Heidegger, Levinas, and Derrida on tradition and history. History and Theory, v. 51, n. 4, 2012, pp. 114-135.

Hayden White: In Memorian. The Historian, 2018, pp. 691-724.

SCOTT, Joan Wallach \& WILDER, Gary. Theses on Theory and History.

Disponível em: <www.theoryrevolt.com>. Acesso em 30 mai. 2018.

KOUFOU, Angelica \& MILIORI, Margarita. The Ironic Poetics of late Modernity. An Interview with Hayden White. Historein, v. 2, 2000.

KUUKKANEN, Jouni-Matti. Frank Ankersmit as a Rationalist. Journal of the Philosophy of History, v. 12, n. 3, 2018, pp. 345-370.

Why we need to move from truth-functionality to performativity in historiography. History and Theory, v. 54, n. 2, 2015, pp. 226-243.

LACAPRA, Dominick. Trauma, History, Memory, Identity. What remains? History and Theory, v. 55, n. 3, 2016, pp. 375-400.

LACLAU, Ernesto. The Time is Out of Joint. Diacritics, v. 25, n. 2, 1995, pp. 85-96.

LA GRECA, María Inés. Hayden White and Joan W. Scott's feminist history: the practical past, the political present and an open future. Rethinking History, v. 20, n. 3, 2016, pp. 395-413.

The Future of Philosophy of History from its Narrativist Past: Figuration, Middle Voice Writing and Performativity. Journal of the Philosophy of History, v. 8, n. 2, 2014.

LANG, Berel. 2017. White, Friedländer, '.... and the rest is history': A Pax Historiana. History and Theory, v. 56, n. 2, 2017, pp. 258-266.

LANG, Johannes. New Histories of Emotion. History and Theory, v. 57, n. 1, 2018, pp. 104-120.

LAVAGNINO, Nicolás. El lugar común de la transfiguración: Historia, representación y filosofía de las asimetrías en Arthur Danto. Páginas de Filosofía, n. 19, jan.-jul. 2015, pp. 33-57.

LEOPOLDO E SILVA, Franklin. Para a compreensão da história em Sartre. Tempo da Ciência, v. 11, n. 2, 2004, pp. 25-37.

LORENZ, Chris. Blurred Lines: history, memory and the experience of time. International Journal for History, Culture and Modernity, v. 2, n. 1, 2014, pp. 43-62. 
Can Histories Be True? Narrativism, Positivism, and the "Metaphorical Turn". History and Theory, v. 37, 1998, pp. 309-329.

LYTJE, Maren. The Ghost of Darwin's Animals: Presence and the return of the real. History and Theory, v. 58, n. 1, 2019, pp. 50-66.

MANDELBAUM, Maurice. The Presuppositions of Metahistory. History and Theory, v. 19, n. 4, Beiheft 19: Metahistory: Six Critiques. 1980, pp. 39-54.

MARWICK, Arthur. Two approaches to historical study: the metaphysical (including 'postmodernism') and the historical. Journal of Contemporary History, v. 30, n. 1, 1995, pp. 5-35.

McCULLAGH, C. Behan. Resenha de Narrative Logic: A Semantic Analysis of the Historian's Language by F. R. Ankersmit. History and Theory, v. 23, n. 3, 1984, pp. 394-403.

- The Truth of Basic Historical Descriptions. Journal of the Philosophy of History, v. 9, n. 3, 2015, pp. 97-117.

MEGILL, Allan. "Big History" Old and New: Presuppositions, Limits, Alternatives. Journal of the Philosophy of History, v. 9, n. 2, The Aesthetics of Scale, 2015, pp. 306326.

\& ZHANG, Xupeng. Questions on the History of Ideas and its Neighbours. Rethinking History, v. 17, n. 3, 2013, pp. 333-353.

MENEZES, Jonathan. Aftermaths of the dawn of experience: on the impact of Ankersmit's sublime historical experience. Rethinking History, v. 22, p. 44-64, 2018.

The Limits of "Autumn of Historiography": On Frank Ankersmit's

Postmodernist Moment. Journal of the Philosophy of History, 2019, pp. 1-22. Ahead of print.

MINK, Louis O. Comment on Stephen Toulmin's 'Conceptual Revolutions in Science'. Synthese, v. 17, n. 1, 1967, pp. 92-99.

$777-783$.

. Everyman His or Her Own Annalist. Critical Inquiry, v. 7, n. 4, 1981, pp.

. Historical Perspectives on American Philosophy. The Review of Metaphysics, v. 5, n. 4, pp. 587-598.

. Interpretation and Narrative Understanding. Journal of Philosophy, v. 64, n. 20, 1972, pp. 735-737.

. Resenha de Faith and Reason: Essays in the Philosophy of Religion, de R.

G. Collingwood. Journal of the American Academy of Religion, v. 38, n. 1, 1970, pp. 118-120.

. Resenha de Historians' Fallacies, de David Hackett Fischer. History and Theory, v. 10, n. 1, 1971, pp. 107-122.

. Resenha de Our Knowledge of the Historical Past, de Murray G. Murphey.

The American Historical Review, v. 79, n. 2, 1974, pp. 482-483.

. Resenha de The Logic of Religion, de Joseph M. Bochenski. The Journal of Religion, v. 47, n. 2, 1967, pp. 150-152.

. Resenha de The Philosophy of Henry James, de Frederic Harold Young.

The New England Quarterly, v. 25, n. 3, 1952, pp. 415-416.

MOSES, A. Dirk. Hayden White, Traumatic Nationalism, and the Public Role of History. History and Theory, v. 44, 2005, pp. 311-332.

.The Public Relevance of Historical Studies: A Rejoinder to Hayden White.

History and Theory, v. 44, 2005, pp. 339-347.

MOSKALEWICZ, M. Sublime Experience and Politics: Interview with Professor Frank Ankersmit. Rethinking History, v. 11. n. 2, 2007, pp. 251-274. 
MOMIGLIANO, Arnaldo. The Rhetoric of History and the History of Rhetoric: On Hayden White's Tropes. Comparative Criticism: a Yearbook, n. 3, 1981, pp. 259-268.

MOYN, Samuel. Fogueira das Humanidades. Tradução de João Ohara. Disponível em: $<$ https://campohistoriografico.wordpress.com/2015/11/01/fogueira-das-humanidades/> Acesso em dez. 02, 2015.

MUNSLOW, Alun. 2014. On 'Presence' and conversing with the past. Do historians communicate with the past. Rethinking History, v. 18, n. 4, 2014, pp. 569-574.

Resenha de MUNSLOW, Alun. 2015. Postnarrativist Philosophy of Historiography. Rethinking History, 2015, pp. 1-3. Ahead of print.

MURPHY, Richard J. Metahistory and Metafiction: Historiography and the Fictive in the Work of Hayden White. Sources: Revue d'etudes anglophones, n. 2, 1997, pp. 3-30.

NASCIMENTO, Fernando. Narrative, Mimesis, and Phronetical Deliberation. StoryWorlds: A Journal of Narrative Studies, v. 6, n. 2, 2014, pp. 29-48.

NELSON, John L. Resenha de Meta-História, de Hayden White. History and Theory, v. 14, n. 1, 1975, pp. 74-91.

NOSÁL, Martin. The Gadamerian Approach to the Relation Between Experience and Language. History and Theory, v. 54, n. 2, 2015, pp. 195-208.

OHARA, João Rodolfo Munhoz. Ética, Escrita e Leitura da História: os problemas da expectativa e da confiança. Revista de História (USP), n. 178, 2019, pp. 2-28.

PAUL, Herman. A Loosely Knit Network: Philosophy of History After Hayden White. Journal of the Philosophy of History, v. 13, 2019, pp. 3-20.

A Weberian Medievalist: Hayden White in the 1950's. Rethinking History, v. 12 , n. 1, 2008, p. 75-102.

. Distance and Self-Distanciation: Intellectual Virtue and Historical Method Around 1900. History and Theory, Theme Issue 50, 2011.

. Metahistorical Prefigurations: Toward a Re-Interpretation of Tropology in Hayden White. Journal of Interdisciplinary Studies in History and Archaeology, v. 1, n. 2, 2004, pp. 1-19.

. No historian worthy of the name is only an historian. Práticas da História, n. 7, 2018, pp. 15-22.

Performing History: how historical scholarship is shaped by epistemic virtues. History and Theory, v. 50, n. 1, 2011, pp. 1-19.

Resenha de The Fiction of Narrative, de Hayden White. Journal of the

Philosophy of History, v. 5, 2011, pp. 131-145.

. Relations to the past: a research agenda for historical theorists. Rethinking

History, v. 19, n. 3, 2015. Ahead of print.

. What is a Scholarly Persona? Ten Theses on Virtues, Skills, and Desires.

History and Theory, v. 53, n. 3, 2014, pp. 348-371.

\& VAN VELDHUIZEN, Adriaan. 2018. A Retrieval of Historicism: Frank

Ankersmit's Philosophy of History and Politics. History and Theory, v. 57, n. 1, 2018, pp. 33-55.

PEDEN, Knox. Hayden White's Metahistory and the Irony of the Archive. Journal of the Philosophy of History, 2015, pp. 177-195.

PENMAN, Leigh T.I. The Hidden History of the Cosmopolitan Concept. Journal of the Philosophy of History, v. 9, n. 2, The Aesthetics of Scale, 2015, pp. 284-305.

PETERS, Rik. Calliope's Ascent: defragmenting philosophy of history by rhetoric. Rethinking History, v. 20, n. 3, 2016, pp. 235-258.

PIERCEY, Robert. Narcissism or Facts. A Pragmatist Approach to the Philosophy of History. Journal of the Philosophy of History, 2017, pp. 1-21. Ahead of print. 
PIHLAINEN, Kalle. Jean-Paul Sartre and the post-1968 ethic of antirepresentationalism. In: DORFMAN, Ben (Org.). Dissent! Refracted: Histories, Aesthetics and Cultures of Dissent. Peter Lang, 2016, pp. 209-228.

Messing with Mr. In-between. Or, how being second-rate can rescue history. Rethinking History, ahead of print, 2017, pp. 1-19.

. Rethinking Narrative Constructivism. Rethinking History, v. 17, n. 4, 2013, pp. 509-527.

. The Distinction of History: On valuing the insularity of the historical past. Rethinking History, v. 20, n. 3, 2016, pp. 414-432.

The Eternal Return of Reality: on constructivism and current historical desires. Storia della Storiografia, v. 65, n. 1, 2014, pp. 103-115. pp. 575-582.

There's Just no Talking with the Past. Rethinking History, v. 18, n. 4, 2014, The Moral of the Historical Story: Textual Differences in Fact and Fiction. New Literary History, v. 33, n. 1, pp. 39-60.

. The View from the Fence. Rethinking History, v. 19, n. 2, 2015, pp. 310321.

What if the past were acessible after all? Rethinking History, v. 16, n. 3, 2012, pp. 323-339.

POLLAK, Michael. Memória e Identidade Social. Estudos Históricos. Rio de Janeiro, v. 5, n. 10, 1992, p. 200-212.

Memória, Esquecimento, Silêncio. Estudos Históricos. Rio de Janeiro, v. 2, n. 3, 1989, p. 3-15.

PORTER, James I. Disfigurations: Erich Auerbach's Theory of Figura. Critical Inquiry, v. 44, 2017, p. 80-113.

RAMOS, André da Silva. Ethan Kleinberg: Theory of History as Hauntology. História da Historiografia, n. 25, dez. 2017, pp. 212-228.

RIBEIRO, Naiara Damas. A morfologia histórica de Johan Huizinga e o caráter pragmático do passado. História da Historiografia , n. 4, v. 1, 2010, p. 234-254, 2010. Clio e Melpomene: a correspondência entre Johan Huizinga e André Jolles sobre a escrita da História. Topoi, v. 17, n. 33, 2016, pp. 626-647.

"O mundo em ruínas": notas sobre a decadência do Ocidente e a questão da morfologia histórica em Johan Huizinga e Oswald Spengler (1910-1940). Anais do XIV Encontro Regional da Anpuh-Rio: Memória e Patrimônio. Rio de Janeiro, 2010.

RICOEUR, Paul. The Metaphorical Process as Cognition, Imagination, and Feeling. Critical Inquiry, v. 5, n. 1, 1978, pp. 143-159.

Narrative Time. Critical Inquiry, v. 7, n. 1, 1980, pp. 169-190.

ROBERTS, David D. Rethinking Hayden White's Treatment of Croce. Rethinking History, v. 17, n. 4, 2013, pp. 448-470.

ROSS, Alison. Historical Citation and Revolutionary Epistemology: The Image/Word Distinction in Walter Benjamin's Arcades Project. Journal of the Philosophy of History, v. 9, n. 2, The Aesthetics of Scale, 2015, pp. 258-283.

ROTH, Michael S. Ebb Tide. History and Theory, v. 46, n. 1, 2007, pp. 66-73.

ROTH, Paul A. Back to the Future: Postnarrativist Historiography and Analytic Philosophy of History. History and Theory, v. 55, n. 2, 2016, pp. 270-281.

Hayden White and the Aesthetics of Historiography. History of the Human

Sciences, v. 5, n. 1, 1992, pp. 17-35.

. Hayden White in Philosophical Perspective. Resenha de Hayden White: The Historical Imagination, de Herman Paul. Philosophy of the Social Sciences, v. 43, n. 2, 2013, pp. 1-10. 
- History and the Manifest Image: Hayden White as a Philosopher of History. Resenha de The Fiction of Narrative, de Hayden White. History and Theory, v. 52, n. 1, 2013, pp. 130-143.

1, 1988, pp. 1-13.

.Narrative Explanations: The Case of History. History and Theory, v. 27, n.

.The Pasts. History and Theory, v. 52, n. 4, 2012, pp. 313-339.

$121-136$.

. Undisciplined and Punished. History and Theory, v. 57, n. 1, 2018, pp.

. Whistling history: Ankersmit's neo-Tractarian theory of historical representation. Rethinking History, v. 17, n. 4, 2013, pp. 548-569.

RUNIA, Eelco. Reply to Jenkins. Rethinking History, v. 14, n. 2, 2010, pp. 249-250.

WHITE, Hayden, KLEINBERG, Ethan, JAY, Martin \&

HAROOTUNIAN, Harry. Tears in the Fabric of the Past: New theories of narrative and History. Disponível em: <https://www.youtube.com/watch?v=Mr5DgDv1two>. Acesso em jan. 15, 2015.

\& TAMM, Marek. The past is not a foreign country: a conversation.

Rethinking History, ahead of print, 2019.

RÜSEN, Jörn. Como dar sentido ao passado: questões relevantes de meta-história.

História da Historiografia, n. 02, 2009, p. 163-209.

RUSSON, John. Self-Consciousness and the Tradition in Aristotle's Psychology. Laval théologique et philosophique, v. 52, n. 3, 1996, pp. 777-803.

The Self as Resolution: Heidegger, Derrida, and the Intimacy of the Question of the Meaning of Being. Research in Phenomenology, v. 38 n. 1, 2008, pp. 90-110.

SAARI, Heikki. On Frank Ankersmit's Postmodernist Theory of Historical Narrativity. Rethinking History, v. 9, n. 1, pp. 5-21.

SCHINKEL, Anders. History and Historiography in Process. History and Theory, v. 43, n. 1, 2004, pp. 39-56.

SCHWERHOFF, Gerd. Spaces, Places, and the Historians: A Comment from a German Perspective. History and Theory, v. 52, n. 3, 2013, pp. 420-432.

SCOTT, Joan W. The Evidence of Experience. Critical Inquiry, v. 17, n. 4, 1991, pp. 773-797.

SIMON, Zoltán Boldizsár. (The Impossibility of) Acting Upon a Story That We Can Believe. Rethinking History, v. 22, n. 1, 2018, 105-125.

. Experience as the Invisible Drive of Historical Writing. Journal of the

Philosophy of History, n. 7, v. 2, 2013, pp. 183-204.

. History Manifested: making sense of unprecedented change. European

Review of History: Revue européenne d'histoire, v. 22, n. 5, 2015, pp. 819-314.

of print.

History set into motion again. Rethinking History, 2014, pp. 1-17. Ahead

2015, pp. 178-194.

The Expression of Historical Experience. History and Theory, v. 54, n. 2,

\& KUUKKANEN, Jouni-Matti. Introduction: Assessing Narrativism.

History and Theory, n. 54, v. 2, mai. 2015, pp. 153-161.

SMITH, Roger. Does reflexivity separate the human sciences from the natural sciences?

History of the Human Sciences, v. 18, n. 4, pp. 1-25.

SÖDER, Hans-Peter. The Return of Cultural History? 'Literary' Historiography from

Nietzsche to Hayden White. History of European Ideas, v. 29, 2003, pp. 73-84. 
SPIEGEL, Gabrielle. Above, about and beyond the writing of history: a retrospective view of Hayden White's Metahistory on the 40th anniversary of its publication. Rethinking History, v. 17, n. 4, 2013, pp. 492-508.

. David Carr's Theory of Experiencing Times Past. History and Theory, Theme Issue 56 responses, janeiro de 2019, s15-s19.

. History, Historicism, and the Social Logic of the Text in the Middle Ages.

Speculum, v. 65, n. 1, 1990, p. 59-86.

STONE, Dan. Excommunicating the past? Narrativism and rational constructivism in the historiography of the Holocaust. Rethinking History, v. 21, n. 4, 2017, pp. 549-566.

STONE, Lawrence. The Revival of Narrative: Reflections on a New Old History. Past and Present, n. 85, 1979, pp. 3-24.

STUEBER, Karsten R. The Cognitive Function of Narratives. Journal of the Philosophy of History, v. 9, n. 3, 2015, pp. 393-409.

TAMM, Marek \& ZELENAK, Eugen. In a Parallel World: An Introduction to Frank Ankersmit's Philosophy of History. Journal of the Philosophy of History, v. 12, n. 3, 2018, pp. 325-244.

TOZZI, Verónica. A pragmatist view on two accounts of the nature of our 'connection' with the past. Hayden White and David Carr thirty years later. Rethinking History, v. 22, n. 1, 2018, pp. 65-85.

Dewey, Mead, John Ford, and the Writing of History: Pragmatist

Contributions to Narrativism. European Journal of Pragmatism and American Philosophy, v. 3, n. 2, 2016, pp. 1-22.

Pragmatist Contributions to a New Philosophy of History. Pragmatism

Today, v. 3, n. 1, 2012, pp. 121-131.

THOMPSON, Paul. História Oral e Contemporaneidade. História Oral, 5, 2002, p. 928.

TURNER, Stephen. Meaning Without Theory. Journal of the Philosophy of History, v. 5, 2011, pp. 352-369.

VAN DEN AKKER, Chiel. Frank Ankersmit and Hayden White on the Politics of Historical Representation. Journal of the Philosophy of History, v. 12, n. 3, 2018, pp. 410-431.

. Mink's Riddle of Narrative Truth. Journal of the Philosophy of History, v. 7, n. 3, 2013, pp. 346-370.

The Exemplification Theory of History: Narrativist Philosophy and the Autonomy of History. Journal of the Philosophy of History, v. 6, n. 2, 2012, pp. 236257.

VANN, Richard. Louis Mink's Linguistic Turn. History and Theory, v. 26, n. 1, 1987, pp. 1-14.

143-161.

The Reception of Hayden White. History and Theory, v. 37, n. 2, 1998, pp.

VASCONCELOS, José Antonio. A História e a sedução da narrativa. Revista Uniandrade, v. 11, n. 2, 2010, pp. 19-29.

O passado irrevogável na justiça de transição. História da Historiografia, v. 11, 2013, pp. 305-311.

VIVEIROS DE CASTRO, Eduardo, DANOWSKI, Deborah \& BRUM, Eliane. Diálogos sobre o fim do mundo. El País. Disponível em:

<http://brasil.elpais.com/brasil/2014/09/29/opinion/1412000283_365191.html>. Acesso em 23 nov. 2015.

VIVEIROS DE CASTRO, Eduardo, NATÁLIO, Rita \& MARQUES, Pedro Neves. O que estamos vendo no planeta hoje é um combate de povos e não de classes. Ou as 
classes estão voltando a se redefinir como povos. Instituto Socioambiental, 2017. Disponível em: <https://pib.socioambiental.org/pt/Not\%C3\%ADcias?id=178023>. Acesso em 22 de maio de 2017.

WINKLER, Rafael. Husserl and Bergson on Time and Consciousness. Analecta Husserliana, v. 90, 2006, pp. 93-115.

WHITE, Hayden. An Old Question Raised Again: Is Historiography Art or Science? (Response to Iggers). Rethinking History, v. 4, n. 3, 2000, pp. 391-406.

. Anomalies of Genre: The Utility of Theory and History for the Study of Literary Genres. New Literary History, v. 34, n. 3, 2004, pp. 597-615. . Commentary: Good and Their Kind. New Literary History, v. 34, n. 2, 2003, pp. 367-376.

. Conventional Conflicts. New Literary History, v. 13, n. 1, 1981, pp. 145160.

. Croce and Becker: A note on the evidence of influence. History and Theory, v. 10, n. 2, 1971, pp. 222-227.

. Figural Realism in Witness Literature. Parallax, v. 10, n. 1, 2004, p. 11324.

. Hayden White: "Lean a Marx; él les contará cómo sucedió". Clarín, Argentina, 04/05/2011. Disponível em: <https://www.clarin.com/rn/ideas/politicaeconomia/Lean-MarX-contara-sucedio-White_0_rJC4WJXpDme.html>

. History as Fulfillment: Hayden White's Keynote Address. Disponível em: <http://www.tulane.edu/ isn/hwkeynote.htm>. Acesso em 11 abr. 2012.

n. 1 , pp. 43-59.

Historical Fictions: Kermode's Idea of History. Critical Quarterly, v. 54,

Introduction: Historical Fiction, Fictional History, and Historical Reality.

Rethinking History, v. 9, n. 2/3, 2005, pp. 147-157.

1970, pp. 173-185.

Literary History: The Point of It All. New Literary History, v. 2, n. 1,

Reflections on Gendre in the Discourses of History. New Literary History, v. 40, n. 4, 2009, p. 867-877.

. Resenha de Idealism, Politics and History, de George Armstrong Kelly.

History and Theory, v. 9, n. 3, 1970, pp. 343-363.

Resenha de The Later Philosophy of R. G. Collingwood, de Alan Donagan. History and Theory, v. 4, n. 2, 1965, pp. 244-252.

2, 1995, pp. 233-246.

Response to Arthur Marwick, Journal of Contemporary History, v. 30, n.

. The aim of interpretation is to create perplexity in the face of the real. Hayden White in conversation with Erlend Rogne. History and Theory, v. 48, 2009, p. 63-75.

196 The Future of Utopia in History. Historein: A Review of the Past and Other Stories, v. 7, 2007, pp. 5-19.

v. 19, n. 2, 2008, pp. 9-34.

The Historical Event. Differences: A Journal of Feminist Cultural Studies,

. The Narrativization of Real Events. Critical Inquiry, v. 7, n. 4, 1981.

. The Practical Past. Historein, v. 10, 2010, pp. 10-19.

. "We're Here to Discuss the Meaning of Life". The Chronicle of Higher

Education, 03 de abril de 2019. Disponível em: <https://www.chronicle.com/article/We-re-Here-to-Discuss-the/246047>. Acesso em 10 de abril de 2019. 
WURTH, Kiene Brillenburg. 2007. The Musicality of the Past. Sehnsucht, Trauma, and the Sublime. Journal of the Philosophy of History, v. 1, n. 1, 2007, pp. 219-247.

ZAGORIN, Perez. Historiography and Postmodernism. Reconsiderations. History and Theory, v. 29, n. 3, 1990, pp. 263-274.

. History, the Referent, and Narrative: Reflections on Postmodernism Now. History and Theory, v. 38, 1999, pp. 1-24.

ZAMMITO, John. Ankersmit's Postmodernist Historiography: The Hyperbole of "Opacity". History and Theory, v. 37, 1998, pp. 330-46.

. Rorty, 'Historicism' and the practice of history: A polemic. Rethinking History, v. 10, n. 1, 2006, pp. 9-47.

Ankersmit and Historical Representation. History and Theory, v. 44, n. 2, 2005, pp. 155-181.

ZELENAK, Eugen. How to Cure Narrativism with Rational Evaluation. Journal of the Philosophy of History, v. 11, 2017, pp. 22-32.

. Two versions of a constructivist view of historical work. History and

Theory, v. 54, n. 2, 2015, pp. 209-225. 